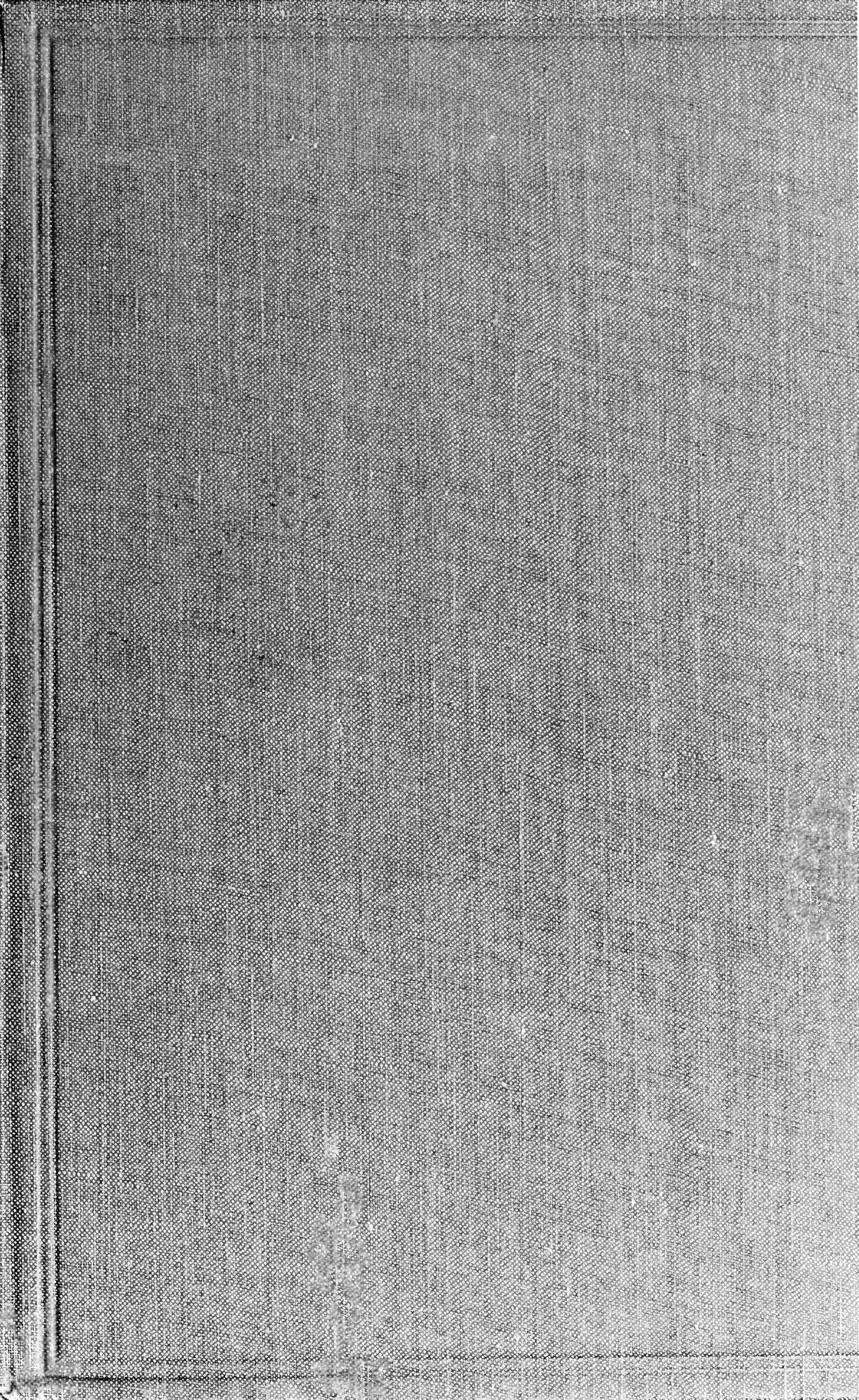




\section{Digitized by the Internet Archive in 2007 with funding from Microsoft Corporation}





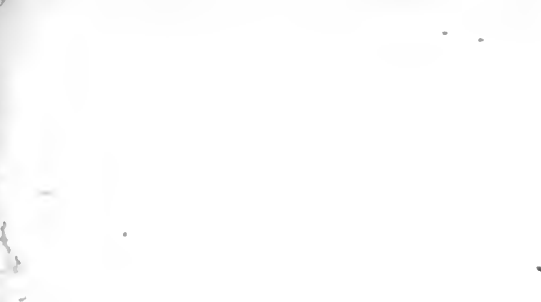


Publications of the

Carnegie Endowment for International Peace

Division of Economics and History

John Bates Clark, Director 



\title{
THE FISCAL AND DIPLOMATIC FREEDOM OF THE BRITISH OVERSEA DOMINIONS
}

\author{
BY \\ EDWARD PORRITT
}

EDITED BY

DAVID KINLEY

PRESIDEN'T OF THE UNIVERSITY OF ILLINOIS

OXFORD : AT THE CLARENDON PRESS

London, Edinburgh, New York, Toronto, Melbourne and Bombay HUMPHREY MILFORD

I 922 
PRINTED IN ENGLAND AT THE OXFORD UNIVERSITY PRESS 


\section{PREFACE}

This book is ostensibly a story of fiscal progress, of trade and industry. Knowing this, the ordinary reader will feel impelled to turn from it as a dry record of facts and figures. But the book is more than that. It is a story of growth of nationalities, of adjustments of the economic and political life of her colonies to the mother country. It is a story of the growth to mature womanhood and independence of the greatest of the colonial daughters of the mighty Empire of Britain. It is a story of her independent action, of the ebb and flow of her affection, of the alternate strengthening and weakening of the bonds that join her to her mother land, yet on the whole always resulting in the strengthening of the more deeply laid and hidden ties that bind that wonderful world empire which has played so great a part in the war.

The fiscal history of Canada resembles in some respects that of the United States. Discussion of tariff and protection has played a large part. Many of the great movements, like the protectionist, sprang from the sordid motives of individuals; yet not infrequently, as in our own country, they worked out for the public weal. There is no minimizing of the blindness, the selfishness, and the sordidness of the views of many British statesmen. Not only to the average Englishman, but to many Englishmen above the average, charged with responsibilities of great colonial government, the colonies have frequently seemed matters of minor importance and the colonist entitled to something less than the full consideration of stay-at-home Englishmen. This point of view is well and frequently shown in the history of the great commonwealth to the north of us. However, the colonies, including Canada, were not themselves altogether 
free from blame. They have at times shown a desire to retain the advantages of the British imperial connexion and at the same time to have independence in fiscal and other matters. Such a spirit and point of view are not uncommon in national as well as individual affairs.

The belief was common in Canada as well as in England for many years that independence was the inevitable outcome for the colonies, and that, therefore, there was little need for giving attention to their relations to the mother country in the meantime. Now the colonies want both home rule and British citizenship. It is the task of British statesmen to find a way to grant their wishes. For certain it is that the world will be worse off if some arrangement is not devised to preserve the unity of that great spiritual commonwealth, the British Empire, whose members by their attitude and action in the late great war showed that spiritual bonds are more powerful after all to bring men together in the accomplishment of a common duty and the maintenance of common standards and ideals, than are the acts of lawgivers, the practices of politicians, the wiles of diplomats, or the theories of statesmen.

In tracing the history of the relations of Canada to the mother country, Mr. Porritt brings out very clearly the change of attitude of Great Britain towards the colonies after the American Revolution. The loss of the American colonies undoubtedly went far to produce in the minds of Englishmen the belief that ultimately all the colonies would separate themselves from the mother country and, therefore, to cultivate the indifference which at that time and at many later times the mother country showed towards her children.

Early in the nineteenth century fiscal policies, both colonial and British, so crossed one another that they both made for economic independence for the colonies. The protectionist 
movement, which began early in Canada, led in this direction. The development of industries and the establishment of a national domestic policy stimulated the demand for responsible government, and this again led the Canadians to feel more and more that they could stand on their own feet. In the home country the feeling manifested towards Canada was indifference. The main interest of the people at home in the colonies was to have them as markets. It was half a century before the idea that the colonies were mere commercial appendages of the mother land was abandoned. As they felt the colonial markets to be just as much theirs whether they kept the colonies or not, the people at home became indifferent as to their retention and lost interest in maintaining those less tangible spiritual connexions which, after all, are the lasting binding cords between the colonies and the home country. There was through a generation or more on the part of Great Britain a strange blindness and indifference to a proper sense of obligation to her fellow countrymen who were colonists.

Meantime the great commonwealth of Canada has been developing into a really independent country. Yet when the World War broke out, all differences of fiscal policy, diplomatic quibbles, and estrangement over minor matters were swept away by the feeling of common brotherhood among members of the Empire, whether they were in the British Isles, in Canada, in Australia, or in the islands of the sea. The conduct of the colonies showed beyond question that it is the spiritual bond that the commonwealth of Great Britain must rely on for continuance. Mr. Porritt's history reveals this idea in manifold ways.

David Kinley.

URBANa, ILLINoIS, July 13, 1921. 



\section{CONTENTS}

\section{INTRODUCTION}

THE OLD COMMERCIAL SYSTEM AND THE NEW

PAGE

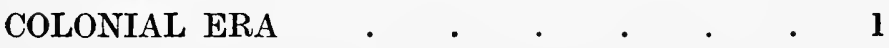

\section{PART I}

\section{THE NEW BRITISH FISCAL SYSTEM}

CHAPTER

I. The Dominions and the Crown Colonies-The Fiscal Policy of the Crown Colonies . $\quad . \quad$. $\quad . \quad 71$

II. Crown Colonies not of the Movement for Fiscal FreedomAmerican Influence on the Movement in Self-governing Colonies . . . . . . . .

III. The Old Commercial System and its Enforcement in the Colonies . . . . . . . .

IV. Inroads in the Colonies on the Old Commercial SystemColonial Bonuses and Aids to Industry, 1820-1846 . 86

V. The Declaratory Act of 1778-The Charter of Financial

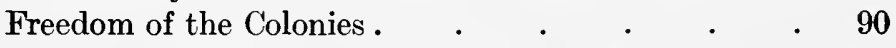

VI. The Critical Period in Nineteenth-century Colonial

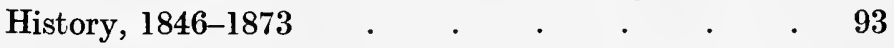

VII. New Zealand's Fiscal Freedom under the Constitution of

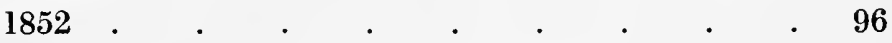

VIII. The Movement of 1867-1873 for Larger Fiscal Freedom for the Australian Colonies . $\quad$. $\quad$. $\quad$. $\quad$. $\quad$. 98

IX. Overtures for Reciprocity with the United States-The New Zealand Overtures of 1869-1870 . . . 102

X. The Australian Colonies and Differential Duties . . 107

XI. Free Trade Propaganda from Westminster 1846-1895 . 112

XII. The Australasian Colonies and the Free Trade Propaganda

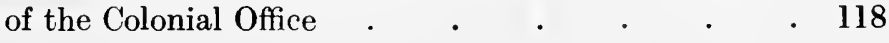




\section{PART II}

THE PROTECTIONIST MOVEMENT \& PROTECTIONIST LEGISLATION IN THE SELF.GOVERNING COLONIES, 1858-1914

CHAPTER

I. The Beginnings of the Protectionist Movement in the Australasian Colonies . . . . . . . 123

II. Vietoria adopts Proteetion-Tariffs of 1865-1870 . $\quad 125$

III. Bonuses for Industry in New Zealand and Tasmania' The Made in New Zealand ' Movement of 1870 . 128

IV. Retaliatory Duties in Early Australasian Tariffs . . 134

V. Proteetion against Low Wages in Great Britain . . 138

VI. Low Wages in British Industries and the British Preference, $1897-1914$. $. \quad . \quad . \quad . \quad . \quad . \quad 142$

VII. Colonies as Dumping Markets for British Manufaeturers, 1858-1914 . . . . . . . . . 149

VIII. The Failure of the Propaganda against Differential and Proteetive Duties in Canada, 1846-1859 . . . 154

IX. High Peaks in the Movements towards Fiscal Freedom, 1846-1873

\section{PART III}

\section{FISCAL FREEDOII AND DIPLOMACY, 1848-1907}

I. Early Stages of the Movement for Power to Negotiate Commereial Treaties, 1848-1849 . . . . .

II. Attitude of the British Ministers at Washington towards the New Claim of the Colonies _ . . . . 164

III. Developments in the Movement for Treaty-making Power, 1850-1865 . . . . . . . . .

IV. The Interprovineial Council on Commereial Treaties of 1865-The Varied Interests of the British North American Provinces

V. The Clain of Direct Representation in Treaty-making Conceded-A Mission to Washington that Failed, $1865-1866$ 
CHAPTER

VI. British Recognition of the New Place of the Colonies in

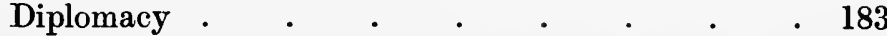

VII. Galt and Tupper press Claim of Dominions for more Power in Diplomacy, 1880-1893 . $\quad . \quad$. $\quad . \quad 188$

VIII. A Halt in the Progress toward Diplomatic Freedom, 1893-1898-Reaction at the Colonial Office . . 193

IX. Freedom to Negotiate Treaties achieved, 1898-1907 198

X. Transference of New Power to the Dominions . . . 203

\section{PART IV}

RESPONSIBLE GOVERNMENT AND FISCAL AND DIPLO. MATIC FREEDOM.

I. The End of an Era in the Fiscal History of the Empire . 213

II. Protectionist and Free Trade Colonies in 1873 . . . 218

III. The Constitutional Position of the Colonies at the Crisis of 1867-1873 . . . . . . . . . 221

IV. The Old and the New Type of Colonial Governor . . 227

V. The Rebellion Losses Act of 1849 and the Contest for Fiscal Freedom . . . . . . . . . 230

VI. Attitude of Parliament after 1849 toward Legislation in

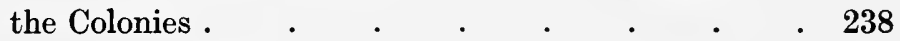

VII. Parliament and the New Colonial Policy, 1849-1914 . 244

VIII. The Passing of the Veto on Colonial Legislation . . 252

IX. Factors and Influences that Restricted the Veto on Colonial

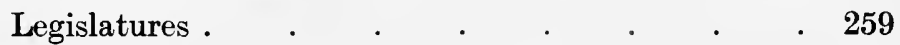

X. The Australian Colonies and the Veto . . . . . 265

XI. The Last Stage of the Veto . $\quad . \quad$. $\quad$. $\quad$. $\quad$. 272

PART V

THE ERA OF INDIFFERENCE IN GREAT BRITAIN TO COLONIES AND EMPIRE

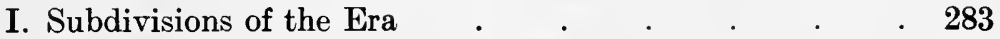

II. Influences that made for Indifference . . . . . 285

III. Manifestations of the Indifference . $\quad$. $\quad$. $\quad$ • $\quad$. 289 
IV. Willingness of British Statesmen to abandon Colonies, $1827-1852$

V. Legislation for Colonies and Colonial Questions

VI. The Attitude of Downing Street toward Legislation for the Colonies.

VII. Colonial Polieies, Bills for Colonies, and their Vicissitudes at Westminster

VIII. The Expectation that the Colonies would Secede from the Empire, 1816-1887 . . . . . . . . 323

IX. Attitude of the House of Commons toward Secession . 327

$\mathrm{X}$. The House of Commons and the Commercial Value of the Connexion with the Colonies

XI. Diseussions of the Colonial Connexion in the House of Lords

XII. Indifference to the Colonial Connexion in the Constitueneies

XIII. Reassurances to the Colonies-Elgin's Message of 18471854

\section{PART VI}

THE SECOND HALF OF THE ERA OF INDIFFERENCE, 1859-1887

I. Continued Languid Interest of Parliament in Colonial Legislation . 359

II. Colonies in Literature-History, Biography, and Political Seience

III. Changes in London consequent on Responsible Government 368

IV. Protectionist Tariffs and Indifference to the Colonies . 372

V. The Manchester School and the Colonies . . . . 378

VI. Separatists of Other Sehools of Political Thought 384

VII. Indifference to Colonies in all Political Parties, 1783-1887 393

VIII. The Colonies and British Indifference . . . . . 395

IX. The End of the Era of Indifferenee _ . . . . . 399 SOLRCES AXD ACTHORITIES . . . . . 409 
II. Documents Illustrative of the Working of the Old Commercial System in the Period 1783-1846 :

1. Instructions to Colonial Governors .

2. Table from Tariff of Nova Scotia of 1834 showing (1) Imperial Duties on Foreign Produce, (2) Colonial Duties on British Produce, and (3) Colonial Duties on Foreign Produce, including the Imperial Duty . . . . .

3. Table from Tariffs of United Kingdom of 1842 showing Rates of Duties on Imports from Foreign Countries and from British Possessions

4. William Lyon Mackenzie's Memorial of 1832 to Goderich, Secretary of State for the Colonies .

5. A Protest in 1834 from the Legislative Assembly of Upper Canada . . . . . .

6. Taxation without Representation-An Upper Canada Protest of 1835 . . . .

7. 'Hasty, Partial, and Injurious Legislation in England' . . . . . . .

8. Power to enact Tariffs urged by Legislative Assembly, Upper Canada, 1839 . . .

9. Sydenham's Case for Acceding to the Claim for Larger Powers in Enacting Provincial Tariffs .

10. Powers Regarding Trade Withheld from Legisla. ture of Province of Canada by Imperial Act of 1840 for Union of the Provinces . . .

11. Attitude of Labouchere, President of Board of Trade, toward Claim of 1840 . . . .

12. Lord Stanley's Statement of the Policy of the Peel Administration of 1841-1846, as Embodied in the British Possessions Act of 1842 . .

13. Discriminating Duties in Colonial Tariff ActsLord Stanley's Circular Dispatch of June 28, 1843

14. An Adverse Reply to a Petition for Preferential Treatment of Canadian Tobacco, July 30, 1845 
15. Instances of Colonial Office Control of Colonial Fiscal Legislation

16. Canada Tariff Act of 1845 Amended at Instance of Colonial Office

17. Discriminating Duties in the Interest of the St. Lawrence Route, and Discriminating Duties in General in Colonial Tariffs . . . .

18. Colonial Import Duties on Supplies for British Military Forces in Canada . . . .

III. Documents of the Transition Period-1846-1854 :

1. Colonial Office Intimation to Canada of Approaching Change in British Fiscal System-Gladstone's Dispatch of March 3, 1846

2. Movements in Canada for the Retention of Preferences in British Tariffs on Canadian Grain and Flour $\quad . \quad$. . . . .

3. Manifesto of Free Traders of Montreal, March 1846

4. Overtures from Downing Street to Washington for Reciprocity in Trade between the United States and the British North American Provinces

5. Enabling Act of 1846 . $\quad$. $\quad$.

6. Great Britain's Free Trade Policy and its Dangers to the Tie with the Colonies. A Petition to the Queen in 1848 from the Montreal Board of Trade

7. Address of the Annexation Association of Montreal of 1849

IV. Documents Illustrating the Spirit and Purpose of the Colonial Office Propaganda for Colonial Tariffs in Accordance with the Principles of Free Trade, 1846-1895:

1. Grey's Exposition of the New Fiscal Policy of the United Kingdom to Elgin, on his Appointment as Governor-General of Canada . . .

2. Objection by Grey to Increases in Duties on British Manufactures in Canadian Tariff of 1847

3. The Colonial Office and Bounty Legislation in British North American Provinces-1845-1849 
4. Opposition of Colonial Office to Differential Duties in Canadian Tariff Framed with a View to Reciprocity with the United States-December 21, 1848 .

5. Grey's Conception of Fiscal Policy best Calculated to Promote Development of Canada-August 1, 1851 .

6. Opposition in Downing Street to Free Trade between Canada and the West Indian Colonies -Molesworth's Dispatch of August 15, 1855 .

7. Canadian Tariff Act of 1859-Newcastle-Galt Controversy over Duties to Protect Canadian Industry . $\quad . \quad$. $\quad . \quad$.

8. Differential Duties in the Tariffs of Australian Colonies-Kimberley's Dispatches of July 13, 1871, and April 19, 1872

9. Nearing the End of the Colonial Office Propaganda -Ripon's Circular Dispatch of June 28, 1895 .

V. Protests at Westminster against Protectionist Duties in Canadian Tariffs, 1859-1887 :

1. Comparison of Fiscal Freedom of Colonies of the Old and New Era-Gladstone's Observations in 1859

2. A Question in the House of Commons in 1864 .

3. Canadian Duties Higher than American and French Protectionist Duties-A Complaint by Bright in 1865 . . . . . .

4. Questions in the House of Commons Respecting the National Policy Tariff of Canada of 1879Exposition of Position of Canadian Government by Hicks Beach, Secretary of State for the Colonies

5. Protests against the Tariff of the Dominion of Canada of 1887-Extracts from Speeches of Granville, Onslow, and Carnarvon 
VI. Extra-parliamentary Protests in Great Britain against Protectionist Duties in Canadian Tariffs, 1847-1887 :

1. A Protest from Glasgow against an Increase in Duties on Iron in the Canadian Tariff of 1847 . 469

2. Protest from Glasgow against Reciprocity not Extended to the United Kingdom, 1848 . $\quad$. 470

3. Protests at Manchester against the Canadian Tariffs of 1855-1862 ; Galt's Defence of Canadian Fiscal Policy before the Chamber of Commerce, September 25, $1862 \quad$. . . 470

4. A Second Protest from the Manchester Chamber of Commerce. Macdonald's Defence of the National Tariff Policy of 1879, August 6, 1880 .

5. Bright and the Denial by Canada of Free Exchange of Commerce with the United Kingdom, January 29, 1885

6. Protests from the British Iron Trade Association, and from English Chambers of Commerce against Increases in the Iron and Steel Duties in the Tariff of the Dominion of Canada of 1887 


\section{INTRODUCTION}

\section{THE OLD COMMERCIAL SYSTEM AND THE NEW COLONIAL ERA}

Two leading statesmen of the nineteenth century, one of the Conservative and the other of the Whig party, were responsible for the legislation at Westminster that made an end to the old commercial system, and established the British Empire-the United Kingdom, what are now the self-governing colonies and the crown colonies-on the basis of free trade. Sir Robert Peel was Premier of the Conservative administration that, with the aid of Whig and Radical votes in the House of Commons, carried through Parliament the two measures of $1846,{ }^{1}$ by which the corn laws were repealed, an end was made to all preferences in British tariffs in favour of imports from the colonies, and protectionist duties were abandoned or were reduced to the point at which they became merely revenue duties, affording no protection to any British industry. ${ }^{2}$

These free-trade measures received the Royal Assent on June 26. On June 25 Peel was defeated in the House of Commons on an Irish Coercion Bill. The Whig party, with Lord John Russell as Premier, succeeded to office, and remained in office until 1852. It was this administration, in which Earl Grey was Secretary for the Colonies-an administration which in its fiscal legislation had the support in the House of Commons of the Conservative free traders under the leadership of Peel-that carried the Act of 1846, under which the legislatures of the five British North American provinces, Upper and Lower Canada, New Brunswick, Prince Edward Island, Nova Scotia, and Newfoundland, were empowered to repeal the duties, enacted by Parliament at

1 An Act to amend the laws relating to the importation of corn $(9 \& 10$ Vict., c. 22); and an Act to alter certain duties of customs (9\& 10 Vict., c. 23).

2 On the second reading in the House of Commons of the Bill for the repeal of the corn laws (February 27, 1846), there voted with Peel 112 supporters of the Government of which he was Premier, and 227 Whigs and Radicals. The minority against the Bill was 242-Protectionist-Conservatives, 231, and Protectionist-Whigs, 11. Cf. Charles Stuart Parker, Sir Robert Peel, iii, p. 342. 
Westminster, which had protected British manufactures in these provinces from American and other foreign competition.

The Whig Government was also responsible for the Act of $1849,{ }^{1}$ by which the old navigation code-the most important division of the old commercial system-was repealed, and the carrying trade of the Empire was thrown open to the maritime nations of the world. In the years from 1849 to 1860 there was other legislation at Westminster rounding out or supplementing the free-trade measures of 1846. But the fiscal revolution, which placed the Empire on a free-trade basis-a basis on which the whole of the Empire remained only until 1858, when to the dismay of Great Britain, the legislature of the United Provinces of Upper and Lower Canada began to enact protectionist tariffs against all comers-was effected by the Acts of 1846 , for which Peel was responsible, and the Acts of 1846 and 1849 , which were carried through Parliament by the Russell Administration.

Only a few months after the navigation code had been repealed, and the legislatures of the British North American provinces had exercised their new power under the Enabling Act of $1846^{2}$ to free these provinces completely from the tariffs of the old commercial system, Russell reviewed and interpreted to the House of Commons, and to the Empire at large, the legislation of 1846 and 1849. He defined with precision the position of the United Kingdom and of the colonies under the new fiscal system of the Empire; and he did so, moreover, at a time when two of the five British North American provinces, Upper and Lower Canada, still entertained a hope that, despite the sweeping fiscal reforms of 1846 and 1849, Great Britain might re-establish at least part of the old preferences for colonial products.

'By the repeal, last year, of the navigation law', said Russell, in the House of Commons, February 8, 1850, 'I conceive we have entircly put an end to the whole system of commercial monopoly in our colonies. We have plainly declared that, on the one hand, if we require productions similar to those which our colonies produce, we shall he ready to take them from other parts of the world ; and, on the other hand, we have left our colonies free to provide themselves with the products of other countries than

1 An Act to amend the laws in force for the encouragement of British shipping and navigation, June 26,1849 (12 \& 13 Vict., c. 29).

$29 \& 10$ Viet., c. 14. 
our own, and to impose upon the manufactures of Great Britain equal duties with those imposed on foreign manufactures.' 1

The system of commercial monopoly which Russell thus described as swept away by the legislation of 1846 and 1849 was not the commercial system in existence at the time of the revolt of the thirteen American colonies. It was not the rigid and comprehensive monopolistic system based on laws enacted by the score at Westminster in the seventeenth century and the seventy-five years of the eighteenth century that preceded the American Revolution. ${ }^{2}$ It was not the system for which Joshua Gee had contended so persistently in the reigns of the earlier Hanoverian sovereigns. ${ }^{3}$ Nor was it the system, so commercially isolating for the colonies, so exclusively binding them to Great Britain, and so repressive of every form of manufacturing industry in the colonies, that tradition says was so highly eulogized by Chatham.

Between the beginning of the American Revolution and the four free-trade measures of 1846-1849, England had been moving, gradually it is true, but by long and well-marked steps, toward the day foretold in 1713 by Pope :

The time shall come, when, free as seas or wind,

Unbounded Thames shall flow for all mankind;

Whole nations enter with each swelling tide,

And seas but join the regions they divide. ${ }^{4}$

Ireland, while England was still at war with the American colonies, had demanded, and demanded with a show of force, both larger constitutional freedom and larger commercial freedom. The demands were made at a time when the fortunes of war in America were adverse to Great Britain; and when political conditions in Ireland were so threatening, and so grave, that Great Britain had to concede them both.

1 Parliamentary Debates, III, cviii, 541.

2 Cf. speech by Earl of Liverpool, in moving in the House of Lords (June 17, 1822) the second reading of the Commercial Statutes Repeal Bill. Parliamentary Debates, II, vii, 1119.

3 Joshua Gee, Trade and Navigation of Great Britain Considered, shewing that the surest way for a nation to increase in riches is to prevent the importation of such foreign commodities as may be raised at home: that this kingdom is capable of raising within itself and its colonies materials for employing all our poor in those manufactures, \&cc. The first edition of Gee's treatise was published in 1729 . A second edition was published in 1730 .

"The Poetical Works of Alexander Pope (Globe edition), 'Windsor Forest', p. 39. 
The American Revolution brought with it a remarkable revival of political life in Ireland. Ireland was then more stirred, and more alive politically, than at any time during the existence of its parliament. ${ }^{1}$ Poyning's Law was repealed as a concession to the demand for larger constitutional freedom; and in 1778 England was also compelled to free Ireland from most of the shackles of the old commercial system, and in particular from the most burdensome conditions of the navigation code. ${ }^{2}$

In the decade that followed the Peaee of Versailles of 1783 trade had been resumed with the revolted colonies under conditions that acknowledged the nation status of the new Republic, ${ }^{3}$ and also eased the regulations under which the trade of the West Indies with the United States and with the colonies of European nations in America, ${ }^{4}$ was carried on. These were the changes in the old commereial system that developed directly out of the Ameriean Revolution; and there were other inroads in the navigation code, due to the exigencies of England's long war with Franee in the closing decade of the eighteenth century and the opening decades of the nineteenth century.

\section{Inroads on the Old Colonial System in 1822}

Robinson, who was afterwards Baron Goderich and Earl of Ripon, recalled these inroads into the old commercial system, when, in April 1822, he introdueed a Bill into the House of Commons effecting the important changes in the old system that are associated with his name and with his tenure of the office of President of the Board of Trade in the Liverpool Administration of 1812-1827. Twenty years later Robinson would have been classed as a free trader. He would have been grouped with Pecl, Russell, Grey, and Gladstone, and with Cobden, Bright, and Villicrs; for two years before he carricd the Colonial Trade Bill through the House of Commons he had declarcd that the old commereial system was founded on error and calculated to defcat the objeet for which it was adopted. ${ }^{5}$

1 Cf. E. and A. G. Porritt, Unreformed House of Commons, ii, pp. 441-449.

2 Cf. 18 Geo. III, c. 55, and 18 (ieo. 1 III, c. 56.

3 Cf. 48 Geo. III, c. 85, an Act which re-enacted various Acts passed in the years immcdiately following the Amorican Revolution, for carrying into execution the treaty of amity, commerce, and navigation between Great Britain and the United States. 4 Cf. 28 (ieo. III, c. 5.

5 Cf. Dictionary of National Bingraphy, xlix. p. 8. 
In introducing the Bill of 1822 Robinson reminded the House of Commons of the original principle of the navigation laws, as it applied to the trade of the colonies. It was to restrict the colonies to a direct trade with England; to compel them to concentrate their produce in England; and to draw all their supplies from England. 'But,' continued Robinson, in recalling the inroads on the old system since the American Revolution, 'in most of its essential particulars, this principle has been entirely abandoned in respect to many, and greatly modified in respect to the remainder of our foreign possessions.'

'If we look to the dominions of England in the eastern hemisphere,' he proceeded, in going a little into detail in his survey of the inroads that had already been made on the old system, "we shall find that however wise or beneficent the restrictive system may have been in its original adoption, it has nevertheless in that quarter of the world been entirely and systematically abandoned. The trade of Ceylon, of Mauritius, and of the Cape of Good Hope is at this moment comparatively free. The trade of the East India Company's territories has never been shackled by the peculiar restriction of the navigation laws; and in our own day has received great additional freedom and extension.'

The Colonial Trade Bill was a measure exclusively for British colonies in America ; and in his speech of April 1, 1822, Robinson emphasized the inroads on the old commercial system that had affected these colonies and their trade and navigation relations with Great Britain, with the United States, and with the world at large-inroads that had been made, as Robinson conceded, in consequence of conditions that came in the train of the American Revolution, and of the exigencies of the war with France.

'If we look to the western hemisphere, and if we examine the laws which now regulate its commerce,' he said, 'even there the committee will perceive that the rigid application of our ancient colonial policy is no longer in existence. The relaxation may have been the result of accident and circumstances rather than of design. But it is sufficient for my argument to show that the change has taken place.'

How far 'accident and circumstances '-in other words the Revolution of 1776-1783, and the war of 1793-1814-had impelled Parliament at Westminster to relax the eighteenth-century rigour of the old commercial code as regards colonies in closest touch 
with the United States was described with some detail by the President of the Board of Trade, whose manifestly congenial undertaking in 1822 it was to ask the House of Commons to make still further inroads on the old system.

So far from our West Indian and North American colonies being hermetically sealed against foreign commerce [he said] there is scarcely one which has not a free port open by the Act of $1805^{1}$ and various subsequent laws-open to the importation of foreign produce in foreign ships. The articles which may be thus imported comprise almost all the productions of the Spanish and Portuguese colonies calculated for the markets of this country, as well as various other articles, the produce of the United States, most essential to the successful cultivation of our colonial soils, and the comfortable maintenance of our colonial population. Foreign vessels are allowed, on the other hand, to export from the same free ports, not only various productions of our colonies, but almost every species of manufacture which the ingenuity of our native artisans can supply for foreign consumption. ${ }^{2}$

These were the first inroads on the old commercial system-the inroads effected from 1776 to 1822 . They were made not because there was in the period from the commercial emancipation of Ireland to the creation of free ports in the West India colonies in 1805 any general or obvious weakening in the popular belief in the advantages to Great Britain of the old restrictive systemnot because as yet the view of the old commercial system expressed in the House of Commons in 1820 by Robinson was largely affecting economic thought and public opinion. Robinson was a pioneer of the new era; and there were few indications that the new era was opening when free ports were regarded as a great innovation on the old exclusiveness of the British commercial system.

The changes that Robinson recalled and commended in $1822^{3}$ were made because it was realized at Whitehall and Westminster that under conditions then existing-the war of 1776-1783, the coming into existence of the United States and the war with France-there was no alternative to making these large inroads on the old commercial system as it existed and was functioning on the eve of the American Revolution.

In the first four decades of the nineteenth century the rigorous

145 Geo. III, c. 57. Free ports in the West Indies were created by this Act.

2 Parliamentary Debates, II, vi, 1415-1417.

3 "Who will say that the interests of either eommerce or navigation have suffered; or rather who will deny that they have materially benefited by the freedom which they have thus enjoyed?' - Robinson, House of Commons, April 1, 1822, Parliamentary Debates, II, vi, 1416. 
exclusiveness of the old commercial system-an exclusiveness designed to hold every advantage and every penny of conceivable profit for British manufacturers and British shipowners-had been further mitigated and softened by legislation at Westminster tending to greater freedom of trade in nearly every part of the Empire.

Quite apart from the departures resulting directly and immediately from the revolt of the American colonies and from the war with France, the old commercial system, for nearly a quarter of a century before 1846, had been shorn in part at least of the rigidness and exclusiveness that had characterized it at the time of the Declaration of Independence. Inroads were made on it in the last three decades of the eighteenth century that were of much advantage to Ireland, where the old commercial system had been most repressive, and also of some advantage to the United States in its trade with the West India Islands.

In the twenty-odd years that preceded the revolutionizing changes of 1846-1849, the old system had gradually been made less burdensome in some particulars to the people of the United Kingdom. It had been made less restrictive and less oppressive as regards both trade and navigation to the British North American provinces ; and in these provinces, moreover, from 1809 onward, the old system had been framed so as to confer some new privileges in the form of tariff preferences on lumber and wheat and flour at ports in the United Kingdom. It had been made a little easier also for some of Great Britain's competitors in the world of trade and commerce; more particularly as concerned the carrying trade between the colonies and non-British countries that desired to draw on the natural products of the British North American provinces-fish, lumber, grain, and flour.

\section{Forces Working against Protection}

These changes of the first forty years of the nineteenth century had come, not as the result of any altruistic spirit in British policy and British trade, but partly as a result of economic conditions in some of the colonies, and partly as a result of the declining popular belief in the efficacy of the old commercial system-in its adaptability to the needs of the United Kingdom in the first half century of the factory era, during which England easily led the world as a manufacturing and exporting nation. 
The vested interests of the commercial system-the landowners in England who cherished the corn laws, the planters of the West Indies who had a monopoly of the sugar trade of the United Kingdom, and the merchants and shipowners who profited so greatly from the preferences for lumber from the British North American provinces-held, of course, to the old belief in the commercial system.

But the manufacturing interests were an influence in politics at Westminster even before the reform of the House of Commons in 1832. So were the Radicals who at this period were of the House of Commons. Radical opinion as to the advantages that manufacturing in England and England's export trade would derive from less restricted trade conditions was shared by men who were not of the Radical party. It was shared by men at Westminster who had no sympathy with the movements for constitutional reform with which the Radicals of the unreformed House of Commons at this time were actively associated; and gradually in the first forty years of the nineteenth century, and particularly between 1805 and 1832 , there was an obvious liberalizing of the old commercial system.

Its liberalizing was the direct result of a series of measures enacted from 1805 to 1843 . With one exception-Hume's Act of 1824 repealing the part of the old commercial code that restricted the export of machinery and penalized the emigration of men skilled in manufacturing industries ${ }^{1}$ - they were all government measures ; for under the procedure at Westminster it is not possible for private members (members not of the Ministry) to introduce Bills which affect taxation.

All these inroads on the old system from 1805 to the eve of the fiscal revolution of 1846 were made by Acts which are associated in parliamentary history and in the fiscal and economic and colonial history of Great Britain with the names of Liverpool, Canning, Robinson, Huskisson, Hume, Peel, Gladstone, Russell, and Grey.

Even before the reform in the electoral system of 1832 Great Britain was unmistakably moving in the direction of less rigid trade restriction, and away from the exclusiveness of the old commercial system. New conditions-exigencies external to the Empire that could only be met by inroads on the old system${ }^{1} 5$ Geo. IV, c. 97. 
were responsible for the first important changes in it-those made between 1776 and the end of the eighteenth century.

It was not possible to deny the demands for a larger commercial freedom that were pressed by Ireland while Great Britain was at war with the American colonies ; and after the revolt of these colonies had achieved success, economic conditions in the West India Islands were such that it was impracticable to deny the demand that came from these islands for easier trade relations with the United States-especially as concerned supplies drawn from the United States and as to the carrying trade between the West Indies and the United States-than were possible under the old commercial system at the time Great Britain was compelled at Versailles to acknowledge the independence of the United States.

It cannot be claimed that either of these inroads on the old system-one long overdue in the interest of Ireland, and the other in the interest of the colonies in the West Indies-was made willingly. Both were, in fact, forced from Great Britain much in the same way as in the years from 1828 to 1859 the United Provinces of Upper and Lower Canada forced administrations in Downing Street to concede, first, responsible government or political autonomy ; next, in 1848, the right of the legislature of these provinces to enact tariffs with differential duties, and finally, in 1859, when the Galt tariff was the issue, the right to enact tariffs in which there were high protectionist duties against manufactures imported from the United Kingdom that were imposed avowedly in the interest of manufacturing industries in the Canadas.

Part at least of the history of the abandonment of the old commercial system - the complete abandonment that was gradually effected in the seventy-one years from 1778 to 1849-has much similarity with the history of responsible government in the colonies now of the five oversea dominions of Great Britain, ${ }^{1}$ and also with the history of the fiscal and diplomatic freedom of these colonies that was finally and fully achieved in 1907. The similarity in history, however, is characteristic of only the inroads on the commercial system that were made in the interest of Ireland and of the West Indies in the period from the beginning of the American Revolution to the end of the eighteenth century.

1 The dominions of Canada, Newfoundland, New Zealand, the Commonwealth of Australia, and the Union of South Africa. 
Responsible government and fiscal freedom for the colonies were denied by both Conservative and Whig administrations at Whitehall as long as it was practicable and safe to deny them. They were denied as long as it was possible to hold what are now the self-governing colonies in leading strings, and to withhold from people of British blood in these colonies as full and as complete political and fiscal freedom as was enjoyed by the people of the United Kingdom, who moulded their political civilization as they desired through their control of the House of Commons at Westminster, and through the control that the majority of the House of Commons exercised over the Cabinet in Downing Street.

Full fiscal freedom was, by the written constitution of the Australian colonies enacted by Parliament at Westminster in 1850, denied the Australian colonies until as long after the fiscal revolution in the United Kingdom as 1895 . Like the concessions of the last quarter of the eighteenth century that involved abandonment of parts or divisions of the old commercial system, responsible government and its corollaries, fiscal freedom and diplomatic freedom as regards the negotiation of treaties of commerce and reciprocity, were conceded at Whitehall only when conditions were exigent, and when manifestly nothing but concession was possible.

In this important respect the series of quite material and obvious inroads that were made on the old commercial system in the first half of the nineteenth century-in the three decades before all that remained of it was swept away by the legislation of Peel and Russell-differ from the inroads on the old system which were made by Parliament in the years from 1778 to 1800.

Great Britain, it will have been realized, was literally forced to make the later eighteenth-century concessions to Ireland and the West Indies. Nearly all the inroads of the nineteenth century before the legislation of 1846-1849--certainly all the inroads of 1822-1842--were effected because it was to the interest of the United Kingdom or of the Empire at large that there should be a larger freedom of trade than was possible under the old system as it existed after the concessions to Ireland and to the West Indies, or after the inroads that were due to the long war with France.

At least five measures had been necessary to bring the old 
commercial system into the greatly modified condition in which it stood on the eve of the sweeping fiscal and commercial reforms of 1846 and 1849. Five measures had been necessary, in addition to the legislation of the eighteenth century rendered imperative by the American Revolution, or by conditions in the West India colonies, which had developed out of the successful revolt of the American colonies.

All these nineteenth-century measures effected well-marked inroads on the old commercial system; inroads that, like the ending of the system in 1846-1849, were demanded in the interest of British Empire trade, or by nineteenth-century conceptions of what was most advantageous for British trade, insular or colonial and for the general welfare of the people of the United Kingdom. ${ }^{1}$.

Vested interests were entrenched upon or threatened when these inroads were made on the old system, as they were when Ireland was conceded its commercial freedom in $1778 .^{2}$ Excluding those inroads that were forced by trade conditions arising out of the wars with Napoleon, it may be affirmed that governments at Whitehall willingly made themselves responsible for the legislation by which these nineteenth-century inroads were effected. It is noteworthy, moreover, as indicating the time when the movement in England for less restrictive trade conditions and away from the rigidity of the old commercial system of the Empire began to influence legislation at Westminster, that at least four of the Acts of Parliament for relaxing or abandoning statutory regulation of trade and navigation were carried through the unreformed House of Commons. ${ }^{3}$

\section{Measures Liberalizing the Old Colonial System}

The measures for which credit must be given to the unreformed House of Commons, in which it was never claimed that there

1 'Recollecting that for centuries it has been a settled maxim of public policy in all great states having dependencies, to make the interest of those dependencies subservient to the interests, or the supposed interests, of the parent state; there is, perhaps, no country where the consequences of perseverance in such a system, on the one hand, and of its relaxation, on the other, can be so forcibly illustrated as in our own.'-Huskisson, House of Commons, March 25, 1825. Parliamentary Debates, II, xii, 1100-1101.

2 'Our merchants and manufacturers, our ship owners, our country gentlemen, all took alarm. All were to be ruined.'-Huskisson's retrospect of the agitation in England and Scotland against the concession in 1778 of commercial freedom to Ireland. House of Commons, March 21, 1825. Parliamentary Debates, II, xii, 1102.

3 Robinson's two Acts of 1822 are taken here as forming one measure. 
was an adequate representation of manufacturing and industry other than agriculture, were (1) the Act of $1809^{1}$ that extended the free port system of 1805 to the Canadas, New Brunswick, Nova Scotia, Prince Edward Island, and Newfoundland, and permitted direct trade between these provinces and European ports south of Finisterre ; ${ }^{2}$ (2) Robinson's outstanding Acts of $1822,{ }^{3}$ which repealed over thirty Acts, mostly of the reign of George III, forming part of the old restrictive code ; continued the system of free ports in the West Indies and extended it to the British North American provinces; greatly liberalized the navigation laws as they affected the inward and outward trade of these provinces, in many lines of goods other than manufac- tures, with countries other than Great Britain ; and substituted specific or ad valorem duties for the old prohibition; (3) the Act that Joseph Hume in 1824 carried though the House of Commons with the spirited help of Huskisson, then President of the Board of Trade in the Liverpool Administration, ${ }^{4}$ for the repeal of the many eighteenth-century enactments which prohibited the export of partly finished material for manufacture in the colonies ; prohibited the export of machinery used in manufacturing industries, alike to the colonies and to non-British countries, and made it a penal offence to attempt to recruit artificers in England to go overseas, and an offence, punishable with outlawry, for men skilled in trade, artificers in manufacturing industries, to emigrate from Great Britain to work at their trade in any of the colonies, or in any country overseas $;^{5}$ and

149 Geo. III, c. 47.

2 The free ports established by this Act were St. John's, Newfoundland; St. John, New Brunswick; Halifax, Sydney, and Shelbourne, Nova Scotia; Charlottetown, Prince Edward Island, and Quebec, Lower Canada.

33 Geo. IV, c. 44 and c. 45.

4 Cf. Huskisson, House of Commons, February 12, 1824. Parliamentary Debates, II, $x, 147-150$.

${ }^{5}$ Little has been written on the subdivision of the old commercial system that was based on the laws repealcd by Hume's Act of 1824. One of the most informing descriptions of the actual working of the laws which prohibited artificers from emigrating is to be found at pages 226-230 of Julia Wedgwood's Personal Life of Josiah Wedgwood. Wedgwood, who was the leading spirit-apparently the organizer-of a society of master potters to enforce this subdivision of the code, wrote a pamphlet in support of the policy it embodied. It was addressed to his work people at Etruria ; and was entitled 'On the Subject of Entering into the Service of Foreign Manufacturers'. Despite the laws, and the drastic penalties for contravening them, potters from Staffordshire, in the decade that preceded the American Revolution, emigrated to work at potteries in Siouth Carolina and Pennsylvania. Cf. Julia Wedgwood, Life of Wedguood, pp. 226-227 
(4) Huskisson's epoch-making Act of $1825,{ }^{1}$ which made the largest inroad on the old system of the seventy years from the American Revolution to the repeal of the corn laws; for the Act of 1825 greatly curtailed what was left of the old exclusiveness of the navigation laws, ${ }^{2}$ established the warehousing system as it existed in Great Britain at ports in the West Indies and the British North American provinces, and opened the ports of these colonies practically to all non-British goods-natural products or manufactures-subject to the payment of duties for the protection of British manufacturing interests in these colonial markets. ${ }^{3}$

Protectionist duties, in British North American colonies, in the West Indies, in Newfoundland and in the provinces east of the Great Lakes now of the Dominion of Canada, as distinct from colonies in Australasia and South Africa, and also the free lists of imports into the British North American colonies were, until the end of the old system, determined by what are known in colonial history as British Possessions Acts.

These Acts were passed by Parliament at Westminster to safeguard British manufacturing and commercial interests in the colonies, and in the framing of these enactments the legislatures of the British North American provinces, and the inhabitants generally of these provinces, had no more part than they had in the framing and enactment of tariffs for the United States at Washington.

Some revenue, collected at ports of entry by customs house officers appointed by the Treasury in London, and entirely under control from London, accrued to the colonies under these Acts. Their purpose, however, was not so much to raise revenue towards the expenses of civil government in the colonies now of the dominions, as it was to establish and maintain a rigid system of

16 Geo. IV, c. 73.

2 For an official detailed account of the extent to which in the years from 1825 to 1843 Huskisson's measure admitted on a reciprocal basis other maritime nations into the ocean-carrying trade of the Empire, see Rules and Regulations for Her Majesty's Colonial Service, pp. 104-106.

3 'The importation of foreign goods into the colonies, I propose, should be made subject to moderate duties, but such as may be found sufficient for the fair protection of our own productions of like nature. The duties already established by the Acts to which I have referred (Robinson's Acts of 1822) it is proposed to leave as they are, and to establish a further scale of ad valorem duties, varying from seven and a half per cent. to thirty per cent., upon all articles the importation of which from foreign countries has hitherto been prohibited.'-Huskisson, House of Commons, March 21, 1825. Parliamentary Debates, II, xii, 1108. 
differential duties in order to hold colonial markets for exports from the United Kingdom.

The system of differential duties to this end was in service from 1822 to 1847-1849, the years in which the legislatures of the United Provinces of Upper and Lower Canada, and of the Maritime Provinces and Newfoundland, acting under the Enabling Act of 1846, repealed the tariff of the British Possessions Act of $1843,{ }^{1}$ the last in the series of Possessions Acts, and began to enact tariffs entirely free from any of the statutory restraints of the old commercial system; but, as will be realized in subsequent chapters, by no means free from interference or attempted interference from the Board of Trade and the Colonial Office, which greatly desired that the tariffs of all colonies should harmonize with the tariffs enacted at Westminster after 1846 for the United Kingdom.

The old British Possessions Acts were of the revenue systems of the British North American provinces until 1847-1849. These provinces, however, had not the slightest influence, direct or indirect, in framing them. They were framed to meet British, as distinct from colonial, needs ; and willy-nilly the provinces had to accept them and to accommodate themselves to the differential duties they imposed to protect British manufactures, and to the other conditions and restrictions that characterized them, just as they had to accommodate themselves to the navigation laws; and as, in the era before responsible government was established in 1841-1849, all colonies had to accept any man whom the Crown, at the instance of the Colonial Office, chose to appoint as governor.

Revenue derived from the duties imposed by British Possessions Acts was, in accordance with the terms of sections in these Acts, covered into the treasuries of the provinces. But despite the Declaratory Act of 1778 , not more than one of the British North American provinces-Upper Canada-had full and unrestricted control of all the revenues of the province, until responsible government was established or was well in sight. Until the advent of responsible government the Act of 1778 was often ignored or pushed aside by the Treasury or the General Post Office in London.

16 Vict., c. 1. 


\section{British Tariff Preferences for Colonial Imports}

Preferences in tariffs of the United Kingdom for products of the British North American provinces-the only colonies now of the dominions for which the preferences of the old commercial system were ever of much value-were, it need scarcely be said, also determined by Parliament at Westminster. Revisions of British Possessions Acts were made, as a rule, in the same session of Parliament as revisions of British Tariff Acts; for in these two measures were embodied the fiscal system of the Empire as that system was interpreted and made operative by Parliament at Westminster.

In the discussion of colonial preferences at these revisions of the tariffs for the United Kingdom, the representatives in the House of Commons of the Colonial Office, usually the Parliamentary Under Secretary, and of the Board of Trade were, except as regards preferences on lumber, usually the only spokesmen for the colonies. The preferences on lumber, in practice, benefited British shipowners and timber merchants much more than they benefited holders of timber limits and settlers in the Maritime Provinces and the Canadas. Consequently the preferences on lumber, quite substantial at times in the years from 1809 to 1846 never lacked parliamentary champions at Westminster.

The colonies themselves, until nearly the end of the old commercial system-until 1843, when there was an increase in the preference on wheat and flour from the Canadas-had no direct voice in determining preferences. They could, and occasionally did, petition the Colonial Office for better terms in existing preferential schedules, or, as Upper Canada did in 1835, in regard to tobacco, petition for the inclusion of other products in the preference list. But such petitions only in rare cases got beyond the Colonial Office. Parliament was afforded no opportunity of considering these claims, unless some private member brought them to the attention of the House. As was the case with the British Possessions Acts, colonies had to accept what was handed out to them from Westminster. They had to make the best of any preferences that were conceded, generally with some uncertainty as to the degree of permanence that attached to any of these concessions, especially after the preferences on lumber and 
the corn laws began to be continuously assailed by fiscal reformers at Westminster.

Revisions of British tariffs and of British Possessions Acts made after the reform of the representative system, that is to say, in the years from 1832 to 1846 , resulted in some further minor inroads on the old commercial system. But the obvious and more important inroads, which deprived the old system of much of its exclusiveness and rigidity of the period from the Revolution of 1688 to the Declaration of Independence of 1776 , were made in the years from 1776 to 1832 .

The important inroads, that were effected in these years because British trade interests generally demanded a less restrictive system, were those of 1822 and 1825, that for nearly a century have been linked with the names of Robinson and Huskisson. These reforms in the old system, like that made in 1824 at the instance of Hume-reforms obviously in the interest of the United Kingdom, or of the Empire at large-must be credited to Parliaments which are associated with the fame, or otherwise, of the unreformed House of Commons. They must be credited to Parliaments in which there was no direct representation of Manchester, Leeds, Bradford, Sheffield, Birmingham or Wolverhampton, all great manufacturing communities of the first half century of the factory or industrial era; all to a large extent creations of the era of steam as a motive power, and of the expansion of British oversea trade that can be roughly dated from the end of the war with the American colonies. ${ }^{1}$

England's manufacturing interests in the first half of the nineteenth century demanded increasingly large supplies of cheap food and also of cheap raw materials. From 1832 to 1846 it was the political influence of the territorial aristocracy, then much more the governing class than it has been since the break-up of the old Liberal party over Gladstone's Home Rule Bill of 1886, that prevented the repeal of the corn laws. There then also stood with the territorial aristocracy, in opposition to further inroads on the old commercial system, especially inroads that

1 Manehester, Leeds, Bradford, Sheffield, and Birmingham to-day are cities. They have long had that status in the munieipal economy of England. Before 1832 they were towns, and, despite their importance in trade and commerce for at least fifty years before 1832, towns that had no place in the old system of parliamentary representation. But freeholders in towns could vote for knights of the shire, and to this extent Manchester. Leeds, Bradford, Sheffield, Birmingham, and Wolverhampton were represented in the unreformed House of Commons. 
affected protectionist duties or preferences for colonial products, the sugar interests of the West Indies-interests that were well entrenched at Liverpool, Bristol and Glasgow-and also the mercantile and shipping interests at these and other British ports, that profited exceedingly from the substantial preferences in British tariffs on lumber from the Canadas and Nova Scotia and New Brunswick-interests which between them absorbed practically all the advantage which was conceded by British tariffs to the lumbering industry in the British North American provinces.

There were inroads on the old commercial system effected in the first decade of the nineteenth century that were manifestly due to the exigencies of the war with France. They were as manifestly due to these exigencies as the inroads from 1778 to 1794 were due to the American Revolution, or to conditions arising out of the Revolution of 1776-1783 that were permanent.

The preferences on lumber from the Canadas and the Maritime Provinces first established in $1809,{ }^{1}$ or at any rate established on a liberal basis in that year, were, like some innovations in the navigation code of the first decade of the nineteenth century, also due to the war with France. The purpose of their enactment was to afford a supply of lumber at a time when communication with the Baltic countries was difficult or uncertain.

During the war an alternative source of supply was regarded as necessary for shipbuilding, as well as for trade purposes generally. At the end of the war preferences were continued in response to the pleas that the North American timber fleet was a reservoir from which men for the Royal Navy could be drawn; that the preferences were necessary for the development of the British North American provinces; and that they were in harmony with the old commercial system.

Exigencies of war were responsible for none of the innovations of the years from the final downfall of Napoleon to the legislation of Peel and Russell of 1846. England was not again at war until the expedition to the Crimea in 1854-1856. By this time the old navigation laws were of the past; and from 1849 to 1858 , except for the differential duties in the tariffs of the British North American provinces to promote interprovincial trade and to comply with the Elgin-Marcy treaty of reciprocity between all

\footnotetext{
1 Cf. 49 Geo. III, c. 98.
} 
British North America except British Columbia and the United States-the treaty of 1854-1866-the Empire, as a whole, was on a free trade basis.

The measures of the third decade of the nineteenth century associated with the names of Robinson, Hume and Huskisson, owed nothing to conditions arising outside of the Empire. They owed nothing to conditions that were beyond the control of governments at Whitehall and Parliaments at Westminster. Altering conditions of British trade-trade of the United Kingdom and trade and material development of the colonies of the western hemisphere-demanded them; and they were in harmony with the newer views in England of the advantages and drawbacks of the old commercial system.

From at least as early as the enactment at Westminster of the four measures of 1822-1825, England was unmistakably moving toward free trade. Moreover, as will be unfolded by this history of the fiscal and diplomatic freedom of the dominions and of the changes from 1840 to 1867 in the relations of the self-governing colonies to the Colonial Office, to governments in Downing Street and to the Imperial Parliament proceedings, England at this time, 1822-1830, was becoming manifestly indifferent to the colonies and hostile to the extension of Empire.

\section{The Era of Indifference to the Colonies}

The era of indifference to colonies, that continued to a greater or less degree to 1887 , had begun before the inroads into the old commercial system of 1822,1824 and 1825 ; and one of the characteristics of the era, that persisted almost to the confederation of the British North American provinces in 1867, was the attaching of much less importance to the tie with the colonies as a means of maintaining and extending the export trade of England than had been attached to the colonial tie in the era from the Revolution of 1688 to the loss of the American colonies.

Neither the war of the Revolution of 1776-1783 nor the War of 1812-1814 had been followed by any loss of trade with the United States. On the contrary, there was a continuous increase in export trade with the United States from the Peace of Versailles to the Civil War of 1861-1865. There was a continuous increase of trade until the Republican party assumed power at Washington, and there began the era of high protectionist duties in tariffs of 
the United States-duties which, in the years from the Civil War to the Great War between Germany and the Allies, reached their peak in the Payne-Aldrich tariff of 1909.1

The revolt of the thirteen American colonies, the creation of the United States, its political civilization, and the ideals and principles on which its political civilization is based, its long unassailed stability, its marvellous material prosperity, the amazing rapidity with which its population increased, its fiscal and maritime policies, and finally the fact that the United States is the only neighbour to the three and three-quarter millions of square miles of the British Empire that lie on the North American continent-all these conditions influenced the general political development of all the self-governing colonies of Great Britain more than any other factors that were potent in world history from the Declaration of Independence to the invasion of Belgium and France by the military forces of Germany in the summer of 1914.

At every stage of the political development of the colonies that are now of the dominions-responsible government, fiscal freedom and diplomatic freedom-at each well-marked step of the colonies toward their now long recognized and unassailable status of nation within the British Empire; at the creation in the years from 1791 to 1907 of each new and more beneficent relation of the colonies with the Colonial Office, the Treasury, the Board of Trade, the Cabinet, and Parliament at Westminsterrelations that to-day differentiate them from British possessions in the Crown Colonies Division at the Colonial Office-the influence of the United States is traceable. Usually it is obvious, and needs no tracing.

American factors and influences in the formation of these new relations, which to-day are the pride of the Empire, are often as manifest, as much on the surface, as English precedent, English constitutional usage and English example are manifest in the moulding of the political civilizations, all much alike, of the Dominions of Canada, Newfoundland, New Zealand, the Commonwealth of Australia, and the Union of South Africa ; for all these political civilizations, with their parliaments, cabinets, executive departments of state, and judicial systems, are fashioned to the last detail after English models.

\footnotetext{
1 Acts of 61st Cong., lst Sess., c. 6, August 5, 1909.
} 
The Earl of Durham, in his report on the affairs of British North America in the decade that preceded the rebellions in Lower and Upper Canada of 1837-1838 - the famous report that has been more frequently reprinted, more frequently edited and annotated, and more widely read over the English-speaking world than any other British state paper of the nineteenth century ${ }^{1}$ - brought some of these American influences on British North America and the political ambitions of the people of the Canadas and the Maritime Provinces to the attention of the administration in London, of Parliament, and also of the people at large of the United Kingdom, ${ }^{2}$ whose interest in the colonies had been aroused, for a bricf period, by the rebellions in the Canadas which to-day are associated with the names of Louis Joseph Papineau and William Lyon Mackenzie.

But long before Durham went out to Quebec in 1838 and made known to England how variously 'Canada's only neighbour' was influencing conditions in four of the British North American provinces, and especially in what since 1867 have been known in the political geography of the Empire as the provinces of Quebec and Ontario, the successful revolt of the American colonies, the creation of the United States, what may be described as its political prosperity, its growth in population and in material wealth, and in particular the increasing extent to which it drew on the manufactures of the United Kingdom were greatly influencing public opinion in England in regard to the colonics that remained of the Empire after 1783 and their continued connection with Great Britain.

Much of the indifference to colonies in England that persisted for a century after the Peace of Versailles was due to conditions growing out of the Revolution of 1776-1783. At first there was regret, and some soreness over the loss of the American colonies. ${ }^{3}$

1 Cf. Porritt, Evolution of the Dominion of Canada; Its Government and its Politics (1918), p. 97. The authoritative edition of the report in three volumes, extending to 1,054 pages, is edited with an introduetion, by Sir Charles P. Lucas, who was at the Colonial Offico as Assistant Under Secretary from 1897 to 1911. It was published by the Clarendon Press, Oxford, in 1912.

2 ('f. Durham, Report, ii, PP. 91-92, 99-104, 112-113, 134, 185-186, 201, 211, $261-263$.

3 'George III was convinced that in his policy towards America he was acting in the best interests of the Empire; and ho was anxious that posterity should eommend his conduct. "I offer my most fervent prayers to Heaven," he wrote, when the struggle was at an end, "that posterity may not lay the downfall of this once respeetable Empire at my door; and that if ruin should attend the 
Then, as these feelings subsided, there gradually developed in England the conviction that continued more or less until the first jubilee of Queen Victoria's reign and the first colonial conference, which was part of the Empire-wide celebrations of 1887, that the separation of the colonies of what are now the dominions from Great Britain was inevitable. It came to be held as a popular conviction that, even had there been no rebellion of 1776, sooner or later the American colonies would have separated from Great Britain and established themselves as an independent nation.

From American experience of $1776-1783$ it was argued that all the British North American provinces would inevitably end the connection with Great Britain as soon as it suited their policies and their convenience to do so; and, as will appear in subsequent chapters, when what was represented as the inevitable tendency of colonies to cut adrift from parent countries was discussed at Westminster, or in the press, or in the literature of political science, it was contended that separation of the colonies would involve no loss of export trade for Great Britain.

Trade relations with the United States after 1783, especially as these relations existed and throve between the War of 18121814 and the beginning, in the forties of the nineteenth century, of the two decades of moderate protectionist duties in the United States, were cited in support of the argument. In a word, the attaching of much less value, in the first half of the nineteenth century, to the colonial tie as a means of holding and extending export trade in manufactures than was attached to the colonial tie in the first three quarters of the eighteenth century was largely, but not entirely, due to England's highly satisfactory trade relations with the United States in the sixty years that followed the Revolution of 1776-1783.

measures that be adopted, I may not survive them." This was written on September 11, 1782, when the treaty was pending. After the independence of the United States was finally assured, the king was inclined to a more cheerful view. "I can not conclude," he wrote to Lord Shelburne, on" November 12, 1782, "without mentioning here how sensibly I feel the dismemberment of America from the Empire; and that I should be miserable indeed, if I did not feel that no blame lay at my door; and did I not also know that knavery seems to be so much the striking feature of its inhabitants, that it may not, in the end, be an evil that they will become aliens to this island." , Edward Porritt, 'England's Last Royal Political Boss', Century Magazine, New York, June 1908, p. 310 . 
Indifference to colonies, partly due to American experiences, political as well as commercial, and partly due to the financial burden of the colonial tie, until the middle fifties of the nineteenth century, by which time responsible government had been established in nearly all the colonies now of the dominions, unmistakably had its influence on the traditional popular conception of the value to Great Britain of the old commercial system. It was a factor of some account in the inroads of 1822 and 1825 on the old exclusiveness. It was as obviously a factor in the change in public attitude toward the old system that explains its complete and final passing in 1846-1849.

\section{Preferences for the Colonies in British Tariffs}

In the movement of 1822-1846 away from the old commercial system, in the series of important departures from it that England regarded as in her interest to make, it is not possible to trace any free trade opposition to the preferences in British tariffs for wheat and flour from Upper and Lower Canada, the only colonies now of the dominions that under the old commercial system ever enjoyed any really appreciable tariff advantages for their wheat or flour in the ports of the United Kingdom. All the opposition to these preferences, and there never was a time from 1820 to 1843 when there was not opposition to them at Westminster, was from the representatives of the agricultural interests, who quite naturally regarded them as invasions of the monopoly which it was the purpose of the corn laws to create for the landowners and grain growers of England.

Free traders, and the men of the Anti-Corn Law League in particular, assailed the corn law system as a whole. They condemned the preferences on lumber, as free traders in the House of Commons had done for nearly twenty years before the AntiCorn Law League was organized by Cobden, Bright and Wilson at Manchester in 1839. They had no eulogies for the preferences on wheat and flour, either for the meagre preferences of 18281842-preferences that were not only meagre but also uncertain in their operation-or for the more liberal preferences for the Canadas exclusively that survived from 1843 to the repeal of the corn laws.

These preferences of $1828-1846$ aroused no admiration from 
free traders because they realized that, while they were to some extent inroads on the monopoly of the English grain-growing interests, little advantage ever accrued from them to consumers of wheat in the United Kingdom. The men of the Anti-Corn Law League were also aware that when the corn laws were repealed preferences for grain from the colonies would automatically come to an end.

These preferences, moreover, were not of much value to the Canadas so long as the admission of grain from all parts of the world was regulated by a sliding scale governed by prices of grain in the United Kingdom. The preferences did not become of appreciable value to Canada until grain and flour were admitted at a low fixed duty under an Act passed in 1843 ; and the grain business at St. Lawrence ports, under the preference of 1843, had not been long adjusted to the new conditions when the corn laws were repealed, and the preferences abolished.

In Parliament there was much opposition to the preferences on lumber from the four British North American provinces-the Canadas, New Brunswick, and Nova Scotia-preferences which added materially to the cost of building in the United Kingdom, and led to the use of inferior timber from British North America at a time when better and cheaper timber would have been available from the Baltic countries, had it not been that until 1846 it was the commercial policy of Great Britain to hold the market in the United Kingdom for lumber from British North America.

Preferences in British tariffs on lumber from what are now four provinces of the Dominion of Canada-preferences that dated only from 1809-were chiefly a British shipowners' vested interest, as distinct from a concession in British tariffs that profited the British North American provinces and the people of those provinces to any material degree. The port of Quebec profited from the handling of lumber. So did St. John and other ports of the Maritime Provinces. But lumbering, despite the preferences in the British tariff, was notoriously poorly paid work for the men in the woods in the British North American provinces ; and no men in the British Empire who followed the sea for a livelihood were subject to more miserable conditions afloat than the men who sailed in the British North American timber fleet. Anything that would hold together afloat was deemed 
good enough to cross the Atlantic westward in ballast, and return with deals from the Maritime Province ports, or with square timber from Quebec. ${ }^{1}$

Twice at least during the existence of the preferences on lumber Parliament was forced to intervene to protect seamen of the North Atlantic timber fleet from the rapacity of shipowners, who were exploiting the preferences and drawing to themselves nearly all the advantage of this minor subdivision of the old commercial system. ${ }^{2}$ The first measure to protect seamen of the timber fleet was passed in 1839 at the instance of a private member, George Palmer, ${ }^{3}$ knight of the shire of Essex, in early life in the naval service of the East India Company, who in moving for a committee of inquiry startled the House of Commons by the statistics he submitted of wrecks of North Atlantic timber vessels in the years from 1834 to $1838,{ }^{4}$ and by his description of the mortality of the trade. In 1838, Palmer told the House, wrecks numbered sixty-one-sixteen on the coast and forty-five in the open sea. Nothing was ever heard of the crews of twenty-six of the timber vessels that foundered in 1838 .

'The sufferings endured by the crews of those vessels lost in the open sea,' continued Palmer, ' were of the most heart-rending description. It was well known that timber vessels did not sink immediately, like other vessels when overturned; and the crews frequently got upon the hulls, where they remained without food or water, until they were picked up by some other vessel; but

1 Cf. discussion at second reading of Bill to prohibit deck loads on timber vessels in North Atlantic trade. House of Commons, July 17, 1839. Parliamentary Debates, III, xlix, 421-422.

2 "Whereas great loss of life and severe sufferings have been occasioned amongst the crews of ships and vessels laden with timber from ports in British North America from the practice of having a portion of the eargo of such ships stowed on or about dcck.' Preamble to $2 \& 3$ Vict., c. 44 (1839), an Act by which deck loads were prohibited. See also 5 \& 6 Vict., e. 17 (1842).

${ }^{3}$ Labouchere, afterwards Lord Taunton, who was President of the Board of Trade in the Melbourne Administration from August 1839 to August 1841, gave Palmer as much eordial assistance in earrying the Act of 1839 through the House of Commons as Huskisson gave to Hume in carrying through the House in 1824 the Aet that repealed the statutes of the old commereial law that prohibited the export of maehinery and of partly finished materials of manufacture, and also penalized the emigration of artisans skilled in manufacture.

* 'The number of vessels lost in the vears from 1832 to 1838 , inclusive, was 309 , and of these 2.52 were lost on the royage from British North American ports to ports in the United Kingdom. Cif. speech by Warburton, House of Commons, July 17, 1839. Parliamentary Debates, III, xlix, 421. 
in many cases they perished from want, after having undergone the most frightful sufferings.' 1

The lumber trade from the British North American provinces, now of the Dominion of Canada, under the old system of preferences in British tariffs was in existence not more than forty years. Its brief history is peculiarly marked by some of the deviltries of commerce. Old vessels, little better than rafts, were in service in the North Atlantic fleet. Overloading and overinsurance were notorious $;^{2}$ and it was long equally notorious that fraud was systematically perpetrated to secure the entry at customs houses of the United Kingdom of timber that was not entitled to the preferential rates of the British tariff.

Timber from States of the American Republic contiguous to British North America was shipped from St. Lawrence ports and ports of the Maritime Provinces as the produce of the British provinces. It was, moreover, a practice of shipowners or timber merchants in the United Kingdom to send cargoes of timber from the Baltic westward across the Atlantic to British North America ; to obtain certificates of origin at ports in these provinces; and to carry back these cargoes, and enter the timber at ports in the United Kingdom as the produce of the British North American provinces, obtaining by this fraud the substantial reductions under the preferences in British tariffs. ${ }^{3}$ Norwegian timber was of a better quality-or was then so regarded-than timber from British North America; and as the duty on it was much higher than the duty on timber from the Canadas and the Maritime Provinces, the fraudulent trade in it was peculiarly lucrative.

Unlike wheat and flour from Canada and wool from Australia, lumber from the British North American provinces did not come into immediate and general competition with any product of the

1 Parliamentary Debates, III, xlvi, 1302-1303.

2 Cf. discussion on second reading of Timber Vessels Bill, House of Commons, July 17, 1839. Parliamentary Debates, III, xlix, 420-422.

3 . By one of the clumsy contrivances of the system of protection, the timber of Norway was sent to Canada and brought back to England, with a view to evade the high duty on foreign timber.' Earl Russell, Recollections and Suggestions, 1813-1873.

- We (Canadians) profited at the expense of the British consumer, not only by sending our own timber to England, but by shipping American, as well as by encouraging Baltic ships to cross the Atlantic to Canadian ports where we furnished them with bogus certificates of origin. Armed with these they recrossed the Atlantic, and sold their cargoes in Liverpool, getting by this device the benefit of our differential.' 'Reciprocity and Preference in Canada,' The Economist (Iondon), March 18, 1911. 
land of the territorial aristocracy of England. Timber grown in England-in the woods and parks of the great estates and in the hedgerows on the farms-was used for other purposes than those to which timber imported from the British North American provinces and from the countries bordering on the Baltic was usually applied.

\section{British Aristocracy and Prolection}

The non-competition of British North American timber with British grown timber would seem to explain the fact that, so far as is traceable in the reports of parliamentary discussions at revisions of the tariffs of the United Kingdom, there was no opposition from the landed interests to the preferences on lumber from the Canadas and the Maritime Provinces.

The representatives of the landed interests did, however, as has already been recalled, oppose preferences on wheat and flour from the Canadas. Their position with regard to these preferences was exactly the same as that of manufacturers in Canada from 1897 to 1914 in regard to preferences in tariffs of the Dominion for manufactures imported from the United Kingdom.

Canadian manufacturers in these years insisted at Ottawa that they must have adequate protection against every country, British or non-British; and in the thirties and forties of the nineteenth century, protagonists of the corn laws at Westminster demanded for the British agricultural interest adequate protection against competition from all wheat-growing countries, whether thesc were British colonies or British possessions such as the Canadas, Australia, Cape Colony, or India, or non-British countries such as the Unitcd States or Russia.

The privileged position of the landed aristocracy under the corn laws and its influence in the House of Commons had always to be considered when there was a revision to be made of the preferential schedules of British tariffs-corn law tariffs and general tariffs-under the old commercial system; and in particular when preferences on wheat and flour from the Canadas and other colonies werc under review. The preferences on wheat and flour from 1843 to 1846 were of more value to the Canadas than at any other period in the history of the old commercial system. But to the end of the corn laws the landed interest had 
sufficient influence at Westminster to prevent wheat and flour from Canada being admitted duty free.

As late in the history of the old commercial system as 1844, moreover, the influence of the landed class with the Conservative Government of 1841-1846, in which Peel was Premier, was sufficiently powerful to impel Gladstone, who was then President of the Board of Trade, to call upon the supporters of the Government in the House of Commons to vote down a motion in favour of extending to wheat and flour from Cape Colony, India, and Australia, tariff preference similar to that which had been conceded by an Act passed in 1843 to wheat and flour from the Canadas. ${ }^{1}$

Tariff debates at Westminster, when preferences for wheat and flour from the Canadas were the issue, were, as will appear in subsequent chapters, singularly like tariff debates at Ottawa in the sixteen or seventeen years after the enactment of the British preferential tariff by the Dominion Parliament, at the instance of the Laurier Government, in 1897.

In the case of preferences under the old commercial system that impaired no insular British protected interest-preferences for instance such as those on sugar, fish, lumber, and wood ashesthere was no opposition at Westminster from supporters of the old commercial system. Opposition-strong, vigilant, assertive, and to the last effective-promptly developed when it was proposed to establish a preference that to any appreciable degree did impair or threaten to impair a protection that was enjoyed under the old system by any British interest.

The continuity and certainty of this opposition, the strength in the House of Commons that it could command, and the fact that no Government before 1846 could ignore it, ${ }^{2}$ explain why the preferences on wheat and flour were of so little value to the Canadas until 1843. These conditions also explain the lateness in the era of the old commercial system of any preference of much value in favour of wool from Australia ; the denial of any preference at ports in the United Kingdom for the output of the cotton

1 Cf. discussion and division on motion by Hutt, March 26, 1844. Parliamentary Debates, III, xxiii, 1553-1574.

2 Cf. speech by Lord Stanley, Secretary of State for the Colonies in Peel's administration of 1841-1846, against motion in favour of preferences in British tariffs for wheat and flour from Australia, Cape of Good Hope, and India. House of Commons, March 26, 1844. Parliamentary Debates, III, Ixxiii, 1570-1573. 
looms of India ; and the unequivocal denial in 1844 and again in 1845 of petitions for a preference for wheat and flour from Cape Colony, India, and Australia similar to that conceded to the Canadas in 1843.

At Ottawa and elsewhere in the Dominion, the contention of Canadian manufacturers for sixteen or seventeen years before the war of 1914-1918 - the contention they persistently advanced whenever and wherever the preferential tariff of 1897 was discussed-was that while the principle of a tariff preference for manufactures from the United Kingdom was admirable, and while tariff preferences might well serve as a link of empire, protection against imports from the United Kingdom was as necessary to the prosperity and extension of manufacturing in Canada as protection against the United States, Germany, or France.

At Westminster in the period from the peace after Waterloo to the fiscal revolution there was little emphasis on links of empire. The phrase, in fact, was in these ycars not of the vocabulary of English political discussion ; for this was a period of widespread indifference to colonies and to an expanding empire. It was a pcriod of much and serious questioning-some of it, as will presently appear, in high places at Whitehall and Westminsterof the value of the colonial tie, of its permanency, and also of its necessity as a means of holding and extending markets for the output of British factories.

But when colonies and colonial preferences werc discussed in the House of Commons the attitude of the agricultural interest was that, come what might of colonies and of empire, adequate protection must be afforded English grain growers even against competition from the colonies now of the dominions and also from India. Trade of the colonies and of India was not, according to the case of the landed interest, to be encouraged to follow the flag, if by so doing it came into eompctition with protected interests in the United Kingdom. The colonics might be British, and settled mostly by men and women who had emigrated from the United Kingdom; but at ports in the United Kingdom, if produce from the colonies came into eompetition with insular British products proteeted by British tariffs. colonial products must, according to the contention of the graingrowing interest in England, be treated as though they were 
from non-British countries. There must be a tariff wall against them.

At this time, and as long as the old commercial system survived, colonial products could be carried from colonies to the United Kingdom only in British ships. The flag covered the ship. It did not cover all cargoes from all colonies if covering the cargo with the flag meant that colonial products were to go into the markets of the United Kingdom on equal terms with similar goods produced within the four seas-in England, Scotland, or Ireland.

Australia, the Cape of Good Hope, and India were bluntly told that this was the policy of the Government at Whitehall, when in 1844 they were denied the preference in British tariffs that had been conceded to the Canadas. They were told, moreover, by Lord Stanley, who was then Secretary of State for the Colonies, that this was the policy of the Government, because the landed interests of Great Britain demanded this policy toward the colonies, and toward some departments of colonial trade.

Both Gladstone and Stanley, ${ }^{1}$ in their speeches against similarity of preferential treatment for wheat and flour from the Canadas and from Van Diemen's Land, Cape of Good Hope, and India, made it manifest that no further inroads on the corn laws in the interest of the colonies could be regarded as coming within the realm of practical politics ; and by a vote of 117 to 47 the House of Commons rejected a motion by $\mathrm{Hutt}^{2}$ of Gateshead for an

1 Gladstone based his argument against an extension of the preference chiefly on the ground that Van Diemen's Land, Cape Colony, and India had but small uncertain quantities of wheat for export, and that markets for what surplus these colonies and India might have could be found much nearer to them than the United Kingdom. Stanley, as usual, was frank. He told the house the real reason for the opposition of the Government to an extension of the preference on wheat and flour. 'He did not believe, he said, that the practical effect of acquiescing in the present motion would be any serious injury to the agricultural interest, or lead to any large importation of corn from the colonies. But still, he thought, it was generally admitted that if there was one question which it was unwise above all others to tamper with, except on a great emergency, it was the question of the laws which regulated the importation of corn and exercised so great an influence over the agricultural and other classes. Was it desirable, he asked, to create uncertainty, alarm, and confusion in the operation of those clauses for this object, comparatively insignificant, but which would be misrepresented as of great importance.' Parliamentary Debates, March 26, 1844, III, lxxiii, 1570 .

2 Hutt, afterwards Sir William Hutt, a colonial reformer and a free trader who at this time represented Gateshead. 
extension of the preference-for uniformity and equality of treatment of all colonies in the preferential schedules of British tariffs. 1

So far as British tariffs and the colonies now of the dominions were concerned, the preferences on lumber from the Canadas and the Maritime Provinces were the only preferences that for long were of value either to the colonies, or to the mercantile and shipping interests in the United Kingdom that specialized in trade with the colonies.

Except as regards wool from Australia, which to the last enjoyed a small preference at British ports varying, according to value, of one halfpenny to one penny per pound, ${ }^{2}$ no colonies now of the dominions, except the Canadas and New Brunswick and Nova Scotia, in practice, derived any material advantage from preferences under the old commercial system for colonial products marketed in the United Kingdom. Elsewhere than in the British North American colonies, in the years from 1800 to the fiscal revolution, populations were small and scattered and political and material civilization was as yet only in the making. Labour costs were high in all except the British North American provinces. There was little capital, and no manufacturing, as the word manufacturing was then understood in the United Kingdom and the United States.

Political and material development in all the British North American provinces had much outrun the development in the colonies of Australia and South Africa. The British North American provinces, and in particular the Canadas and Nova Scotia, in the years from 1828 to 1846 , were, as regards political development, making the pace, pioneering the way, for political development that after 1850 was to come for the colonies now of the Commonwealth of Australia, the Dominion of New Zealand, and the Union of South Africa. But there was little manufacturing in either the Canadas or the Maritime Provinces until ten years after the passing of the old commercial system.

None of the colonies now of the dominions outside of the North American group of 1791-1867 had products for export to the United Kingdom and consumption there other than wool, wheat, and flour. To the end of the old commercial system, as will be

1 Parliamentary Debates, March 26, 1844, III, Ixiii, 1553-1576.

2 Cf. 5 \& 6 Vict., c. 47 , Class xii. 
remembered, preferences of any value-those equal to the preferences for the Canadas-were denied on wheat and flour from Australia and Cape Colony ; and to these colonies the old preferences in British tariffs never served with manifest efficiency as a link of empire.

To colonies now of the dominions the advantages of the old commercial system-advantages that did not go beyond preferences for colonial natural products at ports in the United Kingdom -were, in the main, confined to the British North American provinces and practically to the Canadas, which had lumber, wheat, and flour, and to New Brunswick and Nova Scotia, which had only lumber to market in the United Kingdom.

\section{Inroads on the Old Colonial System from 1832 to 1846}

In the fourteen years that intervened between the first reform of the House of Commons and the epoch-making legislation of Peel and Russell of 1846-1849-years in which colonial preferences were more discussed at Westminster than at any other time in the new era of colonial history that began with the peace of 1783-England, as in the last decade of the unreformed House of Commons, was moving towards the abandonment of the old system. The inroads on the old system between 1832 and the end of 1845 were not as striking or as manifest to the world at large as those that were effected by the measures of Robinson, Huskisson, and Hume.

The inroads that were made from 1832 to the eve of the final and complete revolution in commercial policy affected tariffs, British and colonial. They affected protectionist duties as distinct from the division of the old commercial system that was based on the navigation laws ; for to the last, to its repeal in 1849 , the navigation code was much as it was left after Huskisson's inroads of 1825 on its old exclusiveness. ${ }^{1}$

While thus from 1832, from the assembling of the first House of Commons elected on the new franchises, to the famine in Ireland of 1845-1846-to what Stanley in 1844 would seemingly have conceded was a great emergency, warranting a reopening in Parliament of the disturbing question of the corn laws' ${ }^{2}-$

1 Cf. Rules and Regulations for Her Majesty's Colonial Service, edition of 1843, Trade and Navigation, pp. 104-110.

2 Cf. Stanley, speech on the corn laws and his reasons for not admitting 
there were no inroads on the old commercial system that compared in importance with those of 1809-1825, there had been a great change in the popular attitude toward the system. In the first three decades of the nineteenth century the old system had been assailed piecemeal. By the end of the thirties it was assailed in its entirety.

British protectionist tariffs, British Possessions Acts and the navigation laws were all assailed in and out of Parliament, and especially in the constituencies. Moreover, what was of much significance at this time, the laws forming part of the old commercial system, which so drastically restricted the fiscal freedom of the six North American provinces, so obviously hamstrung their legislatures in a vital realm of law making and subordinated them to Parliament at Westminster, ${ }^{1}$ were assailed in at least one of these provinces. These laws were assailed in Upper Canada, in a province settled largely by United Empire Loyalists from the revolted American colonies-a province in which in the period from the American Revolution to the rebellion of 1837 there had developed and prospered a Toryism based on the tie with the Crown, the Church, and the Empire, that was even more Bourbon and unyielding than the Toryism of England that was developed by the wars with France of 1793-1815. ${ }^{2}$

One division of the old commercial system disappeared completely with the enactment of Hume's Bill of 1824, which repealed the eighteenth-century statutes conceived and framed in the spirit of Joshua Gee which prohibited export of machinery, of partly finished raw material and penalized the emigration of artisans skilled in manufacturing. All these statutes had gone into the limbo of laws and institutions which have outlived their usefulness. They had disappeared as the result of the persistent effort of Hume, which to the present day seems to have had no recognition either by Hume's biographers ${ }^{3}$ or by historians of the passing of the old commercial system.

Four divisions of the old system survived from 1824 to $1846-$

wheat from Australia and Cape Colony on same preferential terms as wheat from the Canadas. House of Commons, March 26, 1844. Parliamentary Debates, III, lxxiii, 1554.

1 Cf. Rules and Regulations for Her Majesty's Colonial Service (1843), pp. 106-108.

2 ('f. Porritt, Evolution of the Dominion of Canuda, p. 84.

3 Cf. Joseph Hume, Dictionary of Nationul Biography, xxviii, pp. 230-231. 
1849. These were navigation laws; British protectionist tariffs, including the corn laws; British Possessions Acts, and the numerous laws, the spirit of which was always embodied in instructions from the Colonial Office to newly appointed colonial governors, which restrained colonies from any fiscal legislation, or any legislation, affecting either coastwise or ocean navigation, which was in the least degree antagonistic to the old commercial system, or that contravened any of the laws enacted at Westminster on which the old system was based or by which it was safeguarded.

The first three divisions of the old commercial system, navigation code, British tariffs and Possessions Acts, were all in service at this time in a modified form. They had been greatly modified, it will be recalled, as a result of the inroads made on the system in the sixty-odd years from the American Revolution to the widespread popular agitation in England and Scotland against the corn laws that had its beginnings in 1839. In the fourth division, the laws restricting colonial legislatures in their fiscal enactments, there had been no modifications.

It was possible, as will presently appear, for the legislatures of Upper and Lower Canada, New Brunswick, Nova Scotia, Prince Edward Island, and Newfoundland to enact tariff laws. But no law passed by any of these legislatures could go inta effect if it conflicted with British Possessions Acts. It could not go into effect if, for instance, it reduced the differential duties which were embodied in the Acts passed at Westminster to wall in British North American colonial markets for manufactures from the United Kingdom.

Until the Enabling Act was passed at Westminster-until the Act, hurried through Parliament in the closing days of the memorable session of 1846 , which was one of the vitally important colonial Acts of the nineteenth century, was on the statute bookslegislatures in the British North American provinces were, as regards fiscal legislation, as subordinate to the imperial Parliament as were the legislatures of Upper and Lower Canada which first assembled under the provisions of the Quebec Government Act of 1791. Division IV of what survived of the old commercial code was intact and functioning with regularity and certainty until 1846.

By the end of the thirties each of the four divisions of the old 1569.29 
commercial system of 1824-1846 was assailed. Three of these divisions were assailed in the United Kingdom. Two of them, British Possessions Acts which determined import duties at ports in British North America, and sections in these Acts and other statutes which restricted the fiscal freedom of the legislatures at Toronto, Quebec, Fredericton, Halifax, Charlottetown, and St. John's, were assailed overseas. They were assailed, as has been stated, in Upper Canada, the most ultra-British of the colonies now of the dominions of the era from the American Revolution to the Confederation of the British North American provinces in 1867.

Nor does this brief survey of the obviously precarious position of the old commercial system, at the end of the thirties of the nineteenth century tell quite the whole story of the old system, its application to the colonies and to the political or constitutional position of colonies now of the dominions as respects British export trade.

The colonial system, with its advantages for British export trade, with its handicaps on many British industries of which timber was the raw material, with its heavy charges on the British treasury for civil government and the internal and external defence of colonies, was in the later thirties subject to more searching criticism than at any time since England in the seventeenth century began to rank as a colonial power. ${ }^{1}$

The Anti-Corn Law League, which concentrated its seven years' campaign on the corn laws as the keystone of the old commercial system, entered on its mission in 1839. It soon developed into the most widely extended and most powerful organization for propaganda known up to this time in the political history of England. It was led with skill and sagacity. It never for long lacked ample funds, and almost from the first it had the

1 'In truth,' wrote Cobden, in 1835, 'we have been planting and supporting and governing countries upon all degrees of habitable, and some that are not habitable, latitudes of the earth's surface; and so grateful to our national pride has been the spectacle, that we have never, for once, paused to inquire if our interests wcre advanced by so much nominal greatness. Three hundred million: of permanent debt have been accumulated-millions of direct taxation are annually levicd-restrictions and prohibitions are imposed upon our trade in all quarters of the world, for the acquisition or maintenance of colonial possession:. And all for what? That we may repeat the fatal Spanish proverb--."The sur never sets on the King of England's dominions!" For we belicve that no candid investigator of our colonial policy will draw the conclusion that we latve derived, or shall derive, from it advantages that can compensate for these formidable sacrifices.' Cobden's Political I'ritings, i, p. 26. 
continuous aid of the section of the newspaper press that voiced the economic views and championed the political aspirations and opinions of the middle classes of urban England.

The league in particular, at a time when publicists, as distinct from organizers of the collection, presentation, and publication of news, were in control of the more influential newspapers, had the energetic support of the press that represented the manufacturers of England and Scotland, and their commercial and social entourage.

The Anti-Corn Law League had this support because by the thirties of the nineteenth century manufacturers in the United Kingdom realized that their position in the world's trade was such that no tariff protection was necessary to secure for them the home market. They were convinced, moreover, that as they had succeeded in entering, and to a large extent in holding, the markets of the United States despite some revenue duties and some duties that were protectionist in design, they could easily hold the markets of the colonies even with comparatively high revenue duties.

Until 1858-1859, when the Canadas went on to a protectionist basis, it was, it should be kept in mind, never imagined in Downing Street, in Parliament at Westminster, or by British manufacturers, merchants, or shipowners, that with the end of the old commercial system there would emerge, almost at once, tariffs in British colonies avowedly to protect manufacturing industries in the colonies from competition from the United Kingdom.

British manufacturers were no longer in need of protection at ports in the United Kingdom. The supremacy of British manufacturing had by this time carried it far beyond need of the tariff protection that was afforded it in the eighteenth century by the old commercial system. Manufacturing England threw itself into the agitation for an end of the old system because the advantages of the old system for manufacturers were of the past, while the disadvantages that had survived the inroads of 18091825 , and in particular the corn law of 1828 , were regarded as hampering to the industrial and social development of the United Kingdom.

From 1832 to as late as the second reform of the electoral system in 1867, the political affiliations of manufacturers in England and Scotland were, in the main, with the Whig, Liberal, 
or Radical parties; and for nearly twenty years after 1867 the Whigs were in control of what may be described as the progressive forces of the House of Commons. Liberals and Radicals from 1832 to 1867 did the voting at parliamentary elections for Whig, Liberal, and Radical candidates. Liberals and Radicals were returned to the House of Commons in quite large numbers, but it was Whig leaders who from 1832 to 1867 organized administrations, who assumed all, or nearly all, the high offices in these administrations as their prerogative, and also to a very large extent exercised control over the Whig, Liberal, and Radical groups in the House of Commons.

Whig leadership and Whigs as the manifestly dominant partners in the association at Westminster of Whigs, Liberals, and Radicals, however, carried as an obligation some deference to Liberal and Radical opinion on constitutional, fiscal, and economic issues. The Whigs, moreover, except for a small group $^{1}$ whose members put the corn laws first in their political and economic thinking, and viewed these laws exclusively from the standpoint of landed proprietors, were moving away from the eighteenth-century valuation of the old commercial system and its importance as an asset of the Empire.

So much was this the case that by 1841 a Whig administration - that of 1835-1841, of which Viscount Melbourne was Premierwas willing to take heavy risks, and did take these risks, in the House of Commons, to attempt further inroads on the old restrictions of the commercial code. ${ }^{2}$ In particular such risks were taken in an attempt to curtail greatly the protection to grain growers in England, and to curtail, again in the interest of consumers in the United Kingdom, the preferences in British tariffs for sugar from the West Indies and lumber from British North America.

\section{Colonial Opposition to the Old System}

Restlessness at this time in Upper Canada under the constitutional and fiscal restrictions of British Possessions Acts, passed at Westminster and enforced through the Colonial Office and the Board of Trade at. Whitehall, was not a factor in ending

1 Only eleven Whig members of the House of Commons roted against Peel's Bill for the repeal of the com laws.

2 (f. Russell, Recollections and Suggestions, p. 269) debate and division on sugar duties, May 18, 18+1. Parliamentary Debates, III, Iviii, 562-673. 
the old commercial system. The end came in 1846-1849 solely because the old system had manifestly outlived its usefulness for the United Kingdom of the middle years of the nineteenth century, and especially for manufacturing England to which the export trade was all important. Restlessness in Upper Canada under the restrictions of the old system apparently attracted no attention in Parliament at Westminster and none outside Parliament.

The agitation in Upper Canada against two divisions of the old system is, however, of significance as indicating that forces overseas, that developed much greater strength after 1849, were at this time, 1836-1840, lining up against restrictions imposed on the colonies solely in the interest of British trade. It is of significance as suggesting that had the old system survived much longer it would inevitably have brought governments in Downing Street into conflict with governments at the capitals of colonies now of the dominions, much as in the years from 1828 to 1873 Downing Street was, as will be seen in subsequent chapters, continuously in sharp conflict with the administrations of the United Provinces of Upper and Lower Canada, of Nova Scotia, and of all the Australasian colonies, over the questions of responsible government and fiscal freedom.

The restlessness of Upper Canada of 1836-1840 under the old system is significant also because it shows the early date at which the United States, and its fiscal and economic policies, began to influence opinion on these questions in the colonies now of the dominions.

\section{American Influence on Canada}

American influence, quite unconsciously exerted, so far as the Government and the people in the United States were concerned, first affected politico-economic thought in Upper Canada. It first and most directly affected a province that always had least admiration and most criticism for American political institutions and their fundamental principles ; for from 1791 to 1841 Upper Canada was much more royalist, more monarchical, than England was from the American Revolution to the middle period of the long reign of Queen Victoria.

After the union of the provinces of Upper and Lower Canada in 1841, American fiscal and trade politics affected opinion and 
fiscal policies in the United Provinces even more generally and more obviously than they had affected opinion in Upper Canada in the years from 1836 to 1840 . Galt's tariff of 1859 -the germ of the national policy of the Dominion of Canada, as this policy was developed from 1870 to 1914 - is a monument to the influence of American opinion and policies on the fiscal and trade policies of the United Provinces of 1841-1867.

Australia and New Zealand in the later sixties and early seventies of the nineteenth century were affected in their fiscal policies, in the adoption of protectionist tariffs, by American influence and example exercised over the Australasian colonies by way of Canada.

In this way American influence, always unconsciously exerted, on economic thought in Upper Canada, first perceptible in the thirties of the nineteenth century, has, since 1836, greatly affected the fiscal policies of all the dominions.

Through the dominions, as will be manifest as this history proceeds, it has also materially affected the commercial diplomatic policy of Great Britain. It affected it first at the time the ElginMarcy treaty was negotiated; but it affected it more obviously and more generally during the last fifteen or sixteeen years of the colonial era of 1783-1914, the years from the abrogation by Great Britain, in 1898, of its commercial treaty with Germany, and the other twenty-odd commercial treaties that hampered the complete fiscal freedom of the dominions, to the beginning of the World War of 1914-1918.

Of the six British North American provinces of 1791-1841, Upper Canada was the only one that chafed under British Possessions Acts, or at any rate Upper Canada was the only province that went so far as to inform Downing Street that it was chafing under subdivisions of the old commercial system. There was apparently no chafing under the old system in the Maritime Provinces. There was none apparent in Nova Scotia; for in 1839 Joseph Howe, the protagonist in Nova Scotia of responsible government, was willing to accept a form of responsible government that would have left tariffs and trade, as under the old colonial system, exchusively within the jurisdiction of Parliament at Westminster.

The explanation of the apparent absence of chafing under the old colonial system in the Maritime Provinces-the lack of 
protests against British Possessions Acts and restricted fiscal freedom-would seem to lie in the different conditions in Upper Canada and in the Maritime Provinces. None of the Maritime Provinces bordered on manufacturing States of the American Republic. Halifax and St. John, unlike Toronto, Montreal, and Hamilton, are remote from the centres of manufacturing and trade in the United States; moreover, there were then no manufacturing industries in the provinces 'down by the sea' for which tariff protection was urged, and there were no protectionist movements, nor protectionist tariffs, in any of the Maritime Provinces as long as these provinces were autonomous and each was in control of its own fiscal system.

But in the years from 1836 to 1840, Upper Canada was, as has been recalled, protesting against British Possessions Acts, against tariffs enacted for the North American provinces by Parliament at Westminster, and also against statutory restrictions on colonial legislatures that, as will be realized from subsequent chapters, were a mainstay of the old commercial system. These restrictions on the legislatures, as will at once be realized, were necessary to safeguard the tariff protection of British manufacturers in the colonies, to secure uniformity of fiscal legislation all over the Empire and to prevent any contraventions of commercial treaties entered into by Great Britain before 1878 without consultation with the self-governing colonies, treaties, moreover, by which the colonies now of the dominions were bound until as late as $1898 .^{1}$

It was easily possible for both Upper and Lower Canada in the later thirties of the nineteenth century, and especially for Upper Canada with its thousands of miles of frontage on Lakes Huron, Erie, Ontario, and the St. Lawrence, to draw upon the United States for most of the manufactured goods they required. There were American manufactures-lines of hardware, farm and lumbermen's equipment, and leather and felt goods-that were admittedly better adapted to Canadian requirements and conditions than corresponding lines of goods exported from the United Kingdom under the protection of British Possessions Acts.

These lines of goods not only met Canadian conditions better than similar imports from England, but they could be seen

1 Cf. Rules and Regulations for Her Majesty's Colonial Service (1843), pp. $106-107$. 
before they were imported. They were much more easily procured than similar goods from the United Kingdom; for long before what are now the provinces of Ontario and Quebec were linked by railway to Buffalo, Detroit, New York, and Boston, there was regular and cheap communication by means of the Great Lakes and the lake and St. Lawrence canals, on which navigation is continued for as long a season as it is from the Atlantic ocean to the tide-water ports on the St. Lawrence River. ${ }^{1}$

Canadians, at this time mostly farmers, lumberers, storekeepers and artisans for whom work is always offering in pioneer communities, realized these conditions. They also realized the hampering restrictions of British Possessions Acts, and the quite subordinate powers of the legislature of Upper Canada. The result was that from 1835 to 1840 Upper Canada, despite its emphasis on the value of the tie to Great Britain, despite also the fact that as a province it was supposed to profit more than any other North American province from the preferences in British tariffs, found tariffs enacted at Westminster irksome. Upper Canada also realized that British Possessions Acts were greatly retarding to import trade with the States of New York and Ohio, in which at this time manufacturing was well advanced.

The Legislative Assembly at Toronto accordingly expressed its view of these conditions in petitions or addresses to the Colonial Office in London. It complained of the irksomeness of British Possessions Acts. It pointed to differentials in favour of British manufacturers, ranging from seven and a half per cent. to as high as twenty per cent., in some cases even to thirty per cent., and it stressed the importance of the people of Upper Canada being permitted to buy in the best markets. With much frankness, the Legislative Assembly also expressed its impatience over the modicum of fiscal freedom which was permitted under the old commercial sistem to colonies with representative institutions. and contrasted the small part that Upper Canada had in determining its fiscal system with the part that States of the neighbouring republic, through their representatives and

1 Navigation on the Sit. latwrence usuatly begins about April 25. The river is then free of iee. It usually closes not later than December 15. Iake navigation extends over a little longer period. 
senators in Congress at Washington, enjoyed in framing the tariffs of the United States. ${ }^{1}$

There was no concession in response to the agitations in Upper Canada of 1836-1840; and with the union of the provinces of Upper and Lower Canada in 1841 other issues, and in particular the vitally important issue of responsible government, occupied popular attention until the fiscal revolution in the United Kingdom brought preferences in British tariffs for lumber and wheat to an end, and confronted all the British North American provinces with the problem of securing a treaty of reciprocity with the United States.

Among manufacturers in the United Kingdom there was shock and dismay, when in 1858-1859 protectionist tariffs were enacted by the legislature of the United Provinces. There was surprise and dismay also at the Colonial Office, at the Board of Trade, and in Downing Street generally, at the disturbing use to which the United Provinces were applying the new constitutional and fiscal freedom that accrued to them under the Enabling Act. There would have been less of this surprise had it been popularly realized in the United Kingdom to what extent economic thought and fiscal policies in the United States had for twenty years before 1858-1859 been influencing public opinion in the Canadas. There would have been less surprise also had there been a popular realization in England of the full significance of the restlessness of Upper Canada from 1835 to 1840 under two of the subdivisions of the old commercial system.

There was a general election in the United Kingdom in 1841, contested almost exclusively on the corn laws and the preferences in British tariffs to hold the market in the United Kingdom for

1 'Laws for the regulation of our trade and commerce are enacted in the Parliament of the United Kingdom and continually changed and varied without our being consulted for our interest, although the value of our labour and property is unduly affected by this ever-varying system of legislation. In the United States the different sections of the several States are fairly and equally represented according to their numbers in the body which regulates their commerce, and thereby raises or depresses the value of their industry and estates.' First Report on Trade and Commerce of Select Committee of Legislative Committee of Upper Canada, Journals of House of Assembly, 1835, Appendix J, ii. 2. The petitions and addresses on trade conditions and fiscal laws, and the replies from the Colonial Office and the Board of Trade-the official literature of this movement of 1835-1840 of the Legislative Assembly of Upper Canada - are to be found in the appendices to the Journals of 1835-1840. See also 'Reciprocity and Preferences in Canada', The Economist (London), March 18, 1911. 
colonial sugar and colonial timber. ${ }^{1}$ It resulted in the return to power of the Conservatives under the leadership of Peel, with a majority in the House of Commons of seventy-six over Whigs, Liberals, and Radicals.

Had the Melbourne Government been returned to power at the elections in July 1841, it was to have been their policy, as Russell recalled in 1874 , "to pursue the path of free trade with regard to corn, sugar, and timber.' Further reductions in the duties enacted to hold the market in the United Kingdom for home grown wheat, and for the sugar of the West Indies and the lumber of the Canadas and the Maritime Provinces, were contemplated by the Melbourne Administration. These reductions, moreover, were intended to open 'the way to further changes, which would save the people at a future period from monopoly prices on behalf of the West India planters, the Canadian producers of timber, and the landowners and farmers of England, who insisted upon prices of sugar, timber, and corm sufficient to protect their own interests '.2

With the progressive party in Parliament at WestminsterWhigs, Liberals, and Radicals-committed to free trade to the extent Russell described, the United Kingdom by 1841 was obviously moving, and moving quickly, towards the fiscal revolution that was effeeted, hastened a little by the famine in Ireland, for the Empire as a whole by Peel's two measures of the closing months of his last administration, and by the Enabling Aet, which Russell piloted through the House of Commons and Grey through the House of Lords, in the closing hours of the session of 1846, and by the Aet of 1849 which repealed the old

1 'The Ministry (the Melbourne Administration) and its partisans were wise enough to see what was the safest ground for them to take in appealing to the people. Their ultimate defeat (in the House of Commons, May 18, 1841) had happened in consequence of certain financial measures which they brought forward in their Budget. These measures bore the specious character of a removal of disabilities from trade. The interests which they attacked were called " monopolies ", a worl odious in its significance, which was for the first time applicd to every species of protection given to eommerce or agriculture. Thus the whole of the landowners were styled monopolists, because for the encouragement and protection of native agriculture the legislature had imposed a duty on the admission of foreign corn. The same term was applied to the body of West Indian proprietors, because their interests were protected by a duty on foreign sugar. In the same way it was at tempted to excite popular odium against other classe's as favoured in the acquisition of wealth at the expense of the eommunity. The supporters of the Melbourne (Bovernment assumed to themselves the name of anti-monopolists.' Annual Register, 1841. pp. 144-145.

2 John, Earl Russell, Recollections and Suggestions, 1813-1873 (1875), p. 271. 
navigation code and opened the way for the colonies of the dominions to control their own coastwise navigation laws.

The dominions to-day, as for half a century previous to the World War, enjoy the status of nation within the Empire. The United Kingdom and the dominions, long before the war, had constituted a league of nations under the British flag; and except at Berlin, during the crisis over the refusal of Canada after 1898 to concede to imports from Germany the same preferences as were conceded under the Dominion tariff of 1897 to imports from the United Kingdom, ${ }^{1}$ the power and status of the dominions have never been questioned, either within or without the British Empire.

The source of much of the freedom and power that the dominions can and do exercise, but by no means of all of it, is to be found in the legislation of 1846-1849. It can be seen in the Enabling Act of 1846-an Act that apart from the preamble occupies less than half a page in the Pickering edition of the statutes ${ }^{2}$-and in the Act of 1849 that freed colonies now of the dominions from all that remained of the old navigation code of 1846-1849, and made it possible for all the self-governing colonies to enact their own coastwise navigation laws.

On the eve of the emancipating legislation of 1846-1849, four divisions of the old commercial system were in operation in all the British North American colonies with representative institutions-the colonies in which, in the years from 1846 to 1854 , to representative institutions there was added and applied the great principle of responsible government, the principle under which no administration can retain power unless it is supported by a majority in the lower or popularly elected house of the colonial Parliament.

But all the colonies now of the dominions were not similarly affected by the statutes of the old colonial system. The then existing colonies in Australasia and South Africa, as has already been shown, derived little or no advantage from preferential schedules in British tariffs under the old system. Nor, moreover, did these colonies come within the scope of British Possessions Acts.

In the early forties of the nineteenth century differential and

1 Cf. Porritt, Evolution of the Dominion of Canada, pp. 442-446.

2 Pickering, The Statutes of the United Kingdom, lxxxv, pp. 532-533. 
import duties in the Australasian colonies of New South Wales, Van Diemen's Land (now Tasmania), South Australia, and New Zealand, were regulated by local ordinances, ${ }^{1}$ passed by legislative councils that through the system of nominated members were under the control of the governor. Import duties were low. They were imposed exclusively for revenue; and owing to conditions of trade there was little need for high differential duties-as in British Possessions Acts for British North American provinces-to protect the interests of manufacturers in the United Kingdom. The differential duties ranged from only four to seven per cent.

As long as the old commercial system survived the Cape of Good Hope was the only colony in South Africa. Import duties in the Cape Colony, on the eve of the fiscal revolution, were regulated by order in council, dated at Whitehall, March 11, 1842, ${ }^{2}$ and in Cape Colony as in Australasia the differentials were much lower than in the British North American provinces.

The navigation law of 1825, Huskisson's Act, applied to the British North American provinces and to the Australasian colonies. It did not apply, in all particulars, to the Cape of Good Hope; for, as Robinson had reminded the House of Commons in 1822, the trade of Ceylon, of the Mauritius and of the Cape was at that time comparatively free. ${ }^{3}$ Exports from British North America and Australia to the United Kingdom, and imports into these colonies from the United Kingdom had to be forwarded in British vessels. In the British North American provinces there long was complaint of this monopoly; and one of their first demands after the free trade legislation of Peel of 1846 was for the immediate repeal of the navigation law.

Under Huskisson's Act the navigation code was made much less exclusive than it had been in the eighteenth century. Foreign ships were permitted to carry to any British colony goods that were the produce of the countries to which the ships belonged. For outward bound trade the law of 1825 was more liberal than for inward bound trade. It permitted foreign ships to carry the produce of British colonies to any non-British country.

Huskisson's object, and the object of the Liverpool Govern-

1 ('f. Rules and Regulations of Her Majesty: c 'olonina service, p. 109.

2 lbid.

3 ('f. P'arliamentary Debates, II. vi, $1+16$. 
ment in which he was president of the Board of Trade, was to establish an open trade directly between the British colonies and foreign countries. But it was not the policy of the Liverpool administration to throw open this trade to countries that would not reciprocate. Power was accordingly given to the Crownin practice to the Cabinet in Downing Street-to open the trade, by orders in council, to those foreign countries that would concede corresponding maritime advantages to Great Britain. ${ }^{1}$

In the years from 1825 to the end of the old commercial system seventeen countries ${ }^{2}$ had entered into treaties with Great Britain by virtue of which vessels under their flags could engage in the colonial trade. Most of them could engage in it to the full extent permissible under Huskisson's Act.

For the provinces of British North America the most important navigation treaty of the period from 1825 to 1849 was that between Great Britain and the United States. In the first half of the nineteenth century there was an increasing trade between New England ports and what to this day along the water front at Boston are still styled colloquially and on signboards on the wharfs, 'The Provinces.'

It was a trade that was greatly stimulated to the advantage of the British provinces, and also to the advantage of the United States, by the reciprocity treaty of 1854-1866, the first commercial treaty ever negotiated by British plenipotentiaries exclusively for the advantage of British colonies, a treaty which was a direct outcome, it must be remembered, of the fiscal reforms for which for nearly three quarters of a century credit has been accorded to Peel, Gladstone, Russell, and Grey.

\section{British Tariff Policy in 1842}

The other three divisions of the old commercial system operative in the British North American provinces, when an end was made to a system which dated back in parts to 1646 , or at any rate to

1 Cf. speech by Labouchere, President of the Board of Trade in the Melbourne Administration, House of Commons, March 12, 1841. Parliamentary Debates, III, lvii, 152.

2 Prussia, Hanover, Sweden and Norway, Oldenburg, Free Hanseatic Republics (of Lubeck, Bremen, and Hamburg), Colombia, United Provinces of Rio de la Plata, United States of Mexico, Russia, Portugal, Austria, United States of America, Denmark, Chile, France, and Spain. Rules and Regulations of Her Majesty's Colonial Service, p. 105. 
$1660,{ }^{1}$ were : (1) British tariffs with preferential duties for colonial products ; (2) British Possessions Acts ; and (3) statutes, or sections in statutes, which restrained the freedom of the legislatures of the United Provinces of Upper and Lower Canada, New Brunswick, Nova Scotia, Prince Edward Island, and Newfoundland in the enactment of tariff bills.

The tariff in force in the United Kingdom on the eve of the repeal of the corn laws and the excision of protectionist duties from the British fiscal system, was that of $1842 .^{2}$ This was the tariff by which colonial preferences, except those on wheat, were regulated. The Act had been carried through Parliament by the Conservative administration of which Peel was Premier, Henry Goulburn, Chancellor of the Exchequer, Stanley, Secretary of State for the Colonies, the Earl of Ripon (Robinson, of the inroad of 1822 on the old commercial system) at the Board of Trade, with Gladstone as Vice President of the Board.

Peel himself had unfolded the Bill in the House of Commons on May 10, 1842. In so doing he had formulated the principles which had guided the Government in framing it. 'We have sought,' he told the House, 'to remove all prohibitions-all absolute prohibitions-on the import of foreign articles; and we have endeavoured to reduce duties which are so high as to be prohibitory, to such a scale as may admit of fair competition with domestic produce.' 3

In accordance with these principles there was a considerable reduction in the high duties on timber from the Baltic countries. It was a reduction that Peel estimated would involve a loss of revenue amounting to $£ 600,000$. But he quoted the dictum of Hume, of the Board of Trade, ${ }^{4}$ in support of this inroad on the monopoly or partial monopoly of the lumber interests of the British North American provinces in the markets of the United Kingdom. Peel assured the House, moreover, that he did not know of any article in which a reduction of price would be more useful. ${ }^{5}$

1 Cf. R. H. Inglis Palgrave, Dictionary of Political Economy, iii, p. 9.

2 An Act to a mend the laws relating to customs (5\& 6 Vict., c. 47$)$, July $9,1842$.

3 Parliamentary Debates, III, Ixiii, 354.

- James Deacon Hume, famous for his consolidation of the customs laws from the reign of Edward I to that of George IV. and for his advocacy of free trade. "We have abundance of untaxed coal, abundance of untaxed iron: we only want abundance of untaxed wood, in order to be provided cheaply with the three great primary materials of employment and industry.' Ibid.. p. 360 .

Ibild. 
Even with the reductions in the duties on Baltic timber effected by Peel's revision of 1842, the differentials in favour of timber from the Canadas and the Maritime Provinces were left at an exceedingly high level. They were high enough to have secured the commendation of Joshua Gee ; even when account was taken of the difference in the length of voyage from the timber ports of the Baltic and from Quebec or St. John.

Five items from the comprehensive timber schedule of the tariff of 1842 will suffice to show the value of the preference to the lumber and ship-owning interests in the three years that preceded Peel's free trade measures of 1846.1

\section{Class V-Timber and Woods}

Deals, battens, boards or other timber or wood, sawn or split, and not otherwise charged with duty, the load of $50 \mathrm{cu}$. $\mathrm{ft}$.

Staves, the load of $50 \mathrm{cu}$. ft. . .

Lathwood, the fathom of $216 \mathrm{cu}$. ft. $\cdot$.

Spars or poles of all lengths, 4 in. and under 6 in. in diameter, per 120 . $70^{\circ}$.

Handspikes not exceeding $7 \mathrm{ft}$. in length, Ker $120 \quad 5$ in. square and under $\dot{8}$ in. square, per 120

From Foreign
Countries
$£$ s. d.

$\begin{array}{lll}1 & 12 & 0\end{array}$

$\begin{array}{lll}1 & 8 & 0\end{array}$

$\begin{array}{lll}2 & 0 & 0\end{array}$

2000

$\begin{array}{lll}1 & 0 & 0\end{array}$

200

\section{From British Possessions s. d.}

20

20

10

10

$\begin{array}{ll}0 & 6\end{array}$

10

(There was another revision of the tariff of the United Kingdom in 1845. No change, however, was then made in these duties on timber. Cf. 8 \& 9 Vict., c. 90.)

In the three years that preceded the repeal of the corn laws, preferences in British tariffs on wheat and flour from the Canadas had been determined by an Act carried through Parliament in 1843 by Stanley, who was then at the Colonial Office. Until Stanley's Act was passed the duties on wheat and flour from the Canadas were determined by a general Act, passed in 1842 , governing the importation of corn into the United Kingdom. Duties in this Act on Canadian and foreign wheat were regulated by a sliding scale.

From 1828 to 1842 wheat from all colonies or possessions, other than those in Europe, had been admitted at ports in the United Kingdom at a duty of five shillings per quarter, whenever the price of wheat grown in the United Kingdom was below

1 The lower duties on timber in the Act of 1842 did not go into effect until seventeen months after Peel introduced his Bill to the House of Commons on May $10,1842$. 
sixty-seven shillings a quarter. When the price of home grown wheat exceeded sixty-seven shillings a quarter, the duty on wheat and flour from the Canadas and other British colonies was sixpence a quarter. ${ }^{1}$

\section{The Last Revision of the Corn Laws}

In 1842 there was a revision of the corn law of 1828 . It was the last revision before the repeal of all the old corn laws in 1846. The revision of $\mathbf{1 8 4 2}$ was effected by a Bill that was carried through the House of Commons by Peel, who in 1828 had advocated the enactment of the corn laws then passed by the Wellington Administration of 1828-1830. Changes in the interest of consumers were made by the Act of 1842 in the duties both on foreign wheat and on wheat imported into the United Kingdom from British possessions overseas.

Peel told the House of Commons, when he introduced the resolutions on which the Bill of 1842 was based, that he proposed to give the same advantage to colonial wheat respecting the reduction of prices at which it should be admissible as were given by the Bill to wheat from non-British countries. 'But,' he continued, 'considering that the sudden drop in duty from five shillings to sixpence, on account of one shilling difference in the price, is at variance with the principle of the law, which seeks to establish as equable and uniform a reduction of duty as possible, we propose to make a new arrangement. We propose that when the price of British wheat is under 55s., the duty upon every quarter of British colonial wheat shall be $5 s$.; that when at 55s. and under $56 \mathrm{~s}$, it shall be $4 \mathrm{~s}$.; when at $56 \mathrm{~s}$. and under 57. ., it shall be $3 s$. ; when at $57 s$. and under $58 s$, $2 s$.; when at 58s. and upwards, it shall be $1 s$. Thus,' added Peel, 'we take away that sudden fall in the amount of duty levied upon colonial wheat which takes place under the existing law; but we give to colonial wheat that advantage in the reduction of prices which is given to other descriptions of wheat.' 2

'The accompanying table shows the duties imposed by the Act

1 Cf. 9 (ieo. IV, c. 60; also Peel's speech on introducing the Corn Importation Bill of 1842 (5 \& 6 Vict.. e. 14). February 9. 1842. Parliamentury Debales, III. Ix, 2:29.

: Parlintuentury Ifbates (February 9, 1846). III, 1x, 231. 
of 1842 on foreign wheat, and also the duties payable in accordance with the preferential schedule on wheat from the colonies:

Sliding Scale governed by price of
English Wheat

Under 51s.

51s. and under $52 s$.

52s. and under $55 s$.

$55 s$. and under $56 s$.

56s. and under 57s.

$57 s$. and under $58 s$.

58s. and under $59 s$.

\section{Foreign \\ per quarter}

f s. d.

$\begin{array}{lll}1 & 0 & 0\end{array}$

190

180

$17 \quad 0$

$16 \quad 0$

150

140
Canadian per quarter

s. d.

50

50

50

40

30

20

Under the statute of 1842 , as under the preceding corn law, or rather under an interpretation of the Act of 1828 long accepted, flour milled in the Canadas from wheat imported from the United States was admitted into the United Kingdom as Canadian. It thus secured the advantage of the British preferential tariff.

For several years before 1843 there had been a persistent movement in the United Provinces-a movement in which the legislature had an active part-to secure the admission into the United Kingdom of wheat and flour from the Canadas at a nominal duty or duty free.

There had been much political trouble in the Canadas in the decade from 1833 to 1843 . There were the rebellions in 1837 . Then came the union of the provinces, which was greatly disliked in Lower Canada. Later, growing out of conditions in both provinces from 1828 to 1840 , there was friction between Downing Street and the United Provinces over responsible governmentover a demand which until 1847 was resisted by both Whig and Conservative Governments in London.

It is an axiom with engine-room artificers and machine-shop men that 'the wheel that creaks the loudest is the wheel that gets the grease'. In accordance with this axiom, the petitions from the Canadas for more favourable preferential terms for wheat and flour were at last acceded to by the Peel Government ; and from October 1843, until the corn laws were repealed, wheat from the Canadas paid a duty of only a shilling per quarter at ports in the United Kingdom ; and a barrel of flour ${ }^{1}$ was admitted on payment of a duty equal to the duty on thirty-eight and a half gallons of wheat. ${ }^{2}$

1 The barrel contained 196 pounds.

2 Cf. 6 \& 7 Vict., c. 29. 
Under Stanley's law of 1843 , moreover, wheat imported into the Canadas from the United States and re-exported to the United Kingdom, either as wheat or flour, paid only the duty of one shilling a quarter which was imposed on Canadian wheat. The object of this concession was to encourage the flour milling industry in Canada. A further object was to attract American wheat en route to the United Kingdom to what since the forties of the nineteenth century has been developed into the splendidly equipped national grain route of the Dominion of Canada. ${ }^{1}$

The two concessions of 1843-the fixed duty of one shilling a quarter on wheat, and the inclusion of American wheat, reaching the United Kingdom by way of the Canadian national grain route, within the terms of the preference-are, so far as is traceable, the only instances from the American Revolution to the end of the old commercial system in which colonies now of the dominions exercised any influence in determining preferences for colonies in tariff Acts of Parliament at Westminster.

The concession as to wheat passing into the Canadas from the United States was of obvious value to millers in Upper Canada, in particular to the milling industry at St. Catherine's on the Welland Canal, the canal that connects Lakes Erie and Ontario. It was of value also to forwarders in both provinces, and also of some advantage to British shipowners in the trade between tidewater ports on the St. Lawrence and ports of the United Kingdom.

At no time were there large importations of wheat or flour from the Canadas. In 1841 the shipments of wheat to the United Kingdom were 68,834 quarters. The shipments of flour in the same year amounted to 594,000 hundredweight. In 1843 the shipments were 207,000 quarters of wheat and 325,900 hundredweight of flour. As long as the old commercial system with its preferences for colonial products survived, the Canadas were the only colonies that ever in one season sent as much as a full shipload of wheat into the markets of the United Kingdom.

It might almost be said that before 1846 not a colony other than the Canadas had ever contributed as much as a barge-load of wheat to the granary of the United Kingdom. As will be recalled, moreover, the Canadas before 1846 were the only

1 Cf. Porritt, 'Canada's National Grain Route', Political Science Quarterly, September 1918, pp. 344-377. 
colonies that by any certain and considerable preferences in British tariffs had been encouraged to develop grain growing.

The landed interests in England, when the corn laws were at issue, made no pretence to 'thinking imperially'. Had the British aristocracy developed an imperial as distinct from an insular conscience, the Australasian colonies, Cape Colony, and India would in $\mathbf{1 8 4 4}$ have been brought fully instead of partially within the orbit of the old preferences; and wheat and flour from these colonies and India would for two years at least have enjoyed the same advantages as in 1843 were conceded to the Canadas. ${ }^{1}$

These were the advantages that the British North American provinces enjoyed under tariff legislation at Westminster for the United Kingdom in the three years that immediately preceded the end of the old exclusive system of trade. Preferences for lumber, wheat, and flour stood on the credit side of the ledger. On the debit side were the differential duties in the British Possessions Act of $1842,{ }^{2}$ and the sections in these statutes of the old commercial system that so greatly restricted the fiscal legislation of the British North American provinces.

The last of the series of British Possessions Acts was much less elaborate than some of the Possessions Acts from 1783 to 1842. The table of prohibitions was reduced to six or seven items. ${ }^{3}$ The free list included nearly forty items, chiefly foodstuffs, raw materials, equipment, and stores for the fishing fleets, and 'all goods imported from the United Kingdom after having there paid the duties of consumption, and imported thence without drawback'.

The duties on foreign goods-differentials as they were termedintended to hold the colonial markets for products and manufactures of the United Kingdom or of British colonies ranged from seven to fifteen per cent. ad valorem. The highest duties, fifteen per cent., were on manufactures of silk and glass from non-British countries. Manufacturers in the United Kingdom

1 Cf. speech by Stanley, Secretary of State for the Colonies, in the debate on corn from the colonies, House of Commons, March 26, 1844. Parliamentary Debates, III, lxxiii, 1572.

2 An Act to amend the laws for the regulation of the trade of British possessions abroad (5 \& 6 Vict., c. 49), July 16, 1842.

3 The most important prohibitions were gunpowder, ammunition, arms and utensils of war, except when imported from the United Kingdom ; and 'sugar, not being refined in bond in the United Kingdom '. 
of cotton, linen, and woollen goods, of leather and fancy goods, of soap and candles, of clocks and watches, and of hardware, were protected by duties of only seven per cent.

All protectionist duties of twenty or thirty per cent. in the interest of British trade-duties imposed by Robinson's Act of 1822, or by Huskisson's Act of 1825, of which, it will be remembered, there were complaints in Upper Canada in 1835-1840- had completely disappeared at the revision of the Possessions Act in 1842 .

Gladstone, who was then Vice President of the Board of Trade, was in charge of the revision of 1842 ; and when he asked the House of Commons to reduce the differentials he recalled the legislation of 1822 and $1825 .^{1}$ He recalled also that the differentials in other colonies than those in British North America had never been higher than from four to seven per cent.

As though anticipating opposition to lower differentials for the colonies in America, an opposition that did not develop, certainly not in any strength, Gladstone sought to forestall criticism by recalling and examining the arguments against interference with the existing differentials. He characterized as groundless any fears that British manufacturers would suffer loss of trade if the differentials in the British Possessions Act-exclusively a measure for British North America-were brought nearer to the level of the differentials that protected British manufacturing interests in colonies in Australasia and elsewhere in the eastern hemisphere.

Gladstone, furthermore, asked the House to accept the new and lower scale of differentials because "it afforded an opportunity, with practical convenience, of giving more full and striking

1 'The eolonial system as it existed between this eountry and its dependencies,' said Gladstone, in reealling the old eommercial system as it stood at the end of the wars with Franee of 1793-1814, "was one of extreme strictness. The relaxation of the late system had commenced sixty years ago; and since the peace of 1815 material ehanges had been effected in the poliey of the commereial system of the colonies. In the year 1822, under the present Iord Ripon, then Mr. Robinson, and again in the year 1825, under the lamented Mr. Huskisson, measures were introduced into the British Parliament the general effeet of which was to substitute protective duties for the prohibitory duties levied before. Although this had been done, and although the result had been, so far as it went, satisfaetory . . . yet the duties which were still leviable by the authority of the Imperial Parliament were fixed at rates which could not be justified, either with regard to the eolonies themselves, or with regard to the principles laid down by Parliament (in the Declaratory Act of 1778) with respect to its colonial legistation. In eertain cases the operation of the system as it at present stood was extremely onerous.' House of Commons, February 8, 1842. Parlia. mentary Lebates, III, $\mathrm{lx}, 152$. 
application to a principle which they had long adopted-that of rendering to our colonial fellow subjects another of those acts of goodwill to which alone they were to look for cementing the connexion between the colonies and the mother country'. $\mathrm{He}$ was confident, he said, as he closed his speech, and handed in at the table the resolutions on which the Possessions Bill was based, that the measure would be hailed by the colonies as a measure of goodwill on the part of the Imperial Parliament ; and therefore, both on commercial and national grounds, he ventured to recommend it to the favourable consideration of the House. ${ }^{1}$

The foregoing quotation from Gladstone's speech of February 8, 1842 , in fact the whole of his speech, and also its reception by the House of Commons, illustrate the wearing down process to which the old commercial system was subjected in the twenty years from Robinson's inroad on it to 1842, when its end was unmistakably in sight.

The differential duties to protect British manufactures from 1842 until they were all repealed by the legislatures of the United Provinces, Nova Scotia, New Brunswick, Prince Edward Island, and Newfoundland in 1847-1848, under powers suddenly and unexpectedly conferred upon them by the Russell-Grey Enabling Act of 1846, had been reduced by Parliament at Westminster much as in the period from 1825 to 1842 duties in British tariffs to protect British manufactures in the markets of the United Kingdom had been reduced. These reductions in the duties in both tariffs, British tariffs and Possessions Acts, from 1842 to 1846 exemplified the growing confidence of British manufacturers in their ability to hold their own in all British markets, insular and colonial, against competition from any other manufacturing countries.

The duties in the Possessions Act of 1842, even the highest of them, were only half as high as some of the duties in the tariffs of 1858-1859 of the United Provinces of Upper and Lower Canada-the first protectionist tariffs enacted in any of the colonies now of the dominions.

Comparison of the differentials of 1842-1846 with the high protectionist duties of the Cayley and Galt tariffs of 1858 and 1859 partially explains the surprise and dismay of manufacturers and exporters in England and Scotland when they suddenly

1 Ibid., pp. 154, 160. 
discovered that under the commercial freedom that had accrued to the self-governing colonies from the Enabling Act of 1846, it was possible for the colonies to impose protectionist duties avowedly intended to reduce the volume of imports from the United Kingdom, and discovered also that it was quite impossible for either the Colonial Office or Parliament at Westminster to effect any reduction in these protectionist duties in tariffs of self-governing colonies.

\section{Colonial Governors as Guardians of British Interests}

The position of the British North American provinces on the eve of the complete abandonment by Great Britain of the old commercial system under the operation of three of its subdivisions-navigation code, British tariffs, and British Possessions Acts-has been described with some detail. Only one other subdivision-restrictions on the fiscal freedom of the legislatures of the British North American provinces-now remains to be examined.

Some fiscal powers were possessed and exercised by all the legislatures for nearly half a century before 1846. The legislatures could and did enact tariff duties on imports. They could and did enact these duties for revenue purposes alike on British and non-British imports. But it was not possible for any of the legislatures to reduce the differentials of British Possessions Acts, which afforded imports from the United Kingdom an easy precedence over non-British imports on entering colonial markets.

The fiscal enactments of the provincial legislatures were always and invariably subordinate to tariff legislation at Westminster for the colonies ; and every colonial tariff Act carried somewhere within its four corners a stereotyped intimation that the Act was effective only in so far as it did not contravene fiscal legislation enacted at Westminster.

A colonial Bill that did contravene fiscal legislation of the Imperial Parliament had little likelihood of receiving the Royal Assent. The governor stood guard at the political capital of the province. He was ready, as the legislature was never permitted to forget, with his veto. In the rare event of a Bill that contravened a British enactment receiving the Royal Assent from the governor, it had to run the gauntlet of the Board of Trade at Whitehall. 
From the Board of Trade, contraventions of legislation of the Imperial Parliament or of treaties entered into by Great Britain were reported to the Colonial Office, and acting on the counsel of the Colonial Office, the Cabinet advised disallowance. The Cabinet itself, in practice, disallowed the Bill, because as regarded legislation from the colonies, the proceedings of the Privy Council at the final stage of a Bill were for the most part little more than formal.

Governors of colonies, on their appointment, received in writing long, explicit, and detailed instructions as to their duties and responsibilities in the administration of the laws on which the old commercial system was based, and the laws by which it was safeguarded. The supervision of the operation of the old system in the colonies centred, in fact, about the governor, who, in particular, had always to keep a watchful eye on the proceedings of the legislature, especially in those colonies where the lower house was popularly elected.

\section{Instructions to Governors}

In addition to the instructions given in London to each governor on his appointment-instructions which usually had reference to the particular conditions of the colony to which he was goingeach outgoing governor was also furnished with a copy of printed rules and regulations for the colonial service. Here again, as in the written instructions to governors, much emphasis was laid on vigilance in the administration of the laws of the old commercial system.

Against one contingency, one line of departure by colonial legislatures, governors in these rules and regulations were particularly cautioned. On no account must a colonial legislature be permitted to pass a colonial tariff Bill in which there were any differential or discriminating duties.

'As the imposition of discriminating duties on goods imported into British colonies, when the discrimination is made for the protection of some branch of British or colonial industry, is an office of great difficulty, to the right discharge of which an intimate acquaintance with commercial treaties and political relations between this kingdom and foreign states is indispensable,' reads a paragraph in the rules and regulations for the colonial service, as they stood on October 1, 1843, ' much serious 
inconvenience would result from any attempt to legislate on such a subject in ignorance of those treaties and relations.'

'This knowledge', continued the rules and regulations, as they were revised only three years before the end of the old system, and only six years before the contest in the United Provinces of Upper and Lower Canada over responsible government ended in a complete victory for the United Provinces, and led to radical changes in the position and functions of governors in all colonies now of the dominions, 'can not be possessed in the required degree by the various local legislatures of the colonies of this kingdom, as they have no means of knowing the state or objects of pending negotiations, nor even of ascertaining with absolute precision the terms of treaties actually concluded; nor is it possible that so many distinct legislatures, having no means of mutual communication and concert should act consistently with each other on such subjects.'

'The local opinions or interests of each colony', continue these instructions for the guidance of governors in restraining legislatures in enacting tariffs to supplement British Possessions Acts, 'would dictate the laws of each, and the general code of the Empire, compiled from so many different sources, would be at the utmost variance with itself on a subject on which unanimity and consistency are indispensable. In such a state of law, her Majesty's government could not negotiate or treat with confidence with any foreign state for commercial purposes; nor could they fulfil such treaties as might be made. Painful and injurious discussions with those states would arise, and perhaps indemnities and compensations would have to be paid.'

'Her Majesty's government, therefore, objeet in principle', reads another paragraph of these instructions framed to secure absolute uniformity in tariff legislation all over the Empire, 'to the assumption by the local legislatures of the office of imposing differential duties on goods imported into the respeetive eolonies. Parliament having already prescribed the rules by which sueh duties are to be discriminated ${ }^{1}$ with reference to the place of origin or of export, to Parliament alone the power of altering these rules must be reserved.'

'The single exception to this general rule', continues this explicit statement of the powers denied colonial legislatures in

1 By British Possessions Acts. 
enacting tariffs or imports, "will occur in any cases in which her Majesty's government may have suggested to any local legislature the enactment of any such discriminating duties. If such cases should arise the ministers of the Crown would be able to take the necessary measures for obtaining the subsequent sanction of Parliament for any such innovation.'

Then came, in these instructions of 1843 , a mandatory clause. 'The governor will therefore', it reads, 'exercise all the legitimate influence of his office to prevent the introduction into the colonial legislature of any law by which duties may be imposed on goods in reference to their place of production, or to the place from which they may be exported, or of any law imposing on refined sugar imported into the colony higher duties in the case of sugar refined in this country in bond from foreign sugar, than in the case of sugar refined here from British colonial sugar.'

\section{The Colonial Governor's Veto Power}

As will be recalled it was at this time possible for a governor to veto any Bill passed by a legislature. Certain Bills he was, in accordance with his instructions, compelled to transmit to London for the Royal Assent. These were known as reserved Bills. Assent to a reserved Bill was given or withheld, as was deemed expedient by the Colonial Office. In addition to the veto of the governor, and the withholding in Downing Street of assent to reserved Bills, there was also the general power of disallowance. At least two opportunities were thus afforded of vetoing any Bill of any colonial legislature-one at the capital of the colony, and the other in Downing Street.

These opportunities were not deemed sufficient in 1843 to hold legislatures in check as regards tariff Bills ; for as will have been realized from the clause last quoted from the rules and regulations it was mandatory on the governor to prevent Bills which in the least degree threatened the 'unanimity and consistency' of the fiscal system of the Empire from being introduced into the legislature. On such Bills, if they should have passed all their stages in the lower and upper houses of the legislature, the veto of the governor was a certainty. Obviously from the clause in the general instructions to governors which has been quoted, it was the policy of the Colonial Office to prevent the subject of discriminating duties from being discussed in colonial legislatures. 
Both by particular and general instructions it was the duty of a governor to withhold his assent from any Bill embodying differential duties. It was his imperative duty to veto such Bills, because ' her Majesty could not be advised to sanction any laws of this nature which her Majesty's government had not previously recommended, or which Parliament had not expressly sanctioned '.

It was also made incumbent on a governor to procure, whenever it might be in his power, the exclusion from general revenue Acts, and the enactment by distinct and separate statute, of all such laws as the colonial legislature might desire to pass, affecting external trade. ${ }^{1}$

The purpose of the last instruction was apparently to prevent 'tacking'. It was to avoid the failure of a revenue Bill, through veto, on account of the incorporation in it-tacked on to it-of what were regarded as unacceptable proposals affecting tariffs or external trade. A veto on a revenue Bill might create a financial crisis for a colonial government. It might even impair its credit by disorganizing its revenue system.

A veto of a separate Bill, affecting in some degree extemal trade, might thwart the policy of a legislature. Further than that it could create no serious crisis ; and it was always possible for a governor who had vetoed a Bill of this description to inform the legislature that the Bill impaired the unanimity and consistency of the fiscal system of the Empire, or, in other words, that the vetoed Bill was in conflict with imperial statutes on which the old commercial system was based. Such an intimation stopped further proceeding; for a legislature was always aware that in all that concerned the old commercial system Parliament at Westminister was supreme and colonial legislatures subordinate.

The legislature at Halifax had been established for seventeen or eighteen years when the Declaration of Independence was signed and promulgated at Philadelphia. Nova Scotia to-day has the distinction of possessing the oldest law-making body in any of the British dominions." It was created in 1758; and between that time and the end of the old commercial system legislatures were established in Prince Edward Island in 1773,

I ('f. Rules and Regulations of Her Majestyj C'olonial Service, pl). 106-10s.

" (f. Bunpee, Samiford Fleming, Empire Builder, p1. 271-275. 
in New Brunswick in 1784, in Lower Canada in 1792, in Upper Canada in 1792, in Newfoundland in 1832, and, in 1841, with the union of Upper and Lower Canada under the constitution of 1840, there came into existence a new legislature for the United Provinces.

\section{The Nullification of Representative Government}

The powers that these legislatures could exercise before Parliament at Westminster passed the Enabling Act of 1846, and before responsible government was conceded to all the British North American provinces east of the Rocky Mountains in the decade that followed the end of the old commercial system, were exceedingly small. No one legislature had larger powers than another. Prince Edward Island, with its population of thirteen thousand, had as large powers as the provinces of Upper and Lower Canada of 1791-1840, which on the eve of the union of 1840 had an aggregate population of not less than one million.

The legislatures of this period, an era of old style crown colony government at its worst, were hampered at every turn. Sometimes the hampering was due to the power that the governor and the executive council-then under no control by the popularly elected house-could exercise through the control of the nominated legislative council. ${ }^{1}$ At other times it was statutes of the old commercial code that hampered the freedom of the legislatures of British North America-the only statutory restrictions, as distinct from the prerogative of veto, that at this time restrained their fiscal freedom.

Again, at times when the house of assembly and the legislative council happened to be in agreement, the legislature was hampered by the veto power of the governor; by the usage as to reserved Bills; and also by the general power of disallowance that was exercised, nominally and ceremoniously, by the Crown, but in reality, as will become evident in succeeding chapters, by one or two members of the permanent staff of the Colonial Office in London.

\footnotetext{
1 'It may fairly be said that the natural state of government in all these colonies is that of collision between the executive and representative body. In all of them the administration of public affairs is habitually confined to those who do not co-operate harmoniously with the popular branch of the legislature and the government is constantly proposing measures which the majority of the assembly reject and refusing its assent to bills which that body has passed.' Durham, Report, ii, p. 73.
} 
By these hampering processes, some of them possible by statute, others possible through the exercise of the veto, and still others due to the extent to which representative institutions had been warped away from their original intent and purpose, representative government in all the older provinces now of the Dominion of Canada, by the decade that preceded the fiscal revolution, had been to a large extent nullified. ${ }^{1}$

Durham realized this early in his investigation of 1838-1839. His sympathies were with democracy and with a democratic working of representative institutions. Ignoring apparently the old commercial code, and the extent to which this code hamstrung the legislatures of British North America, Durham declared that he could see no imperial interests " which require the complete nullification of representative government.' 2

'But if there be such a necessity,' added Durham, 'it is quite clear that a representative government in a colony must be a mockery and a source of confusion.' 'To suppose that such a system would work well', he continued, 'implies a belief that the French Canadians have enjoyed representative institutions for half a century without acquiring any of the characteristics of a free pcople; that Englishmen renounce every political opinion and feeling when they enter a colony ; or that the spirit of Anglo-Saxon freedom is utterly changed and weakened among those who are transplanted across the Atlantic.' 3

For cighty years Durham's searching, detailed, and destructive criticisms of the working of representative institutions in the British North American provinces, and his exposure of the failurc of political civilization that had caused the rebellion of 1837 , have been acceptcd as well grounded. The restrictions on the legislatures of the period from 1791 to 1840 were as Durham described them, and nonc of these rcstrictions was more obvious or more hampcring than those which affected trade, tariffs, and navigation.

Durham either overlooked or purposely ignored one imperial intercst for the close and rigid protcction of which some of the restrictions had bcen established and maintaincd. These had been maintained in the interest of what the rules and regulations for the colonial service of 1843 described as "unanimity and consistency' in the fiscal system of the Empire. They were all

1 Durhain, Report. ii, p. 75. 2 Ibill, pp. 7!-80. 3 Ibid., pp. 80-81. 
in the interest of the old commercial system, which was originally devised for the commercial aggrandizement of Great Britain and not for the commercial development of oversea dominions, or for the creation in these dominions of a political civilization of which freedom was to be as much a characteristic as it was of the political civilization of Great Britain.

\section{The Movement for Responsible Government}

In the British North American provinces responsible government was an older issue than fiscal freedom. It dated from 1828 , and there was no movement in any of these provinces for fiscal freedom earlier than that in Upper Canada in 1835-1840. Complete success attended the movement for responsible government in 1849. The question was settled when Parliament at Westminster in this year voted down resolutions embodying petitions to the Crown to disallow the Rebellion Losses Act, passed by the legislature of the United Provinces of Upper and Lower Canada.

The principle of responsible government was thereafter unassailable, either in the self-governing colonies, or at Whitehall or Westminster. With the powers that accrued to the colonies after responsible government had been conceded, and with the influence of the fiscal policies of the United States on political thought and movement in Upper and Lower Canada, it is not conceivable that the restrictions of 1791-1846 on the fiscal freedom of the legislatures of the British North American provinces could have survived for a decade after responsible government was established, even if it had been possible to hold back the fiscal revolution in the United Kingdom for another twenty years.

The shackles of the old commercial system were too obvious, too harassing, too burdensome, and too humiliating to have been tolerated for long by colonies of the era that began after the Colonial Office, the Cabinet in Downing Street, the House of Commons, and the House of Lords had all accepted and endorsed Elgin's comprehensive and beneficent interpretation of the term, responsible government.

The total population of all the colonies as estimated by the Colonial Office in 1842 was $4,674,335$. In the British North American provinces in 1842 the aggregate population was $1,621,152$. In the West Indies it was 901,082 . In the Australasian 
and other colonies of the eastern hemisphere the aggregate population was $2,152,101 .^{1}$ At that time, 1842 , there were in existence only eleven of the colonies that are now of the dominions. The white population of these colonies in 1842 was approximately $1,268,000 .^{2}$

From the beginning in the seventeenth century of England's acquisition of dominions overseas to the Great War of 1914-1918, there had been seven eras in the evolution of political civilization and government in British colonies that are now of the dominions. Bricfly described these eras were :

1. The cra of personal rule of the governor, acting under instructions from the Colonial Office.

2. The era of a legislative council, nominated by the governor.

3. The era during which part of the legislative council was the instrument of an informal kind of representation-a means of feeling and in some degree conforming to public opinion.

4. The era in which part of the legislative council was electivea minority of the council, but none the less an influential minority.

5. The era in which came the separation of the legislature into two chambers, one nominated and the other elected-in brief the era of representative institutions.

6. The era of responsible government, by which the executive was placed in the hands of men practically nominated by the majority in the popularly elected house ; and

7. The era of confederation, with the status and weight of

1 Cf. Knight, Political Dictionary, (1845), i, p. 567.

2 Aecording to estimates made by the Colonial Office between 1835 and 1839 and eompiled by Robert Mont. Martin, the white populations of the colonies now of the dominions were then as follows:

\begin{tabular}{|c|c|c|c|c|}
\hline Upper Canada & & & & 400,000 \\
\hline Lower Canada & & • & ${ }^{\circ}$ & 600,000 \\
\hline New Brunswick & & - & - & 27,704 \\
\hline Nova Scotia. & & • & $\cdot$ & 15,617 \\
\hline Cape Breton Island & & & & 3,125 \\
\hline Prince Edward Island & & & & 2,131 \\
\hline Newfoundland & & & & 36,000 \\
\hline New South Wales & & & & 80,000 \\
\hline Van Diemen's Land & & & & 45,000 \\
\hline West Australia & & & & 2,500 \\
\hline South Australia & & & & 3,000 \\
\hline Cape of Good Hope & & & 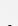 & 50.000 \\
\hline
\end{tabular}

New Zealand is not included in the statistical tables prepared by Mr. Martin. Stratistics of the Colonies of the British Empire. prepared from Official Record.; of the Colonial Office. By Robert Mont. Ilartin, Esq., 1839. From table used as Frontispiece. 
confederation, the era which began with the confederation of the British North American provinces under the constitution of 1867 ; which witnessed the creation of the Commonwealth of Australia in 1900 ; and finally the creation of the Union of South Africa in 1910.1

At the time Peel carried through Parliament his two free trade measures of 1846, and the Russell administration, in the same session, called upon Parliament to pass the Enabling Act, only the colonies in British North America were nearing the era of responsible government. Colonies in Australasia and South Africa were either in the era of political development in which there were legislative councils that were partly elected, or they were in the era in which legislatures were of two chambers, one nominated and the other elected.

From 1791 to 1846 all the British North American provincesthe Canadas, New Brunswick, Nova Scotia, Prince Edward Island, and Newfoundland-were in this era of nominated legislative councils and popularly elected houses of assembly. They were in the era in which the governor had large powers, and chose his executive council mainly from the nominated upper chamber, and was usually little concerned as to the views and opinions of the men who were in a majority in the lower house.

Revenue bills originated in the lower house. In accordance with the usage at Westminster, revenue bills could originate only in the popularly elected chamber. Otherwise, only to a small degree was the governor or the executive council dependent on the goodwill of the House of Assembly.

The assembly might refuse or pass bills. It might vote or withhold supplies; but from 1791 to the establishment of responsible government the assembly could exercise no influence on the nomination of a single servant of the Crown. The executive council, the law officers, and the heads of the various state departments were all appointed without any regard to the wishes of the people or their representatives.

Moreover, however decidedly the assembly might condemn the policy of a government, the men who advised that policy, usually members of the executive council and heads of state departments, retained their offices, and, as Durham phrased it, ' their power of giving bad advice.' If a law was passed after

1 Cf. G. E. Marindin, The Letters of Frederic Lord Blachford, p. 300. 
repeated conflicts between the legislative assembly and the executive council, it had to be carried into effect by men who had strenuously opposed it. ${ }^{1}$

It has never been claimed by writers on the colonial history of Great Britain that any glory attached to the era of the nominated legislative councils and popularly elected lower houses, with the governor or executive council, or both combined, in control of both houses of the legislature or partly independent of the House of Assembly.

In the history of the development of political civilization in the colonies now of the dominions from 1783 to 1914, the fifth era is one to which in these later days nobody points with pride while every Englishman points with satisfaction and pride to the era of responsible government-the era of the creation of nations within the Empire. The older era through which nearly all the colonies that are of the dominions passed in the years from 1791 to $\mathbf{1 8 6 7}$ is an era that as regards the British North American provinces is never recalled with satisfaction.

It is as dismal in its memories and traditions as the pigsty era in the history of the poor law of England. If it is recalled, as it sometimes is, it is perhaps to emphasize that since it came to an end British troops have never been called upon to suppress a rebellion of men of British or European origin in any British colony. Sometimes it is recalled as proof that the loss of the American colonies brought with it no immediate change in the attitude of Downing Street toward colonies that after 1783 remained of the Empire-as proof that Great Britain did not learn the lesson from the revolt of 1776 until after the rebellions in Canada of 1837-1838.

At other times era No. 5 is recalled in order that endorsement may once more be given to Durham's classic comment on it, when its characteristics revealed themselves to him, "that it is difficult to conceive what could have been their theory of government who imagined that in any colony of England a body invested with the name and character of a representative assembly could be deprived of any of those powers which in the opinion of Englishmen are inherent in a popular legislature.' 2

In two of the British North American provinces, the Canadas and Nova Scotia, the fifth of these eras in the evolution of

I Durham, Report, ii, p. 7 . 2 Ibid., ii, 1. 76. 
government in British colonies was manifestly nearing its end when the fiscal revolution in the United Kingdom astonished the world. In the Canadas the struggle for responsible government was practically won when at the end of 1847 Elgin, who was appointed by the Russell Administration, succeeded Sir Charles T. Metcalfe as Governor-General.

In the brief period from the union of the provinces to the appointment of Metcalfe, in the years from 1840 to 1843, responsible government had been partially conceded, first by Lord Sydenham, and then by Sir Charles Bagot, who succeeded Sydenham at the end of 1841. Metcalfe conceived that it was his special mission in Canada to withhold a full concession of responsible government. From 1843 to 1845 he worked energetically and persistently with this object as his goal. He wrought to th's end, moreover, with the full support of the Peel Administration, and in particular with the whole hearted support of Peel, Wellington, and Stanley; and also, as is now known, with the commendation and endorsement of his policy and its aims by Queen Victoria. ${ }^{1}$

Metcalfe's attempt to stay the progress of responsible government was, from the first, as hopeless as the long continued counter movement to the agitation for parliamentary reform in England and Scotland of 1781-1832. The Russell Administration, when it assumed power after the downfall of Peel, realized this.

Elgin accordingly was instructed to concede what was demanded by Baldwin and La Fontaine, the leaders of the Liberals and Radicals in Upper and Lower Canada, leaders who at this time commanded a majority in the House of Assembly. ${ }^{2}$

The new Governor-General acted on his instructions loyally and to the full, for Elgin's sympathies were with the constitutional reformers in the Canadas, and by marriage he had been related to Durham, whose Report had aroused new hope in the men who were associated under the lead of Baldwin and La Fontaine.

\section{The Conflict over Colonial Fiscal Policies}

Responsible government was completely and firmly established by 1849 , and with its establishment contemporaneously with the

${ }^{1}$ Cf. Benson and Esher, The Lêtters of Queen Victoria, 1837-1861, ii. pp. 111-112.

2 Cf. Earl Grey, The Colonial Policy of Lord John Russell's Administration, i, pp. 208-209. 
revolution in the fiscal and commercial policy of the Empire there began almost immediately the conflict between the Colonial Office and the self-governing colonies over the fiscal policy of the colonies that went on from 1847 to 1895 .

It had been the confident expectation in Downing Street that the end of the old commercial system would be followed by a uniformity of fiscal legislation throughout the Empire. Parliament controlled the fiscal policy of the United Kingdom. Through the Colonial Office it controlled the general fiscal policy of the crown colonies, and in the early years of the new fiscal system it was assumed, as a matter of course, that the self-governing colonies, in possession of their fiscal freedom, would not use it to diverge from the fiscal policy of the United Kingdom and the crown colonies.

Free trade, it was conceived at Whitehall and at Westminster, and in the constituencies of the United Kingdom, was henceforward to be the permanent and unvarying fiscal policy of the Empire, as in the days of the old commercial system restriction had been the policy in force in the United Kingdom and in all the oversea possessions of Great Britain.

All the self-governing colonies except Newfoundland sooner or later developed quite other views as to the fiscal policies most advantageous to their particular conditions. One after another, as will appear as this history of the fiscal freedom of the dominions proceeds, their legislatures enacted tariffs with comparatively high protectionist duties, duties that until 1897 were in all the protcctionist colonies imposed alike on manufactures from British and non-British countries.

During these forty-eight years, 1847-1895, what may be appropriately described as a propaganda for tariffs all over the Empire based on the principles of free tradc, and for uniformity in tariff legislation, was carried on from the Colonial Officc. With one exception, duly notcd in subsequent pages, every Secretary of State for the Colonies from Earl Grey to the Earl of Kimberley - every statesman who was at the Colonial Office from 1846 to 1895-was morc or lcss engaged in this propaganda. Every Colonial Secretary of this period was a minister of propaganda with all the self-governing colonies as the realm of his propaganda activities.

In the history of the activities of state departments at White- 
hall from 1832 to 1914 there is nothing that can be compared with this Colonial Office propaganda for a fiscal system for the Empire based on the principles of the fiscal reforms of the United Kingdom of 1846-1849. Its aims were to ensure that in the tariffs of the autonomous colonies there should be no differential, retaliatory, discriminating, or protectionist duties.

These aims were sometimes impressed on newly appointed governors about to proceed over sea. At another time, as in 1850, when there was framed a new constitution for colonies now of the Commonwealth of Australia, Parliament came into the propaganda and, at the instance of Grey, embodied in the Constitution Act a section that estopped any of the legislatures of the Australian colonies from enacting tariffs with differential duties. ${ }^{1}$

Thousands of pages of dispatches went out from the Colonial Office in these years in support of the principle of free trade and emphasizing its applicability to the Empire as a whole. Accompanying these dispatches, practically as part of them, there were long and detailed minutes from the Board of Trade, in which objections were taken to Bills of the legislatures-Bills that had been reserved-by which it was proposed to enact either differential or protectionist duties, or in some cases to stimulate local industries by bounties.

There were dispatches and also minutes from the Board of Trade that were as long as pamphlets, and that were written, consciously or unconsciously, in a spirit of earnest controversy. A library almost big enough to meet the needs of the Cobden Club could be formed of these dispatches of the Colonial Office and minutes of the Board of Trade of 1847-1895.

In reply to these dispatches and minutes there were sent to London from the capitals of the British North American provinces, or from Ottawa after Confederation, or from the capitals of the colonies of Australasia, dispatches or minutes of council almost as long as the dispatches that had been received from the Colonial Office. These dispatches were usually quite as controversial in character as those that went out under the signatures of Colonial Secretaries.

From these dispatches there could be formed a library that would serve the Canadian Manufacturers' Association, or the

1 Cf. An Act for the better government of her Majesty's Australian colonies (13 \& 14 Vict., c. 59 , sec. 27 ). 
Home Market Club of Boston ; for there were pens at the colonial capitals that were pushed as zealously in support of protectionist tariffs in the colonies as those at the Colonial Office and at the Board of Trade in London were so long pushed in the interest of a fiscal system for the Empire based on the principle of free trade.

As will be realized from succeeding chapters, this unique propaganda from a department of state at Whitehall failed. Apart from estopping the Australian colonies for at least twentythree years from establishing tariff systems of which differential duties were a part, it achieved no outstanding success. It achieved no success that has been deemed worth mention in the fiscal and economic history of the Empire. Part of the propaganda was discontinued after the Palmerston Administration, in which the Duke of Newcastle, as Colonial Secretary, had refused to shoulder the responsibility of advising the withholding of the Royal Assent to Galt's tariff of 1859.

The history of the propaganda is a histony of failure. It is a history of failure that is obvious to the world ; for when Great Britain went to the aid of France and Belgium in the war of 1914-1918, Newfoundland was the only one of the dominions in whieh there was not a protectionist tariff, with high duties enacted to protect manufacturers in the dominions from competition of manufacturers of the United Kingdom.

At times the propaganda of 1847-1895 created friction and irritation between the Colonial Offiee and administrations at the political capitals in British North Ameriea and Australasia. There were interchanges between the Colonial Office and Toronto in 1859 and between the Colonial Offiee and several of the Australasian colonies in 1871-1873, that were at times tart and rasping in tone and spirit; so much so, as regards the interchanges of 1859 over Galt's tariff, as to attraet attention beyond the limits of the British Empire.

Outspoken utteranee at times characterized speeches of members of the House of Commons or of the House of Lords, when these members identified themselves with a propaganda for an Empire on a free trade basis, and protested against the high duties imposed on British manufactures by the national poliey tariffs of the Dominion of Canada of 1879-1896.

But by 1887 these protests at Westminster were of the past, 
and between 1873 and 1895 there was not much life or continuity in the Colonial Office propaganda, although it was not until 1895 that the Australian colonies were completely free of the restraining section of the Constitution Act of 1850 .

For twenty-five years before the Great War there had been a well-established and loyally observed understanding that the United Kingdom was to follow its own course as regards its fiscal system, and that the self-governing colonies were to enjoy similar liberty of action in the realm of fiscal legislation. The propaganda failed. But every trace of friction and irritation that it had ever aroused had completely disappeared before the celebration of the Diamond Jubilee of Queen Victoria's reign in the summer months of 1897. 


\section{PART I}

\section{THE NEW BRITISH FISCAL SYSTEM}

\section{CHAPTER I}

\section{THE DOMINIONS AND THE CROWN COLONIES-THE FISCAL POLICY OF THE CROWN COLONIES}

A CHANGE of much significance was made in 1907 in the organization of the Colonial Office in London. It was a change which was long overdue, for it would seem that the last previous reorganization of the department had been made as long ago as $1830 .^{1}$ The change was made in 1907 because of a series of important changes in the relations of Parliament at Westminster, the Ministry in Downing Street, the Colonial Office, the Treasury, the Customs Department, and the General Post Office in London, to the provinces or states that are now of what are known as the British oversea dominions.

These changes, which had their beginnings in the old British North American provinces of Lower and Upper Canada, New Brunswick, and Nova Scotia, had been going on from at least as early as the union of the provinces of Upper and Lower Canada in 1840-1841. ${ }^{2}$ They had proceeded in all the colonies of British North America, Australasia ${ }^{3}$ and South Africa at an accelerated

1 Lord Blachford was at the Colonial Office from 1847 to 1871 , being Under Secretary from 1860 to 1871 . ' Fifty years ago,' he wrote, in a detailed memorandum prepared in or about the year 1885, "the colonies were divided in general into two classes-crown colonies, in which the Crown was almost absolute, and colonies having representative institutions, that is to say; colonies in which money could not be granted, or laws passed, without the consent of an elected assembly. The executive government was in all cases alike composed of permanent officers, appointed by the Crown.' George Eden Marindin, Letters of Lord Blachford, p. 296.

2 Cf. 3 \& 4 Vict., c. 35 ; G. Poulett Scrope, Memoir of Charles Lord Sydenham, pp. 139-163.

3 The term Australasia, or Australasian colonies, as used in these pages, is to be understood as used in the same sense as it was at the colonial conference at Ottawa in 1894. It was then decided, July 4, that if the words ' be used in any motions or amendments that may be brought before the conference, they shall mean the colonies of Australia and New Zealand'. Official Report, p. 173. 
pace from 1847, when the Earl of Elgin became Governor-General of Canada, to the creation of the Commonwealth of Australia, which came into existence by virtue of the action of the people of Australia and of an Act of Parliament at Westminster to which Royal Assent was given by Queen Victoria on July 9, $1900 .{ }^{1}$

At the reorganization in 1907 of the department of the Secretary of State for the Colonies, all the oversea possessions of Great Britain, with the exception of India, were grouped in one or other of two divisions. ${ }^{2}$ The grouping was by political status. It was determined by the constitution of each of the oversea possessions, which in turn determines the relation of the colony to Parliament and to the Colonial Office.

In one group, and the group with which in these pages I am almost exclusively concerned, are the dominions. These are the larger oversea possessions of Great Britain, possessions in which there are aboriginal inhabitants, but in which, except in South Africa, the people of the British race are in a majority. The dominions call for no continuous attention from Parliament at Westminster. Their internal affairs demand attention only at long and irregular intervals; their relations with the world at large have, at least since 1907, created little work for the Foreign Office; and, as regards their internal affairs, they throw no heavy or continuous duties on the Colonial Office.

In the second division of the Colonial Office are the crown colonies and the protectorates. These oversea possessions receive some attention from Parliament, larger and more continuous attention than Parliament is called upon to bestow on colonies in the dominions class.

The crown colonies and protectorates, of which in 1914 there were nearly fifty, receive infinitely less attention than was bestowed on the colonies now of the dominions from 1783 to 1850 . But they do receive some regularly recurring attention from the House of Commons and the House of Lords. In particular, some attention is bestowed on them when the annual vote for the Colonial Office is before Parliament; for the Colonial Office vote is one on which any aspect of crown colony government can be discussed. ${ }^{3}$

$163 \& 64$ Viet., c. 12.

('f. Colonial Office List, 1910, x.

3 "This is one of the few, perhaps the sole oceasion in the year, on whieh either the House or the country has any opportunity of receiving an aecount of 
These colonies and protectorates are, unlike the dominions, not autonomous. Representative institutions-legislative assemblies or legislative councils, some of them elected on democratic franchises-are established and have long been established in most of them. But representative institutions, plus responsible or Cabinet government, are necessary to an oversea possession as a qualification for entry into the dominions group; and in none of the crown colonies or protectorates has responsible government, as it exists in Canada or Newfoundland or New Zealand, been established.

The internal and external concerns of all the crown colonies, and in particular their tariffs of import duties, which since 1846 have all been framed solely with a view to the raising of revenue, ${ }^{1}$ are constantly under the supervision of the Colonial Office, which deputes to the governors of crown colonies in regard to tariffs and other matters larger and more varied powers than can be deputed to the governors of colonies in the dominions group.

The long-established general policy of the Imperial Government in its relations with the crown colonies can be summarized in a few pages; for the crown colonies and protectorates, as well as the Indian Empire, lie outside the scope of this history of the fiscal freedom of Canada and the other British oversea dominions.

The principles of this policy-the general, broad, and abiding principles, on which the crown colonies in the old and the new

the stewardship of those to whom is entrusted the government of the dependencies, which are known as crown colonies.' Harcourt, Secretary of State for the Colonies, House of Commons, June 27, 1912. Parliamentary Debates, V, $\mathrm{xl}, 504$.

1 'Apart from Hong Kong and Singapore, which have no domestic exports, and in which free trade exists in the strictest sense of the term, the fiscal system of the productive crown colonies is established on a basis of free trade, modified by the exigencies of revenue. The policy of protection, in the accepted sense of the term, does not enter into the fiscal system of the crown colonies, for the best of all reasons : as a rule they have nothing to protect. So far from imposing duties of customs for the purpose of protecting their own industry, their custom revenue is derived entirely from commodities which it is to their interest to admit, and on the admission of which their very existence depends. With the exception of duties on spirits and tobacco, countervailed by duties of excise, there are no duties which it is to the interest of any class of the community to maintain. They are, therefore, in no sense protective duties. But as these colonies are generally dependent on foreign imports, not only for all manufactured goods, but in many cases for their food supply, it has come to be recognized that the burden of taxation can most fairly be distributed among those who participate in the wage fund, by duties of customs. The tariff, accordingly, is so constituted as to secure a just incidence of taxation on the various classes of the community.' Sir Charles Bruce, The Broadstone of Empire: Problems of Crown Colony Administration, ii, pp. 300-301. 
world are governed from Downing Street-are determined (1) by Parliament as the interpreter of the spirit of the British constitution, 1 and (2) as regards tariffs and the general fiscal policy of the crown colonies, by Parliament as the guardian of the fiscal and commercial policy of the United Kingdom, and of the crown colonies and protectorates, as this fiscal and commercial policy was established at Westminster by the free-trade legislation of 1842-1850.

All the crown colonies in 1918, as regards their fiscal policies, are in much the same subordinate position as were all the British oversea possessions-colonies now in the dominions group, and possessions now in the crown colony division-before Parliament in 1846 established the United Kingdom and the crown colonies on the basis of free trade, and in 1849 repealed the old navigation codc.

Tariffs on imports in the crown colonies in which there are legislative assemblies or legislative councils are always and consistently framed to harmonize with the free-trade policy of the United Kingdom. They must, in their general principles, be in the same key with the tariff enactments that are to be found on the statute book that is in the keeping of Parliament at Westminster.

For nearly scventy years before the outbreak of the Teutonic war-from 1846 to 1914 - whether a Conservative or a Liberal Government were in power at Westminster, a tariff for a crown colony in which there were customs duties intended to afford protection to industries in the colonies was impossible.

Until as long after the abandonment of the old commercial system as 1878 the instructions issued to the Governor-General of Canada on his appointment, and the instructions issued from the Colonial Office to all governors of colonies in which there were legislative assemblies or legislative councils specifically forbade governors to assent in the name of the Crown to any Bill by which differential duties were imposed. ${ }^{2}$

Similar prohibitions were cmbodicd in all instructions to governors of British North American provinces from 1758, when

1 Bruce, loc. cit., i, Preface, p. xix.

2 Cf. Instructions to Governors, 1763-1867, Sessional Papers (Canada), 1906, No. 18; Instructions to the Earl of Dufferin, (iovernor-General of Canada, 1872-1878, quoted by Z. A. Lash. The Working of Federal Institutions in Canada, in the Federation of Canada, 1867-191\%, pp. 81-82. 
a legislature was established in Nova Scotia, until 1878, when the Marquess of Lorne was appointed Governor-General of Canada. Instructions continued to be framed according to the old form until 1878, notwithstanding the fact that in Canada for nearly a quarter of a century before Lorne became Governor-General there had been tariffs of the United Provinces of Upper and Lower Canada, tariffs in the Maritime Provinces, and also tariffs of the Dominion of Canada, under which differential duties were or could have been imposed. ${ }^{1}$

The old prohibition-one of many devices of the old commercial system intended to establish and maintain uniformity in commercial policy throughout the Empire ${ }^{2}$-was, moreover, continued in instructions to governors until 1878, notwithstanding the successful revolt in the United Provinces of Upper and Lower Canada in 1859 against the fiscal policy, which from 1846 to 1873 the Colonial Office persistently pressed on all the colonies that are now of the dominions. ${ }^{3}$

It was continued for thirty-two years after the adoption of free trade as the policy of the United Kingdom, despite the fact that from 1858 to 1867 there were, in the tariffs of the United Provinces, duties which were avowedly enacted to protect manufacturers in what are now the provinces of Ontario and Quebec against competition from England, Scotland, and Ireland, as well as against competition from the United States.

The prohibition remained also as part of the instructions to governors-general of Canada, notwithstanding the fact that differential duties, frequently protested against by the Colonial Office in the period from 1846 to 1873 , were possible under the tariffs of the Dominion of Canada of 1867, 1868, and 1870. It was continued, moreover, until as late as 1878 , despite three outstanding facts in the fiscal history of the Empire from 1846 to the year in which the old instruction to governors of British North American colonies was discontinued.

These facts are : (1) That the tariff enacted by Parliament at Ottawa in 1870 imposed new duties on imports from the United Kingdom, and in particular on coal, which had previously reached

${ }^{1}$ Cf. speech by the Earl of Kimberley, Colonial Secretary, House of Lords, May 20, 1873. Parliamentary Debates, III, ccxvi, 156-157.

2 Cf. Rules and Regulations for Her Majesty's Colonial Service (1843), pp. 106-108.

${ }^{3}$ Cf. Porritt, Sixty Years of Protection in Canada, pp. 223-260. 
Quebec and Montreal in comparatively large quantities as ballast in timber-carrying vessels on the outward voyage from England; (2) that in 1867 the legislature of Victoria, now a State in the Commonwealth of Australia, enacted a tariff to protect manufacturers in the colony from competition of manufacturers in the United Kingdom; and (3) that by 1871 the Colonial Office had abandoned its long-continued efforts to dissuade colonies with responsible government from adopting tariff policies which were not in harmony with the free-trade policy of the mother country. ${ }^{1}$

\section{CHAPTER II}

\section{CROWN COLONIES NOT OF THE MOVEMENT FOR FISCAL FREEDOM-AMERICAN INFLUENCE ON THE MOVE- MENT IN SELF-GOVERNING COLONIES}

There is no parallel between the two groups of British oversea possessions in regard either to their constitutional history or to their fiscal history. There is certainly no parallel in regard to fiscal history between the dominions group and the crown colonies. Except for some measure of freedom to make agreements for reciprocal trade, ${ }^{2}$ the crown colonies made no appreciable progress in the direction of fiscal freedom. They made no progress, and, unlike the colonies now of the dominions, they attempted no progress in the years from 1858 to 1873 , the ycars in which the colonies of the dominions, both as regards constitutional development and fiscal and diplomatic freedom, were pushing steadily forward to the status of nation within the Empire.

The earlicr of these years, 1858 , is a date-line in the fiscal history of the dominions. It witnessed the enactment by the legislature of the United Provinces of Upper and Lower Canada of the first protectionist tariff in any part of the Empire, after Great Britain had adopted free trade as its fiscal policy in 1846.

1 Cf. Porritt, op. cit., pp. 265-270; Ambrose Pratt, David Syme, the Father of Protection in Australia ; Kimberley, Dispateh of July 13, 1871, to (rovernors of Australian Colonies; Correspondence with the Australian Colonies with Reference to Proposed Intercolonial Tariffs, Colonial Accounts and Papers, 1872 , p. 5 .

2 Cf. Porritt, The Evolution of the Dominion of Canada: its Government and it.: Politics, p. 445 ; Bruce, The Broadstone of Empire, ii, p. 304. 
In fiscal history the Act of the legislature of the United Provinces is known as the Cayley tariff. It took the name from William Cayley, born in Sussex, England, in 1807, who was educated at Eton and Christ Church, Oxford, an emigrant to Upper Canada in 1834, who in 1858 was Inspector-General, or Minister of Finance, in the Government of the United Provinces. ${ }^{1}$

The first conflict between the Colonial Office and a self-governing colony over a protectionist tariff-a tariff antagonistic to the fiscal policy and also to the manufacturing interests of Great Britainwas provoked, not by the Cayley tariff, but by a still more protectionist tariff, enacted by the legislature of Upper and Lower Canada in 1859-a tariff known in the constitutional and fiscal history of the Empire as the Galt tariff, from the name of the Minister of Finance, Alexander Tulloch Galt, who framed it and carried it through the House of Assembly of the legislature at Toronto.

There was no conflict between the Government of the United Provinces and the Colonial Office over the Cayley tariff. It seems somehow to have escaped the attention of the Colonial Office, despite its comparatively high protectionist duties against manufactured imports from the United Kingdom, and its obvious clash with the propaganda of the Colonial Office for tariffs in all the colonies based on free trade.

But the Cayley Act of 1858 was the first protectionist tariff in any British colony after the fiscal revolution in Great Britain of 1846 for which Sir Robert Peel and Lord John Russell were responsible; and it was in the years from 1858 to 1873 -from the enactment of the Cayley tariff ${ }^{2}$ to the repeal in 1873 by the Imperial Parliament ${ }^{3}$ of part of section 31 of the Australian Colonies Government Act of $1850^{4}$-that the self-governing colonies now of the Dominion of Canada and the colonies of

1 Cayley has found no place in the Dictionary of National Biography. For some biographical details I am indebted to his only surviving son, Mr. H. S. Cayley, of the British Columbia bar.

2 Cf. Statutes in Canada; 22 Vict., c. 76.

336 \& 37 Vict., c. 22.

4 'Provided also, and be it enacted,' read section 31 , 'that it shall not be lawful for the legislatures of any of the said colonies to levy any duty upon articles imported for the supply of her Majesty's land or sea forces; nor to levy any duty, impose any prohibition or restriction, or grant any exemption or bounty, drawback or other privilege upon the importation or exportation of any article, nor to impose any dues or charges upon shipping, contrary to or at variance with any treaty or treaties concluded by her Majesty with any foreign power.' 13 \& 14 Vict., c. 59. 
Australasia ${ }^{1}$ achieved the larger part of the complete and unrestrained fiscal freedom that all the colonies now of the dominions have enjoyed since 1898 .

Complete and absolutely unrestricted freedom dates only from 1898 , when the colonies were emancipated from the last remaining restrictions on their full fiscal freedom, restrictions that were due to the existence of twenty-one or twenty-two commercial treaties made by Great Britain before $1878,{ }^{2}$ in which the colonies had been included without consultation and without their consent.

The repeal of section 31 in the Australia Act of the Imperial Parliament, or rather the repeal of part of it in 1873, is another landmark in the history of the fiscal freedom of the colonies nearly as outstanding as the Galt tariff of 1859 , the modern charter of the fiscal freedom of the dominions. The amending Act to the Constitutional Act of 1850 is a landmark of much importance, because the section which was then repealed in part was one that was embodied in the original Act as a matter of fiscal policy by the Whig and free-trade administration of 1846-1852.

It was a part of the written constitution of the Australian colonies that for twenty years estopped any of these colonies, not from enacting protectionist tariffs ${ }^{3}$ uniformly applicable to imports from all countries and similar in aim to the Cayley and Galt tariffs of 1858 and 1859 , but from enacting tariffs in which there were differential duties.

In practice, moreover, section 31 in the Australia Act of 1850 prevented New Zealand from enacting differential duties with a view to agreements for reciprocal trade with any of the Australian colonies. It had this restraining effect, although in the Imperial Act of 1852 for New Zealand, the written constitution of the colony, no section had been inserted by the Conservative Government of 1852 for the express purpose of estopping the legislature of New Zealand from enacting tariffs with differential duties, tariffs in conflict with the principles on which in 1846-1850 the modern commercial and fiscal system of Great Britain had been based.

1 Cape Colony and Natal had no part in the struggle for fiscal freedom of $18+6-1873$.

2 In 1878 self-governing colonios ceased to be ineluded without their consent in eommereial treaties made by Great Britain.

3 Victoria established a protectionist tariff against the United Kingdom and all other countries in 1867 . 
In these fifteen years, 1858-1873, the colonies in Canada and Australasia-not all of them, but most of them-put themselves sharply into conflict with the propaganda from the Colonial Office for tariffs all over the Empire based on free trade ; and, as will be realized from subsequent chapters, these colonies secured for themselves a large measure of fiscal freedom. They secured this freedom, moreover, in face of persistent protests from the Colonial Office, as well as of much adverse criticism in Parliament at Westminster, and many unavailing protests from manufacturing interests in England and Scotland-interests that were exceedingly slow to reconcile themselves to the protectionist duties against British exports in tariffs in British colonies, and slow also to abandon the long existing tradition that England 'holds her colonies for the sole purpose of extending her commerce '. 1

The crown colonies, which in 1917 had a population of forty millions, among whose inhabitants are to be found, in the words of the Book of Daniel, ' all peoples, nations, and languages that dwell in all the earth,' ${ }^{2}$ prospered in the era of British colonial rule that began in 1841. They profited from the partnership between the white and the coloured races by which the resources of the crown colonies are still being developed. ${ }^{3}$ But while both crown colonies and colonies of the dominions have materially prospered in the new era which may be dated from the beginning of responsible government in the British North American provinces in 1841-1849, and the abandonment of the old commercial system by Great Britain in 1846-1849, the crown colonies, unlike the self-governing colonies, point to no advances since 1846 in the direction of fiscal freedom.

Economic and industrial conditions in the crown colonies, although from at least as early as $1862^{4}$ they had impelled some of the West Indian colonies to desire power to make reciprocal tariffs and tariff agreements, never impelled any of the crown colonies to attempt to draw to themselves, as the United Provinces of Upper and Lower Canada had done with complete success in the years from 1858 to 1867 , power to enact protectionist tariffs.

1 Hugh Finley to Sir Evan Nepean, Quebec, February 9, 1789. W. P. M. Kennedy, Documents of the Canadian Constitution, 1759-1915, p. 195.

2 'The Crown Colonies and Protectorates,' Guardian (Manchester), March 20, 1917.

3 Cf. Bruce, op. cit., i, pp. 34-36.

$\checkmark$ Cf. J. H. Gray, Confederation, pp. 353-354. 
None of the crown colonies developed manufacturing industries in respect of which the claim could be advanced that they were in need of protection against British or non-British competition. There were no manufacturing industries, infant or adult; and, moreover, the crown colonies, unlike the provinces of British North America, when they were without infant or adult industries, and when they imported all the manufactured goods they required from the United Kingdom or the United States, had no manufacturing or protectionist neighbours.

The provinces of British North America, and especially Upper and Lower Canada, in the two extremely critical decades of their constitutional and economic history-the twenty years that followed the abandonment of the old commercial system by Great Britain in 1846-had, on the other hand, as their next neighbour, a great non-British country peopled by the same race as were four of the British North American provinces. It was a neighbouring country, moreover, in which a protectionist system was established, and in which in these critical years for the British provinces manufacturing industries were manifestly thriving.

The economic policies of all the British colonies that since 1907 have been of the dominions group, and also the commercial diplomatic policy of Great Britain since 1878-1898, as will become manifest as this history of the fiscal freedom of the dominions proceeds, have been enormously influenced by two conditions which affected the British North American provinces, conditions which were non-existent in the crown colonies, and also non-existent in the colonies of Australasia and South Africa.

These were (1) the fact that Upper and Lower Canada, now Ontario and Quebec, and in 1918 pre-eminently the industrial and manufacturing provinces of the Dominion of Canada, ${ }^{1}$ lie alongside the great manufacturing States of the American Republic ; and (2) that when the opportunity was unexpectedly afforded, through the medium of the Enabling Act passed by Parliament at Westminster in 1846 to free the then existing self-governing colonies from the old commercial system. ${ }^{2}$ of drawing to themselves almost complete control of their fiscal

1 Cf. Porritt, Evolution of the Dominion of Canada, pp. 22-28; Alpheus Todd, P'arliamentary Government in the British C'olonies, p. 184.

2 Cf. $9 \& 10$ Vict., c. 94. 
policy, the United States was already well established on the protectionist basis from which it has never swerved to any marked degree, or with any permanency.

The legislature of Upper Canada had moved for fiscal freedom six years before the Enabling Act was passed by the Imperial Parliament as a measure essential to the rounding out of the freetrade legislation at Westminster of 1846. Fiscal freedom was denied Upper Canada by the Imperial Government in 1840. When it was unexpectedly conceded to all the British North American Provinces in 1846 as incidental to the fiscal revolution of that year in the United Kingdom, manufacturing was prospering in those States nearest to the international line with which by the middle years of the nineteenth century the commercial and social relations of Upper and Lower Canada, long known as the Canadas, were nearly as close as they are or ever were between Scotland and England.

A century and a half intervened between the British and French war of 1756-1763, and the great war which began to convulse the world in the autumn of 1914. In these one hundred and fifty years no factor in world history, not excepting England's struggle with France of 1793-1815, more directly or more variously influenced the constitutional, fiscal, diplomatic, economic and social history of Great Britain, and of the present day dominions, than the American Revolution of 1776-1783.

Had Franklin's boldly advanced plea of 1783 that Great Britain concede the whole of Canada to the United States been granted, it is probable, nay, it appears certain, that the fiscal history of Australasia and the Union of South Africa from 1846 to 1918 would not be the history that, as the facts present themselves, must be unfolded in these pages.

Through its tariff policy, the United States has indelibly impressed itself on the economic and fiscal policies of all the autonomous dominions of Great Britain. Even Newfoundland need not be excepted from this statement; for, while Newfoundland has never had protectionist tariffs, its economic history was influenced by the Elgin-Marcy reciprocity treaty of 1854-1866, and in more recent years by concessions made in tariffs enacted at Washington to fish and other commodities for which the Dominion of Canada and the Dominion of Newfoundland have long sought markets in other than British countries. 


\section{CHAPTER III}

\section{THE OLD COMMERCIAL SYSTEM AND ITS ENFORCE- MENT IN THE COLONIES}

There is no lack of authority for the statement that it was not the intention of the Russell Administration that was responsible for the Act of August 28, 1846, 'an Act,' as the title reads, 'to enable the Legislatures of Certain British Possessions to Reduce or Repeal Certain Duties of Customs,' " that any colonies, coming under the provisions of this Act to complete and round out Peel's free-trade measures of the same eventful session of Parliament, should draw to themselves power to enact tariffs with differential duties, or tariffs in which there were protectionist duties against imports from the United Kingdom or any part of the British Empire.

England was scarcely more taken aback by the Continental Congress at Philadelphia in 1774 , or by the resolutions of the American Association of October of the same year to end all trade relations with Great Britain, than were the Colonial Office, the statesmen and politicians at Westminster, and the commercial and manufacturing classes of the United Kingdom by the enactment in 1859, by the legislature of Upper and Lower Canada, of the protectionist tariff framed and carried through the House of Assembly at Toronto by Galt, a comparative newcomer to Canada from Scotland, who at that time was Minister of Finance of the United Provinces.

The old commercial system extended over the whole of the British Empire. Every detail of it was under the control of Parliament at Westminster, with the Board of Trade, the Treasury, and the Colonial Office in charge of its administration. Legislation of a fiscal and commercial character cnacted in the years from 1783 to 1846 by the legislatures of Newfoundland, Nova Scotia, New Brunswick, Prince Edward Island, and Upper and Lower Canada, the only legislatures in colonies now of the dominions group that before 1846 were empowered to pass any tariff measures,

1 Duties, it will be recalled, that had been imposed on imports into the colonies by legislation cnacted at Westminster in 1843 or earlier. 
was supplementary to the fiscal legislation enacted at Westminster for the Empire at large.

All laws enacted by any of these legislatures of the British North American provinces were not only supplementary to the fiscal legislation of Parliament ; they were subordinate to the Acts of the Imperial Parliament. Every Act of a legislature of a colony concerning customs duties had embodied in it the statement that it was effective only in so far as it did not contravene any Act passed by Parliament at Westminster. There were, moreover, as long as the old commercial system survived, at least five agencies of the Imperial Government whose constitutional or statutory duty it was to prevent any contravention in the colonies of the great body of laws enacted at Westminster to keep the old commercial system intact.

At the capitals of the provinces there were (1) the governors, whose instructions as to their duties and responsibilities in the administration of the fiscal and navigation code of the Empire were detailed, explicit and peremptory ; and on whom extremely heavy penalties might fall in the event of any contravention of the code. ${ }^{1}$ At the ports of entry in all the colonies there were (2) inspectors general of customs duties, who were appointed in London ; and (3) comptrollers and collectors of customs duties, who were appointed by the Treasury, who acted on instructions from London, and were responsible to the Treasury, through which department of state they received their salaries. ${ }^{2}$

At Whitehall there was (4) the Colonial Office, whose political chief was of the Cabinet, by which in practice, though not in form, any Bill of a colonial legislature to which the governor might have given assent for the Crown could be disallowed within two years of its enactment. At Whitehall also there was (5) the committee for trade of the Privy Council, now long known as the Board of Trade.

Under its old, or its modern name, the Board of Trade was a department, closely associated with the Colonial Office, that, in the working of the old commercial system and for half a century after 1846, was vigilant in its microscopic examination of all Bills

\footnotetext{
1 Cf. Instructions to Lord Dorchester, Governor-General of Canada, 1786-1796, dated September 16, 1791, pp. 3-26, Part I, Archives Report (Ottawa), 1904.

2 Parliamentary Debates, III, lvii, 901-902; Return of the Imperial Officers of Customs at Ports in Canada, Nova Scotia, New Brunswick, Prince Edward Island, and Newfoundland, on January 1, 1852, pp. 1-3.
} 
of colonial parliaments or legislatures directly or indirectly affecting tariffs or treaties. It was a department, moreover, that, when legislatures of colonies began to exercise the freedom which accrued to them under the Enabling Act of 1846 and to enact protectionist tariffs, was in practice the guardian at the metropolis of the Empire of commercial treaties cntered into by Great Britain to which colonies now of the dominions willingly or unwillingly were parties.

Until as late as 1876 writers of text-books on the working of the British constitution and on the functions and powers of the various state departments at Whitchall, held that formal sanction of the Board of Tradc must be given to tariff Acts of colonial legislatures before they could receive the assent of the Crown. ${ }^{1}$

One feature stands out prominently in the history of the Board of Trade. It was continuously loyal to the old commercial system. It was also continuously loyal to the new commercial policy of Great Britain, of 1846-1850, as long as the Colonial Office, acting always on the counsel of the Board of Trade, could (1) estop the enactment by legislatures in colonies with responsible government of tariffs with differential duties, or (2) as long as the Colonial Office deemed it worth while to attempt to persuade colonial executives, or colonial Cabinets, not to embark on tariff legislation in which differential duties were embodied. ${ }^{2}$

Only once apparently did the Board of Trade report adversely and strongly to the Colonial Office against a tariff that conflicted with the commercial policy of Grcat Britain, solely by reason of the fact that it embodied protectionist duties that were uniformly applicable to imports from all countries, including the United Kingdom.

The Board of Trade furnished the Colonial Officc with what might not inaptly be described as a free-trade pamphlet against Galt's tariff of 1859 . But, as will subsequently appear, responsible government was firmly established in 1859 in the United Provinces of Upper and Lower Canada, whence came this second protectionist tariff enacted by a colonial legislature after the Enabling Act of the Imperial Parliament went into effect in 1846. Responsible government also by this time was as well established in all the

1 ('f. Alpheus Todd, Parliamentury Corernment in England. II. p. 791.

2 Cf. dispatehes and minutes concerning Tariff Act of Dominion of Canada of 1s68. Sessional Papers (Canada), 1869, Fo. 47. 
British North American provinces, in nearly all the colonies that are to-day of the Commonwealth of Australia, and in New Zealand.

The result of these conditions, all distinctly adverse to the Colonial Office propaganda for colonial tariffs in harmony with the tariff policy of Great Britain, and adverse to any continuous or effective control from Downing Street over fiscal legislation in the self-governing colonies, was a reluctant and avowedly grudging acceptance of the tariff of 1859 of Upper and Lower Canada. The Duke of Newcastle, who as Earl of Lincoln had lost his seat for South Nottinghamshire at the general election of 1846 because of his adhesion to Peel and his free-trade policy, ${ }^{1}$ was at that time, 1859, at the Colonial Office.

Newcastle did not dare to advise Lord Palmerston's Government of 1859-1866 to counsel the withholding of the Royal Assent. The Act went into effect. ${ }^{2}$ A precedent was established for all the other self-governing colonies, in Australasia, as well as in British North America. One division of the propaganda for free-trade legislation all over the Empire completely collapsed within twelve or thirteen years after it had been begun at the Colonial Office in 1846 ; and thereafter it was useless, as a measure of practical politics, for the Board of Trade to trouble itself with tariff Bills from the self-governing colonies that conflicted with British fiscal policy only because they embodied duties for the protection of colonial manufacturing industries.

From 1846 to 1878 , however, there was other work for the Board of Trade in connexion with the fiscal and commercial legislation of the colonies. For ten or eleven years after the acceptance of Galt's tariff had established a precedent in regard to merely protectionist tariffs that could not be ignored in Downing Street, the Board of Trade reported adversely to the Colonial Office on all Bills of colonial legislatures that embodied differential duties.

From the earliest years of the new fiscal system of the United Kingdom, and for as long as the Colonial Office deemed it expedient to estop the British North American provinces from enacting Bills to establish bounty systems to aid colonial industries,

1 Lincoln was the son of the fourth Duke of Newcastle. His father, who was a protectionist, controlled the borough of Newark and also exercised great political influence in the county of Nottingham. Gladstone owed his first seat in the House of Commons to the Duke of Newcastle, who, in 1846, in the exercise of his power as a political boss, dropped both his son and Gladstone, because they had, in the House of Commons, supported the free-trade legislation of Peel.

2 Cf. Porritt, Sixty Years of Protection in Canada, pp. 242-260. 
the Board of Trade reported adversely to the Colonial Office in respect also of these Bills. ${ }^{1}$

The functions of the Board of Trade in connexion with legislation in the colonies were nearly as old as those subdivisions of the old commercial system that had their beginnings in the seventeenth and eighteenth centuries. Notwithstanding the fiscal freedom that accrued to the self-governing colonies from 1846 to 1873 , as a result of their persistent assertion of freedom or persistent demands for freedom, the Board of Trade exercised some functions in regard to tariff legislation in the colonies until as recently as 1898.

In 1898 the self-governing colonies were freed from all commercial treaties made by Great Britain to which they had not been consenting parties. ${ }^{2}$ By this reform, long demanded by the colonies now of the dominions, the Board of Trade was relieved to a large extent, if not entirely, from the duty of safeguarding British commercial treaties from infraction by tariff Acts of colonial parliaments. The Board of Trade has still some functions in connexion with the dominions, chiefly with a view to the extension of the trade of the United Kingdom. But its earlier functions as an advisory authority to the Colonial Office in regard to tariff legislation in the dominions are of the past.

\section{CHAPTER IV}

\section{INROADS IN THE COLONIES ON THE OLD COMMERCIAL SYSTEM-COLONIAL BONUSES AND AIDS TO INDUSTRY, 1820-1846}

THE old commercial system involved as part of its policy the discouragement of all manufacturing in the colonies in the interest of manufacturing in Great Britain. There were many laws with drastic penal provisions to this end, most of them enacted at Westminster in the century from the revolution of 1688 to the successful revolt of the American colonies of 1776-1783.

1 Cf. Iord Norton, 'How Not to Retain the Colonies,' Nineteenth Century, July 1879, p. 187.

2 The treaties denounced by Great Britain in 1897-the treaties which came to an end in 1898-were of an earlier date than 1878, the year in which (ireat Britain began the practice of eonsulting the self-governing colonies before including them in treaties. 
It is not possible to trace any enactments of colonial legislatures earlier than 1825 that were antagonistic to these statutes of the Imperial Parliament. Even after 1825 colonial enactments that conflicted with the purpose of these eighteenth-century British laws were few. They were confined, moreover, to the British North American provinces, the only colonies with large populations until the Australasian colonies, in the middle period of the nineteenth century, began to take on a new importance and began their career as colonies in which responsible government was established.

But in the years from 1825 to 1846 legislatures in the British North American provinces, and in particular the legislatures of Nova Scotia and New Brunswick, in their zeal for industrial development occasionally aided local industries. Government aid was afforded (1) by refunds of duties paid on machinery or on raw materials that had been imported, or (2) by grants in aid to new industrial undertakings, such as iron foundries and forges for the manufacture of iron bars, or woollen mills. ${ }^{1}$

The first of these movements toward what in Canada at any time since 1859 would have been described as a national policy began in 1825. The legislature at Halifax then appropriated $£ 500$ as a bonus to a forge in which bar iron was made. ${ }^{2}$

This was the first direct Government aid to the iron and steel industry, or to any other branch of manufacturing, in any part of the British Colonial Empire. It was the first aid to an industry in Canada to which, from 1883 to 1912 , large bounties were paid from the Treasury at Ottawa under bounty codes enacted at the instance of both Conservative and Liberal Governments. In the years from 1896 to 1912 companies engaged in the manufacturing of iron and steel received nearly seventeen million dollars from Ottawa, in addition to half a million dollars from the government of the province of Ontario, and many concessions of much value from the Dominion Government, from the government of Nova Scotia, and from municipalities in Nova Scotia, Quebec, and Ontario, the iron manufacturing provinces of the Dominion. ${ }^{3}$

All the laws on the statute book at Westminster restraining artificers from emigrating oversea, and prohibiting the export of

1 Cf. Statutes of Nova Scotia, 6 Geo. IV, c. 18 ; 9 Geo. IV, c. 1 ; 5 Vict., c. 1 ; also Statutes of Newfoundland, 3 Vict., c. 12.

2 Cf. Statutes of Nova Scotia, 6 Geo. IV, c. 1 and c. 18.

3 Cf. The Canada Year Book, 1915, pp. 459-640; Porritt, Sixty Yeurs of Protection in Canada, pp. 30, 170, 324, 366, 398-410. 
tools and machinery, had been repealed shortly before the legislature of Nova Scotia granted the bonus of $£ 500$ to the undertakers of the mill for the manufacture of bar iron, for which there was a large and continuous call at the numerous shipbuilding yards for which as early as 1825 Nova Scotia was famous.

These British laws of the eighteenth century, enacted in the spirit of Joshua Gee's conception of 1729 of the old commercial system, 1 and also in the spirit of Chatham's often quoted declaration of his conception of it, ${ }^{2}$ were repealed in 1824 and $1825 .^{3}$ They were repealed, in spite of some opposition from the lace manufacturers of Nottingham, as the result of the investigations and reports of a select committee of the House of Commons.

It was a committee appointed on February 12, 1824, on the motion of Joseph Hume, a motion which was promptly and spiritedly supported and cordially accepted by Huskisson, one of the earliest of fiscal and colonial reformers, who, in 1824, was President of the Board of Trade in the Earl of Liverpool's Administration of 1812-1827.4

In the British North American colonies from 1783 to 1824 these two sub-sections of the code of the old commercial system, one applicable to skilled workmen and the other to machinery, and in particular an Act of $\mathbf{1 7 5 0}$ prohibiting the export of any description of equipment for the manufacture of iron at a stage beyond the blast furnace, ${ }^{5}$ were regarded as imposing an absolute prohibition on the establishment of steel furnaces and slit mills, as a prohibition on any but the primary stage of the iron manufacturing industry. ${ }^{6}$

There was no prohibition on the manufacture of pig iron in

1 'Manufacturers in American colonies should be discouraged-prohibited. We ought always to keep a watchful eye over our colonies to restrain them from setting up any of the manufactures which are carried on in Great Britain. Any such attempt should be crushed in the beginning; for if they are suffered to grow up to maturity, it will be difficult to suppress them.' Joshua Gee, Trade and Navigation of Great Britain (1767), pp. 267, 268. For interpretation and denunciation of Gecism, by advocates of protection for Canadian industries against competition from Great Britain, sce lsaac Buchanan, The Relations of the Ind ustry of C'anada with the Wother Country and the United States, pp. 123-127.

2 "The British colonists in America had no right to manufacture even a nail or a horsc shoe.' Bruce, The Broadstone of Empire, i. p. 145.

33 Geo. IV, c. $97 ; 6$ Geo. IV. c. 105.

4 ('f. Parliamentriry Debates, II, x, 148.

5 Cf. 23 (ieo. II, c. 13; 6 Geo. IV, c. 107 ; sec James Deacon Hume, Dictionary of National Biography, xxviii, p. 22:9.

${ }^{6}$ ('f. (A. F. Drummond, The Iron Industry: What it is to Cireat Britain and the Enited States. What it may be to C'anada, 1. 13. 
British colonies, either before or after the American Revolution. The smelting of pig iron in the colonies was regarded in England, in the eighteenth century, as advantageous to British trade. It was advantageous, it was insisted, for three reasons. It tended to agricultural development in forest areas of the colonies by creating a demand for wood for conversion into charcoal. It reduced the demand on the forest resources of England for wood and charcoal at iron furnaces at home, ${ }^{1}$ and iron production in the colonies added to the quantity of cheap raw or semi-finished material available in England.

Cheapness of pig iron from the colonies was ensured by laws in the old commercial code which prohibited owners of iron furnaces in the colonies, or any other manufacturers, from carrying the iron industry beyond the primary stage, from manufacturing any other description of iron than pig iron, and also by the laws which prohibited the export of colonial made pig iron to any other country than England.2

Parliament at Westminster, accordingly, gave its sanction and full approval to the manufacture of pig iron in the colonies; and, until the American Revolution, bounties were paid on pig iron exported from the colonies to England. ${ }^{3}$

There was an iron furnace at St. Maurice, Three Rivers, Quebec, long before Quebec came under British rule in 1763. The first furnace in Upper Canada, a small charcoal furnace at Gananoque, eighteen miles east of Kingston, went into service in 1800. A mill for the manufacture of bar iron was also established at Gananoque about the same time, notwithstanding the law of 1750 that prohibited the export of tools and machinery for the secondary stages of the iron manufacture. Neither the furnace nor the mill at Gananoque survived beyond $1803 .^{4}$

Other furnaces were established in Upper Canada in the years from 1800 to 1846 , one at Marmora in 1820 , and one at Charlotteville in 1823. It was part of the plan of the promoters of the

1 Cf. Gee, op. cit., pp. 127-128.

2 For many years the ports at which pig iron from the colonies could be landed were restricted to London and one or two ports on the south coast of England. The object of this restriction was to afford the Admiralty the first opportunity of purchasing the imported pig iron for use at the navy yards and the ordnance factories.

${ }^{3}$ Cf. A. P. Newton, The Old and the New Empire, p. 84.

4 Cf. J. H. Bartlett, The Manufacture, Consumption, and Production of Iron and Steel and Coal in the Dominion of Canada, p. 13. 
Marmora furnace to carry the industry beyond the primary stage-to manufacture bar iron and hollow ware. But the legislature of Upper Canada refused either bonuses or bounties to the Marmora undertaking. It refused, moreover, to sanction a Government loan to the promoters; nor would the Governor of Upper Canada, who was responsible for the administration within the province of the code of the old commercial system, sanction the recruiting in England of men skilled in iron manufacturing for the operation of the bar mills. ${ }^{1}$

Governors of British North American colonies not infrequently gave the Royal Assent to Bills of the legislatures for aiding industries by exempting the materials used in these industries from customs duties imposed by Acts of the legislatures. As long as the old commercial system survived, two distinct sets of customs duties were levied at all ports of entry in the British North American provinces. Duties were levied (1) under successive British Possessions Acts, passed by Parliament from 1784 to 1843 , to safeguard the interests of British manufacturers and exporters; and (2) duties were imposed by the legislatures of the provinces to supplement revenues raised under the British Possessions Acts.

Over these local duties the legislatures had control. There was no interference with the collection of these duties on the part of the Treasury in London, and governors evidently were of the opinion that if legislatures exempted certain raw materials from these local customs duties it was no business of theirs to frustrate these efforts to aid local industries.

\section{CHAPTER V \\ THE DECLARATORY ACT OF 17T\&_THE CHARTER OF FINANCIAL FREEDOM OF THE COLONIES}

The revenue raised at ports in the colonies under both the imperial and provincial customs laws, under tariffs enaeted at Westminster and tariffs enacted by the legislatures of the provinces accrued to the treasuries of the provinces or to their eredit. The duties collected under the Possessions Acts accrued to the exehequer of the eolony by virtue of the provisions of the

1 Cf. Bartlett, op. cit., pp. 14-15. 
Declaratory Act of 1778,1 an imperial Act passed while the American colonies were still at war with Great Britain, that in the period from 1778 to the end of the old commercial system and the establishment of responsible government in the colonies, 18411852, was sometimes described as the charter of the financial freedom of the British North American provinces.

In its origin and history the Declaratory Act is nearly as interesting, but far from as important as the Enabling Act of 1846. The Enabling Act, for which Russell and Grey and the other members of the Whig Administration of 1846-1852 were responsible, is at the basis of all fiscal freedom that the dominions enjoy and exercise to-day. It is, moreover, an Act that has never been infringed by any Government at Whitehall, although, unlike the Declaratory Act of 1778, it has had little mention in Canadian or colonial history.

The Declaratory Act, on the other hand, was but an ineffectual charter of financial autonomy for the colonies. Still much value was always attached to it, and it has a unique distinction. It was an Act that was more frequently quoted in debates in Parliament at Westminster, and in the legislatures of British North America, and was more frequently referred to, or embodied in Acts of Parliament and Acts of colonial legislatures, than any other Act of the Imperial Parliament of a later date than the Petition of Right of 1626.

In the second half of the nineteenth century the Act of 1778 came to be regarded as applicable to the colonies of Australia, although at the time it was passed, and until 1788 , there were no British colonial settlements in Australasia. As a charter of the financial autonomy of colonies with representative institutions, at no time from 1792, when popularly elected legislative assemblies and nominated legislative councils were established in Upper and Lower Canada-at no time from 1792 to 1846-was the Declaratory Act continuously and consistently observed. ${ }^{3}$ It was

1 'An Act for removing all doubts and apprehensions concerning taxation by the Parliament of Great Britain in any of the colonies, provinces, and plantations in North America and the West Indies; and for repealing so much of an Act made in the seventh year of the reign of his Majesty (7Geo. III, c. 86) as imposes a duty on tea imported from Great Britain into any colony or plantation in America, or relates thereto' (18 Geo. III, c. 12).

2 Cf. Sydney Smith Bell, Colonial Administration of Great Britain, pp. 346, 347.

3 A typical instance of its non-observance developed in Canada in the second decade of the ninetcenth century. Large surpluses accruing from postal services 
sometimes encroached upon by Parliament, or regarded in the colonies and by advocates at Westminster of democratic and autonomous government in the North American British colonies as having been encroached upon.

It was, moreover, interpreted by Governments at Whitehall, acting through the Colonial Office, and by the General Post Office and the Treasury, in a spirit that aroused continued discontent in Quebec from 1810 to 1837 , and some discontent in Upper and Lower Canada for several years after the union of the provinces in 1840. In Australasia also, even after the Government Act for those colonies of 1850, there were complaints of contraventions of the law of $1778 .^{1}$

One distinction of the Declaratory Act has been mentioned. It has still another distinction that in its way is quite as interesting. For sixty years after the American Revolution, the Declaratory Act was the only indication on the statute book that Great Britain had learned any lesson from the revolt of the American colonies. It was in those years the only statutory indication that the American Revolution had wrought any change in the colonial policy of Great Britain.

Popular indifference to colonial possessions, an indifference that continued in a greater or less degree for a century after 1783, was manifestly one of the results of the loss of the American colonies. It was the most obvious result until the decade from 1840 to 1850 , for no new policy at the Colonial Office resulted from the American Revolution; and from 1778 to 1840-1841,

in Upper and Lower Canada were, despite the Act of 1778, transmitted from Qucbee to London and absorbed into the revenues of St. Martin's-le-Grand, wrongly so, as was held in 1832, by the law officers of the Crown in London. Cf. Opinion of the Law Offieers, November 5, 1832, British Post Offiee Transcripts, Canalian Archives, vol. iv.

1 Cf. Huskisson, House of Commons, May 2, 1828, Parlinmentary Debates. II, xix, 311 ; Lord Goderich, House of Lords, September 5, 1831. 1II, vi, 1183 1185; ; Roebuck, House of Commons, April 15, 1834, III, xxii, 7741, and January 22, 1838, III, xl, 271-272 ; Sir William Molesworth, House of Commons, Deeember 22, 1837. III, xxxix, 1457-1458; Lord Howick, House of Commons, January 16, 1838, III, xl, 83; and Sugden, January 23, 1838. These speeches, and others in the same spirit that it is not necessary to cite, were made in discussions in Parliament on the operation of the Quebee Customs Act of 1747 and of the Deelaratory Aet of 1778. See also instructions to Dorehester, September 16, 1791, and instructions to l'oulett 'Thomson, afterwards Earl of Sydenlam. September 1, 1839, Archives Report (canada). 1905, i, pp. 6-7 and 102; Lord Stanley's circular to governors of colonies, June 28,1843 ; and for the operation of the Act of 1778 in New South Wales, Bell, Colonial Administration of Great Britain, PP. 246-247. 
the year of the union of the provinces of Upper and Lower Canada under an Act of the Imperial Parliament, not a single Act of Parliament was passed that suggested that it was ever realized at Whitehall and Westminster that conditions in the British North American provinces after the American Revolution demanded great and far-reaching changes in British policy toward all the colonies that are now of the dominions.

\section{CHAPTER VI}

\section{THE CRITICAL PERIOD IN NINETEENTH-CENTURY COLONIAL HISTORY, 1 \&46-1873}

THe three decades from 1846 to 1873 were, as regards autonomy, the critical years for the colonies of British North America and of Australasia. These were the decades in which the North American provinces were struggling for responsible government, not only for themselves, but, as events developed, for all the colonies which are now of the dominions. They were the years also in which the United Provinces of Upper and Lower Canada forced the Colonial Office and the British Government to concede to them, and subsequently to the colonies of Australasia, freedom to enact tariffs in which British commercial treaties were safeguarded, but which otherwise were framed without regard to any manufacturing or commercial interests in the United Kingdom.

The colonies in the Australasian group-New Zealand as well as New South Wales, Victoria, South Australia, Queensland, Western Australia, and Tasmania-in these years also forced a reluctant Secretary of State, Kimberley, who was at the Colonial Office from 1870 to 1874 , to move an equally reluctant Cabinet ${ }^{1}$ to call upon Parliament to repeal part of the section in the Australian Government Act of 1850 which estopped the legislatures of all the Australian colonies from enacting tariffs with differential customs duties. ${ }^{2}$

It was the enactment by legislatures in the British North American provinces in the years from 1846 to 1866 of tariffs with

1 Gladstone's Cabinet of 1868-1874.

2 Cf. Kimberley, House of Lords, May 15, 1873, Parliamentary Debates, III. cexv, 1998-2001. 2010-2111; Australian Colonies Duties Act, May 26, 1873, 36 \& 37 Vict., c, 22. 
differential duties that, as will become evident as this history proceeds, impelled the Australian colonies to the persistent and at times bitter agitation of $1867-1873$ for the repeal by Parliament at Westminster of the restraining section of the Constitution Act of 1850 .

The legislatures of the British North American provinces had enacted tariffs with differential duties for the specific purposes (1) of facilitating agreements for reciprocal trade between themselves, and (2) of fulfilling the conditions of the Elgin-Marcy treaty of 1854. The Parliament of the Dominion of Canada in 1867 had also enacted tariffs with differential duties with a view to a new treaty of reciprocity with the United States.

The Colonial Office, as part of the propaganda of 1847-1873 for tariffs in the self-governing colonies in harmony with the free trade principles on which British tariffs were based, had protested against all these tariffs with differential duties in British North America from 1847 to 1870 . But the provinces were unyielding. The tariffs had gone into effect; and as the result of the British North American provinces and the Dominion thus forcing acceptance of their policies on the Colonial Office, and entering into reciprocity agreements among themselves, and also with the United States, the Australasian colonies demanded power to make reciprocity agreements with each other, based on differential duties in colonial tariffs, which were not possible as long as the restraining section of the Imperial Act of 1850 (the Australian Colonies Government Act) was in force.

The Act of 1850 was a measure of the Whig Government of 1846-1852 which assumed power after Peel's defeat in the House of Commons on the Life and Property Bill for Ireland on June 25, 1846. Grey, son of Earl Grey, Premier of the Whig Ministry that carried through Parliament the first reform of the representative system, was Colonial Secretary from 1846 to 1852.

Grey's convictions on free trade were as strong, as rooted, and as assertive as those of Cobden or Bright. The colonial secretaryship in the Russell Administration of 1846-1852 was the last Cabinet office held by Grey. But from the end of that Administration until within two years of his death in 1894, Grey, in the House of Lords and in the press, ${ }^{1}$ continued his

1 Grey eontributed an artiele to the Nineteenth Century for January 1892 in support of the policy of free trade for Great Britain, in which he expressed his 
vigorous advocacy of the principles of free trade, as applicable to all the self-governing colonies as well as to the United Kingdom.

As Colonial Secretary, Grey was primarily responsible for the Australian Colonies Government Act of 1850. His subsequent speeches and writings, political and autobiographical, put it beyond doubt that he was responsible for, and that he attached much value to, the section of the Act which prevented the legislatures in any of the Australian colonies from enacting customs tariff Bills in which there were differential duties.

In the four eventful years that lay between the Enabling Act that received the Royal Assent on August 28, 1846-an Act for which, it.will be recalled, the Russell Administration was also responsible-and the introduction of the Australian Colonies Bill to Parliament, Grey, as Colonial Secretary, intent on moulding the tariffs of all the British North American colonies to harmonize with the new fiscal policy of the United Kingdom, had had discouraging and disconcerting experiences. For the most part he had failed. ${ }^{1}$

Obviously these experiences were in mind when Grey was framing, or closely supervising the framing, of the constitution for the Australian colonies of 1850 ; and to the last, as a Whig member of the House of Lords, unattached to the Gladstone Government of 1868-1874, Grey fought for the retention of the restraining section in the written constitution of the Australian colonies to which he had attached so much value when he was at the Colonial Office in 1846-1852.

great regret that free trade had not been made the policy of the colonies. Late in the same year he published The Commercial Policy of the British Colonies and the McKinley Tariff, a pamphlet in which he condemned the commercial treaty between Great Britain and France of 1860 , and also appealed to the Dominion of Canada to make no more overtures for reciprocity with the United States.

1 Cf. Grey, The Commercial Policy of the British Colonies and the McKinley Tariff, pp. 10-11 ; Kimberley, House of Lords, May 20, 1873, Parliamentary Debates, III, ccxvi, 156-157. 


\section{CHAPTER VII}

\section{NEW ZEALAND'S FISCAL FREEDOM UNDER THE CONSTITUTION OF 1852}

New Zealand did not come within the provisions of the Australian Act of 1850. As regards fiscal freedom its position from 1852 to 1895 was superior to that of the Australian colonies. The New Zealand constitution was enacted at Westminster in 1852. It was framed by the short-lived Conservative Government of February-December 1852. The Earl of Derby, who as Stanley had been Colonial Secretary in 1833-1834 and again in 1841-1845, was Premier. Sir John Pakington, created Baron Hampton in 1874, was at the Colonial Office, a Colonial Secretary who is remembered for the New Zealand Act and also for the fact that, unlike Grey during his administration of the colonies, he sanctioned the establishment of bounty systems to aid industries in the British North American provinces. ${ }^{2}$

Derby, at the Colonial Office in 1841-1845, was vigilant in checking any tendency on the part of the legislatures of the colonies to enact differential duties. ${ }^{3}$ But he exercised that vigilance before the Enabling Act of 1846, and the other free trade legislation of Peel and Russell were on the statute book. It was part of the duty of the Colonial Secretary in the era of the old commercial policy to prevent legislatures in the colonies. from making any inroads on the system, or drawing to themselves in the least degree powers in connexion with fiscal and commercial legislation that were exclusively reserved for Parliament at Westminster.

Unlike the Administration which had preceded it, the Derby Administration was not committed to the policy of establishing free trade all over the Empire. The Conservatives, who in 1846 had acted with Derby, Bentinck, and Disraeli, had opposed the free trade measures of Peel and Russell; and it was not until

\footnotetext{
An Act to grant a representative constitution to the colony of New Zealand, June 30, 1852 (15) \& 16 Vict., e. 72 ).

2 ('f. Journals of the House of A ssembly (Prince Elward Island), March 1, 1852, Aprendix, F, pp. 27-29.

3 Cf. Circular dispateh, by Stanley, (olonial secretary, June 28. 1843. Accounts and P'apers (Colonies), 1846, xxviii, p. 107.
} 
1853 that Disraeli proclaimed to the Conservative party that it was useless for it 'to cling to the rags and tatters of a protective system '. 1

Pakington, Secretary of State for the Colonies in this Administration, unlike Grey who preceded him, and unlike most of the thirteen or fourteen secretaries who followed him in the twentyone years from 1852 to 1873 , had no part in the long continued propaganda from the Colonial Office for tariffs in the self-governing colonies which should embody neither protectionist nor differential duties.

It was fortunate for the fiscal autonomy of New Zealand that a Government not committed to this propaganda of 1847-1895 was in power when the Act under which representative and also responsible government for the colony was established was passed at Westminster in June 1852. It was fortunate because in this Act there was no section estopping the New Zealand legislature from enacting customs laws by which differential duties were established. ${ }^{2}$

The General Assembly of New Zealand, from its first session at Auckland ${ }^{3}$ in 1853 , was, as regards statutory prohibition of differential duties, as free as were any of the legislatures of British North America from 1846 to Confederation, or the Dominion of Canada from the time of its creation in 1867.4 Like these legislatures of British North America, the General Assembly of New Zealand was, until 1898, hampered in enacting tariff laws by commercial treaties entered into by Great Britain before 1878. There were twenty-one or twenty-two of these treaties. The Parliament of New Zealand was also hampered (1) by the fact that until 1873 none of the Australian colonies could make a reciprocity agreement with New Zealand or with any other colony, if that agreement were dependent on differential duties, and (2) by the power of the Government at Whitehall to withhold assent to a reserved Bill, or to disallow an Act of the legislature to which the governor had given his assent. ${ }^{5}$

In the twenty years from 1853 to 1873 the legislature of New

1 Cf. Monypenny and Buckle, Life of Benjamin Disraeli, iii, p. 506.

2 Cf. 15 \& 16 Vict., c. 72 ; Kimberley, House of Lords, May 15, 1873, Parliamentary Debates, III, xxv, 1999.

3 The capital of New Zealand was transferred from Auckland to Wellington in 1865 .

${ }^{4}$ Cf. Grey, Colonial Policy, i, p. 247.

5 Cf. Vogel Memorandum, November 15, 1872.

1569.29 
Zealand, under the written constitution of the colony, could exercise a larger freedom in tariff legislation than the legislatures of the Australian colonies. The power that could be exercised in London to disallow a Tariff Bill from Auckland or Wellingtonany Bill that did not conflict with British commercial treatieswas the same, neither more nor less than the power that might have been exercised by the Palmerston-Russell Administration when it was confronted with Galt's tariff of 1859 .

But in the epoch-making conflict of 1859 between Downing Street and Toronto, between the most aggressive of all the British colonies when any principle of responsible government was at stake and the Whig Government of 1859-1866, the power of disallowance was one which Downing Street no more dared exercise than George $\mathrm{V}$ dared exercise the veto of the sovereign in the case of a Bill that had been carried through Parliament at Westminster by the Cabinet. ${ }^{1}$

By the time the legislature of Upper and Lower Canada determined to establish a national policy for these provinces, determined to protect manufacturing in Canada from all outside competition, British as well as American, responsible government was so firmly established and so unassailable that Galt and his colleagues of the Conservative Government at Toronto were perfectly certain that they took no risks when they intimated to Newcastle and to the Palmerston Government that the only alternative to acceptance of the Tariff Bill was military rule for the United Provinces.

\section{CHAPTER VIII}

\section{THE MOVEMENT OF 1867-1873 FOR LARGER FISCAL FREEDOM FOR THE AUSTRALIAN COLONIES}

Is the zeal of the Colonial Office for its free trade propaganda, which ultimately failed in all the self-governing colonies, one Bill for bounties to industries, and one Bill for differential duties

1 Cf. Todd. Parliamentary Government in the British Colonies, p. 181. In 1879 there was some discussion in England-irresponsible and extra-parliamentary discussion-as to whether the ( iovernment could disallow the Tariff Act of that year of the Dominion Parliament at Ottawa. 'Would this,' asked Lord Norton, who was at the Colonial Office as Parliamentary Under Secretary in $1866^{\circ}$, "have been the way to retain Canadian loyalty, or a very likely way to have lost it ? The question too closely rescmbles that of the Boston tea party to be pleasant.' Norton, 'How Not to Retain the Colonies,' Nineteenth Century. July 1879, p. 176. 
-both measures that had been passed by legislatures of the Maritime Provinces of British North America-were refused the Royal Assent or disallowed in London. ${ }^{1}$

Bounties to industries, it will be recalled, never formed a part of the fiscal and commercial policy of the United Provinces of Upper and Lower Canada. The Colonial Office never had an opportunity of allowing or disallowing a Bill of this character from these provinces. Four or five Bills embodying differential duties were passed by the legislature of the United Provinces. But no Tariff Bill of these provinces ever failed by reason of the withholding of the Royal Assent in Downing Street, or by reason of disallowance there.

Only two, or at most three, bounty or differential duties Bills from any of the British North American provinces in the years from 1846 to Confederation in 1867 failed as the result of action by a British Cabinet. In the British North American provinces this was the extent to which the Colonial Office pushed its propaganda for free trade to the length of advising the Cabinet to veto Bills that were contrary to the principles of the British fiscal system of 1846 .

The Maritime Provinces from 1820 to 1867 were never as aggressive in their attitude towards the Colonial Office as were the provinces of Upper and Lower Canada, where in the years from 1820 to 1867 most of the constitutional history of the provinces now of the Dominion of Canada was made, ${ }^{2}$ and as will become evident in succeeding chapters, it was a characteristic of the Colonial Office to take a high hand with small and weak colonies, and to be much more conciliatory and accommodating when it was at issue with politically aggressive colonies such as the provinces of Upper and Lower Canada. Scarcely a concession insisted upon by Upper and Lower Canada from 1841 to 1867 was denied by the Colonial Office; and in these years the concessions demanded by Upper and Lower Canada affected constitutional and also fiscal and diplomatic freedom.

In the Australasian colonies the Colonial Office used its power in the interest of the propaganda for free trade more frequently than in the British North American colonies. It framed the

1 Cf. Pakington, House of Commons, March 4, 1853. Parliamentary Debates, III, exxiv, 1078-1080.

${ }_{2}$ Cf. Porritt, Evolution of the Dominion of Canada, pp. 89-179. 
Australian Colonies Government Act of 1850 with its propaganda well in mind. Nearly twenty years later it used its power to veto Tariff Bills out of harmony with the principle on which the fiscal system of the United Kingdom was established.

But it used it with much more serious consequences to its propaganda for free trade than had followed the use by Grey of the power to veto Bills for bounties to industry, or Bills for differential duties, which in the years from 1846 to 1852 had originated with the legislatures of the Maritime Provinces. The Colonial Office in the years from 1867 to 1873 used its statutory power under the Act of 1850 and also used the prerogative of the Crown to suspend or disallow a Bill of the legislature of New Zealand.

The first Tariff Bill of an Australian legislature to come into conflict at the Colonial Office with the Imperial Act of 1850 was passed by the legislature of Tasmania in 1867. It was a customs Bill in which there were differential duties. It was disallowed because it was in conflict with the section in the Act of 1850 that had been embodied in it by Grey for the special purpose of estopping the enactment of any such Bills.

Three years later, a Bill with differential duties was again passed by the legislature of Tasmania; and in the same year, 1871, the legislatures of South Australia and New Zealand passed similar Bills. The Tasmania Bill of 1867 precipitated a crisis. Seemingly that was one of its aims, to bring about the repeal of the restraining section in the Act of 1850, and at the Colonial Office the Bills from South Australia and New Zealand were held in suspense, not vetoed or disallowed, pending the fate of the Tasmania Bill of 1871 , a Bill that did provoke a crisis which was not over until 1873, when the Colonial Office, the Gladstone Cabinet, and Parliament all agreed to concede the demands of the Australasian colonies.

The purpose of the two Tasmanian Bills, and also of the New Zealand and South Australian Bills, was to enable these colonies to enter into reciprocal agreements for trade with each other, and with sister Australasian colonies. What were aimed at were agreements similar to those that were operative in the British North American provinees from 1850 until the older provinces now of the Dominion of Canada had come into confederation. The provisions of all the Bills of the Australasian legislatures of 
1867-1871 were identical with those of Acts for intercolonial reciprocity passed by the legislature of Upper and Lower Canada in 1850,1860 , and 1866.1

These Bills from the Australasian colonies were contemporaneous with movements in these colonies in the direction of protection and direct Government aid to manufacturing industries. Victoria had already adopted a protectionist policy, and about the time that the Differential Duties Bill of 1867 was passed in Hobart Town the legislature of Tasmania, following a precedent set by the legislature of Nova Scotia in 1825, was contemplating granting bonuses to aid the establishment of iron and woollen industries. ${ }^{2}$

At the time the Differential Duties Bill of the New Zealand legislature of 1871 was passed at Wellington, the legislature there was not only desirous of reciprocity agreements with the Australian colonies, but was also hopeful, without much ground for hope so far as Washington was concerned, ${ }^{3}$ of effecting a treaty of reciprocity with the United States. New Zealand was thus the first of the Australasian colonies to follow the example of the British North American provinces-the first of the Australasian colonies to move for a reciprocity treaty with the United States, or with any non-British country.

What was desired by the Government at Wellington from the Government at Washington was a treaty on the lines of the ElginMarcy treaty of 1854-1866. This was a treaty urgently desired by all the British North American provinces, and especially by Upper and Lower Canada, after the abandonment of the old commercial system by Great Britain, when tariff preferences at British ports for grain, flour, and lumber from British North America were at an end.

It was the first commercial treaty ever negotiated by British plenipotentiaries exclusively for a colony or a group of colonies. It was a treaty in which there was not a single direct advantage for any manufacturing or commercial interest in the United Kingdom ; and for nearly forty years the Elgin-Marcy treaty, a beneficent treaty for all the British North American provinces

${ }^{1}$ Cf. Colonies and Foreign Possessions, Accounts and Papers, 1873, c. 576 ; No. 6, Vogel Memorandum, pp. 7-14.

2 Cf. Journals of the House of Assembly (Tasmania), 1868, Appendix, No. 88, pp. 3-4.

3 Cf. Porritt, Evolution of the Dominion of Canada, pp. 425-430. 
and also of much advantage to the United States, had one further distinction.

In those years it stood out as the only reciprocity treaty for any British self-governing colony. It ceased to have that place in the diplomatic and economic history of the oversea dominions in 1892, a quarter of a century after its abrogation, in 1866, at the instance of Congress at Washington. In 1892 Sir Charles Tupper, one of the fathers of Confederation, in association with the Earl of Dufferin, the British Ambassador at Paris, negotiated a reciprocity treaty between the Dominion of Canada and France, ${ }^{1}$ and since 1892 there have since been continuous reciprocal trade relations between the Dominion and the French Republic.

\section{CHAPTER IX}

\section{OVERTURES FOR RECIPROCITY WITH THE UNITED STATES -THE NEW ZEALAND OVERTURES OF 1869-1870}

ALL the British North American provinces, except British Columbia, ${ }^{2}$ were included in the reciprocity treaty of 1854-1866. All of them, and in particular Upper and Lower Canada, derived

1 Cf. E. M. Saunders, Life and Letters of Sir Charles Tupper, ii, p. 168.

2 Vancouver Island was organized as a colony in 1849 . It had, however, no legislative assembly until two years after the Elgin-Marey treaty was eoneluded at Washington in 1854. In 1857 the Government of the United States deelined to eoneede to Vaneouver the privileges of the treaty so mueh valued by the provinees east of the Great Lakes. Cf. Journals of the Legislative Assembly (Vaneouver Island), July 16, 1857. The island eolony was united with the eolony on the mainland in November 1866; and from 1868 until British Columbia entered Confederation in 1870, the Paeifie eoast provinee was as desirous as the provinees east of the Great Lakes that there should be a seeond reeiproeity treaty with the United States, a treaty in whieh British Columbia should be ineluded. Cf. Journals of the Legislative Assembly (British Columbia), January 15, 1869.

The legislature of the eolony of Vaneouver Island enaeted in 1865 a tariff in whieh there were duties ranging from twelve and one-half per eent. to twentyfive per eent., and there ensued a small tariff war between the island eolony and the mainland in 1865-1866. British Columbia beeame a eolony with responsible government on the eve of its entry into Confederation. At this time it had a tariff on its statute book as avowedly proteetionist as the tariffs of 1858 and 1859 of the United Provinees. British Columbia also, before cntering Confederation, had unsueeessfully endeavoured to develop iron and woollen industries by bonuses offered by the provineial government. The Pacific coast province from 1870 to 1918 was eontinuously one of the proteetionist provinces of the Dominion. During these forty-eight years it was as steady in its parliamentary support of proteetionist Administrations at Ottawa as the province of Ontario. 
great and manifest advantages from it, and thyre was in 18651866 serious apprehension as to the future $e_{-y}$ the agricultural, lumbering, fishing, and mining industries of British North America when the United States made an end to the agreement.

News as to the prosperity of the British North American provinces under the Elgin-Marcy treaty, and also of the working of the agreements for interprovincial reciprocity, travelled to Wellington and to the capitals of the Australian colonies. Hence the indirect overtures to Washington of 1869-1870 by William Fox, ${ }^{1}$ Premier of New Zealand, for a reciprocity treaty with the United States, and also the Bill of 1871 of the New Zealand General Assembly for differential duties, with a view to agreements for reciprocal trade with the Australian colonies.

The likelihood that New Zealand could at any time between 1865 and 1893 have secured a reciprocity treaty at Washington was exceedingly small. There were no fewer than nine overtures to Washington from the North American provinces, or from the Dominion of Canada, from the end of the Elgin-Marcy treaty in 1866 to $1898 .^{2}$

All these overtures were from Canada. It was intimated at Ottawa in 1898 that overtures to Washington were at an end. No more overtures were made by the Dominion. The overtures for the agreement of 1910-1911, the agreement for reciprocity by concurrent legislation at Washington and Ottawa that was repudiated at the general election to the Dominion Parliament in September 1911, were made by the United States Government. These overtures of 1910-1911 were, with one exception, ${ }^{3}$ the first that Washington made to any province now of the Dominion of Canada, or to the Dominion, after Great Britain adopted free trade in 1846 and abandoned the restrictive policy of the old navigation code in 1849 .

1 Fox, who was knighted in 1880, was a graduate of Wadham College, Oxford, and a member of the Inner Temple. He went out to New Zealand in 1843, as the resident agent at Nelson of the New Zealand Company. He was Premier in 1856, 1861-1862, 1863-1864, 1869-1872, and again in 1873 .

2 There is a diagram summarizing the numerous efforts of the British North American provinces, or of the Dominion of Canada, to secure agreements for reciprocal trade with the United States from 1846 to 1898, at page 126, volume ix, Short and Doughty, Canada and its Provinces-A History of the Canadian People.

3 There was an overture from Washington to Prince Edward Island in 1868not from the State Department, as in 1910, but from a committee of the House of Representatives. Cf. Charles B. Adderley (first Baron Norton), Colonial Policy of Lord John Russell's Administration, p. 67. 
From 1783 to 1846 the United States made several overtures to London for con. ssions in trade with the West Indies, with the Maritime Provinces, and in connexion with the navigation laws. These overtures from Washington came to an end after 1849 , and in the half century from 1849 to 1898 , with the one exception of an overture to Prince Edward Island in 1868 by a committee of the House of Representatives, all the overtures were made to Washington. All told, including the overtures from New Zealand of 1869-1870, there were twelve or thirteen of them. All were for trade or navigation concessions for Great Britain or for British colonies with responsible government.

Except for an overture from London in 1849 for the admission of British ships into the United States coastwise trade, the trade from United States ports on the Atlantic to ports on the Pacific coast, and vice versa, all the overtures were in the interest of colonies that are now of the dominions. ${ }^{1}$

From the end of the Elgin-Marcy treaty in 1866, despite these many overtures on behalf of British colonies with responsible government, there was no reciprocal trade arrangement between Canada and the United States until the enactment of the Underwood-Simmons tariff of October, 1913. In this United States tariff $^{2}$ an offer of reciprocal trade in wheat was made to the Dominion of Canada. It was dependent on concurrent legislation, as was the tariff offer of the United States of 1910. The offer of 1913, unlike that of 1910, was accepted at Ottawa, and from April 1917 there was free trade in wheat between the United States and Canada, as there had been from 1854 to $1866 .^{3}$

1 In this enumeration is not included the reciprocity treaty of 1892 with the United States in respeet of the West India Islands, a treaty under whieh sugar from these Crown colonies was admitted into the United States with the full advantage of the free list. Cf. Bruee, The Broadstone of Empire, ii, p. 304.

${ }^{2}$ Seetion 66 provides that wheat shall be subject to a duty of ten eents per bushel ; that wheat flour shall be subjeet to a duty of forty-five cents per barrel of 196 pounds ; and semolina and other products of wheat not speeially provided for in this seetion ten per eent. ad valorem when imported direetly or indirectly from a eountry, dependeney. or other subdivision of government, whieh imposes a duty on wheat or wheat flour imported from the United States. An Aet to reduee tariff duties, and to provide revenue for the Government and for other purposes, October 3, 1913.

3 The Act making this change in the tariff of the Dominion was passed at the instanee of the Conservative Government of 1911-1917, a Government that had eome into power as a direet result of the defeat of the Reeiproeity Bill of 1911 . The Aet of 1917 plaeing wheat and wheat produets on the free list was a war measure. The Conservative Government was eharged by Liberal newspapers whieh had supported the Reeiprocity Bill of 1911, the Bill of the Laurier Govern. 
But movements for reciprocity with Canada, movements with any prospect of success in Congress, and particularly in the Senate, were developments in American tariff politics that did not come until the second year of Mr. Taft's term as President (1909-1913). Conditions were peculiarly adverse to any reciprocity agreements with British colonies, and especially with the British provinces on the mainland of North America, from the end of the Civil War of 1861-1865 to 1874 .

Only lack in New Zealand of intimate knowledge of political conditions at Washington in these years could explain the movement at Wellington of $1869-1870^{1}$ for reciprocity with the United States. It could not have been realized at Wellington that in March 1867 there had been opposition in the House of Representatives, and also in the Senate ${ }^{2}$ at Washington to the confederation of the British North American provinces. Nor could it have been known in New Zealand that President Grant, in his Message to Congress of December 6, 1869, had declared emphatically and unequivocally against any renewal of reciprocity with Canada. ${ }^{3}$

It had been known in London from as early as July 1859nearly two years before the Civil War began, and friction that

ment of 1896-1911, with stealing the policy of the Liberal party. 'It may be admitted at once,' said the Gazette of Montreal, a Conservative journal (April 19, 1917), "that the action recently taken by the Government seems to be a departure in policy; seems to be, but is not. When the national policy tariff was introduced in 1879 there was embodied in the Tariff Act a provision for reciprocity with the United States in natural products, and this provision remained on the statute book for many years. If now wheat and flour are placed on the free list in order to obtain a free market for these articles in the United States, no abnegation of policy or principle is involved. We are confronted with a condition, not a theory. Lower grade wheat has not an adequate market in Canada; nor can it, under war conditions, be exported to Great Britain and Europe; and unfortunately much of the north-western wheat crop of 1916 graded low because of adverse weather conditions. And so an outlet for this product is sought in the United States, where a demand for the grain exists.'

1 Cf. Letter of W. Fox, Premier of New Zealand, 1869-1872, to H. Driver, United States consular agent at Dunedin, March 19, 1870. Journals of the House of Representatives (New Zealand), 1870, D. No. 1, A.

2 Cf. Porritt, Evolution of the Dominion of Canada, pp. 200-205.

3 'The question of renewing a treaty for reciprocal trade between the United States and the British Provinces on this continent,' wrote Grant, 'has not been favourably considered by the Administration. 'The advantages of such a treaty would be wholly in favor of the British producer. Except, possibly, a few engaged in the trade between the two sections, no citizen of the United States would be benefited by reciprocity. Our internal taxation would prove a protection to the British producer almost equal to the protection which our manufacturers now receive from the tariff.' J. D. Richardson, Messages and Papers of the Presidents, vii, p. 34-5. 
was threatening developed between the United States and Great Britain, and also between the United States and at least three of the British North American provinces, Upper and Lower Canada and Nova Scotia-that there was little likelihood that Washington would renew the reciprocity treaty of $1854^{1}$

At Washington, Galt's protectionist tariff of 1859 , with its high duties against manufactured goods from the United States, was regarded as antagonistic to the spirit of the treaty of 1854 . There had been friction, moreover, over discriminatory tolls on the Canadian canals, tolls imposed to divert trade from American lake ports to Montreal and Quebec.

All this friction had developed before the Civil War. Then came the much more serious friction arising out of the war. This friction continued after the denunciation of the treaty in 1865. It continued for nearly ten years after the war, and at no time was the outlook at Washington for tariff concessions to any British colony less promising than it was from 1865 to the winter of 1874-1875.

Sir John A. Macdonald, Premier of the Dominion of Canada from 1867 to 1873 , and again from 1878 to 1891 , realized these conditions when the treaty of Washington was negotiated in Mareh 1871. So also did George Brown, one of the fathers of Confederation, when he was in Washington in 1874, as commissioner from the Mackenzie Government of 1873-1878, to renew an attempt for another reciprocity treaty, an attempt in which Macdonald and his colleagues of the British mission of 1871 had eompletely failed. ${ }^{2}$

The overtures of 1869-1870 of the Government at Wellington for reciprocity with the United States did not reach a formal stage. At the instanee of the Colonial Offiee, the Foreign Offiee in London took an active part in the negotiations of 1865-1874 for the renewal of the reeiprocity treaty bctween the United States and Canada, quite as aetive a part as it had taken in the negotiations of 1848-1854, which prceeded the Elgin-Narey treaty.

But in 1869-1870 the Foreign Offiee was little disposed to push

1 Cf. Thomas, second Baron Newton. Lord Lyons: A Record of British Diplomacy, i, p. 17 ; Porritt, Sixty Yars of Protection in Canada, pp. 129-146.

2 Cf. Newton, Life of Lord Lyons, i, p. 74; Joseph Pope, Memoirs of Sir John A. Macilonald, ii, pp. 90-94; Alexinder Mackenzie, Life and Speeches of George Brown. pp. 136-137; R. White, House of Commons, Ottawa, March 19. 1883, Parliamentury Debates (Ottawa), 1883, i, 269 ; Porritt, Exolution of the Dominion of 'canada, pp. 465-467. 
at Washington for a reciprocity treaty for New Zealand, and it is not possible to discover that it made any move there. It was well aware of the precarious chance of a renewal of the treaty with Canada and also of the mood at Washington toward Great Britain arising out of the Alabama difficulty; the claim of the Dominion of Canada arising out of the Fenian invasion of Upper Canada at the end of the Civil War ; and other disturbing questions then at issue between Great Britain and the Dominion of Canada and the United States.

Fiscal freedom, as will become evident in later chapters, pushed the British North American provinces and the Dominion of Canada into diplomacy. Out of fiscal freedom there soon developed the demand on the part of the British North American provinces of 1840-1867 that they be permitted by the Foreign Office in London to name their own plenipotentiaries to conduct negotiations for reciprocity treaties with non-British countries, and in process of time, 1865-1907, this demand was fully conceded by Great Britain.

The overtures to Washington of $1869-1870$ were the first venture of New Zealand, or of any of the Australasian colonies, into diplomacy. Fox, the Premier of New Zealand, apparently did not ask Downing Street for permission to negotiate. He opened negotiations directly with the United States consul at Dunedin. The negotiations were not carried far, and it is not conceivable that had the Government at Wellington been informed of conditions at Washington in 1869-1870 even these informal overtures for reciprocity would have been made.

\section{CHAPTER $\mathrm{X}$}

\section{THE AUSTRALIAN COLONIES AND DIFFERENTIAL DUTIES}

There was obviously no hope in 1869-1870 for a reciprocity agreement between New Zealand and the United States. Nor would it have been possible in 1867-1868 for Tasmania, or any of the other colonies now of the Commonwealth of Australia, to have entered into reciprocity agreements with New Zealand, until Parliament at Westminster, moved thereto by the Cabinet at tine instance of the Colonial Office, had repealed or modified the 
section of the constitution of 1850 which prevented the legislatures of the Australian colonies from establishing customs duties which were not uniformly applicable to imports from all countries.

A Conservative Administration was in power at the time the Tasmania Bill of 1867, which had been reserved by the Governor, ${ }^{1}$ reached London for action by the Colonial Office and the Gabinet. Like all preceding Governments, Liberal and Conservative, the Conservative Government of 1866-1868 was continuing the propaganda begun by the Russell Administration of 1846-1852 for fiscal legislation in the self-governing colonies that would harmonize with the fiscal policy of Great Britain.

Derby and Disraeli were successively the Premiers of the Administration of 1866-1868. But these Conservative and formerly protectionist leaders had for nearly twenty years accepted as established and unassailable the fiscal policy of Great Britain, although Disraeli, to the end of his career in 1881, was of opinion that the United Kingdom would return to protection. ${ }^{2}$

In accordance with the policy of endeavouring to hold the self-governing colonies to free trade - the policy at the Colonial Office which Grey had inaugurated and pushed with such vigour and persistence from 1847 to 1852 , and also, as he thought, adequately safeguarded in the Australian Colonies Act of 1850 the Royal Assent was withheld from the Tasmania Bill with its provision for differential duties.

By this time, as will be recalled, Victoria, Tasmania, and New Zealand were moving toward protectionist policies. In New Zealand the movement was toward bonuses, as well as tariff

1 A reserved Bill is a measure that has gone through all its stages in a eolonial legislature-through both Houses in colonies in which there are two Chambersbut from which the Governor has withheld his assent, and transmitted the Bill to the Colonial Office. If assent is refused, the Bill fails. It is a measure to which the veto of the Crown has been applied. A Bill that is disallowed is a measure to which the Governor has given the Royal Assent, but on which the power of disallowance, nominally by the Crown, in practice by the Cabinet, on the advice of the Colonial Office. has been exercised. As will be noted in subsequent chapters, sweeping changes as regard reservation of Bills and disallowance of Bills came quickly in the train of responsible government in all the colonies now of the dominions.

2. In this opinion he never varied. Lord Rowton, after the tariff reform movement began (the Chamberlain movement of 1903-1914), though a free trader himself, told a friend that Lord Beaconsfield had always said that England would return to protection.' W. F. Monypenny and (i. E. Buckle, The Life of Benjamin IDisraeli, Earl of Beaconsfitld, iii, 1). 26. Rowton was private secretary to Disraeli from 1866 to 1881 . 
protection, for industries. 1 There had as yet, moreover, been no official intimation to any of the colonies, British North American or Australasian, that the Colonial Office, thwarted after 1859 in its efforts to hold the British North American provinces to free trade principles, had abandoned part of its propaganda. There had been no intimation that after its experience with Galt and the tariff of Upper and Lower Canada of 1859, the Colonial Office had narrowed its propaganda to efforts to restrain the colonies from establishing differential duties.

Official intimation to this effect was not made until July 1871. Governors and executive councils-colonial Cabinets-were then informed by Kimberley, Secretary of State for the Colonies in the Gladstone Administration of 1868-1874, that Downing Street had relinquished 'all interference with the imposition, by a colonial legislature, of equal duties upon goods from all places, although these duties might really have the effect of protection to the native products '. ${ }^{2}$

This landmark in the progress of the dominions to complete fiscal freedom, a landmark nearly as outstanding as the Galt and Newcastle correspondence of 1859, was, however, not set up by Kimberley until the contest between the Colonial Office and the Australasian colonies over differential duties was well advanced, ${ }^{3}$ and the issue was undoubtedly tending in favour of the colonial executives and legislatures.

From 1867 to 1873 the Australasian colonies were intent on securing all the fiscal freedom that the United Provinces of Upper and Lower Canada had won for themselves in the sixteen years from 1850 to 1866 , and won by the same tactics that they had adopted from 1828 to 1849 in the contest with Downing Street for responsible government.

The tactics adopted by Baldwin and La Fontaine, the leaders of the Liberal party in the United Provinces in the contest for

1 Cf. John Johnston, Legislative Council, New Zealand, August 11, 1870. Parliamentary Debates (New Zealand), viii, 447 ; Pratt, David Syme, pp. 156-157; Adderley, Colonial Policy, pp. 110-111.

2 Dispatch by Kimberley to governors of Australasian colonies, Downing Street, July 13, 1871. Correspondence with the Australian colonies with reference to proposed intercolonial tariffs, Colonial Accounts and Papers, 1872, p. 5.

3 Kimberley's dispatch was dated July 6, 1871. It was written at the time when the decision of the Gladstone Cabinet as to giving or withholding the Royal Assent to the second Bill from Tasmania, and also as to giving or withholding the Royal Assent to the Bills for differential duties of the legislatures of New Zealand and South Australia, was pending. 
responsible government, and by the Conservative Government of these provinces when the tariff of 1859 was the issue, were much the same. Baldwin and La Fontaine and their supporters in the legislature insisted on the establishment, in connexion with the provincial government, of a constitutional usage, or unwritten law of the constitution, similar to that at Westminster which had been established and continuously recognized there from as early as the reign of William III. If this usage were not established, Downing Street was to be confronted with a deadlock at the political capital of the provinces, a deadlock that could be permanently ended only by a suspension of parliamentary government and a reversion to Crown Colony rule, supplemented by military force.

In the second case - the demand of the United Provinces to be permitted to enact a tariff without regard to the effect on manufacturing, exporting, and shipping interests in the United Kingdom - the Cartier-Macdonald Government carried the Bill through the legislature, the Tariff Bill of 1859, and then made it plain to the Colonial Office, the office that Derby once described as 'the office at war with the colonies', 1 that sooner or later ${ }^{2}$ it would be compelled to concede all that was at issue.

These were the methods by which both responsible government and fiscal freedom were secured by the United Provinces ; and at Confederation in 1867 , as regards responsible government and fiscal freedom, the Parliament of the Dominion of Canada merely succeeded to what had been won by the United Provinces-to nothing more nor less. ${ }^{3}$

Inspired by the example and by the long series of successes of the British North American provinces in drawing to themselves constitutional and fiscal freedom, all the Australian colonies in 1867-1873 were much in the mood towards the Colonial Office

1 Cf. Adderley, op. cit., p. 99.

2 'If you make it as pointed as possible, it takes a long while to stick it into the official mind in Downing Street.' George E. Foster, Minister of Finance, Dominion of Canada, 1888-1896. Colonial conference at Ottawa, July 4, 1894. Official Report, Sessional Papers (Canada). No. 5, B. 1894, p. 163.

3 - Confederation did not give us any new constitutional powers-any powers wo had not before. Confederation simply consolidated together the self-governing colonies. .. . The prowers possessed by the colonies before confederation were undoubtedly as great as those now possessed by the Dominion of Canada. 'Sir Wilfrid Laurier. leader of the Liberal party, 1891-1896; Premier of the Dominion, 1896-1911. House of Commons, Ottawa, September 30, 1891. Parliamentary Debates, 1891, iii, 6316. Cf. Porritt, Evolution of the Dominion of Canada, pp. 245-261. 
that had characterized Upper and Lower Canada in its relations with Downing Street in 1841-1859, the period during which the contests for responsible government and for fiscal freedom were going on.

In the Australasian colonies after 1850 and 1852, after the constitutions framed and enacted at Westminster for these colonies were in operation, the power of the legislatures to enact protectionist tariffs was not questioned, or its exercise protested by the Colonial Office ; for there were no protectionist tariffs in the Australasian colonies until 1867, eight years after the provinces of Upper and Lower Canada had abandoned free trade, and established themselves on a protectionist basis.

Nor is it possible to trace any protests from the Colonial Office against the statutes of the Australasian colonies under which bonuses and bounties were authorized to be paid to aid in the upbuilding of manufacturing industries, or under which, as in New Zealand, preferences were established in regard to Government contracts for colonial-made goods.

These methods of affording direct Government aid to industry were all antagonistic to the principles of free trade. Grey, when he was at the Colonial Office, it will be recalled, had vetoed Bills to the same end, Bills enacted by the legislatures of New Brunswick and Prince Edward Island. But in the case of the Australasian colonies there would seem to have been no objection from the Colonial Office to Acts of the legislatures of this character.

The history of the fiscal freedom of Australia and New Zealand is marked by sharp, almost rasping, interchanges between the Colonial Office and colonial premiers and other colonial ministers. In some of these interchanges colonial ministers were as outspoken as Galt in his interchanges of 1859 with Newcastle. But all these sharp interchanges were of the years from 1867 to 1873 . They developed out of the contest over differential duties, the only contest between the Australasian colonies and Downing Street over tariffs, until all the self-governing colonies began to demand freedom from the operation of British commercial treaties to which they had been made parties without their consent.

These interchanges of 1867-1873 belong to what may be described as the second division of the Government propaganda for a free trade Empire. Kimberley, who made the last stand at 
the Colonial Office for the fiscal policy of 1846, was the unfortunate recipient of the protests from the Australasian colonies, as Newcastle was the equally unfortunate recipient of the epochmaking minutes of council, prepared by Galt, in justification of the tariff policy of 1859 of the Cartier-Macdonald Administration at Toronto.

These communications from the Australasian colonies -minutes of council, written usually by the Minister of Finance-reached Kimberley through the governors of colonies, the medium of all dispatches from and to the Colonial Office. In at least two instances, governors wrote dispatches in which, with no reserve or qualifications, they supported the claims of their ministers.

These dispatches and all the minutes of council from the capitals of the colonies were in answer to dispatches from Downing Street. They were in reply to dispatches from the Colonial Office, in some cases as long as pamphlets, in which Kimberley, the Colonial Secretary, contended academically for the fiscal policy of Great Britain and argued with the zeal of a pamphleteer against the policy of differential duties. ${ }^{1}$

\section{CHAPTER XI}

\section{FREE TRADE PROPAGANDA FROM WESTMINSTER 1846 TO 1895}

There were, as will have been realized, two divisions of the Colonial Office propaganda for tariffs in the self-governing colonies in accordance with the principles of free trade. It was, moreover, a propaganda in which the House of Commons and the House of Lords, or rather members of the two houses of free trade convictions, at times had a part until as late as 1895 .

Only once did the Colonial Office ask Parliament to associate itself with the propaganda. This was in 1850 , when Parliament gave its approval to the section in the Australian Colonies Government Bill which Grey had introduced into the measure in order to prevent the legislatures of any of the Australian colonies from enacting customs Bills with differential duties.

1 A summary of the correspondence over the question of differential duties-Kimberley's dispatehes and the rephies thereto-will be found in the Appendices. 
Later than 1850 members of the House of Commons and the House of Lords volunteered their services to the propaganda as opportunity offered. Opportunities came in 1873 and 1895 when Bills, Government measures, were before Parliament: (1) for partially liberating, and (2) for completely liberating, the Australian colonies from the restraining section of the Imperial Act of 1850. Opportunities for aid to the propaganda were made in 1879,1883 , and 1887 , when there were strongly expressed protests in the House of Commons and in the House of Lords, by members of free trade convictions, against the high duties on imports from the United Kingdom in the tariffs of the Dominion of Canada. ${ }^{1}$

The first division of the propaganda was for tariffs, and other fiscal and commercial legislation in all the colonies, in which there should be no protectionist duties and no bounties or bonuses or other governmental aid to manufacturing industries. Only in the British North American provinces were attempts made to push this division of the propaganda.

The second division of the propaganda, pushed from 1846 to 1895, in the British North American provinces, in the Australasian colonies, and also to some degree in Cape Colony, was for tariffs in which there should be no differential duties. The purpose of this division was to secure the enactment by colonial legislatures of tariffs uniformly applicable to imports from all countries, British and non-British. The two divisions, each with a distinct and easily traceable history, overlapped from 1846 to 1859 .

After Newcastle, who was Secretary of State for the Colonies in the Palmerston Government of 1859-1866, gave way to political conditions in Upper and Lower Canada-after he had realized the impasse that confronted him at Toronto, ${ }^{2}$ and that he dare not risk a Boston tea party in Canada, ${ }^{3}$ and consequently could not recommend the Cabinet to advise the Crown to withhold

1 These protests at Westminster against tariffs of the Dominion of Canada, the only colonial tariffs that were ever criticized in the Imperial Parliament, with the answers to them by the Secretaries of State for the Colonies, will be found in the appendices.

2 A summary of the correspondence over the Galt tariff of 1859 , that made this impasse unmistakably evident to Newcastle and his colleagues of the Palmerston Cabinet, is given in the appendices.

3 Cf. Norton, 'How Not to Retain the Colonies,' Nineteenth Century, July 1879, p. 176.

1569.29 
assent from the Tariff Bill of 1859, the first division of the propaganda came to an abrupt end.

The propaganda for tariffs in which there should be no protectionist duties could obviously not be carried on longer with any hope of success. After Galt's tariff had been acceptedmost reluctantly accepted by the Colonial Office and the Government in Downing Street-it was useless to attempt to continue it in any of the other British North American provinces.

Up to this time, 1859, there had been no movement towards protection in any of the Australasian colonies. It was 1860 before Syme, of the Melbourne Age, began the movement for protection in Victoria. It was 1867 before the first protectionist tariff in any of the Australasian colonies, the tariff of Victoria, went into operation.

But after the Palmerston Government in 1859 had surrendered to the protectionist movement in Upper and Lower Canada, led in the constituencies by Buchanan and Weir, and in the legislature at Toronto by Cayley, Galt, Cartier, Macdonald, and Rose, it was useless to attempt to begin the propaganda in the Australasian colonies for tariffs with no protectionist duties. What had been conceded to Upper and Lower Canada - the right to enact tariffs with protectionist duties against all comers-could not, with responsible government established in all the colonies, be withheld from the Australian colonies or from New Zealand.

The Colonial Office by 1859 had ceased to object to Acts of the legislatures of the Maritime Provinces of Canada granting bounties or bonuses to industries; and it was only in the Maritime Provinces that attempts had been made to aid industry by such means. Movements toward a national policy are of the economic history of all the British North American provinces from 1846 to 1859. But bounty legislation found favour only in the Maritime Provinces; while in Upper and Lower Canada efforts in the direction of a national policy were confined to the enactment of tariffs with high duties in the interest of infant industries in these provinces.

Galt's tariff fell automatically into the class of reserved Bills. It was a Bill to which the Governor-General could not give the Royal Assent. His instructions specifically prohibited his giving the Royal Assent to a Bill of this character. The Royal Assent, in the case of the Tariff Bill of 1859, could be given only in London. 
It was there that the question of giving or withholding the assent had to be determined by the Cabinet.

It was the most difficult colonial question that ever came before a Cabinet after responsible government had been conceded to the colonies now of the dominions. The Royal Assent was given to the Bill from Toronto ; and thereafter the first division of the colonial propaganda was at an end, although, as will be recalled, the Colonial Office did not proclaim the failure and abandonment of the propaganda against protectionist duties and bounties and bonuses to industries until July 1871.

The second division of the propaganda - the movement from the Colonial Office to persuade colonial governments not to call upon legislatures to pass tariff Bills in which differential duties were embodied, or to restrain colonial legislatures from passing such Bills-was pushed in the British North American provinces from 1846 to Confederation. It was also pushed at Ottawa until 1870 , with as little success as it had been from 1846 to 1867 in the United Provinces of Upper and Lower Canada. About the time this second division had reached a hopeless stage at Ottawa, or at least from as early as 1868 , it was transferred to the Australian colonies, where up to this time there had been no general tariff Bills with differential duties.

Despite the concession to these colonies in 1873, a concession which permitted of tariffs framed to facilitate agreements for intercolonial trade between the Australasian colonies similar to the agreements between British North American colonies of $1850-1867,{ }^{1}$ the second division of the propaganda was continued, but within a much narrowed field, until 1895 .

A second concession was then made, a concession which constitutionally affected only the Australian colonies, but after March 1895, it was possible for all the colonies under responsible government, without any interference from the Colonial Office, to enact such tariffs as would facilitate agreements with each other for reciprocal trade, with the United Kingdom, and also with countries not within the British Empire.

The Australian colonies - New South Wales, Victoria, Tasmania, Queensland, Western Australia, and South Australia - from 1873 to 1895 could enter into trade agreements based on concurrent legislation, with each other and also with New Zealand. Agreements

${ }^{1}$ Cf. Official Report, Ottawa Conference, 1894, pp. 74-75. 
of this character were, it was hoped, in sight from 1867 to 1873 , when all the Australasian colonies were pressing the Colonial Office to relieve them from the restraining section of the Australian Colonies Government Act of 1850.

No such agreements, as a matter of fact, were made in the twenty-two years from 1873 to 1895 . There were none, despite the hopes of 1867-1873, because the several colonies could come to no agreement as to the tariff concessions to be made to establish reciprocal trade. For the same reason there was no general customs union among the colonies until after the Commonwealth of Australia was created in 1900.1

In these years, 1873-1895, all the Australasian colonies were constitutionally free to make agreements for reciprocal trade. All the legislatures were free, so far as interference by the Colonial Office was concerned, to enact tariffs with differential duties to that end. But until complete freedom from the restraining section of the Imperial Act of 1850 was conceded by Parliament at Westminster in 1895, these agreements could be made only with each other and with New Zealand.

As a result, consequently, of the policy of the Russell Administration of 1842-1852 in framing the constitution of 1850-as a result of the propaganda begun by Grey when he was at the Colonial Office - the states now of the Commonwealth of Australia, from 1850 to 1873 , and again from 1873 to 1895 , could exercise much less fiscal freedom than that which was actually exercised by the British North American provinces from 1850 to 1867, and less than was exercised by the Dominion of Canada from 1867 to 1895 .

For forty-five years the Australian colonies, organized under the Imperial Aet of 1850, had far less fiscal autonomy than New Zealand possessed under its constitution of 1852. The Australian colonies, in these years, had even less power as regards tariff legislation than Cape Colony and Natal; for in 1889 the Colonial Office sanctioned a Bill of the legislature at Cape Town for a eustoms union with the Orange Free State, in which, moreover, there were differential duties.'

1 'For twenty years wo have had this power of making mutual agreements ; yet we have never exercised it. - A. J. Thynne, Representative of Queensland, at Colonial Conference, Ottawa, 1894.

2 "If the ficrmans in the adjoining territory liked, they conld, of course, claim the same privileges as the Orange River State mnder the Zollverein treaty:Sir Charles Miles, one of the Representatives of Cape Colony, at the Ottawa 
The estopping of the Australasian colonies from enacting tariffs with differential duties in the years from 1850 to 1895 -differential duties which were general in character, as distinct from differentials that could be applied only between one Australasian colony and other colonies in Australasia -was the only success that attended the Colonial Office propaganda for free trade that was persisted in against great odds for half a century by Colonial Secretaries and by administrations in Downing Street of both political parties. But except for the extent to which the fiscal powers section of the Constitution Act of 1850 directly restrained all the Australasian colonies, and indirectly restrained New Zealand from enacting differential duties, no success to which any permanency attached can be credited to the propaganda.

It entailed much hard work, sometimes harassing work, for successive Secretaries of State for the Colonies. At least twice during the period from 1846 to 1895 -in 1859, when the Galt tariff was at issue, and in 1870-1873, when the Australasian colonies were demanding freedom from the restraining section of 1850 - the propaganda developed embarrassing situations for Cabinets in Downing Street. Moreover, after the episodes in Montreal and at Westminster that developed out of the Rebellion Losses Act of 1849, an enactment of the legislature of Upper and Lower Canada, no policy of the Colonial Office caused more friction between the self-governing colonies and Downing Street than the long-continued effort of the Colonial Office to mould the tariff and commercial legislation of the colonies to accord with the free trade policy of Great Britain.

Conference, June 30, 1894, Official Report, p. 70. The differential duties of the South African customs union of 1889 to 1893 were applicable only to imports coming in overland. The Colonial Office, in its policy of 1846-1895 in regard to differential duties, insisted that the Act of the legislature at Cape Town should not apply to imports from overseas. Report of Ottawa Conference, 1894, pp. 67-82. Parliamentary Debates, III, xxxi, 647, 852-853; an Act to amend the law with respect to customs duties in the Australian colonies, March 28, 1895 (58 \& 59 Vict., c. 3); Keith, iii, p. 1181. 


\section{CHAPTER XII}

\section{THE AUSTRALASIAN COLONIES AND THE FREE TRADE PROPAGANDA OF THE COLONIAL OFFICE}

The withholding of the Royal Assent in January 1868 by the Disraeli administration, in which the Duke of Buckingham and Chandos was Colonial Secretary, to the Bill of 1867 of the legislature of Tasmania enacting differential duties ${ }^{1}$ precipitated the second of the memorable conflicts between Colonial Governments and the Colonial Office, the second conflict that marks the history of the struggle in the colonies now of the dominions for complete and unrestrained fiscal freedom.

The Bill was intended as a preliminary to reciprocity agreements with Victoria and other of the Australian colonies. All these colonies were keenly interested in the fortunes in Downing Street of this Bill of 1867. So was New Zealand; and the exercise of the veto on the Tasmania Bill by the Conservative Government of 1866-1868 provoked the most long drawn out of any of the conflicts between the self-governing colonies and Governments in London, arising out of Great Britain's fiscal policy of 1846 and the new constitutional relations of 1840-1867 of the colonies now of the dominions to Parliament, the Colonial Office, and the Treasury.

All the Australasian colonies, and particularly New Zealand, Victoria, New South Wales, Tasmania, and Queensland, were in a mood to push for a settlement of the issue raised by the veto of the Tasmania Bill. They were determined on a settlement which they fully realized must necessarily be contrary to the convictions held for a quarter of a century by statesmen of both political parties at Westminster concerning the fiscal policy of the United Kingdom.

At all the political capitals in Australasia after news was received in 1868 of the failure of the Bill from Hobart Town to receive the Royal Assent, the attit ude of the Colonial Governments towards Downing Street was the same. Correspondence with the

1 ('f. Journals of the Legislative Assembly of Tasmania. 1868, Appendix, No. 53. 1; Quick and Garran, The Annotated C'onstitution of the Australian Commonuealth, p. 697. 
Colonial Office of 1871-1873, dispatches from governors, and minutes of council transmitted by governors to Downing Street, Bills for differential duties passed by the legislatures of Tasmania, South Australia and New Zealand in 1871, and intercolonial conferences at Melbourne in 1870 and at Sydney in 1873, all made this attitude of revolt unmistakably plain to Kimberley and the Gladstone Cabinet of 1868-1874.

The Disraeli Cabinet had vetoed the Tasmania Bill of 1867 on January 5, 1878. The Conservative party went out of office in December of the same year. The Gladstone Administration was consequently compelled to take over the conflict with the Australasian colonies as an inheritance from its predecessor.

But on the policy at issue there was no difference of opinion or conviction between Liberal and Conservative Governments; and although the Earl of Carnarvon in 1873 expressed his sympathy with the demand of the Australian colonies for power to enact differential duties, ${ }^{1}$ it is not possible to trace the development of any difference of opinion as to the fiscal policy of Great Britain among statesmen of Cabinet rank at Westminster until the general election in Canada in March 1891.

W. H. Smith, afterwards First Lord of the Treasury and Leader of the House of Commons in the Salisbury Administration of 1886-1892, then wrote Macdonald a letter marked 'in strictest confidence ', in which he congratulated the Canadian Premier on his success in the elections, and in a strain of regret reminded Macdonald that it was impossible for Great Britain to enact differential duties in retaliation for the new tariff of the United States-the McKinley Act of October 1, 1890. ${ }^{2}$

Both political parties at Westminster in 1868-1873 regretted the protectionist policy of Conservative Governments in Canada, and also regretted the adoption of protectionist policies by several of the Australasian colonies. Both political parties were, moreover, opposed to differential duties in colonial tariffs, although

1 House of Lords, May 15, 1873, Parliamentary Debates, III, ccxv, 2008-2009.

2 "Let me congratulate you on success. It is not so big as I could have wished; but I am very glad indeed for the sake of the old country that you have won.'- -Smith to Macdonald, March 7, 1891, Pope, Memoirs of Macdonald, ii, p. 217. The letter was written two days after the general election in Canada, an election at which the Liberals had advocated commercial union with the United States, and had maintained, as they did at every general election, from 1879 to 1896 , that the national policy of Canada was a failure. Cf. Official Report, Liberal Convention, Ottawa, 1893, p. 71. 
by 1870 all interference by the Colonial Office with the enactment of these duties by the Parliament of the Dominion of Canada was at an end.

The fact that in the century and a quarter from the American Revolution to the Great War the House of Commons at Westminster was never elected on a colonial issue has already been noted. It was the vicissitudes of domestic politics in the United Kingdom that carried a Whig Government in 1859 and a Libera' Government in 1868-1873 into these epoch making conflicts with the British North American and the Australasian colonies.

It was the executive action of a Conservative Government that precipitated the crisis in the Australasian colonies. The defence of the fiscal policy of the United Kingdom and the burden of the second division of the propaganda for uniformity in the principles of tariff legislation all over the Empire fell in 1868-1873 upon a Liberal Government.

The attitude of the Governments at Hobart Town, Melbourne, Sydney, Adelaide, Brisbane, and Wellington on the issue raised by the Tasmania Bill of 1867 was determined and unshakable. It was an attitude toward the administration in London, and its stand for the free-trade policy of the United Kingdom and for uniformity of policy over the Empire, that was exactly the same from both the constitutional and the fiscal point of view as the attitude of the Cartier-Macdonald Government at Toronto when the Galt tariff was challenged by Newcastle.

At both of these crises in the history of the dominions the attitude of the Colonial Governments-Canadian in 1859, and Australasian in 1868-1873-could have been expressed in a few words. 'We have responsible government. It is our intention to determine our own fiscal policy as we decm most expedient and most to our advantage, irrespective of the fiscal policy of Great Britain. Free trade may be all very well for Great Britain. It does not meet our nceds; and we must determine our own trade policies.' 1

The Australian colonies, unlike the provinces of Upper and

1 Cf. Galt and Newcastle correspondence of August-October 1859; Galt's speech in the Legislative Assembly in which he explained the fiscal changes made by his Tariff Bill. Globe (Toronto). March 14, 1859; and dispatches and enclosures from governors of colonies in Australasia, 1871-1872, correspondence witl the Australian colonies with respect to proposed intereolonial tariffs. Colonial Accounts and Papers, 1872. 
Lower Canada, had not been directly and continuously influenced in tariff making by the protectionist movement and high tariffs in the United States. Unlike the Dominion of Canada from 1867 to $1907,{ }^{1}$ none of the legislatures of the Australasian colonies had been influenced in enacting tariffs by the refusal of the United States, or any other non-British country, to enter into reciprocity agreements.

But the fiscal policies of most of the Australasian colonies had been quickly and permanently influenced by the protectionist movement and the protectionist tariffs of Upper and Lower Canada, and of the Dominion of Canada. In this roundabout way the fiscal policies of the Australasian colonies, as protectionist speeches in the legislatures make abundantly clear, were much influenced by the United States; and as early as the crisis of 1868-1873, Victoria and New Zealand had followed the example of the United Provinces of 1858-1866 in enacting protectionist tariffs and also followed the example of the Dominion, the Parliament of which in 1870, at the instance of the Macdonald Government of 1867-1872, had enacted the first national policy tariff ${ }^{2}$ for the new Dominion of Canada. ${ }^{3}$

At this stage in their fiscal and economic history these two Australasian colonies, Victoria and New Zealand, as regards protection and their attitude toward the fiscal policy of Great Britain, and also toward imported manufactured goods from the United Kingdom, had reached about the same position that the United Provinces of Upper and Lower Canada had reached in

1 Cf. Porritt, Evolution of the Dominion of Canada, pp. 462-464.

2 'In the thirty-five years from 1879 to 1914 , and in particular from 1879 to 1897, there was no phrase in political discussion in Canada in more frequent use than the one "the national policy of the Dominion". In the earlier part of the period the term was used to describe (1) the imposition of duties in the Dominion tariff to protect home industries against all outside competition; $(2)$ the paying of bounties from the Dominion Treasury to aid the upbuilding of industry ; and (3) the attempt to secure reciprocity agreements with the United States and other non-British countries, with a view to extending the export trade of the Dominion. In the decade before the war the phrase had come to have a meaning much more comprehensive. It included, as of old, protectionist duties in the interest of Canadian industries. It included, until 1911, lavish bounties to iron and steel companies in Nova Scotia, Quebec, and Ontario. But it also included (1) the continuous and wide immigration propaganda for the peopling of the provinces west of the Great Lakes, and (2) the development of the national grain route, by rail, lake, and canal from all the grain growing provinces to tidewater ports on the Atlantic.' Ibid., pp. 427-428.

3 Cf. Statutes of the Dominion of Canada, 33 Vict., c. 9 ; Porritt, Sixty Years of Protection in Canada, pp. 265-275. 


\section{AUSTRALASIAN COLONIES AND FREE TRADE}

1858 and 1859, when the Cayley and Galt tariffs were enacted and the foundations were thereby laid for the national policy of the Dominion of Canada.

There were no duties in the tariffs of Victoria and New Zealand of those years as high as those in the Canadian tariffs of 1858 and 1859. But the protectionist tariffs of the Commonwealth of Australia of 1900-1914 had their beginnings in the tariff of Victoria of 1867. 


\title{
PART II
}

\section{THE PROTECTIONIST MOVEMENT AND PROTECTIONIST LEGISLATION \\ IN THE SELF-GOVERNING COLONIES, 1858-1914}

\author{
CHAPTER I
}

\section{THE BEGINNINGS OF THE PROTECTIONIST MOVE- MENT IN THE AUSTRALASIAN COLONIES}

BEFORE the long drawn out and heated controversy of 1867-1873 between the Colonial Governments and the colonial legislatures of Australasia and the Colonial Office was far advanced - even before the Gladstone Cabinet of 1868-1874 had on its hands the question of advising the Crown to give or withhold the Royal Assent to the Bills of 1871 for differential duties from New Zealand, Tasmania, and South Australia-Victoria and New Zealand were protecting colonial industries by customs duties against competition from the United Kingdom and from sister colonies in the Australasian group. ${ }^{1}$

Tasmania and Queensland were moving in the same direction, ${ }^{2}$ and already as early as December 1871 the Australian colonies, like the wee infant colonies of Vancouver Island and British Columbia in 1865-1866, were embarked in tariff wars against one

1 'The Parliament of Victoria is unlikely to yield the present policy of discriminating duties, or its right to amend its own tariff as circumstances may from time to time require.'-J. C. Francis, representative of Victoria, at intercolonial conference on differential duties, also on proposed customs union, June 21, 1870. Correspondence with Reference to Intercolonial Tariffs, 1872, p. 33.

'It may be observed that the tariffs of the Australasian colonies have, in effect, for some years past imposed duties on British manufactures, either intentionally or unintentionally protective.'-Memorandum by J. M. Wilson, September 11, 1871. Correspondence with Reference to Intercolonial Tariffs, 1872, p. 49. Cf. Adderley, Colonial Policy, pp. 110-111 ; Pratt, David Syme, p. 157; H. C. Turner, A History of the Colony of Victoria, ii, pp. 118-122; discussion in Legislative Council, August 11, 1870, Parliamentary Debates (New Zealand) viii, 447.

2 Cf. Journals of the House of Assembly (Tasmania), 1868, Appendix, 88, 3-4 ; motion by W. H. Groom, in Legislative Assembly, Junc 17, 1869, Parliamentary Debates (Queensland), 1869, iii, 9, 347. 
another. They were enacting retaliatory tariff duties; and the scheme for a customs union, that was first suggested by South Australia in $1862,{ }^{1}$ but was never carried out so long as each colony partially (1850-1895) or completely (1895-1900) controlled its own tariff legislation, was thrown into the discard. ${ }^{2}$ Once in the discard the scheme of $\mathbf{1 8 6 2}$ for a customs union remained there for nearly forty years.

In Canada, in the period from 1846 to 1867 , stock raisers, grain growers, and tanners were of the first interests to be safeguarded from outside competition by a protective tariff. Shoemakers, saddlers, cabinet makers, and tailors, and also soap manufacturers, who had no protection in the tariffs from 1847 to 1858 , came in for their turn in the Cayley and Galt tariffs ; and from 1858 to 1918 there were no tariffs in which these industrial interests were not protected from competition from the United Kingdom as well as from the nearer competition of the United States.

Brewing was the first industry in New Zealand to secure protection. $^{3}$ New Zealand grain was well adapted to brewing. The climate of the island was also favourable to the maturing of beer ; and the fact that a popular thirst for New Zealand beer developed in Australia, where climatic conditions were then not regarded as quite the best for brewing, in a measure accounted for the movement at Wellington of 1871-1873 for reciprocity with the Australian colonies. ${ }^{4}$

1 "That in the opinion of this council it is desirable that an uniform tariff should, as far as practicable, prevail throughout the Australian colonies; that in order thereto three delegates should be appointed to proceed to Melbourne for the purpose of conferring with delegates from the adjoining colonies; and that it is desirable that such conference should be held prior to effecting any considerable alterations in our fiscal system.'-Resolution of the Legislative Council of South Australia, July 8, 1862, Proceedings of the Parliament of South A ustralia, 1862, i, p. 43. Also Quick and Garran, The Annotated C'onstitution of the Australian Commonuealth, pp. 101-103.

2 'Retaliatory tariffs of a protective character have grown up, and the way to confederation, or to a customs union, has in conscquence become more difficult. Several of the protective tariffs now in force in the colonies owe their origin to feelings of self-defence or rctaliation. The most ardent frce traders have admitted that the tariffs of some colonies have forced protective duties on others.' Vogel memorandum, Wellington, December 8, 1871. Correspondence with Reference to Intercolonial Tariffs, 1872, p. 58.

3 'Take the article of beer, upon which to protect her brewers Victoria has a cluty of sixpence per gallon. We, in order to outrival Victoria, put a duty of one shilling and threepence on bottled beer, and one shilling on beer in bulk.'John Johnson, Legislative Council, New Zealand, August 11, 1874. Parliamentary Debates (New Zealand), viii, 447.

4. New Zealand is eminently celebrated for the production of beer. It has 
The wet goods trade, bottle and barrel, was a large factor in the movement of 1867-1873 against the statutory restriction on differential duties in the Australian colonies. Tasmania, where it will be recalled the movement had its origin, desired to market its wines and beer in the other Australasian colonies. New Zealand also desired a wider market in Australasia for its beer. ${ }^{1}$

The brewing interest, apparently, had at Wellington what in the phraseology of American politics would be described as a 'political pull'; for the brewing industry was the first of New Zealand's industries (1) to secure a low duty on its imported raw material, (2) to secure a high duty to protect its product in the home market, and (3) to stir the Government at Wellington to move for an extension of the export trade with the other Australasian colonies. ${ }^{2}$

\section{CHAPTER II}

\section{VICTORIA ADOPTS PROTECTION-TARIFFS OF 1865-1870}

THE first protectionist tariffs of Victoria, enacted at Melbourne in the years from 1865 to 1870 , followed closely the lines of the protectionist tariffs of the United Provinces of Upper and Lower Canada of 1858-1859. The purpose of these Victoria tariffs was to protect the men and women who had adventured their skill, business ability, and capital in the final stages of the textile and leather industries, for which the raw materials were then imported, as they mostly are still in 1918, from the United Kingdom.

It was the merchant and custom tailors, dress and cloak makers

become now an established manufacture. But we cannot interchange our beer for Australian wine, as we should be able to do, in consequence of our being obliged to put a high duty for revenue purposes on wine in general. I suppose the same reason exists in Victoria; and we have not been able, from fancied legal difficulties, to make a reciprocal remission on these articles-beer and wine.'-Gisborne, Legislative Council of New Zealand, August 11, 1870. Parliamentary Debates (New Zealand), 1870, iii, 437.

1 Cf. Correspondence with Reference to Intercolonial Trade, 1872, pp. 33-38.

2 "It seems to me that the predilections of our legislature are in favour of colonial beer, as everything is done to facilitate its manufacture in the colony. In Victoria hops are charged for duty twopence per pound. That article is the one exception in regard to which our tariff is lower than that of Australia. New Zealand, with a discriminating preference in favour of local brewers, charges only one penny per pound.'-Johnston, Legislative Council, New Zealand, August 11, 1870. Parliamentary Debates (New Zealand), viii, 447. 
and milliners, the boot and shoe makers, the saddlers and the harness makers in Melbourne who first secured protection against the competition of the cheaper labour, larger capital, and larger and more varied output of London, Leeds, Manchester, Leicester, and Walsall. ${ }^{1}$

The spirit in which tariffs for Victoria, on the lines and with the aim of those of 1865-1870, were popularly advocated, and the attitude of the pioneers in the protectionist movement in Victoria toward manufactures imported from the United Kingdom, can be realized from a typical quotation from the writings of David Syme, the father of protection in Australia. ${ }^{2}$

'It is then,' wrote Syme, in The Age in 1869, in an article which his sympathetic biographer has satisfied himself was the first unequivocal protectionist article published in any Australian paper, ' a question for our consideration whether there is anything in the

1 Cf. Customs duties in 1869, Colonial Office Papers, No. 419, pp. 43-44.

2 David Syme, whose biographer, Ambrose Pratt, fully establishes the claim that he was the father of protection in Australia, was from 1860 to 1908 the owner of The Age of Melbourne, the most widely cireulated and most influential proteetionist newspaper published in any of the dominions. It is a daily news. paper that as an organ of the protectionist movement in Australia holds a position eorresponding to that of the Gazette of Montreal and the Mail and Empire of Toronto in the protectionist propaganda of Canada.

In the history of the movement for fiscal freedom in Australasia, 1860-1898, the place of David Syme and The Age eorresponds to the place of Isaac Buehanan and the Spectator of Hamilton, Upper Canada, now Ontario, and of Robert Baldwin Sullivan, also of Upper Canada. All three men were pioneers in the advocaey of proteetion in the press, on the platform, and in the eolonial legislatures.

Sullivan, who was Canadian born, was a lawyer who beeame a judge. Buehanan was a merchant and importer, at one time in a large way of business. He was born in Seotland. He was a speeial eontributor to the newspaper in which his proteetionist artieles appeared. He was a man who, in his zeal as a publicist, permitted his importing business to decline and accumulated only a meagre prorision for his old age.

Buehanan has so far not been awarded a niehe in the Dictionary of National Biography, a negleet which he shares with William Cayley, who as InspectorGeneral (Finanee Minister) of the United Provinees framed, with some assistance from Buehanan, the Tariff Aet of 1858, the first avowedly and eomprehensively protectionist tariff enaeted in any of the eolonies now of the dominions.

Syme, like Buehanan, was a native of Seotland, who emigrated to Victoria in 1852. For fifty years he was a journalist and publicist-a publieist who was for this long period in the fortunate position of being the owner of the newspaper in whieh he expressed his views and convictions, and who at his death in 1908 left a fortume of nearly $£ 900,000$. Cf. Pratt, Dacid Syme: Official Report, Colonial Conferenee, Ottawa, 1904, p. 265; Neusp per Ouner, London, Deember 24 . 1910; and for Sullivan and Buchanan. I. W. Kave. Life and Correspondence of Charles Lord . Wetcalfe, ii, p. 339 ; Porritt. Sixty Years of Protection in C'amudu, pp. 39, 190; H. J. Morgan's edition of the Irritings and Speeches of Lsanc Buchenan (1864), pp. 525-531. 
present State of Victoria which should cause its inhabitants to set a ban upon any attempts here to manufacture their commodities ... and thus give an impetus to the employment of domestic skill, or " native industry," as the phrase is, in the handicraftsman's arts of tailoring, boot making, and other occupations of the kind. We can not perceive that there is any one predisposing cause in this country to prevent us making such an attempt, and certainly none which should induce us to put a special ban upon that attempt.

'Nevertheless,that is what we do when we wholly expose any effort on the part of our fellow colonists here to localize any of those branches of industry referred to to the ever-widening competition of the multitudinous, inferior, low priced-not cheap-articles made of refuse material, especially for the Australian market, with which we are inundated from the crowded factories and workshops of Great Britain. By this system of naked competition, our manufacturers are prevented from even making a beginning in the work of opening up new sources of industry amongst us. A ban is put upon the attempt at the very outset.' 1

How tariffs, conceived in the spirit and to the intent of the first stage of the propaganda for protection, worked out was described forty years after the publication of Syme's article in The Age, by Turner, in his history of the colony of Victoria, a history that was written from the standpoint of a free trader.

'Millinery and articles made up of silk,' wrote Turner, in recalling in 1904 the duties in the tariffs of 1865-1870, 'paid duty at the rate of five shillings per cubic foot, on the outside measurement of the package containing them. Apparel and slops, boots and shoes, hosiery, gloves, and other personal effects were four shillings per cubic foot of enclosure. The fixed duties on the external measurement of packing cases acted most inequitably. It taxed a gentleman's dress suit, worth ten guineas, at the same figure as a digger's moleskins and jumper, worth perhaps thirty shillings. Under this system the rich man paid less than five per cent on his apparel, and the labouring man from twenty to fifty per cent.' 2

1 Pratt, op. cit., p. 119.

2 Turner, History of the Colony of Victoria, ii, p. 122. 


\section{CHAPTER III}

\section{BONUSES FOR INDUSTRY IN NEW ZEALAND AND TASMANIA-THE 'MADE IN NEW ZEALAND' MOVEMENT OF 1870}

IT will now havc been realized that by the time the Colonial Office and the Gladstone Administration were in the much troubled waters of controversy over the Bills for differential customs duties passed at Hobart Town, Adelaide, and Wellington in 1867-1871, at least two of the colonies, Victoria and New Zealand, had in principle, progressed as far in protectionist legislation as Upper and Lower Canada had done from 1858 to 1867.

In some respects these two Australasian colonies, New Zealand in particular, had made more progress with their legislative policies for upbuilding colonial industries than was achieved by Upper and Lower Canada from the enactment of the Cayley and Galt tariffs to Confederation. They had made this progress, moreover, under the written constitutions of 1850-1852, which, so far as the colonies now of the Commonwealth of Australia were concerned, admitted of much less fiscal freedom than was possible from 1859 to 1867 under the written and unwritten constitution of Upper and Lower Canada. ${ }^{1}$

The tariffs of Victoria and New Zealand in 1867-1873 were not uniformly as high as the tariffs of the United Provinces of 18581866. In these Canadian protectionist tariffs, duties ranged from fifteen to twenty-five per cent. in the tariff of 1858 , and from twenty to twenty-five per cent., with a few duties of thirty per cent., in the tariff of $1859 .^{2}$

There were high spots in the tariffs of Victoria of 1865-1870, and these peaks were the more obvious because of the method of imposing duties, a method which as regards tariffs of English speaking countries was peculiar to the fiscal legislation of Victoria. These high spots, with duties determined by measurement of packing cases, occurred where there were discriminations in farour of the local industries, whose interests David Syme, at great

1 ('f. Porritt, The Evolution of the Dominion of C'anada, P). 164-165.

2 Cf. 22 Vict., c. 76 ; 23 Vict., c. 2 (Canada). 
pecuniary loss to himself, ${ }^{1}$ in 1860 had begun to champion in the editorial page of The Age of Melbourne.

New Zealand at this time, it will be recalled, had high duties in its tariff in the interest of the brewers-in the interest of an infant industry that was more assiduously nursed by Parliament and the Government at Wellington ${ }^{2}$ than any other industry in the colony. Brewing in New Zealand was, in fact, more assiduously nursed in these early years of the protectionist movement than any other industry in any Australasian colony.

With these exceptions in the cases of infant industries in Victoria and New Zealand, duties in the tariffs of 1867-1873 of the Australasian colonies were not nearly so high as those in the tariffs of Upper and Lower Canada of 1858-1867. Few of them exceeded ten per cent. ${ }^{3}$ But in these years, 1867-1873, the movement in the Australasian colonies toward national policies had not been confined, as in Upper and Lower Canada from 1858 to 1867, to protectionist tariffs in the interest of infant industries.

Bonuses to encourage the cultivation of sugar beets, to facilitate the establishment of woollen mills and to encourage the production of charcoal pig iron in Tasmania, were recommended by a select committee of the House of Assembly in that colony in $1868 ;^{4}$ and in 1870 bonuses to aid the establishment in New Zealand of paper mills, of malt houses, and of bottle factories-again

1 'The great mercantile, financial, and pastoral interests met together and determined to put him down. "David Syme must be destroyed!" Their plan was simple. They controlled all the great channels of advertising in the state. Cut off this source of supply, then, and his paper must perish of inanition. They struck it hard, and without warning. They withdrew every advertisement within their control, and confidently expected that The Age would not live a month. In a single day the journal shronk to half its size, and was constrained to depend exclusively upon its circulation. This was one of the darkest hours of Syme's career.' Pratt, David Syme, p. 130.

${ }_{2}$ A select committee of the House of Representatives at Wellington reported on September 5, 1870, ' that there are many industrial pursuits peculiarly adapted to the colony which might be introduced with advantage, and would become sources of wealth to the colony if adequately protected during infancy; that the present position of the brewing and malting branches is stated by witnesses to be due to the protection they have received, which has raised them to such a state of efficiency that in a short time protection will probably cease to be necessary.' Journals of the House of Representatives (New Zealand), September 10,1870, p. 278 . The same committee, of which Julius Vogel, Colonial Treasurer in the Fox Administration of 1869-1872, was chairman, reported on the same day in favour of bonuses for the malting industry and also for bottle factories. Journals, p. 279.

3 Cf. Customs Duties in the Colonies, 1869, No. 419, pp. 43-51; Turner, A History of the Colony of Victoria, ii, p. 122.

${ }_{4}$ Cf. Journals of the House of Assembly (Tasmania), Appendix 88, pp. 3-4. 1569.29 
as an aid to the brewing industry - were recommended by a committee of the House of Representatives at Wellington. As was the case in Tasmania the committee at Wellington was appointed at the instance of the Government, and like the Tasmania committee of 1868 the New Zealand committee of 1870 was presided over by a member of the Cabinet.

Still another movement toward a national policy was made in New Zealand in 1870. Advertisements were published by the Government at Wellington, calling for tenders for blue and white serge and for blankets, 'the whole to be exclusively of New Zealand manufacture,' for the equipment of the local defence force of the colony. ${ }^{1}$

The national policy of the Dominion of Canada, which in the forty-four years from 1870 to the outbreak of the war in 1914 so greatly influenced the fiscal policies of the Australasian and South African dominions, the trade policies of Crown colonies in the West Indies, the commercial diplomatic policy of Great Britain from 1878 to 1898 , and the domestic politics of Great Britain from the revival of the protectionist movement in 1903 to $1914,{ }^{2}$ had its origin in Upper and Lower Canada in the years from 1847 to 1866.

At its later stages, 1870 to 1918, the legislatures of British Columbia, Ontario, Quebec, New Brunswick, and Nova Scotia and hundreds of municipalities in these five provinces associated themselves with the national policy, and supported its advancement. They supplemented the national policy legislation at Ottawa by concessions of various kinds, all of much value to local industries.

There was none of these various aids to Canadian industry in the formative years of the national policy, in the years during which it was slowly developed by the legislatures and Governments of Upper and Lower Canada. Municipal bonuses, exemptions from municipal taxation, free supplies of water, gifts by municipalities of sites for factories, and municipal guarantees of debenture stocks in manufacturing companies, all belong to the second stage of the national policy in Canada. ${ }^{3}$

Manufacturers in Upper and Lower Canada from 1847 to 1866 could appeal only to the legislature for aid. Appeals for bonuses

1 Cf. Johnston, Legislative Council, August 11. 1870. Parliamentary Debates (Now Zealand), viii, 447.

2 Cf. Porritt, 'Canada's National Policy,' Political Science Quarterly (Columbia University. New York), xxxii. pp. 18:3-190.

3 Cf. Porritt, Sixty Years of Protection in Canada, pp. 289, 410-413. 
and loans were made to the legislature, but concessions to industry in these years did not go beyond the enactment of low duties on raw materials imported by manufacturers, or the inclusion of raw materials in the duty-free schedules of tariffs, and the enactment of comparatively high duties to protect the output of manufacturing undertakings from all outside competition, regardless as to whether this competition came from sister colonies in British North America, from the United Kingdom, or from non-British countries, such as the United States.

It was in connexion with Government aid to industry other than such provisions as can be embodied in a tariff schedule, that New Zealand, by the time that she and all the other Australasian colonies were sharply at issue with the Colonial Office over the question of differential duties, had advanced its national policy beyond the stage to which Upper and Lower Canada had carried theirs up to the time these provinces went into Confederation in 1867. In 1870, as has already been made evident, there was a Government at Wellington, supported by a good majority in the House of Representatives, that was committed to bonuses to manufacturing undertakings.

Bonuses were not bestowed on manufacturing undertakings by the legislature of the United Provinces, and were never a part of the national policy as it was developed by Parliament at Ottawa in the years from 1870 to 1918 . In the last decade of this period bonuses were bestowed on manufacturing undertakings by three of the provincial legislatures, or at any rate they were offered by these three legislatures with a view to the development of the iron and steel industry in British Columbia $;{ }^{1}$ and with a view to the establishment of yards for the building of coastwise and oceangoing vessels with hulls of steel at Dartmouth, Nova Scotia, and at St. John, New Brunswick. ${ }^{2}$

Bonusing of industries in Canada, except for these three instances, was relegated to the municipalities. It was safeguarded and regulated by statutes of the legislatures in five provinces in which the system of exemptions, bonuses, and guarantees of debenture stocks was established as a sub-division of the national

${ }^{1}$ Cf. Statutes of British Columbia, an Act respecting bounties on iron products in the province, April 23, 1918, 7 Geo. V, c. 11 ; an Act to make provision for further aid for the purpose of developing a process for the treatment of complex ores, April 23, 1918, 7 Geo. V, c. 16.

${ }^{2}$ Cf. Statutes of Nova Scotia, 1907. 
policy, with the sanction of the legislatures. It was a sub-division in which Parliament at Ottawa never had any part. The Dominion Government from 1883 to 1911, under various Acts of Parliament, paid tonnage bounties on puddled iron, pig iron, steel ingots, and wire rods, and during part of this period, and until as late as 1916, it paid bounties on lead, erude petroleum, and Manila fibre, used in the manufaeture of binder twine and eordage.

But bounties, and also subsidies to shipbuilding eompanies on the Great Lakes and on tide-water in respeet of dry doeks, whieh were first paid in 1882 , were developments at the seeond stage of the Canadian national policy ; and after the United Provinees in 1858-1859 had imposed proteetionist duties on imports from the United Kingdom, New Zealand was the first of the eolonies to move for a bonus system to aid local industries in withstanding eompetition from overseas.

The second particular in which New Zealand, before or during the controversy over differential eustoms duties of 1867-1873, outran the United Provinees of 1841-1867 in protectionist legislation was in the ereation in 1870 of a 'made in New Zealand' policy, under whieh tenders for elothing for the loeal defenee foree were burdened with the eondition that the goods furnished were to be of exelusively New Zealand manufacture.

It was 1900 before a similar movement in Canada received reeognition from the Dominion Parliament. The railway eode was then amended, and a seetion added which made it a condition of the granting of Dominion subsidies in respect of new railway eonstruetion, that the eompanies should lay the roads with new steel rails made in Canada, if Canadian rails were proeurable upon terms as favourable as those upon whieh other rails eould be procured. ${ }^{1}$

There were no rail mills in the Dominion in 1900. Nills for the rolling of rails were in process of equipment at the time the railway eode was amended; and in 1904 the 'made in Canada' seetion of the law of 1900 went into operation ${ }^{2}$ in the interest of mills at Sault Ste. Marie, Ontario, and at Sydney, Nova Scotia, both undertakings by American promoters.

In subsequent years it also beeame the policy of governments at Ottawa, with the sanction of Parliament, to give preference to shipyards on the St. Lawrence and on the Great Lakes, in the

1 Statutes of the Dominion of Canada, $63 \& 64$ Vict., c. 58.

- Cf. Orders in Council (Ottawa), August 2, 1904. 
building of new tonnage for the Department of Marine and Fisheries and for that of railways and canals, instead of awarding contracts, as in previous years, to the lowest bidders, irrespective of whether the bids were from shipbuilding companies in the Dominion, in Great Britain or in the United States. ${ }^{1}$

As a popular propaganda, organized by the Canadian Manufacturers' Association, the 'made in Canada ' movement was pushed continuously all over the Dominion from 1901 to $1918 ;^{2}$ and in these years it received statutory recognition at Ottawa in at least two of the spending departments of the Dominion Government. It was, however, a departure in protectionist legislation in colonies of the dominions which had its origin in New Zealand thirty years before Parliament at Ottawa adopted it as a policy governing the granting of subsidies to railways, and the awarding of contracts for the building of lake and tide-water tonnage for Dominion service. $^{3}$

At Wellington the first exponent in the House of Representatives of the 'made in New Zealand' policy in regard to government contracts was Vogel, from 1875 to his death in London in 1899, Sir Julius Vogel, who was Colonial Treasurer in 1869-1870, Premier from 1870-1876, a copious talker ${ }^{4}$ and, as Kimberley discovered in the correspondence of the controversy of 1870-1873, a vehement and copious writer, whom it would not be incorrect to describe as the father of protection in New Zealand.

${ }^{1}$ Cf. Brodeur, Minister of Marine, House of Commons Debates (Ottawa), March 31, 1911.

2 Cf. 'Adopts Commonsense View' :

We don't need the marts of Europe, nor the trade of the eastern isles,

We don't need the Yankees' corn and wine, nor the Asiatic's smiles,

For what so good as our home-made cloth, and under the wide, blue dome,

Will you tell me where you have tasted bread like the bread that is baked at home?

And we are young and strong, and who so fit for the fight as we ?

With our hands of steel and our iron heel, and our hearts like the oaken tree.

For we are the home-bred, home-fed men, the pride of a princely land,

And the things that are made in Canada are the things that her sons demand. Pauline Johnstone, in Industrial Canada, July 1918, p. 146.

3 'I see the Canadian Manufacturers' Association are to call upon the people to use home-made goods. Benjamin Franklin did the same thing. So did Isaac Buchanan in 1858; and I remember his entering the House of Assembly in a suit of étoffe du pays-grey homespun-to the great amusement of his fellow members.' Weir, Sixty Years in Canada, p. 128.

${ }^{4}$ Cf. Dictionary of National Biography, Supplement iii, pp. 500-502. 


\section{CHAPTER IV}

\section{RETALIATORY DUTIES IN EARLY AUSTRALASIAN TARIFFS}

Is still another direction the Australasian colonies, by the time they were in conflict with the Colonial Office over the section in the Australian Colonies Government Act of 1850 restraining their legislatures from enacting differential duties, had gone farther in the development of protectionist policies embodied in legislation than the provinces of Upper and Lower Canada.

There were retaliatory duties in several of the tariffs of the Australasian colonies, ${ }^{1}$ duties imposed in one colony in retaliation for duties in the tariff of a neighbouring colony. Upper and Lower Canada had both discriminating and differential duties in the tariffs of 1847-1867. The differential duties were to meet the terms of the Elgin-Marcy treaty of 1854-1866, and also to encourage reciprocal trade with the lower provinces, New Brunswick and Nova Scotia.

In 1849-1850, the years of the movement in Upper and Lower Canada for annexation to the United States ${ }^{2}$ out of the disappointment over the failure at Washington of a bill for reciprocity, there developed a movement in the constituencies, and in the legislature of Upper and Lower Canada, for a retaliatory tariff on imports from the United States. ${ }^{3}$ The legislature and the Government at this exceedingly trying crisis for both, but especially for the Government and also for Elgin, the Governor-

1 Cf. Vogel memorandum, Correspondence with Reference to Intercolonial Tariffs, 1872 , p. 38 .

2 Cf. C. D. Allin and G. M. Jones, Annexation, Preferential Trade, and Reciprocity, pp. 105-161 ; Weir. Sixty Years in Canada. pp. 41-97.

3 The popular attitude toward the United States at this erisis in Canadaa erisis partly political. but in the main economic-ean be judged from resolutions at public meetings. At a meeting of freeloolders and louseholders of the township of Louth in the Niagara distriet, Upper Canada, on January 5, 1850, it was resolved 'that a petition be presented from this township to the provineial legislature to exereise its influenee with the Imperial Government to obtain for this provinee reeiproeal free trade with the United States; but if free trade eannot be obtained, proteetion duties be put on the staple produets of the province in aceordance with the tariff of the said Cnited States.' The Examiner (Toronto), February 20, 1850. Cf. Allin and Jones, ${ }^{p} p$. cit., pp. 330, 331. 
General, were disposed to comply with the popular demand for retaliatory duties.

But Grey, who, it will be remembered, was at this time Secretary of State for the Colonies, intervened; and in retrospecting his term at the Colonial Office, and appraising the contributions which the Russell Government of 1846-1852 had made to the constitutional and economic development of the colonies now of the dominions, he congratulated his colleagues of the late administration, and incidentally himself, on the fact that the United Provinces did not in 1850-1852 enter on a tariff war with the United States.

'I consider it', wrote Grey, in September 1852, 'by no means one of the smallest services which it was in our power to render to the colony while we were entrusted with the direction of affairs, that we succeeded in preventing the adoption of any measures of this kind-not by direct and formal refusal to sanction them, but by unofficially discouraging their being brought forward.' 1

For Grey, who as long after the Galt tariff of 1859 as 1873 told the House of Lords that he was willing to see the colonies declare their independence if they were permitted to enact tariffs hostile to the United Kingdom, ${ }^{2}$ the side-tracking of the movement in Upper and Lower Canada, and also of a similar movement in New Brunswick in 1851-1852 for retaliatory duties against imports from the United States, was one of only two successes in the British North American provinces that, in his five and a half years at the Colonial Office, ${ }^{3}$ attended the vigorous and persistent propaganda for a fiscal system for the Empire uniform with that of the United Kingdom and the crown colonies.

The other success to be credited to Grey in the provinces now of the Dominion of Canada was a quite minor one. It was achieved in 1848, with much resulting irritation at Fredericton and St. John. He then prevented the establishment in New Brunswick of a bounty system to stimulate the cultivation and dressing of hemp. ${ }^{4}$

Grey in 1851-1852 also intervened to prevent the legislature of

1 Grey, Colonial Policy, i, p. 247.

2 Parliamentary Debates, III, ccxv, 2005.

3 July 1846 to February 1852.

$4 \mathrm{Cf}$. Statutes of New Brunswick, an Act to encourage the raising and dressing of hemp, March 23, 1847 (10 Vict., c. 32); Grey, Colonial Policy, i, pp. 279-283. 
Prince Edward Island from establishing bounties for vessels and crews in the mackerel fisheries-bounties to counterbalance bounties at this time paid by the United States Government to vessels from New England ports. But he only involved himself in some needless correspondence; for in May 1852, Pakington, Secretary for the Colonies in the Derby Administration, declined to advise the Cabinet to disallow the Act of the Prince Edward Island legislature. ${ }^{1}$

From 1846 to 1852 the estopping of retaliatory duties in Upper and Lower Canada and New Brunswick, and the prevention of the establishment of bounties in New Brunswick for the cultivation of hemp, were the only successes of the propaganda in the British North American provinces. Grey's outstanding success was achieved in the Australian Government Act of 1850 ; and even there the restraining section to which as late as 1895 he attributed much value only involved a delay of not more than six years ; for it was not until 1867 that any of the Australian colonies were desirous to have power to enact tariffs with differential duties.

The efforts of the Colonial Office from 1846 to 1852 , and from 1852 to 1870 , to prevent the enactment of differential duties by legislation in British North America were a complete failure. Of this Grey was reminded in the House of Lords in 1873, by Kimberley, when Grey opposed the Bill of the Gladstone Administration for so amending the Australian Colonies Government Aet of 1850 as to concede to the legislatures in these eolonies freedom to enaet differential duties.

Grey's tenure at the Colonial Office came to an end in February 1852, when Russell as Premier gave place to Derby. As Grey was nearing the end of his interesting and informing retrospect of the colonial poliey of the Russell Administration, he was much disturbed by newspaper reports that the movement for retaliatory duties in the United Provinces had been revived. In a footnote, dated September 10, 1852, he reealled his sueeess in preventing the adoption of them in 1850 . 'I have observed with regret in the colonial papers', he added, 'that different views are now likely to be acted upon by the eolonial government.' 2

1 Cf. Journals of the House of Assembly (Prince Edward Island). March 1, 18:32, p. 83; Appendix F, pp. 27-29; Adderley. Colomial Policy, pp. 66-67.

2 Grey, Colonial Policy, i, p. 252. 
But about this time there was a distinct improvement in the prospect for the much desired reciprocity treaty with the United States. No retaliatory duties were enacted by the legislature of the United Provinces, which in 1852 would certainly not have accepted the disallowance of any tariff Act in the accommodating spirit in which New Brunswick finally accepted the disallowance of the Bounty Act of 1847 .

The reciprocity treaty was in operation from 1854 to 1866 . All the British North American provinces east of the Great Lakes were prosperous during the twelve years of free trade in agricultural products, lumber, coal, and fish between these provinces and the States of the American Republic, ${ }^{1}$ and there were no retaliatory duties, as distinct from discriminatory and differential duties, in any Canadian tariff until 1870.

In 1870, at the instance of the Macdonald Administration of 1867-1872-an avowedly protectionist Government during its last two years in office-Parliament at Ottawa enacted duties on salt and coal, ${ }^{2}$ imported in large quantities by the provinces of Ontario and Quebec, from the State of New York and from Ohio and Pennsylvania. These duties were embodied in the tariff of 1870 in retaliation for high duties in the tariff of the United States, on agricultural products, lumber, coal, and fish imported from the Dominion.

In the Dominion tariff of 1870 also there were retaliatory duties on flour, which during the era of reciprocity, and in the years before 1854, had been imported by the Maritime Provinces from Portland, Boston, and New York, all commercial centres with which the Maritime Provinces had in these years much closer connexions than with Montreal and Toronto.

1 ' I cannot speak with the same assurance in regard to other parts of the Dominion as I can in regard to the part from which I come-Prince Edward Island. But I say this, that since the Maritime Provinces were peopled there never was a decade when prosperity was so marked among all classes, when land rose in value so quickly, when the wharves were so lined with shipping, when the workmen had such steady employment, when the farmers had as good a market, as between 1854 and 1866 , when we had reciprocal trade with the United States,'-Louis H. Davies, M.P. (now Sir Louis Davies, Supreme Court of Canada, Ottawa), at Liberal Convention, Ottawa, June 21, 1893. Official Report, p. 79.

2 Dominion Statute, 32 \& 33 Vict. 'These duties, which leave a now quite insignificant free list of commodities, so far as American trade is concerned, were avowedly levied in retaliation for the protective rigor of the United States tariff.' Learned, 'State of Trade with the British North American Provinces,' Executive Documents (Washington), No. 94, 41st Congress, 3rd Session, 1870-1871, p. 9. Cf. Porritt, Sixty Years of Protection in Canada, p. 270. 
Discriminatory and differential duties came into service in the tariffs of Upper and Lower Canada in the first twenty years after Great Britain had adopted free trade as its fiscal policy. But the colonies in Australasia were the first to enact retaliatory duties; and the enactment in 1865-1872 of these devices of tariff war was all the more out of harmony with the fiscal policy of the United Kingdom, because the duties were directed not against a non-British country as were the retaliatory duties of the tariff of the Dominion of Canada of 1870, but against sister colonies under the sovereignty of Great Britain.

\section{CHAPTER V}

\section{PROTECTION AGAINST LOW WAGES IN GREAT BRITAIN}

In the propaganda of 1860-1873 in the Australasian colonies for protectionist duties against imports from the United Kingdom, as in the propaganda in Canada from 1847 to 1914, to the same end, there was much emphasis on the inability of the manufacturers in all these colonies to compete with success against manufacturers in the United Kingdom who had the advantage of the low wages paid to men and women and children in the factories of England and Scotland.

Comparatively speaking this argument in favour of protection was as much used in Canada and Australia, from about 1850 to 1914, as it was in the United States from 1840 to the end of the nineteenth century. It was advanced in these colonies by members of legislatures and by publicists through the newspaper pressoften by men who were newcomers from the United Kingdom and familiar with industrial and social conditions there as they existed in the manufacturing counties in the first half-century of the peace after Waterloo.

To newcomers to the colonies of the wage-earning classes, and especially to men who had emigrated to Canada, or to the more distant Australasian colonies to escape the hardships and hopelesiness of their condition in England or Scotland, the argument that colonial manufacturers must be protected against these low wages and long hours made an immediate and effective appeal. 
David Syme, and the school of protectionists in Victoria that gathered around him, in particular made much of this argument of the low wages paid in labour camp communities in England and Scotland. Syme's position as a protectionist was that the object of industry, or the labour by which men live, was not the greatest development of foreign trade, but was the comfort, well being, and moral progress of the masses of each nationality.

Syme's newspaper, The Age, in the first decade of the protectionist propaganda in Victoria was pre-eminently the newspaper of the wage and salary earners of Melbourne and Victoria generally; and in The Age these men and women were continually assured that the establishment of manufactures, made possible under the fostering care of protectionist duties, would enable every man desirous of earning his living to earn it in a manner suitable to his training and character, by furnishing scope for diversity of talent and disposition. ${ }^{1}$

In Upper and Lower Canada, at least two years before Syme began his campaign in Melbourne for a protectionist tariff, the Association for the Promotion of Canadian Industry, an organization which was founded by Isaac Buchanan, and which from 1858 had its head-quarters in Toronto, was making use of the argument for protection based on the low wages in the factories of Great Britain.

One of the first propaganda enterprises of the association was the circulation from Toronto, in 1858, of Horace Greeley's Labour's Political Economy, or the Tariff Question Considered. Greeley and the Tribune of New York, in the forties, fifties, and sixties of the nineteenth century, held much the same aggressive position in the protectionist movement in the United States ${ }^{2}$ that Syme and The Age held in the protectionist movement in Victoria; and Greeley, like all the advocates of protection in the United States from 1840 to 1900 , emphasized the low wages of workpeople in the textile factories and other manufacturing industries in Great Britain. ${ }^{3}$

It may almost be said that the protectionists of Upper and

1 Pratt, David Syme, pp. 123, 127.

2 W. A. Linn, Horace Greeley, pp. 110-122.

3 "Where cheapness is only to be attained by a depression of the wages of labour to the neighbourhood of the European standard, I prefer that it should be dispensed with.'-Greeley, at the Tabernacle, New York, November 1843. Linn, Horace Greeley, p. 118. Cf. Morgan, The Relations of the Industry of Canada with the Mother Country and the United States, pp. 459, 478. 
Lower Canada imported from the United States the argument that there must be high customs duties to counterbalance low wages, long hours, and child labour in industries in Great Britain. They certainly imported the form in which this argument was popularly presented in the United States.

In the form in which it was thus imported, it was one of the earliest arguments used after Buchanan and Weir, who had arrived in Canada in 1842 from Scotland, organized in 1850 the manufacturers of Montreal, Toronto, Hamilton, London, Belleville, and Kingston - all except Montreal cities in Upper Canadaand inaugurated a legislative campaign in the United Provinces which was to culminate almost immediately in the Cayley tariff. ${ }^{1}$

In Canada the argument based on lower wages current in manufacturing industries in the United Kingdom, and the lower scale of living of the wage-earning classes in England and Scotland thus brought into service, was never abandoned, or permitted to fall for long into desuetude, in the fifty-six years that lie between the organization in 1858 of the first protectionist association in any British colony and the beginning in 1914 of the war of the Teutonic powers for dominion over the old and the new world.

After Confederation the argument was used in the constituencies and in Parliament at Ottawa in the dominion-wide propaganda that preceded the enactment of the second national policy tariff in 1879. During the seventeen years 1879-1896, when the Liberal party at Ottawa was continuously in opposition, and when, in and out of Parliament, it was assailing first protection, and, from 1883 to 1896 , as ceaselessly assailing in addition to protection the bounty policy of the Conservatives, and pledging itself to sweep away all national policy enactments, ${ }^{2}$ the argument was continuously used by the Conservatives. It was used in and out of Parliament by the men who followed the lead of John A. Macdonald in support of the policy to which the Conservative party had committed the Dominion in 1879.

1 Morgan, op. cit., pp. 483-487; Weir, Sixty Years in Canada, pp. 9, 98-104, 105-117.

2 'We, the Liberal party of Canada, in eonvention assembled, deelare that the eustoms tariff of the Dominion should be based. not as it is now, upon the proteetive prineiple, but upon the requirements of the publie serviee... that the tariff should be redueed to the needs of honest, eeonomieal, and effieient government ; and that it should be so adjusted as to make free, or to bear as hightly as possible, upon the neeessaries of life. and should be so arranged as to promote freer trade with the whole world. more partieularly with Great Britain and the 'nited States.' Official Report of the Liberal Concention at Ottaua, 1893, p. 71. 
The Liberals came into power at Ottawa in 1896. In 1897 they completely abandoned their attitude of 1879-1896 towards the national policy. They adopted both the tariff policy and the bounty policy of the Conservatives. They increased some of the protectionist duties, and they greatly extended the bounty policy of 1883-1896. But in the tariff of 1897, the first protectionist tariff for which a Liberal Government at Ottawa was responsible, there was an unexpected and far reaching innovation in fiscal legislation in British colonies.

A preference was established in favour of imports from the United Kingdom. It was a preference for which no equivalent nor any consideration was asked from Great Britain. ' England', said Mr. William Stevens Fielding, an ex-Premier of Nova Scotia, who was Minister of Finance at Ottawa from 1896 to 1911, when he announced the innovation of 1897 to the House of Commons, ' has dealt generously with us in the past. She has given us liberty to tax her wares, even when she admits ours free; and we have taxed them to an enormous degree.' 1

For forty years before 1897, from as early as 1858, imports from the United Kingdom into the United Provinces of Upper and Lower Canada, or after 1867 into the Dominion of Canada, had encountered exactly the same protectionist duties as imports from the United States or any other non-British country. From 1867 similar conditions had confronted imports from England, Scotland, and Ireland in several of the colonies of Australasia.

In the half century during which the colonies now of the Dominion of Canada, the Dominion of New Zealand, the Commonwealth of Australia, and the Union of South Africa were working forward to the complete fiscal freedom that all the self-governing colonies have been able to exercise since $1898,{ }^{2}$ not one of them, in its protectionist tariffs, had made the slightest concession in favour of imports from the United Kingdom. In all the protectionist tariffs enacted in Canada and Australasia from 1858 to 1897 there was not a single schedule in which duties were lower on imports from the United Kingdom than on imports from non-British countries, which were competing with British

1 Parliamentary Debates (Ottawa), April 22, 1897, i, 1135.

2 The year in which an end was made by Great Britain to all commercial treaties entered into before 1878 to which the colonies were parties, but to which their consent had not been asked. 
manufacturers and British exporters for trade with these British colonies.

These were the conditions under which for nearly fifty years British manufacturers sent their goods into the markets of the colonies in which there were protectionist tariffs. These were the conditions, despite the fact that until about 1870 taxpayers in the United Kingdom, rich and poor alike, were carrying the burden of both the internal and external defence of all the colonies. British taxpayers, moreover, in those years, as was the case up to the beginning of the war in 1914, were providing the interest and sinking fund of a national debt, much of which had been incurred in the eighteenth century in wars directly or indirectly arising out of the acquisition or defence of Great Britain's oversea possessions.

Canada, which led the way in enacting protectionist tariffs against Great Britain, which had had protectionist tariffs on its statute books since $1858,{ }^{1}$ was also the first of the dominions with protectionist tariffs to establish a preference for imports from the United Kingdom. ${ }^{2}$

\section{CHAPTER VI}

\section{LOW WAGES IN BRITISH INDUSTRIES AND THE BRITISH PREFERENCE, 1897-1914}

THE innovation at Ottawa of 1897 was a complete surprise for the electorate of the Dominion. Tariff polities had been discussed from every conceivable angle in Parliament and in

1 In the years from 1858 to 1867 the United Provinces of Upper and Lower Canada were the only provinces now of the Dominion in which there were protectionist tariffs against imports from the United Kingdom.

2 New Zealand followed the example of Canada in 1903, the Customs Union of South Africa in 1906, and the Commonwealth of Australia in 1907. Newfoundland has not adopted a policy of preference for imports from the Unitcd Kingdom because there never have been any protectionist duties in the tariffs enacted at St. John's. All the duties in the Newfoundland tariff are imposed solely for the purpose of raising revenue. The first use that the legislature of Newfoundland made of its new powcr under the Enabling Act of 1846 was to establish a preference for imports from the United Kingdom. But revenue conditions soon led to its abandonment.

- The dominions do not profess to sacrifice home manufacturcrs in order to give a preference to British imports. All they aim at doing is to give British traders and manufacturers an advantage over those of foreign count ries.' 'Preference and Negotiation,' The Times (London). January 8, 1910. 
the constituencies during the Conservative régime of 1878-1896. But it had been held by the Conservatives in the years when they were in power at Ottawa, and correctly held, that no preferences for imports from the United Kingdom could be embodied in tariff Acts of the Dominion without the concession of similar preferences to imports from twenty-odd countries with which Great Britain had favoured-nation treaties.

The Conservatives, moreover, were convinced that Great Britain would not denounce all these treaties, and run the risk of negotiating new treaties equally favourable to the export trade of the United Kingdom, merely to secure the advantage of preferential rates in Canadian tariffs.

In this conviction, as developments in 1897-1898 in the commercial diplomatic policy of Great Britain resulting directly from the preferential tariff of 1897 subsequently proved, the Conservatives at Ottawa were entirely wrong; for when confronted with the new tariff, the Salisbury Government of 1895-1901 promptly denounced all the commercial treaties that heretofore had hampered the fiscal freedom of Canada and the other selfgoverning colonies.

The protected manufacturing interests in Canada were opposed to any lowering of the tariff wall to facilitate imports from Great Britain. These interests had had the support of the Conservatives from 1879 to 1896 . They had been conceded a large part in framing the tariffs of $1879,1883,1887$, and 1894 . The sympathies of the extreme protectionists of the Conservative party in the House of Commons at Ottawa were with the manufacturing interests in their opposition to any changes in the tariff that would encourage competition from the United Kingdom.

In the Conservative party in Parliament also there was a comparatively large and assertive group, whose members insisted that there should be no preferences for imports from the United Kingdom, unless Great Britain would return to the old commercial system and establish tariff preferences for grain, flour, and lumber exported from the Dominion. ${ }^{1}$

1 A return to the old system of preferences, practically a return to the old commercial system minus the power of the Imperial Parliament over the tariffs of the self-governing colonies, was urged by the Imperial Federation League of Canada, an organization largely composed of members of the Conservative party, that was in existence from 1885 to 1894 when it was merged in the British Empire League. At a meeting of the Imperial Federation League at Toronto, on March 24, 1888, a resolution was adopted declaring that the League made it 'one of the 
The Liberals, during their eighteen years in opposition, had demanded lower duties all through the tariff schedules, and were elected on a platform, adopted at a national convention in 1893, which pledged the party to a return to a tariff for revenue as distinct from a protectionist tariff. There had been no continued discussion either in or out of Parliament of tariffs in which concessions should be made in favour of imports from the United Kingdom regardless of the fiscal policy of Great Britain. ${ }^{1}$

The new departure in tariff making had been a well guarded Cabinet secret at Ottawa. Neither the rank and file of the Liberal party in the House of Commons nor in the constituencies had had any information, direct or indirect, that it was to be made. It was equally a surprise for the Colonial Office, for the Salisbury Government, for Parliament at Westminster, for manufacturers and exporters in the United Kingdom, and for the Governments of all the Australasian and South African colonies. ${ }^{2}$

Many developments followed the new Canadian tariff. Some of these affected tariff politics in Canada-the movement for objects of their organization to advocate a trade policy between Great Britain and her colonies by means of which a discrimination in the exchange of natural products will be made in favour of one another, and against foreign nations.' George T. Denison, The Struggle for Imperial Unity, pp. 91-92.

1 At a meeting of the Imperial Federation League of Canada on May 29, 1894, the League gave expression to the opinion that 'as a first step towards arriving at a system of preferential trade within the Empire, the Government of Canada should lower the customs duties now imposed on goods manufactured in and imported from Great Britain.' Ibid., p. 204. The Dominion tariff was revised during the parliamentary session of 1894 , but the resolution of the Impcrial Federation League was entirely ignored by the Conservative Government. Large increases in the duties on cotton goods from Lancashire, first imposed in the tariff of 1883 in the interest of cotton mills in Montrcal, were altered in form but continued at the former high level. Cf. 'The National Policy and the Development of the Cotton Industry in Canada,' The Economist (London), August 25, 1917.

2 W. S. Fielding, member for Shelburne and Queen's, Nova Scotia, in the House of Commons that was elected in Decenber 1917, Minister of Finance in the Liberal Government of 1896-1911, in answer to a question asked by me in the lobby of the House on April 30, 1918, stated that the Colonial Office had absolut ely no knowledge that the preferential section was to be embodied in the 'Tariff Aet of 1897 . He intimated also that he was willing to be quoted as making this statement. Mr. Fielding's explanation of the unwillingness of the Government at Ot ta wa to inform the Colonial Office beforehand of the important depart ure of April 22. 1897, was due to a conviction on its part that the British Government would have strongly discouraged the innovation beeause of the friction it would cause between Lomblon and Berlin. Germany, it will be recalled, had a commercial treaty with Great Britain under which she could, and lid, claim equality of treatment of German and British imports in British colonial possessions. It was to end this advantage accruing to Germany that Great Britain in 1897 denounced the German treaty and all other commercial treaties in which the self-governing colonies had before 1878 been included without their consent. 
tariffs with less protection for manufacturers which in the decade before the war was increasing in strength in the three graingrowing provinces west of the Great Lakes and also the movement of the manufacturers from 1897 to 1914 for higher duties against imports from the United Kingdom than those of the tariffs of 1897 and 1907.1

Other developments of the preferential tariff of 1897 affected the commercial diplomatic policy of Great Britain, and also the domestic politics of the United Kingdom from 1903 to the war. Still others affected the tariff policies of the colonies in Australasia and South Africa, and also those of the Crown colonies in which, it will be recalled, there are no protectionist tariffs. Newfoundland and India, in the years from 1897 to 1914, were, in fact, about the only parts of the Empire which were not directly or indirectly affected in their fiscal policies and oversea trade conditions by the innovation at Ottawa in 1897.

But in these pages I am not concerned with the detailed history of the preferential tariff of 1897, nor indeed with the detailed history of any particular colonial tariff policy of the years from 1846 to 1914. Only two developments of the epoch-making tariff enacted at Ottawa in 1897, each within the Dominion of Canada, consequently call for attention in these chapters devoted to the growth of the protectionist movement in the self-governing colonies from the fifties of the nineteenth century to the great war, and in particular to characteristics which were common to the protectionist movement in both the Canadian and the Australasian colonies.

These developments in Canada, following in the train of the first preferential tariff of any British colony, were (1) the attitude toward the preference of the Conservative party at Ottawa, in opposition from 1896 to 1911 ; and (2) the attitude of the organized manufacturing interests in the Dominion toward the lowering of the tariff wall against imports from the United Kingdom.

The Conservative party from 1897 to 1911 was hostile to the preference because (1) it exposed manufacturers in Canada to new competition, and (2) because Great Britain made no tariff concessions to Canada in return for it. ${ }^{2}$

1 Cf. Porritt, Evolution of the Dominion of Canada, pp. 437-438.

2 'The preference that Sir Charles Tupper, and those who followed him, advocated was a give-and-take policy. ... The preference we advocate and we ask the people of Canada to turn to, was not the jug-handled preference in force 1569.29 
The manufacturers, acting through the Canadian Manufacturers' Association, an organization which in 1918 had 3,400 members and an income of nearly eighty thousand dollars, ${ }^{1}$ the strongest protectionist organization that ever existed in any part of the Empire, opposed the preference on the first of the grounds taken by the Conservative party in the House of Commons at Ottawa. ${ }^{2}$

As protected interests the Canadian manufacturers based their opposition on the plea that adequate protection against competition from manufacturers in the United Kingdom was as essential to the success of manufacturing in Canada as adequate protection against the United States or Germany.

As a political party, as a unit, the Conservatives abandoned opposition to the preference when they were returned to power in 1911. Thereafter the Conservative Government regarded the preference, or at least the principle of preference, as an established factor in tariff legislation; and the Conservatives at this time also abandoned their former contention that there should be no preference in Dominion tariffs for imports from the United Kingdom, unless there were tariffs in the United Kingdom in which there were preferences for imports from Canada. ${ }^{3}$

now, but a preference in which we would reeeive something for something given.' -W. F. Cockshutt, M.P. for Brantford (Ontario). House of Commons, Ottawa, March 14, 1912. House of Commons Debates, 5231.

1 Industrial Canada. July 1918, p. 209.

2 Preference for British manufacturers over non-British manufaeturers, Canadian and Australian manufacturers were, after 1897, willing to concede. But in Canada and Australia the elaim of the manufacturers was that in preference tariffs there must be adequate protection against eompetition from the United Kingdom, and still higher tariffs against non-British manufacturers.

- Sir George Reid [High Commissioner in London of the Commonwealth of Australia, who died September 12,1918] always maintained that if a fiscal basis were possible for the Empire, it must be a genuine arrangement of give-and-take; and that Australia must offer the British manufaeturer terms which would really enable him to come in, and not merely to have a nominal advantage over some foreign rival. The simile with whieh Sir George presented this ease was a good example of his shrewd eommon sense and his amusing good humour. "If." he said, "you build a wall three feet high between a dog and a bone, it is little satisfaction to it if you build a wall four feet high to keep out another dog." Yorkshire Post (Leeds). September 13, 1918.

3 'As Canada claims and exercises the right absolutely to control her own tiscal policy, so the representatives of our Dominion necessarily refrain from attempting any interference in the fiscal poliey of the United Kingdom. Moreover, the people of Canada would not desire the people of the United Kingdom to shape or modify their fiscal policy for the sole purpose of giving a preference to the products of Canada, cspecially if such change should involve any supposed injustice, or should be regarded as unfair or oppressive by a eonsiderable portion of the people of the Cnited Kingdom,' Borden, Prenier of the Dominion of ('anada, London, July 31, 1918. 
But before the war there were seventeen years of agitation against the British preference by the manufacturers of Canada. In these years, 1897-1914, the argument for high duties against imports from the United Kingdom, based on lower wages in industries in England and Scotland, was used more continuously and persistently, with more resourcefulness, and with more immediate and obvious success ${ }^{1}$ than at any time since 1858 , the year in which Horace Greeley's pamphlet was scattered broadcast over Upper and Lower Canada by the Association for the Promotion of Canadian Industry.

It was the mission of Industrial Canada, the official organ of the Canadian Manufacturers' Association, to rid manufacturers and exporters in the United Kingdom of 'the delusion that access to the Canadian market is the natural right of the British manufacturer, regardless of the will of the country'. ${ }^{2}$

The organ of the Association laboured long and assiduously to this end ; and the meetings of the Association in the years from 1897 to 1914 seldom came to an end without an appeal to the Government, at Ottawa for curtailments of the preference on imports from the United Kingdom. The grounds for these appeals were always the same - that duties higher than those in the preference schedules were necessary to offset the much lower labour costs of manufacturers in England, Scotland, and Ireland, who were exporting the output of their factories to Canada. $^{3}$

These appeals were reiterated and emphasized between one

1 There were curtailments of the preference in 1904, and many more at the general revision of the tariff in 1907. Cf. Statutes of Canada (4 Edw. VII, c. 11 ; 6 \& 7 Edw. VII, c. 11) ; Porritt, Evolution of the Dominion of Canada, pp. 432-436.

2 Industrial Canada (Toronto), October 1908.

3 'We are sometimes asked what we mean when we say that Canadian manufacturers do not demand a prohibitive tariff against the United Kingdom, but that we must at least have sufficient protection to put our Canadian manufacturers on an equivalent footing with those of Great Britain. Perhaps our meaning may be better understood when I cite the case of one of the members of our association who had large factories in Montreal and London. The difference in the wages paid in these two factories of England and Canada is remarkable. Figures taken from the pay rolls, and strictly accurate, show that common labour is $\mathbf{8 2}$ per cent. higher in Canada than in England; gang leader, or sub-foreman, is 85 per cent. higher; machinists 64 per cent. higher; carpenters 40 per cent. higher; girls by the hour, 33 per cent. higher ; and for piece-work 66 per cent. higher. Are not these figures alone sufficient to show the necessity of maintaining an equalizing tariff against British goods ?' C. C. Ballantyne, President, Canadian Manufacturers' Association; annual meeting of the Association, Winnipeg, September 18, 1906. 
annual meeting of the Association and the next by Industrial Canada. ${ }^{1}$ The campaign against the British preference, begun by the Manufacturers' Association in 1897, went on in Industrial Canada contemporaneously with the 'made in Canada' propaganda of 1901-1914. In the campaign for higher duties against imports from the United Kingdom, and in particular for higher protectionist duties on woollens and ready-made clothing imported from England and Scotland, no opportunity was lost of contrasting wages in Canada, and the creature comforts of wage earners in the Dominion, with wages in England and Scotland, and the fewer comforts enjoyed by the proletariat in Great Britain.

Canadian protectionists, from the days of Buchanan and Weir, were always quick to adopt the slogans and tactics of protectionists in the United States. The campaign against the preference was characterized by American methods of propaganda. In some of its phases it was closely modelled on the 'full dinner pail' campaign, that made the presidential and congressional elections of 1896, that preceded the enactment of the Dingley tariff of 1897, memorablc in the political and tariff history of the United States. ${ }^{2}$

1 'Employecs of industrial concerns, who feel disposed to vote for politicians who want to lower the duties against British goods should study the following Government statistics dealing with wages: Of the 8,000,000 adult wage-workers in England 4 per cent. receive less than $\$ 3.65$ a week ; 8 per cent. are paid from $\$ 3.65$ to $\$ 4.87 ; 20$ per cent. receive from $\$ 4.87$ to $\$ 6.10 ; 21$ per cent. get from $\$ 6.10$ to $\$ 7.30 ; 21$ per cent. get from $\$ 7.30$ to $\$ 8.52 ; 13$ per cent. get from $\$ 9.75$ to $\$ 10.96$; and only 6 per cent. get more than $\$ 10.96$ per week. The people who receive these wages make goods which are partially kept out of Canada by the duty. If the duty is lowered, more British goods would enter Canada. If Canadian inanufacturers have to cut selling.prices to meet the increased competition, part of their loss must fall on the employees. Do Canadian workmen want these wages ?' Industrial Canada, December 1912.

2 In the issue of Industrial Canada for June 1913, there was an article entitled 'Three Good Meat Meals'. It was based on a letter written to The Coloniser (London) by an immigrant from England. 'The working classes', he wrote, in telling of his expcriences in Canada, 'are better off. The workman gets three good meat meals a day as a rule, which compares very favourably with what he has been accustomed to before arrival in Canada.' 'Free traders will kindly notice', said Industrial Canada. in commenting on the letter, 'that it is protection in Canada which provides the "three meat meals " which the English workman could not get in free-trade England.' 


\section{CHAPTER VII}

\section{COLONIES AS DUMPING MARKETS FOR BRITISH MANUFACTURERS, 1858-1914}

For over half a century, 1858 to 1914 , low wages in manufacturing industries in the United Kingdom were urged as a ground for duties in tariffs in Canada and in Australasia that would protect colonial manufacturers from British competition. In these years there was another argument which was common to the protectionist propaganda in Canada and ili Australasia. It was used in Canada as early as 1858 .

Its first use in any colony was in the United Provinces; for it was in these provinces, it will be recalled, that the protectionist movement in the British oversea dominions had its beginnings. This second argument for protection against imports from the United Kingdom was based on the allegation that British manufacturers dumped their surplus or refuse stocks on colonial markets to the disadvantage of colonial manufacturers. ${ }^{1}$

Syme in his editorial writings in The Age of Melbourne, brought the same argument into service in Victoria in 1860. It was first used in Upper Canada-first advanced in the Legislative Assembly at Toronto, by Rose, the Attorney-General -in the interest of Canadian manufacturers of soap. In Victoria it was first used in the interest of manufacturers of men's and women's clothing. ${ }^{2}$

Possibly there may have been ground for objections to the quality, the fabrication, and also the style of some of the manufactures of the United Kingdom, particularly textiles, men's and women's clothing, millinery and men's hats, exported to the colonies under the old commercial system. It is not at all improbable that at a time when there was little ready money

${ }^{1}$ Cf. speech by John Rose, Attorney-General, in support of a duty in the Cayley tariff of 1858, to protect soap factories in Montreal. Globe (Toronto), July 12, 1858. Rose, on whom a knighthood was conferred in 1878. was, like Buchanan, Weir, and Syme, a native of Scotland. He was domiciled in Canada from 1836 to 1869 . He was a supporter of the protectionist tariffs of 1858 and 1859. Later in his career he was Minister of Finance in the Dominion administration of 1867-1872. In this capacity he wrote the minute of council forwarded to London in 1868, when the Colonial Office made one of its last protests-part of the propaganda of 1847-1895-against differential duties in Canadian tariffs.

2 Cf. Pratt, David Syme, p. 119. 
among colonists in the British North American provinces ${ }^{1}$ and in Australasia, when much of the trade at the local stores was by barter, and when the old commercial system safeguarded British manufacturers from all non-British competition, much poor and out of stylc stuff was exported from the United Kingdom to the colonies.

The doctrine of commerce that is summed up in the modern phrase of the marts, 'all the traffic will bear,' under the old conditions, and when there was no competition to be encountered from manufacturers in the colonies, would be peculiarly applicable to both the quality and the price of exports from the United Kingdom to all the oversea possessions where British manufacturers were easily supreme.

It is not practicable to determine whether before 1846 , before the end of the old commercial system, indifferent or inferior goods, for which no market could be found or made in the United Kingdom, were systematically shipped to the colonies. It is of interest to note that the tradition that this was the case survived for generations after British colonies ceased to be walled-in markets for manufacturers in the United Kingdom.

In Canada the quality of some exports from the United Kingdom was objected to as long ago as 1858 . It was a ground of complaint against a free market for British manufacturers in British North America in the first year of the organized movement for protection in Upper and Lower Canada. Similar complaints were made, usually but not invariably as the basis for protectionist arguinents, for more than half a century after tariffs for the colonies ceased to be enacted by Parliament at Westminster, and enacted solely in the interest of manufacturers in the United Kingdom.

In Cape Colony and Natal in 1902 I frequently heard objections to the quality, and sometimes to the belated style, of some manufactures exported from Great Britain. In general the complaint was that British manufacturers were under the impression that any kind of wares could be marketed in British

1 "This rate (two shillings postage on a letter from Montreal to New York) was quite prohibitive. Governors Murray. of Quebee. and Gage, of Montreal, represented to the Home Government that the people of Canada were almost destitute of cash, and would not write to their friends in England until they found private occasion to send their letters to New York.' William Smith. A History of the Post Office in the American Colonies and in ('anada. "In Canada ineomes were gmall. 'The eount ry was settled by people mostly poor and uneducated.' A. 'T. (ialt, Manchester. September 25, 1862. Guardian (Manchester), September 26, 1862. 
colonies, and that quality and style were immaterial in South Africa.1

These criticisms were not offered by colonial protectionists of the school of Buchanan, Weir, Rose, Syme, and Vogel. Nor were they offered by manufacturers in Cape Colony anxious for tariff protection against competition from the United Kingdom. There were few manufacturers in British South Africa in 1902, fewer factory industries than there were in Upper and Lower Canada in the years in which the Cayley and Galt tariffs were enacted by the legislature at Toronto. There were no textile industries.

The observations were volunteered by distributors, wholesalers and retailers, not as a protectionist argument, but as one explanation of an increase in exports to South Africa from the United States, Germany, and Austria. The survival in South Africa of the tradition of the attitude of British manufacturers toward trade with the colonies was the more noteworthy, because up to 1902 it had not been used, as in Canada and Australia, as the basis of an argument for tariff protection against imports from the United Kingdom.

The argument, in an extreme form, was used in Canada, much to the consternation of the woollen trade of Yorkshire, as late as 1908, with a view to forcing the Dominion Government to make larger curtailments of the British preference. It was used in an unsuccessful effort to impel the Laurier Administration of 1896-1911 to concede more protection to woollen mills in Ontario, Quebec, and Nova Scotia, and to clothing factories in Montreal and Hamilton, from competition from the United Kingdommore protection than had been conceded at the revisions of the Dominion tariff in 1904 and 1907.

It was then asserted in Industrial Canada, which, as the organ of the Canadian Manufacturers' Association, was supporting the manufacturers in their demand for another revision upward of the woollen schedules of the British preferential tariff, ${ }^{2}$ that

1 'Opportunity has been taken of the colonial premier's visit to approach representatives of Cape Colony, Natal, and the Transvaal, on behalf of the second-hand clothing trade in the East End of London, which is seriously threatened by the high tariff. ... Previously the rates levied on second-hand clothing, imported into South Africa, were 25 per cent. and 10 per cent., with a rebate of one-fourth of this duty in favour of England and reciprocating British colonies, whereas the new duty proposed is fixed at two shillings for each coat, rest, or trousers, with no rebate.' 'Old Clothes to Sell,' Yorkshire Post (Leeds), May 18, 1907.

2 The schedule was revised in the interest of Canadian woollen mills in 1904. 
cheap woollen clothing exported from England was made of shoddy; that it was a danger to the health of the people who wore it-so great a menace to the public health, it was urged, that the Dominion Government should 'take measures to put a stop to the importation of such trash, even to the extent of prohibiting it as they would a plague '?

Yorkshire woollen manufacturers, long aware of the agitation in Canada for higher duties on all British woollens, were alarmed at the attack in the organ of the Canadian Manufacturers' Association on the output of their mills. Meetings of woollen manufacturers were held in Bradford and Leeds to make public protest. There was also some comment on the allegations in the House of Commons at Westminster, and a statement from Mr. Winston Churchill, who was then President of the Board of Trade in the Liberal administration of 1905-1915.

'I have', said Churchill, 'no reason to believe that the allegations which appeared in the official organ of the Canadian Manufacturers' Association have any foundation; and I understand that the secretary of the Association has cabled an expression of regret for any injustice that may have been done to British manufacturers by the publication of them. I am of opinion, moreover, that such misrepresentations can best be met by action on the part of the Chambers of Commerce in the home districts concerned.' 2

In the propaganda for more protection for Canadian manufacturers that preceded the national policy tariff of 1879 , and also in the propaganda from 1879 to 1896 in support of the policy adopted by the Dominion Parliament in 1879, it was often insisted that protection was necessary to safeguard Canadian industrics from the competition of American manufacturers who dumped their surplus stocks at slaughter prices in the Canadian market. Much the same argument, this time against cotton manufacturers in Lancashire, was urged on the Dominion Tariff Commission when it was at Valleyfield, a large centre of cotton manufacturing in the province of Quebec, in December 1906. ${ }^{3}$

By this time, 1906, this argument for protection in Canada

1 'Death in the Clothing,' Industrial Canada, August 1908. ('f. 'British Woollens in Canada,' The Times (Iondon), April 12, 1909.

2 Parliamentary Debates, IV, xciv, 1571.

3 Cf. 'Canadian Tariff Commission at Valleyfield,' Transcript (Boston), December 27, 1906 . 
against competition from both the United States and the United Kingdom was familiar and well worn. Canada had been accustomed to it since 1858, when Rose first introduced it in the debate on the Cayley tariff, and told the House of Assembly at Toronto that the Canadian market was flooded with the refuse soap of English manufacturers, which had been entered at the customs house at prices below those at which soap had ever been sold in England.

In Australia, Syme had the distinction of introducing this argument -of objecting, in 1860 , as a protectionist, 'to the overwhelming competition of the multitudinous inferior, low priced-not cheap-articles made of refuse material, especially for the Australian market, with which we are inundated from the crowded factories and workshops of Great Britain.' 1

Both Rose and Syme were immigrants from Great Britain. One of the remarkable features of the early protectionist movements in Canada and Australasia was the zeal with which such newcomers from England and Scotland, who had secured footing in the political life of these colonies, embarked in the propaganda for the tariffs to exclude British manufactures.

The national policy of Canada, as it was developed from 1858 to 1896, was pre-eminently the creation of men from Scotland, or of men of Scottish ancestry. Cayley, who framed and carried through the legislature of Upper and Lower Canada the first protectionist tariff ever enacted by a legislature of a British colony, was an Englishman. He was a graduate of Eton and Christ Church, Oxford, and emigrated to Canada in 1834.

But the extra parliamentary work for the tariffs of 1858 and 1859 was largely done by Buchanan and Weir, both immigrants from Scotland; and in the parliamentary history of protectionist tariffs in Canada from 1859 to 1896 the names that stand out with prominence are those of Rose and Galt, also immigrants from Scotland, and John Alexander Macdonald, whose father and mother were born in Scotland.

Syme's claim to be the father of protection in Australia seems never to have been disputed. Julius Vogel, who was born in London, the son of Jewish parents, is on good grounds regarded as the father of protection in New Zealand.

1 Pratt, David Syme, p. 119. 


\section{CHAPTER VIII}

\section{THE FAILURE OF THE PROPAGANDA AGAINST DIFFERENTIAL AND PROTECTIVE DUTIES IN CANADA, 1846-1859}

There were no fewer than seven distinct crises in the progress of the dominions to the complete fiscal freedom that they have all been able to exercise since 1907. There were at least seven occasions in the period from 1846 to 1907 on which the Colonial Office and Governments in London had to decide whether they would make concessions to demands from the self-governing colonics for larger power over their fiscal legislation, or over developments growing out of the power which had accrued to them in connexion with their fiscal and commcrcial policies.

By the term 'complete fiscal freedom' is meant, it should perhaps be emphasized at this point, more than freedom of the legislatures of the self-governing colonies to enact tariffs of any description-discriminatory, differential, or retaliatory-or to enact other laws for the development of industry in the colonies, without any interference from London.

The tcrm to-day implies more than freedom in all these respects ; because since 1907, as the result of a movement to be followed with some detail in Part III, the dominions, in practice, have becn as free to negotiate commercial treaties, and to enact laws to implement commercial treaties with non-British countries, as the United States or France is free to negotiate and to implement international engagements of this character.

The first of the series of crises in the history of the progress of the dominions to their present fiscal and diplomatic freedom, developed as soon after the adoption of free trade as the commercial policy of the United Kingdom as 1850, when Grey, then Colonial Secretary, unavailingly protested against differential customs duties in a tariff of the United Provinces. ${ }^{1}$

Twenty-one years later, when Kimberley was arguing with the governments of the Australasian colonies against the policy of

1 Statutes of Canada, an Act to faeilitate reciprocal free trade between this province and other British North American provinces, July 24, 1850 (1:3 \& 14 Viet., c. 3). 
differential duties, he urged that no precedent could be based on the differential tariffs of the British North American provinces. These were enacted to facilitate interprovincial trade, or reciprocity with the United States; and, as Kimberley contended, they represented only a small concession on the part of the Colonial Office, only an unimportant departure from the policy of the Colonial Office which had been pursued since 1846. 'They dealt', Kimberley wrote on July 31, 1871, 'with a limited list of raw materials and produce, not imported to these colonies from Europe.' 1

It is a fact of history, however, that the principle for which Grey contended was, as regards the British North American provinces, in effect, abandoned by the Colonial Office after Grey's unavailing intervention in 1850. Protests against differential duties in the tariffs of these provinces were made every time a new tariff with differential duties was enacted, until as late as 1870 . But the crisis was over, and the British North American provinces were on secure ground, when Grey declined to 'go over the top' and ask the Cabinet to advise the Crown to withhold assent from the Act of the United Provinces of 1850.

The second crisis, the most momentous of the series for Downing Street and its fiscal policy, came in 1859. Then Newcastle, after addressing the Cartier-Macdonald Government at Toronto in what was described in a report of the Co Imittee on Commerce of the House of Representatives, at Washington, as 'terms of force, unusual in diplomatic correspondence,' ${ }^{2}$ was, like Grey in 1850, afraid to 'go over the top' and recommend the Palmerston Government to veto the Galt tariff.

The propaganda for an empire-wide fiscal system, based on the principle of free trade, was hopeless after Newcastle and his colleagues of the Cabinet, on or about August 13, 1859, decided not to quit the trenches. One division of the propaganda, it will be recalled, was continued long after 1859. But thereafter all the colonies with responsible government promptly realized that Downing Street dare not disallow a tariff Act merely because it embodied duties intended to protect colonial manufacturers from

1 Correspondence with the Australasian Colonies with Reference to Proposed Intercolonial Tariffs, 1872 , p. 3.

2 Report of Committee on Commerce, House of Representatives, 37th Cong., 2nd Sess., Report No. 22, p. 31. 
competition from Great Britain. The world at large also realized that the British colonies, with responsible government, were henceforward to make their own pace in tariff legislation, regardless of the general fiscal policy of Great Britain.1

\section{CHAPTER IX}

\section{HIGH PEAKS IN THE MOVEMENTS TOWARDS FISCAL FREEDOM, 1846-1873}

A SURVEY of the stages and developments of the several movements toward protection, toward national policies ${ }^{2}$ in Canada and Australasia, in the twenty-nine years from the Enabling Act of 1846 to the conflict of 1867-1873 between the Australasian colonies and the Colonial Office over differential duties, is necessary to an understanding of the series of crises that mark the progress of the dominions to fiscal and diplomatic freedom.

To express the same idea in another way, a survey such as has been attempted is necessary to an understanding of the crises that mark the history of the ineffectual propaganda of Parliament and

1 ' It seems that Great Britain, aequieseing in the prineiple of eolonial selfgovernment, made no further publie attempt to regulate the tariffs of Canada, retaining only the power to make treaties on behalf of the provinees; while Canada assumes and exereises a right to make laws in opposition to their spirit and intentions, the enaetments of the Canadian Government being opposed to the development of those mutual interests whieh on both sides of our vast and eo-terminous frontier eontribute no little to the best system of national defence, although Canada yet relies to a eonsiderable extent for military proteetion upon the armies and expenditures of a power whose poliey and wishes it disregards.' Report of Committee on Commeree, House of Representatives, Washington, February 5, 1862, No. 22, p. 31 .

The report, from whieh the foregoing paragraph is taken, was adopted by the Committee on Commeree at a time when it was a eomplaint at Washingtona eomplaint that was one of many faetors in ending the Elgin-Marey treaty in 1866-that advantages to the United States whieh it had been understood in 1852-1854 would aeerue to Ameriean trade from the treaty were whittled down by Aets of the legislature of the United Provinees, and by orders in eouneil issued by the Government under statutes enacted by the legislature. In partieular, it was eomplained that manufacturers in the United states were diseriminated against in the tariffs of 1858-1859, and that Ameriean transport business on the Great Lakes and on the St. Lawrenee was hampered by diseriminatory tolls on the Welland Canal, levied under orders in eomeil, the purpose of whieh was to divert business to Montreal. Cf. Hateh. Report on Reeiproeity, Executive Documents, House of Representatives, Washington, 1863, No. 96, pp. 5-26.

2 The term national poliey is used here in the same sense as it has been used in the Dominion of Canada sinee 1879. The term is one which Canada eontributed to the politieal terminology of the Empire. 
Governments at Westminster to secure the establishment of a fiscal system common to the Empire at large, and uniformly based on the principle of free trade.

For an understanding of these crises it also seemed expedient to describe some of the characteristics of the several protectionist movements that were common to all the colonies, in which from 1858 to 1873 customs duties were enacted to protect colonial industries from competition from the United Kingdom. An examination of these characteristics of the protectionist movements-an examination a little detailed in places-helps to a realization of the continuously antagonistic attitude of most of the self-governing colonies toward the propaganda from Whitehall and Westminster that went on from 1846 to 1895 , but with manifestly diminishing force in the years from 1859 to 1895 , when the propaganda came to an end.

In a survey such as that to which Part II has been devoted, there stands out a series of facts in the history of the movements in the colonies for fiscal freedom and also in the history of the movements for national policies. These facts are of much importance in the history of the relations of the colonies with Great Britain from 1840 to 1914 . The facts are :

1. That it was not the intention of the Russell Government of 1846-1852, when it asked Parliament to pass the Enabling Act, that the self-governing colonies should exercise the freedom accruing to them under this measure contrary to the principles on which in 1846 the fiscal policy of the United Kingdom was established.

2. That the British North American provinces, and in particular the United Provinces of Upper and Lower Canada, almost at once took a wider view of their powers under the Enabling Act of 1846 than the Russell Government had contemplated.

3. That the Enabling Act was the starting-point of all the movements in the British North American provinces toward fiscal freedom.

4. That when the British North American provinces began to use their legislative powers under the Enabling Act-to use them first to enact tariffs with differential duties, and next from 1858 to enact tariffs with protectionist duties applicable to all comers, British or non-British - the new relations between these colonies and Great Britain, growing out of a reluctant concession of 
responsible government, were such that it was impracticable for the Colonial Office to recommend administrations in London to advise the Crown to withhold the Royal Assent from fiscal legislation in these colonies that was out of harmony with the free-trade system of Great Britain.

5. That a protectionist movement in Upper and Lower Canada successfully asserted itself in the legislature at Toronto, within four years after Great Britain, through its plenipotentiaries at Washington, had negotiated for all the British North American provinces, except British Columbia, a reciprocity treaty, based on differential duties, with the United States.

6. That within five or six years after the old commercial system had been abandoned by Great Britain, at least two of the British North American prorinces, New Brunswick, and Prince Edward Island, attempted to develop colonial industries by the aid of bounties.

7. That in Upper and Lower Canada, and also in the Australasian colonies, there was an early and common use of the argument that while free trade might be well adapted to an old world country, like the United Kingdom with its overflowing population and with its advantages for manufacturing and export trade, free trade was not adapted to new world conditions and small populations, such as existed in the self-governing colonies.

8. That there was a common use of the argument for protection based on low wages in manufacturing industries in the United Kingdom.

9. That there was a common use of the argument that British manufacturers dumped on colonial markets surplus or left over, or cheaply fabricated goods, refuse stuff, as these goods were described by Rose and Syme.

10. That in Canada discriminating, differential, and retaliatory duties had been embodied in several tariffs of the provinces of Upper and Lower Canada, or of the Dominion of Canada, and differential duties in tariffs of the provinces of New Brunswick, Nova Scotia, and Prince Edward Island.

11. That in Australasia discriminating or protectionist duties had been enacted; and retaliatory duties had also come into operation as factors in tariff wars between sister Australasian colonies.

1:2. That schemes for a customs union to include all the 
Australian colonies - schemes which were discussed as early as 1862 - had failed because of the inability of the colonies to agree among themselves as to tariff concessions regarded as necessary to the establishment of a customs union.

13. That all the Australasian colonies in the years from 1867 to $\mathbf{1 8 7 3}$ were intent on a larger fiscal freedom, intent on obtaining power to enact differential duties.

14. That in New Zealand legislative sanction had been given to a 'made in New Zealand' movement, the first organized and legislatively recognized movement to that end in any British colony.

15. That in Tasmania and New Zealand there had been the first movement toward bonuses as aids in establishing colonial manufacturing industries.

From the several chapters in Part II it will also have been realized :

16. That the example of the United States-the permanency that by the fifties of the nineteenth century had come to attach to the protectionist system there-had greatly influenced the protectionist movement and protectionist legislation in Upper and Lower Canada.

17. That by way of the British North American provinces the protectionist movement in the United States had much influenced the fiscal policies of several of the Australasian colonies.

18. That Great Britain had approved of a reciprocity agreement between the British North American provinces and the United States - an agreement in which no advantages were asked for, or conceded, by the United States to Great Britain ; and that from 1865 to 1871, from the denunciation by the United States of the Elgin-Marcy treaty to the negotiation of the treaty of Washington in 1871, Great Britain, through its diplomatic representatives at Washington, was moving for a second reciprocity treaty for all the British North American provinces, in which it was proposed that larger concessions should be made by these provinces, or the Dominion of Canada, than were embodied in the treaty of 1854-1866.

19. That New Zealand in $1869-1870$ was engaged in informal negotiations for a reciprocity agreement with the United States.

20. That the protectionist movement in these years, 1846-1873, 
had made headway even in the remote, isolated, ultra-British infant colony of British Columbia.

21. That in Canada and Australia the leaders of the protectionist movements were, almost without exception, comparatively newcomers from the United Kingdom, and, with the exception of Cayley, Cartier, and Macdonald, ${ }^{1}$ all immigrants from Scotland, and

22. That in the protectionist tariffs of the Canadian and Australasian colonies of this period there were no preferences for imports from Great Britain, notwithstanding the fact that when the earliest of these protectionist tariffs was in operation, Great Britain was responsible for the internal as well as the external defence of all the self-governing colonies.

These were some of the more obvious developments of the protectionist movement in Canada and Australasia - all of them antagonistic to the free trade policy of Great Britain in the years from 1846 to 1873 . These were the features of the movements toward national policies in the self-governing colonies from the passage at Westminster in 1846 of the Enabling Act to the time when the Colonial Office and the Gladstone administration were confronted with the third crisis in the series which marked the history of the Colonial Office propaganda for fiscal systems in the self-governing colonies in harmony with the fiscal systems of the United Kingdom and the Crown colonies. ${ }^{2}$

1 Cayley was born in England; Cartier was born in Lower Canada; and Macdonald, whose father and mother were immigrants from Scotland, was born in Upper Canada.

2 'The Crown colonies, it will be recalled, did not come within the provisions of the Enabling Act of 1846. They were not consulted as to the broad general principles on which their fiscal legislation was based. No opportunity was afforded them of coming into conflict with the Colonial Office on the questions of frce trade and protection. 


\section{PART III}

\section{FISCAL FREEDOM AND DIPLOMACY, 1848-1907}

\section{CHAPTER I}

\section{EARLY STAGES OF THE MOVEMENT FOR POWER TO NEGOTIATE COMMERCIAL TREATIES, 1848-1849}

Two of the crises in the progress of the self-governing colonies toward their fiscal freedom and their present day power to name their own plenipotentiaries for the negotiation of their commercial treaties, were described in a preceding chapter. The first was the crisis over differential duties in which Grey was worsted. The second was over tariffs with protectionist duties, the crisis in which Newcastle gave way much more quickly and much more obviously than did Grey in the contest with the United Provinces of Upper and Lower Canada over differential duties in the tariff of 1850 .

The third crisis came in 1865. It developed directly out of the large measure of fiscal freedom that had accrued to all the British North American provinces since 1850. It grew out of the exercise in particular of the freedom of the provinces to enter into reciprocity agreements with the United States. In 1865 the Governments of the United Provinces and the Maritime Provinces pressed a claim on the Colonial Office that it secure for the provinces direct representation at Washington in any negotiations for a renewal of the Elgin-Marcy treaty, or for an entirely new reciprocity treaty with the United States. ${ }^{1}$

It was not a great and disturbing crisis like that of 1859 when Galt practically dictated the action that the Palmerston government should take on the tariff bill of the United Provinces, or a crisis like that of 1867-1873 when the Australasian colonies lined up in revolt against the propaganda of the Colonial Office, and Parliament had to effect a settlement.

1 Cf. Gray, Confederation, i, p. 315. 
It was not a crisis to which any prominent place has been assigned in the history of the relations of Great Britain with the self-governing colonies. It has so far been left without attention in the treatises on the constitutional relations of Great Britain and the dominions ; and apparently it was not a crisis that attracted much attention or comment in contemporary newspapers, for it has no mention in the standard year books for 1866 .

It was none the less an important crisis in the relations of the colonies to Great Britain. It may almost be described as an epochmaking crisis in the history of the fiscal freedom of the dominions, in the wider meaning of the term 'fiscal freedom'. It was a crisis, moreover, that, like so many of the crises in the constitutional and fiscal history of the colonies from 1840 to 1873 , was provoked by the action of the Government of the United Provinces of Upper and Lower Canada. These provinces from 1828 to 1867 were always in the lead. They were always persistent, aggressive, and unyielding, when larger freedom and new and more extensive powers were deemed by them essential to the development of their political civilization.

A decision had to be made by the Colonial Office and the Cabinet on the new claim of the United Provinces - a claim with which the Maritime Provinces were associated. It was in favour of the claim; and the decision then made and acted upon by the Foreign Office that the British North American provinces were to be directly represented in the negotiations at Washington for a second reciprocity treaty ${ }^{1}$ was of far-reaching consequence. In the half century before the great war this decision of May 1866, and developments that followed in its train, had beneficently affected the world status of all the colonies now of the dominions.

As early as May 1848, at the preliminary stages of the negotiations that finally resulted in the reciprocity treaty of 1854 , William Hamilton Merritt, an active and distinguished member of the House of Assembly of Upper and Lower Canada, and President of the Council of the Baldwin-La Fontaine Administration, was in Washington in the interest of reciprocity. While Merritt was there, and only a year after any of the North American provinces had for the first time exercised its new power under the Enabling

1 Cf. Dispatch of Charles Francis Adams, United States Minister in London, to Seward, Secretary of State, Washington, May 10, 1866. State Papers, 1866 p. 119. 
Act, the Government of the United Provinces suggested further powers for the colonies with responsible government. It was urged that in the negotiations proceeding at Washington-negotiations that were proceeding at a pace that was trying for Canada -there should be direct communication between Washington and Montreal, which in 1848 and 1849 was the seat of the Government of the United Provinces. ${ }^{1}$

Out of the intense desire of the United Provinces in the years from 1847 to 1854 to obtain reciprocal trade with the United States thus came the first suggestion to Downing Street, from any colony, that in treaty negotiations in which the colony was directly interested it should be directly represented.

Within three months after the suggestion was made, in July 1848, La Fontaine, Baldwin's associate at the head of the Ministry of the United Provinces, and Sullivan, one of the fathers of protection in Canada, who was at this time Provincial Secretary, were in Washington in the interest of reciprocity. ${ }^{2}$ Merritt was twice in Washington while he was a member of the Baldwin-La Fontaine Administration, first in May 1848, and again in June 1849.

Exactly what were La Fontaine's and Sullivan's relations with Crampton-Sir John Fiennes Twistleton Crampton, who was at the British Mission at Washington from 1845 to 1853 -it is not easy to trace. There is no doubt, however, about Merritt's position in the negotiations. He carried no diplomatic credentials for presentation to the Department of State, but he was closely, though unofficially, associated with Crampton in endeavouring to convince Fillmore, the President, and Clayton, the Secretary of State, that a larger freedom in trade across the boundary line would be advantageous to the United States as well as to Canada. Crampton had no knowledge of Canadian trade. Merritt was a merchant and miller in a large way at St. Catherine's, Upper Canada, and the burden of the presentation of the case for the United Provinces fell upon him. ${ }^{3}$

1 Cf. Memorandum of Francis Hincks, Inspector-General, United Provinces, May $12,1848$.

2 Cf. J. P. Merritt, Biography of William Hamilton Merritt, p. 337.

3 Cf. Merritt, op. cit., pp. 328, 330, 332, 333. 


\section{CHAPTER II}

\section{ATTITUDE OF THE BRITISH MINISTERS AT WASHINGTON TOWARDS THE NEW CLAIM OF THE COLONIES}

CRAMPTON, who at a later stage in his career was highly regarded by Palmerston, had none of the contempt for statesmen of the self-governing colonies in diplomacy that was characteristic of Lord Lyons, ${ }^{1}$ who was minister at Washington from 1858 to 1865. The attitude of Lyons toward claims of these colonies to direct representation when treaties materially affecting them were in negotiation was that it would be time enough for the colonies to press these claims when they had equipped themselves with an army and navy for their own defence. ${ }^{2}$

Lyons was exceedingly frank in his intimation of 1864 to Viscount Monck that he was not disposed to help forward the colonies to the status of nations conducting their own negotiations for commercial treaties; and his attitude toward representatives of the Government who had been in Washington in the interests of reciprocity without credentials from the Foreign Office was well known at Toronto. ${ }^{3}$ His general attitude toward the wider claims of responsible government, relentlessly pressed to success by the Liberal party in Upper and Lower Canada from 1841 to 1849, was much the attitude of Sir Charles T. Metcalfe, an eminently successful Governor of Jamaica in a time of exceeding difficulty, who, after achieving distinction as governor of a crown

1 'The Canadians appear to me to be acting unwisely about the reciprocity treaty at this moment. I cannot have a Canadian here supposed to be peculiarly in my confidence on the subject. This would impose on me a responsibility which I cannot undertakc. Directly there was the least appearance of a Canadian being here in any such position, I should feel bound to take decisive steps to show that the appearance was false. My own opinion is that the Canadians will only do themselves harm by coming lobbying here; but. if they choose to do so, they must do it entirely independently of me ; and I would suggest that any who eame for the purpose should not be furnished with letters of introduction to me, and should be advised not to eall upon me.'-Lyons to Viscount Monck, Governor-General of Canadia, 1861-1868, Washington, February 28, 1864. Newton, Lord Lyons, i, pp. 123-124.

"I have no idea of going to Washington, as a boby agent, to be snubbed by Iord Lyons for medilling in a matter which he is sufficiently able to settle.' (ieorge Brown to Holton, Toronto, January 29, 1864. Mackenzie, Life of Gieorge Bromin. p. 209.
2 (f. Newton, op. cit., i, p. 127.
3 Cf. Mackenzie. op. cit.. p. 209. 
colony, has a place in the constitutional history of the colonies now of the dominions only because of the complete and abject failure of his efforts of 1843-1845 to hold back the movement for responsible government in Canada. ${ }^{1}$

Crampton's attitude toward responsible government in its broadest sense was that of Elgin, who succeeded Metcalfe as Governor-General. Crampton realized whither responsible government was tending, and he acted in the spirit of this realization when Merritt was associated with him in the reciprocity negotiations of $1848,{ }^{2}$ and again in those of June 1849. Merritt was Crampton's guest for a week during his second visit; and Crampton accompanied Merritt when he called at the State Department (June 28, 1849), to submit the case for reciprocity to Fillmore and Clayton.

Newspapers of Montreal and Toronto chronicled Merritt's doings in Washington in 1848 and 1849. The movement at this time was for reciprocity by concurrent legislation. Public attention in Canada was directed upon Merritt, rather than upon Crampton, who was not known in Canada; and in June 1848, when there seemed a likelihood that the bill before Congress would pass, the Globe of Toronto declared that if success should attend the bill so much desired in Upper Canada and in Montreal, Merritt would have earned the thanks of his fellow countrymen. ${ }^{3}$

In the annals from 1783 to 1914 of diplomatic negotiations at Washington in which material interests of the British North American provinces or of the Dominion of Canada were concerned-boundaries, trade, fisheries, canals, international waterways and coastwise and lake navigation-there is not a more exhilarating chapter than Merritt's own quietly-told narrative of his association with Crampton read in conjunction with Crampton's letters to Merritt.

These two first-hand sources of material necessary to an understanding of the early stages of the movement in the British

1 Cf. Porritt, Evolution of the Dominion of Canada, pp. 119-127.

2 'In reply to your inquiry, I lose no time in stating to you that I should feel much gratified, should it be convenient to you, to visit Washington, to confer with you upon the subject of the desired equalization of duties between Canada and the United States; and I cannot doubt that your presence would very much tend to advance the object her Majesty's Government have in view.'-Crampton to Merritt, March 25, 1818, acknowledging receipt of a letter from Merritt, enclosing a note of introduction from Elgin. Merritt, Biography of William Hamilton Merritt, p. 330.

${ }^{3}$ Globe (Toronto), June 1, 1848 ; Merritt, op. cit., pp. 331-334, 337, 359. 
North American provinces for direct representation in treaty making are peculiarly valuable to students of colonial history whose sympathies are with the movements of the three quarters of a century after the rebellion in Canada of 1837 which carried the colonies forward to the status of nation within the Empire.

The memory of Crampton's career at Washington, despite the episode that brought it abruptly to an end in $1856,{ }^{1}$ is peculiarly worth cherishing in all the dominions; for wittingly or unwittingly_seemingly wittingly_Crampton admirably served them all. Both in his attitude toward the new claim of the selfgoverning colonies to have their part in negotiating treaties that affected their commercial interests, and in his loyalty to the interests of Canada that were at stake from 1848 to 1854, Crampton in any history of Canadian diplomacy, or of the movement from 1848 to 1907 for the diplomatic freedom of the dominions ${ }^{2}$ must rank with Bruce-Sir Frederick William Adolphus Bruce, Elgin's brother, who was Minister at Washington from 1858 to 1866 , and with Viscount Bryce, who was British Ambassador at Washington from 1907 to 1912.

All three, Crampton, Bruce, and Bryce, worked for the coming time; and as the diplomatic representatives of Great Britain in the United States, Canada's only neighbour, they had their part in advancing the status and the dignity of all the dominions.

In the particular field that opened out for these diplomatistshelping the dominions to the stage of their development at which they became completely free to negotiate their own commercial treaties-Crampton, Bruce, and Bryce rendered services to the dominions that stand out almost as much as the services rendered by Durham, Sydenham, Bagot, and Elgin to the constitutional development of the dominions, when these Governors-General threw in their lot with the movement in Upper and Lower Canada in 1828-1849 for responsible government.

1 He was reealled beeause of objections at Waslington to his aetivities in reeruiting soldiers in the United States for serviee with the British armies in the Crimea. He was, in the same year, ereated Knight Commander of the Bath. and in 1857 he was appointed Minister Plenipotentiary and Envoy Extraordinary at Hanover. Crampton died in 1886.

2 'Now let us turn to another aspeet of this history, and that is the treaty poliey into which Canada in partieular has been foreed by cireumstanees over whieh she had no eontrol and whieh lepend upon the fiseal relations between the great manufacturing States of the world. It is the most instruetive braneh of colonial or, perhaps I may say, imperial history.'-A. J. Balfour, House of Commons, July 21, 1910. Parliainentary Lebates, series 1910, xix, 1496. 


\section{CHAPTER III}

\section{DEVELOPMENTS IN THE MOVEMENT FOR TREATY- MAKING POWER, 1850-1865}

IT was the difficult position in which the British North American provinces east of the Great Lakes found themselves in 1847-1850, as a direct result of the abandonment of the old commercial system by Great Britain, that forced all of them to look longingly, almost appealingly, to Washington for easing of the tariff duties on farm products, lumber, coal, and fish available in the Maritime Provinces and in Upper and Lower Canada for export to the larger and constantly expanding markets of the United States.

Out of this movement, on which, to men on the spot, seemed to depend the economic salvation of all the British North American provinces, there developed within two years after the fiscal changes in the United Kingdom in 1846 the second movement for a larger freedom for the colonies, or rather a second phase of the movement which had first manifested itself, as will be recalled, in the United Provinces in May 1848.

New Brunswick came into this movement in 1850. It was thus the second British colony to claim direct representation in negotiations for commercial treaties ; and the House of Assembly at Fredericton, in preferring the claim, used language which admitted of no misunderstanding by the Colonial Office. It adopted a resolution to which the preamble was nearly as remarkable as the resolution itself.

'Whereas,' reads the preamble to the New Brunswick statement of claim of 1850 , 'the mother country has adopted a principle of trade, admitted by the Prime Minister of England ${ }^{1}$ and proved by bitter experience to be calculated to create wellfounded discontent, and to be painful to the colonists, but from which decision it is by the same authority asserted ${ }^{2}$ that the mother country ought not in any respect to attempt to go back ; and whereas the same high authority enunciates the doctrine that the mother country should trade with her colonies on the principle that she was to obtain articles from other countries

1 Lord John Russell, July 1846-February 1852.

2 House of Commons, February 8, 1850. 
which may be produced there better or cheaper than in the colonies, and at the same time states that the colonies should be at liberty to trade with all parts of the world in the manner which might seem to them most advantageous; and whereas the dispatches of the present Colonial Minister ${ }^{1}$ are not only at variance, but entirely hostile to any such liberty ;' . . .

'Resolved, as the opinion of this committee,' reads the final paragraph of this manifesto and claim of New Brunswick of April 24, 1850, 'that the withdrawal of all protection by the mother country, and the placing of the trade and productions of the colonies on the same footing as that of foreign nations in the British markets is disastrous and utterly ruinous to this province as a colony, unless full power is conceded to the colonies to treat with foreign nations on all subjects of trade and shipping, and without which the assertion that the colonies should be at liberty to trade with all parts of the world in the manner which might seem to them most advantageous ${ }^{2}$ is a mockery and a delusion.' ${ }^{3}$

There was an interval of fifteen years between the adoption of the spirited resolution at Fredericton in 1850, and the next definite claim for representation in treaty making. This new claim, the third in the series of claims, was first made by the Government of the United Provinces, and reiterated with added force a few months later at the meeting at Quebec in 1865, of the interprovincial council on commercial treaties, an organization in which all the British North American provinces were represented. ${ }^{4}$

In the intervening years, 1850-1865, representatives of the British North American provinces, and in particular of Upper and Lower Canada, were from time to time in Washington in the interest of reciprocity or some other interest arising out of the connexion of trade and navigation of these provinces with the United States.

Galt, who more than any other Canadian statesman of the first ten or fifteen years after Confederation wrought continuously

1 Grey, 18+6-1852.

2 Russell. House of Commons, February 8, 1850. Parliamentary l)ebates, III, eviii, 548 .

3 Journals of IIouse of Asscmbly (New Brunswick), April 24, 1850, p. 340.

- Cf. Ciray, Confederation, p. 315; Colmies, Accounts and Papers, 1873, c. 756, No. 6. Appendix No. 1. 
for the diplomatic freedom of the dominions, was at Washington in $1861^{1}$ on one of these errands. Lyons was then ministera diplomatist, who, in regard to colonial representation in treaty making, was poles asunder from the framer of the tariff of 1859 and author of the memorable minute of council of that year to Newcastle.

In the early sixties, when the outlook for a long life for the reciprocity treaty of 1854 was exceedingly poor and there was much Canadian business at Washington, Seward, Secretary of State in Lincoln's Administration, suggested to Sandfield Macdonald, Premier of the United Provinces, that a quasi-political agent should be sent to Washington for some months, "with whom he and Lord Lyons could confer informally from time to time on matters concerning Canada.' 2

With the private correspondence of Lyons now available, it is manifest that Seward, who at this time desired to stand well in London, had not consulted Lyons before he made this suggestion to Macdonald in the winter of 1863-1864-not in Washington, but in an interview between the Canadian Premier and the Secretary of State in New York. Sandfield Macdonald offered the mission to George Brown, who ten years later negotiated for the Dominion a treaty of reciprocity with the United States, which was rejected by the Senate at Washington. ${ }^{3}$

But statesmen of Canada during Lyons's tenure of the British mission at Washington had no liking for quasi-diplomatic service in that city, for work of this character, minus the credentials and standing of a diplomatist. They disliked even the risk of snubs from Lyons, ${ }^{4}$ and Brown's counsel to Sandfield Macdonald was that, as the renewal or modification of the reciprocity treaty was an imperial matter, the negotiations must be carried on through the imperial authorities. 'And,' Brown added, 'no doubt Lord Lyons will desire to conduct them in his own way, and according to his own ideas. All that we can do here, I apprehend, is to place before Lord Lyons the wishes of the Canadian Government, and co-operate with him in his efforts to give them effect.' 5

1 Cf. Newton, Lord Lyons, i, p. 60.

2 J. S. Macdonald to George Brown, Quebec, January 7, 1864. Mackenzie, Life of George Brown, p. 83.

3 Cf. Porritt, Evolution of the Dominion of Canada, pp. 451-453.

4 Cf. Mackenzie, op. cit., p. 209.

5 Brown to Macdonald, Toronto, January 25, 1864. Mackenzie, op. cit., p. 84. 
Brown was at this time, 1863-1864, not a member of the Liberal Administration of the United Provinces. But he was supporting it as a member of the House of Assembly, and also in his newspaper, the Globe, of Toronto ; and there is unmistakable evidence in the Brown-Macdonald correspondence concerning Seward's suggestion of a representative of the Government of the United Provinces at Washington, that Brown was well acquainted with the attitude of Lyons toward the presence of Canadians in any such capacity.

Lyons, on January 28, 1864, had enjoined Monck, the GovernorGeneral, not to approve of sending to Washington a Canadian, supposed to be peculiarly in his confidence, with regard to the reciprocity treaty. If such a representative were sent, Lyons told Monck that he should feel bound to take decisive steps to show that the appearance of being in his confidence was false ; and his final injunction to Monck was that, if, despite his warning a representative of the Canadian Government were sent to Washington, 'any one who came for this purpose should not be furnished with letters of introduction to me, and should not be advised to call upon me.' 1

Although Lyons had been within a twenty-four hours' railway journey from Quebec, one of the seats from 1850 to 1866 of the Government of the United Provinces, and although he had been in Washington for about five years when he wrote this remarkable letter to Monck, he could obviously have had no knowledge of how far the development of responsible government had really progressed in all the British North American provinces between the end of Metcalfe's ill-starred régime in November 1845 and Monck's arrival in Canada, in October 1861. Lyons's letter of January 1864 was one that might appropriately have been written to Bond Head, Colborne, or to any of the governors general or governors of Upper Canada-all, with the exception of Bond Head, military men - of the era from 1791 to the rebellion of 1837 .

It was the letter of a man of the junker mind, oblivious or indifferent to what had happened in all the North American provinces since the Papineau-Mackenzie rebellions, a man who was indifferent as to what trouble his actions might raise in the then always much-worried Colonial Office; or else it was the

1 Newton. Lord Lymor. i. p. 124. 
letter of a man who was ignorant of great constitutional developments in the British North American provinces from 1840 to 1864, and quite unaware of the radical change in the position of the Governor-General between the time of Colborne and Bond Head and that of Elgin and Monck. Monck, in January 1864, was powerless to act as Lyons suggested, almost commanded.

Except for the reservation of bills passed by the legislature -bills in two or three well-defined categories specified in his instructions which were part of the unwritten constitution of the provinces- ${ }^{1}$ Monck could not take a step in any direction otherwise than on the advice of the Executive Council or Cabinet ; and the Cabinet in its turn was responsible for all its actions to the legislature, and could not remain in office for a day longer than it had the support of a majority in the House of Assembly.

Even the receipt by the Governor-General of a communication like that from Lyons of January 28, 1864, must have been an embarrassment to him at a time when his Cabinet was intent on preventing any break in the trade relations of Canada as they had existed from 1854. But Lyons, in his way, as the correspondence of Brown and as the speech of Galt on the urgency of the need for diplomatic freedom in the House of Commons of the Dominion in $1870^{2}$ make evident, helped to the diplomatic freedom enjoyed by the dominions to-day.

The British minister at Washington in 1858-1864 helped indirectly to this end, much as Metcalfe indirectly helped to forward the movement for responsible government by bringing about an impasse that made it obvious to the Russell Administration of 1846-1852, and to Elgin, who succeeded to the governorgeneralship, that only with responsible government, as it was

1 Cf. instructions to 'our right trusty and well beloved cousin, Charles Stanley, Viscount Monck, our captain general and governor in chief in and over our province of Canada.' November 2, 1861, pp. 131-132, Instructions to Governors, Sessional Papers (Canada), 1906, No. 18.

2 March 21, 1870. Galt then moved for an address to the Governor-General representing that great advantages would accrue from placing the government of the Dominion in direct communication with all the British possessions and foreign states which might be willing to negotiate for reciprocal commercial arrangements ; that it was expedient to obtain from the Imperial Government necessary powers to enable the government of the Dominion to enter into direct communication for such purpose with each British possession and foreign state, and that in all such cases such proposed commercial arrangements should be subject to the approval of her Majesty. The motion for the address was opposed by the Government; and on a division it was defeated by 100 votes to 58 . House of Commons Debates (Ottawa), 1870, 558-579. 
understood and defined by Baldwin, La Fontaine, and the Liberals of Upper and Lower Canada, could the connexion between the Canadas and Great Britain be maintained.

For Lyons it was not impossible to take the attitude toward the claim of the British North American provinces that was characteristic of him during the later years of his service at Washington, an attitude which was manifest in his letter to Monck and also in a dispatch, three days later, to Russell who was then at the Foreign Office. ${ }^{1}$ As the experience of the Colonial Office in the struggle in the colonies for responsible government had made clear to the Melbourne Administration of 1835-1841, to the Peel Administration of 1841-1846 and to the Russell Administration of 1846-1852, especially to the Peel Administration, which was responsible for Metcalfe and his policy, which was endorsed both by Queen Victoria and the Cabinet, ${ }^{2}$ it was

1 'The Canadian ministers are very anxious to be doing something in the matter [reeiprocity] in order to cover their responsibility as regards their constituents hereafter. They had a desire to send an agent here to advise with me, and to speak to the American Cabinet and to members of Congress. This I have told Lord Monck privately I will not hear of. I eould not undertake to keep the peace for a month if I had a man here by my side, over whoin I could have no practical control, and who would be really guided only by Canadian party politics, but who would yet be supposed to be inore or less in my confidence, and therefore to be entitled to speak for me and her Majesty's Government. My troubles are great enough without adding Canadian electioneering views to the diffieulties I have to contend with.'-Lyons to Russell, February 9, 1864. Newton. Lord Lyons, i, p. 125.

"The views expressed in these two letters [the first to Monck, the seeond to Russell] may appear unsympathetie as regards Canada. But, apart from his rooted and well-founded distrust of amateur diplomatists, Lord Lyons's main task was to keep the peaee, if possible, between England and the United States. He was, therefore, justified in refusing to be assoeiated with any persons who might coneeivably add to the difficulty of a very critical situation. In addition to this, he was always inelined to resent the tendeney of Canadian ministers to do a little diplomaey of their own, and held strongly that it would be time enough for them to think of diplomaey when they had provided themselves with an army and navy.' Ibid., (1913), i, pp. 125-127.

2 'From private information she had been led to expeet that Lord Metealfe would not be able to continue at his irksome post. He will be an immense loss, and the seleetion of a sueeessor will be most diffieult. It strikes the Queen to be of the greatest importanee that the judieious system pursued by Lord Metealfe (and which after a long eontinuation of toil and adversities only now just begins to show its effect) should be followed up by his sueeessor.'-Queen Vietoria to Lord Stanley, November 2, 1845. Benson and Esher, Letters of Qucen Victoria. 18:37-1861, ii, pp. 54-55.

Bagot, Metealfe's predeeessor, had followed the poliey of Sydenham (1840-1841) in regard to responsible government. He had (1841-1843) eoneeded the claims of the Liberals, and formed his Govermment on the prineiple that there must not be an Exceutive Couneil that did not have the support of a majority in the House of Assembly. "I yet see sueh formidable obstaeles to the disavowal of his poliey,' wrote Stanley to Peel, on Oetober 21, 1842, 'that 1 lean to the opinion 
not possible to end an agitation in the Canadas by a dispatch written in the spirit of Lyons's communications to Monck and Russell of January and February 1864.

Newcastle in 1859 had answered Galt in terms that had astonished Washington; and Galt, in his reply, had thrown down the gauntlet, and frankly told Newcastle that if he dared counsel the Cabinet to withhold assent from the Tariff Bill with its protection for Canadian manufacturers, the next step in Downing Street must be to place the Canadas under military rule. The Colonial Office at no time after 1859 could have risked another contest with any of the British North American provinces like that which makes this year stand out with so much prominence in the history of the Empire.

\section{CHAPTER IV}

\section{THE INTERPROVINCIAL COUNCIL ON COMMERCIAL TREATIES OF 1865-THE VARIED INTERESTS OF THE BRITISH NORTH AMERICAN PROVINCES}

Acting on the mandate of a joint resolution of the Senate and House of Representatives that had passed all its congressional stages by January 13, 1865, the Government at Washington on March 17 denounced the Elgin-Marcy treaty. From that time it was known in London, and in the British North American provinces, that on March 17, 1866, these provinces would cease to enjoy the much-valued advantages that had accrued to them under the reciprocity treaty of 1854 .

A period of dislocation and depression in trade confronted the whole of British North America from Lake Superior to the Atlantic Ocean, similar to the dislocation and depression of 1847-1850 due to the ending of the preferences in the protectionist tariffs of the United Kingdom. It was this disturbing outlook that soon brought to an issue the claims of 1848-1852 of the that we must avow and adopt it.' Charles Stuart Parker, Sir Robert Peel, iii, pp. 383-384. Metcalfe (1843-1845) reversed the policy of Bagot. He ruled for months without a Cabinet, and interfered in elections to secure a majority in the House of Assembly that would support his restricted conception of responsible government. It was this policy that the Queen commended in her letter to Stanley, when news was received at the Colonial Office that illness--fatal illnesshad compelled Metcalfe to resign. 
provinces of Upper and Lower Canada and New Brunswick for a recognized place in the diplomacy of commercial treaties.

Out of the threatening crisis in trade of 1865-1866 there developed (1) a renewal, under greatly altered conditions, of the claim of 1848 by the United Provinces for representation in treaty making; (2) the interprovincial council on commercial treaties, and (3) a prompt movement on the part of the Foreign Office in London to secure for the British North American provinces a renewal of the treaty of 1854 , or a new treaty in which the provinces were to concede better terms-larger opportunities for an import trade from the United States-than were afforded by the treaty that Washington had denounced.

The organization of the interprovincial or confederate council of trade was suggested to the Governor-General in a dispatch from the Colonial Office, dated July 22, 1865, that was written in response to the claim of the United Provinces for direct representation in the pending negotiations at Washington. What the Colonial Office desired were the views of the governments of the five provinces, the Canadas, Nova Scotia, New Brunswick, Prince Edward Island, and Newfoundland, on the negotiation of commercial treaties. ${ }^{1}$

Monck, the Governor-General, who at this time was at Quebec, issued the call for the council on August 14. The council assembled in the City of Quebec on September 18, 1865. All five provinces were represented, ${ }^{2}$ the members being chosen from the executive councils or cabinets. The representatives from the four Maritime Provinces ${ }^{3}$ achieved no pre-eminence afterwards in the fiscal or diplomatic history of the Dominion. But Galt and Brown were the official representatives of Upper and Lower Canada, colloquially known as the Canadas, and John A. Macdonald and Cartier-from 1868 Sir Georges Etienne Cartier-were admitted to the council at Quebec by courtesy, and took part in the discussions.

The United Provinces had most at stake at the time when the end of the reciprocity treaty was in sight. These provinces, known in political geography since Confederation as Ontario and Quebec, are separated by the St. Lawrence and the Great Lakes from New York, Ohio, Indiana, Illinois, Michigan, and Wisconsin,

1 Cf. Gray, Confederation, i, p. 315.

2 Ibid., p. 296.

3 Ritchie. Nova Scotia; Wilmot, Now Brunswick; Pope, Prince Edward Island; and Shea, Nowfoundland. 
which in 1866, as in 1918, were the most populous States of the American Republic, the States in which, with the exception of Massachusetts, there were the largest urban populations and also most manufacturing.

The St. Lawrence, the Canadian canals and the Great Lakes, then, as now, were the highway of international trade, a trade chiefly in grain, flour, lumber, and coal. Since 1851, three years before the reciprocity treaty went into operation, Montreal, the commercial metropolis of eastern Canada, and the largest centre of rail and water transport business, had been connected by railway with Boston and New York. ${ }^{1}$

Three hundred miles west of Montreal, at Niagara Falls, the railways of Upper Canada made connexions with Buffalo, the largest city in the northern part of New York; and at Buffalo connexion was made with the railways that stretched from Buffalo to New York, Philadelphia, Pittsburgh, Cincinnati, and the centres of population and trade in the cotton-growing States of the South.

Upper and Lower Canada were in much better communication with the great markets of the United States than were New Brunswick, Nova Scotia, and Prince Edward Island. The central provinces of British North America, provinces with the largest population, ${ }^{2}$ moreover, had a much larger range of products, admitted duty free under the reciprocity treaty, to market in the United States than had the Maritime Provinces.

Lumber, wheat, flour, barley, dairy products, cattle, fruit, hay, and wool-wool for the worsted mills of Massachusettswere the exports from the Canadas to the United States. From the United States the central provinces drew nearly all their supply of bituminous coal and all their supply of anthracite coal. ${ }^{3}$

1 The line was formally opened at Boston with ceremonies of an international character on September 17, 1851. Fillmore, President of the United States, and Elgin, Governor-General of Canada, were present. Elgin, who was an exceptionally good speaker, made a great impression with his address. He was as prominent in the ceremonies as Fillmore. His address-a good example of his fine style of ceremonial oratory-was printed verbatim in an account of the celebration of the opening of railroad communication between Boston and Canada, published by the City of Boston in 1852 .

2 At the census in 1871 the Dominion census taken five years after the end of the reciprocity treaty, the populations of the provinces of the Dominion that had been included in the treaty were Ontario 1,620,851, Quebec 1,191,516, Now Brunswick 285,594, Nova Scotia 387,800, Prince Edward Island 94,021. Cf. Fifth Census of Canada, 1911, i, p. 522.

3 The trade in bituminous coal between Ohio and Upper Canada began with the opening of the Welland Canal as early as 1834. Journals of the House of Assembly (Upper Canada), 1835, I, Appendix, Report on Trade, No. ix, 16. 
Salt and Indian corn for feed for cattle were also imported by the central provinces in large quantities from the United States. The exports of the Maritime Provinces were lumber, coal, gypsum, and fish. Flour was the principal import from the United States into the 'provinces down by the sea'.

The difference in the interests at stake explains the presence of four representatives of the United Provinces at the interprovincial council at Quebec, all men of large consequence in the constitutional, fiscal, and diplomatic history of the Canadas and of the Dominion. Galt, it will be recalled, in addition to being the author of the tariff of 1859 , was long the foremost protagonist of diplomatic freedom for the Dominion of Canada. ${ }^{1}$ Cartier and Macdonald were at the head of the administration ${ }^{2}$ that was responsible for submitting Galt's tariff to the House of Assembly at Toronto. It was the administration also that supported Galt in his encounter with Newcastle.

Macdonald was the first Canadian statesman, the first statesman of any of the dominions, to sign a treaty, the treaty of Washington of 1871 ; and it was Macdonald, it will be remem. bered, who was responsible for the national policy tariffs of 1870 and 1879. Brown, long the opponent of all three of his colleagues from the Canadas on the question of protection, negotiated the reciprocity treaty of 1874 , from which the Senate at Washington withheld its assent.

All four were fathers of Confederation. All four-Galt, Brown, Cartier, and Macdonald-were of the group of thirty-three statesmen from the Canadas, the Maritime Provinces, and Newfoundland, who at the historic conference at Quebec in October 1864, without any supervision or steering from Downing Street, framed the constitution for the Dominion of Canada.

In the constitutional history of the British Empire from the rebellion in Canada of 1837 to the Great War, the interprovincial council on commercial treaties, held at Quebec in 1865, does not rank in importance with the conference or convention held in the

1 Cf. Sir Charles Hibbert Tupper, K.C.. "Treaty-making Powers of the Dominions,' Journal of the Socitty of C'omparative Legislation, New Series, xxxvii, January 1917 . p. 8.

2 'Double-headed administrations. one head the leader of the political party of the inajority in the House of Assembly from Upper Canada. the other head of the corresponding politieal party in Lower Canada. were a feature in the politics of the United Provinces from i8t5 to 1858.' Cf. Weir. Sixty Years of Canada. p. 23. 
same historic city a year earlier, at which the Dominion of Canada came into being, and the era of Confederation within the Empire, the era of 1867-1910, began.

Unlike the convention of 1864 , the council of 1865 is as yet without its historian, and it has so far received but scant attention from writers on the relations of the self-governing colonies with Great Britain. Greater attention by historians and writers on political science to the development and working of these relations, a closer attention that has been made imperative by the war of 1914-1918, will surely correct this oversight in Empire history of the interprovincial council of 1863 ; for it was the first time that the Colonial Office promoted a conference of representatives of the self-governing colonies. It was, moreover, the first time that representatives of the autonomous colonies were convened at the instance of the British Government to discuss questions of diplomacy.

The Quebec council, by reason of results developing out of it, ranks in importance with any of the colonial conferences held in London at the call of the Colonial Office in the years from 1887 to 1914. Finally, it must be emphasized, the council of 1865 was a direct outcome of the fiscal freedom that the British North American provinces had asserted from 1850 to 1865 , and of the movement, growing out of this new freedom, for the direct representation of the self-governing colonies in all treaty making that was undertaken in their interest.

\section{CHAPTER V}

\section{THE CLAIM OF DIRECT REPRESENTATION IN TREATY. MAKING CONCEDED-A MISSION TO WASHINGTON THAT FAILED, 1865-1866}

Two sets of resolutions were the concrete results of the deliberations of the interprovincial council on commercial treaties at Quebec in September 1865, the council over which Monck, the Governor-General, presided. One set called for immediate negotiations to secure a renewal of the reciprocity treaty with the United States. ${ }^{1}$ The second set urged the importance of reciprocal

1 'That the existing treaty of trade with the United States is acceptable, 1569.29 
trade between the British North American provinces and (1) the British West India Islands, (2) the American colonies of Spain, (3) Brazil, and (4) Mexico.

The two movements, originating thus at Quebec, the first for another reciprocity treaty with the United States, and the second for reciprocity treaties with three other non-British countries, at once pushed to the front the claims as old as 1848 , that the colonies should be directly represented in negotiations for commercial treaties in their interest.

In respect to negotiations for a second reciprocity treaty with the United States, the council by resolution asked the Government at Whitehall-the Russell Administration of 1865-1866, in which Edward Cardwell was Secretary for the Colonies, and the Earl of Clarendon Secretary for Foreign Affairs-' to authorize the members of this council, or a committee to be appointed from among them, to proceed to Washington in order to confer with the British Minister there, and to afford him information with respect to the interests of the British North American provinces.' 1

By this time, September 1865, Lyons was no longer at Washington. He had resigned as minister there in February 1865 ; and in September 1865 he was at Constantinople as ambassador, a grade higher in the diplomatic service than minister, ${ }^{2}$ and out of reach of what he regarded as amateur diplomatists from the self-governing colonies.

Lyons was succeeded on March 1, 1865, by Bruce, who had been in Washington in 1842 as a member of the Ashburton and that its renewal, as it now stands, would be assented to by the respeetive provinees.

'That, in the opinion of the Couneil, any reasonable proposals for the modifieation or extension of the treaty that may be suggested by the United States Government ought to be entertained by the provinees.' Resolutions adopted, Monday, September 18, 1865. Gray, Confederation, p. 297.

1 Ibid., i, p. 298.

2 It was the intention of the British Government in 1867 to raise the mission at Washington to the rank of an embassy. Lord Stanky. Seeretary of State for Foreign Affairs in the Conservative Administration of is66-1868, intimated to Adams, United States Minister in London, that this was the intention, because the post at Washington was regarded as one of the most important in the diplomatie service. But until 1893 it was the poliey of the Government at Washington to be represented abroad by no agents of higher rank than Ministers Resident, who were in the ease of the Great Powers, aeeredited as envoys extraordinary and ministers plenipotentiary. In 1893 Congress passed an Aet authorizing the President to aceredit ambassadors to certain European eourts; and in that year the British mission at Washington was raised to the rank of an embassy. (Cf. Adams to Seward. Norember 2, 1867. Diplomatir Correspondence (C'nited states). 1867, p. 170; Cyclipedia of American Gocernment, i, p. 38?. 
mission for the settlement of the Maine boundary question. Bruce was as keenly interested in a renewal of the treaty negotiated in 1854 by Elgin, his brother, as Galt or Brown or any other of the statesmen of the British North American provinces who had been at the Quebec meeting of the interprovincial council.

Bruce had no objection whatever to diplomatic association with members of the cabinets of the Canadian provinces. The authorization asked for at Quebec was promptly secured through the Colonial Office; and in January and Februrary, 1866, Galt and three other delegates from the British North American provinces $^{1}$ were in Washington in the interest of a second reciprocity agreement.

The mission was not to the State Department, the foreign office of the United States. Another treaty was at this time not desired either by the executive at Washington or by Congress. All that Bruce and the delegates could hope for in the winter of 1865-1866 was reciprocity on the basis of concurrent legislation.

The first official call of the delegates was accordingly on McCullogh, Secretary of the Treasury, who introduced them to the Committee of Ways and Means of the House of Representatives, the committee with which tariff and internal revenue bills originate. It was taken for granted on both sides that Great Britain would again concede to the United States free use of the St. Lawrence, ${ }^{2}$ a recognized use of the outlet from the Great Lakes to tide-water that the United States had first enjoyed under the terms of the reciprocity treaty of $\mathbf{1 8 5 4}$.

The St. Lawrence navigation was about the only part of the old treaty in which Great Britain, as distinct from the British North American provinces, had a direct interest. In these pourparlers of 1865 matters affecting reciprocal concessions in tariffs were left entirely to the delegates, who, as instructed by the executives of their several provinces, were prepared to make generous concessions in return for concessions from the United

1 W. P. Howland, Postmaster-General, United Provinces; W. B. Henry, Attorney-General, Nova Scotia; and A. J. Smith, Attorney-General, New Brunswick.

2 'With regard to the first point, the proposed mutual use of the waters of Lake Michigan and the St. Lawrence, we considered that the present arrangements were sufficient, and that the common interests of both countries would prevent their disturbance.' Report of the British North American delegates to Bruce, February 7, 1866, Correspondence respecting the Termination of the Reciprocity Treaty, 1866, p. 8. 
States approximately similar to those of the Elgin-Marcy treaty of 1854 .

Bruce, as British Minister in Washington, had nothing to do with the terms as regards the tariffs of the United Provinces and the Maritime Provinces that were to be offered by Galt and his colleagues. Tariffs in the British North American provinces since 1859 had been, in practice, quite outside the supervision or control of the Colonial Office or the Government in Downing Street. But the delegates consulted with Bruce before going to the Treasury. They went there with his sanction; and from time to time they informed him of their interchanges, usually in writing, with the Committee on Ways and Means. ${ }^{1}$

The mission failed by reason of a manifestation by the Committee on Ways and Means of the House of Representatives of a characteristic in reciprocity negotiations that has never been confined to the Dutch-that of 'giving too little, and asking too much ' $;{ }^{2}$ and on February 6, 1866, when a deadlock had been reached, the delegates intimated to the committee that ' with the concurrence of the British Minister', they declined to enter into the engagement which the committee had proposed. ${ }^{3}$

The result was reported to Bruce the following day in a

1 Cf. Gray, Confederation, i, p. 300.

2 "We remember the dispatch to Sir Charles Bagot, the Minister at the Hague:In matters of commerce the fault of the Dutch, Is giving too little, and asking too much. With equal advantage the French are content, So we'll clap on Dutch bottoms twenty per cent.,

Twenty per cent., twenty per cent.,

Nous frapperons Falck twenty per cent.

That retaliatory policy was found completely successful, and the imposition of twenty per eent. was the means of inducing Holland to adopt a reciprocity treaty which exists to the present time.'-Macdonald. House of ('ommons (Ottawa), March 21, 1870, Parliamentary Debates (Canada), 1870, p. 582.

'The provincial delegates regret to be obliged to state that the proposals in regard to the commercial relations between the two countrics are not such as they can reeommend for the adoption of their respective legislatures. The imposts which it is proposed to lay upon the productions of the British provinces on their entry into the markets of the United States are such as, in their opinion, will be in some cases prohibitive, and will certainly seriously interfere with the natural course of trade. These imposts arc so much beyond what the delegates conceive to be an equivalent for the internal taxation of the United States (an Act to increase the internal revenue huties and for other purposes, March 7,1864 , Statutes of the United States, 1861 . c. $\mathrm{xx}$ ) that they arc reluetantly brought to the eonclusion that the committee no longer desire the trale between the two eomtries to be carried on $n$ pon the principles of reeiproeity.' Memorandum of February 6. 1866. Giray, Confederation. i. p. 299.

3 loid. 
memorandum in which Galt and his colleagues signed themselves 'your Excellency's most obedient servants '.

The tension between Washington and London arising out of the Civil War was much more acute in January and February 1866 than it had been in February 1864, when Lyons informed Russell that he had warned Monck that he would not hear of a member of the Cabinet of the United Provinces being sent to Washington ' to speak to the American Cabinet, and to members of Congress ', and further told the Foreign Office in London that he could not undertake to keep the peace for a month if he had ' a man by his side over whom he could have no practical control, and who would be really guided only by Canadian party politics '.

The feeling of hostility to Great Britain in all the States that had been loyal to the Union in the struggle of 1861-1865 was nearly as great in the early months of 1866 as it was at any time until the treaty of Washington was approved by the Senate on May 8, 1871. Nowhere was freer expression given to this feeling than in Congress. ${ }^{3}$ Hostility to Great Britain and to the British North American provinces had much to do with the mandate of the House of Representatives and the Senate of January 1865 to the President to denounce the Elgin-Marcy treaty. It undoubtedly accounted for much of the opposition in Congress in January and February 1866, to the negotiation of a second reciprocity treaty, or to reciprocity by concurrent legislation. But the presence in Washington of Galt and his colleagues, and their negotiations with the Committee on Ways and Means, did not in the least aggravate the existing diplomatic tension.

The unhesitating response in Downing Street to the Quebec resolutions of September 18, 1865, and the cordial co-operation of Bruce with the delegates-as cordial as that of Crampton with Merritt in 1849-1850 - on the other hand, lubricated the relations of the Colonial Office with the capitals of the provinces in the trying period when the abrogation of the treaty of 1854 threatened depression or dislocation of trade at every tide-water port or lake port in the Maritime Provinces and Upper and Lower Canada.

The mission to Washington of January-February 1866, a direct

\footnotetext{
1 Ibid., i, p. 302 ; Correspondence Respecting the Termination of the Reciprocity Treaty, 1866, p. 2.

2 Lyons to Russell, February 9, 1864. Newton, Lord Lyons, i, p. 225.

3 Cf. William C. Harris, Public Life of Zachariah Chandler, pp. 82-83 ; Congressional Globe (Washington). December 14, 1864, pp. 496-497.
} 
and immediate outcome, it must be kept in mind, of the interprovincial council of trade of September 1865, even ending as it did in complete failure, was not without some usefulness to the British North American provinces from the Atlantic to the Pacific Ocean; and incidentally of usefulness to Great Britain and the Empire. In both respects it was a political as distinct from an economic or trade usefulness.

Confederation was already in sight. The Quebec conference of 1864 had brought it well within the realm of practical politics in all the British North American provinces, in remote and isolated British Columbia as well as in the provinces east of the Great Lakes. But Confederation, first suggested as early as $1783,{ }^{1}$ was not so essential to the political peace and stability of the governments in any of the Maritime Provinces as it was to those of Upper and Lower Canada.

The protectionist tariffs of the United Provinces-the handiwork of Cayley and Galt and of Cartier, Macdonald, and Rosemoreover, were regarded with much apprehension in all the Maritime Provinces; for in none of these three provinces was there a protectionist tariff as long as each province controlled its own fiscal policy. Upper and Lower Canada and British Columbia were the only protectionist provinces in the years from the coming into operation of the Enabling Act, the Imperial Act of 1846 , to Confederation in 1867.

Nova Scotia and New Brunswick, in the early months of 1866 , when the delegates from the British North American provinces were in Washington with a view to a second reciprocity agreement with the United States, were in a hesitating and uncertain mood toward Confederation. But both these provinces were deeply interested, materially interested in fact, in a renewal of reciprocal trade with the United States.

Both of them were as deeply interested in the question of what was to be the next step to stimulate export trade in all the British North American provinces, if the movement for reciprocity with the United States should fail; and it was the conviction of Hamilton Gray, one of the fathers of Confederation, a former Premier of New Brunswick, whom Canadians regard as the official historian of Confederation, ${ }^{2}$ that it was well for the

1 Cf. Porritt, Evolution of the Dominion of Canada, pp. 181-183.

2 (f. Hugh John Macdonald, Foreword, Gosnell. The Story of Confederation, p. 4. 
governments of all the provinces that Galt and his colleagues left Washington in February 1866, without having given so much as a qualified assent to the proposal of the Committee on Ways and Means. 'The provinces', Gray added, 'were thrown together, and Confederation was secured.' 1

\section{CHAPTER VI}

\section{BRITISH RECOGNITION OF THE NEW PLACE OF THE COLONIES IN DIPLOMACY}

The Colonial Office, where, it will be remembered, Edward Cardwell ${ }^{2}$ was in charge from 1861 to June 1866 , acted promptly and cordially in assenting to the claim of the British North American provinces for direct representation in the negotiation at Washington of January-February 1866, for a new reciprocity agreement with the United States, to be based not on a treaty, but on concurrent legislation at Washington and at the capitals of the provinces.

Cardwell, a Colonial Secretary with a distinct place in the history of the new relations of the self-governing colonies to Great Britain, the beneficent new relations of 1840-1914, acted with equal promptness in assenting to the request of the interprovincial council on commercial treaties that the British North American provinces should be enabled to attempt to establish reciprocal trade with Cuba, Brazil, and Mexico.

The council had asked that the provinces should be enabled to open communications with Spain and her colonies, and with Brazil and Mexico, for the purpose of ascertaining in what manner the trade of the provinces with these countries could be extended and placed on a more advantageous footing. ${ }^{3}$ Moreover, as in the case of the reciprocity negotiations at Washington, it was the desire of the council that negotiations with Spain, Brazil, and Mexico should be undertaken by representatives of the provincial governments.

Cardwell communicated with the Foreign Office within a few days after receiving the report of the Quebec conference.

1 Gray, op. cit., i, p. 304.

2 Created Viscount Cardwell in 1874.

${ }^{3}$ Gray, Confederation, i, p. 298. 
Hammond, permanent Under Secretary, ${ }^{1}$ replied on November 11, 1865 , in a letter that is now one of the documents in the history of the movement of 1848-1907 for the diplomatic freedom of the dominions. It defined the conditions under which the Foreign Office would sanction and facilitate visits of representatives of the British North American provinces to the countries with which the provinces desired to enter into agreements for reciprocal trade.

'As regards foreign countries', wrote Hammond, 'the agents who may be sent from the British North American provinces will not assume any independent character, nor attempt to negotiate and conclude arrangements with the governments; but will only, as proposed by the seventh resolution of the confederate council on commercial treaties, as regards negotiations with the United States, be authorized to confer with the British Minister in each foreign country, and to afford him information with regard to the interests of the British North American provinces.

'Lord Clarendon', continued Hammond, ' on receiving from Mr. Cardwell copies of the instructions given to the colonial delegates, will be ready to authorize Her Majesty's Minister at Madrid, as regards the Spanish West Indies, and Her Majesty's Ministers on the continent of America, to communicate with these eolonial delegates; and in the first instance to assist them in their inquiries as to what openings there may be for extending the trade of the British colonies, and afterwards to ascertain how far any overtures with that objeet in view would be likely to be well received by the government to whieh those ministers are accredited.'

' Having thus obtained grounds for further proceedings,' reads the concluding paragraph in this minute from the Foreign Office to the Colonial Office, 'Her Majesty's Government might, in the next plaee, consider with the lords of the Committee of the Privy Council for Trade how far any proposals might be made to foreign countries on behalf of the eolonies, consistently with the general treaty engagements of the British Crown. This point being satisfaetorily ascertained, instruetions might be framed in this country for Her Majesty's Mlinisters in the eountries in question, and full powers issued to them by Her Majesty, under which they

1 Fimund Hammond, ereated a peer in 187t, permanent Under Secretary at the Foreign Uffice, $185 t-1873$. 
would endeavour to bring into the shape of international agreements such arrangements as might be ultimately considered acceptable, not only to the colonies themselves, but also to the foreign powers with whom they were contracted.' 1

These conditions were accepted by the governments of the provinces that were represented at the Quebec conference of September 1865. The Government of the United Provinces appointed four delegates, Nova Scotia two, and New Brunswick and Prince Edward Island each one. Each provincial government framed its own instructions for its delegates. ${ }^{2}$

The mission visited the countries with which reciprocal trade was desired. No agreements were found practicable; and with Confederation of the British North American provinces in 1867, there was necessarily an end to the interprovincial council on commercial treaties. Its importance in the history of the dominions rests on the fact that the council, by its demands, impelled the Colonial and the Foreign Offices (1) to make some concession to the claim of the British North American provinces for direct representation in treaty making, and (2) to give formal notice to at least one Great Power, the United States, that representation in treaty making had been conceded to the colonies.

Galt and his colleagues of the delegation from the British North American provinces that was in Washington in January and February 1866, were not brought into contact with the State Department, the treaty-making department of the United States Government. Their relations were exclusively with MeCullogh, the Secretary of the Treasury, and the Committee on Ways and Means of the House of Representatives, as at that time reciprocity by concurrent legislation was all that the Government of the United States was willing to discuss. But in May 1866, despite the failure of the Galt mission in February, Adams,

1 Colonial Accounts and Papers, 1873, c. 756, No. 6, Appendix No. I, p. 14.

2 Galt, a personality continuously prominent and at times dominant in Canadian polities from 1859 until he went to London in 1880 as the first High Commissioner of the Dominion of Canada, who after Confederation declared himself in favour of the complete independence of Canada, drew up the instructions for the delegates from the United Provinces. 'It would', he wrote in a minute dated November 17, 1865, ' be improper for the Government to anticipate the action of the legislature in reference to taxation. But it is necessary that you should be informed that this Government would be prepared to recommend to Parliament the reduction, or even the abolition of any customs duties now levied on the productions of those countries, if corresponding favour were shown to the staples of British North America in their markets.' Gray, op. cit., i, p. 338. 
the United States Minister in London, and Clarendon, Minister for Foreign Affairs, were hopeful that success might be achieved in another attempt to secure reciprocity for the British North American provinces, and by treaty as in 1854 .

The mode of procedure to this end was discussed by Clarendon and Adams, on the United States Minister ' casually meeting with Lord Clarendon at a reception '.' Adams communicated the details to Seward at the State Department, at Washington, in a dispatch dated May 10, 1866. He had recalled to Clarendon a note from the United States Mission in London, to which there had been no answer from the Foreign Office. 'His lordship', wrote the United States Minister to Seward, 'at once communicated to me the substance of the decision of the Government, which was to send out authority to Sir Frederick Bruce to proceed in conjunction with you, after consultation with the respective provincial authorities.'

'This had been thought the better course, as the latter-the provincial authorities-had now substantially reached such a position of independence as to make it unadvisable for the Government here to attempt to act without regard to them.' 'Lord Clarendon', added Adams, 'asked me whether I would take this conversation as sufficient official notice, and I agreed to do so.' 2

Clarendon's communication to Adams of May 6, 1866, taken as it must be in conjunction with the status accorded to Galt and his colleagues of the Washington mission, and with Hammond's letter to Clarendon of November 11, 1865, is as important in the history of the diplomatic freedom of the dominions as the Galt and Newcastle correspondence of 1859 , and the intimation from Kimberley, of July 13, 1871, to the Australian governments that the Colonial Office had ceased to protest against protectionist tariffs enacted by colonial legislatures, are in the history of the fiscal freedom of these oversea dominions of Great Britain.

These episodes of 1859,1866 , and 1871 are abiding landmarks, that can never be altered or removed, in the steady and continuous progress from 1840 to 1914 of the self-governing colonies towards the status of nation within the Empire.

Negotiations at Washington for another reciprocity treaty did

3 ()n Saturday evening, May 6. 1866.

- Adams to Seward. May 10, 1866. State Papers, United States, 1866, p. 109. 
not begin in May 1866, as Clarendon and Adams had expected. Disturbing questions arising out of the Civil War of 1861-1865questions concerning the cruisers built in British shipyards for the Southern Confederacy, that at one time threatened the continuance of friendly relations between Great Britain and the United States-thrust aside for nearly five years any hope of a second reciprocity treaty between the United States and what are now the Dominions of Canada and Newfoundland.

But practical effect was given in 1871 to Clarendon's intimation to Adams, of May 6, 1866, that the time had been reached when the self-governing colonies must be recognized in diplomacy. Macdonald, Premier of the Dominion of Canada, was in that year appointed under the Great Seal one of the British plenipotentiaries for the negotiation of the treaty of Washington; and in accordance with the new policy or the new attitude of the Foreign Office toward the self-governing colonies-the policy announced by Clarendon to Washington through the United States Minister in London -in 1879 Galt was at Madrid endeavouring in association with the British Ambassador to negotiate a treaty of reciprocity with Spain.

Macdonald did not stand on quite equal terms with the other members of the British Mission at Washington in 1871. There were consultations - caucuses, as Macdonald described them, in his letters to his colleagues at Ottawa -in which he had no part. Interests of the Dominion of Canada were subordinated to the anxiety of Downing Street and the British Mission to effect a settlement of the Alabama dispute ; and at times the position of Macdonald, as he told Tupper in a letter of March 29, 1871, was exceedingly embarrassing. ${ }^{1}$

Galt's status at Madrid in 1879 was not equal to that of Macdonald at Washington in 1871 . It was far from satisfactory to Galt, as the accredited representative of the Dominion of Canada which he had so largely helped to create in the years from 1859 to 1867 . It could not have been otherwise than irksome and disappointing to Galt, who of all Canadian statesmen from 1837 to 1914 was least disposed to sacrifice any of his independence of expression or action in order to stand well in the esteem of Downing Street.

${ }^{1}$ Cf. Pope, Memoir of Macdonald, ii, p. 94. Speech by Macdonald, Montreal, November 24, 1875. 
The extent to which Galt was compelled to step back into a quite secondary position in the negotiations for a reciprocity trcaty at Madrid-negotiations that failed-was graphically described nearly forty years later by Sir Charles Hibbert Tupper, who successively held two Cabinet offices in Conservative Administrations at Ottawa, in the years from 1888 to 1896 , and who was in 1892 the agent of the British Government at the Behring Sea arbitration at Paris.

'Galt', wrote Tupper, 'could do nothing. He had to communieate through the British Ambassador; and as Sir Charles Tupper ${ }^{1}$ quoted him, he said that he found himself generally hampered in discharging the duties imposed on him by the Government of Canada, because he only stood in the position of a commercial commissioner ; and it was necessary that all his negotiations with the Government of Spain should be filtered through Her Majesty's Minister at the court of Madrid.' 2

\section{CHAPTER VII}

\section{GALT AND TUPPER PRESS CLAIM OF DOMINIONS FOR MORE POWER IN DIPLOMACY, 1880-1893}

Sir Charles Adderley, who was Parliamentary Under Secretary at the Colonial Office in 1866 and the representative of the department on the treasury bench in the House of Commons, wrote in 1869 an admirable survey of colonial history. Adderley, known in his later years as Lord Norton, has a distinguished place in the history of the dominions, in particular for his praetical and effective serviee at Westminster in preventing Grcy, Colonial Secretary from 1846 to 1852 , from carrying a plan for establishing convict settlements in Cape Colony.

Adderley's survey of colonial policy was written from the standpoint of a colonial reformer. He approached the subject as a member of the Conservative party at Westminster, who had keenly sympathized with the colonies now of the dominions in

1 Tupper, of Confederation, national poliey. and diplomatie freedon fame, fat her of ('harles Hibbert 'Tupper.

2 ('harles Hibbert 'Tupper, 'Treaty-making Powers of the Dominion.' The Journal of the Serciety of Comparative Legislation. New Series. No. xxxvii. January 1917, pp. $7-8$. 
their demand for responsible government. 'The normal current of colonial history', Adderley then affirmed, 'is perpetual assertion of the right of self-government.' 1

In the twenty years that followed Adderley's commendation of 1869 of the British North American colonies for their insistence from 1828 to 1859 on the concession to them of responsible government, his aphorism became as true of the movement begun in 1848 for diplomatic freedom as it was in 1869 of the movement for political autonomy.

It is proverbial that men who hold power are slow in admitting others to any share in its exercise, no matter how obviously well founded the claim of the aspirants may be. ${ }^{2}$ Even after the recognition of the British North American provinces in diplomacy in 1865-1866, a partial and guarded recognition, and after Macdonald's distinguished services as a plenipotentiary in $1871,^{3}$ the spirit toward the colonies in diplomacy that was so frankly expressed by Lyons in 1864 was not wholly abandoned at the Foreign Office.

Tradition was against its prompt and general abandonment. So was the official attitude ${ }^{4}$ toward colonies and colonists from 1840 to 1887 . But Canada was as persistent in quietly pressing

1 Adderley, Colonial Policy, p. 3.

2 'To propose that Great Britain should voluntarily give up all a uthority over her colonies, and leave them to elect their own magistrates, to enact their own laws, and to make peace and war as they might think proper, would be to propose such a measure as never was and never will be adopted by any nation in the world. No nation ever voluntarily gave up the dominion of any province, how troublesome soever it might be to govern it, and how small soever the revenue which it afforded might be, in proportion to the expense which it occasioned. Such sacrifices, though they might be agreeable to the interest, are always mortifying to the pride of every nation.' Adam Smith, Wealth of Nations, Oxford ed., 1880, ii, p. 198.

3 'Despite the suspicion that his function might be primarily that of the scapegoat, Macdonald served in the joint high commission with force and efficiency, and strengthened pro tanto the prestige at home and abroad of the recently organized Dominion of Canada.' William A. Dunning, The British Empire and the United States, p. 266.

4 Galt was appointed High Commissioner for Canada in 1880. Some time before his establishment in London the Ottawa Government asked that he be appointed Commissioner when treaties were in negotiation that affected Canada. "I have to inform you,' wrote Sir Michael Hicks-Beach, Colonial Secretary from 1878 to 1880 , in a dispatch to Lorne, the Governor-General, 'that it is not thought desirable to appoint a Canadian Commissioner to take part in the negotiation of any treaty. but if your Government desire to send a person enjoying their confidence to advise with her Majesty's Government, or with the British Ambassador, on any questions that may arise during the negotiations, her Majesty's Government will be happy to give attention to his representations.' Charles Tupper, Recollections of Sixty Years, p. 174. 
the claim for the right to name her own plenipotentiaries to negotiate her own commercial treaties, and the correlative claim that these plenipotentiaries must exercise full and unhampered powers, as the United Provinces of Upper and Lower Canada had bcen in insisting on self-government, and also on a fiscal freedom that must be restricted only by the treaty engagements of Great Britain.

Assertion of the claim, moreover, became more continuous and persistent by reason of the fact that from 1880 to 1895 it was pressed, not in minutes of council from Ottawa, transmitted by the Governor-General to the Colonial Office, to which dilatory or evasive replies could be embodied in dispatches to the GovernorGeneral; but was pressed in Downing Street, pressed on the spot, by Galt and Tupper, who successively held the office, created in 1880, of High Commissioner for Canada in London. ${ }^{1}$

Galt and Tupper differed widely as to the value to the Dominion of Canada of the tie to Great Britain. Tupper was pre-eminently an imperialist. When high duties to protect Canadian manufacturers from competition from the United Kingdom were not concerned, he was always eager to emphasize the value of the links of empire, and to add to the number and strength of these links. He was the most enthusiastic and most assertive imperialist in political life at Ottawa from Confederation to the new era in colonial history that began with the war of 1914. Imperialism oozed out of Tupper. No British subject, born in the ovcrsea dominions, ever delighted more in the personal trappings of impcrialism - the garters and stars and the Windsor uniformthan Sir Charles Tupper.

To the tie to Great Britain, Galt, although he was born in Scotland, attached little value, political or sentimental. He was one of the singularly few men to attain first rank in the legislatures of the United Provinces and the Maritime Provinces, or in Parliament at Ottawa - the only one in fact, who, after the collapse of the movement of 1849-1851 for annexation to the

1 Galt was High Commissioner from 1880 to 1883. Tupper held the office from 1883 to almost the end of the long Conservative régime at Ottawa in 1896 . The office was ereated by an Act of the Dominion Parliament (43 Vict., c. 11). As long before Confederation as 1852 a need had been felt in Upper and Lower (anada for a representative in London to fulfil some of the duties that by Aet of Parliament were delegated to the High Commisioner. Cf. Hugh Seymour Tremenheere, Fotes on Public Subjects. made during a Tour in the United States and Canada, pp. 289-290. 
United States, openly declared for the independence of the Dominion.

But Galt and Tupper, though wide apart on the value of the connexion of Canada with Great Britain, were at one on the claim for diplomatic freedom, the claim that the self-governing colonies must be free to negotiate, if they so desired, their own treaties of commerce. Both pushed this claim. They pushed it so successfully that Galt was the last treaty-making commissioner of the Dominion of Canada to complain of limited opportunity, restricted powers and generally hampering conditions ; to complain, as Galt did of his unavailing negotiations at Madrid in 1879 that he was compelled to subordinate himself to the British Ambassador there.

Tupper, soon after he had established himself in London in 1883 as High Commissioner for the Dominion of Canada, began to force the issue, ${ }^{1}$ to make the Colonial Office, and, through the Colonial Office, the Foreign Office and the Cabinet, understand what Canada demanded in the realm of diplomacy. In 1884 when Canada desired to reopen negotiations with Spain for a reciprocity treaty, Tupper impelled the Foreign Office to concede more power and dignity to the representative of the Dominion ${ }^{2}$ than had been conceded to Galt when he was on the mission at Madrid in $1879 .^{3}$

Nothing resulted from the overtures at Madrid of 1884 . But Ottawa took note, and remembered the status conceded by the Foreign Office to Tupper in connexion with this second attempt to negotiate a reciprocity treaty with Spain. 'We have gained the recognition, so far as that goes,' Foster, Minister of Finance, reminded the House of Commons in 1891, 'of our High Commissioner being given co-ordinate power with the British Minister

1 Cf. Tupper, op. cit., pp. 174-175.

2 Tupper was in charge of these negotiations as the representative of the Government at Ottawa.

3 'If the Spanish Government are favourably disposed, the full power for these negotiations [for a reciprocity treaty between Canada and Spain] will be given to Sir Robert Morier and Sir Charles Tupper jointly. The actual negotiations would probably be conducted by Sir Charles Tupper, but the convention, if concluded, must be signed by both plenipotentiaries.'-Foreign Office to Tupper, July 26, 1884. Tupper, op. cit., p. 175 .

"Note the phrase "the actual negotiations would probably be conducted by Sir Charles Tupper" as spokesman of Canada. It was the beginning of the break-up of the old empire treaty system.' Hurd, The New Empire Partnership, p. 215. 
resident at the capital of a foreign state, to negotiate a treaty, subject of course to the approval and sanction of the Queen.' 1

In the negotiation of the treaty of 1888 with the United States for a settlement of fisheries and boundary disputes-the treaty that like the rcciprocity treaty of 1874 was denied the approval of the Senate at Washington-Tupper, who represented the Dominion of Canada, had co-equal power with Chamberlain and SackvilleWest, his colleagues of the British commission. ${ }^{2}$ As the questions at issuc were exclusively Canadian, Tupper was the dominant partner. ${ }^{3}$

By 1890 the Dominion of Canada, which with the exception of Newfoundland and Cape Colony ${ }^{4}$ was the only colony ${ }^{5}$ that in the hundred and forty ycars from the American Revolution to the war of the Allies against the Teutonic Powers ever exercised the power of treaty making, was in practice supreme in these negotiations when the interests of the Dominion were at issue. ${ }^{6}$

1 House of Commons Debates (Ottawa), September 30, 1891, III, 6312.

2 On October 24, 1887, Mr. Joseph Chamberlain, Sir Lionel Sackville-West (then British Minister at Washington), and Sir Charles Tupper were jointly and severally empowered by Queen Victoria to eonsider and adjust 'in a friendly spirit with plenipotentiaries to be appointed on the part of our good friends the United States of America, all or any questions relating to the rights of fishery in the seas adjacent to British North America and Newfoundland, which are in dispute between our Government and that of our good friends, and any other questions which may arise, which the respective plenipotentiaries may be authorized by their Governments to consider and adjust.' Willoughby Maycoek, With Mr. Chamberlain in the United States and Canada, 1887-1888, p. 4. Cf. Tupper, op. cit., pp. 186-187.

3 Cf. Saunders, Life of Sir Charles Tupper, ii, pp. 102-106; Maycock, op. cit., p. 33 .

4 Newfoundland in 1890 made a commereial treaty with the United States, the Blaine-Bond treaty, from which the British Government withheld its sanction. ' On October 20 [1890] Sir Charles [Tupper] met Lord Knutsford [Colonial Secretary in the Salisbury Administration of 1886-1892] and Sir Robert Herbert [permanent Under-Secretary, 1871-1892] at the Colonial Office. Lord Knutsford told Sir Charles that the British Government could not refuse to sanction Premier Bond's arrangement at Washington. Sir Charles positively expressed his dissat is. faction with such a course. The day following Sir Robert Herbert called on Sir Charles and told him the British Government would withhold their approval.' Saunders, op. cit.. ii, p. 141 .

A customs union based on concurrent legislation was establisled between Cape Colony and the Orange Frec State in 1889. Cf. Frcemantle, The New Nation, p. 86.

5 "We had a long and animated debate at the Confederation convention in Sydney in 1891 as to this point (treaty making by the colonies), and the colonies were distinctly of the opinion that the unity of the Einpire would reecive a blow if any lower were given in the federation bill allowing them to make special treatics. We were quite in unison on that point.'- Nicholas Fitzgerald. representative of Victoria, at Ottawa colonial conference, Junc 30. 1894. Official Reports, p. 79 .

6 (f. ('harles W. Dilkc. Problems of Greater Britain, ii, p. 107. 
Tupper, who negotiated and signed the French-Canadian reciprocity treaty of 1893 , was associated with Dufferin, a former Governor-General of the Dominion, then British Ambassador in Paris. He acknowledged some help from Dufferin, but here again, as at Washington in 1887-1888, and for the same reason, Tupper was easily the dominant partner in the negotiations. ${ }^{1}$

The French-Canadian treaty of 1893, the first commercial treaty ever made by Canada or any other of the dominions with a European power - a treaty never of appreciable value to Canada -was, in fact, Tupper's own treaty. It was admitted in the House of Commons at Ottawa in 1895, that in his eagerness to effect a reciprocity treaty of some kind, in his zeal to score a success in diplomacy, Tupper went beyond his instructions from Ottawa, trusting to his great influence there with the Conservative Government, to secure the implementing of the treaty by the Dominion Parliament. ${ }^{2}$

\section{CHAPTER VIII}

\section{A HALT IN THE PROGRESS TOWARD DIPLOMATIC FREEDOM, 1893-1898-REACTION AT THE COLONIAL OFFICE}

THERE was an interval of fourteen years between the negotiation by Tupper of the meagre and almost valueless FrenchCanadian reciprocity treaty of 1893 , a treaty which the Government at Ottawa had extreme difficulty in inducing its supporters in Parliament to accept, ${ }^{3}$ and the next negotiation of a treaty

1 Cf. Saunders, op. cit., ii, p. 168.

2 "The treaty is one of the first results of the treaty-making power conferred upon us, or rather exercised through us, in conjunction with England, through our High Commissioner. It has been formed between Great Britain and France, and has the signatures of the British and French plenipotentiaries; and it becomes a matter of some grave moment when Parliament approaches a treaty formed in that way, as to whether we shall ratify it or not. Other things being equal, it is certainly incumbent on Parliament to give it a careful consideration, and there will have to be weighty reasons against it before Parliament will undertake to refuse its ratification. I hope these do not exist in this case. In my opinion they do not.'-Foster, Minister of Finance, House of Commons Debates (Ottawa), July 10, 1894, II, 5577. Cf. ibid., April 19, 1895, I, 48.

3 Cf. House of Commons Debates (Ottawa), July 10, 1894 ; also debate on the address to the Crown in reply to the speech from the Throne, April 19, 1895. The treaty was postdated October 14, 1895. Cf. Canada Gazette, xxix, p. 629. 
of an exclusively commercial character in which Canada alone was concerned. Between the signing of the treaty by Tupper, at Paris, on February 6, 1893, and its coming into effect on October 14, 1895, the Colonial Office was involved in much correspondence with Ottawa to secure what the Foreign Office regarded as adequate safeguards for the most favoured nation clause in twenty odd commercial treaties to which in 1893 Great Britain was a party. ${ }^{1}$

The action of the Colonial Office made it incumbent on Parliament at Ottawa to pass two bills for implementing the treaty. Intervention of the Colonial Office also accounted for the unusually long interval between the signing of the treaty and its coming into force on October 14, 1895. There was, moreover, much discussion of the treaty-making powers of the colonies at the colonial conference at Ottawa in $1894 ;^{2}$ and the upshot of the negotiation at Paris in 1893 and of the questions raised at the colonial conference of 1894 , was an attempt in June 1895 by the Colonial Office to curb the powers which the Dominion of Canada had been claiming, and to a large extent exercising, in the negotiation of commercial treaties.

The Marquess of Ripon was at this time Colonial Secretary in the Rosebery Administration of 1894-1895. He was the last Colonial Secretary to continue the now attenuated propaganda begun by Grey in 1846 against differential duties in tariffs enacted by colonial legislatures. ${ }^{3}$ This is Ripon's distinction in colonial history -in the history of the contest that went on for almost half a century between the autonomous colonies and the Colonial Office over the demand of the colonies for complete and unrestrained fiscal freedom.

Ripon has at least one other distinction that also accrued to him in the contest of 1848-1907 in the subdivision of the contest that was concerned with the demand of the colonies, chiefly the colonies of British North America, for power to make their own reciprocity treaties.

After the break-up of the Liberal party of 1832-1886 over Gladstone's first bill for home rule for Ireland, Ripon was of the

1 Cf. Answer by Ives. President of the Council, to Edgar, House of Commons Debutes (Ottawa), May 29, 1895, I, 1697-1698.

2 Cf. Dispatch by the Marquess of Ripon, Colonial Secretary to Ciovernors of the Colonies, June 29, 1895, pp. 14-15.

${ }^{3}$ Cif. ibid., par. 35 , p. 9. 
last group of territorial Whigs to hold office in a Liberal Administration at Westminster. True to the Whig tradition of holding on to power, the attitude of Ripon in $\mathbf{1 8 9 5}$ toward the question of the extent of the power that could be conceded to the colonies in the negotiation of commercial treaties was much like that of Grey and the Whigs of 1837-1850 toward responsible government and its corollary, the fiscal freedom of the self-governing colonies.

The questions raised at the colonial conference at Ottawa in 1894 regarding the treaty-making powers of the colonies demanded some statement of the policy of Downing Street-some statement of the attitude of the Government towards the long pressed claims of the colonies. It accordingly became the duty of Ripon, as Colonial Secretary, to formulate this policy, and to make it known to the self-governing colonies. To this end a circular dispatch was forwarded to the governors in all colonies with responsible government.

'A foreign power', wrote Ripon, in this reactionary dispatch of June 28, 1895, ' can only be approached through her Majesty's representative, and any agreement entered into with it affecting any part of her Majesty's dominions is an agreement between her Majesty and the sovereign of the foreign state $;^{1}$ and it is to her Majesty's government that the foreign state would apply in case of any question arising under it.'

'To give the colonies the power of negotiating treaties for themselves without reference to her Majesty's government', continued Ripon, 'would be to give them an international status, as separate and sovereign states, and would be equivalent to breaking up the Empire into a number of independent states, a result which her Majesty's government are satisfied would be injurious equally to the colonies and to the mother country, and would be desired by neither. The negotiation, then, being between her Majesty and the sovereign of the foreign state must be conducted by her Majesty's representative at the court of

${ }^{1}$ In the discussion of treaty-making power at the Ottawa conference on June 30,1894, F. B. Suttor, representative of New South Wales, recalled the signing by Tupper on February 6, 1893, of the French-Canadian treaty. 'Does Sir Charles Tupper', he inquired, ' act directly for Canada, or does he sign the treaty representing the Imperial Government rather than Canada?' "He signs the treaty,' answered Foster, Minister of Finance in the Canadian Government, ' representing the Imperial Government.' Suttor : 'He is a plenipotentiary for the occasion?' Foster: 'Yes.' Official Report, p. 81. 
the foreign power, who would keep her Majesty's government informed of the progress of the discussion, and seek instructions from them as necessity arose.'

'It could hardly be expected, however,' reads the final paragraph of Ripon's instructions to governors in regard to commercial treaties, instructions which, as it developed, were never applied, and were consequently never of more than academic value, 'that her Majesty's representative would be sufficiently cognizant of the circumstances and wishes of the colony to enable him to conduct the negotiations satisfactorily alone; and it would be desirable, generally, therefore, that he should have the assistance, either as a second plenipotentiary or in a subordinate capacity, as her Majesty's government think the circumstances require, of a delegate appointed by the colonial government.' 1

The academic or historical value of the Ripon dispatch of June 28, 1895, lies in the light it throws on the attitude of a Whig Secretary of State for the Colonies, and of a Liberal Administration in which the Whigs were still largely in control, toward the fifty years old claim of the colonies for responsible government in the fullest sense of the term.

Had the Ripon instructions gone into effect, the cabinets of colonial governments would have had less power in the negotiation of commercial treaties than Clarendon in 1866 was willing, as he informed the State Department at Washington, to concede to the British North American provinces. Any commissioner appointed from Ottawa under the terms of the Ripon instructions of 1895 would have been in exactly the same unsatisfactory and undignified position that Galt occupied at Madrid in 1879 .

From the point of view of the volume of reciprocal trade between Canada and France, the treaty negotiated by Tupper at Paris in 1892-1893 was scarcely worth the outlay entailed by Tupper's long sojourn at the French capital, scarcely worth the cost of the hotel bills of the Tupper Mission. From a material point of view, it was certainly not worth the dissension in the ranks of the supporters of the Thompson and Bowell goveruments of 1892-1894 and 1894-1896, that developed when these govern-

1 Ripon, Dispatch of June 28, 1895, to the Governor-General of Canada, the Governors of the Australasian colonies (except Western Australia), and the Governor of the Cape Colony, c. 7553. 1895, No. 2, pars. 6 and 7, p. 15. 
ments were forced by Tupper to obtain sanction for the treaty from the Dominion Parliament.

But Tupper, none the less, did good service for Canada, and incidentally for all the colonies now of the dominions, by assuming with his characteristic assertion, aggressiveness, and fearlessness, ${ }^{1}$ the position of dominant partner when associated with Dufferin, the British Ambassador, in the negotiations at Paris in 1892-1893.

Tupper's provincialism was confined to fiscal legislation. It ended with tariff acts at Ottawa in the interest of Canadian manufacturers, and with bounty legislation also in the interest of Canadian industries. On most other political questions Tupper was a man of long views, a man who worked for the coming time. It must be kept in mind, moreover, that it was the Baldwins and La Fontaines, the Galts, the Macdonalds, the Tuppers, the Edward Blakes, ${ }^{2}$ the Lauriers and the Fieldings of the United Provinces, or of the Dominion of Canada, who waged nearly all the contests for the constitutional, fiscal, and diplomatic freedom which since 1840 has accrued to all the dominions.

It was these Canadian statesmen, and men of the era of 1820 1837 like Papineau and William Lyon Mackenzie, who were always ready to give proof, abundant and beneficent proof, of Adderley's aphorism of 1869 that the normal current of British colonial history was perpetual assertion of the right of selfgovernment.

1 Tupper had two penchants, one for diplomacy and the other, it will be recalled, for the honours and gewgaws of the imperial connexion. Macdonald had a liking for titles and decorations, for Windsor uniform and the trappings of the ceremonial of state. But Tupper, like Galt, and unlike Macdonald, would sacrifice neither independence of expression nor independence of action for the sake of standing well with Downing Street. Cf. Saunders, Life of Sir Charles Tupper, ii, pp. 175 and 215 ; Pope, Memoirs of Macdonald, ii, pp. 236-240.

2 It was Edward Blake, of On tario, who, as a member of the Mackenzie Government of 1873-1878, wrote the Minute of Council of July 1876 that impelled the Colonial Office to revise the instructions to governors general, and to bring these antiquated and cumbersome state documents into complete harmony with responsible government as the term was understood at Ottawa, Sydney, Capetown, and at every other capital of a self-governing colony of the Empire after the Confederation of the British North American provinces in 1867. Cf. Z. A. Lash, The Working of Federal Institutions in Canada: The Federation of Canada, 1867-191\%, pp. 81-84. 


\section{CHAPTER IX \\ FREEDOM TO NEGOTIATE TREATIES ACHIEVED, 1898-1907}

Tupper's term as High Commissioner for the Dominion of Canada was nearing its end at the time that Ripon's dispatch of June 28, 1895, was in circulation among members of the Cabinets at the capitals of ten of the eleven self-governing colonies. ${ }^{1}$ At the end of 1895 the Conservative Government at Ottawa that had been in power since 1878 was in deep water over the Manitoba school question. The downfall that eame in June 1896 was well in sight; and Tupper, long the war-horse of the Conservative party, was recalled to Ottawa, where he re-entered the House of Commons, and from April to July 1896 he was Premier of the Dominion. ${ }^{2}$

Had it been otherwise, had there been no débâcle of the Conservative Government at Ottawa, had Tupper continued as High Commissioner in London - a position that accorded admirably with Tupper's temperament and ambitions-Chamberlain, who, in July 1895, succeeded Ripon at the Colonial Office, would surely have had to withdraw the Ripon circular or become involved in a controversy with Tupper, and through Tupper with the Cabinet at Ottawa, and probably with the Dominion Parliament.

It is inconceivable that Tupper would have reconciled himself to the loss of the position of the colonies in diplomacy that he had secured when Dufferin was associated with him, only a little more than formally and ceremoniously, at Paris in the negotiation of the reciprocity treaty of 1893. Tupper was a masterful personality. Next to Galt he was the most masterful personality in the world of politics in the self-governing colonies from 1837 to the Great War. He was remarkable for his pugnacity and tenaciousness; for his willingness to lead a forlorn hope, and for his equal unwillingness to call a truce when once in a conflict.

1 The Dominion of Canada, Newfoundland, New South Wales, Victoria, Tasmania, South Australia. Queensland, New Zealand, Cape Colony, and Natal. Western Australia, a colony in which responsible government was established in 1890, was not included in the list of colonies to whieh the Ripon Dispateh was sent.

2 Cf. Saunders, Life of Sir Charles Tupper, ii, pp. 181-201. 
Had Tupper, as High Commissioner, entered on a contest with either Ripon or Chamberlain over the instructions of June 1895, he would have had the support of both Conservatives and Liberals in the House of Commons at Ottawa; for after the Rebellion Losses Act of 1849 established responsible government on an unassailable basis, there were no party lines in Canada when any issue affecting the practical meaning and extent of responsible government was raised.

There could have been only one end to any contest over the freedom of the self-governing colonies to make their own commercial treaties. The contest must have ended as Galt's contest of 1859 with Newcastle over the protectionist tariff of the United Provinces ended, with honours on the side of the Dominion of Canada. A contest with Chamberlain might not have been necessary.

Chamberlain was pre-eminently an imperialist of the school that had no fear of expansion for the Empire. ${ }^{1}$ Even before he proclaimed himself a protectionist, and in 1903 left the Colonial Office and the Balfour Administration of 1902-1905 to devote himself to the propaganda for a protectionist tariff for the United Kingdom, Chamberlain had none of the dread of differenvial duties or of reciprocity agreements based on differential customs duties, ${ }^{2}$ that had been characteristic of all his predecessors at the Colonial Office, Whig or Liberal, Tory or Conservative, from Grey to Ripon, from 1846 to 1893.

At the Colonial Office from 1893 to 1903 it was Chamberlain's mission to exalt rather than depress the importance, dignity, and power of the governments of the self-governing colonies. He had emphasized the independence and power of Canada and Australia seven years before he went to the Colonial Office in $1903^{3}$ and his mission at the Colonial Office was to bring the colonies into closer relations with Great Britain. But the question of the diplomatic powers of the colonies was not raised during Chamberlain's tenure of the office of Secretary of State, a tenure that is recalled with satisfaction at the capitals of the dominions from the fact that it was in 1898 that the self-governing colonies

1 Cf. Joseph Chamberlain, Foreign and Colonial Speeches: 'Pegging out claims for posterity,' House of Commons, March 20, 1893, pp. 109-130; Alexander Mackintosh, Joseph Chamberlain. An Honest Biography (1914), p. 205.

2 Cf. S. H. Jeyes, Mr. Chamberlain, His Life and Public Career, pp. 380, 381.

3 Cf. speech at Rawtenstall, July 8, 1886. Boyd, Mr. Chamberlain's Speeches, i, pp. $276-277$. 
were at last freed from the fiscally hampering articles of the Prussian treaty of 1865 , and of a score of other commercial treaties made by Great Britain before 1878 to which the selfgoverning colonies had not been consenting parties.

A joint high commission, representing Great Britain, Canada, and the United States, was created in 1898 with a view to the settlement of eight questions-(1) the Alaskan and Atlantic fisheries ; (2) the Alaskan boundary ; (3) the convention of 1818 limiting the number of war vessels on the Great Lakes ; (4) alien contract labour laws; (5) bonding privileges, applicable to railway and inland water transport; (6) the preservation of fish in contiguous waters; (7) reciprocity in salving and wrecking on the Great Lakes ; and (8) the conveyance of prisoners by officers of the law through the territory of either the United States or Canada ${ }^{1}$ - then at issue between Canada and the United States, and with a hope, on the part of Canada, that it might result in a seeond reciprocity treaty, for which all the provinces east of the Great Lakes had continuously manifested a strong desire for thirty years before the commission began its sessions at Quebec in August 1898.

Four representatives of the Dominion of Canada ${ }^{2}$ were plenipotentiaries at Quebee. Lord Herschell, who had been Lord Chancellor in Liberal Administrations at Westminster, was the only representative of the Imperial Government. All the questions were exelusively Canadian, except that Newfoundland, represented by its Premier, was interested in the fisheries and in reciprocity in trade with the United States.

The status of the Canadian members of the Mission was similar to that of Maedonald at Washington in 1871; and Ripon's instructions of 1895 , as to the status of representatives of colonial governments in diplomacy, and particularly his injunction that such representatives must serve as second plenipotentiaries, or in a subordinate capacity, were regarded as non-existent.

Ripon's instruetions were reealled in July 1907, at a time when Laurier, Premier of the Dominion of Canada from 1896 to 1911 , Fielding, Minister of Finance, and Louis Brodeur, Minister of

1 (f. J. S. Willison, Sir Wilfrid Laurier and the Liberal Party, ii, p. 188.

2 Laurier, Cartwright, and Davies. all members of the administration at Ottawa, and Charlton, a Liberal member of the House of Commons, long regarded in Canada as an authority on trade and navigation between the Dominion and the United States. 
Marine and Fisheries -afterwards Sir Louis Brodeur, and a puisne judge of the Supreme Court of Canada - were about to proceed to Paris to negotiate a second reciprocity treaty with the French Republic. But the instructions of 1895 were recalled in 1907 only that, in practice, an end might be made to them.

In view of the approaching negotiations, Sir Edward Grey, afterwards Viscount Grey of Fallodon, in a dispatch to Sir Francis Bertie, ${ }^{1}$ recalled the Ripon instructions, 'the object of which,' he assured the British Ambassador in Paris, ' was to secure that negotiations should not be entered into and carried through by a colony unknown to, and independently of, his Majesty's government.' The approaching negotiations, Bertie was further told, were to be left to the Canadian ministers, who would doubtless keep him informed of their progress. In the event of a treaty being arrived at, Bertie was instructed to sign the agreement jointly with the Canadian negotiators, to whom full powers were given in London for that purpose.

The connexion of the British Ambassador with the negotiations was at the opening and closing stages. It was purely formal at each of these stages. All the intervening stages, in fact all the negotiations, were left to the Canadian plenipotentiaries, who were as free at these important stages from any interference from the British Ambassador or from the Government in London, as they were from interference by the Ambassador at Paris of the United States or of Italy.

Only Canadian interests-only concessions in the Dominion customs tariff of 1907 in return for concessions in the customs tariff of France-were at stake. It was entirely a Canadian and French negotiation. ${ }^{2}$ It was so much a Canadian negotiation that at the end of the Mission the only report made by the Canadian plenipotentiaries was to the Cabinet at Ottawa. ${ }^{3}$ The diplomatic

1 Dated July 4, 1907, a memorable day in the history of Great Britain's oversea possessions.

${ }_{2}$ "We conduct our own negotiations, but all treaties are in the name of the King.' William Renwick Riddell, Justice of the Supreme Court of Ontario, The Constitution of Canada in its History and Practical Working, p. 152.

3 'It has long been the desire, if I mistake not, of the Canadian people, that we should be entrusted with the negotiation of our own treaties, especially in regard to commerce. Well, this long-looked-for reform has become a live reality. Without revolution, without any breaking of traditions, without any impairment of our allegiance, the time has come when Canadian interests are entrusted to Canadians; and within the last week a treaty has been concluded with France-a treaty which applies to Canada alone, which has been negotiated 
negotiations at Paris in 1907, and the conditions under which Laurier, Fielding, and Brodeur carried these negotiations to success, ended the chapter in the history of the colonies and of the relations of Parliament and the Government at Westminster to the present-day dominions that was opened at Montreal, in 1848, by the plea of the Baldwin-La Fontaine Government of the United Provinces that it might be directly represented in the negotiations then pending for a reciprocity agreement with the Government of the United States.

The Canadian commissioners for the treaty of 1907 were appointed British plenipotentiaries by order in council issued at Whitehall on August 8. In conjunction with Grey's dispatch to Bertie, of July 4, 1907, the Imperial order in council marked a new and important stage in the constitutional and fiscal development of the dominions, in their diplomatic status, and in their standing and dignity among nations in diplomatic relations with Great Britain.

The order in council and the Grey dispatch marked a stage in the progress of the dominions to the status of nation within the Empire in some respects as noteworthy as the attainment of responsible government; the assertion by the United Provinces of fiscal freedom, and the accruing to the colonies in the years from 1845 to 1869 of power to enact their own navigation laws. ${ }^{1}$

by Canadians alone. True, it has been done with the whole assent of the British Crown and with the assent of the Foreign Office. The Foreign Office interposed no objection at all, but on the contrary told us " This is a Canadian matter, which chiefly concerns yourselves. Take the matter in your own hands ". - Laurier, at Canadian Manufacturers' Association banquet, Toronto, September 26, 1907.

- Not only were we face to face with the matter as Canadian ministers, but as plenipotentiaries of His Majesty, with the certainty that all we did would be ratified by him.' Fielding, at Quebec, October 4, 1907.

1 Cf. Peter Mitchell, Minister of Marine and Fisheries, Macdonald Administration, 1867-1873: Report on Navigation Laws, April 20, 1870, Sessional Papers (Canada), 1870, No. xi, pp. $38-42$.

'The legislatures of the dominions can enact coastwise as distinct from gencral navigation laws. "It is commonly said by writers on constitutional law that a colonial legislature, unlike the Parliament of the United Kingdom, has no power to make laws having extraterritorial validity and operation, and therefore that a colonial statute is invalid so far as it purports to prohibit as criminal offences acts done outside the limits of the colony, or so far as it purports to authorize the doing of acts outside those limits which would otherwise be unlawful.' .John W. Salmond. 'The Limitations of Colonial Legislative Power,' Lew Quarterly Revieu, xxxiii (1917), p. 117. 


\section{CHAPTER $\mathrm{X}$}

\section{TRANSFERENCE OF NEW POWER TO THE DOMINIONS}

From the preceding pages it will have been realized when, and in which of the self-governing colonies, the claim for diplomatic freedom originated; how the British North American provinces and the Dominion of Canada respectively pushed the claim ; ${ }^{1}$ why they pressed the claim so persistently after they had secured for themselves a large measure of fiscal freedom, and to what extent action at Washington-protectionist tariffs enacted by Congress, and the granting or withholding of reciprocal trade by the Government of the United States-influenced the British North American provinces in insisting on power to make their own commercial treaties.

The United States, it will have been realized, was quite as much a factor in the movement in the British North American provinces for freedom to negotiate commercial treaties, as it was in impelling these provinces to insist on freedom to enact tariffs with differential duties; and as it was also in the protectionist movement in Upper and Lower Canada, the movement that achieved its first concrete successes in the Cayley tariff of 1858 and the more widely known Galt tariff of 1859.

Furthermore, the attitude of governments in London toward the claim for diplomatic freedom; the vicissitudes in the movement from 1848 to 1907 , and the labours of the statesmen of the British North American provinces and the Dominion of Canada, who did most to press the claim to complete success, will also have been realized from this and the other chapters in the third subdivision of this history of the fiscal freedom of the dominions. ${ }^{2}$

1 'This new status (the status reached in 1907) was not won without a long and severe struggle. British ministers thought it bad enough that the dominions should manage their own tariffs as they pleased. It was even more annoying and dangerous that they should seek to control their own negotiations with foreign powers.' Percy and Archibald Hurd, The New Empire Partnership (1915), p. 214 .

2 These chapters, it should be understood, are not offered as a history of the dominions in diplomacy. I am concerned only with the movement of the selfgoverning colonies for power to make their own commercial treaties, a movement that developed out of the fiscal freedom that the colonies drew to themselves in the years from 1846 to 1898 .

In Upper and Lower Canada, as a matter of fact, the movement for diplomatic 
Assuming that these several outstanding features of the long persisted in movement have been realized, an aspect of it, or rather a question arising out of the movement and its success, will at once suggest itself to students of the beneficent changes in the constitutional relations of the self-governing colonies to Parliament at Westminster and to governments at Whitehall in the three quarters of a century from the rebellion in Canada of 1837 and Durham's mission of 1838 to the beginning of the war in 1914 .

What part, it will be asked, had the Imperial Parliament in the gradual concession of diplomatic freedom to the dominions? The answer to this pertinent inquiry can be given in a few words. Parliament had no part whatever. At no stage in the movement from 1848 to 1907 , notwithstanding the problems that the demand of the colonies presented to successive Cabinets, was Parliament consulted on the policy of conceding or denying the claim; and in these sixty years singularly little information was given to

freedom began within two years after the Enabling Act of 1846 went into operation, and two years before the United Provinces had achieved their first success in their contest with Grey at the Colonial Office over tariffs in which there were differential duties. Not every episode in the struggle for diplomatic freedom has been reeounted. A history which should take note of all the episodes in the sixty years' eontest was not possible within the eompass of this volume.

No attempt, moreover, has been made, nor was any possible for the reasons already stated, (1) to describe the extent to whieh Newfoundland and Cape Colony have availed themselves of the diplomatie freedom now enjoyed by the dominions; nor (2) to diseuss the proeedure of treaty making by the dominions ; nor (3) to traee the development of procedure on bills in parliaments of the dominions for implementing treaties; nor (4) to describe the attitude of cabinets of the dominions toward these bills, as government measures, on whieh the eredit and reputation, or even the fate of a government, may depend; nor (5) to note the opportunities offering in parliaments of the dominions to discuss the diplomatic policy of the governments; nor (6) to discuss the extent to which state documents are available, or are withheld by governments of the dominions when treaties are before Parliament; nor (7) to examine the measure of eontrol which the Foreign Office in London exercises over the submission of papers concerning treaties to parliaments of the dominions; nor (8) to deseribe the proccdure by which governments of the dominions denounee or free themselves from treaties into whieh they have entered; nor (9) to elucidate the reasons for the fact that the lower houses of parliaments of the dominions, in practice, exercise sole power in determining the parliamentary fortune of bills implementing treaties, when these bills, as they usually do, fall within the eategory of finanee bills ; nor (10) to contrast the procedure on bills in dominion parliaments for implementing treaties, with procedure on bills for a similar purpose introduced in Parliament at Westminster.

All these aspects of the treaty negotiating power of the dominions belong to the history of the dominions in diplomacr, as distinct from a history-a brief one such as has been attempted in Part III - of the diplomatic frecdom of the dominions. 
Parliament, either by the Colonial Office or by the Foreign Office, as to the nature of the claim or as to the concessions that from time to time were made to it.

The series of concessions that in 1907 culminated in freedom to the dominions to negotiate their own commercial treatiesfreedom from any practical restraint by the Colonial Office or by the Foreign Office, freedom also from any supervision or interference by Parliament at Westminster - has a constitutional history strikingly similar to the history of winning of the larger part of the complete fiscal freedom that the self-governing colonies have enjoyed since the end in 1898 of the old commercial treaties that hampered their economic freedom.

The concessions made from 1865 to 1907 , by which Galt in 1866, Macdonald in 1871, Brown in 1874, Galt again in 1879, Tupper in $1883,{ }^{1} 1888$, and 1892 , Laurier, Cartwright; Davies, and Charlton in 1898, and Laurier, Fielding, and Brodeur in 1907, acted as diplomatic representatives, nominally of Great Britain, but in practice as the diplomatic representatives of the Dominion of Canada, ${ }^{2}$ were made by executive action at Whitehall.

In this respect these concessions were like the concessions of 1850-1870 to the British North American provinces, and to the Dominion of Canada, to enact tariffs with differential, discriminatory, and retaliatory duties; and also like the concessions of 1865-1870 to the Australasian colonies to enact tariffs with discriminating and retaliatory duties.

It will be recalled that the Enabling Act of 1846 authorized the legislatures in the British North American colonies only to repeal the tariff act passed at Westminster for the colonies in 1843. It delegated no other fiscal power than this to the legisla-

1 ' The first and only time that a Canadian representative took a position independent of Great Britain was at the international congress for the protection of submarine cables, held at Paris in 1883. Twenty-five powers were represented. I attended for the Dominion; and at one session, when an important point was being discussed, I voted against my British colleagues. The next day Sir Charles Kennedy, then at the head of the commercial department of the Foreign Office, asked for a reconsideration of the question. This was agreed to, and the British delegation voted as I did, having in the meantime consulted the Foreign Office.' Tupper, Recollections of Sixty Years, p. 175.

2 In all these instances, except those of $1879,1883,1892$, and 1907, the negotiations in which these representatives of Canada were concerned, or at any rate part of these negotiations, were with a view to securing reciprocity of trade between Canada and the United States. With one exception only, that of 1883 , all the negotiations grew out of the fiscal freedom of the colonies, and out of the desire of Canada to use that fiscal freedom in commercial treaties. 
tures. But neither the Act of 1846 nor the written constitutions of these provinces had embodied in them any provisions estopping differential, discriminatory, or retaliatory duties; and consequently the Colonial Office had no statutory power to support it, only the prerogative of the Crown to veto, when it entered on its contests of 1850-1870 with the North American provinces over tariffs out of harmony with the fiscal policy of the United Kingdom.

Morcover, when power over tariff legislation accrued to the British North American provinces as a result of these contests of 1850-1870 with the Colonial Office, no statutory guarantee was given of these powers. They were exercised thereafter by virtue of usage, or of the law of the constitution. Parliament intervened only twice in the contests between the colonies and the Colonial Office over differential duties. It intervened on these occasions, in 1873 and in 1895 , not to guarantee power to colonies over their tariff legislation, but only to free the Australasian colonies from the restraining section, Grey's section, of the Australian Colonies Government Act of 1850 .

There is no law on the statute book at Westminster to support the existing diplomatic freedom of the dominions. It is a freedom, however, that may now be said to be recognized and guaranteed, like so much else in the polity of Great Britain and in the polity of the Empire, by usage, or the law of the constitution. So far as can be traced in the reports of debates at Westminster, the approval of Parliament to the transference of a new power to the self-governing colonies was never sought. It was never sought, even by a vote or a resolution in the House of Commons which, directly or indirectly, endorsed the actions of the Government, that step by step, sometimes grudgingly, ${ }^{1}$ sometimes with long intervals between steps, gradually effected the transfer.

The diplomatic freedom of the dominions, like their fiscal freedom, has less of parliamentary sanction-less sanction of the Imperial Parliament-than responsible government. The House of Commons, when it accepted the broad and generous interpretation of responsible government of the Russell Administration of 1846-1852, as embodied in the Rebellion Losses Act of 1849 of the Baldwin-La Fontaine Government at Montreal, placed its seal of approval on responsible government, as this tern was understood in all the British North American provinees.

1 Cf. Hurd, The New Empire Partnership, p. 214. 
Inferentially, if not directly, also, parliamentary sanction was given to responsible government in the colonies by the Acts of 1850,1852 , and 1867 , embodying the written constitutions of the colonies now of the Commonwealth of Australia, New Zealand, and the Dominion of Canada.

The change in policy and procedure involved in conceding diplomatic freedom to the colonies meant, in practice, the transfer of an important power from Downing Street to the capitals of the self-governing colonies. But the change went on gradually and almost silently, so far as Parliament at Westminster and the newspaper press in the United Kingdom were concerned, until complete success attended the movement in 1907.

At Ottawa, the capital of the Dominion that from 1867 to 1907 was most concerned in the movement for diplomatic freedom, the gradual winning of the long desired power between 1871 and 1907 attracted a full measure of attention in Parliament. Attention, and quite serious attention, was necessary there, because all the treaties negotiated by representatives of the Dominion, or in the negotiation of which representatives from the Dominion had a direct part, in association with plenipotentiaries representing Great Britain, required legislation, usually to insure their operation, and always to provide for the expenses incurred in the negotiation of the treaties.

Legislation to insure operation was necessary in the case of the treaty of Washington of 1871, in the negotiation of which Macdonald had a part, an unsatisfactory part, as he and his colleagues of the Cabinet at Ottawa regarded it. ${ }^{1}$ Legislation was also necessary in connexion with the treaties of reciprocity between Canada and France, the first negotiated by Tupper in 1892-1893, and the second negotiated by Laurier, Fielding, and Brodeur in 1907. Amendments to Tariff Acts were entailed by these treaties; and at nearly every stage of the progress of the amending bills through the House of Commons and the Senate at Ottawa, there was more or less discussion of the treaty-making powers of the Dominion, as well as of the procedure of treaty making.

1 'Never was there such a bungled matter from beginning to end. You may tell Lord Granville [Secretary of State for Foreign Affairs in the Gladstone Administration of 1868-1874] from me confidentially that if he wants his business done at Washington correctly at any time he must send me alone. But seriously the whole thing was badly managed; first at Washington and still more in England.'-Macdonald to Sir John Rose, Ottawa, June 18, 1872. Pope, Memoirs of Macdonald, ii, p. 149. 
Diplomacy, as it affected the Dominion, and also the power of the Dominion in the negotiation of reciprocity treaties, were wellworn subjects with both the House and the Senate at Ottawa, almost from Confederation to the Canadian-French treaty of 1907. In the early years of Confederation, Galt in 1870 and Blake in 1882 urged in the House of Commons the imperative need of full powers for the Dominion in negotiating commercial treaties. ${ }^{1}$

From 1881 to 1897 , moreover, there were frequent discussions in the House of Commons at Ottawa of the commercial treaties of Great Britain entered into before 1878 , by which all the colonies,

1 Galt on March 21, 1870, moved that an address be presented to the GovernorGeneral, representing that (1) 'the increasing population and productions of the Dominion demand more extensive markets, and a more unrestricted interchange of commodities with other countries; (2) that great advantage would result from plaeing the Government of the Dominion in direct communication with all the British possessions and foreign states which might be willing to negotiate for commercial arrangements tending to this result; (3) that it is expedient to obtain from the Imperial Govemment necessary powers to enable the Government of the Dominion to enter into direct communication for such purpose with each British possession and with foreign states; and (4) that in all cases such proposed commercial arrangements should be subject to the approval of her Majesty'. Galt's motion was opposed by Macdonald and the supporters of the Macdonald Government and was defeated by 100 votes to 58 . Cf. Parliamentary Debates (Ottawa), 1870, 560, 653-654.

The motion that Blake asked the House of Commons to adopt, April 21, 1882, declared that (1) 'the condition of Canada and the system on which her duties of customs have been, and are now, imposed, vary widely from those existent in the United Kingdom, and open to the basis and negotiation of commercial arrangements with other States or British possessions views and consideration, which do not apply to the case of, or harmonize with, the policy of the Unitcd Kingdom, which it is difficult for the Government of the United Kingdom to advance, and which can be best realized and presented by the Government of Canada through a negotiator named by her for the purpose of providing separate trade conventions with countries with which Canada has, or may cxpect, distinct trade'; (2) that 'the complications and delays involved in the reference to the departments of the Government of the United Kingdom of points arising in the course of trade negotiations enhance the difficulties of the situation and diminish the chanees of success, and havc already resulted in loss to Canada', and (3) that "it is expedient to obtain all necessary powers to enable her Majesty through her representative, the Governor-General of Canada, acting by and with the advice of the Qucen's Privy Council for Canada, to enter by an agent or representative of Canada into direct communication with any British possession or foreign State for the purpose of ncgotiating commcrcial arrangements tending to the advantage of Canada. subject to the prior consent or the subsequent approval of the Parliament of Canada, signified by act'. Ibid., 1882, 1075.

Only fifty-eight members voted for Blake's motion. These ineluded Alexander Mackenzie, Premier of the Liberal Government at Ottawa of 1873-1878, Cartwright, and Laurier, who in 1887 suececded Blake as leader of the Liberal Opposition. 'The Government strength against the motion was one hundred and one. Ibiil., 1094-1095.

'This was the last formal debate at Ottawa on direct negotiation. But in litter years there were many debates on the treaty-making power of the Dominion, on the extent of this power, and on the proeedure associated with its exercise. 
self-governing colonies as well as Crown colonies, were bound. There was an address to the Crown from the Dominion Parliament in 1881 asking that the self-governing colonies be relieved from these treaties; and when the much condemned treaties were under review, usually impatient if not hostile review, ${ }^{\mathbb{1}}$ there was incidentally some discussion of the powers of the Dominion in treaty making, and usually some support for the movement for diplomatic freedom. ${ }^{2}$

At one time, 1873-1874, there was some agitation of the question outside Parliament at Ottawa; for the organizers of the 'Canada First ' movement, and of the movement of the Canadian

1 Cf. speech by Laurier, House of Commons, September 30, 1891. Ibid., III, 6315 .

2 Support from both parties in the House of Commons was forthcoming in most of the formal and informal discussions of the Dominion in regard to diplomacy after those of 1870 and 1882 . Galt was a free lance in the House, unattached to either Conservative or Liberal party, when in 1870 he proposed his motion. Blake in 1882 was the leader of the Liberal opposition. Hence the opposition of Macdonald and the Conservatives to the Galt and Blake motions.

But Macdonald, unlike Galt, Tupper, Blake, Laurier, and Fielding, as far as can be traced from the parliamentary debates, parliamentary papers, and his published correspondence, can be assigned no prominent place in the history of the movement for diplomatic freedom from 1848 to 1907 . Except when protectionist duties in Canadian tariffs were concerned, Macdonald was singularly deferential to Downing Street, and he was always alive to the impression his speeches and actions at Ottawa might make in London. Reuter's correspondent in the press gallery at Ottawa was usually in mind with Macdonald when he spoke on any subject that had an imperial aspect.

Macdonald's attitude towards Downing Street is manifest in the speech he made in the House of Commons on March 21, 1870, in opposition to Galt's motion in favour of the direct representation of Canada in the negotiation of reciprocity treaties. Macdonald considered Galt's motion as objectionable in spirit—almost as objectionable as a motion, to which it was an amendment, for commercial union with the United States. He was convinced, he told the House of Commons, that there was no necessity for casting aside the support and sanction of England, ' and trying our own naked strength - trying what we can do in these matters.' 'Is it not of advantage to us,' Macdonald continued, 'that a treaty in the manufacturing or commercial or agricultural interests of the country should be looked upon, not as a treaty with little Canada but with the Empire of Great Britain? Shall we throw away this advantage, and shall we, as a country of four million people, go with bated breath, and in a humble key, to other countries in forma pauperis? Shall we go to the countries of Africa and Asia, and say "We want to trade with you"? The first question we should get would be "Who are you? We don't know you !" "We are a province of England." "Well then, send England to us, and we will deal with her." That would be the answer we should receive. Are we to throw away the advantage of having England make our treaties with us, hearing what we have to say, learning from our envoys or commissioners what our wants really are, carefully considering whether our interests conflict with the interests of Great Britain, and going as far as those interests will allow? Are we to go and say, "Will you give us a letter of introduction to Spain, and to the other nations"? Are we to go and say that we have a power of attorney, that England has nothing to do with the matter, and that we can treat for ourselves ?' Ibid., 1870, 578 .

1569.29 
National Association, both movements that originated in Toronto, made it one of their demands that Canada be conceded the general power of treaty making affecting the Dominion. ${ }^{1}$

For many years before 1907 , and long after the Canadian national movement had died away, Canada in diplomacy, and in particular the power of the Dominion in the negotiation of commercial treaties, was much discussed in the newspaper press of the Dominion. In the early years of the national policy of the Dominion-the policy that the Conservative party at Ottawa first attempted in 1870, and succeeded in 1879 in establishing by means of a high protectionist tariff-emphasis was laid on reciprocal trade, and usually when reciprocity treaties were discussed by supporters of the national policy there was emphasis also on the need of power to negotiate reciprocity treaties by representatives of the Dominion.

It was a complaint at this stage of the history of the national policy, a complaint for which there was adequate ground, that Great Britain had no sympathy with the national policy. It was also a complaint, which would seem to have been groundless, that lack of sympathy at Whitehall and Westminster with the national policy of Canada was likely to influence British plenipotentiaries in negotiating reciprocity treaties in the interest of Canada. ${ }^{2}$

1 'At the time of my settling in the eountry (1871) there was on foot, among the younger men, a movement ealled "Canada First". The tendeney, if not the avowed objeet, was to make Canada an independent nation, hinked by affeetion to the Mother Country. This was my own idea, as it was of the British statesmen from whom my opinions had been imbibed; and indeed of British statesmen generally in my day. It seemed desirable that there should be two experiments in demoeraey on this eontinent. . . The guiding star-the hero of the party-was Mr. Edward Blake, an advoeate and politician of the highest pronise.' Goldwin Smith, Reminiscences, pp. 442-443.

"It cannot be said that nationalism has not stirred the hearts of some of our people. The voiee of the Canadian patriot has never been quite silent; but hitherto it has been usually the voice of one erying in the wilderness. Let me remind you of the somewhat notable appearanee of the "Canada First" Party under the leadership of Mr. W. A. Foster, of Toronto. . . After some prehiminary review articles he produced in 1871 the memorable pamphlet entitled " Canada First". It had such effect that in 1873 the Canadian National Association was formed. with " the eultivation of a national sentiment" as its object; and 1874 witnessed the institution of the National ('lub, which still [1904] exists; of the Nation, a weekly review, nnd the Liberal, a daily newspaper. . . Canada as a whole was irresponsive, and Mr. Foster reluctantly gave ul the task. It wats at that time impossible of aceomplishment. The Liberal lived for about a vear : the Nation two years; and then all was quiet again.' John S. Wwart. The Kingdom of I'anada, p1).76-77. ('f. Lewis. Citorge Brown, p. 240); C'anada First, A Memorial of the lat I' illiam A. Foster, (..'., pl. 1-12.

${ }_{2}$ "Laurier' and other Dominion statesmen have been apt to hy stress upon the so-called supineness of the British Foreign Odfice when eolonial interests were at stake' Hurd, op. cit., p. 214. 
Ottawa all through the long struggle for diplomatic freedom realized far better than Parliament at Westminster what the contest meant for Canada and for all the dominions. Canadian statesmen and parliamentarians were better informed, because many of them, directly or indirectly, at one time or another had been engaged in the struggle for diplomatic freedom.

At Westminster before 1907, Parliament had had practically no opportunity vouchsafed it by succeeding governments from 1865 of realizing the full meaning and significance of the movement that came into imperial politics when the interprovincial council on commercial treaties of 1865 made its demands on the Russell Administration of 1865-1866 for (1) direct representation of the British North American provinces in the then pending negotiations at Washington for reciprocity, and (2) for similar representation in negotiations with Spain, Mexico, and Brazil to the same end.

The history of the diplomatic freedom of the dominions attempted in these chapters has been carried nearly thirty-five years beyond the crisis of 1867-1873 that developed out of the unanimous demand of the Australasian colonies for a larger fiscal freedom. In relation to this crisis it might have stopped at 1871 with Macdonald's appointment as one of the plenipotentiaries for the negotiation of the treaty of Washington, a negotiation in which many questions were involved, some of extreme difficulty, but out of which the Dominion of Canada hoped - vainly as it turned out - to secure again reciprocity with the United States.

The appointment of Macdonald as a commissioner to Washington was the last concession to the movement for diplomatic freedom before the crisis over differential duties in the Australasian colonies was ended by an amendment by Parliament at Westminster to the Australian Colonies Government Act of 1850. It seemed expedient, however, to carry the history to the final success in 1907, for certain obvious reasons. It was a movement for freedom and power to make commercial treaties that was a direct and immediate outcome of the successful assertion of fiscal freedom in the years from 1850 to 1867 by the British North American provinces, and as such its history is a part, and a most important part, of the history of the fiscal freedom of the dominions.

The movement for diplomatic freedom, resulting in one of the 
six great constitutional developments within the Empire in the period from the Revolution of 1688 to the Great War of 1914-1918, proceeded contemporaneously with the movement which culminated in 1878 in the decision of the Conservative Government of 1874-1880 that in future each of the self-governing colonies was to have the opportunity of determining and declaring by minute of council whether it would or would not be included in treaties made by Great Britain ; ${ }^{2}$ with the movement which acquired its greatest force in $\mathbf{1 8 9 4}$ for a second amendment to the constitution of the Australian colonies that would enable these colonies to enter into agreements for reciprocal trade-agreements based on differential duties - with colonies outside the Australasian group $;^{3}$ with Great Britain, and also with non-British countries; ${ }^{4}$ and the movement which had its beginnings at Ottawa in 1881, for the denunciation of all commercial treaties binding on the colonies to which their assent had not been asked or accorded.

The movement of 1848-1907 went on contemporaneously with all these four movements of 1871-1898. It stimulated the movements for the non-inclusion of the self-governing colonies in commercial treaties made by Great Britain, or rather for freedom of choice by the colonies as to inclusion in these treaties ; and it. also stimulated the movement, successful in 1898 , for freeing the self-governing colonies from all British commercial treaties entered into before 1878 .

1 (1) The evolution of the system of government by Cabinet; (2) the roform of the representative system of the United Kingdom in 1832 ; (3) the establish. ment of responsible government in the eolonies, $1840-1852$; (4) the concession of fiseal freedom to the eolonies with responsible government, 1846-1898; (5) the eoneession of diplomatie freedom to these eolonies, 1865-1907; and (6) the curtaikment of the power of the House of Lords, 1911.

2 Cf. Alpheus Todd, Parliamentary Government in the British Dominions (1894), p. 266 ; Sessional Papers (Canada), 1883, No. 89, pp. 13-21.

'Praetieally this is a eharter to us, authorizing us to have a voiee in the negotiation of all treaties made with foreign Powers in which our interests are eoncerned.' General Lauric, in discussion in House of Commons at Ottawa, April 21, 1890, of Carnarvon's eireular dispatch of 1878 announeing the new poliey of the British Goverument. Parliamentary Debates (Canada), $1890,3667$.

3 The amendment of $1873(36 \& 37$ Viet., c. 22) enabled the Australian eolonies to make agreements for reeiprocal trade with each other and with New Zealand, but with no other colonies, nor with any foreign Powers. "Lnder the present system,' wrote Gray in 1868, five years before the anendment by the lmperial Parliament of the Australian Act of 1850, 'Canada has no more material interest in Austrakia, or Australia in Canada, than each may have in S'pain ; and Janaica. so far as eoncerns any benefit to be derived from lier sister colonies, might as well belong to Russia.' 'Gray. 'omfederatiom, i, p. 35.t. For Canada, so far as the Australasian colonies were concernecl. (iray's deseription of intereolonial relations remained true until the seeond amendment of the Australian Aet in 1895.

- (ff. Official Report, Colonial Conference, Ottawa, 1894, py. 178-217, 258-272. 


\title{
PART IV
}

\section{RESPONSIBLE GOVERNMENT AND FISCAL AND DIPLOMATIC FREEDOM}

\author{
CHAPTER I
}

\section{THE END OF AN ERA IN THE FISCAL HISTORY OF THE EMPIRE}

The statement was made in an earlier chapter that there were seven distinct episodes or crises in the propaganda from Whitehall and Westminster for fiscal legislation in the self-governing colonies that should harmonize with the fiscal and commercial legislation of 1846-1849 at Westminster. Three of these crises ${ }^{1}$ have been described. ${ }^{2}$ The fourth in the series, taking them in the order in which they developed, arose out of the revolt of the Australian colonies against the fiscal restrictions of the Imperial Act of 1850, the restrictions of the thirty-first section, to which Grey, its author, for twenty years attached so much value.

Kimberley, at the Colonial Office, and the Gladstone Administration of 1868-1874, as has already been indicated, conceded in 1873 the demand of the Australian colonies. The Government had practically no alternative. It had no more alternative than Newcastle and the Palmerston Government had in the case of the protectionist tariff of the United Provinces in 1859. But, as was the case in 1859, the Gladstone Government in 1873 most

1 Arising (1) out of the elaim of the British North American provinces of 1841-1867 to enact tariffs with differential duties; (2) out of the assertion of fiscal freedom by the United Provinces of Upper and Lower Canada in 18581859 ; and (3) out of the claim of the British North American provinces, and the Dominion of Canada, to direct representation in diplomatic negotiations.

2 Extracts or summaries of the more important documents in (1) the contest of the British North American provinces with the Colonial Office over differential duties, and (2) the contest of 1859 of the provinces of Upper and Lower Canada with Newcastle over Galt's tariff are included in the Appendices. Summaries or extracts from the official documents in the contest of 1867-1873 between the Australasian colonies and the Colonial Office over the power of these colonies to enact tariffs with differential duties will also be found in the Appendices. 
reluctantly yielded to the demand for larger fiscal freedom for the Australian colonies; and, moreover, it told these colonies and the world at large that it was with reluctance and regret that it made the concession. ${ }^{1}$

The concession, delayed as long as possible, and made at last only because, as Kimberley frankly told the House of Lords on May 30, 1873, the principle of self-government was more important than free trade, ended, not completely but for all practical purposes, the propaganda for an Empire with a fiscal system based on free trade.

It ended an era in the history of the fiscal system of the Empire that began with the adoption of free trade and the passage of the Enabling Act of 1846 and ended in 1873 with the repeal by Parliament of part of the section of the Imperial Act of 1850 that was intended by the Whig and free-trade Government of 1846-1852 to hold the Australian colonies in line with the fiscal policy of Great Britain.

As thus marking the end of an era in British fiscal policy, and the manifest failure of the expectations and hopes of most statesmen at Westminster in the period from 1846 to 1873 .that free trade would be the basis of the tariff systems of the Empire, it affords an opportunity for two examinations of conditions in the self-governing colonies as they existed at the time the Imperial Parliament amended the Australian Colonies Act, and thus proclaimed to the world that the propaganda for an Empire with a fiscal system uniformly based on free trade had been abandoned.'

1 'He regretted this bill [Australian Customs Duties Bill] had beeome nees. sary. But the prineiple of self-government was even more important than the prineiple of free trade.' Kimberley, in Committee on the Government Bill for the first fiseal amendment to the Australian Constitution Aet of 1850. House of Lords, May 30, 1873. Parliamentary Debates, III, eexvi, 156.

The essential parts of Kimberley's speeeh in Committee on the Bill of 1873 and of Grey's speceh in opposition to the eoneession to the Australian eolonics will be found in the Appendiees.

2 In praetice, after 1873 . only Britisls commereial treaties curtailed or restrained the fiscal freedom of the Dominion of Canada, Newfoundland. New Zealand. and Cape Colony. Only these treaties and the surviving part of seetion 31 of the Imperial Aet of 1850, after 1873. restrained the fiscal freedom of the Aust ralian eolonies. 'The veto of the Crown. whether exercised in a self-governing colony by the Govemor, or in the case of reserved Bills. exercised in Downing street. was, as will be realized in subsequent chapters in Part $I V$, praetically extinct. (iovernment by Cabinet ended the veto power at Westminster in the first deeade of the eightecnt li century. A eonstitutional flevelopment on parallel lines-responsible goverument - for all practical purposes. and absolutely as regards tiscal lecisla. tion. had thrown the veto of the ('rown into the divearch at the capitals of all the self-governing colonies at least a decade hefore the Australian colonies in 1873. 
The crisis of 1867-1873, resulting as it did in a victory for all the Australasian colonies almost as outstanding in the history of the dominions as the triumph of Galt over Newcastle in 1859, affords an opportunity for a survey and a retrospect.

In the first place it affords an opportunity for a survey of the attitude of all the self-governing colonies in the years from 1846 to 1873 toward the fiscal system that was then so much valued in the United Kingdom, and of the attitude of some of the selfgoverning colonies towards the old widespread and deeply rooted tradition in the United Kingdom that trade with the colonies belonged of right to British manufacturers and British exporters, that Great Britain's colonies were in reality only an extension of the home market. ${ }^{1}$

In brief the crisis of 1867-1873-Kimberley's long, laboured, and futile contest with the six or seven self-governing colonies in Australasia-affords an opportunity for a survey of the position of the various self-governing colonies as regards the fiscal policy of Great Britain at the time when a new measure of fiscal freedom accrued to the colonies in Australia. It affords an opportunity for realizing which of the colonies in the years from 1846 to 1873 had adopted fiscal policies antagonistic to that of Great Britain, and also which colonies were still on a free trade basis.

In the second place, taking the Australian Act of 1873 of the Imperial Parliament as a landmark in the history of the fiscal freedom of the dominions, its erection, almost unnoticed in Great Britain, ${ }^{2}$ affords an opportunity for a retrospect of the progress of responsible government in the colonies from the Enabling Act of 1846 to the abandonment of the propaganda for an Empire on a free trade basis, an abandonment that was inevitable after the Australian colonies had won their triumph over Kimberley and the Gladstone Government.

Such a retrospect or survey, a little detailed in places, is essential in a history of the fiscal freedom of the dominions. Without responsible government, without the broad and generous measure by Act of the Imperial Parliament, acquired a larger freedom in respect of tariff legislation.

1 Cf. Herman Merivale, Lecture on Colonization and Colonies, p. 190.

2 In the Parliamentary Debates for 1873 there is no record of any discussions at any one of the five stages in the House of Commons of the Government Bill amending the Act of 1850 to bestow a larger fiscal freedom on the Australian colonies. Nor is the Act mentioned in The Times summary of the year. or in the Annual Register for 1873. 
of responsible government that was persistently demanded by Baldwin and La Fontaine and the Liberals of Upper and Lower Canada from 1841 to 1849 , and finally conceded by the Russell Government of 1846-1852, the successful contests, first for fiscal freedom and next for diplomatic freedom for the colonies, would not have been possible.

Galt, and also Cartier and Macdonald, who were at the head of the Conscrvative Administration of Upper and Lower Canada of 1858-1862, ${ }^{1}$ were well aware that with responsible government, firmly established as it was by 1859 , there could be only one issue in the contest with the Colonial Office over the tariff that imposed high duties to protect Canadian manufacturers from British competition.

All the Governments of the Australasian colonies in the years from 1867 to 1873 were equally well aware that with responsible government unassailably established, the Colonial Office and the Gladstone Government, object as they might, and argue, beseech, and delay as they would, must eventually concede the claim for a larger fiscal freedom than the Australian colonies could exercise from 1850 to 1873 .

Galt and Tupper also, when they persistently pressed the claim of the Dominion of Canada for direct representation in the negotiation of commercial treaties, were well aware that no claim long pressed by a great colony with responsible government could be indefinitcly denied. They knew that in the long run the Forcign Office, despite its inherent conservatism and its traditions of exclusiveness and of autocratic personnel, must accommodate itself to co-operation and association with the statesmen to whom the self-governing colonies deputed their diplomatic business.

Responsible government was, in short, the key to every concession in the direction of fiscal freedom and diplomatic freedom that in the years from 1846 to 1873 the British North American provinces or the Dominion of Canada and the Australasian colonies compelled Governments at Whitehall to make.

Every concession was made grudgingly and with reluetance, because every Govermment at Whitehall from 1846 to $1873^{2}$ was as a matter of aceepted British poliey intent on an Empire with

1 (f. Boyl. Sir Georgr Etienne 'urlier. p. 11 .

2 The only exception was the first Derby Administration. which was in power only from February to lecember $185:$. 
a fiscal system based on free trade. The aim of a fiscal system so based, and so inclusive, was, moreover, not abandoned even after the Palmerston Government was forced to permit the protectionist tariff of the United Provinces of 1859 to go into operation.

The early protectionist tariffs in Upper and Lower Canada and in Victoria were for a time regarded in Great Britain as phases of fiscal policy in the colonies that could not possibly be enduring. The idea was prevalent that a protectionist tariff enacted at the instance of one colonial government might be repealed at the instance of the succeeding government, and despite the fact that there were no such marked reversals in fiscal policy in Upper and Lower Canada, or in Victoria, the people of Great Britain cannot be said to have accepted protection as the established and permanent policy of any of the self-governing colonies until the second national policy tariff of the Dominion of Canada was enacted at Ottawa in 1879.

Kimberley in 1873 admitted that it was the existence of responsible government in the Australasian colonies that impelled the Gladstone Government to revise section 31 of the Imperial Act of 1850. Newcastle made a similar admission in 1859 when he announced his failure, as Colonial Secretary, to hold the United Provinces to free trade ; and to-day history records the fact that the colonies of the dominions owe their fiscal and diplomatic freedom, and much else that differentiates them from Crown colonies, to the gradual establishment of responsible government in the years from 1840 to 1849 .

Some acquaintance with the development of responsible government in Upper and Lower Canada, the pivotal provinces in the early constitutional history of the dominions, is, moreover, essential to an understanding of the last thirty years of the era of indifference in Great Britain to colonies and widely extended empire ; for as will appear as this study of British colonial policy proceeds, the use that several of the larger colonies made of the generous measure of responsible government they enjoyed, the use they made of it from 1859 to 1887 increased the popular indifference in England and Scotland to colonial possessions.

Indifference to colonies was characteristic of the people of Great Britain for a century after the American Revolution of 1776. It was a characteristic that was most manifest after the legislatures of the self-governing colonies began to enact tariffs to 
protect colonial industries, and after movements were set on foot in the colonies to disabuse manufacturers and exporters of the United Kingdom of the traditional conception of British commerce that Great Britain's colonies were only an extension of the home market for the output of British factories.

\section{CHAPTER II}

\section{PROTECTIONIST AND FREE TRADE COLONIES IN 1873}

OnLy in Canada and in the Australasian colonies, up to the time of the repeal in 1873 of part of section 31 of the Australian Government Act of 1850, had there been any colonial legislation frankly and avowedly antagonistic to the established fiscal policy of Great Britain. In the years from 1847 to 1873 it was only in the United Provinces of Upper and Lower Canada, in the Dominion of Canada, in Victoria, and in New Zealand, that tariffs were enacted in which there were duties intended to protect colonial manufacturers from competition from the United Kingdom ; and only in the British North American provinces, and in the Dominion of Canada, had there been tariffs with differential duties.

In the later decades of the period there were tariffs in British Columbia designed to afford protection against competition from the United States. The legislature of British Columbia in these years had also offered bonuses to secure the establishment of furnaces for the production of pig iron and of mills for the manufacture of woollens.

These bonuses or bounties, which were never claimed because neither furnaces nor mills were established before Confederation, were, in principle, contrary to the principle on which the fiscal system of Great Britain was established in 1846. But until British Columbia went into Confederation in 1872 there were no duties at its ports which were avowedly intended to protect industries in the Pacific ('oast province from competition from the United Kingdom. British Columbia, moreover, was never in conflict with the Colonial Office over any department of its fiscal policy.

From the date of the Enabling Act of 1846 to the beginning of the war in 1914 there were no tariffs in Newfoundland intended 
to protect industries on the island from competition from the United Kingdom. Newfoundland in these sixty-eight years had no manufacturing industries for which claims for protection could be established. All the tariffs enacted in those years at St. John's were for revenue only, a fact which explains why Newfoundland, unlike the Australasian and South African colonies, did not follow the example of the Dominion of Canada in 1897 and establish preferences in its tariffs for imports from the United Kingdom.

In its fiscal history from 1846 to 1914 Newfoundland has another distinction. Its first use of the Enabling Act, it will be recalled, was to enact in 1848 a tariff in which, despite the fact that it was a tariff for revenue only, there were preferences for imports from the United Kingdom. ${ }^{1}$ But the financial needs of the colony did not admit of the continuance for long of this policy toward the mother country, and in April 1850 the preferences completely disappeared.

Newfoundland was the only province that deemed it practicable or advisable to continue to British manufacturers and exporters any part of the tariff advantages that they had enjoyed in the British North American provinces under tariffs enacted at Westminster, and also at the provincial capitals under the old commercial system. Newfoundland was thus the first British colony after the abandonment of protection by Great Britain in 1846 to establish tariff preferences for imports from the United Kingdom.

Nearly half a century intervened before any other self-governing colony followed the Newfoundland precedent of 1848. Canada in 1897 established a new precedent ; for Newfoundland's attempt of 1848-1850 to make concessions in favour of British manufacturers seems never to have found its niche in the fiscal history of the Empire, and it had been long forgotten when the Empire was surprised and Downing Street and the Foreign Office in particular were perturbed ${ }^{2}$ by the new departure at Ottawa, in the Fielding tariff of 1897.

1 Cf. Statutes of Newfoundland (13 Vict., c. 1). All the British North American provinces availed themselves in 1847 or 1848 of the new freedom accruing to them under the Enabling Act. The united provinces of Upper and Lower Canada freed themselves from the last tariff enacted at Westminster for the oversea possessions, the British Possessions Act of 1843 (6 Vict.. c. 1). in 1817. Nova Scotia and New Brunswick also freed themselves from this Act in the same year, and Prince Edward Island and Newfoundland in 1848.

2 The perturbation at the Foreign Office was due to the fact that the preferential 
At the time all the Australian colonies were in revolt against the restrictions on freedom in tariff legislation imposed by the Constitution Act of 1850, and New Zealand, which could exercise a larger freedom in tariff making under its constitution of 1852, was closely associated with the Australian colonies in their movement, the Cape of Good Hope was the only colony in British South Africa that enjoyed the same full measure of self-government as most of the colonies now of the dominions had secured in the years from 1841 to 1859 . Responsible government was conceded to Cape Colony in August 1872. The first Ministry at Cape Town under responsible government was formed in November 1872.

So long as the Cape was under Crown colony rule and there was no administration at Cape Town dependent from day to day, like administrations in Downing Street for over two centuries, on a majority in the Lower House of the Legislature, there could be no legislation antagonistic to the fiscal policy of the United Kingdom.

It was 1893 before Natal, the sister colony of the Cape of Good Hope, was sufficiently advanced in population and political civilization to be grouped with the British colonies in the enjoyment of responsible government ; and it was 1898 before manufacturing and agrarian interests in Cape Colony were able to secure protectionist duties in the tariffs of the customs union of South Africa.

All the contests for fiscal freedom from 1846 to 1873 , and for thirty ycars after Parliament at Westminster in 1873 repealed part of the restrictive section of the Australian Constitution Act of 1850, were waged by the British North American provinces, the Dominion of Canada, and the Australasian colonies. It was these two groups of colonies now of the dominions that revolted against any restrictions on their fiscal freedom, whether these restrictions were (1) possible through the power of the Crown to withhold assent from Tariff Bills, or (2) embodied in statutes of Parliament at Westminster, like the Australian Government Act of 1850 , or (3) in treaties made by Great Britain, in which before 1878 colonies had been inchuded without their consent.

tariff made it inevitable that (ireat Britain's treaty with Germany should he denouneed without delay. It had long been the desire of the Government "t Whitehall to aroid frietion with (iermany or any interference with the British. l'rusian eommereial treat y of 186.5 , although salisbury, who in 1897 was Minister for Foreign Affaim. had in 1896 told a deputation at the Foreign Office that it wits impossible to understand why the colonies were included in the eommereial treaty with Prusia. 
These were the colonies that before the crisis of 1867-1873 over differential duties in tariffs passed in Australia, or during that crisis, bluntly told Downing Street that however well the British fiscal policy of 1846 might serve the United Kingdom, with the many advantages it had long possessed for manufacturing industries and export trade, free trade policies did not meet the need of new and developing countries like the British North American provinces or the Australasian colonies. ${ }^{1}$

It was these colonies, first the British North American provinces and the Dominion of Canada, and then the Australasian colonies, as will have been realized from Part II, that were intent on making an end to the tradition ${ }^{2}$ that had survived the abandonment of the old commercial system, that trade with British colonies was the right of manufacturers and exporters of the United Kingdom.

\section{CHAPTER III}

\section{THE CONSTITUTIONAL POSITION OF THE COLONIES AT THE CRISIS OF 1867-1873}

THE nineteenth century, and especially the middle half of the nineteenth century, was an era of political reform in the United Kingdom, and also of reform in all the colonies of Great Britain. The era of reform in the United Kingdom began before the sweeping changes in the electoral system in 1832 -before corruptions that dated back at least to the reign of Queen Elizabeth were eliminated from it.

The new moulding of the electoral system in 1832 quickened the movement for reform. It greatly accelerated reform, so much so that the political history of the United Kingdom from 1832 to the third extension of the parliamentary franchise in 1884 is in the main a record of long overdue and beneficent reforms

1 Galt's declaration to this effect will be found in the Appendices. Declarations to the same effect embodied in Minutes of Council from some of the Australasian colonies in the controversy of $1867-1873$ with Kimberley will also be found there.

2 The advantages which may result from colonies to the mother country appear to be the extension of the manufactures and trade of the mother country by the demand for home products which arises in the colonies, the consequent impulse given to industry in the mother country, and the opportunities which industrious labourers and small capitalists have of mending their condition by emigrating to a country where labour is wanted, and where land can be had at a moderate price. Charles Knight, Political Dictionary (1843), i, p. 562. 
in almost every department of the political civilization of England, Scotland, and Ireland.

The history of the Empire in the same period, 1832-1884, is to a large extent also a record of equally beneficent reforms in the political civilization not only of the colonies now of the dominions, but also of the Crown colonies.

With one single exception, the abolition of the corn laws in the United Kingdom in $1846,{ }^{1}$ no reform depending on legislation at Westminster, or upon executive action by administrations at Whitehall, was achieved in-a shorter period of time than the reform in the colonial policy - a reform dependent entirely on executive action in Downing Street ${ }^{2}$-which established responsible government in the colonies that are to-day comprised in the Dominions of Canada, Newfoundland, New Zealand, the Commonwealth of Australia, and the Union of South Africa.

The movement for this reform, the greatest and most farreaching reform in the British Empire in the period from the revolt of the American colonies to the war of 1914, began in Lower and Upper Canada in 1828. It began in what were then separate and distinct provinces. Then came the rebellions in Lower and Upper Canada in 1837, followed by Lord Durham's mission to Canada in 1838.

The union of Lower and Upper Canada, effected by the Act of the Imperial Parliament of 1840, was the outcome of Durham's epoch-making mission, and with the actual union of the two provinces under one legislature and one government in 1841 there began the struggle for responsible government that was

1 The Anti-Corn Law League was organized at Nanchester in September 1838 and dissolved on July 2, 1849. Cf. Arehibald Prentice, History of the Anti-Corn Law League, i, p. 65; ii, pp. 400-401.

2 'The term responsible govermment was at least as old as 1828 , for more than ten years before Lord Durham's report was published (18:39) the expression was a household word in Upper (anada, as well as in Nova Seotia. Though not so widely known in Lower Canada, it was not uncommon there' Dent, The Last Forty Y'orars, p. 302.

The term responsible government was derived, I an told, from the marginal notes of Lord Durham's report, previous to the publieation of that document. The demoeratie party in Cpper Canada had been struggling for a greater share than they poswessed in the administration of the government of the country. and eould not exactly define their views. Lord Durham's report gave then this definition; and the words 'irresponsible government', 'responsibility of the government', 'responsibility of the officers of the government' cecurring repeatedly in the narginal notes, it is said, furnished the name.-Metcalfe's Dispateh to Stanley, August 5, 1813. Selections from the Papers of Lord Metealfe, pp. $412-413$. 
immediately to affect the political civilization of all the colonies now of the dominions. The real contest for responsible government began when Sydenham convened the first legislature of the United Provinces in 1841. The struggle was over and complete success achieved when Elgin's term as Governor-General came to an end in 1854 .

The movement had succeeded so quickly, and the system of government that it had established was so rapidly extended, that by the time the Australasian colonies were engaged in their contest with Kimberley over differential duties, 1867-1873, all the colonies in the British North American group and nearly all the colonies in the Australasian group ${ }^{1}$ were in possession of, and were exercising approximately all the constitutional powers, other than those affecting fiscal legislation and treaties, which were possessed by the dominions in the decade preceding the war of 1914-1918.

It is true that until as late as 1878 Great Britain, as a matter of course, included all colonies in commercial and other treaties without taking the trouble to ascertain from the self-governing colonies whether inclusion in these treaties was agreeable to them and in accord with their fiscal and trade policies.

By 1871, however, in practice only British commercial treaties hampered the Parliament of the Dominion of Canada in its fiscal legislation-restricted the freedom of the Government at Ottawa in negotiating reciprocity agreements with the United States or any other foreign power with which treaties of reciprocity based on differential duties were regarded as desirable.

There was never, it will be recalled, in any of the British North American provinces a statutory prohibition of differential duties. There was a clause in the instructions to governors commanding them not to give assent for the Crown to any Bill for imposing such duties. ${ }^{2}$ This instruction, moreover, was not deleted from the instructions to governors of self-governing colonies until 1878 , and then only in response to strong pressure from the Government of the Dominion of Canada. ${ }^{3}$

But from 1847, the year in which the United Provinces first

1 Western Australia was not organized as a colony with responsible government until 1890 .

2 Cf. Earl Grey, 'How shall we Retain our Colonies ?' Nineteenth C'entury, June 1879 , p. 945.

3 'The existing forms, in the case of Canada, have been felt for some time to 


\section{CONSTITUTIONAL POSITION OF THE COLONIES}

acted under the Enabling Act of 1846, no Bill with differential duties from any of the provinces now of the Dominion of Canada, and no such Bill enacted by Parliament at Ottawa, ever failed to receive the Royal Assent. All such Bills fell automatically in the class of reserved Bills to which the governor from 1846 to 1878 could not give the Royal Assent. All Bills for differential duties from the British North American provinces were objected to by the Board of Trade at Whitehall, and at the instance of the Board of Trade protests were made against them by colonial secretaries. But none of them was vetoed in Downing Street; and except as regarded treaties, Parliament at Ottawa was supreme in fiscal legislation before Parliament at Westminster in 1873 made the first amendment to the fiscal powers section of the Australian Government Act of 1850.

In the Australasian colonies, as a direct result of Newcastle's fear to recommend to the Palmerston Cabinet the withholding of the Royal Assent from the Galt tariff of 1859, there had never been any interference by the Colonial Office with Tariff Bills in which there were duties avowedly for the protection of Australian manufacturing interests against competition from the United Kingdom. Nor had any Bills of the legislatures of Australia for bonusing industries been disallowed or refused the Royal Assent, nor any such fate attended Bills like that of 1871 of the New Zealand Parliament, for carrying into effect the 'made in New Zealand ' policy of Government aid to local industries. The restrictions of which the Australian colonies complained in 1867-1873 were only those imposed on fiscal freedom by the Act of 1850 and by the commercial treaties of Great Britain.

Each of the self-governing colonies could at this time enact its own naturalization laws. ${ }^{1}$ All the Australian colonies under the Imperial Act of 1850 had the power to amend their own constitutions in many quite important particulars; ; and any self-governing colony whose constitution did not confer power

be capable of amendment. for reasons which require that special consideration should be given to her position. and which render unsuitable for her the forms which mav be eminently suited to some of the colonies.'-Blake Memorandum of July 1876. quoted at page 33 of Lash's "The Working of Federal Institutions in 'anada,' The Federation of 'anada, 1867-191\%.

1 (ff. Naturalization Laws of 1841 and 1858 of the Cnited Provinees, Statutes of ramada ( 4 \& 5 Vict., c. 1); Naturalization Law of Dominion of Canada of 1868 (31 Vict.. (. 66).

2 ('f. Australian Colonies (Government Act. 1850) (13 \& 14 Vict., c. 59. s. 32. 33). 
of amendment on its legislature had only to transmit an address or petition to Parliament at Westminster, to secure, as a matter of course, any amendment to the constitution of the colony on which its legislature had agreed.

Coastwise navigation, which in Canada included the Great Lakes, was at this time completely under the control of the colonial legislatures. By the provisions, moreover, of the colonial Naval Defence Act of 1865 , a measure for which contemporary writers in sympathy with the movement in the colonies for local autonomy give much credit to Cardwell, who after 1861 was Colonial Secretary in the Palmerston and Russell Administrations of 1859-1866, it was possible for any colony to maintain vessels of war and seamen, and to enact laws for the enforcement of good order and discipline among men and officers of a colonial fleet, while on shore or afloat within the limits of the colony. ${ }^{1}$

In fiscal legislation all the colonies were hampered to a greater or less degree, each of the groups to the extent that has been described earlier in this chapter. Moreover, in addition to the statutory restrictions which applied only to the Australian colonies, and in addition to the general restrictions due to Great Britain's numerous commercial treaties, there was also, as regards all the colonies, the prerogative of veto by the Crown.

The veto, known in the realm of colonial legislation as the power of disallowance, could be exercised in connexion with any Bill that had become an Act by receiving the assent of the governorgeneral or governor as the representative of the Crown. But, as will appear in a subsequent chapter, about this time, 18671873 , the power of disallowance, though not fallen into complete desuetude, was very seldom exercised.

Restrictions on fiscal legislation excepted, the colonies in the North American group-British Columbia, the Dominion of Canada, Prince Edward Island, ${ }^{2}$ and Newfoundland - the colonies in the Australasian group and the Cape Colony, were in 1867-1873 quite near the present status of nation within the Empire. ${ }^{3}$

1 Cf. 28 \& 29 Vict., c. 14 ; Adderley, Colonial Policy, pp. 113-114; H. C. Ferraby, The Imperial British Navy: How the Colonies Began to Think Imperially upon the Future of the Navy, pp. 20-32.

2 British Columbia went into Confederation in 1872; Prince Edward Island in 1873 .

${ }_{3}$ ' I am all for a league of nations. In fact, the league of nations has begun. The British Empire is a league of nations.'-Mr. Lloyd George at Manchester, September 12, 1918. 
Convicts from the United Kingdom, of whom in the years from - 1835 to 1868 the Australian colonies received 137,000, were no longer sent overseas, ${ }^{1}$ and each self-governing colony was as free to enact its own immigration code as the United States. ${ }^{2}$

1 At no time during the nineteenth eentury was Downing Street willing to eoncede anything to the colonies now of the dominions without strong and persistent pressure from overseas and mueh agitation by sympathizers with eolonial demands in Parliament at Westminster. This statement-only another way of expressing Adderley's aphorism that the history of self-government in the eolonies is the history of revolt - is as true of the abolition of the slovenly, despairing, and anti-soeial system of transportation as it is of the belated and grudging eoneession to the demands of the colonies for fiseal freedoin and all that fiseal freedom earried with it.

Convicts after 1776 were never sent from the United Kingdom to any of the Britisl North American provinces, although eonviets from these provinees were sent to Australia. The proximity of the British North Ameriean provinees to the United States, and also the large population of Freneh origin and language in Quebee, made it impraetieable to send men and women senteneed to transportation by eriminal courts in the United Kingdom to any part of what is now the Dominion of Canada. To have done so would have added to the causes of frietion between the British provinces and the United States. The climatc. moreover, was unsuitable to the eontinuous employment all the year round of the men and women eonvicts working under penal eonditions and restrietions. The Canadian provinces also were always desirous of immigration from the United Kingdom. They had to meet the eompetition of the United States for immigrants; and immigration to the British North American provinces, always during the nineteenth century much smaller than to the United States, would have been greatly reduced if the provinces now of the Dominion of Canada had become assoeiated in the popular mind in England with transportation and penal settlement.

The revolt against transportation began in the Australian eolonies in the middle forties of the nineteenth century. There was revolt also in Cape Colony, which was threatened with penal establishments in 1849 , about the time that suecess was attending the revolt in Australia. In Australia and Cape Colony, especially in Cape Colony, the name of Adderley, afterwards Lord Norton, was associated with the agitation at Westminster that helped materially to the abolition of the system. As a tribute to Adderley's services to Cape Colony in the threatening days of 1819, the finest strect in any of Great Britain's oversea possessions-the magnificent thoroughfare in Cape Town that slopes gently down from the stately Parliament House to Table Bay-was given his nanc. (f. IV. S. ChildePemberton, Life of Lord Norton (1814-1905), pp. 93-96; Parliamentary Debates. House of Commons, March 27, 1849, III, ciii, 1371-1372.

2 It was not until 1906-1907 that any of the dominions excreised this power to the extent of excluding immigrants from the United Kingdom. Cf. Statutes of the Dominion of Canada, an Aet respecting immigrants and immigration. July 13, 1906 (6 Edw. VII, c. 19); and an Act amending the Immigration Act. April 27, 1907 (6 \& 7 Edw. VII, e. 19).

- A Dominion immigration law was cnacted as far back as 1886. Practically a new code was created by the legislation of $1906-1907$, legislation against which there were many protests from emigration socictics in England, but which was persisted in by the Government. Much of the old eode was permissive. The new corle is in general mandatory. It exeludes undesirables, defectives, and persons: likely to become a public charge, and gives power to immigration authorities to deport eriminals or paupers at any time within two years of their arrival in Canada. . . . The new code is almost as drastie as the code of the L'nited states. from which it chiefly differs in not exeluding contrnct labour coning from Great 
Ignoring for the moment the restrictions that curtailed the fiscal freedom of the colonial legislatures, it may be asserted that only a specialist in the history of the constitutional development of the dominions could point to any powers of self-government exercised by any of the dominions in the decade that preceded the World War, that could not be exercised by any of the selfgoverning colonies in 1867-1873.

\section{CHAPTER IV}

\section{THE OLD AND THE NEW TYPE OF COLONIAL GOVERNOR}

THE old school of colonial governor, military men as distinct from civilians, ${ }^{1}$ was by 1873 of the past. Earl Cathcart, commander-in-chief of the British forces in North America from 1846 to 1849, who was Governor-General of Canada from March 1846 to January 1847 , in the interval between the resignation of Metcalfe and the arrival in Montreal of Elgin, was the last of the old school of governors in any of the self-governing colonies. Governors drawn mostly from the territorial aristocracy in Great Britain became the rule after the establishment of responsible government. ${ }^{2}$

Britain or European countries. Contract labour from the United States can be excluded under an earlier Act.' 'Canada during the Laurier Régime (1896-1911),' Edinburgh Review, No. 440, April 1912, pp. 480-481.

1 ' Few military men make good rulers of colonies under a popular form of government. Their previous habits require more implicit obedience to their mandates than is consistent with the habits of a free people, especially in America, where cvery man lives upon his own land, and thence imbibes high notions of liberty and independence.' Seventh Report of Committee on Grievances, Appendix, Journal of House of Assembly (Upper Canada), 1835, I, xxi, p. 87.

2 Cf. 'The Evolution of a Colonial Governor,'Macmillan's Magazine, November 1903, pp. 45-46. Queen Victoria objccted to men of the commercial class as colonial governors. In 1856 the Queen vetoed a suggestion by Labouchere, Secretary of State for the Colonies in Palmerston's Administration, that James Wilson. a manufacturer and a financier of national fame, who was also founder of the Economist, should be appointed Governor of Victoria. 'It ought', the Queen wrote, 'to be a man of higher position and standing, and who could represent his sovereign adequately.' Benson and Esher, Letters of Queen Victoria, iii. pp. 24-27. Qucen Victoria's objection to men of commerce as colonial gorernors was not invariably effective, as it was in the case of Jamcs Wilson. Sir John Thurston. Governor of the Western Pacific (1887), had been an island trader ; Lord Brassey, Governor of Victoria (1895-1900), a contractor ; Carrington, Governor of New South Wales (1885-1900), was a banker; and Sir Thomas Buxton, Governor of South Australia (1895-1900), a brewer at one remove.' 'The Evolution of a Colonial Governor,'Macmillan's Magazine, November 1903, p. 46 . 
The office of governor was by this time the only office in any of the self-governing colonies in the gift of the political party in power at Westminster. 1 The mystery of the office of governor, a mystery that had served to enhance the reverence in which it was held by men of colonial administrations and of the colonial civil service who were dependent upon the governor for continuance or promotion in office, ${ }^{2}$ had completely gone.

Under responsible government the mystery had been dissipated like a cloud on a summer day. Its dissipation had been helped a little also by the usage, dating from at lcast as early as 1855 , that the governor of a self-governing colony, on assuming his office, must embody his instructions from the Colonial Office in a return to be laid on the table of both houses of the legislature. ${ }^{3}$

From 1839 onwards, from the time Sydenham became GovernorGeneral of Canada, ${ }^{4}$ governors of colonies with responsible government had been compelled to select the members of their executive councils from the members of the political party which commanded a majority in the lower house of the legislature; and the council or cabinet so organized could not, whatever might be the desire of the governor, hold office for a day longer than it could command this majority.

From the breakdown of Metcalfe's efforts of 1843-1845 to set back the progress that responsiblc government had made from 1841 to 1843 in Upper and Lower Canada, ${ }^{5}$ it had not been within the power of governors of colonies with responsible

1 The mere patronage that Canada affords to the British Government in the nomination of one solitary Governor-Gencral for all British North Aneriea is not worth naming. Gray, Confederation, i. p. 185 ; cf. Pope, Memoirs of Macdonald, ii, p. 243.

2 'In the distribution of patronage of the Government in the colonies great weight must always be attached to local services and experienee. Every governor will, therefore, make onee in each year a confidential rcport of the claims of candidates ... in order that when a vaeaney or an opportunity for promotion oeeurs, the Seeretary of State may have before him the means of judging how far the partieular eandidate reeommended by the governor is on the whole the best qualified.' Rules and Regulations for Her Majesty's Colonial Service (October 1,1843$)$, p. 19.

3 Cf. Journals of the Legislative Assembly of Canada (the United Provinces of Upper and Lower Canada), April 3 and 4, 1855. pp. 791, 796, 803.

4 'The two great prineiples whieh he ever asserted, and whieh formed the lcading rules of his administration, were (1) that as her Majesty's representative, he was himself responsible to the imperial authorities alone; and (2) that it was his duty so to form and eonduet the Government, as to ensure its harmony with the majority of the House of Asscmbly.' G. Poulct Scrope, Life of Charles, Lord Sydenham, p. 273.

- Cf. Metealfe's Dispatch to Stanley, August 5, 1843 ; Kennedy, Documents of the Canadian Constitution, pp. 568-569. 
government to make a single appointment to the civil service, or to take any executive action, except on the advice of the executive council or cabinet.

By this time also the governors of self-governing colonies had ceased to preside at or to attend sessions of the cabinets. In practice, moreover, the power of veto over legislation that of old lay with the governor fell into desuetude with the establishment of responsible government; and in 1873, as will be recalled, the time was approaching when there was to be a drastic revision of instructions to governors, particularly in regard to the reservation of bills for assent in Downing Street.

In the event of a ministerial or cabinet crisis, the functions of the governor might for a few days take on importance ; $^{1}$ for it has always been the function of the governor in a colony with responsible government to undertake that the King's business proceed without halt or jar, regardless of the fortunes of any political party or its leaders. But at no time in a self-governing colony does the office afford a governor any opportunity of influencing in the least degree the policy or actions of his administration, so long as this policy, or these actions, obviously come within the limits of the written or unwritten constitution of the colony. ${ }^{2}$

Under responsible government the discarding of the old type of colonial governor and the evolution of the new type was a process, a constitutional change of much importance, that was accomplished in a surprisingly short time. In all the colonies now of the dominions, certainly in all the colonies in which responsible government was in operation in 1873 , the process had gone on so quietly, and everywhere so completely, that at the time the Australian colonies were demanding a larger fiscal freedom, the office of governor had become little more than a link of empire. Its duties and functions were already chiefly, though not quite exclusively, formal and ceremonial. ${ }^{3}$

1 Cf. 'The Evolution of a Colonial Governor', Macmillan's Magazine, November 1903, p. 53; Porritt, Evolution of the Dominion of Canada, pp. 257, 264-266.

2 'In these responsible governments one sees so much going on which is most objectionable, yet one is powerless either to do good or to prevent evil.' Letter, dated Sydney, November 17, 1860, written by Sir William Denison, Governor of New South Wales, 1855-1861. Denison, Varieties of Vice-Regal Life, i, p. 497.

${ }_{3}$ 'The Governor had become a shadow. The premier of the colony, the prime minister of the dominion or the commonwealth, is now its working king.' 'The Evolution of a Colonial Governor,' Macmillan's Magazine, November 1903, p. 53. 


\section{CHAPTER V}

\section{THE REBELLION LOSSES ACT OF 1849 AND THE CONTEST FOR FISCAL FREEDOM}

THE critical stage in the history of responsible government and constitutional development in the self-governing colonies, the stage from which may be dated the loss by governments at Whitehall of all control over fiscal legislation in these colonies, was reached in 1849 . It was reached ten years before the provinces of Upper and Lower Canada so successfully and so completely asserted their fiscal independence which they carried to the startling length - to Great Britain -of imposing high protectionist duties on imports from the United Kingdom.

The crisis of 1849, as memorable in the history of the Empire as the rebellion in Canada in 1837, with its consequences in British colonial policy, arose out of the Rebellion Losses Bill of the legislature of the United Provinces, to which Elgin, as Governor-General, had given the Royal Assent. It was a crisis that lasted from January 29, 1849, when the bill was introduced in the Legislative Assembly at Montreal, to the memorable debates and division on its allowance or disallowance in the House of Commons at Westminster of June 14 and 15, 1849.

Elgin regretted that his Executive Council or Cabinet deemed it necessary that there should be compensation for property owners in Lower Canada who had sustained losses in the rebellion. He regretted that any money of the United Provinces should be diverted from more useful purposes to make good these losses of 1837-1838. ${ }^{1}$

Neither Russell, the Premier of the Whig Government at Westminster, nor Grey, who was Colonial Secretary, cordially approved the object of the bill, ${ }^{2}$ for which the Baldwin-La

1 Cf. Walrond, Letters and Journals of the Earl of Elgin, p. 76.

2 Gladstone, in the debate on the bill at Westminster, June 14, 1849, called Russell's attention to the fact that on March 6, on a division in the House of Assembly at Montreal, an amendment to the bill that would have exeluded rebels from any share in the compensation fund was defeated by a majority of only sixteen-14 to 28 . ' It is no part of my duty.' answered Russell, ' to say' that the majority were right in every instance. What 1 have to look at is whether the Act, when passed, infringes on the honour of the Crown, or does that which is unjust to the Empire, or to the loyal men of that province.' Parliamentary Debates, III, cvi, 209, 234; Journals of the Legislatice Assembly of the Prorince of C'anada, March 6, 1849, p. 128. 
Fontaine Administration at Montreal was responsible. Both the Premier and the Colonial Secretary made this fact unmistakably clear in the debates in the House of Commons and the House of Lords of June 14 and 15, on motions that were antagonistic, not only to the Act itself, but to the principle of responsible government that was contended for by the Baldwin-La Fontaine Government, and by the supporters of this Government in the Legislative Assembly, the Legislative Council, the press, and the constituencies.

The bill, as framed by the Government at Montreal and carried through the legislature, was a measure that could not have been carried through the legislature at Kingston, Jamaica, the Crown colony whence Elgin went to Canada in 1847, nor through the legislature of any other British possession under Crown colony rule.

But the Rebellion Losses Act, a landmark in the development of Great Britain's nineteenth-century relations with her oversea possessions as towering as the Durham report, the Enabling Act of 1846, or the Galt and Newcastle correspondence of 1859 , had originated with a government at Montreal that was sustained by a majority in the lower house of the legislature. It had been accepted by this majority, and, what was of some importance, it had also been accepted by the majority in the nominated Legislative Council-a council in which English-speaking members were in a majority. ${ }^{1}$

What was of quite as much constitutional import, Elgin, at the preliminary stages of the bill in the House of Assembly, had recommended its favourable consideration to the legislature. Under what may be described as a law of Parliament of long standing, a standing order of the House of Commons at Westminster, no petition for any sum relating to the public service, nor any motion for a grant or charge upon the public revenue, whether payable out of the Consolidated Fund or out of moneys to be provided by Parliament, can be received or proceeded with, unless recommended from the Crown. The House

1 ' It was material in the early days after the Rebellion (1837) that but a very small proportion of French members should be appointed to the Legislative Council. In later times, when the French population are no longer hostile to the British Crown, it is only reasonable that additions should be made to the number of French origin. There are now only a third of French extraction, while half the population are French.' Grey, Colonial Secretary, in debate in the House of Lords, June 19, 1849, on motion by Brougham, for disallowance of the Rebellion Losses Act. Parliamentary Debates, III, cvi, 501-502. 
of Commons, while it can determine the amount of money which shall be granted and the sources from which it shall be drawn, has absolutely precluded itself from determining that any money at all shall be granted, unless the proposal for the grant emanates from the Crown. ${ }^{1}$

After 1839, after the legislature of Upper Canada was in control of all expenditures, subject to the condition that it created a civil list acceptable to the Colonial Office, the standing order of the House of Commons was adopted at Toronto. It was of the procedure of the legislature of the United Provinces from the beginning of Sydenham's tenure of the office of GovernorGeneral.

At the first stage of the crisis over the Rebellion Losses Bill, the stage at which it was introduced to the Legislative Assembly, and had to meet the intense and bitter hostility of an organized and determined opposition from the Conservative minority, the standing order was either overlooked by the Government leaders in the Assembly, or the order had been at first regarded by the Government as not applicable to the measure.

Whatever may have been the cause, the fact was that the House of Assembly had occupied itself during one sitting with the Government motion for the bill and at the second sitting the Opposition had called attention to the fact that the Rebellion Losses Bill was a money bill within the meaning of the standing order, before 'the Honourable Mr. Hincks, a member of the Executive Council, by command of his Excellency the GovernorGeneral, acquainted the house that his Excellency, having been informed of the subject-matter of this motion, recommends it to the consideration of the House.' 2

Elgin had thus constitutionally and publicly committed himself to the Bill, and to the great and far-reaching principle its recommendation involved, on February 22, when Hincks, who was Inspector-General or Minister of Finance, in the BaldwinLa Fontaine Administration, communicated the Governor's recommendation to the House of Assembly. ${ }^{3}$

1 Cf. William R. Anson. The Law and Custom of the Constitution, 1909 ed.. i, p. 271.

$\frac{2}{2}$ Journals of the Legislative Assembly. February 22. 1849, pp. 94-95; cf. Journals, January 29,1849 , p. 42 ; February 13,1849 , p. 82.

3 Gladstone said in the House of Commons on May 16, 1849, when he was protesting against Roebuck's contention that there was responsible government 
For Elgin in Montreal, acting entirely on his own discretion and according to his own conception of what responsible government meant for a British colony, ${ }^{1}$ the long-drawn-out crisis

in Upper and Lower Canada, that if the electors disapproved of the bill, they could turn out the Baldwin-La Fontaine Government at the next election, and that consequently the bill was one in which Parliament at Westminster could have no concern, "this measure was introduced into the Canadian Parliament with the sanction of the Crown. I apprehend that above that there can be no power whatever. Being a matter involving money, it would have been impossible, according to the constitutional forms of the province, to have introduced it without the sanction of the responsible ministers of the Crown. It matters not one rush whether there were previous instructions (from the Colonial Office to Elgin) or not. The responsibility of the Government (in Downing Street) for the acts of the Earl of Elgin is also unquestioned and undeniable. But the honourable and learned member must see that if the sanction of the Crown is required in matters affecting the government of the colony, the very effect of that sanction, so required to be given, must bring them under the cognizance and jurisdiction of this House.... I do not enter into the question whether there should be any interference or not. But I protest against alleging these general grounds which would exclude at all times, and under all circumstances, the interference of this House, and hinder the right and duty of this House to have supervision over all colonial affairs.' Parliamentary Debates, III, cv, 567-568.

At an earlier stage of this speech of May 16, 1849, and before he had begun to emphasize the fact that Elgin, as the representative of the Crown in Canada, had recommended the Rebellion Losses motion to the Legislative Assembly at Montreal, Gladstone had protested 'against a doctrine which interferes with the supremacy of this country over all imperial concerns.' 'Why, sir,' he continued, 'it might be that England might be at war with some foreign power, and that some colonial legislature might be found voting a subsidy to that foreign power. Would that be a reason, because it is not the money of this country, against the interference of this House? I contend that this House has a perfect right to interfere in all imperial concerns.' Ibid., 566-567.

It may be noted that Gladstone, on June 15,1849 , voted for the motion made by Herries in the House of Commons for an Address to the Crown for the disallowance of the Rebellion Losses Act. Peel voted with the Government. 'Upon Canada, a vital question,' wrote Gladstone on June 30, 1849, 'I again spoke and voted against Peel.' Morley, Life of Gladstone, i, p. 353.

John Arthu: Roebuck, of the Inner Temple, Member for Bath, 1832-1837, and 1841-1847, had lived in Canada from 1815 to 1824 . He was elected Member for Sheffield on May 3, 1849, only thirteen days before his defence of Elgin and of the Russell Government-a defence to which Gladstone made his reply. R. E. Leader, Life and Letters of John Arthur Roebuck, pp. 11-31, 221.

1 'I can only state,' said Russell in answer to a question by Herries in the House of Commons on May 2, 1849, ' that when the period arrives at which the Bill passed by the legislature of Canada comes under his observation, the Governor-General will be prepared and ready to exercise those discretionary powers which are invested in him. I may add that the noble earl, the GovernorGeneral of Canada, possesses the entire confidence of the Crown; and that in the exercise of his discretionary powers as Governor-General he will be deemed to have acted in a manner to protect the interest and prerogatives of the Crown, and also to conciliate the interests of the colony and the British Empire.' Parliamentary Debates, III, civ, 1103.

'I have given Lord Elgin,' said Grey, in answer to a question by Stanley in the House of Lords on May 4, 1849, 'neither publicly nor privately, any directions or instructions with respect to the course he is to pursue. I have abstained from doing so deliberately and advisedly, because in my opinion it is absolutely 
over the question of compensation for losses sustained by people in Lower Canada during the Papineau rebellion was a crisis similar to that over differential duties in the Australian colonies which fourteen years later (1867-1872) confronted Kimberley, a crisis at the final stage of which, it will be remembered, Kimberley told the House of Lords that, while the principle of free trade was a great one, the principle of self-government for the colonies he conceived to be much greater.

The principle of responsible government, as it had been slowly and toilsomely developed in Canada between 1841 and 1849, and accepted after 1847 by the Russell Government, was at stake. It is a principle that in the year's from 1841 to 1867 gave a new birth to the colonies that are now of the dominions. ${ }^{1}$ It is a principle of long proven beneficence in its application. It has long been also one of the links of Empire to which men and women in the dominions continuously point with pride.

From 1849, when the principle became established and unassailable from within or without, its application under all conditions served the Empire as a whole as beneficently as the gradual development in the seventeenth and eighteenth centuries of government by cabinet at Westminster and at Whitehall served the United Kingdom all through the nineteenth century, and until the beginning of the World War.

Government by cabinet, moreover, served the United Kingdom as well in war as in peace. Manifestly the same truth must be affirmed of the principle of responsible government and its working in the dominions during the most trying years in the history of the Empire.

A war so stupendous in its intensity and extent and in its issues as the world-convulsing war that began in August 1914, and ended in November 1918, necessarily for the time being entailed some departures at IVestminster from cabinet government

impossible that the affairs of the colonies ean be administered with advantage if the Seeretary of State interferes more with the diseretion of the Governor than is absolutely neeessary. The more experience I have of colonial affairs. the more persuaded $I$ am that the true secret of satisfaetory managentent of our eolonies is to choose the best men that ean be found for governors and to give them a large and wide diccetion; and I never believe they have aeted wrong. unless there is strong evidence to that effect.' Ibid., 1254.

1 Responsible government. it need scarcely be recalled. did not affect two of the colonies now of the Union of South Africa-Urange River Colony and the Transwal until they came under British sovereignty at the Peare of Vreventing of $190 \% 2$. 
usages and traditions, as these traditions and usages were evolved and established in the two and a quarter centuries between the Revolution of 1688 and August 1914.

One of these departures at Whitehall, a departure that would seem to have in it the elements of permanency, brought the Cabinets of the five dominions into much closer relations than heretofore with the Cabinet in Downing Street. At an early stage in the war, in July 1915, Sir Richard Borden, Premier of the Dominion of Canada, and the premiers of the other dominions, attended sessions of the Cabinet in Downing Street, and each year thereafter during the war the dominion premiers were in London to attend meetings of the Cabinet.

Until Cabinet usages were thus varied in the stress of the great struggle of 1914-1918, a premier of a dominion had never attended a meeting of the British Cabinet. The participation of the dominion premiers at the sessions of the Cabinet in July 1915 revolutionized 'the theory and practice of the system by which the British Empire had been governed for more than a century and a half.' 1 A new constitutional link of Empire was thus forged-one of the many new links, constitutional and extraconstitutional, forged by the war; and from July 1915 a new significance attached to the fact, hitherto in practice of little constitutional import, ${ }^{2}$ that premiers of the dominions were usually honoured by being made members of the Privy Council at Whitehall. ${ }^{3}$

1 Daily Telegraph (London), July 15, 1915.

2 Cf. Porritt, Evolution of the Dominion of Canada, pp. 363-364.

3 As a development of these new relations of 1915-1918 between the Cabinets of the dominions and the Cabinet in London, a change of some importance was made in the long-standing procedure of communications between Cabinets of the Dominions and Government at Westminster. The change was described in an official note issued to the press of the Empire on September 13, 1918. 'Considerable misapprehension exists,' read this note, ' with regard to the nature of the arrangement recently concluded whereby the Prime Ministers of the dominions have been given the right of direct communication with the Prime Minister of the United Kingdom on certain matters. It, therefore, seems desirable to state the exact nature of the arrangement.

"After preliminary discussion in the recent Imperial War Conference, the subject was considered by the Imperial War Cabinet, where on July 3, 1918, the following resolutions were passed :

"(1) The Prime Ministers of the dominions, as members of the Imperial War Cabinet, have the right of direct communication with the Prime Minister of the United Kingdom, and vice versa.

"(2) Each communication should be confined to qucstions of Cabinet importance. The Prime Ministers themselves are judges of such questions.

"(3) Telegraphic communications between the Prime Ministers should, as a 
Responsible government stood the test of the war, as it had stood the test of the Rebellion Losses Act of 1849, as it had stood the tests of $1859,1867-1873$, and 1879, all growing out of the struggle of the autonomous colonies for fiscal freedom, and as it had stood the test of that period of indifference in Great Britain to colonies and empire that extended from the enactment of Galt's tariff in 1859 to the first Jubilee of Queen Victoria in 1887.

Responsible government, it remains to be added, is a principlo that Elgin did more to establish, to consolidate, and to make unassailable, than any other man who ever held a commission as governor in any British colony. Elgin, moreover, did more to establish the principle, more to prove that it was practicable under all circumstances, and more also to prove that its effects must be beneficial, as well to Great Britain as to the colonies now of the dominions, than any statesman who has a place of prominence in the constitutional history of the United Kingdom or the Empire. 1

In the hundred and forty years from the creation of the American Republic to the war, one great doctrine in world politics and one great and abiding principle in the politics of the British Empire had their origin, their evolution, and their successful application among people of British stock inhabiting the northern part of the continent of America.

rule, be conducted through the Colonial Office machinery, but this will not exelude the adoption of more direct means of eommunieation in exeeptional cireumstances.

"(4) In order to secure continuity in the work of the Imperial War Cabinet, and a permanent means of consultation during the war on the more important questions of common interest, the Prime Minister of each dominion has the right to nominate a Cabinet Minister, either as a resident or visitor in London, to represent him at meetings of the Imperial War Cabinet to be held regularly between the plenary sessions.",

1 "Elgin, who later in his eareer was British Envoy to China and Vieeroy of India, was Governor-Goneral of Canada from 1847 to 1854 . In these seven years of political turmoil, and also of commercial disloeation and depression, due to the sweeping fiscal reforms of 1846-1847 in the United Kingdom, he did more than any Governor-General before or after him to create a political civilization for Canada. He did much also to establish better relations between the British North American provinees and the United States, for he was primarily responsible for the much valued treaty of reciprocity with the United States that was in force, to the moral and material advantage of both eountries, from 1854 to 1866 . Figin's fame as a statesman of the Empire, like that of Durham and Sydenham, is encluring. It will survive as long as the history of Great Britain's oversea dominions is read. Every Privy Council Chamber in the capitals of C'anada, Australia, New Zealand, South Africa, and Newfoundland is a monument to Elgin's achiovements of 1847-1854.' Porritt, Evolution of the Dominion of Canuda. p. 166. 
The doctrine evolved and applied for nearly a century is associated with the name of Monroe. The principle of responsible government must for all time be associated with the names of Durham, Sydenham, Russell, Grey, and Peel, and pre-eminently with that of Elgin. Both the doctrine and the principle made for the good order and peace of the world and for beneficent political civilizations.

In Montreal, in the winter and spring months of 1849 , the great principle of responsible government was in the balance, with all the conservative and reactionary forces of Upper and Lower Canada, the self-styled Loyalty party, arrayed against the conception of responsible government that Baldwin and La Fontaine and their supporters in the House of Assembly and the Legislative Council were intent on embodying in the Rebellion Losses Bill.

Elgin, it will be recalled, had proclaimed on which side he stood and how he interpreted the principle of responsible government. He had made it manifest that he accepted the interpretation of Baldwin and La Fontaine and the Liberals, when Hincks, Minister of Finance, on February 22 communicated to the House of Assembly, the chamber in which all money bills originated, the Governor-General's recommendation of the measure.

Granted that the Baldwin-La Fontaine Government could hold together its supporters in the House and the Legislative Council and carry the Bill through both Houses, for Elgin, no matter what outcry might be raised in Canada or at Westminster, there was no turning back.

The Government of the United Provinces did succeed in holding its supporters in line. By April 23, the Bill had passed all its stages in the legislature and awaited the Royal Assent. There could be no halt by Elgin at this stage. The crisis for the Governor-General, and also for the Government in Downing Street, had come on February 22.

Elgin had then taken his stand for the principle of responsible government, and for the widest application of the principle; and it was little more than a formal executive act, something in the day by day routine of work of the Governor-General, to attend in the chamber of the Legislative Council on April 25 and, as the Queen's representative, give his assent to the Rebellion Losses Bill. 
Both actions-his recommendation of the Bill to the Legislative Assembly and his giving the Royal Assent to the Bill-were upheld by the Colonial Office and the Russell Cabinet. What was even more vital to the permanence of the principle of responsible government and its immediate establishment in colonies other than those of British North America, Elgin's actions of February 22 and April 25, 1849, were upheld by Parliament at Westminster. ${ }^{1}$

\section{CHAPTER VI}

\section{ATTITUDE OF PARLIAMENT AFTER 1849 TOWARD LEGISLATION IN THE COLONIES}

Parliament at Westminster after 1849 ceased to interest itself in legislation in the self-governing colonies, except occasionally in Tariff Acts, such as those of the Dominion of Canada of 1879 and 1887,2 which adversely affected the iron industry in England and Scotland ; or except when, at the instance of a colonial legislature and a colonial government, amendments were made to the constitution of a colony, a constitution that, as was the case with nearly all these constitutions from 1791, was embodied in or based on Acts of the Imperial Parliament. ${ }^{3}$

Questions concerning the scope and working of laws in colonies with responsible government, questions addressed either to the Secretary of State for the Colonies, or to the parliamentary Under Secretary, at the opening hour of a sitting of the House of Commons or House of Lords are in order to-day as they have been ever since questions to ministers became an established and much valued parliamentary institution over a century and a quarter ago.

1 Cf. Walrond, Letters and Journals of the Earl of Elgin. pp. 76-90; Parliamentary Debates. June 14. 15, and 19. 1849, III, evi, 190-550.

2 (ff. protest by Bright. House of Commons. March 20. 1879; and protests by Lamington and Granville against the large increases in the dutics on pig-iron and puddled-iron bars in tariff of 1887, House of Lords, June 17. 1887. Parliamentary Debates (House of ('ommons). III. cexliv. 1311-1312, and (House of Lords), HI, cecexvi, 375-387.

3 Cf. Australian Colonies Covernment Act. 1850 (13 \& 14 Vict., c. 59. s. 35). a bill respecting the establishment of provinces in the Dominion of (anada. Ibid. (1871). III, cevi, 803. 1171; III, cevii, 138, 219. William Houston, Joruments 1llustrative of the C'andiun ('onstitution. 1) 22.5. 
With the exception of questions to ministers, and the further exception of the two classes of colonial laws which have been described, there were no more attempts by Parliament to interfere with acts of colonial parliaments after the failure of the motions in the House of Commons and the House of Lords for the disallowance of the Rebellion Losses Act of 1849. ${ }^{1}$

Only protests, only expressions of opinion by individual members of the House of Commons or of the House of Lords, were, after the constitutional crisis of 1849 , practicable at Westminster, when there was legislation in the self-governing colonies that was regarded as detrimental to the manufacturing, commercial, and shipping interests of the United Kingdom. There were such protests in Parliament; and some of them, for instance the protests in the House of Lords of 1887 over large increases in the duties on iron exported from England and Scotland to Canada, increases made on the eve of the Empire-wide celebration of the fiftieth year of the reign of Queen Victoria, were quite sharply worded. ${ }^{2}$

There were also agitations by chambers of commerce against nearly all the Canadian tariffs from 1859 to 1887, for British manufacturers were not inclined to 'take lying down' protectionist tariffs which curtailed or hampered their trade with British colonies.

These extra-parliamentary agitations had concluding chapters that were common to all of them. Each agitation culminated in a deputation to the Colonial Office at Whitehall, where it was introduced and supported in its remonstrances by members of the House of Commons representing the industrial constituencies whose interests, it was conceived, were threatened by these adverse changes in the tariffs of the Dominion.

For each of these deputations there was a courteous and sympathetic reception from the Colonial Secretary. But the Secretary's answers were exactly similar to the answers to questions and protests in Parliament. It was unfortunate, it was much to be regretted that British export trade was adversely affected by protectionist tariffs of a colonial legislature, but

${ }^{1}$ House of Commons, June 14. 15, 1849. Parliamentary Debates. III, cvi, 190-283, 302-376; House of Lords. June 19, 1849, 450-548.

2 The more important of these protests in the House of Commons and House of Lords against high duties in the tariff of the Dominion of Canada, the protests from 1879 to 1887 are summarized in the Appendices. 
responsible government existed in these colonies and there could be no interference by the Colonial Office or by Parliament.

Motions for disallowance of colonial legislation, motions like those of 1849 with which Gladstone ${ }^{1}$ and Herries ${ }^{2}$ were associated in the House of Commons, and Brougham, ${ }^{3}$ Stanley, ${ }^{4}$ and Lynd-

1 The restrictions or limitations that Gladstone, who was Colonial Secretary for a few months in Peel's Administration of 1841-1846, contended should be imposed from Downing Street on the working of the principle of responsible government in the colonies were formulated by him on the first evening (June 14) of the two days' debate that in the Hansard Report extends to seventy-three double-column pages.

'I think,' said Gladstone, ' that the first duty of the Home Government should be to interpose a eheek on the action of the colonial advisers of the Governor, and enablc him to apply at home for guidance, when a question is before the local assembly not merely affecting local but imperial interests, and involving the honour and dignity of the Crown of her Majesty. I think that the local legislature of the colony should be left free and unrestrieted in its action upon questions purely and entirely having a bearing upon the local interests of the colony. But we ought to draw the broadest and most marked distinction between questions of a local and imperial character; and with regard to imperial questions, instead of being postponed until the resolutions and deliberations of the loeal legislature are concluded, and are sent home in their ultimate shape to receive the sanetion or disallowance of the Crown, I think that reference to the Home Government ought to be made at the very first moment, and before public opinion may have bcen appealed to in the colony; and that at the first moment it ought to be ascertained how far the Queen's ministers at home think it necessary to fetter the discretion of the colonial authorities, and how far they may freely move in the path to be trodden by them.' Parliamentary Debates, III, cvi, 193-194.

2 John Charles Herries, associated as a financier with Pitt, 1800 ; Financial siccretary to the Treasury, 1823-1827; Chancellor of the Exchequer in Goderich's Administration from August 1827 to January 1828; Secretary at War under Pccl, 1834-1835; and President of the Board of Control in the Derby Administration of February to December 1852. Edward Herries, Memoir of the Public Life of the Right Honourable John Charles Herries.

3 The motion which Brougham (June 19) asked the Housc of Lords to adopt differed in form from the Herries motion. If it had been carried, however, its effect would have bcen the same as that aimed at in the motion in the Commons for the disallowance of the Rebellion Losses Act. Brougham's motion recited the purpose of the Bill of the legislature at Montreal and affirmed 'that it is just and necessary, either by recommending a further and amending Bill to the legislature of Canada, or by such other means as may be effectual, to provide sccurity against any compensation for losses sustained in the said rebellion bcing given to persons engaged in or having aided or abetted the same.' Parliamentary Debates (House of Lords), III, evi, 483.

4. The notion of a supreme local government excludes the power of the Crown ; and the notion of the power of the Crown again excludes that of the local government. The real difficulty as applicd to responsible government is this : it is to state the occasions and to form a judgement of the nature of the questions in respect to which it is wise and expedient to interpose the authority of the Crown through the Secretary of State for the Colonics. But permit me to observe that, if it be laid down that on no oceasion is that authority to be imposed-that a bill which has received the sanction of the local legislature is necessarily. therefore, to pass-then I say that under such circumstances the constitution of Canada, far from being like the constitution of this country, or anything approaching to it, is a constitution infinitely more democratic, more absolutely and purcly demo- 
hurst ${ }^{1}$ in the House of Lords, fell into desuetude. They ceased to mark the relations of Parliament at Westminster with the self-governing colonies. They automatically came to an end as a consequence of the new policy toward colonial legislation which was proclaimed by Russell in the House of Commons, ${ }^{2}$ and by Grey, Colonial Secretary, in the House of Lords, ${ }^{3}$ when they called upon their supporters to vote down the resolutions for disallowance of the Rebellion Losses Act.

There was much preliminary parliamentary skirmishing, chiefly in the form of questions addressed in both houses to ministers,

cratic, than is even the constitution of the United States. For if this is to be the principle that the prime minister of the colony is to advise the governor on every question, and that his advice is always to be implicitly followed ... the result will be that the legislative council, the governor, the Crown itself, will be absolutely made subject to one individual, who for the time being has in his hands the actual majority in one of the Houses of Parliament.'-Stanley, afterwards Earl of Derby, leader of the Conservative opposition in the House of Lords, in support of Brougham's motion for disallowance of the Rebellion Losses Act, House of Lords, June 19, 1849. Ibid., 520-521.

1 'What was the nature of responsible government? How could it be applied to the colonial possessions? he would not take it upon him at that moment to inquire. But he would say this - that unless the effect of responsible government was to establish an entire independence of the State in the chief colonies of the Empire, there were cases in which the Government and Parliament might be called upon directly to interfere.'-Lyndhurst, Lord Chancellor, 1827-1830, 1834-1835, and 1841-1846, House of Lords, June 19, 1849. Ibid., 505.

2 ' If we believe, as we do believe, that the Earl of Elgin has rightly consulted not only the interests of Canada, but the interests of this country and the honour of the Crown; if we believe that he has been guided by a knowledge of the feelings of the people of Canada, and at the same time by a loyal and patriotic attachment to the country of his birth, and the sovereign he is bound to serveI say, if such is our opinion, we should be the basest of men if we were to desert the Earl of Elgin on this critical occasion, and if we were not to take upon ourselves any share of responsibility which this House may think fit to cast upon us. It is in the exercise of his ordinary discretion that he has acted; and it is in pursuance of our duty that we propose to act in deciding upon the conduct of his Government. ... I will tell the right honourable gentleman [Gladstone] that is our belief, and the belief we mean immediately to communicate to the Earl of Elgin, that it will be our duty to leave this Act to its operation.'-Russell, House of Commons, June 14, 1849. Ibid., 226-227, 228.

3 'In calling upon your lordships to reject the resolution of the noble and learned lord [Brougham], I do so far less by way of asking you to express an opinion upon the details of this Bill than to say that this was a subject upon which the wishes of the people of Canada have been shown by their representatives; and that no grounds have been made out for calling upon Her Majesty's Government to interfere to prevent the passing of an Act which the people of Canada, as shown by two-thirds of the representatives, think ought to become law. What I call upon your lordships to do now is, to reject the present motion and pronounce it to be your opinion that this House has no right to interfere with the views of the Canadian legislature.--Grey's speech for the Government, in opposition to Brougham's motion for the disallowance of the Rebellion Losses Act, House of Lords, June 19, 1849. Ibid., 503. 
before the debate and divisions on the Rebellion Losses Act of June 14-15 and June 19.

'Not only', said Russell, in one of these preliminary skirmishes, ' has Canada self-government, but responsible government, which has never been enjoyed to such an extent as it has been since the time of the Earl of Elgin. If the present Ministry in Canada are sustained by popular opinion and by the Assembly, they will remain in office. If, on the contrary, the opinion of the province is adverse to them, the Governor-General will take other advisers, and will act strictly in accordance with the rule that has been adopted here.'

Peel, who had been in opposition since 1846, and since the general election of 1847 at the head of a party of loosely associated free trade Conservatives numbering at this time about fifty members, ${ }^{1}$ strongly supported the Russell Government in the position that it had assumed in regard to the principle involved in the Rebellion Losses Bill. ${ }^{2}$ There was a majority of 141 in the House of Commons against the motion for disallowance. ${ }^{3}$

In the House of Lords, where Stanley and the protectionists were not averse from harassing the Russell Government on any question that afforded opportunity for such parliamentary tactics, ${ }^{4}$ Brougham's motion was defeated by a majority of only

1 Cf. Morley, Life of Gladstone, i, p. 351.

2 'I would deprecate the day,' said Peel, at the end of a speeeh that had extended over nearly three-quarters of an hour, "when the House of Commons should be unwilling to give due eredit to men who, in time of difficulty and danger, rallied under the British standard for the proteetion of British interests. But I cannot allow that feeling, warm and cordial as it is, to influence me to vote for a resolution which I believe would prove destructive of the principle of representative government in the colonies-which would eonstitute a precedent for eonstant interference in the affairs of possessions with whosc local coneerns we are but imperfectly aequainted-interference which would close the prospect I trusted was opening of a long, permanent, and cordial connexion with a colony, in the welfare and prosperity of which England ought to feel the dcepest in terest.' - House of Commons, June 13, 1849. Parliamentary Debates, III, evi, 354.

3 The motion proposed by Herries (June 14) took the form of an amendment to a motion that a sum not exceeding $£ 16,000$ be granted to her Majesty to defray, in the year 1849-1850, the expense of militia and voluntecrs in Canada. It was made in committec. It read : "that a humble address be presented to her Majesty, humbly to pray that her Majesty will be plcased to withhold the Royal Assent to an Act of the Canadian legislature, intituled " an Act to provide for the indemnification of persons in Lower Canada whose property was destroyed during the rebellion in 1837 and 1838", without, and until her Majesty shall have received a satisfactory assurance that no person engaged in, or having aided or abetted that unnatural rebellion, shall be permitted to participate in the indemnification so to be granted.' Ibid.. 252-253.

4 'If all that your protectionist friends want to do,' wrote Elgin from Toronto 
three, in a division in which, including proxies, 195 members voted.

Both motions were in effect motions of want of confidence in the Russell Administration and its colonial policy. They were in effect also votes of censure on Elgin for giving the Royal Assent to the Bill. ${ }^{1}$ Administrations at Westminster need never resign on an adverse vote in the House of Lords. If it were the constitutional usage that resignation follow an adverse vote in the upper house there would have been long periods in the nineteenth century, and in the twentieth century, during which Whig or Liberal Administrations would have been impossible, while Conservative Administrations would also have been impossible because they could not command a majority in the House of Commons.

If the division in the House of Commons on the Herries motion had been adverse, the Russell Government must have resigned, and there would, almost inevitably, have been a general election in the United Kingdom, an election at which responsible government for the British North American provinces would have been the issue. As it was these two important divisions in June 1849, ended a struggle that had been going on in the British North American provinces, and in particular in Upper and Lower Canada, since 1828, and ended it triumphantly for the principle of responsible government.

in May 1850, to Cumming Bruce, who at this time was a member of the House of Commons and of the Peelite group, "is to put themselves, or persons in whom they have greater confidence than the present Ministry in office, their object is, I confess, a perfectly legitimate one. What I complain of is the system of what is termed "damaging the Government", when resorted to by those who have no such purpose in view, or at least no honest intention of assuming responsibilities which they are endeavouring to render intolerable to those who are charged with them.' Walrond, Letters and Journals of Elgin, p. 110.

1 'I have seen it written,' said Russell, on the first evening of the debate in the House of Commons, "written indeed by a person who ought to be of some authority, that we might disallow this Act and yet give our full countenance and support to the Earl of Elgin. The Earl of Elgin, I believe, would consider such a course out of the question. He would say that if this Act were disallowed he was unfit for the situation as Governor-General of Canada.' Parliamentary Debates, III, cvi, 242. 


\section{CHAPTER VII}

\section{PARLIAMENT AND THE NEW COLONIAL POLICY, 1849-1914}

Neither the Declaratory Act of 1778 nor the Enabling Act of 1846, important as each was in the development of selfgovernment in the dominions from the American Revolution to the Great War, outranks in constitutional importance the cleancut unequivocal declarations of the new colonial policy that made the debates on the Rebellion Losses Act of 1849 the most memorable debates on colonial policy at Westminster of the nineteenth century.

Stanley, who was Colonial Secretary from 1841 to 1845 , who in those years was serving a second term at the Colonial Office, admitted in a circular dispatch of June 28, 1843, that the Declaratory Act had not invariably been adhered to. ${ }^{1}$ From the history of public finance in all the British North American provinces, from 1791 until in the early forties of the nineteenth century concessions began to be made to the popular demand for responsible government, it is evident that at the Colonial Office and at the Treasury the administration of the Act of 1778 was continually characterized by an over-cautious, ultra-paternal, and narrow conception of its intent and spirit. ${ }^{2}$ None of the British North American provinces had a full measure of freedom under the Act of 1778 , until they had established civil lists providing for the salaries of judges and other permanent officials, lists which had received the approval of the Colonial Office.

Under the Enabling Act, which until 1850 affected only the British North American provinces, these provinees from 1847 to 1867 secured only the measure of fiscal freedom they were able to insist upon. They secured only the freedom they could force from the Colonial Office, which, as will be recalled, was intent on moulding the fiscal policies of the colonies with responsible government to harmonize with the new fiscal policy of the lnited Kingdom.

1 Accounts and Papers (('olonies), 1846, xxviii.

- 'f. Rules and Regulations: for IIer. Iajesty's C'olonial Sertice (1843), p. 7. 
Until the crises of 1849 at Montreal and Westminster over the Rebellion Losses Act all that any of the British North American provinces had won from the Colonial Office in the way of fiscal freedom was the right to enact tariffs with differential duties. There were no tariffs with discriminatory duties in any of these five provinces until 1858-1859.

There were no tariffs in the United Provinces, New Brunswick, Nova Scotia, or Prince Edward Island, in which there were duties imposed with the avowed purpose of discrimination in favour of Canadian manufactures and against manufactures imported from the United Kingdom or the United States, until the enactment of the Cayley tariff of 1858 and the much better remembered Galt tariff of 1859 . There were in the years from 1846 to 1870 no tariffs with retaliatory duties in any of the provinces east of the Great Lakes. The first retaliatory tariff that had a wide application, enacted by any British colony, was not passed until three years after Confederation, in 1870, when Macdonald convinced his supporters of the Conservative party at Ottawa that he could force a reciprocity agreement with the American Government for the Dominion by imposing retaliatory duties on coal and salt imported from the United States.

The declarations of colonial policy by Russell and Grey in 1849, although they were never embodied in an Act of Parliament, or in any charter, and although they became only a part of the unwritten constitution of the self-governing colonies, supplemented and strengthened both the Declaratory Act and the Enabling Act. They imparted a new value in particular to the Act of 1846, a value and a potency that were not realized at Westminster until Newcastle and the Palmerston Cabinet were confronted in 1859 with the protectionist tariff of the United Provinces.

The new colonial policy, as it was proclaimed by Russell and Grey and endorsed by Peel, affords the key to every development in colonial autonomy from Elgin's term as Governor-General of Canada to the inclusion of premiers of the dominions in the War Cabinet in London in 1915.

Manifestly it affords the key to all the fiscal and diplomatic freedom that the dominions drew to themselves and asserted in the eventful years in the history of the fiscal freedom of the self-governing colonies from 1859 to 1873. 
The new policy, so promptly accepted and welcomed by the colonies, explains Newcastle's fear to recommend to Palmerston's Cabinet the disallowing of the Galt tariff. It explains Clarendon's intimation of 1866 to the State Department at Washington that henceforward the British North American provinces were to be parties to diplomatic negotiations between Great Britain and the United States in which interests of these provinces were involved.

It makes understood the willingness of the Conservative Government of 1874-1880 to sanction in 1874 a reciprocity treaty between the Dominion of Canada and the United States, under which there were to have been important tariff concessions to manufactures from the United States not extended to similar goods from the United Kingdom. ${ }^{1}$ It also explain Kimberley's reluctant surrender of 1873 to the demands of the Australian colonies for power to enact tariffs with differential duties.

In a word the explanation of the complete failure of the propaganda from the Colonial Office of 1846-1895 for fiscal systems based on the principle of free trade is to be found in Russell's statement of colonial policy of June 14, 1849, and its acceptance by both Houses of Parliament.

From 1849 a new principle governed the Colonial Office in its relations with all the colonies with representative and responsible government. It was that the Imperial Government had no interest whatever in exercising any greater influence in the internal affairs of the colonies than was indispensable for the purpose of preventing any one colony from adopting measures injurious to another or to the Empire at large. ${ }^{2}$

The contention that Gladstone advanced on May 16, 1849, that because a governor of a colony with responsible government had, as the representative of the Crown, recommended a measure to a colonial legislature, it was within the power and province of the Imperial Parliament to call the Secretary of State for the

\footnotetext{
1 'In view of the peculiar position in which Canada stands in relation to the [nited States, and to the circumstances of political exigeney and other con. siderations of importance which tend to favour the removal of all restrictions to the establishment of reciprocal trade between the two eonntries, Her Majesty Government approved, from time to time, of proposals to effect the same $b y$ means of reciprocal and eoncurrent legislation by ('anada and the United States. Todd. Parlinmentary Gocernment in the British C'olonies. p. I83.

2 Cf. H. E. Egerton and W. L. Cirant, C'anadian Constitutional Developmert. p. 297 .
} 
Colonies and also the Cabinet to account-to hold them in this way responsible for legislation in the colonies ${ }^{1}$-was never again advanced in Parliament at Westminster. ${ }^{2}$

There were no more protests such as Gladstone had made in 1849 against responsible government as it was then conceived by Baldwin and La Fontaine and Elgin at Montreal, and by Russell and Grey and their supporters in the House of Commons and the House of Lords. There were no more protests supported by the reasons Gladstone advanced on May 16, 1849, that the concession of responsible government interfered with the suprenacy of Great Britain over all imperial concerns. ${ }^{3}$

It was never again contended, as Gladstone contended in one of the preliminary skirmishes at Westminster over the Rebellion Losses Act, that the House of Commons had a perfect right to interfere in all imperial concerns, ${ }^{4}$ whether the concerns were those of a colony ${ }^{5}$ with responsible government or of a possession under Crown colony rule.

1 Cf. Parliamentary Debates, III, cv, 507.

2 Gladstone in 1856 completely abandoned his position of 1849 , a position absolutely fatal to the principle of responsible government. 'I shall', he said, ' ever thankfully rejoice to have lived in a period when so blessed a change in our colonial policy was brought about, a change which is full of promise and profit to a country having such claims on mankind as England; but also a change of system in which we have done no more than make a transition from misfortune and from evil back to the rules of justice, of reason, of nature, and of common sense.' Morley, Life of Gladstone, i, p. 350.

Nearly twenty years later, in 1873, Gladstone made a definite application of the principle he expressed in 1854. 'The Canadian ministers', he said, when, during his Administration of 1868-1874 his attention was called in the House of Commons to the scandal over the first charter for the Canadian Pacific Railway, granted by the Macdonald Government in 1872, ' are responsible to their Parliament, and are not in any way responsible to us for their conduct. I do not think that this is a matter in which it is competent or desirable for us to interfere.' Parliamentary Debates (August 1, 1873), III, ccxvii, 1430.

3 'The Government [of 1765] had no quarrel with the principle that representation should be a condition of taxation. It would have asserted the principle on any occasion. But it could not see that the course it was pursuing (imposing taxation on the colonists of America) was a violation of that principle. Parlia. ment, it declared, was the great council of the nation, representing those parts beyond the seas, as well as those at home, and its measures bound the whole nation.' William Smith, A History of the Post Office in the American Colonies and in Canada, p. 80.

4 Cf. Parliamentary Debates, May 16, 1849, III, cv, 567.

5 ' Of late I have observed a disposition in some quarters to regard the word colony as implying some kind of disparagement. Any one who is so disposed may do well to remember that the ancient Greek cities enjoyed absolute political independence.' Sir Frederick Pollock, Address on Imperial Organization, Royal Colonial Institute, London, April 11, 1905. Journal of Society of Comparative Legislation, New Series, xiv, p. 241. 
Power to interfere still lies technically with Parliament at Westminster, and especially with the House of Commons, in which ministers must justify the policies and actions of the administration, or at a crisis meet with defeat. No statutory amendment to the constitution, such as that of 1911 which restricts the veto power of the House of Lords, has ever deprived Parliament of its power to interfere in all imperial concerns.

But since 1849 the power of the House of Commons to bring about the disallowance of an Act passed by a legislature of any of the dominions has, in practice, been as much in desuetude as the power of the Crown to veto a Bill which a Government may have carried through all its stages in the House of Co amons and the House of Lords.

The term Imperial Parliament, as Sir Frederick Pollock recalled in 1905, did not originate by rcason of powers exercised by Parliament over British dominions. The term is older than Great Britain's oldest colony, older than British sovereignty over Newfoundland, in which there were British settlements as early as $1623 .^{1}$

It is older than the first separate organization in London for the central administration of colonial affairs - the committee of the Privy Council appointed by order in council of July 4, 1660, for the plantations ; ${ }^{2}$ and the present historical term, a term which has been the standing headline of reports in the press of proceedings in Parliament at Westminster since the closing decade of the seventeenth century when news letters in manuscript were superseded by newspapers, is only a survival of the mediaeval protests against the King of England being supjosed inferior to the emperor, and the Reformation protest against papal jurisdiction. ${ }^{3}$

The British Empire, as it existed on the eve of the World War, was the most variegated empire known to history. In it could be found ' every sample of climate, product, race, colour, language, religion, law, and constitution ' 4 The Empire was then, as it had been for seven years previous to the war, divided into the two categories of self-governing dominions on the onc hand,

1 Cf. Colonial Office List, 1910, p. 279.

2 History of the Colonial Office, Colonial Office List, 1910, ix.

3 Pollock, .Joumal of the Sociely of Comparative Legislation, New Series, 1905, xiv, p. 241.

"Sir Charles Lucas, The Empire and the Future, p. 14. 
and Crown colonies and protectorates on the other. It was divided - 'rightly divided', Lucas asserted in 1916-' into provinces the ultimate power over which is in the province, and provinces the ultimate power over which is in Great Britain. ${ }^{1}$

In respect of provinces the ultimate power over which is in Great Britain, Parliament at Westminster is still as supreme as it was in the second half of the eighteenth century, when the assertion of its supremacy entailed on Great Britain the war of 1776-1783 and the loss of the thirteen American colonies. Technically Parliament is still supreme over the provinces, over the dominions the ultimate power of which is in the provinces.

Its supremacy is to some degree acknowledged when the dominions, as Canada did in 1916, apply at Westminster for amendments to their constitutions, or rather ask the Imperial Parliament to ratify and confirm amendments that in principle and detail have already been determined upon, practically made by the parliaments of the dominions. But its supremacy in all respects, as regards the internal affairs of the dominions, is in practice restricted to responses given, as a matter of course, without much discussion, and with no contention of political parties, to these very occasional requests for ratification of amendments to written constitutions.

The newer relation of Parliament to the self-governing colonies, a relation as settled and established for sixty years before the World War as the relation of the Crown to Parliament, was the result (1) of Baldwin and La Fontaine's insistence on their conception of responsible government, as exemplified in the Rebellion Losses Act ; (2) of Elgin's statesmanlike and complete acceptance of the claim of Baldwin and La Fontaine and the Liberals of Upper and Lower Canada; (3) of the acceptance of this claim at the Colonial Office, and by the Russell Administration of 1846-1852; (4) of Russell and Grey's justification of the new colonial policy in Parliament; and (5) of the memorable division in the House of Commons of June 15, 1849.

Acknowledgements of the new position of the self-governing

1 'There are border line provinces. India approximates, or did approximate, to a glorified Crown colony. Some of the West Indian colonies possess no little self-government. But the main dividing line is between self-governing dominions and dependencies. The former are more democratic than the mother country. The latter, in outward appearance and institutions, know little of democracy.; Ibid., p. 15. 
colonies were numerous and frank in the years from 1849 to the Confederation of the British North American provinces in 1867. They were made in and out of Parliament by men of weight and authority. These acknowledgements, moreover, provoked no quibbles or objections at Westminster. They were accepted as a matter of course ; and it was not until after 1859, the year in which the United Provinees established a protectionist tariff against imports from the United Kingdom, that there was public expression of misgivings as to the use that the self-governing eolonies were making of their newly acquired large measure of constitutional freedom.

' Canada, in common with the other British provinces in North America', wrote Grey, in a dispatch to Elgin, dated March 14, 1851, 'now possesses in the most ample and complete manner in which it is possible that she should enjoy it, the advantages of self-government ${ }^{1}$ in all that relates to her internal affairs.' ${ }^{2}$

Eighteen months later, September 1852, Grey employed the leisure that accrued to him after the Russell Administration had come to an end in February 1852, and he was no longer at the Colonial Office, in preparing a history of the developments in colonial government and economy from 1846 to 1852 .

'A system of constitutional government, copied from our own,' he then wrote, in his survey of Canada, 'has been firmly established and is universally aequieseed in. Its prineiples are now generally understood and appreeiated, and the best evidence of the successful working of this system of government has been afforded by the passing of a variety of useful laws, all tending to promote the welfare of the people and the progress of soeiety.' 3

1 Responsible government was conceded to the other British North American provinces in the following order: Nova Scotia, 1848; New Brunswick, 1848; Prince Edward Island. 1853; and Newfoundland, 1855.

2 Grey, Colonial Policy of Lord John Russell's Administration, i, p. 260.

3 Ibid., p. 269.

- A political civilization, extremely democratic in character, was created (in the United Provinces) between 1840 and 1867 . With the political and constitutional opportunities that were afforded by Great Britain to all the British North American provinces in those years, the legislature and statesmen of the United Provinces, aided by Govemors such as Sydenham, Bagot, Elgin, Head, and Monck, created a nation out of two backwoods provinces. Porritt, Evolution of the Dominion of Canada, p. 17!).

- You can mark during that period . . . the extended settlement of your country, the development of your internal resources and foreign trade, the improvement and simplification of your laws. and above all the education which the adoption of responsible governiment has afforded to your statesmen in the well-tried ways of the British constitution.'- Farewcil address of Monck, 
In Parliament at Westminster there were acknowledgements of the new powers of the colonial legislatures as explicit as those in Grey's dispatch to Elgin of March 1851, or in Grey's survey of the colonial policy of the Whig Administration of 1846-1852.

Newcastle, who was Colonial Secretary for eighteen months in the Aberdeen Administration of 1852-1855, was in charge in 1854 of a Bill, introduced in the House of Lords, making a series of democratic changes in the constitution of 1840 of the United Provinces. The amendments were made in response to an address from the legislature. In acquainting the House of Lords with its provisions, Newcastle described the changes desired, and intimated that when the Aberdeen Government acceded to the petition of the legislature of the United Provinces three courses were open to it :

The Government could have (1) adopted a draft measure making these changes in the constitution of the legislature, which had been sent over from Canada, and by following this course Parliament at Westminster would have settled the question for Canada ; (2) it could have asked the legislature to pass, and to send to Westminster, a Bill making these changes, which could be confirmed by Imperial Act; or (3) Government could ask Parliament to repeal the sections in the constitution of 1840 which prevented the legislature from making the desired changes itself.

'To have adopted the first course', Newcastle told the House of Lords, 'would have been at variance with those principles of colonial government which I have endeavoured to carry out during the time I have held the seals of the Colonial Office.' 'The proper course to pursue', he continued, 'is to legislate no more for the colonies than we can possibly help. Indeed, I believe that the only legislation now required by the colonies consists in undoing the bad legislation of former years.' 1

Sir George Grey, cousin of Earl Grey, succeeded Newcastle at the Colonial Office in June 1854. From him as Colonial Secretary there was an acknowledgement of the new relations of Parliament at Westminster and Governments at Whitehall towards legislatures in self-governing colonies, that stands out

Governor-General, to the last legislature of the United Provinces. Journals of the Legislative Council of Canada, August 15, 1866, p. 318.

1 Parliamentary Debates (House of Lords), June 15,1854, III, cxxxvi 497-498. 
with striking prominence in Empire history. It has this prominence because of the proof it affords of the extreme unwillingness after 1849 of the Colonial Office and of administrations in Downing Street even to appear to be interfering, or contemplating interference, with measures that were pending at the capitals of the colonies now of the dominions.

A member of the House of Commons had moved that a copy of a Bill of the legislature of the United Provinces, a Bill for the settlement of the long-vexed question of the public lands reserved for the support first of the Church of England in Canada, and in later years of other religious denominations, ${ }^{1}$ be laid on the table of the House of Commons.

Before 1849 a motion such as this would have been complied with at once, if the Colonial Office were in possession of a copy of the Bill. But the Colonial Secretary moved that the motion be discharged, in effect that the House of Commons do not call upon the Colonial Office for a copy of the Bill. No copy, Grey informed the House, had been forwarded by the GovernorGeneral, 'and', he added, 'if the Government should write to the colony for a copy, it would look like interference on their part with a measure pending before the colonial legislature.' 2

\section{CHAPTER VIII \\ THE PASSING OF THE VETO ON COLONIAL LEGISLATION}

Two other important constitutional developments in the colonies with responsible government--developments affecting the veto power as exercised in connexion with measures of colonial legislatures-marked the period from the crisis over the Rebellion Losses Act to the enactment at Westminster of the law of 1873, which conceded new fiscal freedom to the Australian colonies.

There was no proclamation, at Westminster or elsewhere, of these changes, as there was in 1849 of the new relations of the Colonial Office and of Parliament to the self-governing colonies.

1 ('f. E. R. Stimson's History of the Separation of Church and State in Canadr (3rd ed.). pp. 27-43, 83-148.

2 Parliamentary Debates (House of Commons), December 19, 1854, III, cxxxvi, $497-498$. 
There was, moreover, no circular dispatched to colonial governors from the Colonial Office to announce these changes, as was usually the procedure when a new departure in colonial administration was made.

The changes were effected gradually and silently. They followed, as a matter of course, in the train of the new colonial policy. The new policy made the changes inevitable. Without them, responsible government could not have reached the advanced stage at which it stood when in 1867 the Dominion of Canada came into being.

The first of these changes affected the power of governors in colonies with self-government to withhold assent to bills passed by the legislatures. The second affected the use that the Cabinet in Downing Street, acting on the recommendation of the Colonial Secretary, made of its power to advise the Crown to withhold the Royal Assent from bills that had been reserved by governors in pursuance of instructions, or to disallow acts of colonial legislatures-bills to which governors had given the Royal Assent.

Before responsible government was conceded, it was within the power of a governor to grant or withhold the assent to any bill which had been enacted by the legislature $;^{1}$ and there were certain bills to which a governor could not give the Royal Assent. ${ }^{2}$

The power of a governor to withhold his assent-to veto a bill, and thus make an end to it-fell at once into desuetude with the establishment of responsible government for a reason that is quite obvious. Responsible government automatically transferred to the Cabinet nearly all the powers that under the old system, the system in existence in the British North American provinces from 1792 to 1841-1849, had been vested in and exercised by the governor. ${ }^{3}$

1 Cf. Rules and Regulations for Her Majesty's Colonial Service, 1843, p. 7.

2 A g jvernor could not give the assent (1) to any bill or ordinance for the naturaliation of aliens, without a suspending clause deferring its operation until the pleasure of the sovereign was known; (2) to a bill for the divorce of persons joined in holy matrimony ; or (3) to a bill establishing a title in any person to lands and real estate originally granted to, or purchased by, aliens antecedent to naturalization. Nor could a governor assent to any bill, without authority from the Government in London, whereby any paper, bills, or bills of credit might be created or issued, or any alteration made in the circulating medium of a colony, " or to do any act, by grant, deed, conveyance, or otherwise, whereby the Queen's revenue might be lessened or impaired.' A governor, moreover, could not assent to any ordinance or act for raising money by public or private lotteries. Cf. ibid.

${ }_{3}$ 'Pains are taken that a governor-general to be appointed shall be acceptable 
In regard to money bills, it will be recalled that there must be a recommendation of the purpose and object of a bill of this class from the governor, as the representative of the Crown, to the lower house of the legislature, before the motion on which a money bill is based can be introduced by the minister on the Treasury bench. ${ }^{1}$ The recommendation from the governor must be forthcoming before the Government can place on the order paper of the lower house notice that it intends to ask the house to adopt a motion as a basis for a money bill.

Under responsible government, the recommendation from the governor became little more than a constitutional form, a procedure designed to keep the power of introducing money bills in the lower house of the legislature exclusively in the hands of the Government. The Governor-General could not withhold his recommendation without bringing himself sharply into conflict with the Cabinet and the lower house; without provoking a conflict in which the chances would be infinitesimal that he could carry any point on which he was insisting.

Once having given his recommendation, the assent of the governor to the bill to which this was a prelude became a matter of executive routine. Under responsible government it became also much the same with general bills introduced into the legislature at the instance of the Cabinet, measures for which the recommendation of the Crown is not necessary. It became much the same also in respect of bills introduced into the legislature by private members. ${ }^{2}$ No such bill could be carried through

to the Canadians, and those who are appointed know well what is expeeted of them. Like the King, the Governor-General leaves all the ruling in the hands of his ministry. Like the King, he must find a ministry that will become responsible for his aets. If it should ever happen that a governor-general aeted on his own responsibility and could not find a ministry to take the responsibility, he eould not remain. His usefulness would be gone.' Riddell. The Constitution of Canada, p. 91. ('f. 'Evolution of a Colonial Governor,' Macmillan's Magazine. November 1903, p. 53.

1 Money bills must originate with the Government. They must begin their parliamentary stages in the Lower House. The House ean aet on them only with the leave of the Crown; and the Speaker would deeline to reeeive a motion preliminary to a money bill, until the reeommendation of the Crown had been formally eonmunieated to the House.

'The provision which prevents the House passing any such bill unless it shall first have been recommended by message from the Governor-General emphasize: the responsibility of the Hinistry for the expenditure of every dollar of public moncy.' Riddell, op. cit., pp. $95-96$.

2 'A third opportunity afforded to private members (supporters of the (iovernment, not of the Hinistry. and members of the opposition) is that of subuitting motions to the House in favour of reforms or amendments to the law. The fourth is the opportunity open to members of submitting bills to the House. 
all its stages in both houses, unless the Government accorded it its support. It then practically became a Government measure and the assent of the governor at its final stage became a formality, a matter in which the governor had no discretion.

Under the new procedure, the veto of the governor fell into desuetude as completely as the old usage in accordance with which the governor was an active member of the executive council of a colony. ${ }^{1}$ The veto of the governor fell into desuetude, it may be noted, for exactly the same reason as early in the eighteenth century the veto of the Crown on bills passed by Parliament at Westminster was thrown into the discard. Responsible government, as the term has been used in the colonies now of the dominions since 1840 , is only a variant of the term parliamentary government, as parliamentary government has been understood at Westminster since the Revolution of $1688 .^{2}$

After 1849, with the veto of the governor no longer exercisable, the only checks on a legislature in a colony with responsible government, on a legislature which was acting within the written or unwritten constitution, were (1) that in connexion with bills which the governor was specifically ordered by his instructions to reserve without giving his assent, and to transmit to London for the assent or withholding of assent by the Crown, ${ }^{3}$ and (2) the

Private members' bills are distinguished from (1) bills originating with the Government, and (2) private bills legislation, a description which comprises divorce bills and bills for the incorporation of transport, industrial, and financial undertakings, and of ecclesiastical, educational and philan thropic undertakings.' Porritt, Evolution of the Dominion of Canada, p. 428.

1 Cf. Duke of Argyll, Passages from the Past, ii, p. 412.

2 "The term "responsible government" is a comparatively new one in British colonial history. It was not of British political terminology, certainly not accepted in England as applicable to colonial governments, until Great Britain in the period between 1837 and 1850 at last began to learn the lesson of the American Revolution, and to concede large powers of self-government to the British North American provinces; then to Australia, New Zealand, and Cape Colony, and finally in 1893 to Natal.

"The term " responsible government" as now used in British political science means that in each dominion there is a parliament and an executive, called the Ministry, which, like the Ministry in Downing Street for the last two centuries, is dependent for its tenure on the continuous support of a majority in the House of Commons. In the oversea dominions, as in the United Kingdom, the executive is often described as the Cabinet. The correct term is the Ministry: for it frequently happens, especially at Westminster, that there are men in the Ministry who are not of the inner committee of the Privy Council which is termed the Cabinet.' Porritt, Evolution of the Dominion of Canada, pp. 2, 3.

3 Cf. Instructions to Edmund Walker Head, Governor-General of the Province of Canada, given at Balmoral (Queen Victoria's residence in Scotland), September 20, 1854, Sessional Papers (Canada), 1906, pp. 127-128; Rules and Regulations for Her Majesty's Colonial Service, 1843, p. 7. 
general power of the administration in Downing Street to advise the Crown to disallow within a fixed period, usually two years, any act of a colonial legislature.

In the era of crown colony rule, in the days before responsible government, the power of withholding assent to reserved bills, and the power of disallowing acts of colonial legislatures-powers exercised in practice exclusively by the Colonial Office, although in theory by the Crown, acting on the advice of the Cabinetwere frequently employed under conditions that provoked much irritation and discontent in the colonies ${ }^{1}$ and also among colonial reformers, advocates of self-government for the colonies at Westminster.

'It was almost ludicrous', said Francis Scott, one of these reformers, in the House of Commons on April 16, 1849, 'to find how, and where, the negative on acts of the colonial assemblies rested. If it were not serious, it would be ridiculous that the gravest interest of the colonists, having been by them debated and resolved and passed, should come to a closet in Downing Street to be determined by the fiat or veto of an unknown gentleman. ${ }^{2}$ If they took the word of the noble earl at the head of the Colonial Office, ${ }^{3}$ the mode of procedure was most unfair to the colonies, for the veto on the acts of assemblies was decided in the most light and uncertain manner.'

'The noble earl, in his evidence before the committee on miscellaneous estimates last year', continued Scott, who was a Conservative member for a Scottish county constituency, 'stated that the veto upon the deliberations of legislative assemblies was decided upon the advice of Mr. Wood or Mr. Rogers ${ }^{4}$

1 'It appears to be the fashion in Parliament, as well by those in offiee as by the opposition, to talk about the expedieney of allowing the distant dependeneies of the Empire to manage their own eoneerns. Almost every aet of the administration belies sueh an intention. Everything in the Colonial Offiee appears to be clone in a spirit of supereilious despotism, not with a desire to eoneiliate, but to alienate the best and most loyal feelings of the eolonials.' Letter from a member of the Legislative Couneil of New South Wales, written in Oetober 1848 . read by Francis Seott in the House of Commons, April 16, 1849, Parliamentary Debates, III, civ, 318.

2 "Every partiele of the colonial legislation on all subjeets, great and small, is sent lome for allowanee or disallowanee by what is, in faet, a seeret tribunal. Lord Ixttelton, House of Lords, Jume 22, 1852. Ibid., III, exxii, 1139. ('f. 'The Evolution of a Colonial Governor', Macmillan's Magazine, November 1903, 1. 5.3 .

3 (irev, 1846-1852.

4 A. Wood and Frederick Rogers. Rogers, who was created a peer in 1871 , was Under Secretary for the Colonies, 1860-1871. He was Herman Merivales 
by the Secretary of State. Who were these gentlemen ? Annuit, et totum nutu tremefecit Olympum. Should the authority which extended from pole to pole be hid up three pairs of stairs in a cul de sac in Westminster? Such proceedings destroyed confidence, irritated opposition, and created disgust and indignation. It was hardly decent or creditable to this country that matters of the greatest importance to the colonies should be decided at the suggestion of persons who were hardly known to the parties thus affected, and who at the same time were altogether irresponsible.' 1

A beneficent change in the exercise in Downing Street of the power of withholding assent and of the power of disallowance gradually resulted from the establishment of responsible government, and from the new attitude at Whitehall and at Westminster toward the legislatures of the self-governing colonies.

The veto in Downing Street on bills of colonial legislatures did not fall into desuetude as completely and as instantaneously as the veto of governors at the capitals of the autonomous colonies. Its passing in Downing Street was not so quick or so well marked as the passing of the veto of the Crown on bills of the Imperial Parliament. Its disappearance was more gradual; but for a generation before the beginning of the new era in Empire history that was inaugurated with the World War the veto formerly exercised in Downing Street on bills of colonial legislatures had been so long forgotten that parliaments in the dominions passed bills with as little apprehension of a veto as Parliament at Westminster, where the veto of the Crown, though threatened by George III in 1774, and again by George IV in 1829, has not been exercised since the days of Queen Anne. ${ }^{2}$

In the United Provinces, which in the years from 1841 to 1866 invariably led the way in the movements for larger constitutional freedom for all the colonies, there were after 1849 no conflicts

successor as permanent Under-Secretary. 'I am now in possession of a large first-floor room [at the Colonial Office] looking out on the park; badly furnished, but furniture has been ordered consonant with the dignity of an assistant UnderSecretary. . . . I have been to the emigration office to Wood.'-Frederick Rogers, to Miss Rogers, May 28, 1846. G. E. Marindin, Letters of Frederic Lord Blachford, pp. 130-132.

1 Parliamentary Debates (House of Commons), April 16, 1849, III, civ, 321.

2 Cf. Lash, The Working of Federal Institutions in Canada, pp. 83-85; Keith, Responsible Government in the Dominions, p. 240; Riddell, op. cit., p. 97, and note xix, p. 111 ; James Anson Farrer, The Monarchy in Politics, pp. 82, 128. 
with the Colonial Office over the exercise of the power of disallowance. There was in these years a series of protests from the Colonial Office against bills of the legislature of the United Provinces. Nearly all, if not all, of these protests were against tariff bills. ${ }^{1}$

The protests, often of great length, were made either because the tariff bills embodied differential duties or discriminatory duties in favour of Canadian manufactures and against manufactures imported from the United Kingdom. The most important of them were in the years from 1846 to 1859 . There was vigour in the propaganda for an empire based on free trade in these years; and no colonial secretaries were more zealous for the propaganda than Grey and Newcastle, although Kimberley worked hard for what in these pages has been described as the second division of the propaganda, that against differential duties, which was continued from 1859 to 1873 .

It was, however, characteristic of the Colonial Office in the forties and fifties of the nineteenth century to discriminate with nicety between colonies to which only protests could be addressed and colonies with which it was safe to disallow legislation, or otherwise ignore the wishes of the colonists expressed through their legislatures or through the medium of public petitions or memorials. ${ }^{2}$

Proof of this discrimination, of which there were at times outspoken complaints in the House of Commons at Westminster, is afforded (1) by the disallowance by Grey in 1849 of the Act of the Legislature of New Brunswick for the payment of bounties to encourage the cultivation and preparation of hemp ; (2) by the experience of Prince Edward Island in 1851 with the Act for bounties for fishermen; and (3) by Grey's attempt of 1849 to establish convict settlements in the Cape of Good Hope against the strongest protests of Cape colonists.

Adderley complained in the House of Commons, on March 29, 1849 , that Grey had attempted to establish the system of transportation to Cape Colony, not only without the consent but even

1 The protests are given in the Appendices in the order in which they were made by the Colonial Office.

2 For a characterization of the attitude of Grey in 1845-1852 toward New Zealand in the years preceding the establishment of responsible government there. see 'Evolution of a Colonial Governor,' Macmillan's Magazine, November 1903, p. 49. 
without consulting the wishes of the colony. The Colonial Secretary of the Russell Administration had, moreover, Adderley further complained, proceeded with his convict settlement plan against the general and strong remonstrance of the colony. ${ }^{1}$ 'I appeal to the house', continued Adderley, 'against the impolicy of treating our dependencies in such a manner. I appeal against the gross injustice of selecting a weak dependency upon which to try this experiment, instead of applying the principle impartially to all of them.' 2

\section{CHAPTER IX}

\section{FACTORS AND INFLUENCES THAT RESTRICTED THE VETO ON COLONIAL LEGISLATURES}

Fortunately for the development of responsible government in the widest sense of the term; for the development in the colonies now of the dominions of political civilizations after the model of the political civilization of the United Kingdom; for the permanence of the connexion between the dominions and the United Kingdom ; and fortunately also for the record of political achievement of people under British sovereignty from the American Revolution to the World War, ${ }^{3}$ the United Provinces never were in the category of colonies that Adderley had in mind in his sharp criticism of Grey of March 27, 1849.

At no time from 1841 to 1867 could the United Provinces of Upper and Lower Canada be described as a weak dependency. The United Provinces were never in the category with New

1 ' Earl Grey claimed it as a merit that ministers had conferred on Sir George Grey, in New Zealand (Governor 1845-1853), the power of a dictator.' Ibid.

With a comic want of penetration the Secretary of State (Grey) apologized (in the House of Lords in 1848) to the Governor for throwing on his shoulders the burden of personal rule. James Collier, Sir George Grey, p. 58.

2 Parliamentary Debates (House of Commons), March 27, 1849, ciii, 1373.

3 'As a result of the colonial statesmanship that pressed these demands and the statesmanship at Westminster that conceded them, responsible government for all the colonies that are now of the dominions had been established for at least two decades before 1914; and its establishment, and the success which has attended it in Canada, Australia, New Zealand, South Africa, and Newfoundland, is the greatest political achievement of people under British rule in the 140 years between the American Revolution and the war between Great Britain and her allies and the Teutonic Powers.' Porritt, Evolution of the Dominion of Canada, p. 12. 
Zealand from 1845 to 1853 , the years when Sir George Grey, a governor recruited from the Royal Navy, was established there by Earl Grey with the powers of a dictator. Nor were the Canadian provinces in the category with Cape Colony at the time of the popular uprising at Simonstown, against the landing there of convicts from England and Ireland. ${ }^{1}$

South Carolina from the American Revolution to the Civil War of 1861-1865 was often described as the gamecock State of the American Republic. The same description can appropriately be applied first to Upper and Lower Canada of 17911841 , and also to these provinces in the years when they were united under the constitution of $\mathbf{1 8 4 0}$.

It was these provinces that from the Quebec Act of 1791 to Confederation made most of the constitutional history of what is now the Dominion of Canada. In this respect no provinces in any of the dominions have more beneficially affected the colonial policy of Great Britain. The modern era of colonial policy, the fruits of which were the loyal, unstinting, and whole-hearted support of Great Britain in the war with Germany, had its beginnings between 1837 and 1845 in what are to-day the central and most thickly populated provinces of the Dominion of Canada. ${ }^{2}$

Many and various influences tended to give Upper and Lower Canada of 1791-1841 this pre-eminence in fashioning the political development of Great Britain's oversea dominions, in impressing themselves on the political civilization of the Empire in the era that extended from the American Revolution to the World War.

Among these influences were the proximity of the United States in the growing and assertive period of the American republic ; ${ }^{3}$ the movement in England toward democracy, gradual but always progressing; the virility of the men in Upper and Lower Canada, mostly men of Scottish birth or ancestry, who were the popular leaders in the constituencies, in the newspaper press, and in the popularly elected houses of the legislature; the instinct of these men for self-government as against subordination to rule from

1 Cf. ' The Evolution of a Colonial Governor,' Macmillan's Magazine, November 1903, p. 49 ; J. Collier, Sir George Grey, p. 58.

It was 1872 before responsible government was conceded to Cape Colony.

In 1849 its European population was not much in excess of 165,000 .

2 (f. Porritt, Evolution of the Dominion of Canada, p. 23.

3 Cf. Alpheus Todd, Parliamentary Gocernment in the British Colonies, p. 184. 
Downing Street; their ability to realize what they wanted from the Colonial Office or from Parliament at Westminster, why they wanted it, and how it could be obtained.

These were the characteristics of Papineau and William Lyon Mackenzie, of Baldwin and La Fontaine, of Sullivan and Buchanan, of Cayley and Galt, of George Brown, and to a large extent also they were the characteristics of Macdonald, Cartier, and Rose, the Conservative leaders of the era of 1850-1866.

There were racial differences in the United Provinces that were fortunately not characteristic of any of the Australasian colonies of this period. Party strife between Tories and Radicals was more bitter in the United Provinces than it ever was after the middle of the eighteenth century in the United Kingdom, not even excepting the bitterness of party conflict in England and Scotland that characterized the years from the war with France of 1793-1814 to the first great reform of the system of parliamentary representation in $1832 .{ }^{1}$

But the differences between men of British and men of French origin, active in the political life of the United Provinces, never hindered the progress of the movement for responsible government and autonomy. The Liberals of Upper Canada and the Liberals of the French province worked together in the critical years of the movement. They worked together also from 1851 to 1854, years during which democratic amendments were made at Westminster, at the instance of the colonial legislature, to the constitution of 1840 ; and during which also an end was made by the legislature of the clergy reserves, which for half a century had vexed the political and religious life of Upper Canada and to a great degree had hindered the economic development of the English-speaking province.

After the crisis of the Rebellion Losses Act, the Tories accepted responsible government. They, too, in the years from 1850 to 1866 worked for its advancement. It was a Tory Government, the Cartier-Macdonald Administration, it will be remembered, that forced the issue of the Galt tariff and placed the Palmerston Government in Downing Street in such a position that it had no alternative but concession of the surprisingly large measure of fiscal freedom that the Administration at Toronto then demanded.

The Liberals were opposed to protectionist tariffs. The Liberal

1 Cf. Porritt, Evolution of the Dominion of Canada, pp. 84, 137-143. 


\section{FACTORS AND INFLUENCES THAT RESTRICTED}

party in Canada continuously opposed protection in any form from 1858 to 1896. But had Newcastle recommended disallowance of the Tariff Act of 1859 , there would inevitably have been a coalition of political parties at Toronto in defence of the principle of responsible government.

There was, it must be recalled, in Upper and Lower Canada at any time from 1840 to 1866 a larger population of European origin, English, Scottish, Irish, and French, than the combined population of all the other self-governing colonies. Upper Canada in 1842 had a population of 487,000 ; in 1848 of 725,000 . In Lower Canada in 1844 there was a population of 697,000, and in 1851 of $890,000 .^{1}$

Cities were comparatively numerous. Urban populations stimulated the establishment and maintenance of an efficient newspaper press. On their editorial pages the newspapers of Toronto and Montreal, Hamilton and Quebec, and of the other cities of Upper and Lower Canada, were extremely partisan, and they were bitter in their attacks on political opponents. ${ }^{2}$ But for those times the reporting of debates in the legislature and of political conventions and mass meetings was peculiarly well done. Good reporting in any country and at any time is at the basis of popular political education; for newspaper reporters who are efficient shorthand writers, and who are loyal to their craft and to its best traditions of public service, are the text-book makers of popular political education.

The existence in Upper and Lower Canada in 1841-1866 of comparatively numerous cities, and improvements in railway and water communication during the last twenty years of the period, also made the organization of political agitation less difficult than in eolonies such as those of Australasia, in which cities were few and wide apart and in which the occupations of the people were wholly agricultural or pastoral.

In these geographic, racial, political, personal, social, and material conditions lies the explanation of the fact that after 1849 there were singularly few disallowances of Acts of the legislature of Upper and Lower Canada. ${ }^{3}$ Even from Grey, the

1 Cf. Census of Canada, 1870-1871, iv.

2 Cf. H. S. Tremenheere, Notes on Public Subjects Made During a Tour of the United States and Carada (1852), pp. 234-235.

3 Cf. Lord Norton, 'How Not to Retain the Colonies,' Nineteenth Century, July 1879, p. 172 . 
most didactic and combative of statesmen ${ }^{1}$-a Colonial Secretary who more than any of his successors from 1852 to 1895 was alert and aggressive in the propaganda for fiscal systems in the self-governing colonies based, as in the United Kingdom, on the principle of free trade-there were only protests against Tariff Acts with differential duties. Protests were continued for thirteen or fourteen years after Grey had left the Colonial Office. They were continued to the eve of Confederation. But despite these protests not one of the Tariff Acts of the United Provinces from 1847 to 1866 was disallowed, or denied the Royal Assent by Grey or by any of his successors at the Colonial Office. ${ }^{2}$

The exercise of the power of withholding assent or of disallowance seriously vexed none of the provinces now of the Dominion of Canada after Grey's tenure of the Colonial Office, 1846-1852, came to an end ; ${ }^{3}$ and it was not until after Confederation, not until as late as 1876 , that the exercise of the power to withhold assent to a bill that had been reserved by the Governor-General or to disallow an Act to which the governor had given his assent at the end of its stages in the legislature, was strongly assailed from Canada.

It was then an instruction to governors-general at Ottawa to transmit to London for the Royal Assent bills coming within several clearly defined categories, rather than the refusal of assent to, or disallowance of any particular bills of the Dominion Parliament, ${ }^{4}$ that provoked Blake's memorandum of July 1876. The Blake memorandum, adopted as a minute of council by the

1 Cf. ibid., p. 170.

2 Nova Scotia from 1845 to 1867 ranked with the United Provinces as a strong province with a virile political life. It had leaders, men like Howe and Tupper, who were not averse from contest with the Colonial Office; and in Halifax also there were newspapers that were of much service to the movement for responsible government. Next to the United Provinces, Nova Scotia, among the British North American provinces, had the largest part in the development of provincial autonomy. Cf. Porritt, Evolution of the Dominion of Canada, p. 74.

${ }^{3}$ It was Grey who disallowed the Prince Edward Island Fishermen's Bounty Act of 1851, an Act that was subsequently allowed by Pakington, Grey's successor at the Colonial Office. Cf. Journals of the House of Assembly (Prince Edward Island), 1853, Appendix F 30. It was Grey who objected to the New Brunswick Act of 1847 for bounties to encourage the cultivation of hemp. Statutes of New Brunswick (10 Vict., c. 32, s. 1); Grey, Colonial Policy, i, p. 279.

${ }_{4}^{4}$ From Confederation to 1876 only five bills passed by Parliament at Ottawabills that had been reserved-were cushioned at Whitehall, and in the case of three of these bills in respect of which there was an exercise of the power of veto, the principle was subsequently embodied in a law of the Dominion Parliament. Cf. Return of Bills disallowed presented to the Housc of Lords, August 2, 1894. 
Liberal Government at Ottawa of 1873-1878, is another landmark in the constitutional history of the Dominion $;^{1}$ for it resulted in a drastic and liberalizing revision of the commission and instructions to Lorne, ${ }^{2}$ when in October 1878 he was appointed Governor-General of Canada. ${ }^{3}$

There were similar revisions of instructions, as opportunity offered, to governors of other colonies with responsible government, although it was 1895 before there was an end to all statutory provision estopping the Australian colonies from enacting tariffs with differential duties-tariffs with a view to reciprocity agreements with any British colonies, or reciprocity treaties with any non-British country that might deem it to its advantage to enter into an agreement of this character with an Australian colony. 4

From 1878 the practice of reserving Bills of colonial legislatures and transmitting them to London for the assent of the Crown was curtailed practically to the point at which the old usage became nearly obsolete. It became obsolete after 1878 because it was the policy of Downing Street-a policy to which it was impelled by the insistence of Blake and the Mackenzie Government at Ottawa-to rely upon the prerogative of disallowance as a sufficient security against the enactment of any measure by a colonial legislature of such a character as to call for the interposition of the veto of the Crown. ${ }^{5}$

1 Cf. Quiek and Garran, The Annotated Constitution of the Australian Common. wealth, pp. 692-693.

2 Duke of Argyll, 1900-1914.

3 'In 1876-1877, as the result of mueh eorrespondenee between my predeeessor (Earl of Carnarvon) and the Dominion Government, the instruetions issued to Lord Dufferin's sueeessor were thoroughly revised, and in that revision the elause speeifying eertain elasses of Bills, among them being Bills imposing differential duties, as those which should be reserved for Her Majesty's approval were omitted.' - Sir Miehael Hieks-Beaeh (afterwards Lord St. Aldwyn), Colonial Secretary 1878-1880. House of Commons, Mareh 20, 1879. Parliamentary Debates, III, eexliv, 1312.

4 It will be recalled that the Amending Aet of 1873 to the Australian Government Act of 1850 made possible only agreements by Australian colonies with each other or with New Zealand. Further it will be reealled that in the period from 1873 to the seeond Amending Aet in 1895, which removed all statutory prohibition of differential duties, not a single reeiprocity agreement was effeeted by any of the Australasian eolonies.

${ }_{5}^{5}$ C. Todd, Parliamentary Government in the British Colonies. p. 182. 


\section{CHAPTER $\mathrm{X}$}

\section{THE AUSTRALIAN COLONIES AND THE VETO}

Colonies of the dominions geographically divided themselves into three groups: the British North American group, the Australasian "group, and the South African group. This division also follows the order of their development. After the American Revolution colonization and the development of political civilization proceeded first in the British North American provinces; then in the Australasian colonies, and finally in Cape Colony and Natal, the oldest of the colonies now of the Union of South Africa.

With the order of development and the history of each group in mind, it is not difficult to estimate approximately the part of each group in the struggle for the constitutional, fiscal, and diplomatic freedom that all the dominions now enjoy. As will have been realized the British North American provinces bore much the largest part of the struggle for responsible government and fiscal freedom, and nearly the whole of the burden of the struggle for diplomatic freedom.

There were men in the political life of the Australian colonies, men of prominence, who, like Galt, Blake, and Tupper in Canada, held that the self-governing colonies should have the power of making treaties direct with foreign Powers. There were other men of equal prominence at the political capitals of the Australian colonies, who, on this question, held views similar to those expressed at the colonial conference at Ottawa in 1894 by Francis B. Suttor, at one time President of the Legislative Council of New South Wales, who represented this colony at the Ottawa conference. 'We all feel', said Suttor, 'so long as we belong to Great Britain we must make all our appeals to a foreign power through the proper authorities, and those authorities are the home government.' 1

The view thus expressed by the representative of New South Wales at the conference of 1894 would seem to have been the view that was most generally held in the Australian colonies ; for it was endorsed at the Ottawa conference by Nicholas Fitzgerald,

1 Official Report, Colonial Conference at Ottawa, 1894, p. 4. 
representative of Tasmania, who recalled a discussion of the treaty-making power at the Confederation convention at Sydney in 1891.1

'We had a long and animated debate at the Confederation convention', Fitzgerald told the Ottawa conference, 'as to this point, and the colonies were distinctly of the opinion that the unity of the Empire would receive a blow if any power were given in the Confederation Bill, allowing them to make special treaties.' 2

The Australian colonies had their part, and quite an important part, in the intercolonial movement originating in Canada in 1894, for freeing the colonies from commercial treaties made by Great Britain before 1878. ${ }^{3}$ But colonies in the Australian group,

1 'The memorable convention met in Sydney in Mareh 1891. I call it " memorable" because it was beyond all dispute the most august assembly that Australia had ever seen, and beeause the majority of its members were men who yielded to none of their compatriots in their fitness to do the work whieh had to be done. . . . Their number ineluded all the prime ministers of Australia and nine others. They had been eleeted by all the parliaments of the colonies, and therefore in a eonstitutional sense they represented all the people of Australia.' Sir Henry Parkes, Fifty Years in the Making of Australian History, ii, p. 366; ef. Quiek and Garran, Annotated Constitution of the Australian Commonwealth, pp. 123-124.

2 Official Report, Colonial Conferenee at Ottawa, 1894, p. 79.

${ }^{3}$ Cf. ibid., p. 5.

'If we are proposing to modify our tariff in order to extend our commereial relations, we inust of necessity pray the Government to put an end to the treaties whieh now give Belgium and Germany the right of coming in on the most-favourednation clause, if we inelude Great Britain. Without Great Britain being included I see no ehanee of indueing the Parliaments of Victoria or Tasmania to consent to such modifieation.' Fitzgerald, representative of Tasmania, at Ottawa Conferenee, 1894, Official Report, p. 5.

Five of the Australian colonies-New South Wales, Vietoria, South Australia, Queensland, and Tasmania - were represented at the Ottawa eonference, at which a resolution was adopted expressing the opinion " that any provisions in existing treaties between Great Britain and any fereign power which prevent the self-governing dependeneies of the Empire from entering into agreements of eommercial reeiprocity with eaeh other, or with Great Britain, should be removed.' Official Report, p. 2.

The treaties that the eolonies asked should be denouneed (1) did not prevent differential treatment by the United Kingdom of the eolonies; (2) they did prevent differential treatment by eolonies in favour of the United Kingdom ; (3) they did not prevent differential treatinent by colonies in favour of each other.' Ibid., p. 5.

Two steps were neeessary on the part of the Imperial Government to give effect to the resolution of the Ottawa eonferenee: (1) a simple amendinent to the Australian Government Aet of 1850 repealing the whole of seetion 31, part of whieh was repealed in 1873 ; and (2) the denuneiation of the treaties with Belgium and Germany and of similar treaties with eighteen or nineteen other powers. The amendment to the Act of 1850 was made by Parlianent at Westminster in 1895. But, as will be recalled, the commereial treaties were not denouneed until the hand of the linperial Government was forced by the enactment of the British preferential tariff at Ottawa in April 1897. 
for reasons which have been outlined, had no part in the struggle of 1848-1907 for the right of direct representation in the negotiation of commercial treaties.

Moreover, in the era of colonial history that ended with the war of 1914-1918 only the British North American provinces now of the Dominion of Canada, Newfoundland, and Cape Colony ever exercised the power of treaty making. Cape Colony has a place in the history of the movement for diplomatic freedom, by reason of its negotiation of a South African customs union in 1889.

Apart from its success in this instance, apart from its insistence upon the exercise of a diplomatic freedom that before 1889 had been conceded, or partially conceded, to all the British North American provinces, to Newfoundland, as well as to Upper and Lower Canada and to the three Maritime Provinces, and after 1867 to the Dominion, neither Cape Colony nor Natal had any conspicuous place in the movement of 1840-1907 for constitutional, fiscal and diplomatic freedom for the colonies.

These three movements owed the success they had achieved by 1873 largely, but not entirely, to the struggle for autonomy in the British North American provinces, and in particular to the struggle for larger powers that to a great extent constitutes the political history of the United Provinces from the union of 1841 to Confederation.

But while much of the freedom that accrued to the colonies now of the dominions was thus won by the continuous, persistent and well-directed efforts of the provinces in the North American group, the Australasian colonies had none the less a distinct and obviously serviceable part in the struggle that finally gave the dominions the status of nation within the Empire.

It was the Australasian colonies that ended the use by Great Britain of her oversea possessions as penal settlements, and thereby reversed one of the most deplorable mistakes in the colonial policy of Great Britain of the sixty years that followed the American Revolution. The Australian colonies had, as has been recalled, their part in the movement for the freeing of the autonomous colonies from commercial treaties made by Great Britain; and it was the Australian colonies, as will have been realized, that revolted against provisions in their written constitutions that hampered their fiscal freedom. 
What is of equal importance in this survey of the passing of the veto power over colonial legislatures-the veto as exercised by the governor and the veto as exercised at Downing Streetit was the Australian colonies that most directly and most persistently assailed the veto power in London. They assailed it nearly thirty years before the Dominion of Canada in 1876 frankly told the Colonial Office that the large power that could be exercised by the governor in reserving bills, sending them to London for the assent of the Crown, was inconsistent with the status of the Dominion and not in keeping with its dignity.

Responsible government was established in New South Wales in 1850 and in Victoria and South Australia in 1854. It seems to have been taken for granted in these colonies that with responsible government the power of withholding the assent of the Crown, and the power of disallowance, like the veto of the governor, would at once fall into desuetude.

The Colonial Office was not disposed to accept this view of what responsible government involved; and in September 1854, it was at issue with the Australian colonies on this question. Lord Blachford, at this time Frederic Rogers, and assistant Under Secretary at the Colonial Office, described to one of his correspondents the attitude of the Colonial Office toward the claims of the Australian eolonies for an end to the veto, a subdivision of the movement for larger eonstitutional powers that, as has been indicated, was until 1876, the time of the Blake memorandum, peculiarly an Australian demand.

'Till lately', wrote Rogers, in an intimate letter dated September 15, 1854, ' I have been at work on the largest question I have had yet, being little less than a legislative declaration of independence on the part of the Australian eolonies. The successive Secretaries of State ${ }^{1}$ have been bidding for popularity with them by offering to let them have their own way; and in professed pursuance of these offers they [New South Wales, Victoria, and South Australia] have sent home laws which may be shortly described as placing the administration of the colony in a Ministry dependent on the representative assembly, and abolishing the Queen's right of disallowing eolonial Acts.' 2

1 Grey, 1842-1852 ; Pakington, afterwards Lord Hampton, FebruaryDecember 1852; Nowcastle, December 1852-June 1854; and George Grey, July 1854 -February 1855.

2 Marindin, Letters of Lord Blachford, p. $15 \pi$. 
Blachford, during at least seventeen years of his quarter of a century of service at the Colonial Office, was firmly convinced that the destiny of the self-governing colonies was independence. $\mathrm{He}$ held that the function of the Colonial Office was to secure that the connexion of the colonies with Great Britain, while it lasted, should be profitable to both parties, and that the separation, when it came, should be as ' amicable as possible'.

These views Blachford expressed in a memorandum written after his retirement from the office of permanent Under Secretary $;^{1}$ and he gave utterance to exactly similar views in his letter of September 1854, when obviously he was surprised at the audacity of New South Wales, Victoria, and South Australia, in demanding that there should be no more disallowance in London of Acts of the colonial legislatures.

'What remains to complete colonial independence except command of land and sea forces ', he wrote, 'I don't quite see.' 'I shall', he continued, 'be interested to see what comes of it. It is a great pity that, give as much as you will, you can't please the colonists with anything short of absolute independence; so that it is not easy to say how you are to accomplish what we are, I suppose, all looking to-the eventual parting company on good terms.' 2

Two reasons may be adduced to explain why so quickly after the concession of responsible government to the Australian colonies these colonies assailed the veto in London-why, in the history of the movement for constitutional freedom, the Australian colonies had a more distinct place in the movement against the veto as exercised in Downing Street than the British North American provinces of 1840-1867.

There was no long or continuous struggle in the Australian colonies for responsible government, as there was in the British North American provinces from 1828 to 1849. All the Australasian colonies succeeded to responsible government almost automatically as the result of the culmination in 1849, over the Rebellion Losses Act, of the twenty years' struggle in Upper and Lower Canada and of the shorter struggle to the same end in Nova Scotia.

The second reason for the prominence of the Australian colonies in the movement against the veto in Downing Street, and for the

${ }^{1}$ Ibid., ' Last Years of My Official Life,' pp. 295-305. $\quad{ }^{2}$ Ibid., p. 158. 
lesser part that the British North American provinces had in this subdivision of the movement for constitutional reform, would seem to lie in the fact that the veto as exercised in London did not come into the realm of practical politics in the United Provinces.

These provinces, in the years from 1846 to 1866 , became quite accustomed to protests from the Colonial Office against bills or acts of the legislature. But they had comparatively little experience of protests being followed by the exercise of the veto. Not one of the fiscal measures of the United Provinces of the years from 1847 to 1866 , certainly no bill to which any provincial government attached much value, was vetoed in London. The power of the veto in London was consequently regarded in Upper and Lower Canada as an academic question as distinct from an issue that thrust itself into practical politics.

Governments of the United Provinces, moreover, were intensely practical in all their movements for larger powers. They moved only when they experienced the imperative need of larger powers in their day by day business. This was true of their insistence on responsible government, and on power to enact tariffs with differential duties. Differential duties were necessary to success in negotiating for reciprocity with the United States, and in establishing reciprocity with the Maritime Provinces.

It was true also of the demand of the United Provinces for a full and unrestricted application of the Declaratory Act of 1778 to their finance, and of their demand for complete control of the postal system of the provinces. It was equally true of their immediately successful demand of 1858-1859 for power to enact tariffs with duties for the protection of Canadian industries.

It was essentially true also of the movement, first by the United Provinces, then by all the British North American provinces represented at the Quebec conference of 1865 , and finally by the Dominion of Canada, for direct representation in the negotiation of reciprocity treaties. Both the United Provinces and the Dominion-the United Provinces in 1864, and the Dominion in 1887-had been told from Washington that it would be to their advantage if they could arrange for Canadian representation at Washington in regard to questions which were peculiarly Canadian in their scope and interest. ${ }^{1}$

1 Seward, Secretary of State in $186 \mathrm{H}$, desired the appointment of a political 
The United Provinces never pressed for an additional power for which they had not obvious and immediate need; and they never successfully sought a power which they did not promptly bring into service. Desire to possess power which might be serviceable-power which tended toward the status of nation within the Empire-seems to have been a characteristic of the Australian colonies. They were scarcely in possession of responsible government before they began to assail the veto power in London, although they could in $\mathbf{1 8 5 4}$ have had little or no experience of its exercise under responsible government. ${ }^{1}$

Moreover, after an agitation extending over five or six years for freedom to enact tariffs with differential duties with a view to reciprocity agreements, no reciprocity agreements were effected for at least twenty years after the power to enact such tariffs had been obtained under the Imperial Act of 1873 for all the Australian colonies under responsible government.

agent of Canada at Washington. Cf. A. Mackenzie, Life of George Brown, p. 83 .

Bayard, Secretary of State in the Cleveland Administration of 1885-1889, made a stronger plea for direct negotiation with Canada than Seward had done in 1864. 'In the very short interview afforded by your visit,' wrote Bayard to Tupper, on May 21, 1887, 'I referred to the embarrassment arising out of the gradual practical emancipation of Canada from the control of the mother country, and the consequent assumption by that community of attributes of autonomous and separate sovereignty, not, however, distinct from the Empire of Great Britain. The awkwardness of this imperfectly developed sovereignty is felt most strongly by the United States, which cannot have formal relations with Canada except indirectly and as a colonial dependency of the British Crown ; and nothing could better illustrate the embarrassment arising from this amorphous condition of things than the volumes of correspondence published severally this year relating to the fisheries, by the United States, Great Britain, and the Government of the Dominion of Canada. The time lost in this circumlocution, although often most regrettable, was the least part of the difficulty. The indirectness of appeal and reply was the most serious feature, ending, as it did, very unsatisfactorily. It is evident that the commercial intercourse between the inhabitants of Canada and those of the United States has grown into too vast proportions to be exposed much longer to this wordy triangular duel, and more direct and responsible methods should be resorted to.' Tupper, Recollections of Sixty Years, pp. 177-178.

1 Cf. table of acts of colonial legislatures disallowed and of bills to which the assent of the Crown was withheld. Quick and Garran, The Annotated Constitution of the Australian Commonuealth, pp. 694-698. 


\section{CHAPTER XI}

\section{THE LAST STAGE OF THE VETO}

Even on the eve of the war, as the relations of the dominions stood to Great Britain, it could not be said that the power of disallowance in London of acts of colonial parliaments had fallen completely into desuetude. It could not be said that this, the last of three checks on legislation in the colonies, had become obsolete, like the power of a governor to veto a bill, or the power of a governor, acting always on his detailed instructions, to transmit bills in certain categories to London for the assent of the Crown.

But from 1849 to 1914 , and especially after 1878 , when at the instance of the Dominion of Canada there was a drastic revision of instructions to governors, the history of the power of disallowance of Acts of colonial parliaments that had received the assent of the governor as the representative of the Crown was the history of a constitutional power, at one time in much service, that was travelling slowly, but surely, toward disappearance.

The power of disallowance in these sixty-five years moved toward the discard stage; and moved at an accelerated pace in the last three decades of this eventful period in British colonial history. It moved toward desuetude for exactly the same reason that the veto of the governor, and the power of withholding the Royal Assent to reserved bills, fell into the limbo of political institutions that have outlived their usefulness.

Disallowance of Acts of colonial legislatures gradually, but manifestly, became inconsistent with responsible government. It was inconsistent with the power and dignity of colonies with the status of nation within the Empire. It became as much out of keeping with the growing and unassailable constitutional power of a dominion like Canada, or the Commonwealth of Australia, as the exercise to-day of the veto of the Crown on legislation at Westminster would be antagonistic to the usages and traditions that have developed at Westminster as the result of two centuries of government by Parliament and Cabinet.

Fifty-one bills passed by parliaments in Canada, New South 
Wales, Victoria, Queensland, South Australia, Tasmania, and New Zealand, were disallowed or refused the Royal Assent in the years from 1857 to $1893 .{ }^{1}$ But in respect to twenty-three of these disallowances, or withholding of assent, the principle of each bill so vetoed was subsequently embodied in a law of the colonial legislature. ${ }^{2}$

In these cases the exercise of the veto in London involved only delay to the operation of an act or bill ; and delay so brought about was usually due to some technical flaw in a measure, or to a conflict with existing laws. Changes in drafting usually eliminated these objections.

While responsible government in the years from 1849 to 1867 did not completely make an end to disallowances, or the withholding of assent to bills that had been reserved in Downing Street, it did in practice, as was inevitable, soon make such exercises of power much less frequent than in the years from 1791 to $1849,{ }^{3}$ when all Great Britain's oversea possessions were under what to-day would be described as crown colony rule, and crown colony rule at its worst. ${ }^{4}$

The procedure in London in regard to acts and bills of colonial legislatures-the procedure of the older era ${ }^{5}$-was

1 Canada (1868-1873), 9 ; New South Wales (1875-1887), 4 ; Victoria (18571862), 6 ; Queensland (1860-1881), 6 ; South Australia (1860-1891), 9 ; Tasmania (1859-1890), 7 ; New Zealand (1856-1883), 10.

2 Cf. House of Lords Return, August 2, 1894. A tabular statement of the acts or bills disallowed, or to which assent was refused, a statement based on the return of 1894, can be found at pages 694-698, Quick and Garran, Annotated Constitution of the Australian Commonwealth.

3 ' A return was made to Parliament in 1864 of all bills of the North American legislatures which (in London) had been refused the Royal Assent. It went back to the time of the Canadian rebellion (1837), and the correspondence attached to it, in which successive secretaries of state explained to governors their reasons for such refusals, is very significant of the subsequent advance which this country has made in recognition of colonial self-government.' Norton, 'How Not to Retain the Colonies.' Nineteenth Century, July 1879, p. 172.

4 Cf. Porritt, Evolution of the Dominion of Canada, pp. 86-88.

5 'All acts passed by colonies having legislative government are transmitted to the Secretary of State, to be laid before Her Majesty. These acts are forwarded by the Secretary of State to the clerk of the Privy Council, and are thus submitted to Her Majesty, who thereupon orders a reference to be made to the Board of Trade. The Secretary of State, being himself a member of the Board, communicates with the President by means of minutes, pointing out in the first instance the acts which appear to him to require the peculiar attention of the Board, or which should be referred for the opinion of any other department of the Government, most frequently the Treasury. Those acts which do not appear to him to fall within the peculiar province of the Board of Trade are recommended to be confirmed, or disallowed, or left to their operation, as the case may require, which recommendation is, as a matter of course, complied with; but all the acts of this 
continued. ${ }^{1}$ But with the development of responsible government from 1841 to 1867 , and with the fiscal freedom that accrued to the United Provinces from 1847 to 1866 - a freedom that passed as an inheritance to the Dominion of Canada when it came into being in $1867^{2}$-the sanction of the Board of Trade at Whitehall to all tariff bills of colonial legislatures, a sanction based apparently on usage or custom of the constitution as distinct from statute, ${ }^{3}$ became no longer necessary to assent by the Crown to bills reserved.

It had certainly fallen into desuetude at least as early as 1868, as applicable to tariff bills passed by the Dominion Parliament at Ottawa. The Board of Trade, it will be recalled, was for the propaganda for fiscal systems in the self-governing colonies based on free trade. ${ }^{4}$ It forwarded a minute to the Colonial Office (June 25, 1868) in which there was a series of objections, strongly and emphatically expressed, to the Tariff Bill of the Parliament of the Dominion of 1868, a minute written by Farrer, Under Secretary, who was as firmly convinced a free trader as Grey or Gladstone or Kimberley. But assent to the Act, a

elass nust receive the formal sanction of the Board of Trade before being assented to by the Crown.' Ernest Chester Thomas, Leading Cases in Constitutional Law, p. 81 .

1 Cf. eorrcspondence and dispatches regarding differential duties with a view to reciprocity with the United States, in Tariff Act of Dominion of Canada of 1868, Sessional Papers (Canada), 1869, No. 47.

2 ' Respect for the rights of local self-government, previously conceded to the Canadian provinces-rights which were ratified and enlarged by the operation of the Act establishing the Dominion of Canada-has prevented the Imperial Government from interposing any other hindrances to the adoption by the Canadian Parliament of whatever description of commercial legislation might be gencrally acceptable to the inhabitants of the Dominion.' Todd, Parliamentary Government in the British Colonies, p. 183.

3 ('f. E. C. Thomas, Leading Cases in Constitutional Lau, p. 81.

4 "Thus the old colonial system by which the trade of the colonics was contracted and crippled in order to protect the manufacturers and traders of the mother country will be reversed, and the colony [the Dominion of Canada] will protect its own trade and manufactures at the cost of the mother country: whilst the mother coumtry is at the same time submitting to heavy burdens of another kind for the defence and protection of the colony. It is for the Sceretary of State (Buckingham and (handos) to consider whether this is a result whieh shonlel be sanctioned by Her Majesty's Covernment, as it must necessarily be if this bill receives unqualificd approval.' T. H. Farrer (afterwards Lord Farrer). permanent Cnder-fiecretary of Board of 'Trade, 1865-1886, minute to Colonial Office on Tariff Act of 1868 of Dominion Parliament. June 25, 1868. Sessimal Papers (Canada), 1869, No. 47. pl. 13-14.

Dogmatic in his views, and of a controversial temperament in cenomic matters; a free trader of unvielding temper, distrustful of State interference. he wrote much (1882-1899) in defence of free trade in all its aspects.' Nir 'Tlomas Henry Farrer, Bart., First Baron Farrer. Dictionary of National Biography. Supplement, ii, p. 201 . 
reserved Act, was not withheld by the Beaconsfield Administration of 1868. Nor did the Gladstone Government of 1868-1874 withhold assent from the Dominion Tariff Act of 1870 in which there were new discriminatory duties against imports from the United Kingdom, ${ }^{1}$ and in which also both differential and retaliatory duties were embodied. ${ }^{2}$

From 1849 to 1873 , in the period from the Rebellion Losses Act to the crisis arising out of the insistence of the Australian colonies on their claim to enact tariffs with differential duties, colonial Acts were occasionally disallowed, and assent to reserved bills was occasionally withheld. But the procedure of disallowance and of withholding assent-procedure that after 1878 came to be restricted in practice to exceedingly rare disallowances of Acts of colonial legislatures ${ }^{3}$ was brought into harmony with the new relations of the colonies with responsible government to the Colonial Office, the Board of Trade, the Treasury, and the Cabinet, and also with Parliament at Westminster.

The Hansard reports of parliamentary debates at Westminster record no more complaints from protagonists of responsible government on the House of Commons, like those of 1849, that disallowance or assent-the exercise of the veto power in London -lay with 'persons who were hardly known in the colonies'; with men who were 'altogether irresponsible', who were hidden away ' up three pairs of stairs in a cul-de-sac in Westminster.' 4

${ }_{1}$ In particular, against coal.

2 ' On account of the growing importance of Canada, as well before as after Confederation, exceptional privileges have been conceded to her from time to time in respect to fiscal and commercial matters, wherein the interests of Canada were concerned, with freedom to adopt whatever policy might be approved by the local legislature, irrespective of the opinions or policy of the Imperial Parliament.' Todd, Parliamentary Government of the British Colonies (1880), p. 181.

3 Lord Norton, writing in 1879, sixteen years before the complete repeal of section 31 of the Australian Colonies Government Act of 1850, sixteen years before Grey's section was wiped off the statute book at Westminster, recalled that there were then two ways in which colonial legislation in matters of general concern might be brought in to harmony with imperial requirements. The first was statutory prohibition, as in the Australian Act. The second was by withholding assent or by disallowance.

' Both modes of control have become rarer and rarer of adoption as the principles of English constitutional government more fully developed themselves in the colonies. There have been no actual refusals of bills coming from representative legislatures of quite recent years. It is fully understood that the Queen retains the power of disallowance, but will now hardly ever be advised to exereise it.' Norton, loc. cit., pp. 172-173.

${ }_{4}$ Cf. speech by Francis Scott, April 16, 1849, Parliamentary Debates (House of Commons), III, 10t, 321 . 
After the veto of the governor fell into desuetude (1847-1849), in the years from 1849 to 1878 , when the power of withholding assent to reserved bills and the power of disallowance of Acts of colonial legislatures were both still in service in Downing Street, one or other of these powers was at times used to veto colonial legislation. But adequate explanation in these cases had to be made to the Cabinet of the colony ; and as a veto might bring on a sharp controversy between the colonial Cabinet and the Colonial Office, - a controversy that might provoke questions and even discussion in Parliament-the framing of a dispatch announcing a veto could not be left to 'persons who were hardly known in the colonies'.

In view of the fact that during part of this period, for instance from 1856 to 1866 , no fewer than eleven legislatures in as many colonies with responsible government ${ }^{1}$ were in session every year ; that each colony was using its new constitutional freedom to create a political and social civilization adapted to its needs, and also to develop its natural resources and its trade, the number of Acts that were disallowed, and the number of reserved bills from which assent was withheld, was exceedingly small, and in itself is an indication and proof of the new relations of the Colonial Office with the self-governing colonies.

A return of Acts disallowed, and of reserved bills which failed of assent, laid on the table of the House of Lords in 1894, a return covering the years from 1837 to 1893 , mentions no bill from the British North American provinces in the years from 1857 to Confederation. It shows further that in the years from 1857 to 1871, until the crisis over differential duties in the Australian colonies, the total number of acts or bills which were cushioned ${ }^{2}$ or met with a stay in their progress to the colonial statute book, was only thirty-four. ${ }^{3}$

Over a period of fourteen years this was on an average of only

1 The United Provinees of Upper and Lower Canada, Now Brunswiek, Nova Seotia, Prince Edward Island, Newfoundland, New South Wales, Victoria, South Australia, Tasmania, Queensland, and New Zealand.

2 'Under Poynings' law when the House of Commons in Ireland passed the heads of a bill of which the Privy Couneil in Dublin did not approve, they were neither transmitted to England nor sent baek to the House. When they thus disappeared, it was said that they had been cushioned.' Porritt, Enreformed House of Commons, $\mathrm{ii}, \mathrm{p} .336$.

3 Dominion of Canada, 3; New South Wales, 0 ; Victoria, 0 ; Queenskand, I ; South Australia, 8; Tasmania, 7 ; and New Zealand, 9. Cf. Quick and Garran, op. cit., pp. 694-698. 
a little more than two bills a year, not more than the number of Acts of Congress or Acts of legislatures in the United States that one year with another fail to stand the test of constitutionality in the Supreme Court at Washington.

Five of these cushioned bills or acts of 1857-1871-one from Victoria, and four from South Australia-were for changes in the matrimonial code. They were measures affecting either the marriage laws, or the law of divorce, as these laws had originated and were at the time operative in England; and marriage and divorce were subjects over which in the early years of responsible government there was much friction between the Australasian colonies and the Colonial Office. ${ }^{1}$

Here again, as in the case of fiscal legislation, the Government in London desired uniformity, and uniformity based on English laws. Several of the measures were disallowed, or failed of the assent of the Crown, because there were embodied in them provisions which were then regarded in Downing Street as not consistent with the good of the Empire. ${ }^{2}$ But here again, as in the case of tariff legislation in the self-governing colonies, Downing Street had ultimately to give way, ${ }^{3}$ and the effort of the fifties and sixties of the nineteenth century to secure uniformity in the marriage and divorce laws failed.

It failed as completely and as conspicuously, and for exactly the same reason, as the Colonial Office propaganda of 1847-1895 for uniformity in tariff legislation failed. In both these matters, marriage and divorce laws and tariff legislation, the colonies made up their minds as to what they wanted; and with responsible government they realized, and slowly and reluctantly so did Administrations in London, that what the self-governing colonies wanted could not long be denied them.

1 Cf. Norton, loc. cit., pp. 171-172.

2 - There are questions of universal principle, such as slavery or of common domestic intercommunity, such as marriage laws, or general commercial policy, such as protective duties, over all of which it is a matter of prudence and expediency, and for the judgement of the imperial authority, how far to exert a paramount authority.' Norton, loc. cit., p. 171.

3 All the proposed amendments of 1851-187i to the marriage and divorce laws, including amendments to legalize the marriage of a man with his deceased wife's sister, and another proposed amendment to enable a woman to obtain a divorce on the sole ground of her husband's adultery, were subsequently embodied in the marriage and divorce laws of the colony whose legislature had passed the Amending Bills. Cf. Norton, loc. cit., p. 192 ; Quick and Garran, op. cit., pp. $695-697$. 
Two of the cushioned bills of 1857-1871, the first passed by the legislature of Tasmania in 1867, and the second by the legislature of New Zealand in 1870, were of the series of bills from the Australasian colonies that provoked the crisis of 1871-1873 over differential duties-an episode in the history of the Colonial Office propaganda for free trade nearly as significant as Galt's tariff of 1859, and quite as significant as Grey's reluctant, almost grudging, acknowledgement of 1849-1852 of the right of the United Provinces and of the Maritime Provinces to enact tariffs with differential duties.

A great principle arising out of the establishment sixteen or seventeen years earlier of responsible government in the Australasian colonies was at stake in connexion with these bills from Tasmania and New Zealand. It was exactly the same principle that was at issue in the Rebellion Losses Act of 1849, and also in the Tariff Act of the United Provinces of 1859.

Kimberley, who was at the Colonial Office in 1868-1874, was quite as reluctant to concede the claim of the Australasian colonies as Newcastle had been in $\mathbf{1 8 5 9}$ to leave Galt's Tariff Act to its operation-to tell the Cartier-Macdonald Government at Toronto, and to tell the British Empire and the world at large, that he dared not recommend the Palmerston Cabinet to advise the Crown to disallow an Act of a colonial legislature in which there were high protectionist duties against imports from the United Kingdom.

After four years' delay, much correspondence between the Colonial Office and the capitals of the Australasian colonies, ${ }^{1}$ and two intercolonial conferences in Australia, Kimberley was compelled to concede the claim that was embodied in the vetoed bills, from which the Royal Assent had been withheld.

Consequent on this concession of 1873, moreover, Kimberley, as the Colonial Secretary of a free trade administration, of which Gladstone was Premier and of which for two years Bright had been a nember, was compelled to tell a free trade Parliament at Westminster that the propaganda begun in 1846 for an Empire on a free trade basis was breaking down. He was compelled to announce that one of its subdivisions, that for tariffs in sclfgoverning colonies with no diseriminatory or protectionist duties, had been entirely abandoned. He had to make known also that

\footnotetext{
1 A summary of this correspondence of 1868-1872 will be found in the Appendices, pp. 458-462.
} 
there must be at once a partial abandonment of another subdivision, that in the interest of tariffs in the colonies in which there should be no differential duties.

These admissions had to be made when Kimberley in 1873 asked Parliament to stamp its statutory approval on his acknowledgement of the right of the Australasian colonies, not, it must be kept in mind, to make agreements for reciprocal trade with the Dominion of Canada, with Newfoundland or with Cape Colony, or with non-British countries, as New Zealand at this time earnestly desired, but to make these agreements only among themselves, and base them, if they so desired, upon differential duties embodied in Tariff Acts of the colonies of Australia and of New Zealand. ${ }^{1}$

The larger freedom, freedom to make agreements for reciprocal trade with colonies in South Africa and British North America and with countries not of the British Empire, was withheld by Parliament from the Australian colonies until 1895; although in the years from 1849 to 1895 this larger freedom was enjoyed and exercised repeatedly by all the colonies in British North America, and, at least from 1889, exercised to a limited extent by Cape Colony. ${ }^{2}$

In the House of Commons at Ottawa in 1891, Laurier, who was then the leader of the Liberal opposition, defined the status of the British North American provinces (British Columbia excepted) on the eve of Confederation, at a time when most of them had been in enjoyment of powers of self-government for nearly twenty years-powers which were increased from time to time in the years from the crisis over the Rebellion Losses Act to the constitutional convention at Quebec in October 1864.

'Confederation', said Laurier, ' did not give us any new constitutional powers; any powers we had not before. Confederation simply consolidated together the self-governing colonies. The powers possessed by the provinces before Confederation were undoubtedly as great as those now possessed by the Dominion of Canada.' 3

\footnotetext{
1 Cf. Australian Colonies Duties Act, 1873 (36 Vict., c. 22) ; Quick and Garran, op. cit., pp. 697-698.

2 Cf. Freemantle, The New Nation, p. 86. Natal was created a separate colony in 1856 . It was not conceded responsible government until 1893 .

3 House of Commons, September 30, 1891. Parliamentary Debates (Ottawa), III, 6316-6318.
} 
In its broad lines, and in its statement of general principles, Laurier's declaration of 1891 was absolutcly true. It was so accepted in the House of Commons and in Canada, at a time when there still survived in the political life of the Dominion several of the fathers of Confederation. ${ }^{1}$

Between Confederation and 1914, Canada, in common with all the colonies now of the dominions, was, it will be recalled, freed from all British commcrcial treaties to which she had not given her assent, and the right of Canada, or of any other of the dominions to ncgotiate her own commercial treaties had for all practical purposes become absolutc.

The Australian colonies at the time of the Confederation of the British North American provinces were still ticd by the restraining section of the Imperial Act of 1850. At this time, and for ten years still to come, it was usual for Great Britain to include all colonies in her commercial treaties without asking the selfgoverning colonies for their consent; and until 1898 the fiscal freedom of the Australian colonies, like that of Canada, was hampered by at least twenty commercial treaties into which Great Britain had entered before 1878, in the case of some of these treaties, long before the demand for responsiblc government was first made in Upper and Lower Canada in 1828.

In all other particulars Laurier's declaration of 1891 was well founded. It afforded no opening for contention or dispute. It would, moreover, have been as well founded, and as little open to dispute, if it had been applied to the status of Newfoundland and to that of all the colonies with responsible government in Australasia of the era of Confederation of the British North American provinces. ${ }^{2}$

In their internal concerns, always excepting the restrictions on tariff legislation of the years from 1846 to 1898 -restrictions which varied greatly in the case of the British North American provinces and in that of the colonies in the Australasian groupthe colonies with responsible government were almost completely free from interference by the Colonial Office; and, in practice, quite free from interference in their affairs by Parliament at

1 Galt, 1817-1893; Tilley, 1818-1896: Mowat, 1820-1903 ; and Tuprer, $1821-1915$.

2 There was no eolony with responsible government in South Africa until 1872. In that year cape Colong was advanced to that status. 
Westminster 1 for nearly a quarter of a century before the crises of 1867-1873 over differential duties in the tariffs of the Australasian colonies.

Each of the colonies with responsible government in the North American group ${ }^{2}$ and in the Australasian group was in possession of most, but not quite all, the essential attributes of nation for at least two decades before the era of Confederation began in 1867 .

1 'The legislative authority of the Imperial Parliament is, in theory, transcendent, and extends over colonies and all dominions of the sovereign. But in colonies under governments responsible to their own representative legislatures, it is practically never directly exerted at all. If it were, it would reduce constitutional government-recognized and established in a colony-to a fiction, to a sham and delusion, fraught with mischief alike to the bastard colony and to the mother country so degrading herself abroad.' Norton, loc. cit., p. 170.

2 British Columbia was not advanced to the status of colony with responsible government until 1871 . 


\section{PART V}

\section{THE ERA OF INDIFFERENCE IN GREAT BRITAIN TO COLONIES AND EMPIRE}

\section{CHAPTER I}

\section{SUBDIVISIONS OF THE ERA}

THE era of indifference to oversea possessions-the era during which the people of Great Britain were averse to the acquisition of additional outlying territory, were willing to abandon some outlying possessions that were already of the Empire, were undismayed and even unperturbed by agitation in two of the provinces now of the Dominion of Canada for annexation to the United States, ${ }^{1}$ were undisturbed by boundary arbitrations on the North American continent that entailed loss of territory and were even frankly indifferent whether colonies in British North America or in Australasia remained of the Empire or established themselves as independent nations-extended from the loss of the North American colonies to the first Jubilee of the reign of Queen Victoria in 1887.

It was an era that lasted for a little over a century. It can easily and conveniently be divided into well-marked periods. The first extended from 1783 to the fiscal and commercial revolutions of Peel and Russell of 1846, the Rebellion Losses Act of 1849 , and the Galt tariff of 1859 . The second period extended from 1859 to 1887 , and this period of nearly thirty years easily subdivides into two periods of unequal length.

1 Cf. Allin and Jones, Annexation, Preferential Trade, and Reciprocity, 18491850, pp. 166-170, 364-373.

"We should not go to war for the sterile honour of retaining a reluctant colony. We should not purchase an unwilling obedience by an outlay of treasure or blood.' The Times (London), October 31, 1849.

'We shall', said the Advertiser (Dundee, Scotland), in its comment on the annexation movement, " simply be saved the trouble and expense of the government of Canada, and these have been of no trifling nature. We believe our colonies have cost this country an amount of money which it is impossible to estimate, in wars, in protective duties, and in expenses of government. We shall not regret to see more of them follow the example of Canada, and be at the trouble and expense of maintaining themselves.' 


\section{ERA OF INDIFFERENCE IN GREAT BRITAIN}

The first subdivision of the second period, 1859-1887, extended from 1859 to the crisis of $1867-1873$ over differential duties in the tariffs of the Australian colonies. In these years indifference in England to colonies would seem to have been more widespread, more manifest, and more pronounced, than at any time from the American Revolution to 1859 . The indifference of this period was, moreover, so far as the colonies and their connexion with Great Britain were concerned, regarded in the colonies as more disturbing and more threatening than at any earlier period.

The seeond subdivision of the period from 1859 to 1887 extended from 1873 to 1887 . More or less indifference to colonies marked these years. But except for the years 1879, 1883, and 1887, years in which pronouncedly national policy tariffs were enacted at Ottawa, expressions of indifference and of willingness to sce colonies end the connexion with Great Britain were much less frequent in Parliament at Westminster, at public, political or commercial meetings, and in the press, than in the period from 1859 to 1873 .

In these fourteen years, $1873-1887$, it is easily possible to note the emergence of influences and factors-some within the Empire ; others like the creation of the German Empire and the thrusting of the German Empire into world politics, in the world outside the British Empire-out of which there developed (1) the newer attitude of people in Great Britain toward the oversea dominions; (2) the strong and frequently expressed desire of all the dominions to remain within the Empire; and (3) the greater and more obvious cohesion of the Empire that was characteristic of the twenty or twenty-five years that preceded the war of 1914-1918.

What may be described as the two main periods of indifferenee, 1783-1859 and 1859-1887, were marked by some characteristics that were common to both. Each period also had features peeuliar to itself, and not characteristic of the other. In the period from 1859 to 1873 , the civil government of the autonomous colonies threw no financial burden on Great Britain, although Great Britain continued to be responsible for the external defences of all the oversea dominions.

Other reasons for the differenees that characterized the two periods, as will later appear, were the facts (1) that after 1841, and increasingly after 1865 , there were high proteetionist duties in the United states that eurtailed the relative increase of exports 
of manufactures from the United Kingdom to the United States ; and (2) that from 1859 to 1873 , as at the present time, there were tariffs in the British North American provinces or the Dominion of Canada, and also in the Australasian colonies, that negatived the contention in the United Kingdom, and were avowedly intended to negative this contention, that trade with the colonies belonged as of right to manufacturers and exporters in the United Kingdom. ${ }^{1}$

\section{CHAPTER II}

\section{INFLUENCES THAT MADE FOR INDIFFERENCE}

THE influences or factors existing and operative from 1783 to 1859 , and again from 1859 to 1873 - the influences that to-day would seem to explain the popular indifference in Great Britain to colonies and Empire-were numerous. They are, moreover, not difficult to trace or discover.

Some of the more obvious and more potent of these influences in the first of these periods, 1783-1859, were :

1. Popular disappointment that existed for at least a generation after 1783 over the loss of the American colonies.

2. The enormous addition to the national debt, and consequently to taxation in Great Britain, that was entailed by the war with France for possession of a large part of the North American continent-a war that was waged in North America, on the high seas, and also in Europe-and by the war of the American Revolution.

3. The long prevailing and widely held conviction, growing immediately and directly out of the American Revolution, that the provinces of British North America that continued of the Empire after the revolt of the American colonies, and also the colonies in Australasia and South Africa that were peopled and developed subsequently to the American revolt, would, as soon as they were sufficiently strong and able to stand alone, follow

1 ' Our tariffs are all directed as much against England as against any foreign country. England is willing to acknowledge that. We may love England very much. But our colonial manufacturers are just as tenacious regarding manufactures as the manufacturers of England, of France, of Belgium, or of any other country.' Nicholas Fitzgerald, representative of Tasmania, at Colonial Conference at Ottawa, July 5, 1894, Official Report, p. 184. 
the example of the thirteen colonies, and end the connexion with Great Britain.

4. The financial burden of the internal and external defence of the colonies, and, until at least half way through the nineteenth century, the burden of carrying also a large part of the cost of the civil government of several of the colonies. ${ }^{1}$

5. The fact that until a comparatively late period in the nineteenth century much of the friction between Great Britain and the United States developed out of causes which had their origin in the British North American provinces, causes over which statesmen at Westminster had, or could have, little direct or real control until a diplomatic crisis was in sight, and the Foreign Office at Whitehall became engaged.

6. The popular expectation at the end of the Napoleonic wars that army and navy expenditures would be greatly and permanently curtailed, with a corresponding decrease of taxation, an expectation that was never realized to the full in this period from 1783 to 1859 because of the work thrown upon the army, and to a certain extent also on the navy, by reason of the fact that in these years Great Britain was responsible for both the internal and external defence of the colonies, and was frequently compelled to shoulder the responsibility for the internal defence of the British North American provinces, New Zealand, Cape Colony and Natal.

7. The fact that despite the separation of the American colonies from Great Britain in 1783, and despite the war with the United States of 1812-1814, there was a large and continuing increase of export trade with the United States, until the tariffs of the Republican party at Washington became operative during and after the Civil War of 1861-1865.

8. The extent to which the United Kingdom monopolized the tracle of the world-was the workshop of the world-from the

1 'In 1830 a Tory Chaneellor of the Exehequer (Goulburn) proposed a commission for the purpose of investigating eolonial expenditure; and this is the comment of a distinguished soldier, Sir J. Willoughby Gordon, when invited to take part in the inquiry: " the House of Commons and the publie have their attention very closely fixed upon the state of our colonies. They have for years been made the scapegoat of onr expenditure; and when we are now ealled upon to explain the reasons for keeping up our present military establishment, our answer is ' the eolonies'. There is no branch of the public service which has not a chritin upon its resources from the colonies.", H. E. Egerton. "The ('olonial Reformers of 1830,' King's C'ollege Lectures on C'olonial Problems, pp. 1+4-1+5. 
end of the Napoleonic wars until the Civil War in the United States, and until the emergence of Germany as a manufacturing and exporting country, and the effect of this world trade, with its accruing wealth, on industrial, social, and political conditions in England and Scotland.

9. The association in the popular mind of colonies with revolution and rebellion; with the older methods of crown colony rule; with military government, nepotism, plural office holding, sinecures and offices filled by sweated deputies; with family compacts in the British North American provinces; with jobbery in crown lands in the colonies and with speculations in land ; with slavery in the tropical or semi-tropical sugar-producing colonies; with wars with aboriginal inhabitants; with penal settlements in Australia, born of Great Britain's brutal and inhuman penal code of the eighteenth and early nineteenth centuries $;^{1}$ with famine in Ireland, and forced clearances of crofters in both Ireland and Scotland ; ${ }^{2}$ with emigration organized by poor law guardians in England and Ireland to relieve parishes of the burden of pauper families ; with ill found, poorly provisioned, overcrowded and fever-breeding emigrant ships; with the break-up of families, and partings at tide-water ports in England, Scotland, and Ireland that were for ever ; and with periods of long exile or banishment for needy and unfortunate men, the derelicts or failures or incapables of agriculture, trade, and commerce, and sometimes of the professions, whose circumstances forced them to enlist in the army in the days before Cardwell's reform of $1870,{ }^{3}$ in the days when enlistment in the army involved service for life or for twenty-one years. ${ }^{4}$

1 'We first misused colonies as washpots for the overflow of gaols, having allowed poverty to fill the gaols to overflowing.' Adderley, Colonial Policy, p. 408.

"What we are concerned with here is the influence of the transportation system upon the public opinion of the day against colonies. On this point there can be no question. It caused the very word colony to stink in the nostrils of self-respecting men.' Egerton, op. cit., p. 147.

' Somehow or other, though not without many a squeak for its life, we got the South Australia Bill into the House of Lords. A prince of the blood asked: "Pray, where is this South Australia ?" and the Lord Chancellor, renowned for the surpassing extent and variety of his knowledge, answered, "Somewhere near Botany Bay". Edward Gibbon Wakefield, A View of the Art of Colonization, p. 47 .

${ }_{2}$ Cf. Earl of Carnarvon, Speeches on Canadian Affairs, pp. 318-320.

3 Cf. Robert Biddulph, Lord Cardwell at the Foreign Office, p. 153.

4 'Service in the army was unpopular because two-thirds of a soldier's time was spent on foreign (colonial) service.' Ibid., p. 153. 


\section{ERA OF INDIFFERENCE IN GREAT BRITAIN}

10. The fact that from 1820 until well on toward the end of the century-long period of indifference, from the days of Canning, Ripon, Huskisson, and Peel, and of Grey, Russell, Durham, Althorp, Graham, and Place, to the later years of Gladstone and Disraeli, the United Kingdom was continuously engaged in the reform of its fiscal commercial system, or in overhauling and remodelling the political civilization-parliamentary, administrative, judicial, ecclesiatical, municipal, and educational-that had been inherited in the early decades of the nineteenth century from the sixteenth, seventeenth, and eighteenth centuries.

During this era of reform, in the first three quarters of the nineteenth century, Parliament at Westminster never for long kept pace with the popular demand. Born of impatience for reform, often manifested in the constituencies and at times among groups of radicals and reformers in the House of Commons, came the conviction, soon to become widespread and deeply seated, that with the increase of population in England, with the great extension of manufacturing, commerce and transport, with the creation of many large cities and towns that came in the train of expanding industry and commerce, and with the increasing complexity of modern urban life and its exigent demands on all departments of the political civilization of the United Kingdom, Parliament would inevitably always find itself fully employed with home politics and home problems, and with little time available for the internal concerns of oversea dominions.

To a large extent this popular conviction of the years from 1820 to 1867 explains many of the expressions of these years at Westminster, of willingness to see what are now the self-governing dominions separate themselves from Great Britain.

These expressions at the time were disturbing to the selfgoverning colonies then struggling to their feet. None of the colonies, either in British North America or in Australasia, ever desired to be free of the connexion with Great Britain after complete responsible government had been conceded to them. They recognized the fact, as Chamberlain reminded the selfgoverning colonies in 1896, that 'the life of a great nation is fuller than the life of a small one, and the life of an old nation more instructive than the life of a new one.' 1

But the conviction that provoled these expressions of willing-

1 Chamberlain, Foreign and Colonial Speeches, p. 104. 
ness to shed colonies was widespread. It was a conviction, as will appear in subsequent chapters, held by men of all political parties at Westminster. It was a conviction that obviously influenced the Colonial Office, that influenced Cabinets, and that greatly influenced Parliament. It was, moreover, a conviction exerting an influence at Whitehall and Westminster, that undoubtedly greased the ways for the large concessions of responsible government, and of fiscal and diplomatic freedom that colonies now of the dominions insistently demanded, and came to possess, in the twenty-six years from the union of Upper and Lower Canada to the creation of the Dominion of Canada.

\section{CHAPTER III}

\section{MANIFESTATIONS OF THE INDIFFERENCE}

In the period from 1783 to 1859 , arising from the influences, factors, and causes which have been outlined in the preceding chapter, indifference to colonial possessions and dominion over territory beyond the seas manifested itself in a variety of ways. Some were positive, others were negative.

The more apparent of these manifestations to a twentiethcentury student of the development of the present day dominions, and of the history of the revolutionary changes in the relations of the colonies of British North America, Australasia, and South Africa to Parliament, to the Cabinet in Downing Street, to the Colonial Office, to the Board of Trade, to the Treasury, to the Foreign Office, and to the General Post Office in London, were :

1. The willingness of statesmen of both the Tory and the Whig parties to consider at times the abandonment of outlying territories, and also their unwillingness to sanction additions to territory under British sovereignty.

2. The difficulty that was experienced from 1783 to 1859 , except at times of great crisis, to induce Parliament to centre its attention on legislation for the colonies, or on colonial questions or grievances, and the unconcealed impatience of members of both the House of Commons and the House of Lords, when colonial secretaries or colonial reformers pressed bills for the colonies or colonial questions on the attention of Parliament. 


\section{ERA OF INDIFFERENCE IN GREAT BRITAIN}

3. The many frank expressions in the House of Commons and in the House of Lords of the conviction that the colonies would ultimately separate from Great Britain, and that separation could entail no loss for Great Britain ; and the comparatively few expressions in either the House of Commons or the House of Lords of contrary convictions and opinions.

4. The small esteem in which politicians, who regarded themselves as of Cabinet rank, held the office of Secretary of State for the Colonies; ${ }^{1}$ the short tenures, even in the lifetime of a single administration, that were eharaeteristic of the secretaryship $;^{2}$ the undistinguished and mediocre abilities, parliamentary or administrative, of some of the secretaries of the eolonies of the period; the frequeney with which the colonial secretary was of the House of Lords, the chamber that could exercise no great influence on colonial poliey, and whose proceedings attracted the least attention in the press and the constituencies; ${ }^{3}$ the ignorance of secretaries eoncerning the eolonies, colonial eonditions ${ }^{4}$ and the political aspirations of the eolonies that ultimately

1 'The secretaryship was usually conferred upon one of the lesser members of the Cabinct ; and the tenure of most of its holders was of brief duration.' Arthur Percival Newton, The Old Empire and the New, p. 45.

'How much Downing Street knew of the dominions, even in later days, is illustrated by the story told of Lord Palmerston who, when in office, solved some diffieulty in appointing a new colonial secretary by saying " Well, I'll take the office myself," and then turning to a permanent official, requested him. "Just eome upstairs and show me on the map where these damned places are." 'John G. Findlay, The Imperial Conference in 1911 from Within, p. 1.

Palmerston was never at the Colonial Office. But the story told by Sir John Findlay expresses the opinion long current that statesmen who regarded thenselves as good Cabinet timber looked for an office of morc importanee than the colonial sccretaryship.

2 "The eolonial secretary seldom remained long enough in his office to become acquainted with the concerns of the numerous colonies which he governed.' Sir William Molesworth, House of Commons, January 23, 1838, Parliamentary Jebates, III, xl, 385. Cf. Newton, The Old Empire and the New, p. 43; Durham, Report (Oxford edition, 1912), ii. p. 104.

${ }_{3}^{3}$ ' It is certainly a defect that the Colonial Secretary should not be in the House of Commons.- Cornewall Lewis, August 6, 1848. (i. F. Lewis. Letters of Cieorge Comeuall Lewis, p. I8I.

' 'Hitherto,' wrote William Lyon Mackenzie, from london, July 5, 1832, 'the Houses of Assembly (of Upper Canada) have scarcely excited even a momentary attention in this country when they forwarded complaints; for it appears to inc, by observation, that there is so mueh domestic business of a very important character to be transacted that it is found impossible for Her Majesty's Ministers to spare time nccessary to a full understanding of the state of society in Upper ('anada.' Seventh Report of the ('ommittce on Grievances. Appendix, Journals of House of Assembly (Upper (anadi), 1831, I, xxi, 82.

last summer (1834--less than three years before the rebellions in lower and Lper ('anada) another committee of the Housc of ('ommons entered upon an 
became self-governing; and the great responsibilities that were thrown by secretaries of state, with little supervision on their part, on permanent officials, ${ }^{1}$ who were known only by name to members of the House of Commons who had no special business to take them to the Colonial Office, officials, moreover, whose names even were not known in the colonies, because

investigation of the causes of Canadian discontent. But the committee confined their inquiries to the lower province, the Right Honourable E. G. Stanley (Colonial Secretary, March 1833 to June 1834, in the Grey Administration of 1830-1834) having, under great misapprehension, assured the House that the utmost harmony prevailed between the Lieutenant-Governor and the Council and Assembly of Upper Canada.' Ibid., p. 1.

Stanley's speech of April 15, 1834, in moving for the Lower Canada committee is not reported at length in the Parliamentary Debates. Cf. II, xxii, 818.

'The repeated changes caused by political events at home, having no connexion with colonial affairs, have left to most of the various representatives in the colonial department too little time to acquire even an elementary knowledge of the condition of those numerous and heterogeneous communities for which they have had both to administer and legislate.' Durham, Report, ii, p. 103.

'Molesworth's constant argument was : sweep away the uncontrolled power of the Colonial Office, "government by the misinformed with responsibility to the ignorant." Mrs. Fawcett, Life of Sir William Molesworth, pp. 265-270.

'The secretaries for the home and foreign departments live in the country whose interests they are to protect. . . . The secretary for the colonies lives at a distance, it may be of thousands of miles from the colony he is to govern. He is not necessarily a person who has resided, at some time, out of the mother country; and he cannot by any possibility be one who has resided in each of the colonies. $\mathrm{He}$ must, therefore, be a person ignorant in some degree, if not to a great degree, of the manners, customs, and peculiar ways of thinking of the inhabitants of such colony as well as of the social, municipal, and commercial requirements of the colony.' S. S. Bell, Colonial Administration of Great Britain, 1859, pp. 368369 .

1 ' The persons with whom the real management of these affairs has, or ought to have, rested have been the permanent but utterly irresponsible members of that office.' Durham, Report, ii, p. 103.

'What was deprecated was a system which placed in the hands of a group of officials, living in the artificial atmosphere of a public office, in the cen tre of the Empire, absolute control over the destinies of communities living in the natural atmosphere of an essentially different envrionment between the centre and the circumference.' Bruce, The Broadstone of Empire, i, pp. 198-199.

'The whole conduct of the Colonial Office was extremely reprehensible; for it was confided to the management of Mr. Hay, a clerk in that office. No matter who was secretary-Lord Goderich, Lord Stanley, or Mr. Spring-Rice-the whole of the colonial department was managed by Mr. Hay; and no justice could be expected so long as that person ruled the fate of the colonies.' Roebuck, House of Commons, April 2, 1835. Parliamentary Debates, III, xxvii, 653.

Cf. Francis Scott, House of Commons, April 16, 1849, loc. cit., civ, 321.

'The choice of a permanent under-secretary is, in my estimation, by far the most important function which it can devolve upon a secretary of state to exercise. The direct consequences of that one act extend far and wide through the whole colonial empire, and last in all probability for a long series of years. A bad appointment to this office is the deadliest blow that can be dealt to the colonial service, and a good one is the greatest blessing that can be bestowed upon it.'Henry Taylor (Colonial Office, 1824-1860), May 4, 1860. Autobiography of Sir Henry Taylor, 1800-1875, i, p. 159. 
to the dispatches which they framed only the name of the colonial secretary was appended.

5. The failure of the Colonial Office until as late as 1852 to devise any method by which the then existing six legislatures in the British North American provinces should be furnished regularly, and free of cost, with copies of the journals of the House of Commons and of the House of Lords, with the semiofficial reports of debates in Parliament and with copies of Acts passed by Parliament. ${ }^{1}$

6. The failure of the General Post Office in London, but at bottom really the failure of the Colonial Office and of Parliament at Westminster, to make any attempt earlier than the reduction of postage in 1839, and the introduction in 1840 of the system of postage on letters by weight instead of according to the number of sheets of paper constituting each letter, to provide regular, frequent, and inexpensive postal communication between the United Kingdom and the dominions oversea. ${ }^{2}$

1 As early as 1825 the cost to the British Exchequer of printing Bills and Acts of Parliament at Westminster, and Reports and other documents for the House of Commons and the House of Lords was $£ 80,000$ a year. At this time and for a long time after 1828 the Appropriation Acts of British North American colonies carried votes for paying for these documents; and as late as 1852 these essentials of political education in the colonies necessary to a right understanding, and an easy and orderly working of political institutions on the model of those at West. minster, were lacking at Charlottetown. In that year there was an Address from the legislature of Prince Fdward Island praying that the Governor would be pleased to "apply to the Imperial Government for various parliamentary journals and other works for the use of the legislature of this island.' Journals of the House of Assembly (Prince Edward Island), 1852, p. 171.

2 Until 1851 the postal service in all the British North American provinces was regulated by acts passed at Westminster in 1710 and 1765 . Deputy postmasters in these colonies were appointed by the Postmaster-General in London, and were responsible only to St. Martin's-le-Grand. In the years from 1822 to $1835, £ 91,865$ of surplus earnings of the post office of Upper Canada werc remitted to London. For the last four years of this period, the amounts so remitted from

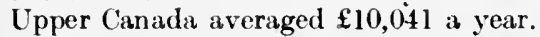

The practice under which these post office surpluses were remitted was denounced by a committee of the House of Assembly of Upper Canada in 1831 as a violation of the fundamental right of the people of the colony, and as an instance of the disregard of the Declaratory Act of 1778, which had cost Great Britain the loss of her American colonics, "now the flourishing and happy United States of America'.

The law officers of the (rown in London. Norember 5, 1832, held that the withdrawing of the surplus revenues of the post office in the provinces, and the covering of thesc sums into the British Treasury. were in contravention of the Act of 1778 ; and some years before St. Martin's-le-Grand in 1851 relinquished its control over the post offices of British North America, the illegal practice of remitting the surpluses to London came to an end.

so long as St. Martin's-le.Grand was in control a new postal route could not be established in any of the British North American provinces unless it was 
7. The failure of the Colonial Office, and again really the failure of Parliament, to establish and to maintain continuously any widely known and energetically conducted Government organization, ${ }^{1}$ completely dissociated from Irish

absolutely certain that it would at once pay its way. In these years it cost two shillings and eightpence to send a letter by post from Fredericton, New Brunswick, to London. A letter from England to Barrie, Upper Canada, was on its travels in the post office from June 12 to October 12. Stayner, Deputy Postmaster of Upper Canada, when the case of this Barrie letter was called to his attention, declared that he was well within the bounds in saying that at that time there were between two and three hundred communities in Upper Canada which, like Barrie, were suffering from lack of postal facilities, which he would be glad to furnish to them if it were within his power to do so.

It was not until 1855 that it was realized in Downing Street that the post office was a link of empire, or that the post office, the Colonial Office, the Government or Parliament had any responsibilities as regards postal communication with the hundreds of thousands of men and women who had emigrated from the United Kingdom to the colonies.

An attempt was made in 1855 to establish a much less expensive postal service to meet the needs of the British North American provinces and the Australasian colonies. It failed, so far as the British North American provinces were concerned, owing to disagreement between the United Provinces of Upper and Lower Canada and the Government in London concerning the conditions under which the mail service between Liverpool and ports of the United States and Canada was carried out by the Cunard Steamship Company, which at this time was in receipt of large mail subsidies from the British Government, and also from at least two of the Governments of the British North American provinces-Nova Scotia and the United Provinces. Cf. William Smith, History of the Post Office in British North America, pp. 132-135, 194-199, 284-294.

'In the report of the Commissioners of the Post Office (London) who held an inquiry in Canada, it was observed that no printed matter coming from England, except stamped newspapers, could pass through the post, unless charged by weight at the rate of letters exceeding one ounce. This, in the case of English reviews, magazines, and pamphlets, acted as a complete prohibition.'-Colebrook, Governor of New Brunswick, to Stanley, Colonial Secretary, Fredericton, July 20, 1843. Journal of Legislative Assembly (New Brunswick), May 4, 1846, p. 195.

1 From 1840 to 1873 there was a colonial land and emigration department as a subdivision of the Colonial Office. Cf. S. C. Johnson, A History of Emigration, p. 22.

"The emigration commissioners should come out of their long hiding-place in Park Street and be part of the colonial ministry. Nothing is more essentially a part of the work of that department than the superintendence, advertisement, and agency of emigration. The information which is crowded into a closelyprinted circular, issuing periodically for sale from those commissioners, might be distributed more widely and intelligibly by advertising frequently the few facts that are wanted through the newspapers; and their agencies throughout the country might be multiplied and made far more attractive than they are.' Adderley, Colonial Policy (1869), pp. 409-410.

There is a chapter in Grey's Colonial Policy of Lord John Russell detailing the work of the emigration commissioners - work which Adderley discusses in the foregoing paragraph from his study of colonial policy. Grey also explains the attitude of the Russell Administration of 1846-1852 toward emigration on a larger scale than that on which the emigration commissioners of 1840-1873 conducted their work. Cf. Grey, Colonial Policy, i, pp. 236-245. 
famine relief funds, and also from the central and local machinery and the dismal traditions and atmosphere of poor law administration and pauper taint ${ }^{1}$ for encouraging emigration to the colonies and for diverting the constantly swelling stream of emigration from the United Kingdom ${ }^{2}$ to the United States, to Canada and the Australasian colonies.

These were some of the manifestations of indifference to colonial possessions at Westminster, at Whitehall, and at St. Martin's-le-Grand, in the period from 1783 to 1859 . In the country at large, away from Parliament and the seat of the Government of the Empire, some of the manifestations of popular indifference to colonies were :

8. The little attention devoted by newspapers in London and in the cities and towns of provincial England to the colonies and their political and material development; the indifference to colonial possessions expressed on the editorial pages of the newspapers; the infrequency with which articles on the colonies and their political civilization were printed in reviews and magazines; the infrequency also with which books descriptive of the colonies, or discussing colonial problems, were issued from the publishing houses of London and Edinburgh; the little attention bestowed on the colonies in general histories of England, and resulting from the indifference or neglect of the press, the consequent popular ignorance in regard to the colonies. ${ }^{3}$

1 Cf. Carnarvon, Speeches on Canadian Affairs, pp. 318-320. "As we have rid emigration of the stigma of transportation, so we must rid it of all connexion with poor rates.' Adderley, Colonial Policy, p. 411.

2 In 1815 there were 1,200 emigrants from the United Kingdom to the United States; in 1825, 5,500; in 1845, 29,000; in 1855, 103,000; in 1865, 147,000, and in 1875, 103,000. Cf. Stanley C. Johnson, $A$ History of Emigration from the United Kingdom to North America, 1763-1912, pp. 344-345.

3 An item of news from the British North American provinces in the years from 1791 to 1859 , except at such times as the rebellion of 1837 , the annexation movement in Upper and Iower Canada of 1849-1851, or the Cayley and Galt tariffs of 1858 and 1859, was as rare in English newspapers as is an item of news from Scotland, except at election times, in the London newspapers of the twentieth century.

Three days before the day appointed for the second reading of the first Reform Bill of 1831, the Grey Government was defeated in the House of Commons on a Bill for increasing the duties on timber imported from the British North American provinces-a Bill which had encountered strong opposition from the shipping interests in the North Atlantic trade. 'Canada', said The Times, in its comments on the crisis," is a respectable colony, and the shipowners are a respectable body. But the British nation would rather see the Canadas swept for ever from the map of the Western world, with all the shipowners dangling from its red and yellow pines, than suffer this grand measure of parliamentary regeneration to be lost.' Cf. Edward Herries, Memoir of John Charles Herries, ii, p. 130. 


\section{The preference for the United States by emigrants from the United Kingdom, ${ }^{1}$ especially by those who commanded a little}

The leaders of the annexation movement of 1849-1851 emphasized the indifference of the press of England and Scotland as to whether Upper and Lower Canada should cut loose from Great Britain and throw in their fortunes with the United States. Cf. Allin and Jones, Annexation, Preferential Trade, and Reciprocity, pp. $162,173$.

In 1859 Sidney Smith Bell, a member of Lincoln's Inn, and a judge of the Supreme Court at Cape Town, in an exceedingly frank discussion of colonial administration, noted the fact that in England there was no public press to voice the opinions and make known the grievances of the colonies. Bell, Colonial Administration of Great Britain, p. 269.

There were before 1826 no articles discussing government in the colonies or the colonial policy of Great Britain in reviews or magazines published in London and Edinburgh. The number of pamphlets discussing these subjects in the century from 1780 to 1880 was sixty-one. The number of books discussing these subjects, issued from the press in the period from the American Revolution to the Confedera tion of the British North American provinces in 1867, was twenty.five. Cf. James R. Boise, librarian of the Royal Colonial Institute, London, Titles of Publications Relating to British Colonies, Their Government, \&c., in Connexion with Imperial Policy, pp. 16-17.

'The people of the mother country are necessarily uninterested and unacquainted with the affairs of their remote dependencies. Therefore, it was only in extraordinary occasions that public attention could be diverted from matters of nearer interest to colonial concerns.' Molesworth, House of Commons, January 23, 1838. Parliamentary Debates, III, xl, 385.

' The committee, of course, cannot suppose that the British Government share the ignorance with regard to the history and character of the federal scheme which appears to prevail among the British public-an ignorance which induces The Times of June 20, 1865, to observe " the two Canadas have put aside their ancient jealousies, and are ready to meet in a common legislature", in apparent forgetfulness of the fact that they have so met for the last five and twenty years (since 1841), and very probably without any consciousness on the part of the writer of the article, that the jealousies between the Canadas, said to have been put aside, are avowedly the cause of the late proposal, and that its authors, in the event of its failure, are pledged to restore to Upper and Lower Canada a great measure of the local independence surrendered by them in 1840.' Report of Committee of Executive Council of New Brunswisk, on Confederation, July 12, 1865, reprinted in the Journals of Legislative Assembly of Canada, September 7, 1865 , p. 164.

"We colonists have frequently had great cause to complain of the little knowledge possessed by the English press, the English people, and by English rulers of our real condition. We have frequently to accept backhanded compliments with a smile and a bow, because we know the bestowers are well intentioned toward us. It is not a little mortifying to our colonial pride that such profound ignorance on Canadian matters should be manifested by them. It is perfectly plain they know nothing whatever about us.' Globe (Toronto), February 6, 1861.

' It is rather unedifying to Canadian readers of British papers to witness the little knowledge manifested therein of our efforts in general and of our climate in particular. The old folks at home evidently think that we live in regions of perpetual snow and ice, no one daring to step out of doors without first en veloping himself in as many furs, blankets, and rugs as he can with the greatest exertion manage to carry. They seem to believe that about one-half of our population have lost their noses, and the other half their toes, through frost-bite.' Ibid., January $16,1862$.

1 'A quarter of a million of emigrants now quit the shores of the United 
money, and eould go where they ehose, to Canada, or Australia, or New Zealand ; and the large number of emigrants who left the United Kingdom with Canada as their intended destination, but who soon made their way across the line from Upper or Lower Canada into the United States, and were lost as factors in British eolonization. ${ }^{1}$

\section{CHAPTER IV}

\section{WILLINGNESS OF BRITISH STATESMEN TO ABANDON COLONIES, 1827-1852}

A воок could be written on almost every one of the forms in whieh indifference to the colonies in the period from 1783 to 1859 manifested itself at Whitehall, at St. Stephens, and in England generally - the forms deseribed in the last chapter. Especially is this true of the unwillingness of British statesmen to acquire additional territory, and of their willingness at times to let go territory already held; of the attitude of Parliament toward legislation for the eolonies, toward eolonial questions, and also toward the retention of the colonies.

It is also true of the laek at the Colonial Office, and in Downing Street, except for the propaganda for a fiseal system based on free trade, of any definite and continuous eolonial policy, until the colonies now of the dominions resolutely and firmly took matters in their own hands, pressed to complete success their demands for self-government, and as a eorollary to this success insisted on adopting their own fiscal and economic policies, regardless of the established fiscal policy of the United Kingdom.'

Kingdom yearly. But the great majority of them find a place of rest not in the colonies, which we maintain at a heavy eost, but in those which were once ours, and cost us nothing.' The Exuminer (London), May 19, 1869.

1 It was 196,7 before the number of British emigrants, sailing for Canada or for the Australasian colonies, exeeeded the number of emigrants leaving the [nited Kingdom for the United States. The figures for 1907 were : Canada, 151.216; Australasian colonies, 24,767; total. 175,983. The number of emigrants to the United States in 1907 was 170.264. The increase in emigration to C'anadia was dne to the long eontinued and vigorous immigration propaganda that was conducted by the Dominion Government from 1898 to 1914. a propagandia on which in the years from 1878 to $1914-1915$, $\$ 1.859,000$ were expended. ('f. S. C. Johnson. op. cit.. 1. 346; Porritt. Evolution of the Dominion of 'anada. p. 47 !

${ }_{2}$ "The dominions successively acquirc self-government and used their fiscal independence in the spirit of the teaching of Alexander Hamilton. in an effort to 
The colonial policy of the British Empire of the period from 1840 to 1873 , so far as it concerned colonies now of the dominions, originated and was formulated and framed not in Downing Street, nor at Westminster. It originated chiefly, though not entirely, at Toronto, at Montreal, at Kingston, or at Quebec, and was formulated in the days when Upper and Lower Canada had no permanently established political capital. It originated partly at Halifax and St. John in the Maritime Provinces, and partly at Sydney, Melbourne, Hobart Town, Adelaide, and Wellington, the capitals of the Australasian colonies.

Reformers at these colonial capitals in the period from 1840 to 1873 , working in groups hundreds of miles apart from each other, and usually with little or no intercourse or communication, or active or continuous political association, devised and framed the colonial policy of Great Britain in the nineteenth century; and willy-nilly the Colonial Office was compelled to accept this policy. Parliament at Westminster, whenever it was necessary, was, moreover, compelled to stamp this policy with its legislative sanction, if not in every case with its cordial approval.

Only in barest outline has it been possible within the limits of this history of the fiscal freedom of the dominions to give illustrations of all of these manifestations of indifference to colonial possessions of the era of 1783-1859. Only in regard to two of them-11) the willingness of statesmen at Westminster to consider the abandonment of possessions already held, and their indifference to colonial expansion, and (2) the attitude of Parliament toward colonies, its indifference and its neglectis it possible to go into a little more detail.

The earliest evidences of willingness of Cabinet Ministers to shed outlying colonies is of the year 1827. Until April of that year the Liverpool Administration ${ }^{1}$ was in power; and in this administration in its closing months Wellington was master of ordnance; Huskisson was at the Board of Trade, and Herries

make their composite and self-contained states symmetrical and not lopsided societies of various enterprises and multitudinous activity, furnishing scope for that diversity of talents and dispositions which discriminate men from each other. In other words, they sought revenue and encouragement of manufacturing industries by imposing protective duties against all countries, including the United Kingdon.' Address by Alfred Lyttelton (Colonial Secretary 1903-1905), on the Empire. Reprinted in W. J. Ashley's British Dominions, Their Present Commercial and Industrial Condition, pp. 10-11.

1 Junc 1812 to April 1827. 
was Secretary to the Treasury. Retrenchment in public expenditure was imperative in the winter of 1826-1827, and to this end Wellington suggested the abandonment by Great Britain of the whole of the coast of Guinea. Huskisson unqualifiedly endorsed Wellington's suggestion for the abandonment of this remote territory.

'I quite agreed ', wrote Huskisson, ' with the Duke of Wellington that the whole of the coast of Guinea ought to be abandoned, and $I$ am prepared to say the same of Sierra Leone. They involve a great deal of expense, without answering the purposes for which we now propose to retain these possessions.' Herries was in agreement with both suggestions. ${ }^{1}$ The Liverpool Administration, however, came to an end in April 1827; and the Gold Coast and Sierra Leone are to-day on the Colonial Office list.

It has often been suggested, sometimes even asserted, that averseness to colonial expansion in the nineteenth century was a characteristic peculiar to men of one political school of thought -to men of the Liberal or Radical parties. ${ }^{2}$ The fact is that indifference to colonial possessions, willingness to abandon possessions already held and unwillingness to acquire new territory were common to Tories and Whigs, Conservatives and Liberals and Radicals, from the end of the long war with France to the new attitude of the statesmen and politicians and people of Great Britain toward the Empire that can be dated from 1887.

Wellington in 1828 was anxious to turn the island of Ceylon over to the East India Company, in order to save taxpayers in the United Kingdom $£ 100,000$ or $£ 150,000$ a year $;^{3}$ and only six or seven years after the Melbourne Government of 1835-1841 had refused in 1836 to ratify D'Urban's extension of the boundaries of Cape Colony to the Kei River, ${ }^{4}$ Peel discussed at length with Aberdeen (May 16, 1842), who was secretary for Foreign Affairs in Peel's Administration of 1841-1846, the desirability, in certain contingencies, of letting go Upper and Lower Canada.

'Let us', Peel wrote to Aberdecn, 'keep Nova Scotia and New Brunswick, for their geographical position makes their

1 Cf. E. Herries, Memoir of J. C. Herries, i, pp. 145-146.

2 Cf. W. H. Woodward, A Short History of the Expansion of the British Empire, 1506 to 1870 , p. 284 ; Monypenny and Buckle, Life of Disraeli, iii, p. 386; Bernard Holland, The Fall of Protection, 1840-1850, pp. 31 I-314.

3 (f. Lord Ellenborough, A Political Diary, 1828-1830, ii, pp. 184-212.

4 Cf. Woodward, Expansion of the British Empire, p. 284. 
sea coast of great importance to us. But the connexion with the Canadas against their will, ${ }^{1}$ nay, without the cordial co-operation of the predominant party in Canada, ${ }^{2}$ is a very onerous one. The sooner we have a distinct understanding on that head the better. The advantage of commercial intercourse is all on the side of the colony, ${ }^{3}$ or at least, not in favour of the mother country.'

'Let us,' continued Peel, in this letter of May 16, 1842a letter partly concerned with the Maine boundary dispute, which was giving the Foreign Office much trouble and worry at this time-let us fight to the last for the point of honour, if the people are with us. In that case we can not abandon them. But if they are not with us, or if they will not cordially support and sustain those measures which we consider necessary for their good government, and for the maintenance of a safe connexion with them, ${ }^{4}$ let us have a friendly separation while there is yet time, rather than recommence a system of bickering and squabbling on petty points, the result of which will be increasing ill-humour and alienation on their part, and ultimately the necessity of our vindicating British honour with Canadian feeling adverse to us, the war at the door of the United States, and three or four thousand miles from our shores.' 5

With the settlement of the Oregon boundary dispute in 1846, Great Britain was confirmed in the possession of Vancouver Island, off the coast of British Columbia. Gold was discovered in California in 1848; and in the same year Oregon, the State lying to the north of California, and between California and British Columbia, was organized as a territory of the American Republic.

A civil government and some systematic colonization on

1 At this time Bagot, the Governor-General, was confronted with the demand for responsible government, a demand that had been to a large extent conceded by Sydenham, Bagot's predecessor.

2 The party led by Baldwin and La Fontaine which, in 1842 and until the erises over the Rebellion Losses Act of 1849 , was continuously pressing for responsible government.

3 The old commercial system was operative in 1842 . Under it there were concessions in the tariff of the United Kingdom in favour of lumber, grain, and flour from all the British North American provinces.

4 Peel's Administration supported Metcalfe, Bagot's successor, in his efforts to withdraw the concession of responsible government, as responsible government was understood by Baldwin and La Fontaine and the Liberals of Upper and Lower Canada.

5 Parker, Sir Robert Peel, iii, pp. 388-389. 
Vancouver Island were at this juncture regarded in Downing Street as immediately necessary. The only plan that commended itself to Grey, or that his ingenuity could devise, was to force the Government and the colonization of the island on the Hudson Bay Company. ${ }^{1}$

The Hudson Bay Company had asked of the Colonial Office and of the Russell Government of 1846-1852 only a lease of lands in the southern part of the island. Neither civil government, as it was understood in British colonies - either Crown colonies or self-governing colonies-nor colonization had at any time from 1670, when it obtained its charter from Charles II, been of the functions of the Bay Company. No dividends could accrue from the administration of civil government; and colonization had hitherto been the last activity to which the Hudson Bay Company cared to turn its attention.

Gladstone, Hume and Goulburn protested against Grey's plan for the settlement and government of Vancouver Island. In the division lobby fifty-eight members supported Hume's motion against the charter. There were protests also in the House of Lords against this farming out of civil government and colonization-against a plan that was similar to the plan Wellington proposed for Ceylon in 1828. But the great seal was duly affixed to the charter soon after these protests in Parliament of 1848 ; and from 1851 to 1859 the Hudson Bay Company's chief factor at Victoria was also Governor of Vancouver Island. ${ }^{2}$

Sir George Cornewall Lewis, who was at this time, 1848, a member of the House of Commons, and Parliamentary Secretary for the Department of State for Home Affairs, and who subsequently held the offices of Chancellor of the Exchequer, 1855-1858, Home Secretary, 1859-1861, and Secretary for War, 1861-1863, in Whig Administrations, in a letter to Edmund Walker Head, then Governor of New Brunswick-an intimate personal letterdescribed Gladstone's vigorous and carefully prepared protest, and the spirit in which it was received by the House of Commons.

Lewis's letter has a value quite apart from the Gladstone and Hume protest against farmed-out colonial government; for it

1 (ff. speech by Gladstone against the Hudson Bay Charter of 1848, House of Commons, August 18, 1848, Parliamentary Debates, Ill, ei, 268-272.

2 Cf. Alexander Begg, History of British Columbia, p. 11; R. E. Gosnell, Year Book of British Columbia, 1911, pp. 34-35. 
is another proof of the indifference of 1783-1859 to colonial possessions, indifference not merely popular, or confined to the rank and file of members of the House of Commons, but of men in high and responsible positions at Westminster, and men of prominence in parliamentary history.

'Gladstone,' wrote Lewis (September 28, 1848), who, ten or eleven years earlier, had declared himself incapable of realizing ' what possible advantages England derives from the possession of Canada,' ' 'Gladstone made a very able speech against the Colonial Office arrangement relative to Vancouver Island. The feeling in the House, so far as there was one, on the subject, went, I think, with him. For my own part, I cannot see what advantage we could gain from a new settlement in this remote region, six months' sail from England and far distant from any of our foreign possessions ; for practically it is in a different world from our provinces on the western coast of North America. ${ }^{2}$ If any people can colonize it with advantage, it must be the Americans.' 3

Cornewall Lewis was of the Whig party ; and it was in discussing one aspect of the colonial policy of the Whig Government that he expressed himself in regard to Vancouver Island. Four years later, 1852, the Conservative party was in power. Derby was Premier; the Earl of Malmesbury was at the Foreign Office; Pakington was Secretary for the Colonies, and Disraeli was Chancellor of the Exchequer.

The new Government had come into office in February 1852. In July and August Malmesbury was troubled by what threatened to be a serious friction with the United States over the claims of New England fishermen under the convention of 1818 in respect of their rights to the fisheries off the coast of what are now the Maritime Provinces of the Dominion of Canada ; and in particular over a circular dispatch which Pakington had written to the Governors of the Maritime Provinces.

It was at this juncture that Disraeli coined and used the phrase, ' these wretched colonies,' that often was quoted against him by political opponents, and that as long after 1852 as 1914

1 G. F. Lewis, Letters of Sir George Cornewall Lewis, p. 88.

2 Lewis italicized the word 'western'. Apparently he regarded the Great Lakes as the western coast of the British provinces in North America.

${ }^{3}$ Lewis, op. cit., pp. 184-185. 
constituted a small problem for his biographers.' 'This fisheries affair', Disraeli wrote to Malmesbury," 'is a bad business. Pakington's circular is not written with a thorough knowledge of the circumstances. He is out of his depth, more than three marine miles from the shore. These wretched colonies will all be independent too, in a few years, and are a millstone round our necks.' 3

Neither in memoirs of statesmen who were of the Cabinet: nor in speeches in Parliament of men who were in office or who had been in office -in none of these sources of history from 1783 to 1859 -is willingness to let go territory already held more clearly expressed than in the letters of Wellington, Huskisson, Herries, and Peel. All four were of the Tory party. ${ }^{4}$ All four were of Tory or Conservative Governments. Wellington and Peel were Premiers of Tory Administrations. But, as has already been emphasized, and as is obvious in Cornewall Lewis's letter of 1848 and in Disraeli's outburst of 1852 , in the period from the American Revolution to the next two disturbing colonial episodes-the rebellion in Canada in 1837, and Galt's tariff of 1859-indifference to colonial possessions and indifference whether colonies remained in the Empire or went out, were characteristic of all political parties. They did not characterize all men in all political parties, but they did eharacterize many leading men in all parties.

These letters of 1827-1828, of 1842 , of 1848 , and of $1852-$ these discussions of colonial possessions by Wellington, Huskisson, Herries, Peel, and Lewis-like Disraeli's well-remembered and

1 "The petulant outburst about the "wretehed eolonies" obviously inspired by the irritation of the moment, and seribbled in eonfidence to a Cabinet eolleague, has sometimes been taken as an indieation of Disraeli's real sentiments about the Empire. This superfieial view is suffieiently disproved by the eorrespondenee with Derby in the previous autumn. in which Disraeli urged the advisability of eolonial representation in the British Parliament, as well as by all his speeehes on colonial affairs. He did. indeed, fear for a moment, as he eonfessed in 1872 , that the radieal poliey of eneouraging the eolonies to set up for themselves might be suceessful; but his own efforts were throughout directed to strengthening the bonds of Empire.' Monypeny and Buckle. Life of Disraeli, iii, p. 386.

2 From Hughenden, his eountry home in Buckinghamshire, August 13, 1852.

3 Ibid., p. 385.

4 . John IVilson Croker. for many years in the first half of the nineteenth eentury an exponent of Conservative principles in the House of Commons, in the Quarterly Rerieu and elsewhere in the press, was doubtful in 18.53 of the value of the eolonial comnexion. He asked Herries for papers embodying data as to the military and naval expenses of Great Britan in comnexion with the eolonies. 'My object,' he wrote on August 15, 1853. "is to examine what colonies ean be worth over which wo have no control.' Herries. Hemoir of J. C. Herries, ii, pl. 278-279. 
often quoted letter of 1852 , have another value. They throw light on the reasons for this widespread and long-continued indifference to extension of empire, indifference even to holding territory that was of the Empire, territory which in these years, save for the American desire of 1783-1871 to possess the whole of the North American continent, no other nation claimed or coveted.

Wellington, Huskisson, and Herries were willing to let three colonial possessions go in order that Great Britain might be relieved of the financial burden of holding them. Peel was willing that Upper and Lower Canada should separate from Great Britain, with the certain loss of the command of the St. Lawrence and of the Gulf of St. Lawrence, and the almost inevitable consequent loss of all the territory westward from the Great Lakes to the Pacific Ocean, for other than financial reasons.

Peel was aware that the rebellions of 1837 had cost British taxpayers three million pounds; but as his letter to Aberdeen plainly shows, he was also weary of the contest between the Colonial Office on the one hand, and Baldwin and La Fontaine and the Radicals of the Canadas on the other, over responsible government. He was willing, moreover, as were many other statesmen and politicians at Westminster of this period, to be relieved of the risk of war with the United States, a risk that from the end of the war of 1812-1814 to the Civil War of 18611865 arose almost exclusively out of friction originating in the British North American provinces.

Grey devised the plan of farming out civil government and colonization on Vancouver Island because it involved less trouble for the Colonial Office, and less expense for Great Britain, than the establishment of even Crown colony rule at Victoria. Cornewall Lewis was willing to cede Vancouver Island to the United States because he had no enthusiasm for widely scattered empire ; and also because he conceived that as there was already State government in California and territorial government in Oregon, the colonization and development of Vancouver Island could be managed morc advantageously from Washington than from London. 


\section{CHAPTER V}

\section{LEGISLATION FOR COLONIES AND COLONIAL QUESTIONS}

IT has never been affirmed by any historian of the Empire, or by any historian of the Imperial Parliament, its functions and its work, that in this period from 1783 to 1859 either the Colonial Office or Parliament understood the colonies that are now of the dominions. There is testimony that they did not; proof in abundance that Parliament and the Colonial Office were negligent of the colonies; and much proof that members of Parliament were impatient or indifferent when colonial secretaries or colonial reformers sought the attention of Parliament with a view to action. ${ }^{1}$

As long as it was possible for commercial interests to purchase or hire a parliamentary borough, or purchase or hire the privilege of nominating a candidate to a perfectly safe seat, West Indian

1 'It cannot be said during the first of these periods, 1794-1848, that colonial affairs were much understood by either the Colonial Office or by Parliament.' Arthur P. Poley, The Federal Systems of the United States and the British Empire, p. 162 .

"The constitution under which the (anadas arc now governed was devised and introduced by some of the greatest statesmen who ever appeared within these walls. But when we consider how littlc the country in question was then known, and to what a limited extent its resources and interests were understood, it will not appear matter of astonishment that under such circumstances the system devised for its government should have been extremely defective.'Huskisson, House of Commons, May 28, 1828. Parliamentary Debates, II, xix, 300.

' Up to the year 1831 the attention of this country had not bcen sufficiently directed to the colonies; and in the Canadas many things had been allowed to grow up which required correction.'-Gladstone, House of Commons, March 8, 1837. Ibid., III, xxxvii, 103.

'He did not profess to be very abundantly versed in colonial affairs.'-Peel, House of Commons, April 21, 1837. Ibid., III, xxxviii, 205.

"Little as the Colonial Office may know of the state of our colonies, it is the only part of our government which does know anything about them. Parliament is as ignorant as it is indifferent.'-Cornewall Lewis to John Austin, December 2, 1839. G. F. Lewis, Letters of George Cornewall Lewis, p. 104.

'Look at the map, with our possessions dotted or sprawling over the globe, and compare their demands with the capabilities of that dingy small building in Downing Street, with five supcriors and sixteen clerks therein. Many a union workhouse has a stronger administrative machinery.' The Examiner (London), April 21, 1849.

"The Secretary of State sometimes did not even know the names of the colonics whose destiny lay in his hands.' .J. S. Cotton and E. J. Payne, Colonies and Dependencies, p. 104. 
planters, with their exporting and importing interests to protect, were never for long without an agent in the House of Commons. Charles Rose Ellis, for nearly a quarter of a century between 1793 and his elevation to the peerage as Lord Seaford in 1826 successively the representative of three boroughs that were always on the market on the eve of an election, was for this long period the parliamentary watchdog of the tariff and other interests of the sugar planters of the West Indies. ${ }^{1}$

Representation at Westminster, secured as the West Indian planters secured a seat for their political and parliamentary agent, did suggest itself to reformers in Upper and Lower Canada. But from the beginning of the reign of George III to the reform of the electoral system in 1832, nominations that were for sale commanded increasingly high prices. In the years from the general election of 1807 to 1832 , from five to six thousand pounds was the ordinary price of a seat purchased for the lifetime of a Parliament; while for a seat rented by the year the price was eighteen hundred pounds. ${ }^{2}$

These prices for nominations to the House of Commons were beyond the means of reformers in the colonies; and except that Roebuck, then Member for Bath, acted as the agent in London of Lower Canada in 1835-1837, none of the self-governing colonies was ever represented in the House of Commons, nor were their interests watched at the Departments of State at Whitehall, as were the interests of the West India colonies from 1793 to 1826.

Had each of the British North American provinces of the years from 1783 to 1859 sent one accredited representative to the House of Commons ; had there been in these years a system similar to that at Washington under which territories not organized as States send delegates to the House of Representatives -delegates who have the right to address the House, but not the right to vote-it is not conceivable that such delegates could have aroused continuous interest in colonial measures and colonial questions. ${ }^{3}$

1 Cf. Dictionary of National Biography, xvii, p. 274.

'It was now more requisite to look to the interests of our colonies since the alteration of the representation by the Reform Act, because the Reform Act rendered it impossible for the colonies to obtain representation by sending a certain sum of money, and thus purchasing a seat in that house.'-Robert Wallace, House of Commons, August 1, 1834. Parliamentary Debates, III, xxv, 891. $\quad{ }^{2}$ Cf. Porritt, Unreformed House of Commons, i, p. 308.

3 S. S. Bell, Colonial Administrations of Great Britain, p. 173.

1569.29 
There were always men in the House of Commons-men who were not of the Treasury or the front opposition benches-men such as Mackintosh, Roebuck, Hume, Warburton, Francis Scott, Grote, Molesworth, Buller, and Adderley, to name only a few -who were ever ready to work for the improvement of the political civilization of the colonies now of the dominions, to help these colonies onward to the status of self-governing nations that they reached by their own continuous exertions in the years from 1840 to $1859 .{ }^{1}$

The constituencies of Great Britain or of the United Kingdom were not interested. They were necessarily uninterested and unacquainted with the affairs of the colonies. 'It was only on extraordinary occasions that public attention could be directed from matters of nearer interest to colonial concerns.' 2

It consequently followed that between 1832 and 1867 , years in which new and closer relations developed between members and constituencies, and the attitude of constituencies became of concern to members who desired to retain their seats, the House of Commons became less and less interested in colonial questions.

Appeals like that of Sir James Mackintosh of 1822 were of little avail. Maekintosh complained that a bill for the union of Upper and Lower Canada - a bill concerning which the people of these provinces had not been consulted, and a bill, moreover, that aroused fierce opposition in Lower Canada-had been introdueed at the fag-end of the session, ${ }^{3}$ and in a house in which not more than forty or fifty members were in attendance. ${ }^{4}$

'If sueh a measure were to pass under such circumstanees, what seeurity', asked Mackintosh, 'would any of our eolonies have that their legislatures might not be taken away from them by surprise? Was it to be tolerated without eonsulting the legislatures of Canada?'

1 'Among sueh members there may be found some to advoeate the interests of a eomplaining eolony. But what is the body to whom sueh an advoeacy is to be addressed ? What interest has a Yorkshire fox-hunting squire, an admiral in Her Majesty's navy, or a lawyer in Lincoln's Inn, what interest can such members of the House of Commons take in the Iocal affairs of Australia or New Zealand.' Ibid.

2 Molesworth, House of Commons, January 23, 1838. Parliamentary Debretes, III, xl, 359.

3 July 22. The session ended on August 6, 1822.

- An important instruction moved by Ellice was defeated, 48 to 14. Partia. mentary Debates, July 22. 1822, II, vii, i714. 
'Colonists', continued Mackintosh, who was one of the earliest advocates at Westminster of responsible government for the colonies, ${ }^{1}$ ' had a claim to a more than ordinary share of attention of the House. They had no representatives of their own in it; and they could not, as colonists, have any legal representation. But that was a stronger reason why they should have a moral representation.' 2

Even Cabinet Ministers, for whom Government whips always keep a House, realized that they would have difficulty in holding the attention of members when they were compelled to submit a colonial measure. In beginning a speech on a bill for a colony, the minister in charge usually apologized, and also usually embodied in his apology the apparently welcome intimation that all unessential details were to be omitted, in order to save the time of the House.

'The subject to which I wish to call the attention of the House ', said Huskisson, Colonial Secretary in the Wellington Administration of 1827-1828, when he stood at the table on May 2, 1828, to ask for the appointment of a select committee to inquire into the state of civil government in Lower Canada under the constitution of 1791, 'is one which, however it may bear on the interests and feelings in a great degree removed from those which ordinarily affect ourselves, is nevertheless a matter of considerable importance.' 3

Huskisson at the time he offered this apology for troubling members with a matter so remote as the civil government of Canada, was addressing the unreformed House of Commons. After the reform of 1832, which infused a new life and a new spirit into the politics of the United Kingdom and gradually imparted a new meaning to political life in the British Isles, these apologies from the Treasury bench in the House of Commons or from the Government bench in the House of Lords-apologies for troubling members with the details of colonial legislationcontinued to be regarded by ministers as necessary and in order. Lord Glenelg, who was Secretary for the Colonies in the Melbourne Administration of 1835-1841, introduced to the House of Lords on May 9, 1837, Russell's ten resolutions defining the policy of the Government in regard to the demands of Papineau and his

1 Cf. ibid., July 18, 1822, II, vii, 1703.

3 Ibid. (House of Commons), II, xix, 301-302.

2 Ibid., 1705. 
supporters of the majority in the House of Assembly in Lower Canada. ${ }^{1}$

These were the resolutions that precipitated the rebellion of 1837. Comparatively few members were present in the Lords; and the Colonial Secretary was aware that thin attendance and the lack of sustained interest had characterized some of the sittings of the House of Commons, at which the resolutions had been discussed and voted upon. ${ }^{2}$

Glenelg, accordingly, when he rose to introduce the resolutions, when he faced the rows of empty benches in the chamber of the peers, prefaced his speech with the customary, and apparently expected, apology. 'In offering his remarks upon the motion', reads the report of the speech of the Colonial Secretary, ' he must bespeak their kind indulgence, because he was afraid the subject in itself, consisting as it did of various dry details, was not calculated to be interesting.' 3

There was a meagre attendance of peers when Glenelg, in these apologetic terms, besought the attention of the House to the Russell resolutions. Only five members discussed them $;^{4}$ and there was a protest from Brougham entered on the journals against a colonial policy of such importance being indorsed by so small a House.

Brougham exercised a peer's right, and protested because the

1 From a parliamentary point of view these resolutions eonstituted a govern. ment measure. But on MIarch 8, when they were before the House of Commons, there was a narrow escape for the Government from a count out. Stanley, who by this time was no longer a Whig, and was aeting with the Tory party, later in the evening explained the eircumstances under which the attempt to eount out the House was made by Roebuek, who, as an advocate of responsible government, was hostile to Russell's resolutions and to the denial of responsible government that was embodied in them. 'He came down to the House', reads the report of Stanley's explanation, "at a quarter before five. On his road he met shoals of members coming away. On asking them whether the House was up, the answer was, " No, but Hume is ".' Ibid., III, xxxvii, 87, 112.

"A common toast of reporters at social meetings was " Joseph Hume getting up and George Canning sitting down ". The meaning was that the reporter who had to report Hume so abridged his task that a quarter of an hour's subsequent work was all that was required of him; while to have an hour of Camming implied three or four hours' toil at the office.' Samuel Carter Hall, Retrospect of a Long Life, i, p. 113.

${ }_{2}$ : When the resolutions were first brought forward, they were considered in a full House ; and this of course would have its effect in the colony. If, however. they were agreed to in a House like the present, when not one-fift hof the inember's were there, they would have little influence in Lower Canada. - Robinson, House of ('ommons. April 14, 1837. Parliamentary Debates, III, xxxvii, 1253.

3 Ibid. (House of Lords). May 9, 1837, III, xxxviii. 707.

t Cilenelg, Brougham. Ripon. Wellington, and Aberdeen. 
resolutions embracing ' a great variety of important subjects upon which different opinions may be entertained by the same persons, were all put to a vote at once, in a House consisting of not a tenth part of the members that frequently attend when questions affecting the interests of political parties, or even individuals, stand for discussion.' 1

As a speaker the fame of Stanley, afterwards Earl of Derby, was a tradition at Westminster to the end of the nineteenth century. But his reputation among his Parliamentary contemporaries, great as it was, ${ }^{2}$ was not sufficient to hold the attention of the House of Commons when colonial questions, other than tariffs for the colonies, or preferences in British tariffs for the colonies, were his theme. The order paper for May 22, 1842, carried two colonial items - a bill for a new constitution for Newfoundland, and a bill for a constitution for Van Diemen's Land, now the state of Tasmania in the Commonwealth of Australia.

The House emptied as soon as the Colonial Secretary began to explain the Newfoundland bill. 'Lord Stanley', reads the report in the Parliamentary Debates, ${ }^{3}$ ' rose to ask leave to bring in a bill for the better government of Newfoundland. Although it might not excite much interest he could assure the House that this was a subject of considerable importance. [Interruption caused by members leaving.] He knew it was impossible to ask the patience of the House, and he was quite ready, if the House thought proper, to ask leave to introduce the measure without saying a single word. But if they wished he should explain the object of the bill, he hoped they would at least allow him to hear what he was saying.'

In the next administration, the Russell Government of 18461852, Sir Benjamin Hawes, the first man of the manufacturing class to hold office in a Whig Ministry, was parliamentary Under Secretary for the Colonies, and Grey's colleague at the Colonial Office. Hawes, who had little of Stanley's ability as a speaker or as a parliamentarian, and none of Stanley's social prestige, ${ }^{4}$

1 Parliamentary Debates (House of Lords), May 9, 1837, III, xxxviii, 748.

Five sittings of the House of Commons were occupied with the resolutions. There was a vote on each of the ten resolutions.

2 'Stanley was a man of nearly the highest powers of oratory.' George Saints. bury, The Earl of Derby, p. 197. 3 Parliamentary Debates, III, Ixiii, 875.

4 'It is certainly a defect that the Colonial Secretary should not be in the House 
had an exactly similar experience to that of Stanley in 1842, when on April 16, 1849, he began his speech in opposition to a motion for a select committee to inquire into the possibility of reducing the charges of the colonies on the British exchequer, and of enlarging the functions of the Colonial Office.

'The House, I am sorry to see,' said the Under Secretary, ' does not appear to take that interest in this important question which I, for one, should desire.' To this report was added a note in parenthesis by the shorthand writer in the press gallery. 'At the time', it reads, 'there were scarcely forty members present,' 1 a brief note, but meaning much, when it is recalled that there was to be a division on the motion, and that it was the duty of the Government whips to keep a House.

Hawes had expected that the whips would keep a House and prevent a count out, at least until he had answered the criticisms that the momber responsible for the motion and his supporters had passed on the department of which Hawes was the representative in the House of Commons.

Either at the beginning or end of a speech on a colonial bill from the Treasury bench in the House of Commons, or from the ministerial bench in the House of Lords, it was regarded as due to the House to apologize for troubling it with a colonial subject; and if a minister or an ex-minister held a House, and held its attention to the end of lis speech, he was even more than ordinarily profuse in expressing his gratitude for the attention bestowed on him. ${ }^{2}$

Many of the divisions on colonial bills afford an indication of the indifference of members of the House of Commons to legislation affecting the colonies-sometimes affecting the colonies most seriously. Only sixty-two members roted in a division on a crucial amendment to the bill of 1822 , a bill that was subsequently abandoned by the Liverpool Administration of 18121827 , for a union of the provinces of Upper and Lower Canada

of Commons. The Under Secretary (Hawes) does not speak with sufficient authority:-Cornewall Lewis to Head, August 6, 1848. G. F. Lewis, Letters of George C'ornewall Lewis, p. 181.

1 Parliamentary Debates, 1II. civ, 335. Forty members have constituted a quorum of the House of Commons since 1640.

2 "He thanked the House for the attention which they had given to his statement, tedious and uninteresting as it might have appeared.--Spring-Rice, Colonial Siecretary, 1834-1835. Purliamentary Debates (House of Commons). Narch 9. 1835, III, xxvi, 994. 
in order to suppress the troublesome House of Assembly at Quebec.1

In the divisions in committee of the House of Commons on proposed amendments to the bill for the union of the provinces - the bill of 1840, based on Durham's report-the largest number of members voting was one hundred and twenty-one. In the division on third reading the number of members voting was one hundred and fifty-six. ${ }^{2}$

Interest, as indicated by the number of members voting in these divisions of 1840 , was so small that when the bill reached the House of Lords, Lord Ellenborough called attention to the indifference of the House of Commons to the new constitution for the Canadas. 'In the House of Commons', he said, 'this great question had not attracted so much attention as it deserved. Not one-fourth of that house had voted upon the question whether the bill should pass.' 3

The failure of the House of Commons as a whole to show more interest in the new constitution for the Canadas, the failure to which Ellenborough called the attention of the House of Lords, was in respect of a bill for placing Lower Canada on its feet again, constitutionally, after the rebellion of 1837. But the news of the rebellion itself, when it reached Westminster, on December 22, 1837 , had aroused comparatively little interest. ${ }^{4}$

'From the appearance of the house, with its half empty benches and half sleepy members present,' said Sir Robert Inglis, a Tory of the Eldon school, who from 1829 to 1854 was one of the members for the university of Oxford, when he rose to comment on the news from Quebec, 'one would suppose they were discussing some bill for the regulation of weights and measures, or something of an equally interesting character, rather than

1 Cf. ibid., July 22, 1822, II, vii, 1714.

2 Cf. ibid., III, liv, 1268.

3 Ibid., June 30, 1840, III, lv, 248.

4 The parliamentary session had opened on November 15, 1837. The House of Commons had news of the rebellion on December 22. It had been intended that the adjournment for the Christmas recess should be from December 22 to February 1, 1838. In view of the news from Canada, Russell, the leader of the House, proposed that the adjournment should be only until January 16. Inglis protested. 'If', he said, 'the statements regarding Canada were correct, the Government ought not to delay the consideration of the subject for a single moment ; and, instead of adjourning for a fortnight, they ought, before the next twenty-four hours elapsed, to attempt to bring conditions to something like a satisfactory settlement.' The adjournment was until January 16. Cf. ibid., III, xxxix, 1431, 1487; III, xl, 42. 
a rebellion in a colony which was one of the brightest jewels in the British crown. The indifference was most striking, considering the magnitude and importance of the question.' 1

There were divisions on bills or measures for the colonies on which the votes were large. In one of the divisions on Russell's resolutions of 1837,374 members voted. ${ }^{2}$ Over two hundred members, 216, went into the lobbies in a division on an address to the Crown in relation to the rebellion $;^{3}$ and on the motion to go into committee on the bill for suspending the constitution of Lower Canada, and establishing a special council with power to pass ordinances having the force of law, 278 members voted.

But these divisions of 1837 and 1838 were at times of crisis. Thinly attended Houses, impatient members, and meagre divisions were the rule. ${ }^{4}$ So much, in fact, were they the rule that when the chamber of the Commons or the Lords was full, or nearly full, for the consideration of a colonial measure, the minister in charge congratulated himself and the House on this rare manifestation of parliamentary interest in a colonial bill or a colonial question. ${ }^{5}$

The Colonial Office, the department that Stanley described as the 'office at war with the colonies ', ${ }^{6}$ in the period from 1820 to 1859 enjoyed less respect and confidence at Westminster than any of the other state departments at Whitehall. Seldom indeed, did there come an opportunity for a parliamentary success, or a parliamentary triumph, for the Secretary of State for the Colonies, whether he were of the House of Commons or the House of Lords; for a well-attended House and a bill or policy that attracts widespread attention in the constituencies of the United

1 Ibid., December 22, 1837, III, xxxix, 1486.

2 lbid, March 8, 1837, III, xxxvii, 138.

3 Ibid., January 16, 1838, III, xl, 93-95.

- A fairly typieal example of the impatience of the House when unofficial or private members-colonial reformers--invited its attention to a colonial subjeet can be found in the reports of the sitting of May 24, 1849. Roebuck had introduced a bill for reform in the Colonial Office. Six members had spoken, and on a seventh member, Aglionby, offering to continue the debate, he was greeted with eries of ' divide, divide'. Toticing these cries, Aglionby expressed his surprise that in a debate on a question of that importance 'so mucl impatience should be exhibited by honourable members whom he could point out who had only just eome into the House for the first time that evening '. Ibid., III, cv, 953.

5 Cf. Russell, House of Commons. January 26. 1838, Parliamentary Debates, III, xl, 546. Grey moved the second reading of the Australian Colonies Government Bill. May 31, 1850, in a House with less than twenty peers in attendance. Ibid. (Honse of Lords), III, cxi, 511.

6 Adderley, Colonial Policy, P. 99. 
Kingdom are essential to a parliamentary triumph for a minister on whom falls the burden of introducing a bill or of unfolding or defining a policy of the Government.

It is not difficult in 1918 to realize why in the first sixty or seventy years of the nineteenth century short tenure characterized the office of Secretary of State for the Colonies. In those years no reputations were made at the Colonial Office. To assume the Colonial Secretaryship was usually a thankless undertaking.

\section{CHAPTER VI}

\section{THE ATTITUDE OF DOWNING STREET TOWARD LEGISLATION FOR THE COLONIES}

EXCEPT for tariff legislation under the old commercial system there were few bills for the colonies in the period from the Quebec Act of 1791 to the Canadian rebellion. Most of the legislation for the colonies now of the dominions was in the years from 1838 to 1858. It was in these years that the constitution for Upper and Lower Canada was enacted at Westminster ; that the last tariff for the colonies - the British Possessions Act of 1843-and the Enabling Act of 1846 were passed; that several liberalizing amendments were made to the constitution of the Canadas of 1840 ; and that constitutions for the Australasian colonies were embodied in statutes of the Imperial Parliament.

Colonies and colonial questions in the nineteenth century never attracted any attention in Ireland. From the Act of Union of 1800 to the World War, Ireland always had troubles of its own. Its politicians specialized in Irish troubles. So did the electorate.

In England and Scotland, in the period now under review, 1783-1859, no popular credit ever accrued to any GovernmentTory or Whig, Liberal or Conservative-for any colonial legislation. No matter how important colonial legislation might be to the colonies and to the Empire, it brought no credit in the constituencies to the Government that was responsible for it. A Colonial Act passed at Westminster for any of the self-governing colonies never helped to hold a vote for a Government candidate, or to attract to a Government candidate a vote that might have gone to a candidate of the opposition. 


\section{ATTITUDE OF DOWNING STREET TOWARD}

In the speech from the throne at the opening of a new session of Parliament, a Government usually announces a larger legislative programme than can be carried out. Hence the phrase at Westminster in use in the closing weeks of a session, 'slaughtering the innocents', which being interpreted means the abandonment for lack of time of bills which have not been advanced beyond a second reading stage, at which stage the House of Commons or the House of Lords accepts or rejects the principle of a bill.

The long established and persistent tendency of all Governments since 1832 to overload their legislative programmes, and the fact that in this period from 1783 to 1859 a Government could hope for no credit in the constituencies for colonial legislation, go a long way to explain a practice of Governments in regard to colonial bills that caused frequent complaint by colonial reformers in the House of Commons, and at times from members of the House of Lords who were interested in colonial legislation and in good government for the colonies.

The practice complained of was that in accordance with which colonial bills were submitted to Parliament at the fag-end of the session, in the days when 'slaughtering the innocents' was in progress and non-official members were betaking themselves to the Continent, or to the moors of England, Scotland, and Ireland for the shooting season.

Mackintosh, it will be recalled, complained bitterly of this practice in 1828. It was a practice that was continued by Governments of both political parties for nearly half a century after his protest. Bills for the colonies were seemingly seldom regarded as urgent, either by the Colonial Office, which was responsible for the form in which they were introduced to Parliament, or by Cabinets when they were apportioning the time of the House of Commons or the House of Lords for the legislative measures to which they were committed.

There was a fair example in 1836 of the leisured, if not dilatory, procedure of the Colonial Office in regard to legislation. A bill for New South Wales and Van Diemen's Land in that year failed even of introduction to Parliament, because the stage at which the 'slaughtering of the innocents' began had been reached before the Colonial Office was ready with the bill. ${ }^{1}$

1 'It is impossible at this period of the session (July 5) to introduce a measure of the kind. But $I$ will give a pledge that the new bill shall not be deferred beyond 
The parliamentary session of 1852 came to an end on July 1. The second reading of the bill in which was embodied the constitution for New Zealand-tine bill for which the short-lived Conservative Administration of 1852 was responsible - was taken in the House of Lords on June 22. Newcastle, who was then in opposition, excused himself for not discussing the bill in detail; and at the same time he made a protest similar to that of Mackintosh of 1828, against the indifference of both the House of Lords and the House of Commons to colonial legislation.

Newcastle, who twice after this protest of 1852 held the office of Colonial Secretary, told the House that he would not go into details; "for he could not but perceive that within the last few days they had arrived at that period of the session - a session too that was to terminate a parliament ${ }^{1}$-when it was vain to expect to secure a full discussion upon the second reading of a bill, or even to rivet their lordships' attention to any brief details upon a subject such as that now before the House. It appeared indeed that the same spirit which pervaded the House of Commons, which had been termed moribund, prevailed equally in that House, which was of a more perpetual and enduring character.' 2

Despite the moribund condition of Parliament in June 1852, the New Zealand Bill was pushed through all its stages; and although the House of Lords had no opportunity of discussing it before June 22, the day of Newcastle's protest, it was soon through committee in the Lords, read a third time, and on June 30 it received the Royal Assent. ${ }^{3}$

next year.'-Sir George Grey (Under Secretary for the Colonies, 1834 and 18351839), House of Commons, July 5, 1836. Parliamentary Debates, III, xxxiv, 1265. The session ended August 20, 1835.

1 Parliament was dissolved on July $1,1852$.

2 Parliamentary Debates (House of Lords), June 22, 1852, III, cxxii, 1145-1146.

$3 \mathrm{Cf}$. An Act to grant a representative constitution to the colony of New Zealand (15 \& 16 Vict., c. 72 ). 


\section{CHAPTER VII}

\section{COLONIAL POLICIES, BILLS FOR COLONIES, AND THEIR VICISSITUDES AT WESTMINSTER}

New Zealand on the eve of the general election in the United Kingdom of 1852 was much more fortunate than were some other colonies now of the dominions in the period from 1828 to 1859 ; it was much zore fortunate than some other colonies for which in these years measures were before Parliament or awaiting framing and introduction to Parliament on the eve of a change of government or of a general eleetion. Until all the colonies now of the dominions were conceded responsible government, the interests of the colonies obviously and notoriously suffered from the vicissitudes of political parties at Westminster.

The select committee of the House of Commons ${ }^{1}$ for which Huskisson moved in 1828 reported in the same year. The committee, so Spring-Rice assured the House of Co mons in 1835, 'were earnest and zealous in their interest and determination to probe to the very bottom every real grievance, and to suggest every real and praeticable remedy.' 2 The report was regarded with much satisfaction by Papineau and his colleagues at Quebec. The reformers were in a majority in the lower house of the legislature; and they carried a resolution in the house deelaring the report to be 'an imperishable monument of the justice and profound wisdom of the committee '. ${ }^{3}$

But the Wellington Administration, with which the proposal for the committee had originated-largely through Huskisson, who was intent on ending the political unrest of the time in Lower Canada-went out of office in November 1830. The three Reform Bills, the Reform Bill agitation and two general eleetions all eame within the next two years. ${ }^{4}$ As a eonsequenee of these disturbed politieal eonditions in the United Kingdom, the report and reeommendations of the Canada eommittee of 1828 were eompletely forgotten.

1 To inquire into the state of civil government in Lower Canada. Cf. antc. pp. 309-310.

2 Parliamfntary Debates, May 9, 1835, III, xxvi, 687.

3 Cf. Kennedy, Documents of the Cunadian Constitution, 1795-1915, pp. 396-397.

- Cf. J. R. II. Butler, The P'assing of the Great Reform Bill, pp. 80-426. 
In 1834 the memorable ninety-two resolutions of the House of Assembly of Lower Canada were adopted, ${ }^{1}$ and transmitted to London-resolutions which were tantamount 'almost to a declaration of war by the Assembly against the Government ' ; ${ }^{2}$ and the rebellion of 1837 was in sight before there was an attempt at remedial measures in the spirit of the report of $1828 .^{3}$

A bill for the settlement of the long vexed question of the civil list in Lower Canada - a bill which would have given effect to the Declaratory Act of 1778 -was introduced by Goderich 4 in the House of Lords in February 1831. Its stages were taken at a leisurely pace, but it reached the House of Commons in October. Then came the rejection of the second Reform Bill on October 8, and the general election that followed this exciting episode in the history of the Reform Act of 1832 ; and like the recommendations of the Canada committee of 1828 , the attempt of 1831 to remedy at least one of the admitted grievances of Papineau and the reformers of Lower Canada came to naught in the Parliament of $1830-1831 .^{5}$

1 These resolutions represent the position of Papineau and the Reformers of Lower Canada on the eve of the Rebellion of 1837. In particular they define the position of Papineau in regard to the claim for responsible government. The resolutions are included in Kennedy's Documents of the Canadian Constitution, 1795-1915, pp. 366-388.

2 Spring-Rice, House of Commons, May 9, 1835. Parliamentary Debates, III, xxvi, 687 .

3 'The people's hopes were raised by these proceedings on the part of the Imperial Parliament (the appointment of the Committee of 1828), and had those recommendations been candidly and honestly acted upon, I feel convinced that the colony would now have been peaceful and contented.'-Roebuck, House of Commons, March 9, 1835. Parliamentary Debates, III, xxvi, 663.

'He believed', said Spring-Rice, in the same debate, March 9, 1835, ' that if in the year 1828 the full recommendations of that committee had been carried into effect, they would never have heard of the ninety-two resolutions or of the existing state of things in Canada.' Ibid., 685.

"This report (of a commission sent to Lower Canada in 1834) was dated May 3, 1836. Nothing was done with the report of the Colonial Office until July 14, 1837, when the Colonial Secretary (Glenelg) sent out instructions to Lord Gosford on the subject.'-Aberdeen, House of Lords, February 2, 1838. Ibid., III, xl, 658; March 16, 1837, III, xxxvii, 651 ; Stanley, House of Commons, March 8, 1837, III, xxxvii, 120.

In a protest entered on the journals of the House of Lords, signed by Lord Brougham and Earl Fitzwilliam, on February 8, 1838, the rebellion in Lower Canada was attributed to "early maladministration of the colony by those branches of the Government which were more immediately connected with the mother country'. Parliamentary Debates (House of Lords), February 8, 1838, III, xl, 888.

4 In parliamentary annals John Frederick Robinson 1806-1827, Viscount Goderich 1827-1833, Earl of Ripon 1833-1859.

5 Stanley recounted the history of the Goderich Bill in a debate in the House of Commons, April 14, 1837. Parliamentary Debates, III, xxxvii, 1230-1232. 


\section{COLONIAL POLICIES, BILLS FOR COLONIES}

A third measure for a settlement of the long continued difficulties with the House of Assembly at Quebec-difficulties that developed out of the refusal of the Government in London to act in accordance with the spirit of the Declaratory Act of 1778,1 and difficulties that culminated in the rebellion, ${ }^{2}$ and the loss of at least three hundred lives of rebels in Lower Canada alone ${ }^{3}$-failed of realization owing to the change of Government that occurred at Whitehall in November 1834 .

There was another committee at Westminster in 1834 on the affairs of Lower Canada. In this year two delegates from the Assembly at Quebec were in London to help in effecting a settlement of the claims of the Assembly to the control of finances. They were in London to demonstrate that the claims of the Assembly were based on its interpretation of the Act of Parliament at Westminster of 1778, an Act which Governments in London long ignored in the ordinary financial business of all the British North American provinces, and also flagrantly ignored in connexion with the surplus revenues of the Post Office in Upper and Lower Canada. ${ }^{4}$

Spring-Rice, who at this time was Colonial Secretary in the Melbourne Administration of July-November 1834, told Viger and Morin, the delegates from Quebec, that if the Assembly would pass an unconditional supply bill for two years, he would go earnestly to work to devise such measures and prepare such instructions for Aylmer, the Governor-General, as would meet the necessities of the case.

The Colonial Secretary prepared a dispatch and instructions that he was confident would at last effect a settlement; for, as he told the House of Commons on March 9, 1835, 'he should have considered it his highest reward, and the greatest honour

1 Cf. Kennedy, Documents of the Canadian Constitution, 1795-1915, pp. 340-341.

2 'In the strict aeceptance of the term there was no definitely planned revolt. But the people spontaneously and without eoncert determined upon protecting their leaders. ... The immediate aim was not the overturn of British dominion. It was a movement of self-protection against an arbitrary exercise of ministerial and judicial power.-Ietter of R. S. M. Bouchette (who took part in the rising), subsequently commissioner of customs at Ottawa. John Boyd, Sir George Etienne Cartior, 1). 65.

"The work was astonished when it eame to see with how feeble means, with what an absence of plan. concert, or the simplest preparation the insurrection was hazarded.' Annual Register. 1838, p. 2.

3 ,John Boyd, Sir George Etienne Cartier, p. 59.

4 ('f. William Sinith, A History of the Post Office in the American Colonies and in c'uncede, 13:-135. 
of his life, to have been enabled to settle the question of Canada in a manner satisfactory to all parties.' 1

The dispatch-Spring-Rice's messenger of peace to Lower Canada-was ready on November 13. 'It was an affair of so much consequence', to quote again from the narrative SpringRice gave to the House of Commons, "that he did not think it right to dispose of it without communicating with his colleagues of the Cabinet. A Cabinet meeting was appointed for the following Saturday, November 14, for the consideration of the dispatch. The packet was to have sailed on the Monday. But the letter of instruction was not dispatched on the Monday, because on the Saturday morning the Cabinet itself ${ }^{2}$ was dispatched two hours before the appointed time at which it was to have met.' 3

'After the event'-the dismissal of Melbourne-continued Spring-Rice, in his explanation of the causes of the miscarriage of his beneficent plan of November 1834 to achieve a settlement of the constitutional difficulties in Lower Canada of 1828-1834, ' he had no other course to pursue but to communicate humbly to His Majesty, through the head of the government, that the packet, having been ordered for Monday, the most convenient

1 Parliamentary Debates, III, xxvi, 691.

2 'The King (William IV) after the very confidential conversation with Viscount Melbourne on the state of the country, in consequence of the removal of Viscount Althorp to the House of Peers, and, therefore, becoming Earl Spencer, thinks it right to inform Lord Melbourne that he conceives that the general weight and consideration of the present Government is so much diminished in the House of Commons and in the country at large ... that the King does not think it would be acting fairly or honourably by his lordship to call upon the Viscount (Melbourne) for a continuance of his service in a position of which the tenure appears to the King so precarious.'-William IV to Melbourne, November 14, 1834. Lloyd C. Sanders, Lord Melbourne's Papers, pp. 222-223.

3 The Melbourne Administration of 1834 was sacrificed to the general and notoriously pronounced anti-Whig feelings and prejudices of William IV, who, it may be noted in parenthesis, was also violently hostile to the claims of Papineau and his colleagues in the House of Assembly at Quebec. "Mind what you are about in Canada. By God I will never consent to alienate Crown lands, nor make the council (legislative council) elective. Nind me, my lord, the Cabinet is not my Cabinet. They had better take care, or by God I will have them impeached!'-William IV to Lord Gosford, on his appointment (July 7, 1835) as Governor-General of Canada.

The Cabinet against which William IV thus expressed himself was that of 1835-1841 of which Melbourne was Premier.

Parenthetically also, it may further be noted that besides much responsibility, moral if not constitutional, for the rebellion of 1837 , William IV has the distinction of being the last British sovereign to permit his personal dislike of advisers drawn from one political party to become notorious; the last sovereign to assume a dictatorial and Bourbon-like attitude to a colony ; the last sovereign to dismiss a Prime Minister; and the last King of England for whom there was widespread and frequently expressed popular contempt. 
course to be taken would probably be to send a dispatch to Lord Aylmer, informing him of the change in the Government. That was done. The draft dispatch, therefore, remained a private document. It had never been fully approved of by the Government, and he had no right to make use of it.' 1

The Peel Administration of 1834-1836 was in office at the time Spring-Rice took the world into his confidence regarding the miscarriage of his plan for quieting the long and disturbing political unrest at Quebec. Aberdeen was at the Colonial Office. As he was of the House of Lords it was most convenient that Peel should take note of the important and revealing statement of the ex-Secretary of State for the Colonies. Peel promptly did so at the same sitting of the House of Commons, and, moreover, he did so in a speech which abundantly justified Adderley's complaint of 1849 , and also complaints in the House of Commons in $18311^{2}$ and again in $1853^{3}$ that the tenure of colonial secretaries, on an average three years, was too short to afford a secretary an opportunity of carrying out any scheme which he might have prepared. ${ }^{4}$

Peel recalled that Spring-Rice had told the House that the principles he had determined upon for a settlement of the difficulties of Quebec had been embodied in instructions, which, but for the ministerial crisis of November 14, would have been sent out to the Governor-General. 'But', continued Peel, who a few years later [1849] became one of the strongest supporters in the House of Commons of responsible government in the colonies now of the dominions, ' of those principles no record was left by the right honourable gentleman at the Colonial Office. For my part, and I am sure I may say the same on the part of my noble friend [Aberdeen], I much wish that such a record was in our possession; because, in addition to the opportunity it would have given us of testifying our respect for the opinions of the right honourable gentleman, it could not but materially have helped us in the task we had to perform.'

The fact that Spring-Rice carried a way the draft of the dispatch and the instructions of November 13 was not complained of by Pecl. It was in accordance with the nage of those days. "The

1 Parliamentary Debates. March 9. 1835. III, xxvi, 687-690. 691-692.

2 'ff. speeeh by George Rohinson, July 1831. Ibid., III, iv, 1442.

3 Cf. speech by Roebuck, March 9, 1835. Ibid., III, xxri, 70I.

4 Ibid., Nay 24, 1849, 1II, cr, 962. 
right honourable gentleman's motive in taking with him all the documents he had prepared on the subject,' continued Peel, ' no one can question. It was that his successor in office should not be embarrassed by his views in framing his decision. But much as I am disposed to do credit to the proper spirit which characterized his conduct, I cannot help repeating my regret that Lord Aberdeen should not have had the benefit of his opinions.' 1

Since the advent of the ocean cable and the organization of news collecting agencies world-wide in the scope of their operations, people in every British dominion, and in every Crown colony that is linked by cable to the United Kingdom, can share in the excitement of a ministerial crisis at Whitehall or of a general election to the House of Commons at Westminster, almost as fully as electors in England, Scotland, and Ireland.

In the era from 1783 to 1859 the British North American provinces could not learn of a ministerial crisis in Downing Street or a dissolution of Parliament in much less than a month; and in the case of a general election the writs were all returned to the clerk of the Crown in chancery in London before it was known in these provinces that there was to be an election in the United Kingdom. By the time news of a Cabinet crisis or a general election reached the Australasian colonies, it was history; and people in England had almost forgotten the month in which the crisis occurred, or that in which the general election had been held.

But the fortunes of those colonies wherein dwelt in largest numbers the men and women of British race might, and in some cases did, actually turn on the changes and vicissitudes of Governments and political parties at Westminster, changes which the colonists could in no wise influence and of which they were not even spectators.

Especially was this true of the years from 1828 to $1849-$ from the time political difficulties at Quebec became acute and

1 Ibid., March 9, 1835, III, xxvi, 701.

' Your lordship will see,' wrote Aberdeen to Aylmer, from Downing Street, February 11, 1835, ' that I have thus been deprived of the fruits of the matured reflection of my predecessor (Spring-Rice) and that on my own accession to office I find this complicated question very much in the same situation in which it was left by the Committee of the House of Commons on July 3 (1834), with this difference, however, that the difficulties of its solution have been materially aggravated by the additional delay of six months.' Kennedy, Documents of the Canadian Constitution, 1795-1915, p. 397. 


\section{COLONIAL POLICIES AND BILLS FOR COLONIES}

threatening to the Rebellion Losses Act, and the final and complete acceptance by Elgin, by the Colonial Office, by the Russell Administration and by Parliament at Westminster, of the great, far-reaching, abiding, and beneficent principle on which the measure of 1849 of the United Provinces was based.

There were six different Administrations in Downing Street. and there were four general elections in the United Kingdom in the ten years that preceded the rebellion of 1837 . In these ten years there were eight secretaries of state for the colonies. ${ }^{1}$

Keeping in mind political conditions in Quebec in these years: (1) Papineau and his majority in the House of Assembly ; (2) the family compact; (3) a legislative council that was nominated, with most, if not all its members antagonistic to the claims of Papineau and the reformers; (4) an executive council that was irremovable, and always in sympathy with the legislative council and the family compact; and (5) the ability of the House of Assembly at Quebec to withhold a large part of the supplies it is only necessary to recall the vicissitudes of political parties and Governments at Westminster from 1828 to 1837 to determine where responsibility lay for the only rebellion of men of British or European origin in any British colony from the American Revolution to the new era in world history that began with the World War.

If a revolution is a rebellion that succeeds, that attains its object, the rebellion in Upper and Lower Canada of 1837 was a revolution. Responsible government was its outcome, not immediately, but within little more than ten years after the last of the rebels of Lower Canada had fallen at the hands of British soldiers.

${ }^{1}$ Cf. Colonial Office List (1910). Robinson (afterwards Viscount Goderich and Earl of Ripon) held the office twice-in 1827 and again from 1830 to 1833. 


\section{CHAPTER VIII}

\section{THE EXPECTATION THAT THE COLONIES WOULD SECEDE FROM THE EMPIRE, 1816-188T}

THE widely held conviction to which expression was frequently given in Parliament at Westminster, in the press, and sometimes in books in which the relations of the colonies now of the dominions were discussed - the conviction that the connexion between these colonies and the Empire could not be permanent-survived for a century after the American Revolution.

It was a conviction that grew directly and immediately out of the loss by Great Britain of the thirteen colonies that formed the Republic of the United States; and out of the popular opinion in Great Britain, an opinion that developed at least as early as the opening decades of the nineteenth century, that on the whole, and particularly as regards trade, the disruption of 1776-1783 had involved no great loss to Great Britain.

Almost until the eve of the first Jubilee of the reign of Victoria in 1887, there survived the argument, based on the experience of 1776-1783, that the colonies now of the dominions-as soon as they had large and virile populations, and had developed their material resources, as soon, in brief, as they were sufficiently strong to stand alone-would declare their independence of Great Britain.

An early expression of the conviction that the British North American provinces that remained of the Empire after the Revolution of 1776-1783 would secede, in this case an extraparliamentary expression, was embodied in one of the singularly few books on the colonies, historical, descriptive or controversial, published in the first half of the nineteenth century.

The book in which this expression was embodied was given to the world under the nom de plume, 'A British Traveller.' It was published in Philadelphia in 1816. In spirit this early anonymous study of the colonial policy of Great Britain in relation to the North American colonies would to-day be described as imperialistic. The author regretted that there was no Government-organized emigration from the United Kingdom to the 
British North American provinces, and strongly urged the immediate adoption of an emigration policy.

Even at that time, 1816, it seemed probable to the 'British Traveller' that the Canadas would follow the American example, and revolt against British sovereignty. But he took comfort in the conviction that if revolt should come the British North American provinces 'must continue for a long time, even after their separation, to enrich us by their trade.' 1

A little beyond the end of the first period of indifference to colonial possessions, 1783-1859, there were two expressions of the conviction that the destiny of the British North American provinces was elsewhere than in the British Empire, that were much more remarkable than the conviction or apprehension expressed by 'A British Traveller' in 1816.

These later expressions are remarkable for two reasons. In the first place they are remarkable because they afford proof of the long survival of the popular conviction growing out of the American Revolution ; and in the second place they are remarkable from the fact that both of these expressions came from inside the Colonial Office. Each was written by a highly placed and responsible official of the department, who, as such, had been an onlooker at close range, of the progress of the colonies now of the dominions from Crown colony rule of the older type to the status of nation within the Empire.

The first of these two expressions of the conviction that the connexion of the self-governing colonies with Great Britain could not be permanent, and that it was undesirable that it should be permanent, was from Henry Taylor, afterwards Sir Henry Taylor, who was at the Colonial Office from 1834 to 1870. The second was from Frederick Rogers, who was at the Colonial Office from 1846 to 1871 , who from 1860 to 1871 was permanent Under Secretary, and who in 1871 was created a peer, Lord Blachford, for his services at the Colonial Office.

In the winter of 1863-1864, owing to the Civil War in the United States, and the resulting friction between the United States, the provinces of Upper and Lower Canada and Nova Scotia, and Great Britain, the military defences of the British

1 ('f. The Colonial Policy of Great Britain, Considered in Relation to the North American Provinces and the West India Possessions, by 'A British 'Traveller, p. 129. 
North American provinces were causing much concern to the Colonial Office, to the War Office, and to the Palmerston Administration of 1859-1865.

In February 1864 a memorandum on colonial defences was ready for submission to the Colonial Secretary. It went first to Taylor, whose duty it was to pass it on to Newcastle, at this time Secretary of State for the Colonies. Before it reached Newcastle, Taylor, in the ordinary course of the business of the office, added a memorandum expressing his views on the question.

'As to our American possessions', he wrote (February 26, 1864), ' I have long held, and often expressed the opinion, that they are a sort of damnosa haeriditas; and when Your Grace and the Prince of Wales were employing yourselves so successfully in conciliating the colonies, ${ }^{1} \mathrm{I}$ thought that you were drawing closer ties which might better be slackened, if there were any chance of their slipping away altogether. I think that a policy which has regard to a not very far off future should prepare facilities and propensities for separation ; and I therefore accede entirely in Sir Charles Elliot's ${ }^{2}$ preferences for a local and indigenous military force.' 3

Taylor's preference for the defence of the British North American provinces by militia regiments raised within the provinces, and the reasons he offered Newcastle in support of this preference are noteworthy; for they were reasons often advanced in Parliament from 1820 to 1859 , and also during the next ten years, by members of both Houses who were willing that the British North American provinces should separate from Great Britain.

'So long as there shall be a single imperial battalion in the provinces,' wrote Taylor, in recommending to the Colonial

1 In 1860 the Prince of Wales (afterwards Edward VII) visited Canada and the United States. The visit was at the invitation of the Government of the United Provinces. The Prince was accompanied by Newcastle. 'The expedition had the effect of strengthening the loyalty of Canada to the mother country, and of increasing the good feeling between England and the United States.' Edward VII, Dictionary of National Biography, Second Supplement, Index and Epitome, p. 36.

2 Sir Charles Elliot, who had served in the Navy from 1816, who directed British military operations in China in 1839 , and who had also served as Governor of Bermuda, Trinidad, and St. Helena, was the author of the memorandum on the defences of the British North American provinces to which Taylor's memorandum to Newcastle of February 26 was appended. Elliot was raised to the rank of admiral in 1865 .

${ }^{3}$ Autobiography of Sir Henry Taylor, ii, p. 234. 
Secretary Elliot's plan for militia regiments in the provinces now of the Dominion of Canada, 'the whole imperial Army and exchequer, and the honour of the Crown, will be committed to its support under difficulties; and circumstances may arise in which a large proportion of the imperial Army and treasure will not be more than enough.' 1

'In my estimation', added Taylor, in these notes for the guidance of Newcastle in acting on the Elliot memorandum, "the worst consequence of the late dispute with the United States $^{2}$ has been that of involving this country and its North American provinces in closer relations and a common cause.' 3

Blachford's expression of his conviction that the destiny of all the self-governing colonies was outside the British Empirethat it was inevitable that they would go - was written thirteen or fourteen years after he had retired from the Colonial Office. It was written within two years of the first Jubilee of Queen Victoria, that of 1887, which established a new date line in the history of the relations of the self-governing colonies with Great Britain; for the first colonial conference was part of the Empire-wide celebrations of 1887.4

'I had always believed, and the belief has so confirmed and consolidated, that I can hardly realize the possibility of any one seriously thinking the contrary', wrote Blachford, 'that the destiny of our colonies is independence ; and that, in this point of view, the function of the Colonial Office is to secure that our connexion, while it lasts, shall be as profitable to both parties, and our separation, when it comes, as amicable as possible.'

'This opinion', continued Blachford, 'is founded first on the

1 A utobiography of Sir Henry Taylor, ii. p. 234.

2 The dispute was over the recognition of the Confederate States as a belligerent power; and also over the easy escape of the Confederate cruiser "Alabama "from the Mersey in 1862. Later in the year, in December, the United Provinces of Upper and Lower Canada became involved in the dispute in consequcnce of the raid from Lowcr Canada by Confederate irregular troops upon St. Albans, Vermont. The raid was a factor in the movement in Congress at Washington for the abrogation of the reciprocity treaty of 1854. Cf. Morgan Dix, Memoir of John A. Dix, ii, pp. 108-116.

3 Autobiography of Henry Taylor, p. 235.

4 The first conference was called by Edward Stanhope, Colonial Sccretary in the Salishury Administration of $1886-1892$, at the suggestion of the Inperial Federation League, an organization that was establishcd in London in 1885, and formally dissolved on November 24, 1893. Cf. Findlay, The Imperial Conference of 1911 from Within, p. 31 ; George T. Denison, The Struggle for Imperial Unity, pp. $77,198$. 
general principle that a spirited nation-and a colony becomes a nation-will not submit to be governed in its internal affairs by a distant government; and that nations geographically remote have no such common interests as will bind them permanently together in foreign policy, with all its details and mutations.' 1

\section{CHAPTER IX}

\section{ATTITUDE OF THE HOUSE OF COMMONS TOWARD SECESSION}

For a definite reason that will soon appear, what can at most be only a brief survey of the attitude of members of the House of Commons and the House of Lords toward the question of the separation of the colonies from Great Britain-a brief survey of this phase of indifference to colonial possession from the American Revolution to Galt's tariff of 1859-has been prefaced by the foregoing chapter, embodying first the observations of 'A British Traveller', and then the observations of Henry Taylor and Blachford, both of whom were so long at the Colonial Office, and both of whom were also of importance in the political and literary worlds of London.

These observations, the first of 1816 , the second of 1864 , and the third of $1885,{ }^{2}$ epitomize and crystallize most of the expressions in the House of Commons and the House of Lords of 1820-1859, that the colonies would separate from Great Britain, that separation was inevitable and would be to the advantage of the people of the United Kingdom.

'A British Traveller' of 1816 was apprehensive that the North American provinces would themselves end the connexion. Taylor was desirous that they should end it. He objected to any efforts on the part of Great Britain to strengthen the existing ties ; and in his memorandum to Newcastle he emphasized one of the reasons why he desired that the connexion should come to an end. With Great Britain absolutely free of the British North American provinces Taylor was convinced that there

1 G. E. Marindin, Letters of Lord Blachford, pp. 299-300.

2 Cf. note by editor of Blachford's correspondence, Marindin, Letters of Lord Blachford, p. 296. 
would be much less risk of war with the United States. Blachford, at no time between 1837 and 1885 , was willing or able to realize any advantages that Great Britain derived from the colonies; and in his retrospect of colonial history in the nineteenth century he emphasized the inevitableness of separation.

All these reasons for not regarding the connexion of the colonies with Great Britain as permanent were advanced in Parliament in the years from 1828 to 1859 . Particularly were they advanced in the years from 1837 to 1859 , the era of the rebellion, and the forcible union of the provinces of Upper and Lower Canada, the Rebellion Losses Act, and Galt's tariff; and it is only the commercial and trade aspect of the question of separation that is not discussed or alluded to in these observations of Taylor and Blachford.

The trade aspect was much discussed in Parliament-almost always also from the standpoint of 'A British Traveller'-for many of the advocates of separation in the House of Commons and in the House of Lords in the years subsequent to the publication of his treatise were convinced, like him, that separation, as in the case of the American colonies, would involve no loss of trade for Great Britain.

As early as 1822 and 1825 there were warnings in the House of Commons that the British North American colonies must be held with a loose rein-warnings that for twenty years were in vain -if it were desired that the connexion of these colonies with Great Britain should be maintained. ${ }^{1}$

It was 1831 before utterance was frankly given at Westminster to the conviction that the colonies would go. Colonel Evans, in a debate on a vote for the maintenance of the Rideau Canal, designed as a defence of Upper and Lower Canada in case of attack from the United States, ${ }^{2}$ in that year besought the House to realize that the Canadas were provinces which Great Britain could not count on per anently retaining. ${ }^{3}$ Hunt-Orator Hunt of parliamentary reform agitations fame-went a little farther

1 Cf. Mackintosh, House of Commons, July 18, 1822, Parliamentary Debates, II, vii, 1703 ; Alexander Baring (afterwards Lord Ashburton), House of Commons, March 25, 1825, Parliamentary Debates, II, xii. 1097-1116.

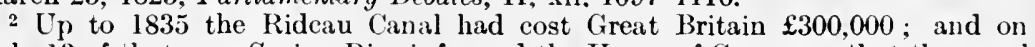
July 13 of that ycar Spring-Rice informed the House of Commons that the canal had been offered to the Government of Upper Canada, but that the Government had declined to takc it as a gift. Parliamentary Debates, III, xxix, 459.

3 Ibid., July 25, 1831, III, v, 206. 
than Evans. 'If there were war with the United States', he said 'we were not likely to retain either of the Canadas.' 1

Botany Bay, its convicts, and the charges they entailed were discussed in the same session on a vote for $£ 120,000$. 'All the colonies ', urged Colonel Torrens, one of the group of Radicals of the unreformed House of Commons, 'ought gradually to be removed from under our control.' 2

The difficulties with the House of Assembly at Quebec of 18281837 , and the rebellion of 1837-1838 elicited many expressions of the conviction that it would be well for Great Britain if the British North American provinces would end the connexion, and some expressions, moreover, of a conviction that the colonies ought to be told to go.

'The House of Commons', said Robinson of Worcester, a member of the Whig party, on March 6, 1837, in a discussion of the demand from Lower Canada for responsible government, ' ought not to sacrifice the privileges and prerogatives of the Crown to any of our colonies. If the Canadians were strong enough to enforce their demands, they should be told at once that the time had arrived when they ight, like the United States, shake off their allegiance altogether.' 3

In this debate of March 6, 1837, there was much insistence on the argument that the United Kingdom would lose no trade if the British North American provinces declared their independence. 'As to our commercial interests,' said O'Connell, 'commerce, instead of being diminished, would be augmented if Canada were freed.' 4

Perronet Thompson, of the philosophical Radicals group, who was at one time editor of the Westminster Review, took the same view of the commercial value of the British North American provinces as $\mathrm{O}^{\prime}$ Connell. ${ }^{5}$ 'If we could but lose Canada', he

1 Ibid., III, v, 307.

2 Ibid., July 18, 1831, III, vii, 1443-1444.

3 Ibid., March 6, 1837, III, xxxvi, 1322.

4 Ibid., 1327.

5 Emphasis on the contention that the separation of the colonies would involve no loss of export trade had characterized extra parliamentary discussion of the value of the connexion with the colonies some years before 1837. In The Black Book, compiled by John Wade, and first issued in 1820 , there was a chapter on the advantages and disadvantages of colonial possessions. "As to commercial advantages,' wrote Wade, ' if the colonial trade were quite free our commercial relations with the colonies would resemble the intercourse between ourselves and independent countries; and with our unrivalled superiority in capital, 
exclaimed, ' what should we gain in a commercial way ?' 'Would not', he asked, 'every man in England who lives in a house, gain a substantial sum, which he might add to the amount of his enjoyment?' 1

This allusion was to the high duties on lumber from the Baltic countries in the tariffs of the old commercial system, duties which were enacted to protect the market in the United Kingdom for lumber from the Maritime Provinces and the Canadas, admittedly an inferior lumber, which was entered at preferential rates.

At a later stage in the discussion on Russell's ten resolutions, and the declaration embodied therein against the concession of responsible government to Lower Canada, ${ }^{2}$ Gladstone, who had been elected to the House of Commons in 1832 as a Conservative, expressed an opinion on the question of the secession of the colonies not much different from the opinions of Thompson, Torrens, and O'Connell. ' He did not think the separation of the colonies from the mother country ', reads the report of Gladstone's speech, 'was at all times and under all circumstances to be regarded with apprehension,' ${ }^{3}$ which was as near to a declaration that he was willing to see the colonies go as Gladstone's habitual circumspection in parliamentary utterance would at that time allow.

Before 1837 these expressions of indifference to the secession of the colonies were mostly from Radical members. But in the debates on the Russell resolutions the Radicals - popular Radicals of the school of Hunt, or philosophical Radicals like Grote or Molesworth, who had entered Parliament with the hall-mark of Cambridge or Oxford - had no monopoly of this attitude toward

manufactures, machinery, and skill, what have we to fear from unrestricted competition? What have we lost by the independence of the United States? Nothing.' John Wade, The Black Book of Corruption Unmasked (1835), p. 380.

- Parliamentary Debates, March 6, 1837, III, xxxvi, 1334.

2 The Whig Administration of 1835-1841, like the Whig Administration of 1846-1852, had no intention of conceding responsible government. The Whigs had other theories of government for the colonies now of the dominions. Colonists, according to Whig theories, ought to be content under Government less free, less controlled by the popular branches of the legislatures than Government at Whitehall was cointrolled by the House of Commons. But between 1837 and 1847 . when Elgin went to Canada, events took their own course, and left Whig theories formulated in Downing Street and in Parliament behind. Cf. Marindin, Letters of Blachford, 297-298.

3 Parliamentary Debates, March 8, 1837, III, xxxvii, 99. 
the colonies-no monopoly of parliamentary expression of opinion or conviction that the colonies would go, and could go, if they were so disposed.

Gladstone, in the debate of March 8, 1837, was followed by Labouchere, in later years Colonial Secretary in a Whig Administration; and then by Peel, who had already been Premier, who was to be Premier again, and who at this time was leader of the Tory or Conservative opposition in the House of Commons.

Labouchere was a little guarded in utterance as to the inevitableness of separation. Otherwise Blachford's observations of 1885 read like a paraphrase of Labouchere's speech of 1837 . It was possible Labouchere realized that the colonies would go, and this possibility should determine the attitude of Great Britain toward them.

' To the last hour, during which the connexion existed,' urged Labouchere, ' "we should act toward the colonies liberally and justly; so that, whenever the moment of separation might come, we should be able to face the world and posterity with a good case, and not stand before either convicted of having neglected the duty of a mother country toward her colonies.' 2

Part of Peel's speech of 1837 is identical in phraseology with his letter of $1841^{3}$ to Aberdeen at the Foreign Office, at the time friction with Washington over the fisheries convention of 1818 , and also the demands of Baldwin and La Fontaine for responsible government for the then recently united provinces of Upper and Lower Canada were so disturbing to Peel and his colleagues of the Conservative Administration of 1841-1846.

Peel in 1837, like Taylor in 1864, was alive to one danger attaching to the connexion of the British North American provinces, which danger he emphasized four years later, when he asked Aberdeen why should Great Britain 'contract the tremendous obligation of having to defend, on a point of honour', Canadian territory against American aggression.

'When he recollected', reads the report of Peel's speech in the

1 Labouchere was at this time a Whig member for Taunton. He took his title, Baron Taunton, from this borough in Somerset when in 1859 he was created a peer. Henry Labouchere, of Truth, and Bradlaugh's colleague in the representation of Northampton from 1880 to 1891 , the most widely known of the Laboucheres, was a nephew of Lord Taunton.

2 Parliamentary Debates, II, xxxvii, 106.

3 October 25. Parker, Sir Robert Peel, iii, pp. 388-389. 
debate of March 8, 1837, 'the state of certain duties which were imposed upon us in connexion with Lower Canada, when he recollected the evil of collision with its powerful neighbour, to which we were exposed on its account, when he recollected that we might at any moment be called upon to defend that colony from all comers, not from any local interests of our own, but from a point of honour, involving our character as its protector, he must say that if it were a mere Canadian question, he should have no objection to see the connexion dissolve, and Lower Canada establishing its own government as an independent State, or if it thought itself incapable of supporting its own independence, secking an amicable alliance with another power.' 1

Five sittings of the House of Commons were occupied with the debate on the Russell resolutions of 1837. On April 14 Henry George Ward, who had been in the diplomatic service from 1816 to 1827 , who at this time was Whig member for Sheffield, and who was subsequently successively Governor of the Ionian Islands, Ceylon, and Madras, anticipated by nearly fifty years Blachford's statement of the reasons that forced him to the conclusion that independence of the colonies was inevitable.

Ward, like Blachford, did not believe that it was possible to perpetuate the connexion between a mother country and her colonies. 'When a colony grew to a certain extent, and became ripe ', Ward assured the House, 'it would drop off.' 'The object therefore', he counselled, 'should always be to separate in such a manner that there would be a continuation of kindly feeling between the mother country and the colony.' It was a speech reminiscent of $1776-1783 .^{2}$

Grote, in the same debate, anticipated Newcastle's frank declaration of 1862 to all the self-governing colonies. 'I trust', said Newcastle, who was then Secretary for the Colonies in the Palmerston Adninistration of 1859-1866, that the day will never return when a single red coat will point a bayonet or fire a shot in hostility to the colonies, if they wish to separate from the mother country.' 3 Grote told the House that he would never consent to the employment of force to maintain the connexion

1 Parliamentary Debates, III. xxxvii, 1283.

2 Ibid., 1254.

3 Speech at Australian anniversary dinner, London, February 12, 1862. 
between the mother country and a colony, whenever the connexion became onerous to the colony. 1

Roebuck had lived in Upper Canada. His uncle, his mother's brother, was secretary to Simcoe, who was Governor-General from 1792 to 1794 . Roebuck's mother was the owner of five hundred acres of land, a Government grant, situated near to what is now the city of Toronto ; and from 1815 to 1824 Roebuck, with his mother and his five brothers, lived and worked on a farm near Prescott, in what is now the province of Ontario. Roebuck was educated in Canada, ${ }^{2}$ and went from Canada to the Middle Temple, where he was called to the bar in 1831. He was, it will be recalled, for some years agent of the House of Assembly of Lower Canada in London $;^{3}$ and in the years from 1828 to 1840 there was no man at Westminster or Whitehall who was more intimate with political, economic, and social conditions of Lower and Upper Canada than Roebuck.

Like Ward in 1837 and like Blachford from 1847 to 1885 , Roebuck was convinced that separation of the British North American provinces from Great Britain must come. But unlike Ward and Blachford, he did not anticipate that the separation would come by mutual agreement. He was afraid that, like the thirteen American colonies, the Canadian provinces would revolt.

' The provinces of Canada, together with our other possessions in America,' said Roebuck, in his speech in the House of Commons (April 14, 1837) in opposition to Russell's resolutions and the declaration of the Melbourne Administration against the concession of responsible government, ' may for a few years remain under our dominion. But fatal discontent will pervade the minds of the colonists, and their every aspiration will be for the happy time of their deliverance from our yoke. They will watch with eager anxiety and impatience for the first opportunity for contemptuously spurning our control, and will, with ardent belief

1 Parliamentary Debates, III, xxxvii, 1262.

2 R. E. Leader, Life of Roebuck, pp. 11-24.

3 ' In the present case $I$ am not a volun tary agent. My duty to my Canadian clients bids me brave everything rather than desert them.'-Roebuck to Francis Place (at the time of the rebellion), January 29, 1838. Leader, op. cit., p. 112.

'The vivid imagination of Mr. Roebuck's assailants enabled them to represent him as in receipt of $£ 1,100$ a year, whereas the Canadians not only failed to pay his salary at the time, but left him to defray the expenses of the defence of Canada in Parliament out of his own pocket, and subsequently repudiated his claim for arrears.' Ibid., p. 67. 
in the glories and happiness of a life of national independence, rear at once the standard of revolt, and assume the name and port of an independent people.'

'Whatever may be the course we may pursue,' continued Roebuck, 'the time must inevitably come when our American colonies will become independent States. But I, for one, am not anxious that this event should be anticipated and brought about before its natural period. Above all I am desirous that when this period does arrive, we may separate in peace and good will toward one another; that we may voluntarily resign our supervising care ; and that the colonies may assume it with our sanction and approval-that no bitterness should result from this new relation, but that reciprocal kindness should beget lasting and reciprocal good will.' 1

There were further expressions of the conviction that the colonies could not be held and that.it would be for the advantage of Great Britain that separation should come, when at the end of the year (December 22, 1837) Parliament had news of the rebellion in Lower Canada. Again much stress was laid on the contention that the United Kingdom would lose no export trade if all the colonies ceased to have any political connexion with Great Britain, a contention which was again supported by the example of the increasing trade of the United Kingdom with the United States.

John Temple Leader, then Radical member for Westminster and a political associate of Grote, Perronet Thompson, and Molesworth, in denying that colonies were of any advantage to the United Kingdom, contended that no loss of trade would follow the secession of the British North American provinces.

'There is', he said, 'an example and proof of this in the case of the United States.' 2 'Two-thirds of the trade with Canada', he continued, 'is forced and fictitious. It originates in the discriminatory duty of forty shillings a load, imposed on timber' from the north of Europe, over and above what is imposed on

1 Parliamentary Debates, III, xxxvii, 1210.

2 This argument was used in and out of Parliament for many years after Leader offered it in the House of Commons in 1837. "Our conmerce with the United States', reads an article in The Examiner (London), edited from 1830 to 1847 by Albany Fonblanque, the foremost Radical publicist of the first half of the nineteenth century (July 21,1849 ), " is infinitely more lucrative than our commerce with the thirteen North American colonies.' 
that brought from a British settlement in North America. There would be this great additional advantage in dealing with Canada as an independent state, that we should not then be compelled to tax ourselves to an enormous amount in taking bad and dear timber from Canada when we could obtain cheap and good timber from the north of Europe. Nor should we be forced to pay for the maintenance of a large military force to keep possession of an unwilling colony.' 'The North American provinces', said Leader, in concluding his plea for an end of the connexion, 'are now strong enough to take care of themselves, and they know it.' 1

It was in this debate of December 22, 1837, that Molesworth made a speech that in after years troubled him and his biographers almost as much as Disraeli was troubled by his coining of the phrase, 'these wretched colonies,' for use in his letter of 1852 to Malmesbury. ${ }^{2}$

Molesworth began with the expression of a fervent desirewhat he described as a sincere desire - that the dominion of Great Britain over Canada should be ended. 'Great', he exclaimed, 'would be the advantages of an amicable separation of the two countries. Great would be the honour this country would reap in consenting to such a separation $;^{3}$ and great would be the renown which a ministry would derive from proposing such a measure.' 4

\section{CHAPTER X}

\section{THE HOUSE OF COMMONS AND THE COMMERCIAL}

\section{VALUE OF THE CONNEXION WITH THE COLONIES}

In the debates on Canada of the years immediately preceding and following the rebellion of 1837 , the Radicals acted together in the House of Commons. Both popular and philosophical Radicals spoke frequently. They often followed each other in debate. They went into the same division lobby on amendments to Bills for Canada-a series of facts, all of record, which to

1 Parliamentary Debates, III, xxxix, 1442.

2 Cf. 'The Colonies ', The Examiner (London), July 21, 1849.

3 Molesworth, who was Under Secretary for the Colonies in Palmerston's Administration of 1855-1858, abandoned his position of December 1837 in 1845 . Cf. Fawcett, Life of Molesworth, p. 266.

* Parliamentary Debates, III, xxxix, 1466. 
a large degree explains the erroneous but long surviving tradition that it was only the Radicals of these years from 1828 to 1859 who were indifferent to colonial expansion and willing that colonies now of the dominions withdraw from the Empire.

The term 'little Englander' was not of the phraseology of British politics of those years. It did not come into service in political controversy at Westminster, on the platform, in the constituencies, and in the press, until some years after the end of the era of indifference in 1887. But all through the whole period of indifference, 1783-1887, men whose attitude toward the colonies and toward colonial expansion any time after the beginning of the South African war of 1899-1902, would have been described as that of 'little Englanders', were by no means all men who sat on the opposition benches at Westminster in the years during which the Tory or the Conservative party was in power, nor were they all of the free trade school. ${ }^{1}$

Warburton followed Molesworth in the debate of December 22, 1837. He also was of the philosophical Radical group, a group that in these years was at the peak of its influence in Parliament as well as in the constituencies and in the press. Like Leader and Molesworth, Warburton was anxious to end the connexion of the British North American provinces with Great Britain. Like Leader, also, Warburton saw less danger of war between Great Britain and the United States, if British dominion over the provinces north of the United States were abandoned.

Like Leader, moreover, Warburton, who was the only member of the philosophical Radical group who was in trade, ${ }^{2}$ emphasized the fact that from the time of the American Revolution, the United Kingdom had enjoyed an increasing export business with the United States. Low tariffs, with little or no protection for domestic manufacturers, were the rule in the United States from the War of 1812 to 1840 . These were the years also in which there was a large emigration from the United Kingdom to the United States.

In the period from 1815 to 1837 , nearly 370,000 emigrants left England, Scotland, and Ireland for the United States. In the same period 482,000 left for the British North American

1 Cf. Cirey, ('olonial Policy, pp. 16-17.

" Warburton was a timber merchant at Lambeth, with a timber yard on the water front within sight of St. Stephen's. 
provinces, most of them for Upper and Lower Canada. ${ }^{1}$ But these figures for the British North American provinces were much swollen by the large number of poor or derelict men, women, and children who emigrated at the charge of poor law authorities in England and Ireland, or at the charge of special funds for the relief of agrarian or industrial distress in England, Ireland, and Scotland.

Tens of thousands of emigrants who left ports of the United Kingdom, nominally for the British North American provinces, moreover, migrated within a year or two, as soon as they could afford to move on, across the line into the New England States, or into New York, Pennsylvania, Ohio, and other States bordering on the Great Lakes. These immigrants from the United Kingdom were merely birds of passage in the British North American provinces. They were so recognized in Canada from at least as early as 1838. ${ }^{2}$ In these years, and indeed until the last decade of the nineteenth century, first the British North American provinces, and after 1867, the Dominion of Canada, were gateways on British soil to the United States. From 1837 to 1867 this was especially the case with what are now the provinces of Ontario and Quebec. ${ }^{3}$

Warburton in the debate in the House of Commons of December 22, 1837, recalled the large emigration to the United States in the years from the American Revolution to the rebellion in Canada.

1 Cf. Johnson, A History of Emigration, p. 344.

2 'Some thirty thousand souls came out [to Upper and Lower Canada from the United Kingdom] for two or three years in succession, three-fourths of whom at least-and many think nine-tenths-found their way to the United States.' W. H. Merritt, to Durham, Governor-General of Canada, St. Catherine's, Upper Canada, October 5, 1838. J. P. Merritt, Biography of W. H. Mlerritt, p. 189. Cf. Charles Buller, House of Commons, June 3, 1839. Parliamentary Debates, III, xliv, 1285 .

${ }^{3}$ 'I have good reason to know that many thousands of Her Majesty's subjects have merely passed through this province (Upper Canada) into the United States because English capital, which was to afford them the means of profitable employment, was to be found there instead of here.'-Sir George Arthur, LieutenantGovernor of Upper Canada, 1838-1841, to Glenelg, Secretary of State for the Colonies, Toronto, November 20, 1838. Journals of the House of Assembly of Upper Canada, 1839, Appendix II, Part II, p. 546.

The life-robbing drain showed little signs of slackening. During the eighties the number of natives of the United States resident in Canada increased from 77,000 only to 80,000 . In practically the same period (1880 to 1890 ) the number of natives of Canada in the United States grew from 717,000 to 980,000. Canada, with its four million people, and its millions of vacant acres, had contributed more of its sons to the building up of the United States than England with its twenty millions in their crowded land.' D. Skelton, Canada and Its Provinces: General Economic History, 1867-1912, ix, p. 152. 
He attributed it to the fact that the United States were prosperous; and they were prosperous, as he conceived, because they were free and independent. The British North American provinces, independent of Great Britain, free to govern themselves without outside interference, would become as prosperous as the United States; and with widely diffused prosperity in these provinces, there would be, as there had been with the United States, a much larger call for the manufactures of Great Britain. Separation of the colonies, as Warburton visualized it, involved neither shame nor disgrace to Great Britain. His devout wish was that the time of separation had arrived. ${ }^{1}$

Grote made a contribution to the debate, and to the trade aspect of colonial possessions that was in a quite different vein from the contributions of Leader and Warburton. 'Surely,' he said, 'the material advantages in point of wealth and commerce must be great indeed if they could be worth purchasing at the cost of eternal coercion, and an increasing struggle to put down the feelings of the great mass of the Canadian people.' ${ }^{2}$

At various stages of the legislation at Westminster in 1838-1840 necessary to a resettlement of the affairs of Lower Canada after the rebellion-the bills empowering the creation of a special council for Lower Canada, and the bills of 1839 and 1840 for the union of Upper and Lower Canada-there were more of these expressions of convictions in the minds of members of the House of Commons that the connexion of the colonies with Great Britain could not be regarded as permanent. ${ }^{3}$

In the debate on the motion to go into committee on the bill of 1840 for the union of Upper and Lower Canada, the bill that became law on July 23, 1840, both Gladstone and Stanley gave expression not to a desire to see an end of the connexion of the British North American provinces with Great Britain, but of their conviction that Great Britain would be quite willing to

1 Parliamentary Debates, III, xxxix, 1474-I475.

2 Ibid., $1+85$.

3 'It did appear to him as rational to talk of the moon belonging to ourselves as to talk of a great and extensive country (Canada) three thousand miles away from the mother country, being a part of our Empire.'-Warburton, January 29, 1838, Parliamentary Debates, III. xl, 637. Cf. Baines, January 25, 1838. ibid., 510 : Roebuek, at the bar of the House of Lords, February 5. 1838, ibid., 769; Wilmot Horton, May 29. 1840, ibid.. III, liv, 334; Stanley, IIay 29, 1840. ibid., 339; Gladstone, IIay 29, 1840, ibid., 730 731; Ewart, Nay 29, 1840, ibid.. 752; Gally Knight, June 15, 1840, ibid., 1176 ; Cochrane, June 18. 1840, ibid., 1267. 
relinquish dominion over these provinces whenever the people inhabiting them made it manifest that it was their desire that the existing connexion should come to an end.

To Gladstone the problem of the relations between the North American provinces and Great Britain was altogether one of the most difficult and delicate problems ever submitted to any legislature. 'No one could look,' he said (May 29, 1840), ' at the colonial laws respecting succession and distribution of property, the habits and development of the colonists, their feelings with regard to aristocracy, and the principles entertained respecting national religion throughout our North American provinces, ${ }^{1}$ and fail to see that there are great differences, original and inherent, in the elements out of which society is composed, which must render increasingly difficult the regulation and the maintenance of the union between a country essentially aristocratic in its feelings and its principles, as he believed England to be, and a country in which some of the elements of society certainly seemed to tend toward democracy, as their final consummation and development.'

'It seemed to him,' continues the report of Gladstone's speech, 'that the maintenance of our connexion with the colonies was to be regarded as a matter of duty rather than one of advantage. $\mathrm{He}$ could understand much better the doctrine that there was a duty incumbent on Great Britain with respect to the colonies than the doctrine of those who said that upon a mere balance of advantages, or as a case of political necessity, we should maintain the connexion. But he conceived that nothing could be more ridiculous, nothing could be more mistaken, than to suppose that Great Britain had anything to gain by maintaining that union in opposition to the deliberate and permanent conviction of the people of the colonies themselves. Therefore, he thought that it should be a cardinal principle of our policy to regard the union between Great Britain and Canada, and her other American colonies, as dependent on the free will of both parties.' ${ }^{2}$

Stanley, who, like Gladstone, spoke from the opposition benches - he was now free of the Whigs, and an accepted member

1 Popular opposition to any church supported by the State or in enjoyment of special political privileges, as in England where the bishops of the established church are of the House of Lords.

2 Parliamentary Debates, III, liv, 730-731. 
of the Conservative party-1 made only the briefest contribution to the discussion of the connexion of the British North American provinces with Great Britain. But it was as significant as Gladstone's more elaborate and detailed examination of the connexion and forecast as to its future.

'If ever the colonies separated from this country, as they must some day or other, in the ordinary course of things,' said Stanley, 'it was in our power still to retain their friendship. But on the results of the deliberations of Parliament depended that power.' 2

Wellington and Stanley were the last statesmen of the Conservative party to oppose the concession of responsible government to the British North American provinces. Stanley, who was of the House of Lords from $1844,{ }^{3}$ and leader of the Conservative party from 1846, was hostile to responsible government in the colonies for nearly ten years after his support of Metcalfe in his unsuccessful efforts of 1843-1845 to withhold responsible government from the Canadas. ${ }^{4}$ Stanley, who became Earl of Derby in 1851, was also the last hostile critic at Westminster of Elgin, and the policy, empire-wide in its beneficent influence and as enduring as the tides, that Elgin pursued in Canada from 1847 to $1854 .^{5}$

As an offset to his long and unrelenting opposition to the concession of autonomy to the colonies now of the dominions, Stanley has the distinction of having been the first of the leaders of the Conservative party to tell the British North American provinces of 1783-1867, and to tell them from the floor of the House of Commons at Westminster, that if they did not like British rule, they were free to end the connexion with Great Britain when it suited their interests to do so.

1 Stanley resigned the Secretaryship of State for the Colonies in the Grey Administration of 1830-1834 in June 1834, on a question affecting the revenues of the established church in Ireland. For a few months he was a free lance. He did not accept the whips of the Conservative opposition until the parliamentary session of 1835 .

2 Ibid., 339. $\quad 3$ He was created Lord Stanley of Bickerstanfe.

4 -Metcalfe had essayed to check the expansion of the great principle of constitutional government, and had met with determined resistance, and inglorious defeat.' William Leggo, History of Lord Dufferiu's Administration in Canada, p. 44. C'f. Parliamentary Debates (House of Lords), June 25, 1852, III, cxxii, 1287.

5 'I cammot help saying and feeling that the leading principle on which Iord Elgin has acted has been concessions one after another to popular demandsconcessions which would enable him to lead an easy life. - Derby, House of Lords, June 29, $18 \%$. 


\section{CHAPTER XI}

\section{DISCUSSIONS OF THE COLONIAL CONNEXION IN THE HOUSE OF LORDS}

The debates in the House of Lords on the policy and measures of the Melbourne Administration for a resettlement of the Canadas after the rebellion, like the debates on those measures in the Commons, are memorable in the history of the relations of Great Britain with the colonies now of the dominions for expressions of conviction on the part of individual peers that the North American provinces could not be held. Brougham, Aberdeen, Ashburton, and Mansfield all expressed this view. Brougham and Ashburton, moreover, expressed the conviction that so far as the United Kingdom was concerned it was not desirable or advantageous that the connexion should be permanent.

Brougham, who had been Lord Chancellor in the Whig Administration of 1830-1834, was the first peer to discuss, in these debates of 1838-1840, the colonies and the colonial tie in the spirit of Grote, Molesworth, Perronet Thompson, and Warburton, and in that of Henry Taylor and Blachford. To Brougham ${ }^{1}$ the North American provinces were worth nothing from a national point of view.

Like members of the House of Commons who had expressed willingness or desire to see the colonies separate from Great Britain, Brougham emphasized the cost of the defence of the British North American provinces-at this time more than half a million sterling a year-and also the cost to the people of the United Kingdom of the preference on lumber from New Brunswick, Nova Scotia, and the Canadas in the tariffs of the old commercial system.

'The severance of the colonies,' said Brougham, in recalling the cost to the United Kingdom of the preference on lumber, 'would not only open our markets to a better and cheaper commodity, which grows near our own doors, but would open the Baltic markets to our manufacturers, restrained as they now are in their

1 January 18, 1838. 


\section{DISCUSSIONS OF THE COLONIAL CONNEXION}

efforts to export to the north of Europe by the want of any commodities which we can take in return. Their produce is grain and timber; and our corn laws, for the benefit of the landed interest, shut out the one, while our colonial laws for the benefit of the planters ${ }^{1}$ exclude the other.'

'Is it not then full time,' asked Brougham, 'that we should make up our minds to a separation so beneficial to all parties, if it shall only take place amicably; and by uniting the whole of our North American possessions form an independent, flourishing, and powerful state which may balance the colossal empire of the west ?' 'These,' Brougham assured the House, ' are not opinions to which I have lately come. They are the growth of many a long year, and the fruit of much attention given to the subject.' 2

Aberdeen had been Secretary of State for the Colonies in the Peel Administration of 1834-1835. Subsequent to these discussions of the colonies in 1838-1840, he was Secretary of State for Foreign Affairs-the secretary to whom Peel addressed his 'let them go' letter of May 16, 1842-and from 1852 to 1855 Aberdeen was Premier of a Coalition Administration.

In a discussion of the colonial tie on February 8,1838 , a discussion in which Brougham reiterated the views he had expressed on January 18, 1837,3 Aberdeen told the House that he regarded separation of the colonies as inevitable, and that he could see 'no reason for closing our eyes to the fact'. 'Perhaps,' he continued, 'the very efforts that they made to increase the wealth, the means, and the prosperity of the colonies would naturally tend to hasten this result. It would be unwise for them to forget this altogether as it would be for any of their lordships, in his full health and vigour, to forget that at some time or other he must taste of death. Both cvents were equally ccrtain.' 'They

1 Colonists, not planters in the present meaning of the word.

2 Parliamentary Debates, III, xl, 214-215. Brougham expressed much the same views in a debate in the House of Lords on June 15, 1854, and reminded the House that similar views had been held and expressed by Lord Ashburton and Lord St. Vincent. Cf. Parliamentary Debates, III, cxxxiv, 175.

In the same debate - a debate on a bill amending the constitution of 1840 of the United Provinces-Lord Ellenborough asked, "whether we should not, in the most friendly spirit towards Canada and the other colonies of North America, consult with the legislatures of these provinces as to the expediency of taking measures for the complete release of these colonies from all dependence on the Crown and Parliament of Great Britain.' Ibid.

3 Ibid., III, xl, 679. 
should endeavour at the same time,' Aberdeen added, 'so to shape their policy that they might hope, if separation did take place, it would be in amity and friendship.' 1

These were exactly the views that Ward and Roebuck expressed in the debates of 1838-1840 in the House of Commons. They were the views also that Blachford put on record in 1885 .

More than Brougham, and quite as much as any of the Radicals in the House of Commons, Ashburton, in this debate in the House of Lords of February 8, 1838, emphasized the view that there could be no loss of export trade for the United Kingdom from the separation of the British North American provinces from Great Britain. Ashburton, who as a member of the House of Commons-Alexander Baring-had in 1825 expressed the conviction that the colonies could not be held, recalled his speech of thirteen years previously, ${ }^{2}$ and reiterated the conviction that he had then expressed.

'If the colonies must go,' Ashburton continued, 'then he would say, "let them go out in a manner worthy of the dignity of a great people-let them go so as to merit their gratitude and affections." ' Arguing further in favour of separation, Ashburton insisted that if the colonies separated the United Kingdom would still have their trade; ' and not the less valuable would be their intercourse because they were under their own government.'

'Would any one,' Ashburton asked, 'say that commercial intercourse with the United States was of less value to us at present than when most of the States were under the sovereignty of England ? On the contrary would it not be admitted that the commercial intercourse with each was of the utmost importance to the other?' 3

These outspoken expressions of indifference to colonial possessions provoked the Earl of Mansfield to ask for some declaration from the Government as to its attitude on the question of the connexion of the colonies with Great Britain, a request which Mansfield prefaced with the complaint that Glenelg, the Colonial Secretary, had been silent on the subject.

Mansfield held and expressed much the same view of the connexion as Aberdeen had unfolded to the House. But he

1 Parliamentary Debates, III, xl, 663-664.

2 March 25, 1825, ibid., II, xii, 1097-1116.

3 Parliamentary Debates, III, xl, 850-851. 


\section{DISCUSSIONS OF THE COLONIAL CONNEXION}

considered it to be important 'to know from Her Majesty's ministers whether they were determined upon maintaining control and dominion over these colonies, or whether they meant to anticipate the separation taking place at some time, if not at that moment.' 1

The Marquis of Lansdowne, who held the office of Lord President of the Council in the Melbourne Administration, responded to Mansfield's request. Without hesitation, he answered that it was the intention of the Government to retain the colonies. ${ }^{2}$ He denied also that anything had been said by members of the Administration that would admit of any doubt on the subject.

'It would be a disgrace to this country,' Lansdowne declared, 'to abandon to themselves the population of her colonies at the present crisis. The theory of the advocates of separation, as far as it has been laid down, supposed that the people of the colony were themselves favourable to a dissolution of the connexion with the mother country. But there was the strongest evidence that the feelings of the great majority of the Canadians, not of the British party alone, but the French party themselves, were strongly opposed to separation. Many of those who had taken part in the discussions in the other House had argued that the inhabitants of Canada were unanimously eager for a separation. But he was firmly convinced that those who cherished that wish formed an inconsiderable section of the population.' 'It is the determination of the Queen's Government,' added Lansdowne in direct reply to Mansfield, 'to uphold the British connexion.' 3

Melbourne supplemented Lansdowne's answer to Ashburton, ${ }^{4}$

1 Parliamentary Debates, 859-860.

${ }^{2}$ One of the earliest speeches from the Treasury bench of the House of Conmons in favour of the retention of the colonies was made by Lord Palmerston, March 4, 1825. 'It may be a fair question, perhaps,' said Palmerston, who was at the time Secretary at War in the Liverpool Administration of 1812-1827, 'how far it is for the benefit of a country to possess colonies. . . . But there can be no doubt as to the course which ought to be pursued by a country having already in its possession such colonies as belong to England. As far as civilization extends in the world, the formation of British settlement and the accumulation of British wealth is to be found. To abandon possessions gained at the cost of so much blood and treasure-many of them important outposts for the protection of our commerce and the security of our dominion - would be a violation of public faith and a forfeiture of national honour.' G. H. Francis. Opinions and Policy of Viscount Palmerston, pp. 31-32.

3 Parliamentary Debates. III, xl, 866.

4 'Lord Melbourne in 1838 told young Queen Victoria that Lord Ashburton 
Aberdeen, Brougham, and Mansfield. He strongly deprecated at a time of crisis statements of opinion such as those which had been made in the debate. 'It was,' he cautioned the House. 'extremely doubtful policy to hold out temptations on every trifling event, on every slight quarrel, on every slight difference. It must be recollected also that however separation might be considered in a commercial or a political point of view, recession, drawback, the contraction of territories, was no trifling matter. It had never been found easy. The boundaries of an empire might easily be pushed too far. It might be difficult to maintain them. But the drawing them within a smaller limit had never redounded to the credit or safety of an empire.' 1

At a much later stage of the proceedings in Parliament on the Canada Bills of 1838,1839 , and 1840 , at a stage at which both Brougham and Ashburton had repeated and emphasized the views they had expressed in the debate of $1838,{ }^{2}$ Melbourne made a second statement of the attitude of the Government, a statement that came after a noteworthy speech by Wellington in which he regretted popular indifference to the colonies, and expressed his conviction of the value of the colonies to the United Kingdom.

Wellington had, he assured the House (June 30, 1840), the sincerest wish to secure for the colonies a permanent union with Great Britain. 'He had observed for some length of time', he continued, ' a growing desire to get rid of their North American provinces-a desire that they should become Republics. This desire prevailed amongst a very large party. He was aware that there were also others, for whom he entertained the highest respect, who felt a desire that the separation should take place tranquilly if possible, but at all events it should take place. In his opinion those gentlemen were mistaken. It was his decided opinion that considering the resources and power of those colonies, this country would sustain a loss indeed if her colonies departed from her.' 3

A twofold importance attaches to Wellington's speech of June 30,1840 . It is a proof that however willing Wellington

had got "that fashionable theory" that it " was better to give up the colonies at once when they became at all unquiet ".' Lord Esher, The Girlhood of Queen Victoria, i, p. 278.

1 Parliamentary Debates, III, xl, 882.

2 Cf. Parliamentary Debates, June 30, Ashburton, III, lv, 259; Brougham, III, lv, 266-267. 


\section{DISCUSSIONS OF THE COLONIAL CONNEXION}

might have been in 1827 to abandon far outlying possessions such as the Gold Coast and Sierra Leone, and in 1828 to turn over Ceylon to the East India Company, he was not willing in 1840 to abandon the British North American provinces.

Wellington's speech also affords additional proof, if additional proof be needed, of the fact that in the years from 1822 to 1859 indifference to the colonies was not a characteristic of men at Westminster who were associated with only one political party. Twelve years later, Grey, who until 1873 never wavered in his conviction of the importance of the connexion of the colonies with Great Britain, emphasized the fact on which Wellington laid stress in 1840 .

'It is impossible not to observe that this policy' - the policy of abandoning the colonies-wrote Grey in 1852, ' unworthy of a great nation, and unwise as I consider it to be, is not only openly advocated by one active party in this country, ${ }^{1}$ but is liardly less effectually supported by persons occupying an important position in Parliament, who, while they hesitate to avow their adherence to it, hold language which obviously leads in the same direction, and advocate measures the adoption of which would inevitably bring about this result.' ${ }^{2}$

Melbourne, who, it will be recalled, was at this time-June 30 , 1840-Premier of the Whig Administration of 1835-1840, made a speech strongly and unequivocally in favour of the maintenance of the connexion with the British North American provinces. He dissociated himself completely from the views of Ashburton and Brougham, and also from those of Aberdeen. He did not feel justified in using the same expressions of strength and force as Wellington, 'who was so conspicuously identified with the military glory of this country.' Yet he did assure Wellington 'that he could not feel more keenly the disgrace of living to see the day when the Canadas should be separated from Great Britain than he should.'

1 The Radical party in which, at the time Grey wrote, 1852, Radieals of the Manchester school of political and eeonomie thought had succeeded Radicals of the philosophical group of the first two deeades after the Reform Aet of 1832 .

'To promote colonial independence was our aim. We (the Manchester school) never wished to make England little. We believed that her greatness was in herself, and was only impaired by the dissipation of her forces and her exposure, through her dependencies, to attack in every quarter of the globe. The England of ('romwell was not little.' Goldwin Smith, Reminiscences, pp. 221-222.

2 Grey, Colonial Policy, i, p. 17. 
'The loss of those colonies', Melbourne continued, 'he should regard as a most serious one, and above all as a heavy blow to the character and reputation of the country.' Melbourne then turned to the insistence by Ashburton, Brougham, and Aberdeen on the contention that when separation came it should be amicable. 'As to expecting an amicable separation,' he said, 'that was an event almost impossible. If we gave them up at all, it must be because we felt that we were unable to keep them; and such an acknowledgement would be very unfavourable to the reputation, and consequently to the strength, power, and influence of this country.' 1

\section{CHAPTER XII}

\section{INDIFFERENCE TO THE COLONIAL CONNEXION IN THE CONSTITUENCIES}

ON most questions that are long discussed at Westminster, on practically all questions, it is soon possible by divisions to test the feeling in the House of Commons and the House of Lords. Especially is this true of the House of Commons, where opportunities of demonstrating or testing the measure of support of any political propaganda are much more frequent and of more parliamentary value than in the House of Lords.

Members of the House of Commons, who in this period of the era of indifference expressed themselves as eager to see a separation of the colonies from Great Britain, were obviously more numerous than members who in these debates put themselves on record as holding the contrary opinion. But there was never any organized propaganda in the House of Commons for separation.

Members indifferent to the retention of the colonies so expressed themselves on Government measures for the colonies that came before the House. None of the many speeches expressive of willingness to end the connexion, however, was followed by a motion or a resolution, as is the usage in an organized propaganda in Parliament for some change in a law or for some popularly desired reform. There never was, moreover, a Government

1 Parliamentary Debates, III, Iv, 268-269. 


\section{INDIFFERENCE TO THE COLONIAL CONNEXION}

bill, or a resolution proposed from the Treasury bench, that afforded an opportunity, direct or indirect, of testing the feeling of the House of Commons on the desirability or otherwise of the colonial connexion. No Government ever declared what its policy on this question was, and then asked the House of Commons, or the House of Lords, by a vote to accept or reject its policy. ${ }^{1}$

In the constituencies of the United Kingdom during this period, except occasionally in the press, colonial questions and colonial policies were never discussed. They were certainly not discussed at elections. Elections-by-elections or general elections-never in any degree turned on any aspect of colonial policy, or on the relations of Great Britain either to the colonies now of the dominions, or to the Crown colonies.

From the end of the American Revolution to the Confederation of the British North American provinces in 1867, elections in the United Kingdom were never even slightly affected or influenced by any phase or department of the colonial policy of any Government at Whitehall.

Canadian politics, or questions arising out of Canadian politics, obtruded themselves much more into the general domestic politics of the United States than they ever did in these eighty-odd years

1 Almost from the time of the carliest expression in Parliament of views and convictions that separation of the colonies from Great Britain was inevitable and also desirable (1822-1823) there were expressions of dissent and of contrary views in both the House of Commons and the House of Lords.

The first expression of dissent was not from the Treasury Bench in the House of Commons, but from a private member-Henry Bright, one of the members for the city of Bristol. "Some of the doctrines laid down by the honourable mcmber', said Bright (February 26, 1823) in answer to a speech on the North American colonies by Joseph Hume, "were at variance with the sound maxims of our forefathers; and broaching such doctrines in that House, if they were suffered to pass unnoticed, would produce the most mischievous effects in the colonies.' Parliamentary Debates, II, viii, 253.

In addition to the specches in support of the connexion with the colonies which have been cited, other speeches in the spirit of those of Palmerston of 1825 , and Melbourne, Lansdowne, and Wellington of 1838-1840, were: Huskisson, May 2, 1828, Parliamentary Debates, II, xix, 314-318; George F. Young. December 22, 1837, III, xxxix, 1478, and Jamuary 25, 1838, III, xl, 509; Lord John Russell, December 22, I837, III, xxxix, 1495-1505, and April 13, 1840, III, liii, 1063 ; E. S. Cayley, January 17, 1838, III, xl, II3; Peter Borthwick, January 17, 1838, III, xl, I18; Peel, January I6, 1838, III, xl, 69-73, April 13, 1840, III, liii, 1063, and June 12, 1840, III, liv, 1840 ; E. R. Rice, January 22, 1838, III, xl, 346; R. Hutton, January 25, I838, III, xl, 515; C. P. Villiers, January 25, 1838, III, xl, 520; Pakington, May 29, 1840, III, liv, 7II ; Lord Howick (afterwards Farl (irey of the Colonial Office). May 29, 1840, III, liv, 747; and Sir George Grcy, July 11, 1839, III, xlix, 153. 
into the general domestic politics of the United Kingdom. The vigour with which President Van Buren enforced the neutrality laws of the United States, and the promptness with which he called on Congress at Washington to amend and strengthen these laws, at the time of the rebellions in Canada of 1837-1838, ${ }^{1}$ estranged more votes from Van Buren and the Democratic party, at the presidential and congressional elections of 1840 , than were estranged from political leaders, or from the rank and file of parliamentary candidates in Great Britain, by any of the policies in regard to colonies now of the dominions of any Administration from the time of Pitt to that of Derby and Palmerston.

Van Buren lost the electoral vote of New York-lost the sixty votes of his home State in the electoral college-largely owing to his strict enforcement of the neutrality laws, an enforcement which had estranged thousands of voters in the northern counties of New York whose sympathies, like those of thousands of electors in Maine and Vermont and other States on the Canadian border, were openly with Papineau and Mackenzie and the rebels in Upper and Lower Canada. ${ }^{2}$

Colonial questions were continuously discussed atWestminster, especially from 1822 to 1849 . But popularly, in the constituencies, they were regarded as apart from domestic politics. They were treated as questions on which the electors would never be called upon to vote or pass judgement. Thus, as in the House of Commons and the House of Lords, opportunity was never afforded of testing the constituencies on the desirability or otherwise of a continuance of the connexion between Great Britain and the colonies.

The movement for annexation to the United States of Upper and Lower Canada, essentially a movement of the commercial classes of the larger cities of these provinces, was the only development in colonial politics between 1822 and 1867 that afforded even an indirect test of public opinion in the United Kingdom on the question of the value of the colonies.

The leaders of the annexation movement in Montreal were convinced that the people of Great Britain were indifferent to whether Upper and Lower Canada remained within the British

1 Cf. United States Statutes at Large, 1838, c. 31, approved May 10, 1838.

2 Cf. Edward M. Shepard, Martin Van Buren, pp. 356-357 ; Edward Stanwood, A History of Presidential Elections (1884), pp. 138-139. 
Empire or otherwise disposed of themselves. Canadian historians of the movement, writing sixty years after its collapse, are also agreed that the people of the United Kingdom were little concerned as to how the annexation movement ended. ${ }^{1}$

\section{CHAPTER XIII}

\section{REASSURANCES TO THE COLONIES-ELGIN'S MESSAGE OF 1847-1854}

EXCEPT for speeches in the Imperial Parliament, such as those of Melbourne, Lansdowne, and Wellington, which have been quoted in preceding chapters--except for these reassuring utterances in the House of Lords during the long-drawn-out crisis in the Canadas of 1837-1840-only thrice, it would seem, in this period of indifference of 1783-1859 were the British North American provinces told that Great Britain was desirous to retain the connexion with these large, comparatively undeveloped and outlying parts of the Empire.

The speeches of Melbourne, Lansdowne, and Wellington were made not directly to the British North American provinces. They were addressed primarily to the House of Lords, and through the House of Lords to the people of the United Kingdom. In course of time it was probable that these reassuring declarations reached part of the people of the Maritime Provinces and the Canadas.

Three times at least, however, in these years from 1783 to 1859 , the people of these provinces were directly told-told on the spot, as distinct from being told on the floor of the House of Lords or the House of Commons - that it was the policy of Great Britain to continue the connexion. Each of these direct messages was delivered at a time of crisis for all the North American provinces.

Sydenham was the bearer of the first of these messages from Downing Street to the Canadas and the Maritime Provinces. The

\footnotetext{
1 ' The discussions of the press did not display any eoercive disposition towards the colonies.' 'Whigs, Tories, and Radicals alike subordinated the interests of the colonies to their own distinctive domestic politics.' Allin and Jones, Annexation, Preferential Trade, and Reciprocity, pp. 364, 373.
} 
message was written by Russell, who at this time, September 7, 1839, was Secretary of State for the Colonies in the Melbourne Administration of 1835-1841. Sydenham was about to proceed to Toronto as Governor-General of Canada, to take up this office in the trying period while the new constitution for the United Provinces was being fashioned at Whitehall and Westminster.

'Finally,' wrote Russell to Sydenham, in instructing him as to the policy he was to pursue in the Canadas, 'I am commanded to direct that in all the provinces of British North America you will inculcate upon the minds of the Queen's subjects Her Majesty's fixed determination to maintain the connexion now subsisting between them and the United Kingdom, and to exercise the high authority with which she has been invested by the favour of divine providence for the promotion of their happiness and the security of her dominions.' 1

Sydenham began his term as Governor-General at Toronto on November 22, 1839. He died at Kingston on September 19, 1841. He was not sent out to concede the demand of the Radicals of the United Provinces for responsible government. In one of his earlier letters to England, December 12, 1839, he congratulated himself that he had already done much to side-track the demand of the reformers 'that the council shall be responsible to the assembly, and that the governor shall take their advice and be bound by it.' 2

But experience with the House of Assembly of the United Provinces under the constitution of 1840 , and of political conditions in the Canadas, gradually convinced Sydenham that the demand for responsible government must be conceded. It had been so far conceded by him by September 1841 that there could be no turning back by his successors, Bagot and Metcalfe ; although Metcalfe made a prolonged and stubbornly persistent effort to give a different meaning to the term responsible government from that understood by Baldwin and La Fontaine and accepted by Sydenham and Bagot.

Sydenham did much toward establishing responsible government. He helped to create this new link of empire. In the Canadas and in the Maritime Provinces also he loyally acted on Russell's instructions of September 7, 1839, and proclaimed

1 Kennedy, Constitutional Documents of Canada, 1795-1915, p. 522.

2 G. Poulett Scrope, Memoir of Sydenham, p. 143. 


\section{REASSURANCES TO THE COLONIES, 1847-1854}

that it was the policy of Great Britain to maintain the connexion with the British North American provinces. ${ }^{1}$

The second message reached all the British North American provinces in June 1846, immediately after Great Britain had adopted free trade, and with no consultation with any of the colonies ${ }^{2}$ had abandoned the old commercial system, with its tariffs so framed as to afford valuable concessions in favour of lumber from the Canadas and New Brunswick and Nova Scotia, and almost equally favourable treatment at ports in the United Kingdom for grain and flour from Upper and Lower Canada.

The third of these messages-a message that was carried across the Atlantic by Elgin and was wrought into the political civilization of the United Provinces and ultimately into the constitutional systems and political civilizations of all the British North American provinces rather than merely delivered-was at the crisis of 1847-1849 in the movement in the Canadas for responsible government.

Gladstone was at the Colonial Office at the time Peel's free trade legislation of 1846 was enacted; and upon Gladstone devolved the duty of informing Cathcart, the Governor-General of Canada, that the Peel Administration could not accede to a petition of the legislature of the United Provinces of Upper and Lower Canada for the remission of even the nominal duty of one shilling a bushel on grain exported from these provinces to the United Kingdom.

It was in conveying this denial of the petition of the Canadas that Gladstone, in his most gracious style, communicated to the United Provinces, and through them to all the British provinces of North America, that it was the desire of the Government that the connexion of all the North American provinces with Great Britain should be regarded as permanent.

'It would indeed be a source of great pain to Her Majesty's Government', wrote Gladstone on June 3, 1846, ' if they could share in the impression that the connexion between this country and Canada derived its vitality from no other source than from the exchange of commercial preferences. ${ }^{3}$ If it were so it might

1 Scrope, op. cit., p. 187.

2 People in the British North American provinces, like those in the United Kingdom, first had news of the approaching tiscal revolution from The Times of February 6, 1846. Cf. J. K. Laughton, Hemoirs of Henry Reeve, i, p. 175.

3 'Countries of this maturity are unquestionably quite fit to walk alone, and 
appear to be a relation consisting in the exchange not of benefits but of burdens. If it were so, it would suggest the idea that the connexion itself had reached, or was about to reach, the legitimate term of its existence.'

'But', continued Gladstone, 'Her Majesty's Government still augur for it a long duration, founded upon a larger and firmer basis-upon protection rendered from the one side, and allegiance, freely and loyally returned, from the other-upon resemblances in origin, in laws and in manners, in what invariably binds men and communities of men together, as well as in the close association of those material interests, which, as Her Majesty's Government are convinced, are destined not to recede, but to advance-not to be severed, but to be more closely and healthfully combined, under the quickening influence of increased commercial freedom.' 1

Elgin, who was Queen Victoria's choice for the GovernorGeneralship of Canada, ${ }^{2}$ never shared in the view held in these years inside the Colonial Office and the view so often expressed by members both of the House of Commons and the House of Lords, and nearly as frequently in newspapers of Radical opinion ${ }^{3}$

no one can hope that they can ever be well or satisfactorily governed at a distance of four thousand miles. The tools by which we contrived heretofore to manage, rather than to govern, them have nearly all disappeared, one after the other. We governed them through the interests of a faction among themselves (the family compact), and this has most properly vanished. They were bound to us by monopolies of our markets (the tariff preferences under the old commercial system), and these have perished, one after another, to the great advantage of both parties. What advantages do we then derive from the possession of these remote and cumbrous colonies? We believe none whatever, except such as they would yield, and to a far greater extent, were they independent of us tomorrow.' The Examiner (London), May 19, 1849.

1 Journals of the Legislative Assembly of the United Provinces of Canada, June 18, 1847, p. 53.

2 The Queen, on November 5, 1845, in a note to Stanley, who was then at the Colonial Office, told him that she knew "nobody who would be as fit for the appointment as Lord Elgin, who seems to have given great satisfaction in Jamaica', where he had served as Governor from 1843 to 1846. Cf. Benson and Esher, The Letters of Queen Victoria, pp. 54, 111-112.

3 'The Government at St. James's, which has recognized the equality of the Government at Washington, must in time recognize the equality of the Government at Sydney and Wellington.' The Examiner (London), February 24, 1849. 'It ought never to be left out of view that with all colonies a time must come when they will assert entire independence in all matters of government.' Ibid., July 21, 1849. 'It is not man y years since Lord John Russell made the statesmanlike avowal that it was our duty to prepare the Canadas for a separation, when that should become inevitable; and the only proper training to this great end is the exercise of responsible government. Lord Elgin has manfully proclaimed this principle; and throughout his Administration has acted upon it honestly and ably.' Ibid., September $8,1849$.

1569.29 


\section{REASSURANCES TO THE COLONIES, 1847-1854}

that the conncxion between the oversea dominions and Great Britain could at best be only temporary.

Success such as marks Elgin's term from 1847 to 1854 could by no possibility have attended his work had he arrived in Canada with the idea that he was merely to aid in perfecting a system of government that was to be only provisional, or with the conviction that the British North American provinces would follow the example of the American colonies and end the connexion with Great Britain.

Elgin's conception of his mission and his messagc to the North American provinces-a conception which was developed and strengthened by his two years' experiences in Canada, by the confidence reposed in him by Russell and Grey and by his own successes-was expressed in a dispatch to Grey, at the Colonial Office. It was written in 1850 , after he had weathered the crisis over the Rebellion Losses Bill; but while he and the BaldwinLa Fontaine Government and the Whig Cabinet in Downing Street were still confronted with the agitation for the annexation of Upper and Lower Canada to the United States.

'For one,' Elgin wrote on March 23, 1850, 'I have never been able to comprehend why, elastic as our constitution is, we should not be able, now more especially when we have ceased to control the trade of our colonies, to render the links which bind them to the British Crown at least as lasting as those which unite the component parts of the union. One thing is, however, indispcnsable to the success of this or any other system of colonial government. You must renounce the habit of telling the colonies that the colonial is a provincial cxistence. You must allow them to believe that, without severing the bonds which unite them with Great Britain, they may attain the degree of perfection and of social and political development to which organized communities of free men have a right to aspire.' 1

As Elgin conccived it, this was the message that it was his duty to proclaim in the Canadas when he went there in December 1847. It was in the spirit of this message that he faced the extraordinary series of erises that are of the history of the United Provinces during his six years' term as Governor-General: (1) the erisis due to the dislocation and uncertainty of trade consequent on the abandonment of the old commercial system ;

1 Walrond, Letters of Lord Elgin, p. 116. 
(2) the crisis that confronted him in the winter of 1847-1848 due to the hopeless failure of Metcalfe's attempt to withhold responsible government ; (3) the crisis over the Rebellion Losses Bill of 1849 ; (4) the agitation of 1849-1851 for annexa tion of Upper and Lower Canada to the United States; and (5) the long continued uncertainty as to whether success would ultimately attend the efforts of 1848-1854 to secure a treaty of reciprocity with the United States.

There were times in these six years when Downing Street wavered in its support of Elgin. It did not weaken or waver in its support of his policy of conceding responsible government in the fullest measure. The Whigs when they were in power from 1835 to 1841 had denied responsible government to the Canadas, but the Russell Government had committed itself to the concession of responsible government beyond possibility of turning back, when Elgin was appointed Metcalfe's successor. Nor did the Russell Government withhold its support from Elgin in his efforts to secure commercial reciprocity with the United States.

But in the parliamentary session at Westminster of 1850 , Russell did weaken in his publicly proclaimed support of Elgin's policy of so conceding responsible government, and so shaping its organization and development, that the United Provinces and all the British North American colonies would realize that possessing responsible government to the fullest extent of their demands, and without any break in the connexion with Great Britain, all these provinces might attain 'the degree of perfection and of social and political development to which organized communities of freemen have a right to aspire.'

Russell in 1850 was much in the mood toward the inevitableness of the separation of the colonies from Great Britain that was characteristic of the speeches of Ashburton, Aberdeen, Brougham; of the philosophical Radicals of the House of Commons, and also of the writings of Taylor and Blachford of the Colonial Office. It was the mood that characterized Russell's speech of February 8, 1850, when, in the House of Commons, he asked leave to introduce the bill for the government of the Australian colonies.

Even the opening sentences of Russell's long and detailed survey of colonial development were characterized by doubt as 


\section{REASSURANCES TO THE COLONIES, 1847-1854}

to the continuance of the connexion of the colonies with Great Britain.1 But as he proceedcd he grouped himself with those of his contemporaries in the House of Commons and the House of Lords who regarded it as inevitable that the connexion could not endure.

'I anticipate indeed, with others,' said Russell, ' that some of the colonies may so grow in population and wealth that they may say " our strength is sufficient to enable us to be independent of England. The link is now onerous to us. The time is come when wc think we can, in amity and alliance with England, maintain our independence." I do not think that time is yet approaching. But let us make the colonies, as far as possible, fit to govern themselves. Let us give them, as far as we can, the capacity of ruling their own affairs. Let them increase in wealth and population; and whatever may happen, we of this great Empire shall have the consolation of saying that we have contributed to the happiness of the world.' 2

'Go when you are ready,' was, in brief, the message that Russell, Premier of a Whig Administration, sent broadcast over the Empire, when he called on Parliament in 1850 to enact a constitution for New South Wales and the other Australian colonies.

It was a disheartening speech for Elgin. It was more. It was a most disturbing and embarrassing exposition of the attitude of the Government in London toward the self-governing colonies in British North America and in Australasia. It reached Canada, moreover, just at the time when the Baldwin-La Fontaine Government, in close and continuous council with Elgin, was determining its policy toward men in the public service, magistrates and militia officers who had openly identificd themselves with the agitation for the annexation of Upper and Lower Canada to the United States. ${ }^{3}$

1 Parliamentary Debates, III, eviii, 536.

2 Ibid., III, eviii, 567.

3 There was a meeting of the Baldwin-La Fontaine Cabinet at Toronto on March 22, 1850. 'Baldwin', wrote Elgin to Grey. Mareh 23. ' had Lord John's speech in his hand. He is a man of singularly placid demeanour ; but he has been seriously ill, so possibly his nerves are shaken. At any rate, I never saw him so much moved. "Have you read the hatter part of Lord John Russell's speech ?" he said to me. I nodkded assent. "For myself." he ackded. " if the anticipations therein expressed prove to be well founded, my interest in public affairs is gone for ever. But is it not hard upon us, while we are labouring through good and evil report to thwart the designs of those who woukd dismember the 
But after an exceedingly frank expression of his views in a protest to Grey, Elgin surmounted the difficulties that Russell's speech of February 8, 1850, had created for him ; and to the end of his term as Governor-General he acted continuously and at every crisis on his conviction that neither responsible government nor growth in population and in material wealth need bring about the separation of any of the British North American provinces from Great Britain.

The era of indifference to colonial possessions-the attitude toward the self-governing colonies that Russell expressed in February 1850-survived, to a greater or less degree, for nearly forty years after Elgin went to Canada in 1847. When indifference came to an end, its passing was due, as will appear in subsequent chapters, to causes and influences which had their origin largely within the colonies themselves, but partly to causes and influences which had their origin in Great Britain and partly to causes whose origin was external to the British Empire, but which greatly influenced both the self-governing colonies and Great Britain. ${ }^{1}$

The most potent of these three sets of causes and influences that combined and created the newer attitude in Great Britain of 1887-1914 were the causes and influences which originated in the colonies themselves; for these influences did much to create the newer attitude toward the colonies in Great Britain.

Durham and Sydenham, by their missions to Canada, each contributed to the creation of the influences in the colonies that did so much to bring about the change and the newer relation between the self-governing colonies and Great Britain. ${ }^{2}$

Empire, that our adversaries should be informed that the difference between them and the Prime Minister of England is only one of time?".' Walrond, op. cit., p. 117.

1 Cf. Lucas, Empire and Democracy, the Empire and the Future, pp. 13-14.

2 'Lord Durham preached his gospel and died. Lord Sydenham, before he too died, set the political machine running in the right direction. Then the machine went on, the way widened, the views widened. Men grew up to contemplate a nation, and after contemplating to create it. Lord Durham's Report gave the inspiration. Sydenham, with his combination of strong popular sympathies and great business capacity, showed how to begin putting principles into practice. The history of Canada has been, on the whole, a history of singular good fortune; and not the least part of this good fortune has been that Lord Durham should have been forthcoming at the particular time when he went to Canada, and that Lord Sydenham should have been available as his successor. It would be difficult to find in the chronicles of any country two men who, within little more than three years in all, did so much to help the coming time.' Lucas, Durham Report, i, pp. 301-302. 


\section{REASSURANCES TO THE COLONIES, 1847-1854}

Most potent of all the forces working within the self-governing colonies from 1847 to 1887 was the message that Elgin threaded into the constitution and the political civilization of Canada, and into the thought and mental fibre of the people of the British North American provinces, in the continuously trying and critical years during which he was Governor-General. More than any other man-more than any other score of men not of the colonies by birth or domicile, but active in colonial administration either oversea or in Downing Street-Elgin helped to the creation of the spirit in the colonies that ultimately changed the attitude of the people of Great Britain toward the oversea dominions of the Empire. 


\section{PAR'T VI}

\section{THE SECOND HALF OF THE ERA OF INDIFFERENCE 1859-1887}

\section{CHAPTER I}

\section{CONTINUED LANGUID INTEREST OF PARLIAMENT IN COLONIAL LEGISLATION}

Alfred Lxtrelton, who in 1903 succeeded Chamberlain as Secretary of State for the Colonies in the Unionist Administration of 1896-1905, told a meeting at Birmingham in 1910 that for a long time the true political relation of Great Britain to the colonies now of the dominions was obscured in wise silence. ${ }^{1}$ As concerns the large powers of self-government that the colonies drew to themselves in the years 1840 to 1873 , the statement is abundantly true.

Responsible government, as it was understood in all the colonies and at the Colonial Office after $1849,{ }^{2}$ was for a long time not popularly comprehended in the United Kingdom. Why responsible government in its fullest extent was not comprehended is obvious. In the second period of indifference-1859 to 1887 the self-governing colonies attracted little more interest at Westminster and in the constituencies than from 1820 to 1859 ; and especially was this true of the years from 1859 to $1873 .^{3}$

1 Ashley, British Dominions, p. 18.

2 'The North American, like the Australian colonies, and like the Cape, have very naturally renounced all consideration of English interests, and renounced and resented every exercise of English power so often as they conflicted in the slightest degree with colonial interests and sentiments.'-Henry Taylor, Colonial Office, March 25, 1865, to Chichester Fortescue (afterwards Lord Carlingford), Under Secretary of State for the Colonies, 1857-1858 and 1859-1865. Auto. biography of Henry Taylor, i, pp. 236-237.

3 . Only forty years ago drift was accepted; and what is more was thought by well-informed public servants to be in the direction of independence. The colonies, as they grew up, had much better go their own way, and leave off troubling us at home with their affairs; and this was not an opinion of one school or party, but a standing tradition of the Colonial Office.'- Sir Frederick Pollock, 
It is true that in 1861 mention began to be made of the selfgoverning colonies in the speech from the Throne at the opening of a new session of Parliament at Westminster. ${ }^{1}$ But the history of the bill for the Confederation of the British North American provinces in 1867, and also of the bill of 1873 for freeing the Australian colonies from part of the restriction imposed by the Constitution Act of 1850 on the enactment of differential tariff duties, affords abundant proof that Parliament, in the years from 1859 to 1873 , was not much more interested in legislation for the self-governing colonies than it was in the years from 1820 to $1859 .^{2}$

A Government supported in the House of Commons by a Conservative majority was responsible for the bill creating the Dominion of Canada. For the bill of 1873, enlarging to a small degree the fiscal freedom of New South Wales, Victoria, and the other Australian colonies, a Liberal Government was responsible.

There was no contention over the bill for the Confederation of the British North American provinces either in the House of Lords, where it was introduced by Carnarvon, Secretary of State for the Colonies, or in the House of Commons. It was before the House of Lords only four days. The House of Commons spent no longer time on it. The bill contained one hundred and fortyseven clauses; and as an Act in the Pickering edition of the British statutes it extends to thirty-three closely printed pages.

Committee stage of the bill, the stage at which clauses are discussed in detail, occupied the House of Commons less than one sitting; for after the Canada Bill had been reported from

Imperial Organization, Royal Colonial Institute, April 11, 1905. Journal of the Society of Comparative Legislation, New Series, xiv, p. 240.

1 ' I am glad to take this opportunity of expressing my warm appreeiation of the loyalty and attachment to my person and throne, manifested by my Canadian and other North American subjeets on the oceasion of the residenee of the Prinee of Wales among them.' Parliamentary Debates, February 5. 1861, III, clxi. 5. At the opening of the next session of Parliament, February 6, 1862, there were again referenees to the British North Ameriean provinces in the speeeh from the Throne. ('f. Ibid., III, elxv, 4.

2 'There is nothing [in the library of the House of commons] except the actual journals sent out by the Canadian legislatures, giving any aecount whatever of legislative procedings in (anada. The Blue Books give no details. The eommunications of offiejal correspondence are meagre. In fact. ('anada has told us nothing. and England has not cared to know. Each has been minding its own affair:; and what was ealled our salutary megligence of each other has returned.' Adderley, Colonial Policy (1869). p. 38. 
committee the House turned its attention-its lively attentionto a bill for increasing the tax on dogs. ${ }^{1}$

Representatives of four of the North American provinces - Upper and Lower Canada, New Brunswick, and Nova Scotiawere in attendance in the public gallery while the House of Commons was in committee on the Confederation Bill, one of the most important measures for the colonies now of the dominions that was enacted at Westminster in the hundred and thirty-odd years that intervened between the American Revolution and the war of 1914-1918.

'The great body of the House,' wrote one of the representatives of the provinces-Garvie, of Nova Scotia-who looked on from the gallery, 'was utterly indifferent. Even the delegates ${ }^{2}$ seemed chagrined at the lazy contempt with which a thin house suffered their bill to pass unnoticed through committee. A clerk at the table gabbled on, not the clauses even, but the numbers of the clauses; and as if that were not a quick enough mode of rushing through a disagreeably dull measure which did not affect anybody's seat-a measure, therefore, which could not be listened to - he read a whole batch of numbers at once. For example, he said, "Moved that clauses 73, 74, 75, pass" ; and they passed without anybody worrying himself about their contents.'

' The house got livelier and better filled,' added Garvie, ' when a dog tax bill came up; for, you see, the country gentlemen who could not, may be, point out Nova Scotia on the map, keep hounds, subject to a tax, which interests them more keenly than a Canadian tariff. I confess this utter indifference was more mortifying to me than positive opposition. It showed that they considered colonists beings as little related to them as the inhabitants of some nameless Chinese mud village.' ${ }^{3}$

Garvie was in London with Joseph Howe, an ex-Premier and one of Nova Scotia's foremost publicists, to oppose the bill for Confederation on behalf of Nova Scotia, a province which in 1866-1867 was hostile to inclusion in the Dominion of Canada. ${ }^{4}$

1 Cf. Parliamentary Debates (House of Commons), March 6, 1867, III, clxxxv, $1316-1322,1324$.

2 The representatives of the British North American provinces in London for conference with the Colonial Office in regard to the bill, and to watch its progress through Parliament.

${ }_{3}$ Letters of William Garvie, Transactions of the Royal Society of Canada, III (March 1917), pp. 462, 463.

4 One of the grounds of objection of Nova Scotia to Confederation was the 
Nova Scotia went into Confederation in 1867. As a province it profited enormously from the development of its coal and iron and steel industries under the national policy tariffs continually in operation from 1879, and also under the bounty system of 1883-1912.

Excepting Ontario and Quebec, no province profited more from Confederation than Nova Scotia. But half a century after Confederation, and at a time when popular hostility to inclusion in the Dominion had long been forgotten, Garvie's description of the attitude of the House of Commons toward the epoch-making bill of 1867 was accepted by Canadian writers on colonial history as an accurate and faithful description of the indifference at Westminster of the era of 1859-1873 toward legislation for the self-governing colonies, and also toward the political fortunes of the British North American provinces. ${ }^{1}$

The grievance to be partly removed by the Australian Customs Duties Bill of 1873 had kept the political capitals of the Australian colonies, and also the political capital of New Zealand, in more or less commotion for five years. It had been the occasion of more dispatches to the Colonial Office than any other question that had arisen in the Australasian colonies from the time responsible government was established in them in 1850-1854.

These dispatches were from the governors of the colonies, but accompanying them were many minutes of council from the colonial cabinets in which were embodied some of the frankest and most unrestrained utterances ever addressed to a Colonial Secretary; for by 1867-1873 cabinet ministers in Australasia had found irksome the propaganda from the Colonial Office for tariffs all over the Empire based on free trade ; and, moreover, they were resolutely intent on securing for the Australasian colonies all the fiscal freedom that the British North American provinces had enjoyed, and repeatedly exercised, after the enactment of the Cayley and Galt tariffs in 1858 and 1859.

proteetionist tariff of the United Provinees and the well-founded apprehension that proteetion would become the fiseal poliey of the Dominion of Canada. From 1846 until it went into Confederation Nova Seotia had tariffs for revenue only. tariffs in which there was no protection for industries in Nova ficotia. Nova ficotia in these rears imported no manufactured articles from the United l'rovinces of I pper and Lower Canada, with which it had much less communieation and trade than it had with Massachusetts.

1 A graphie and suftieiently mortifying pieture of the birth of the Dominion.Lawrence J. Burpec, editor of the Ciarvie Correspondence, loc. cit., III, J. 10. 
In the House of Commons the bill partially freeing the Australian colonies from the restraining section of the Imperial Act of 1850 aroused no interest. Every stage would seem to have been regarded as purely formal-introduction, and first reading, second reading, committee, report from committee and third reading-and in the reports of the parliamentary debates there is no record of any speech on the bill, or any discussion of it at any of its five stages. Kimberley, the Colonial Secretary, was in the Lords; and in the minutes of the progress of the bill through the House of Commons even the name of the member on the Treasury bench who introduced the bill is not mentioned. ${ }^{1}$

\section{CHAPTER II}

\section{COLONIES IN LITERATURE-HISTORY, BIOGRAPHY, AND POLITICAL SCIENCE}

VERY little attention was bestowed on the colonies in the press. There were many complaints from the self-governing colonies of the ignorance of British journalists of conditions in the colonies, and similar complaints of neglect by the press. A newspaper in any country lives and prospers by giving its readers what they want. Only an organ kept on its feet by subsidies from one source or another can ignore this well-recognized and long established canon of newspaper world economy. The complaint from the colonies of neglect really lay not against the editors of newspapers, but against the reading constituencies, whose wants it was the business of the editors to meet. ${ }^{2}$

1 Cf. Parliamentary Debates, III, ccxv, 218, 520, 1024, 1292, 1404 ; III, ccxv, 2008, House of Lords, May 15, 1873, for comment by Carnarvon on the lack of interest in the bill in the House of Commons.

2 'It was melancholy to discover how utterly ignorant the majority of English editors and politicians are concerning us. They did not know the first thing about us ; and they did not care to know. - William Garvie, London, March 15, 1867, to the Nova Scotia Anti-Confederation Committee. Transactions of the Royal Society of Canada (March 1917), III, x, 462.

Duncan Campbell, author of a history of Prince Edward Island, published in 1875 , recalled that Cobbett had described the island as ' a rascally heap of sand, rock, and swamp', and had predicted that emigrants from Scotland who were going to Prince Edward Island at the time he wrote would not stay. "If such are the doctrines which are taught to the people of Great Britain by men like Cobbett, what,' asked Campbell, ' must have been the depths of ignorance 
Books on the colonies in the period from 1859 to 1873 were issued from the publishing houses in London and Edinburgh only a little more frequently than in the years from 1820 to $1859 ;^{1}$ but apparently as frequently as the public demand for them warranted, for publishers of books were under much the same conditions as newspaper editors.

In political biographies and memoirs of statesmen who had been in the front rank at Westminster, but scant attention was paid to any part they might have had in the making of the constitutional and political history of the oversea dominions. It is not conceivable that any country could be more generously supplied with political biography, memoirs, and letters than the United Kingdom. The supply is particularly abundant for the nineteenth century. It is so abundant that if all other material were lacking, it would be possible to write the political history of Great Britain from the Napoleonic wars to the end of the reign of Queen Victoria from biography alone.

But even the most detailed of British political biographies often fail the student who desires to trace the part that Downing Street and Parliament at Westminster had in the almost revolutionary changes in the relations of the colonies to Great Britain

respeeting the North American colonies which pervade the masses ?' Duncan Campbell, A History of Prince Edward Island, pp. 77-78.

'In London newspapers references to the moon occupy six times the spaee devoted to Australia.'-Sir William Snowden, three times Mayor of Melbourne, Member of Legislative Council of Victoria. The Newspaper World (London), September 7, 1918.

"One of the most important of the objects of my appointment in 1910 (as High Commissioner in London for the Commonwealth of Australia) was the spread of information at this end of the world, especially in the British Isles, concerning Australia and the varied openings it affords as a source of raw materials and food supplies, as an attractive home for the emigrant, and as a place for the investment of British capital. It was also necessary to remove a large number of false impressions arising from distance or ignorance. The peaceful annals of a continent at the antipodes, however vast the speed of its development and the potentialities of its future, were crowded out too often by less important, but more interesting cvents ncarer home. The quarrels of insignificant countrics, the etcrnal round of conflict in home politics, events in the theatrical world, sporting news, society gossip-everything, in fact, that had little or nothing to do with the 12,880,000 square miles of the 13,000,000 square miles of British Empire-were the stock-in-trade of everyday English journalism. . . The thief eauses, of course, lay in the insular tastes of its readers. If they had wanted more colonial intelligence in their newspapers thcy would have got more.' Sir George Houston Reid, My Reminiscences, p. 271.

Cf. also Adderley, Colonial Policy, p. 408.

1 ( 1 p to Confederation in 1867 the number of books was twenty-five. By 1880 the number had renched fifty-two. ('f. J. R. Boose, Tilles of Publications lithating to the British Colonies. 
that make the nineteenth century memorable in the history of the Empire.

Ex-colonial governors, if they happened, as was sometimes the case, to be of the House of Lords, commanded attention when they intervened in the infrequent debates at Westminster on colonial questions. Elsewhere to be a returned colonial governor gave a man little distinction. As long after the end of the era of indifference as 1903 it was noted by a writer of authority on colonial history, a writer obviously familiar with records at the Colonial Office, that ' the British governor came home to live in obscurity, and die in neglect.' ' Frere and Grey ${ }^{1}$ alone,' he added, ' their errors forgotten, and their greatness remembered, sleep in St. Paul's Cathedral.' 2

Colonial history in these years was almost ignored in the General Histories of England. It was regarded as dull and uninspiring. There was no popular realization of it as the story of a series of great and successful struggles for the political freedom so much beloved and prized by men and women of the British race. It did not even attract interest as telling the story of the building up in far-off lands of political civilizations modelled after that of the United Kingdom. Colonial history, in brief, was popularly regarded as 'involving nothing but the sordid and wordy warfare about pounds, shillings and pence of utterly undistinguished politicians ' 3

There was little change noticeable in the attitude toward colonial history, and the history of the relations of the colonies with Great Britain, as a result of anything that issued from the press, until Seeley's Expansion of England, with its eloquent plea for a new valuation of the colonies as assets of the Empire, was published in $1883 .{ }^{4}$

1 Sir Henry Bartle Frere, Governor of Cape Colony, and First High Commissioner of South Africa, 1877-1880. Sir George Grey, Governor successively of South Australia, New Zealand, and Cape Colony, and a second time Governor of New Zealand. Grey served in these capacities from 1841 to 1867.

2 'The Evolution of a Colonial Governor,'Macmillan's Magazine, November 1903 , p. 56.

3 Newton, The Old Empire and the New, p. 22.

4. It is true that we in England have never accustomed our imaginations to the thought of Greater Britain. Our politicians, our historians still think of England, not of Greater Britain, as their country. They still think only that England has colonies; and they allow themselves to talk as if she could easily whittle them off and become again, with perfect comfort to herself, the old solitary island of Queen Elizabeth's time " in a great pool, a swan's nest". But the fancy is but a chimera, produced by inattention ; one of those monsters, for 
The period from 1859 to 1873 produced two of the most notable treatises on the colonies, Bell's study of colonial administration, written just before the Palmerston Government was compelled to accept Galt's tariff, ${ }^{1}$ and Dilke's Greater Britain, published in 1868. Each had for its thesis, or for part of its thesis, the desirability of ending the connexion between Great Britain and the colonies.

Bell was confident that no loss of trade or prestige would result to Great Britain if the colonies became independent. 'It fills both the mouth and the ear and the imagination,' he wrote, 'to say that on the Empire of the Queen of Great Britain the sun never sets. Yet this, after the natural exultation of national vanity had been indulged, may be but sound after all. Britain had no colonies when Queen Elizabeth reigned; and Britain had but few colonies, and these few were in but a feeble condition, when Cromwell sat in the monarch's seat. And yet the voices of those monarchs fell not less loudly upon the ears of the sovereigns of Europe than has the voice of any British sovereign in the zenith of colonial power.' 2

It was with the then newly created Dominion of Canada that Dilke was chiefly concerned. ' The position of Canada,' he wrote, ' is in many ways analogous of the two chief sections of our race -that in Britain and that in America. The latter is again split in twain, and one division governed from across the Atlantic. ${ }^{3}$ F'or such government there is no pretext except the wishes of the governed, who gain by the connexion men for their defence and the opportunity of gratifying their spite for their neighbours at our expense.' 4

Canadian loyalty to Great Britain was next discussed by Dilke, who had as little liking for the protectionist tariffs of the United

sueh monsters they are, which are ereated not by imagination, but by the want of imagination.' J. R. Seeley, The Expansion of England (1891), pp. 306-307.

1 Bell wrote his treatise in Cape Colony where he was judge of the supreme eourt. The prefaee is dated February 19, 1859. The book was published in London in that year.

2 Bell, Colonial Administration of Great Britain, pp. 429-430.

3 Dilke, who was not long from C'ambridge when he wrote Greater Britain, eonld not have appreciated the extent to which all the colonies now of the dominions enjoyed responsible government, how near they all were to the status of nation in 1868, the year in which Greater Britain was published. Otherwise he would not have written of the Dominion of Canada being 'governed from across the Atlantic'.

4 Sir Charles Dilke, Greater Britain, i. p. 75. 
Provinces of Upper and Lower Canada-the tariffs of 1858 to 1866-as Grey or Bright, or the Chambers of Commerce of Manchester, Sheffield, or Wolverhampton. 'While we were fighting in China, and conquering the rulers of Japan,' Dilke reminded the people of the United Kingdom, ' our loyal colonists of Canada set upon our goods protective duties of twenty per cent.' 'We might,' he added, in commenting further on these protectionist imposts,' at least fairly insist that the connexion should cease, unless Canada will entirely remove her duties.' 1

'At bottom,' continued Dilke, in urging separation on grounds more general than protectionist tariffs, 'it would seem as though no one gained by the retention of our hold on Canada. Were she independent her borders would never again be wasted by Fenian hordes, and she would escape the terrible danger of being the battlefield in which European quarrels are fought out. Canada once republican, the Monroe Doctrine would be satisfied; and its most violent partisans would cease to advocate the adoption of other than moral means to merge her territories in the Union.'

These, Dilke conceived, would be the chief gains that would accrue to the Dominion from separation. For Great Britain there would be relief 'from the fear of a certain defeat' by the United States in case of war, ' a fear always harmful, even when war seemed most unlikely.' Great Britain, moreover, 'would be relieved from the cost of such panics as those of 1861 and 1866.' 2

The conviction in Canada was that Bell and Dilke, and Dilke in particular, wrote what most Englishmen in those years were thinking. ${ }^{3}$ Greater Britain earned for Dilke the friendship of John Stuart Mill. Mill commended it in ' most ungrudging terms', and told Dilke, who was then Radical member for the London borough of Chelsea, that there were few opinions expressed in any part of Greater Britain with which he did not, as far as his knowledge extended, 'fully and heartily coincide.' 4

There was a popular as well as a library edition of the book. Dilke's fame as a Radical politician of advanced views greatly enlarged its reading constituency. For ten people who read

1 Dilke, op. cit., p. 78.

${ }^{2}$ Loc. cit.

3 Cf. L. J. Burpee, 'Howe and the Anti-Confederation League,' Transactions of the Royal Society of Canada, III, x, 457.

${ }_{4}^{4}$ Gwynn and Tuckwell, Life of Dilke, i, pp. 70-71. 
Grey, Adderley, Bell, or Tremenheere, a hundred read Dilke; and Greater Britain was easily the most widely known and most frequently quoted book on the colonies until Seeley's Expansion of England, a book in quite another spirit, secured so wide a vogue that six reprintings of it were called for in the years from 1883 to 1891 .

\section{CHAPTER III}

\section{CHÁNGES IN LONDON CONSEQUENT ON RESPONSIBLE GOVERNMENT}

MaNy ehanges at Whitehall and Westminster, changes which gradually became apparent, followed in the train of responsible government. Some of these ehanges had the effect of lessening what publie interest there was in the eolonies in the years from 1828 to 1849 - the years when Nova Scotia and Upper and Lower Canada, and after 1840 the United Provinces, were waging the contest with Downing Street for responsible government.

What little organized work had been done under the supervision of the Colonial Office from 1840 for the encouragement and supervision of emigration from the United Kingdom to the self-governing colonies came to an end in the early seventies, as responsible government was established in these colonies, and the complete control of erown lands passed into the hands of the colonial governments. ${ }^{1}$

Emigration in these years was gradually freed from the old stigma of transportation. But much of the organized or assisted emigration was still associated with poor law funds and the poor law taint." Emigration generally was also associated in the minds of the working classes with hard times $;^{3}$ and, moreover, men of the working classes who were interested in polities looked askance at propaganda in the interest of emigration to the

1 Supervision of emigrant oeean transport was in 1872 transferred from the Emigration Board to the Board of Trade. After this ehange the sole duty of the Emigration Board consisted in the supervision of the migration of eoolie labour. Between 1873 and 1877 the Board s eireular was issued only onee a year. In 1878 the Board beeame extinet. Cf. s. C. Johnson, A History of Emigration, p. 26.

'Any inerease in the populations of the colonies attributable to immigration has not arisen from any anxiety shown by the imperial authorities to direct cmigration to their fertile linds, rather than to foreign eountries.' J. C. Colmer. Commercial Federation of the Eimpire (1896), p. 13.

2 Adderley, Colonial Policy. p. 412.

3 Cf. Newton, The Old Empire and the New, pl. 16-17. 
colonies, because they conceived that emigration was offered to the proletariat as a substitute for social and political reform. ${ }^{1}$

There was much less legislation at Westminster for colonies now of the dominions and there were fewer parliamentary committees to inquire into colonial grievances in the years from 1859 to 1887 than in the years from 1828 to 1854 . Responsible government in all the British North American colonies, and in nearly all the Australasian colonies, relieved Parliament of much of the work of inquiry and legislation that had fallen upon it from the time of the difficulties with the House of Assembly of Lower Canada in 1828 to the last liberalizing amendment to the constitution of the United Provinces of 1840 that was enacted at Westminster in 1854.

The burden of the Colonial Office in respect to the self-governing colonies was also greatly lightened as a result of the abandonment of the old commercial system in 1846-1849, and of the concession of responsible government in quick succession to one colony after another. Fewer bills of colonial legislatures came before the Colonial Office for allowance or disallowance. The propaganda from the Colonial Office for tariffs uniform in principle with the tariff of the United Kingdom slackened after the Colonial Office and the Palmerston Government were forced to accept the Galt tariff of 1859.

In these years, 1859-1887, all the autonomous colonies were self-sustaining as regards the cost of civil government. But both the internal and external defence of these colonies was a charge on Great Britain until the early seventies; and for the external defence of all the colonies Great Britain continued to be responsible.

The internal defence of the self-governing colonies, until the colonies themselves became responsible for it, was a problem for the Colonial Office, for the Government, and for Parliament. It was an embarrassing problem for Governments at Whitehallthe most troublesome and embarrassing of all the colonial problems after responsible government had been conceded, and Upper and Lower Canada and Victoria had asserted their fiscal independence, and enacted tariffs that embodied protectionist duties against manufactures from Great Britain. ${ }^{2}$

1 Sir Charles Dilke, Problems of Greater Britain (1890), i, p. 29.

2 "We must seriously consider our Canadian position, which is most illegitimate. 1569.20 
It was a problem, moreover, which it was well known in the colonies was extremely embarrassing to Governments in London, in view of the fact that the colonies, which looked to Great Britain for internal defence, were in the enjoyment of responsible government, and under no supervision or control in their internal affairs from the Colonial Office, or from Parliament at Westminster. 1

Not nearly as much of the time of the House of Commons or the House of Lords was occupied with colonial questions as in the years from 1820 to 1859 , but the questions that did come before Parliament were of a different character from those of the years when Parliament was considering colonial grievances or enacting constitutions for the self-governing colonies or

An army maintained in a country which does not permit us even to govern it. What an anomaly! It never can be our pretence, or our policy, to defend the Canadian fronticr against the United States. . . But what is the use of these colonial deadweights which we do not govern ?... The moment the American elections [the congressional elections of November 1866] are over, we should withdraw our troops, and foster a complete development of self-government.Disraeli, Chancellor of the Exchequer of the Conservative Government of 18661868, to Derby, Premier and First Lord of the Treasury, September 30, 1866. G. E. Buckle, Life of Disraeli, iv, p. 476.

"We have a colonial system, which attempts have been made of late to modify, the characteristic of which was to throw the whole responsibility for defence not only on the exchequer, but on the mind and thought of this eountry, and to place on our military department the charge and expense of the military service for the colonies, just as much as if those colonies were a portion of the three kingdoms and just as if they were not inhabited by an intelligent and free population.'Gladstone, House of Commons, March 28, 1867. Parliamentary Debates, III, elxxxvi, 753.

' I am not able to state the amoun t of our military expenditures for the purpose of Canadian defence. But it must be something enormous, certainly more than $£ 1,000,000$, and this has to be undertaken by a poorer country in favour of a richer, for judged by any test the inhabitants of Canada are indisputably better off than are the taxpayers of this country.'--Robert Lowe, House of Commons, Narch 28, 1867, III, elxxxvi, 759.

Cf. also Dilke, Greater Britain, i, p. 79 ; Autobiography of Henry Taylor. i, pp. 234-238 ; Norton, ' How Not to Retain the Colonies,' Nineteenth Century, July 1879 , p. 177.

$i$ "There is anotlicr thing which you have to bear in mind, that the relations between this country and the self-governing colonies are practically the relations between independent countrics. Canada and Australia are quoted. They are nominally our colonies. They are nominally under our rule. Do we govern them? Are they really under the control of Great Britain? Not a bit of it. If you were to attempt to interfere with either of those colonies in the slightest degree they would cut adrift from you to-morrow.'- ('hamberlain at Rawtenstall, July $\dot{8}$. 1886, Mr. Chamberlain's Specches, edited by Charles W. Boyd, i, P. 277.

Cf. discussion on the Inperial Government and the colonies, House of Assembly, Vietoria, November 2, 1869, Parliamentary Debates (Victoria), 1869. ix, 21-27; report of deputation to Granville, Colonial Secretary. December 15. 1869, reprinted, Appendix to Journals of House of Representatives (New Zealand), 1870, I, No. 6, pp. 5-6. 
amending constitutions in response to petitions or addresses from colonial legislatures.

The questions that came before Parliament in the years from 1859 to 1873 were mostly those that arose out of imperial guarantees for railways, and other public works, in the selfgoverning colonies; and out of wars with the aborigines of New Zealand and in Cape Colony and Natal, or out of the defence of the British North American provinces, and in particular out of the defence of the three provinces whose frontiers bordered on the United States.

Occasionally in the years from 1859 to 1887 there were protests in Parliament-strong protests - against the tariffs of the United Provinces, or after 1867 against those of the Dominion of Canada.

Wars with natives in South Africa and New Zealand, the cost of internal defence of the self-governing colonies, imperial guarantees of colonial loans and tariffs of colonial legislatures with protectionist duties against British manufactures, were subjects which, when discussed at Westminster, were not calculated to arouse a popular and enthusiastic interest in the connexion of the self-governing colonies with Great Britain.

In these years to Mr. Balfour's 'man in the street', when he did for a moment turn his mind to the subject, the self-governing colonies appeared to mean large responsibilities, with corresponding burdens on British taxpayers, and no apparent material or national gain. In the days of the rebellion in Canada, and of the subsequent struggle for responsible government, also in the days of the revolt of the Australian colonies and Cape Colony against the system of convict transportation, popular sympathy was with the colonies that were rightfully asserting themselves and endeavouring to end the era of rule from Downing Street.

The establishment of responsible government in every colony sufficiently advanced for that stage of political development, followed as it was by the imposition of high duties on British manufactures in colonial tariffs, and by extreme tardiness on the part of several of the self-governing colonies in assuming the cost of internal defence, alienated much of this popular sympathy.

These new conditions, two of them distinctly adverse to insular British interests -one adverse to the interests of British industry and the other adverse to the interests of British 
tax-payers - added to popular indifference ; and such questions, affecting the colonies, as were discussed at Westminster aroused no new sympathetic interest in the autonomous colonies to take the place of the earlier interest that had exhausted itself with the end of the struggle for responsible government and of the contest against Great Britain's barbarous system of dealing with her convict problem.

\section{CHAPTER IV}

\section{PROTECTIONIST TARIFFS AND INDIFFERENCE TO THE COLONIES}

What publie opinion there was on the self-governing colonies and their relations with Great Britain was made not exclusively, but to a large extent, by the manufacturing and merchant elasses. It was in the ehambers of eommerce of the large centres of manufacturing in England and Scotland that colonial questions, mostly colonial tariffs, were discussed. Protests in Parliament against high duties in eolonial tariffs almost invariably had their origin with chambers of commeree.

If, as Lyttelton, Colonial Seeretary in the Balfour Administration of 1902-1905, affirmed in 1910, for a long time 'the true political relation of Great Britain to the self-governing eolonies was obseured in wise silence ', and if, as a consequence of this silence, men of the manufacturing and merchant classes did not know with detail and exaetitude just what responsible government had eome to mean, they did at least know the tariff economy of their business.

The men of these two elasses, all more or less interested in cxport trade, did know that in Canada in the years from 1859 to 1873 , and also in some of the Australasian colonies, there were comparatively high proteetionist duties on British manufactures ; that in Canada the proteetionist duties were higher than in some non-British eountries; and that these eolonies were exercising their autonomy, and in particular their newly aequired fiseal freedom, with a view to the exelusion of British manufaetures and in the interest of eolonial manufacturing industry.

These were the years, it will be recalled, in which some of the self-governing colonies were intent on eradicating the popular 
idea in Great Britain that trade with the colonies, furnishing them with manufactured goods, belonged of right to British manufacturers. The process of eradicating the long-standing conception of the place of colonies in the industrial and commercial economy of Great Britain was distinctly irritating. ${ }^{1}$ It was all the more irritating because in these years the United States, and also France and other countries of Europe, were imposing protectionist duties which also hampered the comparative growth of British export trade.

British manufacturers of the generation that was first confronted with protectionist tariffs in Canada and Australia knew by tradition, or had been taught, that wherever England planted a colony she founded a nation of customers for her manufactures. They had been taught that so long as colonists were thinly spread over a fertile country, so long as land was cheap and labour dear, the interests of the colonists would always point out to them that the most advantageous mode of procuring manufactured commodities was giving their own raw produce in exchange. They had been taught also that when the numbers of colonists were multiplied, and their capital had accumulated so far as to render manufacturing profitable, they would assuredly cease to be colonists. ${ }^{2}$

The generation of British manufacturers that sustained the shock of the Galt tariff, moreover, had been well schooled in the belief that the tastes and habits of British colonists were the same as those of their fellow-countrymen in the United Kingdom ; that their modes of conducting business, and their notions of obligation were the same; and that the commodities of Great Britain suited the colonial markets better than the commodities of any other country.

Even when it was becoming almost certain that the old colonial system, with its tariffs for the colonies enacted at Westminster

1 Cf. Memorial of Sheffield Chamber of Commerce to Newcastle, Colonial Secretary, August 1, 1859. Correspondence of the Government of Canada with the Imperial Government on the subject of the Canada tariff, Parliamentary Papers (Canada), 1860; Galt's address before Chamber of Commerce, Manchester, September 25, 1862, Guardian (Manchester), September 26, 1862 ; Mackenzie, Life of George Brown, p. 203 ; Parliamentary Debates (House of Commons), March 18, 1879, III, ccxliv, 1312 ; Grey, ' How Shall We Retain Our Colonies?' Nineteenth Century, June 1879; correspondence respecting Canadian tariff, 1887, Colonial Office Papers (Canada), 1887.

2 Cf. Herman Merivale, Lectures on Colonization and Colonies, 1839, 1840, 1841, p. 218. 
to protect the interests of British manufacturers, was coming to an end, manufacturers had been assured that under a system of free competition the United Kingdom would long retain an advantage in the markets of the colonies from the durability of national tastes and habits. ${ }^{1}$

But within twelve years after free competition was established in colonial markets, as an incidental result of the fiscal legislation at Westminster of 1846-legislation, it will be recalled, that was demanded by conditions in the United Kingdom as distinct from conditions in the colonies-while colonial circumstances as to area of cheap fertile land and dear labour were as they had been before 1846, and while Great Britain was still carrying part of the charges of civil government in some colonies, and bearing all the cost of the internal and external defence of all of them, the self-governing colonies began to restrict all outside competition, British and non-British, by tariffs which, in practice, were framed by colonial manufacturers. ${ }^{2}$

The fiscal revolution in the United Kingdom worked some dislocation of the export trade of the British North American provinces. It disturbed the trade in lumber, grain and flour, on which the preferences at British ports had been considerable. The fiscal revolution which began in the self-governing colonies with the Cayley and Galt tariffs of 1858 and 1859 was fully as disturbing mentally, fully as disappointing and irritating, to manufacturers in the United Kingdom, as the withdrawal of colonial preferences in $\mathbf{1 8 4 6}$ had been to millers, merchants, and shippers at ports in British North America-to traders in the Canadas and in Nova Scotia and New Brunswick, who had come to regard themselves as having a vested and unassailable interest in these preferences in Great Britain on wheat, flour, and lumber from British North America.

The merchants and shippers of Upper and Lower Canada, and chiefly those of English or Scottish stock, who were established at Montreal and Quebec, vented their feelings of disappointment

1 Cf. Merivale, op. cit., p. 190.

2 Cf. Weir, Sixty Years in Canada, p. 115 ; also spcech by Lord Lisgar, House of Lords, May 20, 1873, Parliamentary Debates, III, cexvi, 155-156.

"When Sir John A. Macdonald was asked by a manufacturer (at Hamilton. in 1878) what protection he was prepared to givc, he said : "I cannot tell what protection you require. But let cach manufacturer tcll us what he wants, and we will try to give him what he necds!'" William Buckingham and George W. Ross, Life and Times of Alexander. Machenzie, 1. 508. 
in manifestoes in favour of the annexation of the Canadas to the United States, and in an agitation for annexation that was kept going for three years. ${ }^{1}$

The manufacturers of England and Scotland vented their indignation and chagrin over Canadian tariffs aimed against British trade in resolutions adopted at meetings of chambers of commerce and in protests to the Colonial Office, which was completely helpless so far as protectionist tariffs in the colonies were concerned. They also vented their indignation on any representative of a self-governing colony with a protectionist tariff who appeared on a platform in Great Britain in the interest of a colonial loan-in the interest of an imperial guarantee for a colonial loan or any other colonial undertaking for which financial support was asked from the people or from the Government of the United Kingdom. ${ }^{2}$

In periods of industrial depression in Great Britain, as for example during the depression of 1869 , part of the depression was popularly attributed to colonial tariffs. Responsible government, and the fiscal freedom of the colonies were not at this time

1 Cf. Weir, op. cit., pp. 62-97; Allin and Jones, Annexation, Preferential Trade and Reciprocity, pp. 1-48.

2 "Galt is to address the Manchester Chamber of Commerce on Canadian finances. I have been asked to be present, and also to speak in several other quarters, but have steadily declined. I have no idea of defending Canada before English people; and defence is the only possible attitude at this moment.'George Brown, of Upper Canada (an opponent of the Cayley and Galt tariffs) to L. H. Holton, Edin burgh, September 3, 1862. Mackenzie, Life of George Brown, p. 203.

'He did not know what might be the special object of the honourable gentleman's (Galt) mission. But if it was in the slightest degree to put Canadian hands into the pockets of British taxpayers, he hoped the honourable gentleman would leave Manchester at all events with the unmistakable impression that when Canada came to the distressed operatives of Lancashire [scarcity of cotton owing to the Civil War of 1861-1865 was causing much distress in the textile industry of Lancashire at this time] or to the mill owners of Lancashire, for a portion of their taxation, he would find himself mistaken.'-Hugh Mason (afterwards Member of Parliament for Ashton-under-Lyne) at reception of Galt, by the Chamber of Commerce, Manchester, September 25, 1862, Guardian (Manchester), September 26, 1862. A more detailed account of Galt's interview with the Chamber of Commerce at Manchester will be found in the Appendices, pp. 470-473.

' The policy of the Canadian Government (the adoption of the national policy in 1879) seems to me injurious to the inhabitants of the Dominion, and, if persisted in, will be fatal to its connexion with the mother country. To shut out the manufacturer of England is bad enough; but at the same time to seek to borrow money from her, or seek a guarantee for a loan, is a scheme and a policy so impudent that it cannot succeed.'-John Bright, August 16, 1879, written apropos of Macdonald's mission to London to secure an imperial guarantee for the loan for the construction of the Canadian Pacific Railway. H. J. Leech, The Public Letters of John Bright, p. 237 
popularly understood in England and it was a cause of complaint that over these tariffs, so hostile to British trade, neither the Colonial Office nor Parliament at Westminster could exercise any control or influence. ${ }^{1}$ To the manufacturing and merchant classes in these years of tariff rebuffs from Canada and Australia, it seemed as though Lord Lyndhurst's gloomy prediction of the break-up of Empire which must follow when tariffs for the Empire were no longer all enacted at Westminster, was soon to be realized. ${ }^{2}$

Tariffs hostile to British manufacturing interests in colonies which relied for their defence on the British Army and the British $\mathrm{Navy}$-colonies in which native wars were fought and the frontiers were defended by troops recruited in the United Kingdom and paid from the British Exchequer-had never been imagined before 1858. Men in Parliament, who in the years from 1820 to 1859 had expressed themselves as willing to see the colonies separate from Great Britain, had persuaded themselves that with the self-governing colonies independent there would be no loss of trade. Hostile tariffs in the colonies had never for a moment entered into their calculations.

In support of this position of these members of the House of Commons and of the House of Lords, Wade and Fonblanque and other publicists in the press, who took the same view, relied upon Great Britain's trade experience with the United States from $\mathbf{1 7 8 3}$ until nearly half way through the nineteenth century, ${ }^{3}$ when protectionist tariffs, to be made still more protectionist after 1861, began to be enacted at Washington. These advocates of the severance of the tie with the colonies-these politicians and publicists-had, moreover, like the manufacturers themselves, also relied on the ability of the manufacturers of Great Britain

1 Cf. eireular letter of J. A. Youl, H. Sewell, and H. Blaine, honorary seeretaries, Royal Colonial Institute, London, December 23, 1869.

2 'I remember Lord Lyndhurst onee saying to me that the abolition of differen. tial duties in favour of our colonies was a measure far more serious than the tax upon tea, which produced the Ameriean War; and, in faet, we thereby exchanged throughout our vast dominions a system of assimilation and union for a system of division and individuality.'-Note by Lord Palmerston. Bulwer, Life of Viscount Palmerston (1874), iii, p. 189.

3 "The old English eolonial eeonomie system in theory still held its ground. But the great growth of trade between Great Britain and the independent United States seemed to throw doubts on some of its most eherished doctrines; and under the gospel of reeiprocity, as preached by Huskisson, eolonies played a less leading part than they had played under the old system.' H. E. Egerton, 'The Colonial Reformers of 1830,' K'ing's College Lectures on Colonial Problems, p. 148. 
to meet competition from any quarter, in open markets, or even in countries in which tariffs were imposed for revenue, as distinct from protection.

British manufacturers had had to meet tariffs for revenuetariffs enacted to this end by colonial legislatures-both before and after 1846. They had accommodated themselves to these tariffs, as they had done to the comparatively low tariffs of the United States enacted by Congress before 1840. But when British colonies in North America and Australia pointed to the success of the protectionist system in the United States, pointed with pride to the fact that they were following the example so set, and tariffs avowedly for protection superseded tariffs for revenue only, and this too in colonies whose defence was a charge on British taxpayers, the manufacturing class, more politically influential in the constituencies from 1832 to 1867 than at any time before or after that period, came to the conclusion that colonies were commercially useless. ${ }^{1}$

Once arrived at this conclusion, British manufacturers were not in the least impressed by any imperialist conception of Empire. Nor were they impressed by the plea of altruistic imperialists like Lord Lyttelton, who urged that Great Britain ought not to desire to hold colonies merely for the sake of any supposed material gain, but should hold them in order, as ancient charters recited, 'to propagate through the world the religion and civil institutions of England, and to rear up races of manly, generous, and self-relying men.' 2

In the religious life of England at this time the manufacturing class was in the main associated with the free churches. Through these churches, and their central organizations, manufacturers were usually generous in their support of foreign missions. But they kept their interest in the propagation of religion in the unenlightened parts of the world well apart from their interest in business and their interest in politics.

1 Cf. Bruce, Broadstone of Empire, i, p. 145.

2 Parliamentary Debates (House of Lords), June 22, 1852, III, cxx, 140. 


\section{CHAPTER V}

\section{THE MANCHESTER SCHOOL AND THE COLONIES}

Is Parliament in the years from 1859 to 1887 there were not nearly as many expressions of willingness to see the self-governing colonies break away as there had been in the period from 1828 to 1859. These manifestations of what in the decade before the World War would have been described as 'Little Englandism' did not, however, completely come to an end until 1887-until the last protests had been made in the House of Commons and the House of Lords against high duties imposed in Canadian tariffs, duties imposed, in this instance, on imports of pig and bar iron from England and Scotland.

In the twenty-eight years from 1859 to 1887 colonial questions were discussed at Westminster from an angle quite different from that from which they had been discussed from 1828 to 1859 . At Westminster from 1859 to 1887 the tables were turned as regards grievances. British grievances, or rather burdens and responsibilities arising from the colonial tie, were much discussed in these years; and it was in the discussions of these burdens that there were expressions of willingness, even from statesmen in front rank at Westminster, to see the colonies establish themselves quite independently of Great Britain.

From 1828 to 1859 it was colonists of Upper and Lower Canada, of Australia, of New Zealand, and of the Cape of Good Hope, who had grievanees whieh they desired should be remedied by Parliament. In Canada there were grievances arising out of the working of the crown-colony-like constitution of 1791 ; out of government by family compaets; out of confliets arising out of the interpretation of the Declaratory Act of 1778; out of tariffs for the British North American provinces enaeted at Westminster; and out of the eontrol which St. Martin's-le-Grand exercised over postal services in Upper and Lower Canada.

In the Australian colonies of this period, the grievanees whieh eolonial reformers at Westminster exposed and championed, arose out of the unrepresentative and undemocratic eharaeter of the eolonial governments that preeeded the establishment of responsible government in 1850-1852. In the Australasian 
colonies, and also in Cape Colony, grievances arose out of Great Britain's supine and barbarous method of ridding herself of her convicts, mostly the victims of her penal code and industrial system of the first half of the nineteenth century. ${ }^{1}$

After all the colonies with populations sufficiently large and homogeneous to admit of the satisfactory working of responsible government had been advanced to that much coveted status, there were colonies, it will be recalled, that insisted on larger powers than accrued to them as the result of the acceptance by the Russell Administration of 1846-1852 of the Rebellion Losses Act of the legislature of the United Provinces of Upper and Lower Canada. These colonies desired to advance still further toward the status of nation within the Empire.

But except for the amendments to the constitution of the United Provinces, the Act of 1867 for the Confederation of the British North American provinces, and the amendment of 1873 to the fiscal powers section of the Australian Colonies Government Act of 1850, it was the Colonial Office-in one case also the Foreign Office-acting with the approval of the Cabinet, that conceded the later demands of these colonies.

It was the Colonial Office that, most unwillingly, accepted Galt's tariff. It was the Foreign Office that in 1865-1866, acceded to the demand of the interprovincial council on commercial treaties, that the British North American provinces be directly represented in the negotiations at Washington for a renewal of the reciprocity treaty of 1854 . In these two great

1 'Industrialism when it first developed on a great scale, without the restraints of factory acts, a proper standard of living, and efficien t trade unions, seemed to open out an inferno of mammonism that could only end in revolution.' H. E. Egerton, 'The Colonial Reformers of 1830,' King's College Lectures on Colonial Problems, p. 155.

'When he reflected on the horrors wrought in the nineteen th century by excessive and arrogant individualism, his astonishment was not that the reaction against individualism had gone so far, but rather that it had not rushed to worse extremes. When he heard, or read, of the socialistic excesses of some of the working classes, he asked himself, was the worst thing that they yet had done any more unrighteous and inhuman than were the individualistic excesses of the capitalistic class in the days of their supremacy'.- - Lecture by Bishop of Carlisle (Dr. J. W. Diggle) at Carlisle, October 6, 1918. Yorkshire Post (Leeds), October 7, 1918.

'It is, I think, amongst the most marvellous instances of the vis medicatrix naturae, how little Australia, in the end, suffered from this original wrong. But the woe is none the less on those who cynically exposed its beginnings to such trials. Assuredly, unless public opinion with regard to imperial obligations had been wholly blunted, the practice of such cynicism could never have been tolerated.' Egerton, op. cit., p. 176. 
steps of the British North American provinces toward the status of nation Parliament had no part.

It was not necessary that the sanction of Parliament at Westminster should be given either to the acceptance of the Galt tariff by the Colonial Office and the Palmerston Government or to the precedent-creating decision of the Foreign Office to permit the participation of representatives of Upper and Lower Canada, New Brunswick, and Nova Scotia, in the negotiations for the proposed treaty with the United States. Neither of these concessions to the British North American provinces was ever formally or informally reported to Parliament ; and so far as the reports of the debates at Westminster show, there was no discussion there of the imposition of protectionist duties on British exports by any colonial legislature, until after the second national policy tariff of the Dominion of Canada was enacted at Ottawa in 1879.

In these years from 1859 to 1887 , except for the impatience of the Australian colonies under the restraints of the Constitution Act of 1850 as regards the enactment of tariffs embodying differential duties, there were no colonial grievances to discuss at Westminster. The concession of responsible government had, by 1857 , made an end to grievances in the colonies now of the dominions ; ${ }^{1}$ it had made an end at any rate to grievances that it was within the power of Parliament at Westminster to remedy or remove.

Certainly there were no discussions of grievances of the character of those that persistently intruded themselves on the attention of Parliament from 1828 to 1854 , the years in which Parliament so amended the constitution of the United Provinces as to enable the legislature to make an end to the grievance in Upper Canada, nearly half a century old, arising out of clergy reserves, established by the Quebec Act of 1791.?

1 'During the comparatively short time since we entered public life, see what has been done. The statesmen of the day now agree to repudiate as folly what, twen ty years ago, they accepted as wisdon. Look at our colonial policy. Through the labours of Molesworth, Roebuck, and Hume, more recently supported by us and by Gladstone, every artiele in the creed which directed our colonial policy has been abandoned; and men actually ablior the notion of undertaking the government of colonies. On the contrary, they give to every colony which asks for it a constitution as democratie as that which exists in the United States. Bright to Cobden, April 1857. Morley, Life of Cobden, ii, pp. 194-195.

2 (f. E. R. Stimson, It istory of the Separation of (hurch and State in Canada, pp. 158-182. 
What may be described as the earlier school of colonial reformers-the men who, although they were willing to see the colonies separate from Great Britain, regarded it as their mission to work for the establishment of a democratic political civilization in the colonies while these colonies were still of the Empire 1had passed away. The men of this school of colonial reformers at Westminster had helped to a great and obvious degree in the establishment of responsible government. In particular they had helped to convince Russell and Grey, and the Whig Administrations of 1835-1841 and 1846-1852-a task at first of much difficulty-that the principle as contended for by Baldwin and La Fontaine and the Liberals of Upper and Lower Canada must be conceded to the fullest extent.

By 1854 the constructive work of the earlier school of nineteenthcentury colonial reformers was done. Their mission on its constructive sides had been achieved, fully achieved, to the immediate advantage of the self-governing colonies, and also, as it ultimately became manifest to the world at large, to the great advantage of the Empire.

To the older school of 1822-1854 there had succeeded the Manchester school, another school of colonial reformers, with aims not on all fours with the aims of the colonial reformers of the earlier school. The concern of the Manchester school was not with the type or character of government established in the colonies; for by this time all the self-governing colonies were on a much more democratic basis than the United Kingdom was until as late in the nineteenth century as the third reform of the system of parliamentary representation in 1884-1885. ${ }^{2}$

Except that after 1867 the Australian colonies complained of restraint on their fiscal freedom by section 31 of the Imperial Act of 1850, and that New Zealand also complained that this Act indirectly hampered its legislature in enacting its tariff laws, all the colonies at this time were completely satisfied with the

1 Cf. Egerton, op. cit., pp. 141-180 ; Merivale, Colonization and Colonies, (1861), p. 435 ; Fawcett, Life of Molesworth, p. 271.

2 'Colonial policy explained by Lord John Russell in a long speech, very important. Colonies at the Cape and in Australia to have legislative chambers and to have a liberal self-government. Great agreement in the House on the subject. Marvellous absence of prejudice when the objects are ten thousand miles away. Should like to move that the Bill (Australian Colonies Government Bill, 1850 ) be extended to Great Britain and Ireland.'-Bright's Journal, February 7, 1850. G. M. Trevelyan, Life of John Bright, p. 176. 
constitutions and political institutions in the framing of which the Colonial Office, the Cabinet or Parliament at Westminster had had any part ; or if the colonies conceived that improvement was possible, it was within their own power to effect it. ${ }^{1}$

With the era of political reform in the colonies thus nearly at an end, so far as the British Parliament was concerned, ${ }^{2}$ the mission of the newer school of colonial reformers was quitc different from that of the reformers of the era in colonial history that ended with a general concession of responsible government to the colonies now of the dominions.

The Manchester school did not help in the movement for a larger fiscal freedom for the Australasian colonies. It was out of sympathy with the purpose to which the Australasian colonies wished to put the larger freedom; and, moreover, the concession of 1873 was made without the least preliminary agitation in the House of Commons or in the newspaper press of the United Kingdom. Neither had the Manchester school any part in the movement in the British North American provinces and in the Dominion of Canada for diplomatic freedom, probably because this movement in these years was never agitated in Parliament at Westminster.

It had no part, moreover, in the movement for freeing the self-governing colonies from commercial treaties in which they had been included without their consent; for this was a movement, it will be recalled, that did not come well into the realm of the practical politics of the Empire until after the colonial conference of Ottawa in 1894, and by 1898 success was achieved mainly through the daring of the Laurier Government in asking Parliament at Ottawa in 1897 to enact the British preferential tariff.

The burdens and responsibilities that the connexion of the sclf-governing colonies with Great Britain threw upon the people of the United Kingdom were, in the realm of Empire politics, the chief concern of the Manchester school. It was influencing public opinion on colonial policy at the time Galt's tariff surprised and dismayed the manufacturers of the United Kingdom, who were engaged in export trarle with the colonies. It exercised considerable influence on public opinion in the years in which

1 Cf. Porritt, Evolution of the Dominion of Canada, pp. 151-162.

2 'The intervention of Parliament was still necessary to relieve the Australasian colonies from all the restraint of the Imperial Act of 1850. 
Great Britain was still bearing all the cost of the internal as well as the external defence of all the colonies, and was carrying the burden of native wars in the colonies. ${ }^{1}$

The cost of native wars in South Africa and New Zealand fell entirely on the taxpayers of the United Kingdom. These expenditures had to be explained or justified by ministers on the floor of the House of Commons at Westminster, and these wars, as Gladstone emphasized in 1867, ${ }^{2}$ added to the responsibilities and difficulties of Cabinets in Downing Street. ${ }^{3}$

Apart from the friction between Great Britain and the United States arising out of the Civil War of 1861-1865, it was, moreover, boundary and fishery questions in the British North American provinces, or in the Dominion of Canada, that in this period most. threatened good relations between London and Washington. The United States was at times, moreover, suspected in Downing Street of designs on Canada-of designs to annex the British North American provinces ; and this suspicion added to uneasiness in London at crises when it seemed probable that Great Britain might become involved in war with any of the powers of continental Europe. ${ }^{4}$

It was the conditions that have been briefly described-the burden of the defence of the colonies; the danger of war growing out of the colonies, and colonial tariffs hostile to British export trade-that afforded the Manchester school its opportunities in the years from 1859 to 1887 , and especially in the years from 1859 to 1873, of advocating, in and out of Parliament, the severance of the tie between the self-governing colonies and Great Britain.

1 'Frankly and generously she has, one by one, surrendered all the rights which were once held necessary to the condition of a colony-the patronage of the Crown, the right over the public domain, the civil list, the customs, the post office, have all been relinquished. She guards our coasts, she maintains our troops, she builds our forts, she spends hundreds of thousands among us yearly.'Speech by George Brown in Legislative Assembly of the United Provinces, 1851. Mackenzie, Life of George Brown, p. 50.

2 Cf. Parliamentary Debates, III, clxxxvi, 753.

3 'Alas, as things are, colonial ministers, responsible to local legislatures based on universal suffrage, make war for us, and we cannot refuse the material, men, and supplies.' Norton, 'How Not to Retain the Colonies,' Ninteeenth Century, July 1879 , p. 171.

4 Cf. Malmesbury-Lyons correspondence, May 1859, at the time of war between France and Austria. Newton, Lord Lyons, ii, pp. 15-16. 


\section{CHAPTER VI}

\section{SEPARATISTS OF OTHER SCHOOLS OF POLITICAL THOUGHT}

AFTER the era of indifference to the colonies had come to an end, in the years from 1887 to the beginning of the war, it was a prevalent idea in Great Britain, and also in the self-governing colonies, that men in Parliament in the years from 1822 to 1859 who were willing to see the colonies separate from Great Britain were exclusively of one school of political thought.

It was similarly a prevalent idea after 1887 that only men identified with the Manchester school conceived that the most expedient method of relieving Great Britain of the burdens and responsibilities of which there was much complaint in the years from 1859 to 1873 , was to end the connexion with the selfgoverning colonies. There was, it will have been realized, no basis for this popular idea as concerns the first of these two periods. There was certainly no basis for the later idea that this attitude toward the colonies was peculiar to the Manchester school.

At one stage of the Civil War in the United States of 1861-1865 -at a stage after October 1862-Gladstone, according to the testimony of Goldwin Smith, wrote a letter to one of his colleagues of the Liberal party in which he expressed his willingness, if the South were separated from the North, to see Canada annexed to the northern States. ${ }^{1}$

In 1865, Lowe, afterwards Lord Sherbrooke, gave public expression to sentiments in regard to Canada similar to those which, according to Goldwin Smith, Gladstone had expressed in a private letter to one of his political supporters in the House of Commons.

1 The avowal would not have satisfied those who desirel the extinetion of the slave power: while it might have embarrassed the writer if he had ever been ealled upon again as minister to deal with eolonial questions. It was, therefore, destroyed.' Goldwin Simith, Reminiscences, p. 195.

'Gladstone was willing, fifty years ago, to use Canada as a bribe to the Northern States in the interest of peace. A British statesman to-day would as soon think of giving up Kent or Surrey. - Editorial comment on statement in Goldwin Smith's Reminiscences. (ilobe (Toronto). August 29, 1910. 
Lowe was desirous that it should be represented to Canada that it was perfectly open to her to establish herself as an independent republic. 'It is our duty, too,' continued Lowe, who had lived for six or seven years in New South Wales, 'to represent to her that, if, after weighed consideration, she thinks it more to her interest to join the great American Republic, it is the duty of Canada to deliberate for her own interests and happiness.' 1

Disraeli, as far on in his political career as 1866 , had as regards the British North American colonies, varied very little from his position of 1852 . He had then, it will be remembered, described the colonies to Malmesbury as 'a millstone round our neck'. He had predicted also that they would all become independent of Great Britain. ' In 1866 Disraeli asked Derby, 'What is the use of these colonial deadweights which we do not govern ?' and he emphasized in his letter to the Premier of the Conservative Administration of 1866-1868 the anomaly of Great Britain's maintaining an army in Canada, 'in a country which does not permit us even to govern it.' 3

In the winter of 1866-1867, the winter in which delegates from the British North American provinces were in London in connexion with the bill for the creation of the Dominion of Canada, several of them were dismayed at the frankness with which members of Parliament expressed themselves as to a severance of the tie between those provinces and Great Britain. 'I would not care if Grant were in Montreal to-morrow,' said one member of the House of Commons to Garvie, of Nova Scotia, 'so long as we were not bound to find soldiers to drive him out.' 4

1 Carnarvon, Speeches on Canadian Affairs, p. 217.

2 Monypenny and Buckle, Life of Disraeli, iii, p. 388.

3 Ibid., iv, p. 476. Disraeli, who was created an earl in 1876 (Earl of Beaconsfield), later in his career abandoned his earlier views as to the value of the selfgoverning colonies to Great Britain. In 1879 he made a speech on the colonies at Aylesbury-quite imperialistic in tone and spirit-which evoked much enthusiasm in Canada. 'The gratification of our people,' wrote Macdonald to Beaconsfield (October 7, 1879) in regard to this speech, ' is extreme. They say, truly, that this is the first occasion on which a prime minister has given prominence to Canada-her capabilities and her future-the first time that it has been proclaimed by such high authority that England has an especial in terest in Canada; can look to her largest dependency for food supply, and become independent of foreign nations. The speech will be worth much to Canada and will send thousands of strong arms and cheerful hearts to us, instead of adding to the strength of other and possibly hostile countries.' Pope, Memoir of Macdonald, ii, p. 207.

4 Transactions of the Royal Society of Canada, III, x.

1569.29 
'Mr. Oliphant, M.P. for Stirling, who was Lord Elgin's secretary in Canada, in a conversation with me,' continued Garvie, in a letter dated London, March 13, 1867, 'declared that Confederation would have his support, because it would take these provinces off England's hands, on which they were a useless and dangerous incumbrance.'

'Mr. Lefevre, ${ }^{1}$ who was a junior Lord of the Admiralty in the last Government, and is member for Reading,' added Garvie, ' used similar language to me; and seemed to consider the loyal preference of Nova Scotia for a British connexion a bother, and that Confederation would be a relief to the mother country by framing a convenient excuse for letting us all go. His language indicated further that annexation to the United States, if Nova Scotia did not get on with Canada, would be the best and most natural destiny for us.' 2

Joseph Howe, who was Garvie's colleague from Nova Scotia in London in the winter of 1866-1867, reported in similar terms to his associates at Halifax of the Nova Scotia Anti-Confederation League. 'The general, indeed almost the universal, feeling appeared to be that uniting the provinces was an easy way of getting rid of them; and the wish expressed by The Times, that "independence would speedily follow Confederation", was scarcely discussed by anybody.'

' Lord Normanby,' ${ }^{3}$ continued Howe, ${ }^{4}$ 'told us to our faces ${ }^{5}$ that we might declare our independence or join the United States whenever we chose; and not a peer contradicted him. In the lower house, Mr. Watkin ${ }^{6}$ was the only member who spoke ${ }^{7}$ with any warmth of a continuance of the connexion; and he was heard with chilling indifference.'

'Indeed,' continued Howe, 'the impression left on my mind by all that took place in both houses is that the provinces are

1 G. J. Shaw Ieferre (Baron Eversley, 1906), four times a member of Liberal Administrations in the years from 1856 to 1895 .

2 Transactions of the Royal Society of Canada, III, x, 462.

3 Marquis of Normanby, at member of the Aberdeen and Palmerston Ministries. a Privy Councillor, Governor of Nova S'cotia, 1858-1863, and afterwards successively (iovernor of Queensland, New Zealand, and Vietoria.

4 Howe to W. J. Stairs, London, March 15, 1867.

5 House of Lords, Febmary 19. 1867, Parliamentary Debates, III, elxxxv, 576 b.

6 Edward William Watkin, ereated a knight in 1868 , and in 1880 a baronet. Watkin was a railway promoter. In 1867 he was ehairman of the Cirand Trunk Railway Company of Canada.

7 February 28. 1867, Parliamentary Debates, III, clxxxv, 1187. 
a source of peril and expense, and the sooner the responsibility of their relations with the Republic is shifted off the shoulders of John Bull, the better.' 1

George Brown, the founder of the Globe of Toronto, one of the fathers of Confederation, at one time leader of the Liberal party in Upper Canada, and long an opponent of protectionist policies in Canada, was in London at the same time as Howe and Garvie. He returned to Toronto with much the same impression as the Nova Scotia delegates, concerning the indifference of many members of Parliament at Westminster and of the people of Great Britain whether the newly created dominion ended its connexion with the Empire. ${ }^{2}$

Granville who for eighteen months was Colonial Secretary in the Gladstone Administration of 1868-1874, caused much consternation in New Zealand, and in all the other colonies now of the dominions, in 1869, by two intimations to a deputation that waited on him at the Colonial Office. The first was that the Imperial Government intended for the future to disclaim all responsibility for the internal defence of New Zealand, long the scene of costly native wars. The second was that if New Zealand desired to abandon its allegiance to the Crown, or even to annex itself to a foreign state, however imprudent such a step might be, no forcible measures would be used to hinder that course of action. ${ }^{3}$

In 1872 when Dufferin was about to leave London on his appointment as Governor-General of Canada, Lowe, who was then Chancellor of the Exchequer, counselled the new GovernorGeneral to make it his business to get rid of the Dominion. ${ }^{4}$ In Canada Dufferin was received with little popular enthusiasm, because he had been appointed by the Gladstone Administration, which administration was regarded at Ottawa as indifferent to

1 Transactions of the Royal Society of Canada, III, 457.

2 Cf. John Lewis, George Brown, p. 147; 'Downing Street's Attitude towards Canada,' Sun ('Toronto), July 26, 1911.

3 Cf. Journals of the House of Representatives (New Zealand), 1870, Appendix, Papers relating to the proposed colonial conference in London. I a, VI, 5-6.

${ }^{4}$ Cf. Lyall, Life of the Marquis of Dufferin, i, p. 286. "We are in America somewhat in the position of the Plantagenets in France, about the time that the French monarchy was consolidated-namely encumbered with large dominions which a mistaken sense of honour forbade them to get rid of, although unable to defend them.'- - Lowe in debate on loan for construction of intercolonial railway, Canada, House of Commons, March 28, 1867, Parliamentary Debates, III, clxxxvi, 762 . 
the continuance of the connexion of the Dominion with Great Britain. ${ }^{1}$

Dufferin was Chancellor of the Duehy of Lancaster, without a seat in the Cabinet, when he was appointed Governor-General in 1872 ; and his place in the Gladstone Ministry, as well as his appointment by the Gladstone Administration, told much against his popularity in the early part of his six years' sojourn at Ottawa.

The policy of the Gladstone Government at this time was viewed with dismay in Canada. It was regarded as at most half hearted so far as the connexion of the Dominion with Great Britain was concerned. 'It was urged against Gladstone that he had in tolerably plain terms informed Canada that England would consent to retain her only so long as she cost nothing, and would be ready to cast her off at any moment, and would certainly do so, if her sacrifice became neeessary to secure peace.'2

'Lord Dufferin's position, as Governor of Canada, appointed by a government holding sueh views,' eontinues the Canadian historian of Dufferin's six years at Ottawa, in recalling the diffieulties at the outset of his term, 'beeame embarrassing. He was, in faet, about to undertake the government of a eountry as the representative of an imperial policy whieh was suspeeted of foreing upon that eountry the serious question of separation, and impelling men, whose dearest wish was to strengthen the ties between the eolony and England, to ask whether it would not be better to do at onee themselves ${ }^{3}$ what the imperial power determined upon to do when it suited its own purpose.' 4

1 Gladstone, in the House of Commons on April 26, 1870, had dedueed from the eonnexion of European powers and trans-Atlantic possessions that separation of eolonies from mother eountries was inevitable. Cf. Parliamentary Debates, III, ee. $1900-1901$.

2 Leggo, The Administration of the Earl of Dufferin, p. 26.

3 Carnarvon, who was Seeretary for the Colonies in the Conservative Administration of 1874-1880, in 1874 still regarded it as possible that the Dominion of Canada might move for inclusion in the United States. 'If only you can hold things together in Canada and consolidate the Dominion,' he wrote to Dufferin in April 1874, "we shall have a reasonable ehanee of preserving it from absorption in to its larger neighbour.' Lyall, op. cit., i, p, 228.

* Leggo, op. cit. Lord Monek, who was Governor-General from 1861 to 1868 , was also unpopular at Ottawa owing to a eurrent opinion that he leaned " towards the anti-colonial party in England'; and 'some imprudent expressions of his when he first eame to (anadia strengthened this opinion. Codley, his private seeretary, who is supposed to speak lis opinions, was an out-and-out follower of Bright and Goldwin sinith, and did not hesitate to state his opinion that the sooner England got rid of her colonies the better.'-Note by Maedonald, first 
Grey, who was at the Colonial Office in 1846-1852, and who will be rccalled as the Colonial Secretary who was most persistent in the propaganda for tariffs in all parts of the Empire based on the principle of free trade, was the last statesman at Westminster to intimate from the floor of the House of Lords or the House of Commons, that it might be as well if the self-governing colonies ended the connexion with Great Britain. His intimation of 1873 , the second that he made in the years from 1873 to 1879 , preceded the second reading in the House of Lords of the Bill of the Gladstone Government for so amending the constitution of the Australian colonies as to enable their legislatures to enact tariffs with differential duties.

Kimberley, who had succeeded Granville as Colonial Secretary, was in charge of the Australian Bill. ${ }^{1}$ He was fixed and emphatic in his opposition to the principle of differential duties; and during his term at the Colonial Office he worked nearly as steadily as Grey had done from 1846 to 1852 for tariffs in the self-governing colonies based on free trade. He had vainly pleaded with all the Australasian colonies not to enter on a policy of differential duties. But the colonies were insistent on possessing the power to enact these duties ; and Kimberley's case for the bill amending the Constitution Act of 1850 was that Great Britain ought not to impose its own opinions on fiscal questions on the self-governing colonies, that these colonies might fairly claim to be allowed to judge for themselves what was best for their own interests. ${ }^{2}$

Grey recalled Kimberley's statement of the case for the bill. 'I cannot,' he continued, ' concur in this view ; and I should wish to know, if it is to be acted upon, in what manner the Queen's authority is to be maintained at all. If that authority is not to be upheld by requiring the colonies to conform to the general commercial policy of the Empire-if the imperial government is to have no voice in determining upon the commercial measures of the colonies, and we are even to allow them to impose protective duties more hostile to British interests than the duties of most foreign nations-it seems to me that it will become a very serious question, whether it will be well to maintain the connexion.' 3

Premier of the Dominion of Canada, reviewing the Parliamentary session of 1867-1868. Pope, Memoir of Macdonald, i, p. 16.

1 May $15,1873$.

${ }^{2}$ Cf. Parliamentary Debates, III, ccv, 2004.

3 Ibid. 
It was the enactment of the second national policy tariff by the parliament of the Dominion of Canada in 1879-the tariff with which the name of Macdonald is always associated-that provoked Grey's second intimation to the self-governing colonies that it might be as well for them to end the connexion. The intimation was conveyed to them, not like that of 1873 from the floor of the House of Lords, but in the pages of the Nineteenth Century, then the most widely read and most influential of all the English reviews.

Parts of the Nineteenth Century article were reproductions of Grey's speech in the House of Lords of 1873. 'It may come to pass,' wrote Grey, in the only new paragraph that has any application to the phase of colonial history now under discussion, ' that the people of this country, finding the connexion between the parent state and the colonies thus reduced to a barren responsibility on the part of the former for the defence of its dependencies, may decline to go on submitting to the burden. Should the policy that has of late been pursued toward the colonies be adhered to, ${ }^{1}$ it is by no means improbable that this may be its ultimate result. Nor am I prepared to assert that it would be one to be deplored, since if it is to be deprived of what gave it life and strength, it is not apparent how the connexion between England and its colonies can be of value to either party.' 2

Colonial tariffs hostile to the cxport trade of the United Kingdom were obviously the cause of Grey's new attitude to the self-governing colonies; for in 1852, seven years before there were protectionist tariffs in any of the colonies, he had condemned the view frequently expressed in the House of Commons and the House of Lords, that there could be no permanence in the tic between these colonies and Great Britain.

'I certainly trust,' Grey then wrote (December 27, 1852), 'that such is not the view of this great question which is destined to gain acceptance with parliament and with the public. For my own part-though with the consequences of the American Revolution before my eyes, I certainly am not prepared to say that the loss of our colonial empire must necessarily be fatal to our national greatness and prosperity-still I should regard such

1 The policy of acquiescing in the Galt tariff of 18.59 , the tariff of Victoria of 1867, and the tariffs of the 1)ominion of Canada of 1870 and 1879 .

2 Grey, 'How Not to Retain the Colonies,' Nincteenth C'entury, July 1879. p. 941 . 
an event as a grievous calamity, and as lowering, by many steps, the rank of this country among the nations of the world.' 1

There were protests in Parliament after 1879 against the protectionist duties in tariffs enacted at Ottawa ; and especially against increases in the duties on manufactures from the United Kingdom at the revisions of the Dominion tariff in 1883 and 1887. But Grey has the distinction of being the last member of the House of Lords, the last member of that house who had been Colonial Secretary and as such had held Cabinet rank, if not the last member of Parliament or the last publicist of national fame, to intimate to the self-governing colonies that it would not be amiss for Great Britain if an end were made to the colonial tie.

For sixty years at least, from as early as 1822 until as late as 1879, there were thus men at Westminster, men of both the House of Lords and the House of Commons, who would have seen with satisfaction the separation of what are now the dominions from Great Britain, and who were willing to proclaim from their seats in Parliament that a severance of the tie would be of advantage to the United Kingdom. In this period also, it will be recalled, there were no fewer than five Colonial secretariesStanley, Gladstone, Grey, Russell, and Granville-who, at one time or another, publicly expressed doubts as to the permanency of the connexion.

None of the statesmen whose attitude toward the colonies in the years from 1859 to 1879 was that described in the preceding pages-Disraeli, Russell, Granville, Lowe, Gladstone, Normanby, Lefevre, and Grey-was of the Manchester school. Not one of them was ever closely associated in political propaganda with the men whose names at once come to mind when the Manchester school is mentioned.

Assuredly also there was no representative of the Manchester school in the Conservative administration of 1866-1868. But in the autumn of 1866 pressure for economy in public expenditures led Disraeli to propose to Derby the abandonment of the British settlements of the west coast of equatorial Africa." 'Leave the

1 Grey, Colnnial Policy, ii, p. 305.

2 "It must be remembered that only a year previously a representative committee of the House of Commons on West African affairs had unanimously reported against any further expansion of territory or assumption of government, 
Canadians,' wrote the Chancellor of the Exchequer, to Derby, the Premier (September 30, 1866), 'to defend themselves; recall the African squadron; give up the settlements on the west coast of Africa, and we shall make a saving which will, at the same time, enable us to build ships and have a good budget. What is more, we shall have accomplished something definite, tangible, for the good of the country. In these days, more than ever, people look to results.' 1

The Manchester school was on the wane by 1884 . Cobden died in 1865 ; in 1871 Goldwin Smith, its foremost exponent in the press, settled in Canada. Bright survived Cobden until 1889. By 1884 Bright's speeches in Parliament and on the platform were becoming infrequent; and other Radicals not of the Manchester school were gaining the public ear. But in 1884 Gladstone was opposed to any attempt by Great Britain to maintain a control or veto over the allocation of unappropriated portions of the globe, because such an attempt involved a large increase in naval expenditure. ${ }^{2}$

In the same year the Cabinet had to consider the question of an extension of the Zululand protectorate. Chamberlain was then what in later years would have been described as a 'little Englander', as regards increased responsibilities for Great Britain in South Africa. Kimberley and Derby (son of the Earl of Derby who was twice at the Colonial Office and Premier in 1852, 18581859, and 1866-1868) were in favour of extension. Gladstone was not present at the meeting of the Cabinet (March 22, 1884) at which the question was considered. Chamberlain and Dilke were present. Chamberlain opposed extension, and so apparently did Dilke. At last Kimberley said, 'I see the Cabinet do not want more niggers,' and dropped the scheme. ${ }^{3}$

and that what is now (1916) by far the most valuable and prosperous of British possessions in that quarter (Nigeria) was then unappropriated and practically unknown.' G. E. Buckle, Life of Disraeli, iv, p. 476.

'It was an evil heritage into which the British Government entered (1821). Their possessions were a few disjointed forts or settlements, on the fringe of a savage continent, where savagery had been intensified by white meu's dearings. On the Gold Coast, English forts stood by the edge of the sea, in and out with Duteh and Danish forts and factories. There was a coast and nothing more. Even in 1865, when no little progress had been made, a select committee of the House of Commons reported that the object of British policy should be ultimate withdrawal from West Africa, with the exception of Sierra Leone.' Sir Charles Lucas, The British Empire, p. 124.

2 Cf. Gwynn and Tuckwell, Life of Sir Charles Dilke, ii, p. 86.

3 Memorandum by Dilke, ibid. 
Another memorandum by Dilke of a meeting of the Cabinet in May 17, 1884, reads: 'We decided to defend the Zululand reserve against all comers' ; and later in the year Bechuanaland was annexed. ${ }^{1}$

\section{CHAPTER VII}

\section{INDIFFERENCE TO COLONIES IN ALL POLITICAL PARTIES, 1783-1887}

GoLDwIN SMith, nearly a quarter of a century after he had established himself at Toronto, recalled the aims of the Manchester school in regard to the colonies and the colonial connexion. 'To promote colonial independence,' he wrote, 'was our aim, and a great step toward it was made by the withdrawal of the troops. ${ }^{2}$ By the withdrawal of the troops ${ }^{3}$ the British taxpayer obtained relief from the expenditure on Maori and Kaffir wars which had cost many millions, and would probably have continued so long as the colonists had British troops at their command. . . . We never wished to make England little. We believed that her

1 Ibid.; W. D. Mackenzie, John Mackenzie, South African Missionary and Statesman, pp. 312-351.

2 'An unexpected military drain was caused by the sudden dispatch of troops to Can ada to protect the colony against a threatened Fenian raid (June 1866) from the United States. Disraeli was clear that these troops must be recalled directly the danger was past; and that the colony which repudiated any interference from home with her local government should also learn that in that case she must provide for her local defence, thus enforcing a doctrine which Adderley (Under Secretary for the Colonies in the Conservative Administration of 1866-1868) had vainly pressed on him a year or two before.... As guardian of the public purse he did well to protest against the one-sided relation which some colonies seemed then to think fair. The dominions have long since recognized the obligation on which Disraeli insisted.' Buckle, Life of Disraeli, iv, p. 475.

3 Troops were withdrawn from the self-governing colonies in the years from 1866 to 1872 . As soon after the establishment of responsible government in the United Provinces as 1851, Grey had addressed a dispatch to Elgin, the Governor-General, in which he had pointed out 'that Canada, enjoying as she did the blessings of responsible government, must be prepared to encounter all the sacrifices which freedom and a responsible government demanded of her.' 'Grey's successor, the Duke of Newcastle, made use of the same argument in 1863, when reducing the force in Canada to a little over six thousand men.' Biddulph, Lord Cardwell at the War Office, p. 30.

'In making these reductions, the British Government was not actuated by mere sordid considerations of economy. Nor did they consider that the diminution of force was really weakening any of the colonies. The distribution of a small force of regular troops rather weakened than strengthened the colonists, if it tended to prevent them from exerting themselves to rely upon their own resources.' Ibid., p. 31. 
greatness was in herself, and was only impaired by the dissipation of her forces, and her exposure through her dependencies, to attack in every quarter of the globe.' 1

Part of the doctrine of the Manchester school, as this doctrine was defined with much care and clearness by Goldwin Smith in 1895, was that of men like Disraeli, for instance, who would have repudiated any political affinity with Cobden, Bright, and Goldwin Smith. Nearly the whole of the doctrine of the Manchester school as regards the internal defence of the self-governing colonies, and the extension of the Empire, ${ }^{2}$ was also accepted by Conservatives and Whigs and moderate Liberals, who would have resented any attempt to group them with the Manchester school.

In the era of indifference that extended from 1820 to 1859 it was never possible to test the feeling of the House of Commons or of the constituencies on the question of the connexion of the colonies with Great Britain. It was the same in the period from 1859 to 1887. How far the doctrine of the Manchester school as to the desirability of the self-governing colonies becoming indepcndent was accepted by the electorate of the United Kingdom was never even approximately ascertained; for no attempt was ever made to estimate what support the advocates of independence could command among the electors at large.

One fact is obvious. Students of colonial history are now agreed that the conviction that independence of the colonies was inevitable, and from the point of view of Great Britain, also desirable, was almost the orthodox faith among influential circles of serious Englishmen; that the belief in colonial separation was not confined to one school of political thought, or to onc political party, but was held by leading men in all political parties. ${ }^{3}$

1 Goldwin Smith, Reminiscences, p. 322.

2 'The British State has rarely initiated developments. In most eases in the past our statesmen, almost staggering under the burden of their responsibilities have done their best to restrain any additions to that burden.' Newton, The Old Empire and the New (1917), p. 22.

' On a very rough estimate, not far short of three million square miles were added to the British Empire in the reign of Queen Victoria. 'The main aequisitions were made in the later years of the nineteen th century, and they were made not at the behest of the rulers of England, but rather against their will. Lust of eonquest had died out of state poliey, but state neeessities remained.' Lueas, The British Empire (1915), Pp. 158-159.

3 - With the more enlightened thinkers of England, separation from the colonies has for many years been a favourite idea.' Dilke, ('reater Britaın (1868), i, p. 53. Cf. Sidney Low, 'The Problem of an Imperial Executive,' King's College Lectures on Colonial Problems, p. 190. 
'There was no specially British perversity in this want of foresight,' wrote Sir Frederick Pollock in 1905, in recalling the era of indifference and in emphasizing the fact that the opinion that the colonies would separate from Great Britain was 'not an opinion of one school or party, but was a standing tradition of the Colonial Office.'

'In fact,' he continued, 'during the half century between the fall of Napoleon and the end of the Civil War in the United States, the judgement of the best informed persons in Europe on the future of national politics in both Europe and America was almost invariably wrong. Perhaps it was beyond ordinary human wisdom at that time to perceive that before the end of the nineteenth century there would be other powers, newly grown or consolidated, on land, and other navies on the seas, or that the Antipodes would have become a good deal less remote; still less that the gift of independence, as distinguished from selfgovernment-the renunciation of the British flag and British citizenship-would be so costly and burdensome, that apart from dislike to separation on any other ground, the colonies would desire it least of all things.' 1

\section{CHAPTER VIII}

\section{THE COLONIES AND BRITISH INDIFFERENCE}

THERE is much evidence in colonial history written by colonials, and also much evidence in speeches, memoirs, and letters of statesmen of the colonies now of the dominions, that the indifference of Great Britain to empire of 1859-1887, and especially the indifference of the years from 1859 to 1873 , was regarded in the colonies as more obvious and much more threatening to the connexion with Great Britain than the indifference from 1820 to $1859 .{ }^{2}$

1 Sir Frederick Pollock, Imperial Organization, Journal of the Society of Comparative Legislation, New Series, xiv, p. 240.

2 . The little Englander talked a great deal about that time [the time when the bill for the Confederation of the British North American provinces was pending, or was before Parliament] and without doubt interest in the colonies was at its lowest ebb.' R. E. Gosnell, The Story of Confederation, p. 59.

'As the immediate consequence of Earl Granville's expression, and his declaration of the imperial policy toward New Ztaland (Deccmber 15, 1869), the expediency of declaring the independence of the colony, of refusing to maintain the 
It is not possible to determine whether the indifference in Great Britain to the colonial tie was more really widespread and more manifest from 1859 to 1873 than it was from 1820 to 1859 . It is certain that the self-governing colonies were much more conscious of it than they were of the indifference of 1820-1859. They were also more afraid of it. Communication between the colonies and Great Britain was much more frequent in the second period than in the tirst; and the colonies were aware that from 1859 to 1873 much of the indifference, in fact much of the impatience in Great Britain over the colonial connexion, was due to causes then existing in the colonies, causes that did not exist from 1820 to 1859 .

There were three of thesc causes: tariffs hostile to British vice-regal establishment, and even of annexation to the United States has been freely discussed.' Letter from Wellington, New Zealand, January 21, 1870, The Times (London), March 23, 1870.

A series of quotations from speeches in the legislatures of Now South Wales and Vietoria, most of them expressive of apprehension as to the continuance of the connexion with Great Britain were embodied in a speech by Robert Torrens in the House of Commons (April 26, 1870), when Torrens moved for a seleot committee to inquire into "the political relations and modes of official intercommunication between the self-governing colonies and this country, and to report whether any and what modifications are desirable, with a view to the maintenance of a good understanding.' It was in the debate on the Torrens motion that Gladstone, who at this time was Premier of the Liberal Administration of 1868-1874, told the House of Commons that the history of colonial conncxions of European powers and trans-Atlantic possessions proved that separation of colonies from mother countries was inevitable. Cf. Parliamentary Debates, III, cc (Torrens) 1817-1847, (Gladstone) 1900-1901.

'He thought that it could not have escaped the attention of every nomber who had read the speech of Mr. Gladstone on a late occasion (on the motion in House of Commons at Westminster by Torrens for a committee of inquiry, April 26, 1870 ), or who had read the various articles which had appeared of late in the public prints that there was an imminent danger that within the next few years we should be obliged to receive, if we did not assert, our independence. - Andrew Hamilton Russell, cx-Cabinet Minister, House of Representatives, New Zealand, August 12, 1870. Parliamentary Debales (New Zealand), VIII, 582.

- If England should be mad enough to throw over her colonies, he did not think they should hesitate to take action in their own defence. Indecd it was within the range of possibilitics that we should ultimately join the Unitcd States.'Domett, Housc of Representatives, Ncw Zealand, August 12, 1870, Ibid., 484.

We desirc that the connexion between the mother country and her offspring in this part of the world should long continue; and we cmphatically repudiate all sympathy with the views of those who, in the Imperial Parliament and elsewhere, have expressed a wish that the bonds which unitc us should be scvered.'Resolution adopted at conference of delegates from Governments of New South Wales, Tasmania, South Australia, Queensland, and Victoria, at Melbourne, Septcmber 18, 1871. Correspondence with Australian Colonies respecting Inter. colonial Tariff Arrangements, 1872, p. 14

Cf. .J. C. Colmer, The Commercial Federation of the Empire, p. I3 ; and lecture by Joseph Howe, Secretary of State, Dominion of Canada, at Ottawa, February 27 , $187: 2$; Pope, Memoir of Mílacdonald, ii, Appendix, p. 324, and ii, pp. I14, I5I-156. 
manufacturing interests, the tardiness with which Upper and Lower Canada ${ }^{1}$ and New Zealand undertook their own defence, ${ }^{2}$ and the revelations of corruption in political life in some of the self-governing colonies. ${ }^{3}$

Debates in Parliament at Westminster, discussions in chambers of commerce and in the press, all make it clear that the most potent of these three causes-causes that developed after responsible government was established in the colonies-was colonial tariffs with high protectionist duties avowedly intended to restrict the export of British manufactures to the colonies.

These tariffs, and the admitted powerlessness of the Colonial Office or Parliament at Westminster to bring about any changes in them, or in the fiscal policy of the colonies whose legislatures enacted such tariffs, adversely affected the manufacturing, the merchant, and the shipping classes of Great Britain. High duties in colonial tariffs on exports from the United Kingdom-for

1 Cf. Editorial notes to Howe correspondence of 1867, by L. J. Burpee, Transactions of the Royal Society of Canada, III, x, p. 457.

2 'In the North American colonies the necessity of maintaining a considerable force arises almost entirely from their proximity to the United States and from the fact that if we were unfortunately involved in a quarrel with the Republic, our colonies would be attacked as a means of injuring us.' Grey, Colonial Policy, i, p. 46 .

Our military expenditure on account of the colonies is certainly very heavy, including the charges for the pay of the troops stationed in them. the cost of barracks and ordnance works, that of transport and the large proportion of dead weight of the army which is fairly chargeable to the colonies. Ibid. p. 43.

'We did not teach our colonies to rely upon themselves; but we taught them to rely that, come what would, they would be defended by a Power thousands of miles away. Unless men are taught to rely upon themselves they can never be truly worthy of the name of free men.'-Gladstone, House of Commons, April 26, 1870. Parliamentary Debates, III, cc, 1903.

Cf. Norton, ' How Not to Retain the Colonies,' Nineteenth Century, July 1879, p. 173.

3 'In these responsible governments, one sees much going on which is most objectionable. Yet one is powerless to do good, or prevent evil.'-Sir William Denison, Governor of New South Wales, November 17, 1870. Denison, Varieties of Viceregal Life, i, p. 497.

'We had allowed them [the colonies], and he thought properly allowed them, self-government; but it was notorious that since they had got their own Legislatures there had been gross land jobbings and other corruption.'-Grey, House of Lords, May 20, 1873. Parliamentary Debates. III, ccxvi, 153. A detailed description of some conditions in Upper and Lower Canada which Grey evidently had in mind in this speech is embodied in a report of 115 pages from a select committee of the Legislative Council, a committee that in 1855 investigated charges made against Francis Hincks, Premier of the United Provinces from 1851 to 1854.

Cf. Canadian Pacific Railway scandal, 1872, questions in House of Commons at Westminster, August 1, 1873. Parliamentary Debates, III, ccxvii, 1430; Sir Richard Cartwright, Reminiscences; pp. 109-119; Boyd, Sir George Etienne Cartier, pp. $328-330$. 
Ireland has always sold its woollens and linens in the coloniesthrust themselves into the politics of men engaged in manufacturing or in export trade ; and in the years from 1859 to 1873 these men largely made what general public opinion there was regarding the self-governing colonies and the colonial tie.

At no time after 1859 did the Colonial Office make any protest against any straight line protectionist tariff enacted by a colonial legislature. From 1859 to 1873 the Colonial Office interposed in tariff making in the self-governing colonies only with a view to estopping the enactment of tariffs with differential duties. It was never able to prevent the enactment of differential duties by the legislatures of any British North American province; and it is exceedingly doubtful whether it could have prevented the enactment of such duties in the tariffs of the Australian colonies, had it not been for the restraining section of the Australian Colonies Government Act of 1850.

Nor at any time after the self-governing colonies established themselves on a protectionist basis did the Colonial Office ever ask for, or even suggest, that in Colonial tariffs there should be preferences for imports from the United Kingdom, preferences such as were embodied in the tariffs of nearly all the colonies now of the dominions in the years from 1897 to 1910.

But in 1872 the Australasian colonies were directly told, and the other self-governing colonies were indirectly warned, by Kimberley, who was then at the Colonial Office, that protectionist tariffs and differential duties in colonial tariffs were likely to do more to weaken the connexion between Great Britain and the colonies than any expression of opinion in the colonies themselves in favour of independence. ${ }^{1}$

In 1873, it will be remembered, Gladstone proclaimed in the House of Commons, in answer to a question by Dilke, directing his attention to the scandal at Ottawa, arising out of the granting of the first charter for the construction of the Canadian Pacific Railway, that while Canadian Cabinet Ministers were undoubtedly responsible to the Canadian Parliament for their conduct, they were not in any way responsible for their conduct to the Colonial Office or to Parliament at Westminster. 'I do not think',

1 Cf. Dispatch by Kimberley, Colonial Office, April 19, 1872. Parliamentary Papers, 1872, (. 576, 13; Keith, Responsible Covernment in the Dominions, iii. p. 1179. 
added Gladstone, 'that this is a matter in which it is competent or desirable for us to interfere.' 1

Neither in Great Britain, in Canada, nor in any of the selfgoverning colonies was the attitude thus assumed by Gladstone in 1873 ever questioned. There were no more questions in Parliament concerning revelations in the political life of any of the self-governing colonies. Political scandals in these colonies thereafter were regarded in Great Britain as exclusively the concern of the legislature and the people in the particular colony in which such scandal might be uncovered; for with responsible government established in all the colonies now of the dominions, the government in Downing Street ceased to interfere in any degree in the internal affairs of these colonies. 'It would not think', wrote Mr. Justice Riddell, of the Supreme Court of Ontario, in 1917, ' of directing or even advising the people of Canada, or its Ministry, what to do or what to leave undone.' 2

\section{CHAPTER IX}

\section{THE END OF THE ERA OF INDIFFERENCE}

THE self-governing colonies in the years from 1869 onward gradually assumed all responsibility for their own internal defence. British troops, raised in the United Kingdom and equipped and paid at the cost of the British Exchequer, were withdrawn from all the colonies-from the services which had necessitated colonial military stations for two or three generations before the Cardwell reorganization of the British Army in 1869-1870.3

Wars with aborigines in New Zealand and South Africa came to an end; and when the second Riel rebellion in Manitoba broke out, in 1885, it was suppressed by the North-west Mounted Police and by two thousand militiamen and volunteers from Manitoba and from all the provinces of the Dominion of Canada east of the Great Lakes. ${ }^{4}$

1 Parliamentary Debates, August 1, 1873, III, ccxvii, 1430.

2 W. R. Riddell, The Constitution of Canada, pp. 90-91.

3 By this reorganization over 15,000 men were withdrawn from stations in the colonies now of the dominions. Cf. Biddulph, Lord Cardwell at the War Office, p. 31 .

* 'Quebec, Kingston, Toronto, Winnipeg; and many other places sent their 
From 1897, Cape Colony, Natal, and Newfoundland made voluntary contributions to the cost of the Imperial Navy. Later on the Dominion of Canada took upon itself the maintenance of the imperial naval stations at Halifax and Esquimalt; and before Canada had assumed this responsibility in connexion with the British fleet, troops voluntarily recruited in Canada and in the Australasian colonies had served with imperial troops in the war in Egypt in 1884 and in the South African War of 18991902.

British manufacturers gradually accustomed themselves to the high tariffs of the Dominion of Canada of 1879-1897, to the lavish bounty system in aid of Canadian industries of 1883-1911, and to the protectionist tariffs of the Australasian and South African colonies of the years from 1867 to 1914 . In the fifty-five years from the enactment of the Galt tariff to the war, exporters in the United Kingdom came to regard the protectionist tariffs of the dominions in much the same way as they had regarded protectionist tariffs enacted at Washington after 1861, much as they regarded the McKinley tariff of 1890 and the Dingley tariff of 1897 .

The attitude of British manufacturers was that all these protectionist tariffs, American and colonial, were unfortunate; but that they were inevitable, in view of the strength of the protectionist movements in the United States, in Canada, and in the Australian colonies. In the reports of parliamentary debates at Westminster, there are no records of protests in the House of Commons or the House of Lords against the protectionist tariffs of the Australasian colonies; and apparently there were no deputations of British manufacturers to the Colonial Office to remonstrate against those tariffs.

All remonstrance and protest of chambers of commerce, and of members of the House of Commons or the House of Lords from 1859 to 1887 , was either against the tariffs of the United Provinces of Upper and Lower Canada, 1841-1867, or against the much higher tariffs of the Dominion of Canada. Except for a complaint in 1908, in the form of a question, against the curtailment of the preference on British woollens at a revision

citizen soldiers. The Maritime Provinces also offered men, and the loyal enthusiasm of all proved once more that the sons of Canada are ever ready to defend her in time of need.' Emily 1'. Weaver A 'analian History, p. 286. 
of the Canadian tariff in $1904,{ }^{1}$ all remonstrance and protest, either at the Colonial Office or in Parliament, had come to an end by 1887 .

Chambers of commerce in the United Kingdom after 1887 ceased to agitate against the tariffs of the Dominion of Canada; and statesmen from colonies with protectionist tariffs were no longer heckled concerning import duties on British manufacturers as Galt and Macdonald had been in the 'sixties and the 'serenties, when they appeared on public platforms in England and Scotland.

With the passing of the older school of free trade statesmen a.t Westminster-with the passing of what may be described as the aggressive school to which colonial secretaries such as Grey and Kimberley belonged-statesmen and politicians like British manufacturers and chambers of commerce, in the United Kingdom assumed a new attitude toward the dominions and their fiscal policies and commercial systems.

Chamberlain, who did not abandon free trade and begin to agitate for a return to protectionist tariffs in the United Kingdom until 1903, was one of the first statesmen at Westminster to adopt and proclaim the new attitude of the colonies and their protectionist policies. He visited Canada in 1888, and on his return to England he declared in a speech at the Devonshire Club, London, April 9, 1888, that it was useless to expect that the colonies would abandon customs duties as their chief and principal source of revenue. 'It is hardly to be hoped', he added, 'that the protected interests, fostered by their system, will willingly surrender the privileges which they now enjoy.' 2

The newer attitude which had been assumed by free traders for at least a quarter of a century before the war was well described by Mr. Asquith, Premier of Liberal Governments at Westminster from 1908 to 1916 , in a speech at the conference of the Liberal Federation at Manchester in September 1918.

'We Liberals', said·Asquith, 'are as much concerned as any man or woman can be to strengthen the ties which unite our Empire-our Empire, unique in history, existing and held together because alone among Empires it combines a common loyalty and fraternity with complete local autonomy. We should never dream, not a man amongst us, of seeking to enforce upon

1 Parliamentary Debates, October 26, 1908, IV, xciv, 1571.

2 Boyd, Mr. Chamberlain's Speeches, i, p. 323.

D d 
any of our great dominions fiscal arrangements which were felt by its people to be inconsistent with their own richest and fullest economic development. And the dominions, in turn, as we know from declarations of their responsible statesmen, would never dream of interfering directly or indirectly with the fiscal policy of the mother country.' 1

Statesmen of both political parties at Westminster, from 1850 to 1887 , were slow in realizing that responsible government on the broad and generous lines accepted by Parliament at the crisis over the Rebellion Losses Act of 1849 necessarily carried with it for the colonies the fullest measure of fiscal freedom.

Kimberley acknowledged this in 1873 , when he told the House of Lords that responsible government must be regarded as an even more important principle than the principle of free trade. Even as late as 1887 Kimberley's dictum of 1873 was not wholeheartedly and universally accepted in the United Kingdom. Otherwise there would have been no protests in the House of Commons or in the House of Lords against the tariff enacted at Ottawa in that year, with its large increases in import duties avowedly in the interests of blast furnaces and puddling mills in Nova Scotia and Ontario.

But gradually the principle enunciated by Kimberley when he asked the House of Lords to pass the bill amending the Australian Colonies Government Act of 1850 was universally accepted in the United Kingdom. It was accepted first in the spirit of Chamberlain's declaration of 1888 ; and finally in the spirit of Asquith's speech at Manchester in 1918; and with this full acceptance there was at last an end to friction between the colonies and Great Britain over tariffs, an end to friction that was of at least as long standing as Grey's protests of 1850 against differential duties in the tariffs of the British North American colonies.

Population in the colonies now of the dominions, and especially in Canada, greatly increased in the years from 1887 to $1914 .^{2}$

1 Herald (Glasgow), September 28, 1918.

2 "Hore and more our sons leave our shores and go to distant lands ; and we desire that the lands to which they go should be British, like the land they leave.' Chamberlain, June 10, 1896, Foreign and Colonial Speeches, p. 103.

The Dominion of Canada began its great immigration propaganda in 1898 . In the years from 1900 to 1915 inclusive $1,159,628$ British emigrants left ports in the United Kingdom for ('anadi-English 833,982, Welsh 13,396, Scotch 
These colonies were then perfecting their systems of government. ${ }^{1}$ They acquired a new status at the Colonial Office and in the Empire at large. They developed their natural resources, and all reached a high degree of material prosperity and of political and social civilization.

Money of British investors in this quarter of a century went in increasing volumes into government loans-federal, provincial and municipal-and into railways and industrial undertakings in the colonies. ${ }^{2}$

These investments, many of them made contemporaneously with the great increase in emigration from the United Kingdom to the Dominion of Canada and to the Australasian colonies, created another link of empire and also stimulated a more widely extended popular interest in Great Britain in the dominions.

Even before emigration had so greatly increased, and loans began to swell so enormously in volume, popular interest in the self-governing colonies had been stimulated by the educational work of the Royal Colonial Institute, established in 1868; by the propaganda of the Imperial Federation League of 1884-1893; by the meetings of chambers of commerce of the Empire, which began in 1894; and by the colonial conferences of 1887, 1894, and 1897.

The self-governing colonies in no uncertain tones proclaimed that it was their strong desire to remain of the Empire, that they were in favour of the continuance and perpetuation of the

240,106, and Irish 72,144. Cf. W. J. Roche (Ottawa), Immigration: Facts and Figures, p. 3.

1 The Commonwealth of Australia was created in 1900, and the Union of South Africa in 1910.

2 'Our aggregate investment in the colonies and India now reaches $£ 1,554,000,000$, of which $£ 1,100,000$ had been placed in Canada, Australia, and South Africa.' Sir George Paish, of the Statist, at the Royal Statistical Society, London, December 20, 1910. The Times (London), December 21, 1910.

'If the Dominion Government needs money, it goes to London to get it. If any of the provinces wish to make a loan they seek it in the same quarter. If railway companies need funds they borrow in London. London capital supplies money which our municipal corporations borrow, and nearly every large industrial enterprise is financed in London. Here is a benefit of British connexion that each one of us feels from day to day in his pocket where the most acute nerves of feeling centre. ... Now and then some narrow-minded person asks what the British connexion means to us. We invite such people to reflect upon the fact that this great investment of British capital in Canada has followed closely on the heels of the growth of imperial sentiment.' Colonist (Victoria, British Columbia), quoted in 'The Spirit of the Press,' Globe (Toronto), December 3, 1910.

$$
\text { D d } 2
$$


connexion between the dominions and Great Britain. ${ }^{1}$ Colonial statesmen, moreover, began to discuss among themselves how closer relations could be established with Great Britain ; and singularly enough almost the first suggestion to this end was from Macdonald, Premier of Canada, whose national policy tariffs had added to the indifference to colonies in Great Britain of the years from 1859 to 1887 , and provoked many protests in Parliament at Westminster. ${ }^{2}$

Responsible statesmen in Great Britain frequently responded, often in glowing terms, to these declarations of loyalty to the Empire from the self-governing colonies. The colonies were assured that the era of indifferenee was at an end. They were told offieially and authoritatively in 1896 by Chamberlain, who was then Colonial Seeretary, that it was the hope of the people of Great Britain that the autonomous colonies would never cut adrift from the great history of the motherland and its glorious traditions. ${ }^{3}$

1 'I am well satisfied that the vast majority of the people of Canada are in favour of the continuanee and perpetuation of the eonnexion between the Dominion and the mother eountry. There is nothing to gain and everything to lose by separation. I believe that if any party were to deelare for separation, either by annexation with the neighbouring country - the great Republie to the south of us - or by a deelaration of independenee, the people of Canada would say "No". We are eontent. We are prosperous. We have prospered under the mighty flag of England; and I say that it would be unwise, that we would be lunaties, to ehange the eertain present happiness for the uneertain ehanees of the future. I always remember when this question oeeurs to me, the Italian epitaph, "I was well, I would be better; and here I am." We are well. We know we are well; and I am satisfied that the majority of the people of Canada are of the same opinion whieh I venture to express here. . . I say that ruin and misfortune would follow any separation from the United Kingdom. I believe that sueh is the feeling of the present Parliament of Canada; and I am eertain that any party making an appeal to the people of Canada, or any persons attempt. ing to form a party on the prineiple of separation from England, no matter whether they should propose to walk alone, or join another eountry, would find the people of Canada, almost to a man, rising and saying, "No, we will do as our fathers have done. Wo are eontent; and our ehildren will be content to live under the flag of Great Britain." -John A. Maedonald, at semi-eentennial of Queen's College, Kingston, Ontario. December 15-18, 1889, Queen's College Journal, January 15,1890, p. 85 . 'Sir John resumed his seat,' reads a note added by the shorthand writer who reported the speeeh for Queen's College Journal, ' amid a thunder of applause that almost shook the solid limestone walls of the building.'

2 (ff. letter of Maedonald to Sir Cecil Rhodes, May 8, 1891, in Sir Lewis Michell's Life of C'rcil Rhodes, ii. pp. 29-30.

3 "If I were to ask myself the oft-repeated question whether this Empire is destined to follow the empires of antiquity and to perish, and the memory of it to be forgotten, or whether we are to sink, like some of our rivals, into a condition of medioerity or obscurity. I confess my answer would depend, not so much upon what may be clone or said by the pepulation of these small islands, but rather upon the eventual determination of that Greater Britain whieh forms in space, 
Of the many forces that combined to dissipate an indifference to colonial possessions and to the colonial tie that had lasted for two generations, only those that developed and gained strength in the self-governing colonies and in the United Kingdom itself have so far been described. A third and external force, almost as potent as the two sets of forces working within the Empire, was the appearance on the scene of Germany as a new European competitor for oversea possessions.

The success of Germany in the war of 1870 with France consolidated the German states into an empire; and between 1880 and 1890 Germany acquired colonial possessions in Africa and Asia with a swiftness almost equal to that with which the area in Europe under German rule was extended in the years from 1864 to 1871.1

By this time all the self-governing colonies were, as regards fiscal freedom, in the unassailable position that the British North American provinces had secured for themselves in the period from the Enabling Act of $\mathbf{1 8 4 6}$ to the creation of the Dominion of Canada in 1867.

All their legislatures were free (1) to enact tariffs with protectionist duties against all comers, British and non-British; (2) to enact tariffs with differential duties in order to effect agreements for reciprocal trade with each other, with Great Britain, or with non-British countries; and (3) to enact tariffs

at any rate, the larger portion of the Empire, and upon the arrangements which they may make to bind us together in closer union. The advantages of such a union are now universally appreciated. They are becoming the commonplaces of after dinner oratory. No one now has to argue the principle. We in this country are, I think, pretty well convinced of the assured future of our colonies and dependencies. There may have been times, but it is long ago, when these great countries with their enormous potentialities, were not appreciated in the United Kingdom. . . . Am I wrong in thinking that the colonies share our feelings and share them to the full-that they have no idea of cutting themselves adrift from the great history of the motherland; from the glorious traditions in which we find the germs and origins of the ordered liberty which they enjoy; from the history of the struggles in which their ancestors took no mean part; and from all the common pride in the glories of art and literature which perhaps even more than our victories in arms have made the name of Britain illustrious? No, I believe that our colonies recognize the fact that the life of a great nation is fuller than the life of a small one, and the life of an old nation more instructive than the life of a new one; and I am convinced that none of our colonies will bc backward in the effort to secure and maintain this connexion, nor ready to abandon its part in the heritage which belongs to all of them'-Chamberlain, Congress of Chambers of Commerce, June 10, 1896. Foreign and Colonial Speeches, pp. 102-104.

1 Lucas, Empire and Democracy in the Empire and the Future (1916), p. 14. 
with retaliatory duties, such as those that were embodied in the tariff of the Dominion of Canada of 1870, and also in the tariff of the Dominion from 1903 to 1910 , the years of the tariff war between Canada and Germany. ${ }^{1}$

All that was needed after 1895-the year of the last amendment to the Australian Government Act of 1850-all that was needed to round out the fiscal freedom of the dominions was (1) relief from articles in British commercial treaties, made before 1878, that hampered the colonies in conceding tariff preferences on imports from the United Kingdom and also in making agreements for reciprocal trade ; and (2) full and unrestricted power, power a little more complete than they possessed in $\mathbf{1 8 9 5}$, to name their own plenipotentiaries for the negotiation of their own commercial treaties with non-British countries.

The first of these long-desired augmentations of fiscal freedom and fiscal power came, as will be recalled, in 1898, as a direct and immediate result of the audacity of the Laurier Government of 1896-1911 in asking the Dominion Parliament to enact the British preferential tariff in 1897 , and by so doing to ignore all that had been said at Ottawa for ten years before 1897 about Great Britain's unwillingncss to denounce its commercial treaties with Germany and the other twenty-odd British treaties, in which, as in the Prussian treaty of 1865 , favoured nation articles were embodicd.

1 'The upshot of Germany's procedure (her insistence on the same terms that Canada conceded to Great Britain in the Preferential Tariff Aet of 1897) was that for the first time since Great Britain had adopted free trade in 1846, one dominion of the British Empire was engaged from 1903 to 1910 in a tariff war. Germany was the aggressor. Until July 1898 Canadian exports to Germany were admitted under the German minimum tariff. As soon as the treaty of 1865 had expired, and exports from Germany to Canada were eonsequently no longer admitted on the same farourable terms as exports from the United Kingdom, Germany put her maximum tariff into foree against Canada.

The Dominion was slow to retaliate. The Gorernment at Ottawa eoneeired that there was some misunderstanding on the part of Germany. By diplomatic correspondenee, and also through the German eonsulate at Montreal, efforts were made to assure Berlin that Canada was giving to Germany everything that it gave to any foreign eountry; that it was eoneeding to Germany what it coneeded to Franee, although Franee, with which Canada had had a treaty of cominerce sinee 1893, gave valuable eoneessions in return, and Germany conceded nothing.

All that Canada asked was that her exports to Germany should again come under the minimum tariff. This Germany refused. Her maximum tariff was put into force against Canada in the autumn of 1s98, but it was October 1903 before Canada retaliated. 'Then, by Act of Parliament, a surtax of one-third of the duties in the general tariff was imposed on imports from (iermany. 
The year 1907, with the Canadian-French reciprocity treaty as the occasion, witnessed a full realization of the second of these long-desired enlargements of power-the complete success of the movement for diplomatic freedom, which, as will be remembered, had its beginning in the United Provinces in the days when Merritt was extra-officially associated with Crampton, at Washington, ${ }^{1}$ in the hard spade work preliminary to the first treaty of reciprocity between the British North American provinces and the United States.

Full and absolute fiscal freedom thus came into view for the British self-governing colonies with the end of the century long indifference of the people of the United Kingdom to colonial possessions, and to widely extended empire ; and in the decade that preceded the Great War there was not an issue-constitutional, financial, fiscal, or diplomatic-that was in the least degree disturbing the good relations of Great Britain and the Dominions. ${ }^{2}$

So much could not have been affirmed of any previous decade of British colonial history of the era that began at the end of the American Revolution. It certainly could not have been affirmed of any other decade since 1820 ; for it was in the decade from 1820 to 1830 that sharp and really disturbing friction began between Lower Canada and Downing Street arising out of the unsatisfactory working of the constitution of 1791 .

The next decade, 1830 to 1840 , was productive of friction between Upper Canada and the Colonial Office, arising out of pressure from the legislature at Toronto for preferential terms in British tariffs for Canadian grown tobacco. The last five years of this decade also saw the beginning of a movement against

The result of the surtax was that on many of the imports from Germany duties in the years from 1903 to 1910 ranged as high as forty per cent., the highest tariff duties ever in force in Canada until the war tariff of 1915 was enacted. There was at once a great reduction in Germany's export trade to Canada.

Germany slowly realized that only loss of trade was resulting from persistence in the tariff war ; and in February 1910, on overtures from Berlin, the tariff war was ended in a peace without victory for Germany. Porritt, Evolution of the Dominion of Canada, pp. 444-446.

1 See ante, pp. 163, 165-167.

2 "The outbreak of the war found the whole Empire one. I rejoice to think that the end of the struggle finds the Empire still more closely united by common resolve, held firm through all vicissitudes, by suffering and sacrifice, by dangers and triumphs shared together.'-Message of Congratulation, issued to the British Empire by George V after Germany had accepted armistice terms of Allies. Message dated London, Tovember 12, 1918. 
tariffs for the colonies enacted at Westminster, and the first claim of any British colony for a larger fiscal freedom than was permissible under the old colonial system.

The rebellion in Lower and Upper Canada, moreover, was of this fourth decade of the nineteenth century; and in the train of the rebellion-in the train of what was really the revolution of 1837-there came the series of developments in the constitutions of the colonies and their relations to Whitehall and Westminster that to-day give the five dominions-Canada, Newfoundland, Australia, New Zealand, and South Africa-the universally accepted and unassailable status of nation within the British Empire. 


\section{SOURCES AND AUTHORITIES}

Adderley, Sir Charles Bowyer (First Baron Norton), The Colonial Policy of Lord Russell's Administration. London, 1869.

Allin, Cephas Daniel, A History of the Tariff Relations of the Australian Colonies. Minneapolis, 1918.

Allin, Cephas Daniel, and Jones, George M., Annexation, Preferential Trade, and Reciprocity. Toronto, 1911.

Anson, Sir William R., The Law and Custom of the Constitution. Oxford, 1909.

Argyll, Ninth Duke of, Passages from the Past. London, 1907.

Ashley, W. J. (editor), British Dominions : Their Present Commercial and Industrial Condition. A Series of General Reviews for Business Men and Students. London, 1911.

Ashworth, Henry, Recollections of Richard Cobden, M.P., and the Anti-Corn Law League. London, 1876.

Atton, Henry, and Holland, Henry Hurst. The King's Customs. London, 1908.

Bartlett, J. H., The Manufacture, Consumption, and Production of Iron and Steel and Coal in the Dominion of Canada.

Begg, Alexander, History of British Columbia from Its Earliest Discovery to the Present Times. London, 1894.

Bell, Sydney Smith, Colonial Administration of Great Britain. London, 1859.

Benson, Arthur Christopher, and Viscount Esher, The Letters of Queen Victoria, 1837-1861. London, 1907.

Biddulph, Sir Robert, Lord Cardwell at the War Office, 1868-1874. London, 1904.

Boose, James R., Titles of Publications Relative to the British Colonies, their Government, dic., in Connexion with Imperial Policy. London, 1889.

Bourinot, John G., Federal Government in Canada. Baltimore, 1889.

Boyd, Charles W., Mr. Chamberlain's Speeches. London, 1914.

Boyd, John, Sir George Etienne Cartier, Bart., His Life and Times : A Political History of Canada from 1814 until 1873. Toronto, 1914.

British Traveller, A, The Colonial Policy of Great Britain Considered with Relation to Her North American Provinces and West Indian Possessions. Philadelphia, 1816.

Brodrick, George C., and Fotheringham, J. K., The History of England from Addington's Administration to the Close of William IV's Reign, 1801-1837. London, 1906.

Bruce, Sir Charles, The Broadstone of Empire: Problems of Crown Colony Administration, with Records of Personal Experience. London, 1910.

Buckingham, William, and Ross, George W., The Hon. Alexander Mackenzie, His Life and Times. Toronto, 1892.

Bulwer, William Henry Lytton Earle, Life of Viscount Palmerston. London, $1870-1874$.

Burpee, L. J., Sandford Fleming, Empire Builder. London, 1915. 
Butler, J. R. M., The Passing of the Great Reform Bill. London, 1914.

Campbell, Duncan, History of Prince Edward Island. Charlottetown, 1875.

Canada First : A Memorial of the late William A. Foster, Q.C., with Introduction by Goldwin Smith. Toronto, 1890.

Canada Year Book, 1915. Ottawa.

Carlisle, Henry E., Correspondence of Abraham Hayward, Q.C. London, 1886.

Carnarvon, Earl of (Henry Howard Molyneux), Speeches on Canadian Affairs, edited by Sir Robert Herbert, G.C.B. London, 1902.

Cartwright, Sir Richard, Reminiscences. Toronto, 1912.

Chamberlain, Joseph, Foreign and Colonial Speeches, authorized edition. London, 1897.

Childe-Pemberton, William S., Life of Lord Norton, 1814-1905 : Statesman and Philanthropist. London, 1909.

Clowes, W., and Sons, Rules and Regulations for Her Majesty's Colonial Service. London, 1843.

Cobden, Richard, The Political Writings of. London, 1868.

Collier, James, Sir George Grey, Governor, High Commissioner, and Premier. London, 1909.

Colmer, J. C., Commercial Federation of the Empire. London, 1896.

Colonial Conference at Ottaua : Report by the Earl of Jersey, with the Proceedings of the Conference and Certain Correspondence. C. 7553. London, 1894.

Cote, N. Omer, Political Appointments, Parliaments, and the Judicial Bench in the Dominion of Canada, 1867 to 1895 . Ottawa, 1896.

Ibid., 1896 to 1917. Ottawa, 1917.

Cöte, J. O., Political Appointments and Elections in the Province of Canada, 1841 to 1865 . Ottawa, 1866.

Cotton, J. S., and Payne, E. J., Colonies and Dependencies. London, 1883.

Creighton, Mandell, Memoir of Sir George Grey, with Preface by Sir Edward Grey. London, 1901.

Curtis, L., The Commonwealth of Nations. London, 1916.

Cushing, Caleb, The Treaty of Washington. New York, 1873.

Debates, Parliamentary. (Offieial or semi-offieial reports of debates in Parliament at Westminster, and in the legislatures of eolonies now of the dominions, have been cited as 'Parliamentary Debates'.)

Denison, George T., The Struggle for Imperial Unity: Recollections and Experiences. London, 1909.

Denison, Sir William. Varieties of Vice-Regal Life. London, 1870.

Dent. John Charles, The Last Forty Yeurs. Canada since the Union of 1841. Toronto, 1885 .

1)ilke. Nir Charles Wentworth, Greater Britain: A Record of Travel in Englishspeaking Countries during 1866 and 1867. London, 1868.

Problems of Greater Britain. London, 1890.

1) rummond, George E.. The Iron Industry-IThat $i$ is to Greater Briktin and the I'nited states: What it May Be to C'anade. Montreal, 1894.

Dunning. William A., The British Empire and the C'nited States. New York. 1914.

Egerten, H. E.. and Cirant, W. L., C'anadian C'onstitutional Development shoun by selected specehes and Dispatehes. London, 1907. 
Ellenborough, Lord (Edward Law), A Political Diary, 1828-1830, edited by Lord Colchester. London, 1881.

Esher, Lord, The Girlhood of Queen Victoria. London, 1912.

Ewart, J. S., The Kingdom of Canada: Imperial Federation, the Colonial Conferences, the Alaska Boundary, and Other Essays. Toronto, 1908.

Farrer, James Anson, The Monarchy in Politics. London, 1917.

Fawcett, Mrs., Life of Sir William Molesworth, M.P. London, 1901.

Ferraby, H. C., The Imperial British Navy: How the Colonies Began to Think Imperially upon the Future of the Navy. London, 1918.

Findlay, Sir John G., The Imperial Conference of 1911 from Within. London, 1912.

Francis, George Henry, Opinions and Policy of the Right Honourable Viscount Palmerston. London, 1852.

Freemantle, H. E. S., The New Nation : A Survey of the Condition and Prospects of South Africa. London, 1909.

Frewin, Richard, A Digested Abridgment of the Laws of the Customs. London, 1819.

Galt, A. T., Canada 1849-1859. London, 1860.

Garnett, R., Edward Gibbon Wakefield, The Colonization of South Australia and New Zealand. London, 1908.

Gee, Joshua, Trade and Navigation of Great Britain Considered. London, 1767.

Gesner, Abraham, The Industrial Resources of Nova Scotia. Halifax, 1849.

Gosnell, R. E., The Story of Confederation. Victoria, B.C., 1918.

Grant, G. M., Letters to the 'Globe'. Toronto, 1893.

Gray, John Hamilton, Confederation, or the Political History of Canada from the Conference at Quebec in October, 1864, to the Admission of British Columbia in July, 1871. Ottawa, 1872.

Greville, Charles C. F., Greville Memoirs (second part): A Journal of the Reign of Queen Victoria from 1837 to 1852. London, 1885.

Grey, Charles, third Earl Grey, The Colonial Policy of Lord John Russell's Administration. London, 1853.

Gwynn, Stephen, and Tuckwell, Gertrude, M., Life of Sir Charles Dilke, M.P. London, 1917.

Hall, Samuel Carter, Retrospect of a Long Life—from 1815 to 1883. London, 1883. Harris, Wilmer C., Public Life of Zachariah Chandler. Lansing, Michigan, 1917. Hearnshaw, F. J. C. (editor), King's College Lectures on Colonial Problems. London, 1913.

Herries, Edward, Memoir of the Public Life of John Charles Herries. London, 1880.

Holland, Bernard, The Fall of Protection, 1840-1850. London, 1913.

Houston, William, Documents Illustrative of the Canadian Constitution. Toronto, 1891.

Hurd, Percy and Archibald, The New Empire Partnership. London, 1915.

Jenkyns, Sir Henry, British Rule and Jurisdiction beyond the Seas. Oxford, 1902. Jeyes, S. H., Mr. Chamberlain: His Life and Public Career. London, 1903.

Johnson, Stanley, C., A History of Immigration from the United Kingdom to North America, 1763-1912. London, 1913. 
Kaye, Sir J. W., Life and Correspondence of Charles Lord Metcalfe. London, 1858.

Keith, Arthur Berriedale, Imperial Unity and the Dominions. Oxford, 1916.

Responsible Government in the Colonies. London, 1915.

Kennedy, W. P. M., Documents of the Canadian Constitution, 1759-1915. Toronto, 1918.

Knight, Charles, Political Dictionary. London, 1845.

Laughton, John Knox, Memoirs of the Life and Correspondence of Henry Reeve. London, 1898.

Leader, Robert Eadon, Life and Letters of John Arthur Roebuck. London, 1897.

Leech, H. J., The Public Letters of John Bright, M.P. London, 1885.

Leggo, William, History of the Administration of the Earl of Dufferin, GovernorGeneral of Canada. Montreal, 1878.

Lewis, Sir George Cornewall, Letters to Various Friends, edited by his brother, the Rev. Sir Gilbert Frankland Lewis, Bart. London, 1870.

Liberal Convention, Ottawa, 1893, Official Report of. Toronto, 1893.

Linn, William Alexander, Horace Greeley, Founder and Editor of the 'New York Tribune'. Now York, 1903.

Low, Sidney, and Sanders, Lloyd C., The History of England during the Reign of Queen Victoria, 1837-1901. London, 1907.

Lowe, Joseph, The Present State of England in Regard to Agriculture, Trade, and Finance. London, 1822.

Lucas, Sir Charles, The British Empire: Six Lectures. London, 1915.

Lyall, Sir A., Life of Marquis of Dufferin and Ava. London, 1905.

Mackenzie, Alexander, The Life and Speeches of George Brown. Toronto, 1882.

Mackenzie, W. Douglae, John Mackenzie, South African Missionary and Statesman. London, 1902.

Mackintosh, Alexander, Joseph Chamberlain: An Honest Biography. London, 1906-1914.

Marindin, George Eden, Letters of Frederic, Lord Blachford. London, 1896.

Mayeock, Sir Willoughby, With Mr. Chamberlain in the United States and Canada, 1887-1888. London, 1914.

Merivale, Herman, Lectures on Colonization and Colonies. Delivered before the University of Oxford in 1839, 1840, and 1841. London, 1861.

Merritt, J. P., Biography of William Hamilton Merritt. St. Catherine's, Ontario, 1875 .

Mills, Richard Charles, The Colonization of Australia, 1829-1842. London, 1915.

Monypenny, William Flavelle, and Buckle, George Earle, Life of Benjamin Disracti, Earl of Beaconsfiell. London, 1910-1915.

Morgan, Henry J., The Relations of the Industry of Canada with the Mother Country and the United States, being a Speech by Isaac Buchanan, Esq., M.P., December 10, 1863. Montreal, 1864.

Morley, John, Life of Richarl C'obrlen. London, 1881.

Life of IIilliam Euart Giladstone. London, 1903.

Newton, A. P., Stcel-Mraitland, 1. 1)., Sadler, Miehael E., Lucas, Sir Charles. Smith, A. L., Fisher, H. A. I., Kerr, P. H., and Parkin, G. R., The Empire and the Future. London, 1916.

Newton, A. P., The Old and the Neu Empire. London. 1917. 
Newton, Lord, Lord Lyons-A Record of British Diplomacy. London, 1913.

Palgrave, R. H. Inglis, Dictionary of Political Economy. London, 1901-1908.

Parker, Charles Stuart, Sir Robert Peel. London, 1899.

Parkes, Sir Henry, Fifty Years in the Making of Australian History. London, 1892.

Pitman, Frank Wesley, The Development of the British West Indies, 1700-1763. New Haven, 1917.

Poley, Arthur P., The Federal Systems of the United States and the British Empire. London, 1913.

Pope, Joseph, Memoirs of Sir John Alexander Macdonald, First Prime Minister of the Dominion of Canada. Ottawa, 1894.

Porritt, Edward, Evolution of the Dominion of Canada : Its Government and Its Politics. New York, 1918.

Sixty Years of Protection in Canada. London, 1908.

Porritt, Edward and A. G., The Unreformed House of Commons. Cambridge, 1903.

Pratt, Ambrose, David Syme, The Father of Protection in Australia. London, 1908.

Prentice, Archibald, History of the Anti-Corn Law League. London, 1853.

Prothero, Rowland E., English Farming, Past and Present. London, 1917.

Quick, John, and Garran, Robert Randolph, The Annotated Constitution of the Australian Commonwealth. London, 1901.

Reid, Sir George Houston, My Reminiscences. London, 1917.

Richardson, James D., Messages and Papers of the Presidents, 1789-1897. Washington, 1896-1899.

Ridges, Edward Wavell, Constitutional Law of England. London, 1905.

Riddell, William Renwick, The Constitution of Canada in its History and Practical Working. New Haven, 1917.

Roche, W. J., Immigration: Facts and Figures. Ottawa, 1915.

Rogers, James Thorold (editor), Speeches on Questions of Public Policy, by John Bright, M.P. London, 1868.

Russell, John, Earl, Recollections and Suggestions, 1813-1873. London, 1873.

Saintsbury, George, The Earl of Derby. London, 1892.

Sanders, Lloyd C., Lord Melbourne's Papers. London, 1889.

Saunders, E. Mr., Life and Letters of Sir Charles Tupper. London, 1916.

Scrope, G. Poulctt, Memoir of the Life of Charles, Lord Sydenham, G.C.B. With a Narrative of His Administration in Canada. London, 1843.

Seeley, J. R., The Expansion of England. London, 1891.

Seymour, Charles, Electoral Reform in England and Wales. New Haven, 1915.

Shepard, Edward M., Martin Van Buren. Boston, 1899.

Shortt, Adam, and Doughty, Arthur 1). (general editors), Canada and Its Provinces : A History of the Canadian People and Their Institutions. 1914-1917.

Smith, Adam, Wealth of Nations, edited by J. E. Thorold Rogers. Oxford, 1880. Smith, Goldwin, Reminiscences, edited by Aınold Haultain. London, 1910.

Snow, Freeman, Treaties and Topics in American Diplomacy. New York, 1894. Stanmore, Lord, Sidney Ilerbert, Lord Herbert of Lea. London, 1906.

Stanwood, Edward, A History of Presidential Elections. Boston, 1884. 
Statutes of Imperial Parliament and of Colonies now of the Dominions.

Stimson, E. R., History of the Separation of Church and State in Canada. Toronto, 1888.

Taylor, Henry, 1800-1875. Iondon, 1885.

Thomas, Ernest Chester, Leading Cases in Constitutional Law. London, 1876.

Todd, Alpheus, Parliamentary Government in the British Colonies. London, 1894.

Tremenheere, Hugh Seymour, Notes on Public Subjects Made during a Tour in the Lnited States and Canada. London, 1852.

Tupper, Sir Charles, Recollections of Sixty Years. London, 1914.

Trevelyan, George Macaulay, The Life of John Bright. London, 1913.

Turner, Henry Gyles, A History of the Colony of Victoria from its Discovery to its Absorption into the Commonwealth of Australia. London, 1906.

Wade, John, The Black Book of Corruption Unmasked. London, 1835.

Wakefield, Edward Gibbon, A View of the Art of Colonization. With Present Reference to the British Empire: in Letters between a Statesman and a Colonist. London, 1849.

Walpole, Spencer, The Life of Lord John Russell. London, 1891.

Walrond, Theodore, Letters and Journals of James, Earl of Elgin, Governor of Jamaica, Governor General of Canada, Envoy to China, Viceroy of India. With Preface by Arthur Penrhyn Stanley, Dean of Westminster. London, 1872.

Wedgwood, Julia, The Personal Life of Josiah Wedgwood, the Potter. London, 1915 .

Weir, William, Sixty Years in Canada. Montreal, 1903.

Willison, J. S., Sir Wilfrid Laurier and the Liberal Party: A Political History. London, 1903.

Worsfold, W. Basil, The Empire on the Anvil. London, 1916.

Wrong, G. M., Willison, Sir John, Lash, Z. A., and Falconer, R. A., The Federation of Canada, 1867-1917. Toronto, 1917.

\section{ARTICLES IN REVIEWS AND PERIODICALS}

Adams, Gcorge Burton, 'The Influence of the Ameriean Revolution on England's Government of Her Colonies.' Proceedings of American Historical Association, 1896.

Allin, C. D., 'Federal Aspects of Preferential Trade in British Empire.' American Political Science Review (Baltimore), August 1918.

Bigelow, Poultney, 'Britain, Motler of Colonies.' World's Work (New York), November 1917 .

'Erolution of a Colonial Governor, The.' Macmillan's Magazine, November 1903. (irey, Earl, 'How Shall We Rotain the Colcnies?' Ninetcenth C'entury, June 1879.

'Letters of William ('arvie.' 'Transactions of the Royal Society of C'anada. March 1917.

Norton, Lord, 'How Not to Retain the Colonies.' Nineteenth C'entury, July 1879.

Pollock, Sir Frederiek, 'Imperial Organization.' Journal of Society of Compuratize Legislation, New Series, V'I. l'art 2, 1905. 
Porritt, Edward, 'Iron and Steel Bounties in Canada.' Political Science Quarterly (New York), June 1907.

'Canada's National Policy.' Political Science Quarterly (New York), June 1917.

'Canada's National Grain Route.' Political Science Quarterly (New York), September 1918.

Schuyler, Robert Livingston, 'British Imperial Preference and Sir Robert Peel.' Political Science Quarterly (New York), September 1917.

'The Abolition of British Imperial Preference, 1846-1860.' Political Science Quarterly (New York), September 1918.

Taft, William Howard, 'Great Britain's Bread upon the Waters.' National Geographic Magazine (Washington), March 1916.

'Tariffs, Preferential, for British Products.' Industrial Canada (Toronto), January 1919.

Tupper, Sir Charles Hibbert, 'Treaty-making Powers of the Dominions.' Journal of the Society of Comparative Legislation, New Series, XVII, No. 37, 1917. 


\section{APPENDICES}

\section{INTRODUCTORY NOTE}

As an aid to easy referenee, these appendices are grouped into six divisions. These are : (1) the Declaratory Act of 1778, one of the most noteworthy enactments passed at Westminster affecting British eolonies in the one hundred and thirty-cight years from the Declaration of Independence to the beginning of the World War; (2) documents, or extracts from documents, illustrative of the working of the old commercial system in the period from 1783 to 1866 ; (3) documents, or extracts from documents, illustrative of the transition period, 1846 to 1854, from the adoption of free trade as the fiscal policy of the United Kingdom to the negotiation at Washington of the Elgin-Marcy Reciprocity Treaty of 1854-1866, a treaty that was manifestly servieeable in ending, or at any rate allaying, the dissatisfaction and discontent in the British North American provinces that were developed by the new commercial policy of the United Kingdom ; (4) documents, or extracts from documents, illustrative of the spirit and purpose of the Colonial Office propaganda of 1846-1895 for Colonial tariffs in accordance with the principles of free trade; (5) protests at Westminster from 1859 to 1887 against protectionist duties in tariffs of the province of Canada or the Dominion of Canada ; and (6) extra-parliamentary protests in Great Britain, from 1847 to 1887 , against protectionist tariffs in the Canadas or the Dominion of Canada.

In none of the divisions from (2) to (6) has an attempt bcen made to eover the entire field. It would nced a series of volumes, if this were done, especially in the case of the working of the old commercial system, or as regards the Colonial Office propaganda of 1846-1895. In each of these five divisions all that has been attempted has been to select representative or typical documents, or other official or semi-official documents, in order to illustrate (I) the spirit in which the old eommercial system was worked from the Colonial Office or the Board of Trade at Whitchall; (2) the spirit in which the Canadas accepted, or accommodated themselves to, the fiscal revolution in the United Kingdom; (3) the zest with which the Colonial Office and the Board of Trade carried on the propaganda for an empire with a fiseal system based on the prineiple of free trade; and (4) to show the attitude of members of administrations at Whitehall, members of the House of Lords and of the House of Commons, and members of ehambers of commerce and other commercial organizations in England and Scotland toward the increasingly high protectionist tariffs that, in the years from 1858 to 1887, were enacted either at the political capitals of the Canadas--Toronto. Guriber. or Ottawa-or after 1867 at Ottawa, the seat of the Covernment of the Dominion of Canada. 


\title{
THE DECLARATORY ACT OF 1778
}

Anno decimo octavo GeoraII III. c. 12.

\author{
C A P. XII.
}

An act for removing all doubts and apprehensions concerning taxation by the parliament of Great Britain in any of the colonies, provinces, and plantations in North America and the West Indies; and for repealing so much of an act, made in the seventh year of the reign of his present Majesty, as imposes a duty on tea imported from Great Britain into any colony or plantation in America, or relates thereto,

Preamble.

Whereas taxation by the parliament of Great Britain, for the purpose of raising a revenue in his Majesty's colonies, provinces, and plantations, in North America, has been found by experience to occasion great uneasinesses and disorders among his Majesty's faithful subjects, who may nevertheless be disposed to acknowledge the justice of contributing to the common defence of the empire, provided such contribution should be raised under the authority of the general court, or general assembly, of each respective colony, province, or plantation: and whereas, in order as well to remove the said uneasinesses, and to quiet the minds of his Majesty's subjects who may be disposed to return to their allegiance, as to restore the peace and welfare of all his Majesty's dominions, it is expedient to declare that the King and parliament of Great Britain will not impose any duty, tax, or assessment, for the purpose of raising a revenue in any of the colonies, provinces, or plantations: May it please your Majesty that it may be declared and enacted ; and it is hereby declared and enacted by the King's most excellent majesty, by and with the advice and consent of the lords spiritual and temporal, and commons, in this present parliament assembled, and

No tax to be hereafter imposed, by the King and parliament of Great Britain, on any of the colonies in North America or the West Indies : except, etc. by the authority of the same, That, from and after the passing of this act, the King and parliament of Great Britain will not impose any duty, tax, or assessment whatever, payable in any of his Majesty's colonies, provinces, and plantations, in North America or the West Indies ; except only such duties as it may be expedient to impose for the regulation of commerce; the net produce of such duties to be always paid and applied to and for the use of the colony, province, or plantation, in which the same shall be respectively levied, in such manner as other duties collected by the authority of the respective general courts, or general assemblies, of such colonies, provinces, or plantations, are ordinarily paid and applied. 
So much of an act 7 Geo. III. as imposes a duty on tea imported from Great Britain into America, repealed.
II. And be it further enacted by the authority aforesaid, That, from and after the passing of this act, so much of an act, made in the seventh year of his present Majesty's reign, intituled, $A n$ act for granting certain duties in the British colonies and plantations in America; for allowing a drawback of the duties of customs upon the exportation from this kingdom of coffee and cocoa nuts of the produce of the said colonies or plantations; for discontinuing the drawbacks payable on China earthen ware exported to Ameriea ; and for more effectually preventing the clandestine running of goods in the said colonies and plantations; as imposes a duty on tea inported from Great Britain into any colony or plantation in America, or has relation to the said duty, be, and the same is hereby repealed.

\section{DOCUMENTS ILLUSTRATIVE OF THE WORKING OF THE OLD COMMERCIAL SYSTEM IN THE PERIOD 1783-1846}

\section{No. 1. Instructions 'to Colonial Governors}

\section{Extracts from Instructions of September, 1791, to Lord Dorchester, Governor of Lower Canada ${ }^{1}$}

ORDERs and instructions to our right trusty and well-beloved Guy, Lord Dorchester, Knight of the Most Honourable Order of the Bath, our Captain fieneral and Commander in Chief in and over our province of Lower Canada, in pursuance of several laws relating to the trade and navigation of our Kingdom of Great Britain and Ireland and our eolonies and plantations in America. Given at our eourt at St. James's, the 16th day of September 1791, in the thirtyfirst year of our reign.

First. You shall inform yourself of the several laws relating to the plantation trade, and for the encouragement of the trade and navigation of our Kingdom of Great Britain and Ireland, and shall take the oath ordained by law, to do your utmost that all clauses and things contained therein, or which shall be enaeted in any act of Parliament hereafter to be made, relating to our plantation or to the trade and navigation of our said kingdoms be punctually and bona fide observed, according to the true intent and meaning thercof; and, in particular, you are to take especial eare that the several acts of Parliament of Great Britain for allowing the importation and exportation of certain goods, wares, and merchandise into and from our Kingdom of Ireland from and to our plantations in America. in like manner as the same are exported and imported from and into our kingdom 
of Great Britain from the said plantations, be strictly complied with in your government.

8. You shall not assent to any act of Assembly, or allow any usage to prevail within your government, which shall be repugnant to the acts of Parliament hereinbefore mentioned, or to any that may hereafter be made, as far as the same relate to our plantations in America.

14. ... You are to take notice that we consider the good of our plantations, and the improvement of the trade thereof by a strict and punctual observance of the several laws in force concerning the same, to be of so great importance to the benefit of this kingdom, and to the advancing of the revenue of our customs, that, if we shall hereafter be informed that at any time there shall be any failure in the due observance of those laws, and of these present instructions, by any wilful neglect or fault on your part, we shall esteem such neglect to be a breach of the same ; And we think proper to apprize you that it is our fixed and determined will and intention to remove you, or our commander in chief for the time being, from your employments for any such offence, and that we shall strictly levy and inflict as well the fine of one thousand pounds, imposed by an act passed in the seventh and eighth of King William the Third, chap. 22d, as all other fines, forfeitures, pains, and penalties, to which you shall for such offence be liable by any acts of Parliament now in force or otherwise-and that you will further, on the same account, receive the most rigorous marks of our highest displeasure.

\section{Extract from Instructions of August 30, 1840, to Lord Sydenham, Governor General of Canada, 1839-1841 ${ }^{1}$}

20. You are to reserve for the signification of our pleasure thereon every bill which you shall consider to be of an extraordinary or unusual nature, or requiring our especial consideration and decision thereupon, particularly such as may affect the property, credit, or dealings of such of our subjects as are not usually resident within our said province, and whereby duties shall be laid upon the shipping of the United Kingdom of Great Britain and Ireland, or upon the produce or manufacture of Great Britain and Ireland.

1 Canadian Archives, Sessional Papers, No. 18, 1906, p. 118. 
No. 2. Table from Tariff of Nova Sco'sia of 1843 (4 W. IV, c. 1) Showing (1) Imperial Ddties on Foreign Produce ; (2) Colonial Duties on British Produce, and (3) Colonial Duties on Foreign Produce, including the Imperial DuTY

\section{TABLE OF COLONIAL IMPOST DUTIES AND EXEMPTIONS FROM DUTY}

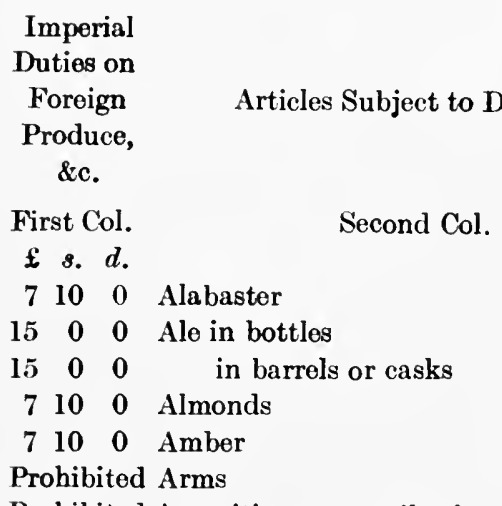

Prohibited Amunition or utensils of war for every $100 l$. of the value

$1500 \quad 0 \quad$ Anchors and Grapnells

$7 \quad 10 \quad 0$ Anchovies

$\begin{array}{llll}7 & 10 & 0 & \text { Aniseed }\end{array}$

$\begin{array}{llll}7 & 10 & 0 & \text { Argol }\end{array}$

Duty free Apples, fresh or dried

for every $£ 100$ of the value for every $100 l$. of the value for every $100 l$. of the value for every $100 l$. of the value for every $100 l$. of the value for every $100 l$. of the value for every $100 l$. of the value for every $100 l$. of the value for every $100 l$. of the value for every $100 l$. of the value the barrel

Colonial Impost Duties.

Duty free Ashes, to wit, Pot or Pearl Ashes, for every $£ 100$ of the val.

0120 Bacon the cwt.

Duty free Baggage and apparel accompanied by the owner, worn and in use, and not made up or brought as merchandize or for sale

Duty free Do., not accompanied by the proprietor, but proved to be as aforesaid

Duty frec Barley unground

$1500 \quad$ Hulled or Pcarl Barley

Duty frec Beans, Kidney or French

$0 \quad 120$ Beef salted of all sorts, the cwt. $\begin{array}{lllllll}0 & 0 & 9 & 0 & 12 & 0\end{array}$

duty free duty free

On British On Foreign Pro

Produce. duce includin

Imperial Duty

Third Col. Fourth Col. $5 \mathrm{t}$

\& $s . d . \quad$ £ s. d. Co

$\begin{array}{llllll}5 & 0 & 0 & 17 & 10 & 0\end{array}$

$\begin{array}{llllll}7 & 10 & 0 & 22 & 10 & 0\end{array}$

$\begin{array}{llllll}5 & 0 & 0 & 20 & 0 & 0\end{array}$

$\begin{array}{llllll}5 & 0 & 0 & 17 & 10 & 0\end{array}$

$\begin{array}{llllll}5 & 0 & 0 & 17 & 10 & 0\end{array}$

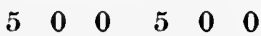

$\begin{array}{llllll}5 & 0 & 0 & 5 & 0 & 0\end{array}$

$\begin{array}{llllll}2 & 10 & 0 & 17 & 10 & 0\end{array}$

$\begin{array}{llllll}5 & 0 & 0 & 17 & 10 & 0\end{array}$

$\begin{array}{llllll}5 & 0 & 0 & 12 & 10 & 0\end{array}$

$\begin{array}{llllll}5 & 0 & 0 & 12 & 10 & 0\end{array}$

$\begin{array}{lllllll}0 & 4 & 0 & 0 & 4 & 0 & \text { fre }\end{array}$

$\begin{array}{llllll}5 & 0 & 0 & 5 & 0 & 0\end{array}$

$\begin{array}{llllll}0 & 6 & 0 & 0 & 12 & 0\end{array}$

duty frec duty free duty free duty free

$\begin{array}{llllll}7 & 10 & 0 & 22 & 10 & 0\end{array}$

duty free duty free

Duty frec

Duty free

Duty free fresh brought by land or inland navigation the fresh, otherwisc brought

Biscuit or Brcad

Fine, called crackers or cakes the cwt. duty free the cwt. duty free $\begin{array}{lllllll}\text { the ewt. } & 0 & 0 & 9 & 0 & 1 & 8\end{array}$

Duty frec Bonnets, see Hats

Prohibited Books, prohibited to be imported into the United Kingdom duty free duty free $\begin{array}{lllllllll}30 & 0 & 0 & \text { not so prohibited for every } f 100 \text { value duty frec } & 30 & 0 & 0\end{array}$ 
1000 Boots, Shoes, and Galoshes not of leather or gum

$710 \quad 0$ Botargo

$710 \quad 0$ Box-wood

Brandy, see Spirits

150000 Bristles

$7 \begin{array}{lll}70 & 0 & \text { Brimstone }\end{array}$

$\begin{array}{llll}15 & 0 & 0 & \text { Bricks, Clinkers, or Tiles }\end{array}$

Duty free Bullion, Gold or Silver

$1500 \quad 0 \quad$ Butter

15000 Burr Stones

$\begin{array}{lll}15 & 0 & 0\end{array}$

1500

1500

$710 \quad 0$

$30 \quad 0 \quad 0$

$30 \quad 0 \quad 0$

Duty free

of iron of tallow

Canvas, see Sail Cloth

\section{Capers}

Cascasoo,

Cards for playing

to be sold, elastic or Indian rubber for every $£ 100$ value

1500 Bottles empty, of earth or stone for every 100l. value

for every $100 l$. of the value

for every $100 l$. of the value

for every $100 l$. of the value

for every $100 l$. of the value

for every $100 l$. of the value

for every $100 l$. of the value

for every $100 l$. of the value

Cables, of hemp or other vegetable substances

for every $100 l$. of the value

for every $100 l$. of the value

Candles of spermaceti or wax, for every $100 l$. of the value $\begin{array}{lllllll}7 & 10 & 0 & 22 & 10 & 0\end{array}$

$5 \quad 0 \quad 0015 \quad 000$

$\begin{array}{llllll}5 & 0 & 0 & 20 & 0 & 0\end{array}$

$\begin{array}{llllll}5 & 0 & 0 & 12 & 10 & 0\end{array}$

$\begin{array}{lllllll}5 & 0 & 0 & 12 & 10 & 0 & \text { free }\end{array}$

$\begin{array}{llllll}5 & 0 & 0 & 20 & 0 & 0\end{array}$

$\begin{array}{lllllll}5 & 0 & 0 & 12 & 10 & 0 & \text { free }\end{array}$

$\begin{array}{llllll}5 & 0 & 0 & 20 & 0 & 0\end{array}$

duty free duty free

$\begin{array}{llllll}5 & 0 & 0 & 20 & 0 & 0\end{array}$

duty free $\quad 15 \quad 0 \quad 00$ free

$\begin{array}{llllll}2 & 10 & 0 & 17 & 10 & 0\end{array}$

$\begin{array}{llllll}2 & 10 & 0 & 17 & 10 & 0\end{array}$ for every 100l. of the value $\quad 5 \quad 0 \quad 0 \quad 20 \quad 0 \quad 0$

of wire, for carding for every $100 l$. of the value

Carriages of travellers not for merchandize or intended

for every $100 l$. of the value $10 \begin{array}{lllllll}10 & 0 & 0 & 17 & 10 & 0 & \text { free }\end{array}$

for every $100 l$. of the value $\quad 5 \quad 0 \quad 0 \quad 12 \quad 10 \quad 0$

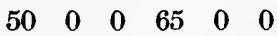

$\begin{array}{llllll}5 & 0 & 0 & 35 & 0 & 0\end{array}$

duty free duty free

No. 3. Table from Tariffs of United Kingdom of 1842 (5 \& 6 Vict., c. 47) Showing Rates of Duties on Imports from Foreign Countries and from British Possessions

TABLE (A)-GOODS, WARES, AND MERCHANDIZE IMPORTED—cont.

Articles.

Class XII.-Cotton, Hair, Linen, Wool, and MaNUfactures thereof-continued.

Linen, or Linen and Cotton-continued.

_- Sails . . . for every $100 l$. value in actual use of a British ship, and fit and necessary for such ship, and not otherwise disposed of . for every $100 l$. value
Rates of Duty.

Of or from Of and from

Foreign British

Countries. Possessions.

£s. d. $\quad$ \& s. $d$.

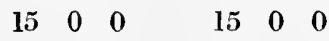

Free. Free.

$\begin{array}{lllllll}15 & 0 & 0 & & 15 & 0 & 0\end{array}$ 


\section{DOCUMENTS ILLUSTRATIVE OF THE WORKING}

- Manufactures of Linen, or of Linen mixed with Cotton or with Wool, not partieu. larly enumerated or otherwise charged with duty . . for every $100 l$. value Thread, not otherwise enumerated or deseribed,

Wool, viz.

for every $100 l$. value $\quad \begin{array}{lllllll}10 & 0 & 0 & 5 & 0 & 0\end{array}$

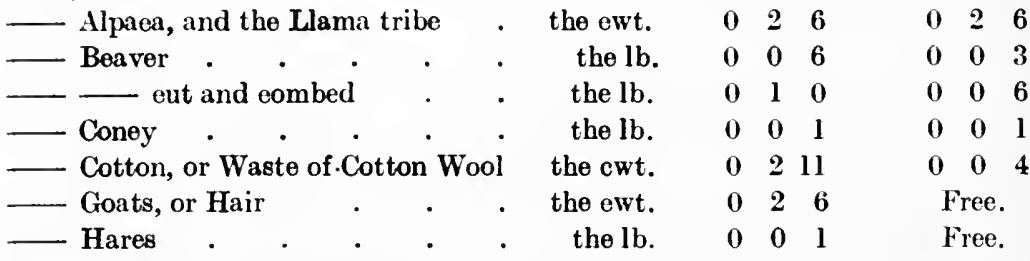

Sheep or Lambs Wool, viz.

- not being of the value of $1 s$. the $\mathrm{lb}$. thereof . . the lb.

— being of the value of $1 s$. the lb., or upwards . . . the lb. $\begin{array}{llllll}0 & 0 & 1 & \text { Free. }\end{array}$

Woollens, riz.

Manufaetures of Wool, not being Goats Wool, or of Wool mixed with Cotton, not partieularly enumerated or deseribed, nor otherwise eharged with duty

for every $100 l$. value

$15 \quad 0 \quad 0$

$5 \quad 0 \quad 0$

Articles of Manufaetures of Wool, not Goats Wool, or of Wool mixed with Cotton, wholly or in part made up, not otherwise eharged with duty for every $100 l$. value

Yarn, raw Linen . . . . the ewt.

\begin{tabular}{|c|c|c|c|c|c|}
\hline $100 l$. value & 20 & 0 & 0 & 10 & 0 \\
\hline the ewt. & 0 & 1 & 0 & 0 & 1 \\
\hline the $l b$. & 0 & 0 & 6 & 0 & 0 \\
\hline the lb. & 0 & 0 & 1 & 0 & 0 \\
\hline
\end{tabular}

\section{No. 4. William Lyon Mackenzie's Memorial of 1832 to Goderich, Secretary of State for the Colonies}

While the eitizens of the United States are enabled to trade freely with the Chinese, Upper Canada and Lower Canada are a monopoly of and for the benefit of the East India Company, and compelled to pay a dear priee for an inferior quality of tea, purchased by the company at an inferior price in the Chinese market, expressly for the use of Canadians and Nova Scotians. History might have taught England the expedieney of adopting another poliey. . . With regard to trade generally, England deelines to give the eolonists a monopoly of her markets for their produce, and she declines to permit them to supply themselves with sueh things as they want from abroad at the eheapest market. At the ports of Liverpool and Glasgow, there is no protective duty in favour of 
a cargo of Canadian flour beyond what is allowed to a cargo of flour from New York, Pennsylvania, Michigan, and Ohio ground on the north bank of the St. Lawrence ; while should the Canadian owner desire to buy tea in China, or foreign goods in the Union (U.S.A.), he finds a prohibition on the former, and heavy protection by British duties against the latter. Americans carefully exclude the people of Canada from the use of their canals, and grain and produce markets by prohibitory duties; while England orders American producewheat, flour, beef, and pork-to be admitted duty free for domestic use and exportation. ${ }^{1}$

\section{No. 5. A Protest in 1834 from the Legislative Assembly of UPPER Canada}

Acts passed by the legislature of Upper Canada in 1833, affecting the banking system of the province, were disallowed in London. In 1834 an address to the Crown, protesting against this disallowance of the acts, was adopted by the House of Assembly-32 in favour to 1 opposed-an address in which it was affirmed that interference in such matters by the Imperial Government was 'inconsistent with those sacred constitutional principles which are essential to a free government'. A larger and more inclusive claim for the provincial legislature-a claim incidentally for larger freedom in legislation affecting trade-was also advanced in the third paragraph of this address to the Crown.

III. We respectfully claim the same rights in behalf of your Majesty's subjects in this province to be consulted in the making of laws for their peace, welfare, and good government which our fellow subjects in Great Britain enjoy in respect to laws to which their obedience is required; and although from the necessity of the case, power must be granted to the head of the Empire of preventing colonial laws being adopted and enforced which are incompatible with treaties between your Majesty's government and foreign states, or with the just rights of any other of your Majesty's colonies, yet within these exceptions, we humbly submit that no laws ought to be, or rightfully can be, dictated to or imposed upon the people of this province, to which they do not freely give their consent through the constitutional medium of representatives chosen by and accountable to themselves....

We, therefore, respectfully and humbly pray your Majesty, taking these matters into your favourable consideration, will be graciously pleased not to disallow these provincial acts, and not to permit your Majesty's ministers to interfere with our internal affairs, but to leave the same entirely to the discretion and control of the legislature of this province. ${ }^{2}$

1 Memoir left by William Lyon Mackenzie with Viscount Godirich (afterwards Earl of Ripon), Colonial Secretary, 1830-1833, on August 27, 1832. Seventh Report of Committee on Grievances, Journals of Legislative Assembly (Upper Canada), Appendix I, No. 21, p. 87.

2 Journals of Legislative Assembly, 1835, Appendix I, No. 21, p. 73. 


\section{DOCUMENTS ILLUSTRATIVE OF THE WORKING}

\section{No. 6. Taxation without Representation-an Upper Canada Protest of 1835}

Laws for the regulation of our trade and commerce are enacted in the Parlia. ment of the United Kingdom, and continually changed and varied without our being consulted for our interest, although the value of our labour and property is unduly affected by this ever-varying system of legislation. In the United States the different sections of the several States are fairly and equally represented, according to their numbers in the body which regulates their commerce and thereby raises or depresses the value of their industry and estates. ${ }^{1}$

\section{No. 7. 'Hasty, Partial, axd IxJurious Legislation in ENGland}

A committee of the Legislative Assembly of Upper Canada, in the session of 1835 , held an inquiry at Toronto into conditions affecting the trade of the province. James Wilson, member for Prince Edward Island, appeared before the committee on February 10.

Question : "What check would you propose on hasty, partial, and injurious lcgislation in England affecting the commerce, and, through it, the general interests and prosperity of this colony ?' Answer: 'I think we should have an agent in England near his Majesty's ministers; and that, should measures be brought forward affecting our trade and interests, he would be enabled to remonstrate against whatever would operate to our disadvantage.'

In answer to a similar question (March 10) C. A. Hagerman, also a member of the legislature, and solicitor-general, said: 'It would in my opinion be of advantage to the province if a person of enlightened and dispassionate judgement, with whom the Secretary of State for the Colonies could hold free communication, were appointed as its agent to reside in London.' 2

\section{No. 8. Power to Exact Tariffs Urged by Legislative Assembly, Upper CaNada, 1839}

- That the local legislature have powcr to originate duties, or reduce them, from time to time, as they may deem necessary and advisable, subject, however, to restrictions similar to those of section 42,31 Geo. III, c. 31, respecting certain local acts.' ${ }^{3}$

The foregoing was one of a series of resolutions adopted by the Legislative Assembly of Upper Canada on March 27, 1839, embodying conditions which the Assembly regarded as necessary to the successful working of the proposed union of Upper and Lower Canada. ${ }^{4}$

1 First Report of Seleet Committee on Trade and Commerce, Legislative Assembly of Upper Canada, 1835, Journals of Legishatize Assembly, 1835, Appendix I, No. 2, p. 2.

2 Seventh Report of Committee on Grievances, Journals of Legislative Assembly (Upper Canada), 1835, Appendix 1, No. 21, p. 21: Second Report on Trade, Ibid., Appendix II.

${ }_{3}$ The Constitutional Aet of 1791 , see. 42, provided that aets of the legislature affeeting religion or granting waste lands should lie on the table of the House of Lords and on the table of the House of Commons for thirty days before reeeiving the assent of the Crown.

- Journals of Legishatice Assembly (Upper Canada), 1839, II. Part 2, p. 792. 


\section{No. 9. Sydenham's Case for Acceding to the Clatm for Larger Powers in Enacting Provincial Tariffs}

In the final session of the legislature of Upper Canada, the session that preceded the union of the provinces in 1841, a claim was advanced by the House of Assembly for larger powers in respect of tariffs. It was embodied in an address to Baron Sydenham, who was Governor-General of Canada from 1839 to 1841, an address which Sydenham discussed in correspondence with Lord John Russell who was Secretary of State for the Colonies from 1839 to 1841.

Sydenham, in a dispatch to the Colonial Office (Montreal, May 26, 1840), assured Russell that he realized that 'Great Britain ought in general to control colonial trade.'

But [he continued] whilst I admit this to its fullest extent, I have been obliged to observe the great inconvenience, and even loss, which results to the colony from the necessity which now exists for all changes in this respect originating in England. There are a vast number of small points seriously affecting the interests of colonial trade, and not at all disturbing to the general principle, or the objects sought to be established by imperial legislation, in which a change is frequently found to be desirable. Great difficulty exists, in the first place, in explaining these points at home, and next in proving that they are of sufficient importance to demand legislation there. But even if this be done, I know myself from experience in that department, ${ }^{1}$ too much difficulty and delay unavoidably arise in carrying such measures through Parliament. I am, therefore, very much disposed in favour of the middle course now suggested by the Assembly. If the local legislature be permitted to originate measures of this description, I entertain no doubt that they would be able to introduce many improvements very beneficial to the trade of the colony, and not at all injurious to imperial interests. These, when sent home, could receive the assent of the Crown and Parliament; whilst if they meddled improperly with matters affecting the general interest of trade, their work would be without effect, and be open to immediate rejection. If your lordship shall concur in this view of the case, and shall be inclined to grant this extension of power to the colony, subject to the restriction I have stated, it would be better perhaps to pass an act specially for this purpose, than to incorporate it in the Union Bill.

Russell replied to Sydenham's dispatch on July 1, 1840, intimating that the claim of the Legislative assembly had been communicated to the lords of com. mittee of Privy Council for Trade ${ }^{2}$ for their lordships' consideration. In another dispatch to Sydenham (March 3, 1841) Russell reverted to the claim of the Legislative Assembly. 'It will,' he wrote, 'be the object of the Queen's Government to free the trade of Canada from restrictions which are unnecessary, and at the same time to do justice to the industry and manufactures of the United Kingdom.' Sydenham was reminded by Russell that to effect the changes he had advocated in his dispatch of May 26, 1840, alterations would be necessary in the instructions to governors which prohibited them from giving the Royal Assent to bills which affected the trade of the United Kingdom. ${ }^{3}$

1 The Board of Trade at Whitehall. Thomson was Vice-President of the Board in 1830 , and President in 1834 .

2 The Board of Trade.

s Journals of Legishative Assembly (Upper Canada), 1842, Appendix II, p. 10. 


\section{DOCUMENTS ILLUSTRATIVE OF THE WORKING}

\section{No. 10. Powers Regarding Trade Withheld from Legisla- ture of Province of Canada by Imperial ACt of 1840 For Union of the Provinces}

In section 43 of the Act of 1840 of Parliament at Westminster for the union of the provinces of Upper and Lower Canada, ${ }^{1}$ the Declaratory Aet of 1778 was referred to. 'And whereas,' eontinucd section 43, 'it is neeessary for the general benefit of the Empire that such power of regulation of eommeree should eontinue to be exercised by her Majesty and the Parliament of the Unitcd Kingdom of Great Britain and Ireland, subject, nevertheless, to the conditions hereinbefore reeited with respect to the application of any duties which may be imposed for that purpose; be it therefore enacted that nothing in this Act contained shall prevent or affeet the execution of any law which hath been, or shall be made, in the Parliament of the said United Kingdom, for establishing regulations and prohibitions, or for the imposing, levying, or collecting duties for the regulation of navigation, or for the regulation of the commerce between the province of Canada and any other part of her Majesty's dominions, or between the said province of Canada, or any other part thereof, and any foreign country or state, or for appointing and direeting the payment of drawbacks of such duties so imposed, or to give to her Majesty any power or authority, by and with the adviee and consent of such Legislative Council and Assembly of the said provinee of Canada, to carry or repeal any such law or laws, or any part thereof, or in any manner to prevent or obstruct the execution thereof : Provided always, that the net produce of all duties which shall be so imposed shall at all times hereafter be applied to, and for the use of, the said province of Canada ; and (except as hereinafter provided) in such manner only as shall be directed by any law or laws which may be made by her Majesty, by and with the advice and consent of the Legislative Council and Assembly of such province.'

\section{No. 11. Attitude of Labouchere, President of Board of Trade, toward Clain of 1840}

'When the colonies were ealled upon to contribute toward these expenses (expenses incurred by the Imperial Government in connexion with the colonies) they had a right to say "You prevent us from raising any income. You oblige us to pay all these heavy cxpenses; and whilst you tax foreign goods so high that they produce very little revenue, you prevent us from taxing your goods. ... An address had been lately submitted to his noble friend, Iord Sydenham, by the last Assembly that had sat in Upper Canada, asking that they might bc left almost to themselves to deal with these questions, liable to have their laws disallowed by either house of Parliament. Although he did not think it advisable to comply with this request of the Asscmbly, yct they ought to consider what changes the colony required, and to comply with them, so far as was con-

$13 \&+$ Vict., c. 35, an Act to re-unite the provinces of Upper and Lower Canada and for the Covernment of Canada. 
sistent with the general interests of the other parts of the Empire. The true principle was that they should place the colonial legislatures under as little restriction as possible. The home government, and the house, should tell them what they absolutely required by way of general regulations, rendering them as little onerous as possible, and then permitting the colonial legislatures to make such other regulations consistently with these, as they might think best for themselves, and which they were sure to do infinitely better for themselves than others could do for them.", 1

\section{No. 12. Lord Stanley's Statement of the Policy of the Peel Administration of 1841-1846, as Embodied in the British Possessions ACt of 1842}

The last of a long series of British possessions acts- -5 \& 6 Vict., c. 49 , an Act to amend the laws for the regulation of trade of the British possessions abroadreceived the Royal Assent on July 16, 1842. Lord Stanley, who was at the Colonial Office from 1841 to 1845 , on July 30,1842 , issued a circular dispatch to governors of West Indian colonies, explaining changes made by the Act, and also explaining the general tariff policy of the Peel Government.

Her Majesty's government having undertaken, soon after their accession to office, the revision of the laws by which the commerce of the United Kingdom is governed, felt it to be their duty to consider, with equal care, the regulations bearing upon the trade of the colonies; and having in view the experience which has now been obtained by the legislation promoted by the late Mr. Huskisson, and some of his successors in office, and being satisfied with its results, their object has been to give fuller effect to the spirit in which that legislation was conceived. They have applied themselves, therefore, to remove restrictions upon colonial industry; to bring the provisions of the imperial law more and more into accordance with the terms of the Declaratory Act of 1778 ; and to afford new practical recognitions of the principle of equality and impartiality in the dealings of the imperial legislature with the colonial possessions of the Crown. The Act now sent to you is the fruit of these endeavours, and I trust that the legisla. tive bodies, and the colonists at large, will find its enactments calculated to be of essential advantage to their commerce and to afford them relief as consumers of imported goods. ... .

On the important article of foreign lumber there is now an entire exemption from duty. The ad valorem duties on foreign glass and silk manufactures are reduced from twenty and thirty per cent. respectively to fifteen per cent. ; those on foreign linen, leather, and paper manufactures, and on clocks and watches from thirty to seven per cent.; those on foreign cotton manufactures, to bacco, and soap from twenty to seven per cent. ; and those on unenumerated articles from fifteen to four per cent.; whilst salt fish of foreign taking or curing, instead of being prohibited, is admitted at a duty of $2 s$. per cwt.... Thus the West Indian colonists will find that the attention of her Majesty's government and Parliament has been devoted not only to the relaxation of restrictions, but also to the removal of such indulgences and exemptions in favour of some colonies as rendered the law unjust in its bearing on others. ...

1 Henry Labouchere, afterwards Baron Taunton, President of Board of Trade, 1839-1841, on Colonial Customs Bill, House of Commons, March 12, 1841. Parliamentary Debates, III, lvii, 154-155. 


\section{DOCUMENTS ILLUSTRATIVE OF THE WORKING}

In particular colonies, the revcnue derived from some of the duties imposed by the Possessions Act, or from duties of similar amount otherwise imposed, may be indispensable as ways and means for carrying on the public services. The degree to which the colonial revenues may or may not be affected by the changes in the imperial law in particular cases must be a matter of uncertainty until determined by experience; and it may be requisite in some instances to provide beforehand for a contingent deficiency, and perhaps to reimpose by local acts a part, or even the whole, of the duties now repealed.

I have, therefore, to request that you will invite the attention of the legislature under your government to the fiscal bearings of the present act, and acquaint them that in thus confining the operation of the imperial law to a narrower gauge, and enlarging the sphere of colonial legislation in matters of commerce, her Majesty's government are assured that the local authorities will bring to that legislation a judgement at once enlightened by local knowledge and guided by a just sense of what is due to public credit, and to the maintenance of a proper provision for the wants of the public service. In inviting the attention of the colonial legislature to this important subject, you will bring under their especial notice the principle involved in the tenth section of the present act, by which you will observe that the duties thereby imposed are differential duties in favour of the produce and manufactures of the United Kingdom and its possessions, and that while the colonial legislatures are left at liberty to fix, subject to her Majesty's approval, such rates of duty as they may think necessary for purposes of revenue, the effect of the section above referred to is to maintain discriminating duties in all cases at least equal to the duties imposed by this act.

\section{No. 13. Discriminating Duties in Colonial Tariff Acts- Lord Stanley's Circular Dispatch of June 28, 1843}

Stanley, Secretary of State for the Colonies, on June 28, 1843, addressed a circular dispatch to governors of her Majesty's colonial possessions. It was as follows :

I have to desire that you will call the attention of the colony under your government to the following statement and suggestions.

The imposition of discriminating duties on goods imported into the British colonies, when the discrimination is made for the protection of some branch of British or colonial industry, is an office of great difficulty. To the right discharge of it an intimate acquaintance with the commercial treaties and political relations between this kingdom and foreign states is indispensable. To legislate on such a subject in ignorance of these treaties and relations would be to render inevitable much serious practical error.

But in the nature of the case it is impossible that this knowledge should be possessed in the requisite degree by the various local legislatures of the colonies of this kingdom. They have no means of knowing the state or the objects of pending negotiations, nor even of ascertaining, with absolute precision, the terms of treaties actually concluded. If they legislate on these subjects, they must do so in ignorance of some facts which cannot be safely excluded from consideration.

Neither is it possible that forty distinct legislatures, having no means of mutual communication and concert, should act consistently with each other on such subjects. The local opinions or interests of each colony must dictate the laws of each; and the gencral code of the Empire, compiled from so many different sources, must be at the utmost variance witl itself

$$
1 \text { Acromets and Papers (Colonial), 1846, xxviii, p. } 105 .
$$


on a subject on which unanimity and consistency is indispensable. In such a state of the law her Majesty's government could not negotiate or treat with confidence with any foreign state for commercial purposes; nor could they fulfil such treaties as might be made. Painful and injurious discussions with those states must arise, and perhaps indemnities and compensations must have to be paid.

For these reasons her Majesty's government decidedly object in principle to the assumption by the local legislatures of the office of imposing differential duties on goods imported into the respective colonies. Parliament having already prescribed the rules by which such duties are to be discriminated, with reference to the place of origin or of export, to Parliament alone the power of altering these rules must be reserved. The single exception to this general rule will occur in any cases in which her Majesty's government may have suggested to any local legislature the enactment of any such discriminating duties. If such cases should arise, the ministers of the Crown would be able to take the necessary measures for obtaining the subsequent sanction of Parliament for such innovation.

You will, therefore, exercise all the legitimate influence of your office to prevent the introduction into the legislature of the colony under your government of any law by which duties may be imposed on goods in reference to their place of production, or to the place from which they may be exported. In the same way, you will exert yourself to prevent the introduction of any law, imposing on refined sugar imported into any colony higher duties in the case of sugar refined in this country in bond from foreign sugar, than in the case of sugar refined here from British colonial sugar.

If, unfortunately, your efforts should be unsuccessful, and if any such law should be presented for your acceptance, your duty will be to withhold your assent from it. From the discharge of this duty, however unpopular, you will not shrink ; for by declining to undertake it, you would only subject her Majesty's government and the colony itself to a still more serious inconvenience.

Her Majesty could not be advised to sanction any colonial law imposing discriminatory duties which her Majesty's government had not previously recommended, or which Parliament had not expressly established, or enacting such duties on any terms which Parliament has not prescribed. The disallowance of any such enactments would, therefore, be inevitable; and that measure would be attended with far more serious inconveniences than any which could result from your own refusal to accept them. I trust, however, that there is no good reason to anticipate or to provide against such a contingency. ${ }^{1}$

\section{No. 14. An Adverse Reply to a Petition for Preferential Treatuent of Canadian Tobacco, July 30, 1845}

One of the last petitions from a colonial legislature for preferential treatment for colonial products in tariffs of the United Kingdom originated with the Legislative Assembly of Canada in 1845. In a petition dated April 10 the Assembly asked for preferential treatment for tobacco grown in Canada. 'As the principle of equalizing the duties on foreign and colonial tobacco has been so recently decided upon in Parliament,' wrote Stanley, from the Colonial Office, on July 30, 1845, to Metcalfe, Governor-General of Canada, ' I have not felt myself at liberty to bring that subject again under the consideration of the legislature.' 2

\footnotetext{
1 Accounts and Papers (Colonies), 1846, xxviii, p. 107. Cf. Grey, Colonial Policy of Lord John Russell's Administration.

2 Journals of the Legislative Assembly (Canada), March 24, 1846.
} 


\section{No. 15. Instances of Colonial Office Control of Colonial Fiscal Legislation}

The legislature of Jamaica, in 1843 , enacted a tariff act ${ }^{1}$ which was objected to by the Colonial Office on the grounds (1) that in certain cases it imposed discriminating duties, and (2) that the duties generally levied under it were excessive. The Earl of Elgin, who was Gorernor at Kingston from 1842 to 1846, wrote a long dispatch (June 23, 1843) to the Colonial Office, in explanation of the changes in the tariff. To this dispatch Stanley replied, on August 31, 1843 :

Her Majesty's government are still of opinion that the high rate of duty established by this act on the importation of salt beef and pork, is objectionable, inasmuch as it is calculated to check the consumption of articles which are in general use amongst the labouring classes, and consequently to limit the trade and injure the dealers in those articles. .. Upon the whole, therefore, her Majesty's government are of opinion that the present high duty should be reduced. But if the Assembly of Jamaica a re unwilling to consent to this reduction, it would be advisable that the duty should be imposed under a distinct aet, which, when sent home for her Majesty's decision, should be accompanied by a statement of the quantities of beef and pork imported into the colony under the proposed high duties, so as to enable her Majesty's government to form an accurate judgement of the effect of them. ${ }^{2}$

In 1843 the Council of Mauritius passed an ordinance ${ }^{3}$ for altering and a mending the colonial laws imposing duties on, or exempting from duties, goods, wares, and merchandise imported into the island of Mauritius. By the ordinance a preference was established for salt provisions from Madagascar. Objection was taken to the ordinance by the Board of Trade. 'Under several of the reciprocity treaties,' reads a minute of the Board of Trade, November 11, 1843, 'the like advantage might be claimed by other countries in respect of the like articles, the produce of such countries, and demands for compensation might result. It appears to my lords that if the circumstances of the labouring classes require the introduction of such commodities at the lowest rate, the exemption should be made general, and without reference to the place of origin or export.' 4

No. 16. Canada Tariff ACt of 1845 Anended at Instance of Colonial Office

The legislature of the provinee of Canada, sometimes described as the United Provinces of Upper and Lower Canada, in the session of 1845 passed an act ${ }^{5}$ imposing provincial duties of customs-an act to which much objection was taken by the Colonial Office. Gladstone, who was Sccretary of State for the Colonies in 1845-1846, embodied the objections to the Tariff Act of 1845 in a dispatch to Metcalfe, Governor-Gencral of Canada, dated February 3, 1846.

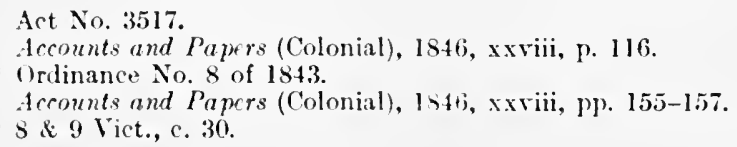


Gladstone urged that the measure involved two principles of great importancethe first directly, and the second virtually. The dispatch continues :

The first principle is the distinction between goods sea borne and goods otherwise imported. On this subject I need simply refer you to what I have stated in regard to the proposal to levy inland countervailing duties upon goods generally.

I also find that in place of the duty of five per cent., which has hitherto been payable upon leather and leather manufactures, imported into Canada, duties have been substituted which appear to range generally from ten per cent. to twenty-five or thirty per cent. ad valorem. In some cases a distinction is taken in favour of the sea borne article ; in others the application is uniform.

Her Majesty's government are not prepared to assent to the imposition on such British goods as are ordinarily sent to Canada from the United Kingdom or from a British possession, of a rate of duty substantially higher than those which are levied under previous provincial customs acts, ${ }^{1}$ although they take no objection to the substitution for duties ad valorem of such fixed amounts as may be considered on the average equivalent to these. Your lordship will consider this as their fixed decision, and will make it known accordingly that an amendment to the act to bring it into conformity with this decision is indispensable.

Her Majesty's government would very reluctantly consent to an increase of the duties on foreign goods, as they stood before the passing of the act under consideration.... It would need strong and special considerations to support these. Whatever influence or persuasion your lordship can exert you will employ for the purpose of recommending an adherence to the commercial principles of my predecessor, set forth in the circular dispatch of June 28, 1843, or at least of moderating the disposition to call for augmentation of differential duties upon foreign productions. ${ }^{2}$

In the next session of the legislature (1846) the Act of 1845 was amended in compliance with the dispatch from the Colonial Office of February $3,1846 .{ }^{3}$

\section{No. 17. Discriminating Duties in the Interest of The St. Lawrence Route, axd Discriminating Duties in General ix Colonial Tariffs}

An address to the Crown urging discriminating duties in the interest of the St. Lawrence route to Upper and Lower Canada, as against the route via New York or Boston or Portland, was adopted by the legislature of the province of Canada in April 1846. To this address, Gladstone, Secretary of State for the Colonies, replicd in a dispatch (February 3, 1846) to Metcalfe, Governor-General :

An important question was brought in the above address under the notice of my predecessor [Stanley] with respect to the imposition of differential duties upon goods brought into Canada otherwise than by sea. The purpose of such duties would avowedly be to offer a premium upon the traffic by way of the St. Lawrence, as compared with the traffic by way of New York and other ports of the United States.

1 Every encouragement would bc given to home manufacturers; and for this purpose the duty upon raw matcrials would be reduced to one per cent. The one per cent. duty was retained merely for statistical purposes.-W. B. Robinson, InspectorGeneral or Minister of Finance, province of Canada, 1844-1845, in moving second reading of Tariff Bill of 1845 . Cf. Mirror of Parliament (Canada), February 18, 1845.

2 Journals of Legislative Assembly (Canada), March 26, 1846, p. 31.

${ }^{3}$ Cf. Statutes of Canada, an Act to alter and anend the laws imposing provincial duties of customs, 9 Vict., c. 1, schedules A and B, assented to May 18, 1846. 
In respect to any proposal having this object, her Majesty's government have to consider, in the first place, whether they shall adopt such a policy, make it their own, and introduce measures into the Imperial Parliament for the purpose of giving effect to it; and in the second, if they are not inclined to such a course, whether they shall still leave it open to the provincial legislature to deal with the question as one of internal rather than imperial concern.

After intimating that the Government-the Peel Administration of 1841-1846would not adopt the first course, Gladstone continued :

Their opinion is that both the St. Lawrence and the route of the United States have their own commercial advantages. The imperial statutes already throw an additional weight, which $I$ hold to be not inconsiderable, into the scale of the former route; and I do not think it would either be advisable in a particular case, or benefit the commercial policy of the British legislature, that it should undertake further to affect the competition between them.

As a consequence of what I have already stated, you will readily infer that I cannot authorize your lordship to recommend the introduction of any measure of the kind with the authority which you possess as the representative of her Majesty.

But, on the other hand, I must give a different reply to the question whether you are to intimate disapproval of such a measure if you should find it to be unequivocally demanded by the general sentiment of the community, and should it be presented to you for legislative sanction.

You are aware that it is a rule of imperial policy generally to reserve to Parliament the consideration of any question of differential or protective duty which may arise in the colonies. Not refusing to make due allowance for subsisting irregularities of practice in this respect, I am desirous in prospective legislation to adhere to this maxim. But I grant that it is more strictly applicable to maritime commerce than to the case of a colony having direct and extended relations along a frontier of many hundred miles with a foreign country. Your lordship is, therefore, authorized to view the question as one to be determined according to the convictions of the people of Canada whatever they may be, when constitutionally brought before you in the form of a legislative measure.

In the preceding part of this dispatch I have had occasion to state the principles upon which her Majesty's government are prepared to act with respect to the imposition in Canada of inland or even of avowedly differential duties.

Your lordship is aware that the general maxim on which such duties are founded docs not command the assent of her Majesty's government. They must be justified, if justified at all, upon the ground of special circumstances. Among the special circumstances bearing upon their merits in the case of Canada the deliberate and wcll-asccrtained inclinations of the people must hold a prominent place. ...

And I must request your lordship carefully to avoid anticipating the advice which her Majesty's government might hereafter tender to the ('rown upon the subject to which this dispatch refers, as it is their intention to reserve an unfettcred discretion in regard to it. ${ }^{1}$

' Journals of Legiskative Assembly (Canada), March 24, J846, pp. 12-13. 


\section{No. 18. Colonial Imporit Duties on Supplies for British Milltiary Forces in Canada}

In the Tariff Act of Canada of $1845^{1}$ no provision was made for the exemption from import duties of supplies for British military forces in the province, although, at this time and for at least twenty years thereafter, the cost of maintaining military forces in British North American provinces was a charge on the taxpayers of the United Kingdom.

In a dispatch dated February 3, 1846, addressed to Metcalfe, the GovernorGeneral, Gladstone called attention to the omission of an exemption clause in favour of the military forces of the Crown. 'I could have wished,' he wrote, 'to find in this act the usual exemption from duty of supplies required for her Majesty's forces. Your lordship will endeavour to procure the adoption of such a provision.' 2

An answer was made by the Legislative Assembly on June 18, 1846, to Gladstone's remonstrance. It was conceded that it was a principle usually observed that 'supplies required for the use of her Majesty's forces ought not to be enhanced in price by means of import duties placed upon them for the advantage of the provincial Treasury.' 'But on the other hand,' continued the answer of the Assembly, 'as it has been found by experience that a direct exemption by an anticipation from customs duty has led to fraud, and threatens in certain cases to neutralize the effect of laws which have been passed by the Provincial Assembly and Legislative Council, and have received the assent of the Crown, such exemption ought not tc be continued.' Drawbacks, instead of exemption, were suggested by the Assembly, which in the last paragraph of its answer insisted that the rule as to relief of military supplies from the burden of import duties 'should not inconveniently interfere with the general structure or operation of the law.' 3

\section{III}

\section{DOCUMENTS OF THE TRANSITION PERIOD, 1846-1854}

\section{No. 1. Colonial Office Intimation to Canada of Approach- ing Change in British Fiscal System-Gladstone's Dispatch of March 3, 1846}

As soon as it was realized in Canada that the corn laws were to be repealed and other changes in the direction of free trade were to be submitted by the Peel administration to Parliament at Westminster in the session of 1846, Lord Cathcart, who was administrator or Governor-General of Canada from November 1843 to January 1847, urged on the Colonial Office the importance to Upper and Lower Canada of the existing preferences in the British tariff for wheat and flour, and also of the preferences for lumber from the Canadas. 'Even if a relaxation

$18 \& 9$ Vict., c. 3.

2 .Journals of Legislative Assembly (Canada), March 26, 1846, p. 31.

3 Journals of Legislative Assembly (Canada), June 18, 1846 p. 54.

1569.29 
of the system of protection to the colonies is to be adopted,' wrote Catbcart. in a dispatch dated Montreal, January 28, 1846, "it is of infinite consequence that it should not be sudden. The ruin that such a proceeding would cause would be incalculable.'

Lord Stanley, afterwards Earl of Derby, who had held the office of Secretary of State for the Colonies in the Peel Administration of 1841-1846, resigned in December 1845, and was succeeded at the Colonial Office by Gladstone. On March 3, 1846, Gladstone wrote a reply to Catheart's dispatch of January 28. It read :

The interests of Canada have occupied the place to whieh they are justly entitled in the deliberations of the House of Commons upon this important subjeet, and upon others that are akin to it. At the same time I need hardly point out to your lordship that there are matters in which considerations immediately connected with the supply of food for the people of this country, and with the employment of its population, must be para mount. Both in respect to corn and in respeet to timber, her Majesty's government have determined to propose and to use whatever influenee they may possess for the purpose of carrying through Parliament the proposal that the alterations about to be made should be gradual, and among the motives which have led them to this determination have been the belief that the delay would be acceptable and would also be advantageous to the people of Canada. . . .

Further, in regard to corn, I have much satisfaction in reflecting that if Canada will have to enter in to competition with the western States of America, and to engage in this rivalry when no longer covered with any protective duty, at least she will not be called upon to make the effort without some advantages on her side. Among them I reckon her light taxation, and the assistance she has received from British credit and funds in the construction and improvement of her internal communications; her more regular and steady course of trade with this country; her low tariff, so favourable to importations, and on that account powerfully tending to encourage her reciprocal commerce outwards ; some advantage in the point of proximity, as compared with the most westerly States of the Union, which are also her formidable rivals in cheapness of produetion ; and lastly, the means of carriage without trans-shipments by the St. Lawrence, which cannot be had by way of the Erie Canal. She will likewise have this in her favour, that her corn trade will have bccome a settled one, of some standing, with all its arrangemen ts made and in full operation, while any regular commerce in that article from the United States must be a new creation, and must go through the process attending its self-adjustment to circumstances yet untried.

And if it be true that New York offers some advantages as compared with Montreal, particularly in regard to the rate of insurance, on the other hand I consider that the shipping of British North America has many advantages over that of the United States in the competition for freights, as it is constructed at far less expense, and is, I must assume, navigated with equal vigor and cqual economy.

It is beyond doubt that Canada has felt a very in vigorating influcnec from the augmented facility of access to the British market, which she has en joyed since the act of 1843 , and that it perceptibly stinulated the extension of her agriculture. But the average prices of wheat during the years ' 43 , '44, and ' 45 have been only $50 \mathrm{~s}$. $10 \mathrm{~d}$., $51 \mathrm{~s} .3 \mathrm{~d}$., and $50 \mathrm{~s}$. $1 \mathrm{~d}$. respectively. Not presuming to anticipate the ruling prices of grain after a perfect frcedom of trade shall have been established, I venture to think they will not exhibit any reduction greatly below the rates I have just cited; and I trust we may look forward to reduction in cost of conveyance from the place of growth to IIon treal. I cannot participate in the apprehensions of those who conceive 
that the measures now under consideration will involve ruin to the trade in Canadian corn.

I now pass to timber. I have much satisfaction in drawing your lordship's attention to the fact that the colonial timber trade prospers under the operation of those changes in the law which were enacted in 1842, and which had taken full effect before the end of 1843. The increased facilities of inland transit in this country, independently of the very good temporary demand in connexion with the construction of the railways that are to effect this great improvement, promise a considerable and permanent extension of the market for foreign wood. . . . The description of wood which is supplied by the British North American colonies, the yellow pine, is not chiefly to be regarded as competing with the wood of the Baltic, but rather as available for different though concurrent uses. For example, the increase of Baltic timber, tending to encourage the construction of new buildings ... gives use for Canadian lumber for insides. Her Majesty's government proposes to retain a duty of $15 \mathrm{~s}$. per load upon foreign lumber, which I apprehend may be considered as on the average nearly covering the difference between the freights from the Baltic and from British North America to the United Kingdom. Not only are they free from apprehension that the proposed remission of $10 s$. per load on foreign timber and 12s. on foreign deals, will cause a contraction of the trade from British North America, but they are sanguine that the trade will nevertheless continue to extend itself.

\section{No. 2. Movements in Canada for the Reten'tion of Prefer- ences in British Tariffs on Canadian Grain and Flour}

The Board of Trade at Montreal, a commercial organization, on February 25, 1846, in a memorial forwarded by Cathcart to the Colonial Office, asked for the admission of wheat from Canada free of the duty of one shilling a quarter which was imposed by the Act of 1846 on all importations of wheat into the United Kingdom. In the memorial, the Board of Trade recalled the Canada Corn Act of $1843,{ }^{1}$ under which wheat and flour from Canada, and also wheat from the United States provided it reached the United Kingdom via Canada, were admitted in to the United Kingdom at a fixed and uniform duty of one shilling a quarter, subject to the condition that the legislature of Canada enacted a law imposing a local duty of three shillings a quarter on foreign wheat imported in to the province.

That as the proposed imperial law [the bill that Peel introduced into the House of Commons at Westminster on January 17, 1846] departs from the principle upon which the provincial law above referred to was founded and neutralizes the favour accorded to Canadian breadstuffs, your petitioners humbly hope that her Majesty's government will be pleased to recommend the repeal of said provincial act; that by the alterations lately proposed in the imperial Parliament the protection on Canadian wheat and flour will be so much diminished that they cannot compete with the United States; that a protection of even one shilling a quarter, small as it may appear, will aid in securing to Canada a share of north-west American trade, to the encouragement of British shipping; that unless some protection be given to produce imported by way of the St. Lawrence, the public works, constructed at a vast expense, and for the completion of which a loan was raised in England, guaranteed by her Majesty's government, instead of bcing a source of revenue, will become a charge to the province. Wherefore your petitioners humbly pray that so much of the Imperial Act $(5 \& 6$ Vict.,

$$
\begin{gathered}
15 \& 6 \text { Vict., c } 49 . \\
\text { F f } 2
\end{gathered}
$$


c. 49) as imposes a duty of two shillings per barrel on foreign flour imported into Canada be repealed, and that grain, flour, and meal from Canada, of whatever origin, be allowed to be imported into the United Kingdom duty free.

Gladstone, writing from the Colonial Office in April 1846, replied to the memorial from the Montreal Board of Trade, in a dispatch addressed to Cathcart. He recalled a dispatch he had written to Cathcart on Mareh 3, 1846, in whieh he had explained the free trade policy of the Peel Government, and had, moreover, sought to show that the new policy would work no harm to the grain and lumber export trade of Canada, and continued :

But as it is necessary $I$ should return a distinct answer to the memorial which is now before me, I have to instruet your lordship to acquaint the memorialists that if Parliament shall adopt the changes in the corn laws of this country which have been submitted to their deliberation, her Majesty's government will regard the local duty of three shillings on corn as an exclusively provincial question; and if the legislature of Canada shall think it expedient to pass an act for the repeal of that duty, her Majesty will not be advised to disallow that act. You will state to the memorialists that, according to the view of her Majesty's government, any proposal to alter the imperial duty on flour imported in to Canada should follow and be dependent on, but should not precede, the abrogation of the three shilling duty on wheat ; that with respect to their application for the free introduction in to this country of grain, flour, and meal, of whatever origin, her Majesty's government regret that they do not think it entirely compatible with the spirit of the commercial treaties between this country and other powers to revive the system which once prevailed of allowing the introduction of goods from colonies at colonial duties with reference not to their origin but solely to their place of export. 1

An address to the Crown, urging a continuance of a tariff preference for Canadian wheat and flour at ports in the United Kingdom was adopted by the Legislative Assembly of Canada on March 26, 1846. The address was proposed by the Inspector-General or Finance Ministcr, W. Caylcy, who twelve years later, in 1858, carried through the House of Assembly the first avowedly protectionist tariff enacted by any British colonial legislature after free trade had been adopted in 1846 as the fiscal policy of the United Kingdom. ${ }^{2}$

The answer to the address of March 26 was transmitted to Cathcart, who served as Administrator, or as Governor-General, from the death of Metcalfe, in November 1845 to the arrival at Montreal, in December 1847, of Elgin. It was written by Gladstone, ${ }^{3}$ and dated April 18,1846 . It reads :

I have received the Queen's commands to instruct your lordship to convey to the Housc of Assembly the assurance of her Majesty's gracious desire and intention to pay every regard to the commercial interests of Canada, even in the consideration of measurcs which must be regarded as mainly and properly appertaining to the internal condition of this country, which may be compatible with justice to other classes of her subjects. . . .

As respects the question immcdiatcly affected by the address, her Majesty's

1 Colonial Office Papers. April 1, 1846.

2 Cf. Journals of Legislative Assembly (Canada), Mareh 26, 1846 ; Globe (Toronto), April 7, 1846.

3 'Mr. Gladstone composed an argumentative despateh on the eommercial relations between Canada and the Mother Country, endeavouring to wean the Canadian Assembly from its economic delusions. It was, in effect, little better than if written in water.' Morley, Life of Gludstone, i, p. 359. 
government are of opinion that the reduction of the duty on Canadian wheat from one shilling to one penny would fail to have the effect which the Assembly have, it is probable, anticipated and desired. Use and convention rather than any abstract principle, have established the rule that in the customs law of this country one shilling per quarter shall be regarded as the standard of a nominal or register duty upon corn. To reduce the charge upon foreign grain to a rate corresponding with this description, her Majesty's government stand pledged to Parliament; and if her Majesty's government were to concede the request which is preferred, the effect would not be the establishment of a minute preference amounting to $11 d$. per quarter in favour of Canadian grain as against the foreign article, but it would without doubt be this - that the same reduction would be applied by Parliament to foreign grain also, and an entire equality between the two would thus be maintained. For this reason, her Majesty's government are of opinion that it would not be expedient to propose to Parliament the alteration which it is the object of the address to recommend. ${ }^{1}$

Quite a series of addresses to the Crown was adopted by the Legislative Assembly, of Canada in 1846 and 1847, all or nearly all of them urging free admission into the United Kingdom of exports from Canada. Earl Grey succeeded Gladstone at the Colonial Office in July 1846 when the Peel Administration of 1841-1846 was succeeded by the Russell Administration of 1846-1851.

Grey, on October 13, 1847, replied to an address of the Legislative Assembly, adopted in the session of 1847, asking the removal of all duties on Canadian produce. In a dispatch to Elgin the Colonial Secretary reminded the GovernorGeneral that butter, cheese, and clover seeds were at that time about the only imports from Canada on which any duties were imposed. These duties were moderate, he added, and all of them were imposed exclusively for revenue purposes. Grey con tinued :

It is material to observe also that as English manufactures are liable to revenue duties in Canada of an amount equal to the duties paid on similar articles imported in to the province from foreign coun tries, the en tire abolition of duties on the importation of Canadian produce into the United Kingdom would, if acceded to on the ground urged by the Assembly, require the necessary repeal of all Canadian duties levied on English produce- a measure which would, I apprehend, occasion serious inconvenience to the provincial treasury, unless the deficiency arising therefrom were met by some other mode of taxation. ${ }^{2}$

\section{No. 3. Manifesto of Free Traders of Montreal, MARCH 1846}

The Earl of Aberdeen, Secretary of State for Foreign Affairs in the Peel Administration of 1841-1846, told Delane, editor of The Times, on December 3, 1845 , that the corn laws were to be repealed. The news was published (as Aberdeen had desired) in The Times of December 4, 1845.3 Peel's speech in the House of Commons, announcing the policy of the Government, was made on January 17 ; and before the end of February 1846 newspapers in Montreal and Toron to were

1 Journals of Legislative Assembly (Canada), May 12, 1846, p. 229.

2 Journals of Legislative Assembly (Canada), March 15, 1848, p. 43.

3 Cf. John Knox Laughton, Memoirs of the Life and Correspondence of Henry Reeve, i, p. 75 ; Greville Memoirs, Part II, pp. 311-315 ; Parker, Sir Robert Peel, iii, p. 324 ; Stanmore, Memoir of Sidney Herbert, Lord Herberl of Lea, i. pp. 49-50. 
in possession of Iondon newspapers eontaining full reports of the speeeh. In Mareh 1846, long before it was known in Canada that the Enabling Aet was to be passed at Westminster, free traders in Montreal, under the leadership of John Young, organized a free trade association, and issued a manifesto to the people of Upper and Lower Canada.

It was urged in this address that under the new eonditions the property of Canada eould be retained only by its trade being rendered free,

allowing industry and eapital to seek out their natural distribution and employment. But apprehensive at the same time that our legislature is not yet prepared to give effeet by law to these liberal views, we have deemed it prudent and expedient to form ourselves in to an assoeiation for the purpose of eolleeting into one body all who agree in opinion with us. United on the basis of free trade, we shall respeetfully but firmly demand in the first place the removal of all imperial aets imposing diseriminatory duties or regulating duties; in the second place the repeal of all duties, imperial and local, levied on American wheat, provisions or corn of any kind whatsoever ; and lastly, we pledge ourselves to resist by every lawful means the future enactment of any proteetive, prohibitive, or merely regulatory duties whatever-believing such to be detrimental to the general interests of soeiety and at variance with sound policy. We further avow that we entertain the opinion that duties should be levied solely for the purpose of creating revenue to provide for the necessities of the government and the extension of internal improvements, and that for these objeets such artieles only should be seleeted for duty as will afford it, without restricting or fettering the general commeree or the carrying trade, or the agrieultural industry of the country. ${ }^{1}$

\section{No. 4. Overtures from Downing Street to Washington for Reciprocity in Trade between The United States and the British North American Provinces}

A seeond address to the Crown was adopted by the Legislative Assembly of Canada on May 12, 1846. It was urged in this address that the Imperial Government endeavour to seeure a reciprocity agreement between the British North American provinees and the United States; also that Canadian produee be admitted duty free at ports of the United Kingdom. 'The expense of transportation,' reads a paragraph in that part of the address that prayed the repeal of all duties on Canadian produee, 'is in itself all the proteetion that our fellow subjeets in the United Kingdom can reasonably expeet as respects the imports of a eolony situated at such a distance from the mother eountry and with the ports closed to eommeree for so large a portion of the year. ${ }^{2}$

We would further remind your Majesty [reads the paragraph in which reciprocity with the United States was urged by the Legislative Assembly] that while, in compliance with the reeommendations of the Imperial Government, we have passed a law repealing all duty on American produce coming through our eountry for exportation, no similar advantage is accorded by the American Government to the people of this province, but that duties amounting in most eases to prohibition are rigorously maintained by that government on every article of ours entering their ports. The disadvantage

1 Globe (Toronto), April 7, 1846.

2 Navigation on the St. Lawrence opens about April 25. Vessels seldom leave Montreal or Quebee at a later date than December 15 . 
we must labour under in this respect is so apparent that we must respectfully request your Majesty will be pleased to cause the necessary steps to be taken for opening a negotiation with the Government of the United States for the admission of our products into their ports on the same terms that theirs are admitted into those of Great Britain and this colony.

In answer to this address Gladstone wrote Cathcart from the Colonial Office on June 3, 1846. He intimated as regards the free admission of Canadian products that the Government could not recede from the position explained in his dispatch of April 18, 1846, and continued :

With respect to that portion of the address which prays her Majesty to invite the Government to establish an equality of trade between the dominion of the Republic and the British North American colonies, I am commanded to instruct your lordship to assure the Assembly that her Majesty will readily cause directions to be given to her minister at Washington to avail himself of the earliest suitable opportunity to press this important subject on the notice of that government; and it will afford her Majesty the most sincere satisfaction if any communication which may hereafter be held for this purpose shall have the effect which is desired by her faithful Commons of Canada.

Her Majesty's government have, as may be known to the Assembly, on several occasions endeavoured to make arrangements with foreign powers for the mutual relaxation of tariffs, and similar attempts have taken place among foreign powers one with another; but almost uniformly with ill success. Whatever arguments may be used to show the great increase of benefits that would accrue on both sides if the United States could have been induced to act simultaneously for the purpose, experience has sufficiently shown the difficulty of effecting these combined operations upon matters which are properly of domestic concern, and has suggested the wisdom of securing the incomplete advantage which depends upon our own free agency alone, rather than foregoing it in the vain endeavour to realize benefits larger indeed but not within our reach.

Should the government of the United States continue to maintain the scale of import duties now in force upon its frontier, her Majesty's government would view with regret a policy injurious to Canada, but they will reflect with satisfaction on the prevalence of laws more fa vourable to commerce on the Canadian side, and will anticipate from those laws both a direct benefit to the people and trade of the province, and the further advantage which a consistent example given by this country, and by its colonies, will, as they believe, not fail to realize in disposing foreign states towards the removal of restrictions on trade. ${ }^{1}$

Aberdeen, in a dispatch dated June 18, 1846, instructed Sir Richard Pakenham, British Minister at Washington (1843-1847), to invite the Government there to "the consideration of the question of establishing an equality of trade between the United States and the British North American colonies.' In June 1846, on the downfall of the Peel Administration, Palmerston succeeded Aberdeen at the Foreign Office; and in December of that year Palmerston sent to Pakenham another dispatch with respect to the overtures for reciprocity. A paragraph in this dispatch reads :

To this important subject her Majesty's government earnestly request the attention of the government of the United States. It seems to her Majesty's government that the measure of relaxation desired by Canada on its own account would be almost, if not quite, as advantageous to the United States as establishing a free and unrestricted commercial intercourse

${ }^{1}$ Journals of Legislative Assembly (Canada), June 18, 1847, pp. 52-53. 
between the two countries, and thereby affording a much more extended demand for the produce of the United States than the Canadas, in their present restricted power of mutual exchange, are enabled to sustain. Without entering into unnecessary details, her Majesty's government would submit that the mutual benefits to be derived from the relaxed commercial intercourse between a country of such vast dimensions as Canada, lying on their extended frontiers, are so obvious, and lie so completely on the surfaee, that they scarcely fail to strike everyone who duly reflects upon the subject.

Pakenham, in a dispatch to Palmerston, dated Washington, May 13, 1847, informed the Foreign Secretary of the action he had taken on his instructions, and of the position in which the movement at Washington for reciprocity stood in May 1847. The Washington dispatch was communicated to the Colonial Office, and made the subject of the following dispatch, June 22, 1847, by Grey, Colonial Secretary, to Elgin, Governor-General of Canada :

In pursuance of the intention communicated to your predecessor [Cathcart] on August 1, 1846, her Majesty's government directed her Majesty's minister at Washington to submit a proposal to the government of the United States for the establishment of an equality of trade between that country and Canada. I regret to state that the measures which have been adopted by her Majesty's representative at Washington have not hitherto been attended with success, owing to circumstances over which the British minister could have no control. But no opportunity will be lost of bringing the subject under the renewed consideration of the government of the United States, with a view of meeting the wishes of the House of Assembly of Canada. ${ }^{1}$

In the session of the legislature of Canada of 1851 an address to the Crown was adopted by the Assembly (May 28, 1851) recalling Pakenham's efforts of 18461847 to seeure a reciprocity agreement with the United States; calling attention to the fact that up to that time nothing had been achieved at Washingtonthat the Government of the United States had shown no inclination to accede to the request of the British Government-and praying the Queen to recommend retaliatory legislation by Parliament at Westminster.

This House [reads the paragraph in the address which urged retaliatory legislation-the penalizing of imports from the United States at ports in the United Kingdom] does not seek for the adoption of any measure the effect of which would be to enhance the cost of the productions of Canada at the cost of the consumer in Great Britain; neither does this House ask for protection. Its only aim is to be placed on an equal footing with the produccr in the United States, and this can only be effected by extending the navigation act to the following productions of the province : grein and foodstuffs, vegetables, fruits, seeds, animals, hides, bone, cheese, tallow, horns, salted and fresh meats, ores of all kinds, which will make it the interest of both the United States and of all other nations to remove any duty at present imposed by them on these articles.

In particular the Queen was petitioned to ' recommend to the Imperial Parliament to enact that a like duty may be henceforth imposed on the productions (herebefore enumerated) of all nations when imported in to Great Britain as such foreign nation may impose on the importation of similar productions of Great Britain and her dependencies.' 2

1 Journals of Legislative Assembly (Canada), July 21, 1847, pp. 173-175.

- Journals of Iegislative Assembly (Canada), May 28,1851, p1. 33-34. 


\section{No. 5. Enabling Act of 1846}

Whereas, by an act passed in the session of Parliament holden in the eighth and ninth years of the reign of her present Majesty, intituled an act to regulate the trade of the British possessions abroad, certain duties of customs set forth in a certain table in the said act contained are imposed upon the importation into any of the British possessions in America, or unto the Island of Mauritius, of the several articles therein mentioned, not being the growth, produce, or manufacture of the United Kingdom, or of the British possessions therein enumerated, and a certain duty of ten pounds for every one hundred pounds of the value thereof is imposed upon the importation thereinto of certain sugars refined in bond in the United Kingdom ; And whereas, by the said act it is enacted that all laws, by-laws, usages or customs which shall be in practice, or endeavoured or pretended to be in force or practice, in any of the British possessions in America which are in any wise repugnant to the said act, or to any act of Parliament made or to be made in the United Kingdom, so far as such act shall relate to and mention the said possessions, are and shall be null and void to all intents and purposes whatsoever; And whereas it is expedient to enable the legislatures or other proper legislative authorities in the said British possessions with the assent of her Majesty in council to reduce or repeal all or any of such duties of customs as aforesaid, so far as the same may be in force in such possessions respectively; Be it therefore enacted by the Queen's most excellent Majesty, by and with the advice of the lords, spiritual and temporal, and commons, in this present Parliament assembled, and by the authority of the same, that if and when the legislature or other proper legislative authority of any of the said British possessions in America, or the Mauritius, make or pass any act or ordinance, acts or ordinances, reducing or repealing all or any part of the said duties of customs so imposed as aforesaid by the said recited act upon any articles imported into such possession, and if her Majesty, by and with the advice of the Privy Council, assent to such act or ordinance, acts or ordinances, such duties of customs, shall, upon the proclamation of such assent in the colony, or at any time thereafter which may be fixed by such act or ordinance, be reduced or repealed in such possession as if such reduction or repeal had been effected by an act or acts of the imperial legislature, anything in any act to the contrary thereof notwithstanding.

And be it enacted, that all such acts and ordinances shall be laid before both houses of Parliament by one of her Majesty's principal Secretaries of State, within thirty days after her Majesty shall have assented thereunto, if Parliament be then sitting, or if not, then within thirty days after the next meeting of Parliament. ${ }^{1}$

19 and 10 Vict., c. 94. An act to enable the legislatures of certain British possessions to reduce or repeal certain duties of customs. The measure received the Royal Assent on August 28, 1846. 


\section{No. 6. Great Britain's Free Trade Policy and its Dangers to the Tie with the Colonies. A Petition to the Queex in 1848 from the Montreal Board of Trade}

The Montreal Board of Trade on December 14, 1848, addressed a petition to the Queen in whieh stress was laid on the danger to the tie between Canada and the United Kingdom resulting from the new fiseal poliey. It was hinted, moreover, that the new poliey of Great Britain might result in the absorption of Canada by the United States. ${ }^{1}$ The petition set forth :

(1) That the abandonment by the mother eountry of her proteetive poliey is produeing important ehanges in the eommereial relations of this eolony, whieh, unless regulated or eounteraeted by wise legislation, may lead in the end to eonsequenees whieh every loyal subjeet would deplore.

(2) That the most prominent of the ehanges referred to is a growing eommereial intereourse with the United States, giving rise to an opinion, which is daily gaining ground on both sides of the boundary line, that the interests of the two eountries, under the changed poliey of the imperial government, are germane to eaeh other, and under that system must sooner or later be politieally interwoven.

It was further represented :

(1) That the result of a total eessation of the differential duty on grain in England will be to make Now York the port of shipment for the great bulk of the produee of Canada, in eonsequenee of the greater eheapness of forwarding it to the markets of England by way of the United States than by the former route of the St. Lawrenee.

(2) That the port whieh is found to be the most eligible for the exports will also be found to be the best suited for the imports of a country, for one reason among many others in this ease, that the inward freight eheapens the outward freight, and vice versa. Aeeordingly, New York must inevitably beeome the port of import for Canada, to the serious injury of the trade of the St. Lawrenee.

The development of these eonditions, it was affirmed, would 'ereate and eement ties of benefieial interest between Canada and the United States, and proportionately weaken the attaehment which the eolony entertains for the mother country.' The address eontinued :

Your petitioners are indeed aware that it has been asserted by a elass of politieal eeonomists that the eolonies are a souree of peeuniary loss to England, and that she might profitably abandon them altogether. But your petitioners have too mueh confidenee in the wisdom of your Majesty's government to suppose that sueh sentiments are shared in by them, or that even were the proposition to be true, they would draw the same preeipitate eonclusion from it. In nations there are interests infinitely transeending those of mere peeuniary gain; and your petitioners would regard the integrity of the British dominions, the preservation of Britain's politieal power and influence, as eheaply purehased by any peeuniary loss the colonies might oeeasion her.

It is with this belief and with the desire to avert the dismemberment of the Empire, so far at least as Canada is eoneerned, that your petitioners

1 The petition was not adopted unanimously by the Board. There was in fact a counter petition, signed by thirteen members of the Board. The first signature to the counter petition was that of John Young, who for many years after the fiscal revolution in Great Britain of 1846-1849 was the most prominent and active adrocate of free trade in Fastern Canada. 
at this time approach your Majesty. They do not seek the restoration of the old system of protection. On the contrary, they have no objection to the utmost freedom of trade, compatible with the safety of the ties subsisting between this country and the mother country. But having respectfully shown how that connexion must be endangered when the measures of Sir Robert Peel take full effect, they will briefly point out those remedial measures which in their opinion would avert the evil and continue to attach this province to England by chains of interest as well as of affection and duty.

The measures to be embodied in legislation by Parliament at Westminster were (1) the repeal of the navigation laws, as they related to Canada, and the throwing open of the navigation of the St. Lawrence, ${ }^{1}$ and (2) the enactment of a moderate fixed duty, say not less than five shillings a quarter, on foreign wheat imported into the United Kingdom, colonial wheat to be admitted free. The petition continued :

In the event of this suggestion being approved by your Majesty's government your petitioners would strongly urge that, if not inconsistent with existing treaties, the exemption from duty of Canadian produce should be extended to all breadstuffs from a Canadian port, whether of Canadian or foreign origin-the effect of which would be to pour the whole trade of Upper Canada, and a vast portion of that of the western States, through the river St. Lawrence, adding immensely to the revenue arising from the public works of the province, and giving a powerful impulse to the prosperity of British North America. Indeed, it is the opinion of your petitioners that the increase of revenue arising from the canals, under the system proposed, would be such as would admit of our legislature materially reducing, if not entirely repealing, the import duties on British manufactures imported into the provinces.

It would be no violation of the new fiscal principles of the English Government, inasmuch as such a duty as that prayed for would be simply a tax for revenue; and your petitioners see no reason why grain should not be moderately taxed as well as any other commodity. Your petitioners are of opinion, from practical observation, that such a duty would not come out of the pocket of the consumer, but out of that of the producer; that it would not, in the general course of things, add to the price of breadstuffs in England, but would reduce the price of breadstuffs in the markets of foreign countries. Such a moderate fixed duty on foreign grain would increase the revenues of the country on the average by about a million sterling; which, as it would not come out of the pocket of the consumer, would be a great national gain, combining a most seasonable relief to the country in its present financial position, with other advantages of perhaps even paramount consideration. A duty of this kind in favour of Canada would preserve the trade of the St. Lawrence, add to the revenue derivable from the provincial canals, diffuse universal satisfaction throughout the colony, and what, in the opinion of your petitioners is all important, would continue to attach Canada to the mother country, thus perpetuating the present connexion and preserving inviolate the British dominions. ${ }^{2}$

1 Vessels of the United States wcre accorded no regular and recognized use of the St. Lawrence as an outlet from the Great Lakes to the sea, until the negotiation of the Elgin-Marcy Treaty in 1854.

2 Correspondence between the Governor-General of Canada and the Secretary of State for the Colonial Department, upon the operation of the navigation laws, 1849, pp. 4-9. 


\section{No. 7. Address of the Annexation Association of Montreal oF 1849}

The reversal of the ancient policy of Great Britain, whereby she withdraws from the colonies their wonted protection in her market, has produced the most disastrous effeets upon Canada. In surveying the actual condition of the eountry, what but ruin or rapid deeay meets the eye? Our provincial government and eivic corporations embarrassed, our banking and other seeurities greatly depreciated, our mercantile and agricultural interests alike unprosperous, real estate scarcely saleable upon any terms, our unrivalled rivers, lakes, and canals almost unused; whilst commerce abandons our shores, the eireulating eapital amassed under a more favourable system is dissipated, with none from any quarter to replaee it.

Thus without available eapital, unable to effeet a loan with foreign states, or with the mother eountry, although offering seeurity greatly superior to that whieh readily obtains money both for the United States and Great Britain, when other than the colonials are the applicants - crippled, therefore, in the full career of private and publie enterprise, this possession of the British Crown, our country stands before the world in humiliating contrast with its immediate neighbours, exhibiting every symptom of a nation fast sinking to deeay.

Among the statesmen of the mother country, among the sagacious obscrvers of the neighbouring Republic, in Canada, and in all British North America, amongst all elasses, there is a strong pervading conviction that a political revolution in this eountry is at hand. Such forebodings cannot really be dispelled; and they have, moreover, a tendency to realize the events to which they point. In the meantime, serious injury results to Canada from the effeet of this anticipation upon the more desirable classes of set tlers, who naturally prefer a country under fixed and permanent forms of government to one in a statc of transition.

Having adverted to some of the causes of our present evils, we would eonsider how far the remedies ordinarily proposed possess sound and rational inducements to justify their adoption.

Six of the proposed remedies were then discussed. Thesc were (1) the removal of protection in the markets of the United Kingdom; (2) the protection of home manufaetures; (3) a federal union of the British North Amcriean provinees; (4) the independence of the British North American provinces as a federal republic ; (5) reciproeal free trade with the United States as respeets the products of the farm, the forest, and the mine ; and (6) annexation to the United States.

The first five of these proposed remedies were dismissed as schemes whieh could not then be realized, or which failed of applieability to the crisis at this time confronting Upper and Lower Canada. Emphasis was laid on the sixth of the proposed remedics.

Of all the remedies that have been suggested for the acknowledged and insufferable ills with which our country is afflicted [continued the address, which was scnt out broadcast from the office of the Annexation Association in Montreal on December 7, 1849], ${ }^{1}$ there remains but one to be eonsidered. It propounds a sweeping and important change in our political and social condition, involving considerations which demand our most serious consideration. This remedy consists of a friendly and peaceful separation from the British conncxion, and a union upon equitable terms with the great North American confederaey of sovereign States.

$$
1 \text { (f. Weir, sirty Years in Canada, p. is. }
$$


We would premise that towards Great Britain we entertain none other than sentiments of kindness and respect. Without her consent we consider that separation is neither practicable nor desirable. But the colonial policy of the parent state, the avowals of her leading statesmen, the public sentiment of the Empire, present unmistakable and significant indications of the appreciation of colonial connexion. That it is the resolve of England to invest us with the attributes, and compel us to assume the burdens of independence is no longer problematical. The threatened withdrawal of her troops from other colonies-the continuation of her military protection to ourselves on condition that we shall defray the attendant expenditurebetokens intentions towards our country against which it is weakness in us not to provide. An overruling conviction then of its necessity, and a high sense of the duty we owe our country, a duty we can neither disregard nor postpone, impel us to entertain the idea of separation; and whatever negotiations may eventuate with Great Britain, a grateful liberality on the part of Canada should mark every proceeding.

The proposed union would render Canada a field for American capital, into which it would enter as freely for the prosecution of public works and private enterprises as into any of the present States. It would equalize the value of real estate upon both sides of the boundary, thereby probably doubling at once the entire present value of property in Canada, whilst, by giving stability to our institutions and introducing prosperity, it would raise our public, corporate, and private credit. It would increase our credit both with the United States and foreign countries, and would not necessarily diminish to any great extent our intercourse with Great Britain, into which our products would, for the most part, enter on the same terms as at present. It would render our rivers and canals the highway for the immigration into and exports from the west, to the incalculable benefit of our country. It would also introduce manufactures into Canada as rapidly as they have been introduced into the northern states; and to Lower Canada especially, where water power and labour are cheap, it would attract manufacturing capital, enhance the value of property and agricultural produce, and give remunerative employment to what is at present a comparatively nonproducing population. Nor would the United States merely furnish capital for our manufactures. They would also supply for them the most extensive market in the world, without the intervention of a customs house officer.

The simple and economical State government, in which direct responsibility to the people is a distinguishing feature, would be substituted for a system at once cumbrous and expensive.

In place of war and alarms of war with a neighbour, there would be peace and amity between this country and the United States. Disagreement between the United States and her chief, if not only, rival among nations would not make the soil of Canada the sanguinary arena for their disputes as under our existing relations must necessarily be the case. That such is the unenviable condition of our state of dependence upon Great Britain is known to the whole world; and how far it may conduce to keep prudent capitalists from making investments in the country, or wealthy settlers from seeking a foredoomed battlefield for the home of themselves and their children, it needs no reasoning on our part to elucidate.

Fellow colonists, we have thus laid before you views and convictions on a momentous question, involving a change which, though contemplated by many of us with varicd feelings and emotions, we all believe to be inevitable, and one which it is our duty to provide for and lawfully to promote. ${ }^{1}$

1 Allin and Jones, Annexation, Preferential Trade and Reciprocity, pp. 106-114 Weir, op. cit., pp. 50-79. 
In recounting the history of the address prior to its wide publication on December 7, 1846, Messrs. Allin and Jones wrote:

A eommittee of six prudent annexationists undertook the task of securing signatures to the document. Their efforts met with immediate success, for in five hours 325 names were obtained, almost without solicitation. Within ten days somewhat over one thousand signaturcs were secured, without much labour on the part of the canvassers. ${ }^{1}$ But the personnel of the signers was even more significant than the number of signatures. On the list were to be found many of the leaders in the political and finaneial life of the city. A stronger and more influential body of men could scareely have been recruited. The banking and the larger industrial and commercial interests were espeeially well represented. Although the great majority of the signers were Conservatives in their political affiliations, the names of a few prominent reformers were included in the list. ${ }^{2}$

At the time of the annexation movement Elgin wrote to Russell :

The disaffeetion now existing in Canada, whatever be the forms with whieh it may clothe itself, is due inainly to commereial eauses. I do not say that there is no discontent on political grounds. Powerful individuals and even classes of men are, I am well aware, dissatisfied with the eonduct of affairs. But I make bold to affirm that so general is the belief that, under the present cireumstances of our commereial condition, the eolonists pay a heavy pecuniary fine for their fidelity to Great Britain, that nothing but the existence to an unwonted degree of politieal eontentment among the masses has prevented the cry for annexation from spreading, like wildfire, through the province. This, as your lordship will pereeive; is a new feature in Canadian politics. The plea of self-intercst, the most powerful weapon perhaps, whieh the friends of British eonnexion have wielded in times past, has not only been wrested from my hands, but transferred since 1846 to those of the adversary. ${ }^{3}$

IV

DOCUMENTS ILLUSTRATING THE SPIRIT AND PURPOSE OF 'THE COLONIAL OFFICE PROPAGANDA FOR COLONIAL TARIFFS IN ACCORDANCE IVITH THE PRINCIPLES OF FREE TRADE, 1846-1:95

\section{No. 1. Grey's Exposition of the New Fiscal Policy of the United Kingdon to Elgin, on his Appointment as Goveryor-General of Canada}

Elgin (James, Earl of Elgin and Kineardine) reccived his instruetions on his appointment as Governor-Gencral of Canada on Oetober 1, 1846. He assumed the government on January 30, 1847. On Decenber 1, 1846, Grey, Colonial Seeretary, addressed to Elgin a long dispateh in regard to the fiscal poliey of the United Kingdom and the colonies.

Your lordship is about to assume the government of British North Ameriea at a time when a change of policy is in progress which is of no ordinary importanee to the interests of every part of the British Empire.

1 The list of signatures to the address, printed in Weir's Sixty Ycars in Canada, extends to sixteen pages $(63-79)$ and eontains 991 names. At pages 50 and 51 in Sixty Years in Canada, there is a list of the officers of the association.

2 Allin and Jones, op. cit., pp. 114-115.

3 Walrond, Letters and Journals of Eiarl of Elgin, pp. 103-104. 
and perhaps of none more than of that large portion of the Queen's dominions in which her Majesty has been pleased to select you as her representative.

I need scarcely say that I refer to those commercial changes which in the last session of Parliament, after long and anxious deliberation, received the sanction of Parliament. By the acts then passed it has been provided that with respect to some of the chief articles of national consumption there should be a considerable immediate reduction, and an eventual abolition of those duties upon imports from foreign countries....

This is not an occasion upon which I could, with propriety, enter into any discussion of the grounds upon which this change of policy has been adopted; but without doing so I may express my firm conviction that eventually the welfare of the colonies, even more than that of the mother country, will be promoted by the abandonment of a system of artificial restrictions upon trade.

Looking to the great natural advantages possessed by the British colonies, and especially by the five provinces of North America, I cannot doubt that adopting a policy of which the object is to render industry productive by leaving it to follow its natural channels of employment, and by affording every possible facility for commerce, must lead to their rapid advancement in wealth and prosperity. But with a view to these results, it is of the utmost importance that the provincial legislatures should strenuously co-operate with the Imperial Parliament. So far as the repeal of the differential duties hitherto imposed upon imports into the colonies from foreign countries for the purpose of favouring the British producer, I can have no doubt that the colonial legislatures will gladly avail themselves of the power conferred upon them ${ }^{1}$ by at once putting an end to these duties. Indeed, so obvious does it appear, that this measure ought to be the consequence of repealing differential duties imposed by this country to favour the importation of colonial produce, that Parliament, instead of enabling the colonial legislatures to a bolish the duties alluded to, would probably have at once proceeded to do so by its own authority, had it not been for the late period of the session at which alone it was possible that the subject should be considered, and the difficulty of determining, without more information than could at that time be procured, how far the simple repeal of those duties, unaccompanied by any precautions, might have affected the finances of some of the colonies.

I assume, therefore, that these duties will be speedily put an end to. But it does not appear to me that this is by any means the whole of what is required in order to give to the commerce of British America all the facilities it ought to enjoy.

At present each of these colonies has its distinct establishment of officers for levying them, the trade between one province and another being burdened by duties like that between countries entirely unconnected with each other. From their geographical position relatively to each other, Canada, New Brunswick, and Nova Scotia being divided only by arbitrary and in some points still unsettled lines of boundary, and Prince Edward Island being separated from them only by a narrow strait, it is obvious that this state of things must be attended with very great inconveniences. . . . The correspondence recorded in this office proves this to be not merely a speculative inconvenience.

To end these conditions Grey strongly urged the desirability of a customs union, and pointed to the German customs union, or Zollverein, as an example that might be followed by the British North American provinces. He continued :

It is true that in many very important particulars the circumstances of the German states, which formed this union, were altogether unlike those of the British North American provinces, and that, therefore, what

\footnotetext{
${ }^{1}$ Enabling Act, 1846.
} 
was done in the one case forms no preeedent for the other. But still, the example of Germany proves that there is no insuperable diffieulty in affecting an arrangement by which not merely different provinees of the same empire, but a large number of independent states may eombine together for the purpose of establishing a eommon system of customs house duties and dividing the revenues which these duties produce. And further, this example also proves that, in spite of no ineonsiderable faults in the mode of effeeting sueh an arrangement, and above all the great one of having adopted a scale of duties far higher than is eonsistent with sound, eommercial, and finaneial views, this union is admitted to have exercised a highly benefieial influenee upon the trade and industry of the states that belong to it.

I do not antieipate that the intelligent inhabitants of British Ameriea will differ from us as to the advantages which would arise from the adoption of such a measure. They will readily pereeive that by moderate duties upon imports thus levied, the revenues required for the publie serviees might be raised at less eost for eolleetion, and with infinitely less of obstruetion to eommercial enterprise than by the existing system ; and I am eonvineed that they will appreeiate the importanee at this particular time of giving sueh a stimulus to industry and to trade....

In what manner this important subjeet should be brought under the eonsideration of the different provineial legislatures, and how it would be expedient to submit to them the question of delegating to some central authority a portion of the eonstitutional powers, I must leave to your lordship's government to determine upon the spot. I may, however, remark that should sueh an authority be ercated, its funetions need not be eonfined to the single subjeet to which $I$ have already referred. ${ }^{1}$

\section{No. 2. Objection by Grex to Increases in Duties on British Manufactures in Canadian Tariff of 1847}

Ironfounders in Glasgow, and merchants, manufacturers, and shipowners at that port, in February 1848 protested in memorials to the Colonial Office ${ }^{2}$ against inereases of duties in the tariff of Canada which was enaeted in 1847-the first Tariff Aet of the legislature of Canada after the Enabling Aet of 1846 had been passed at Westminster.

Grey, Colonial Seeretary, on Mareh 6, 1848, transmitted the seeond of the memorials from Glasgow to Elgin, the Governor-General. In the dispateh which aeeompanied the memorial, Grey wrote:

Her Majesty's government readily aeknowledge the propriety of leaving to the eolonists the task of raising the revenue whieh they may require by sueh methods of taxation as may appear to them most expedient; and in the present ease we disclaim any wish to interfere with their liberty of aetion in this respect for the sake of proteeting the exelusive interests of the British manufacturer. But if, as is alleged by the complaints and as in some instanees would appear to be the case, any duties comprised in the tariff have been imposed not for the purposes of revenue, but with the view of protecting the interests of the Canadian manufacturer, her Majesty's government are clearly of opinion that such a course is injurious alike to the interests of the mother country and of the colony.

('anada possesses natural advantages for the production of articles which will always exchange in the markets of this country for these manufactured goods of which she stands in need. By such exchange she will obtain those

1 Journals of Legishative Assembly (Canada), 1847, VI, Appendix K

2 See Appendices, Division VI, Nos. 1 and 2. 
goods much more cheaply than she could manufacture them for herself; and she will secure an advantageous market for the raw produce which she is best able to raise. On the other hand, by closing her markets against British manufactures, or rendering their introduction more costly, she enhances their price to the consumer, and by the imposition of protective duties for the purpose of fostering an unnatural trade, she gives a wrong direction to capital by withdrawing it from more profitable employment, and causing it to be invested in the manufacture of articles which might be imported at a cost below that of their production in the colony, while at the same time she inflicts a blow on her own export trade by rendering her markets less eligible to the British customer.

You will remind the provincial legislature that the abandonment by this country of her former restrictive system has left the British merchant at liberty to draw his supplies from those markets of the world from [sic] whence he can purchase them most cheaply. If the merchant finds that, by exporting his goods to Canada, they produce him in return a large quantity of corn, and thus yield a greater profit than they would if exported to any other country, he will, of course, give the preference to Canada. But if, by reason of increased import duties, those goods produce a diminished return, the result will be either that the Canadian farmer must submit to a proportionate reduction in the price of his produce or the British manufacturer must resort to another market. It is obvious, therefore, that it is no less the interest of Canada herself than of Great Britain that this tariff of import duties should undergo a complete revision.

\section{No. 3. The Colonial Office and Bounty Legislation in British North American Provinces-1848-1849}

The legislature of New Brunswick in 1848 enacted a bill providing for payment of bounties to encourage the cultivation of hemp. It received the assent of Sir William M. G. Colebrook, the Lieutenant-Governor. Disallowance was possible; and on March 2, 1848, Grey wrote a dispatch in condemnation of the Act, and gave his reasons for not recommending its disallowance. The dispatch was as follows:

The act No. 1755, which grants a bounty on the cultivation of hemp is so objectionable in principle that it is only in consideration of its limited duration and from a desire to obviate the loss and inconvenience which its disallowance would occasion to those who may have already embarked their property in the cultivation of hemp on the promise of such bounties, that her Majesty's government have felt themselves justified in advising the Queen to leave this act in operation. Experience has so fully demonstrated the impolicy of artificially direeting capital and industry into channels which they would not naturally follow, that I must request that you will withhold your assent from any law which may hereafter be passed by the provincial legislature involving a principle of this objectionable and impolitic nature.

At the next session of the legislature at Fredericton, an address to the Crown was adopted (April 12, 1849) praying the Queen to direct that the instructions given to the Lieutenant-Governor by Grey, on March 2, 1848, might be reconsidered. ${ }^{1}$

Grey's dispatch in answer to this address was dated December 11, 1849. It was addressed to Sir Edmund Head, Colebrooke's successor as Lieutenant-

${ }^{1}$ Cf. Journals of House of Assembly (New Brunswick), 1849, pp. 339-340. 1569.29 
Governor, who was informed by Grey that her Majesty's servants had given the fullest consideration to the subject, but had not felt themselves able to advise the Queen to comply with the prayer of the address.

Other paragraphs in Grey's dispatch-a dispatch typical of Grey's many contributions to the Colonial Office propaganda for fiscal systems throughout the Empire based on free trade principles-are as follows :

Parliament has for many years steadily persevered in a course of policy which has had for its object gradually to relieve the commerce of this Empire from restrictions, and to abandon all attempts to direct capital and industry by artificial means into channels which they would not naturally seek. In pursuance of this policy, laws enacting such restrictions and imposing high duties upon imports have been successively repealed, and bounties which were formerly granted to some extent in this country, have been gradually discontinued, until the trade of the Empire may now be said to stand on the footing of being nearly free from such interference.

The benefits which are expected to arise from this policy will be greatly increased through its general adoption by the principle nations of the world, which her Majesty's government hope to see eventually brought about. But it would materially interfere with the attainment of this happy result, if it should be observed by foreign countries, that the former and narrower policy of endeavouring by bounties, or restrictions, to divert capital and industry to other than their natural channels, was again adopted with her Majesty's assent in any part of her dominions.

I cannot therefore alter the instructions given to your predecessor, and thus authorize you to assent, in her Majesty's name, to enactments which would be prejudicial to the interests of the Empire at large.

Her Majesty's government have felt it the more necessary to come to this determination because they are persuaded that measures of the kind thus proposed, injurious as they would be to the Empire for the reasons already assigned, would be peculiarly so to New Brunswick itself. Indeed, one of the grounds assigned by the Assembly, in favour of the policy which they recommend, seems to afford strong reasons against it. They state that in a new colony where capital is scarce, and the resources of the country com. paratively little developed, the granting of bounties may be not only consistent with good policy, but in many instances necessary. But this argument appears to lose sight of the principle, that the scarcer capital may be, the more nccessary it is that it should be applied to the best advantage. The cffect, and indecd the object of bounties is to cause capital to be employed in pursuits, which, without the assistance of such bounties, would not afford sufficient returns to induce individuals to follow them, while it is obvious that no capital can be devoted by any country to new branches of industry unless it be withdrawn from old ones : and, consequently, the effect of the bounty would be to induce individuals to give up some business, naturally remunerative, in order to embark in some other, in which they would have a bounty in addition to the natural and legitimate return. And this bounty would of course be derived from the taxes levied on the general industry of the colony.

I trust that the Asscmbly will on further reflection perceive how little such a result would tend to the real advantage of the province. ${ }^{1}$

1 Journals of Legislative Assembly (Canada), 1856, Appendix, No. 28, pp. 3-5. 


\section{No. 4. Opposition of Colonial Office to Differential} Duties in Canadian Tariff Framed with a View to Reciprocity With the UNited States-December 21, 1848

In the early years of the movement in Canada for a reciprocity agreement with the United States (1846-1850) the expectation was that reciprocal trade would be established by concurrent legislation. In the session of the legislature of Canada in the winter of 1848-1849 a bill to effect reciprocity by this method was pending. This proposed legislation was the subject of a dispatch from Grey to Elgin (December 21, 1848) in which Grey stated the position of the Russell Administration in regard to differentiai duties in tariffs enacted by the legislature of the British North American provinces.

Grey intimated to Elgin that he thought it advisable to communicate to him beforehand the general views of her Majesty's government with regard to the pending bill, as, he added, he had 'recently done to the Lieutenant-Governor of New Brunswick, where an act for this purpose is in contemplation.' Grey continued :

Her Majesty's government are prepared fully to approve and ratify a measure with this general object, should your legislature consider it desirable. But this is on the assumption that it would not be so framed as to establish differential duties in favour of the produce of the United States. I apprehend that the articles to which such intended enactment would apply (judging from the list contained in the bill which failed last session in Congress) are such as would ordinarily be imported into Canada from the United States only, or perhaps from some of the other North American possessions of her Majesty; and the free admission of these articles from the latter has been already provided for by the Canadian Customs Act, 10 \& 11 Vict., c. 31 . But I observe that at least one article in that list (ores of metals) is likewise produced in, and exported, by, Great Britain, and is at the same time subject to a duty of $£ l$ per 100 pounds, under the existing customs law already referred to. This duty, in the event of free importation of ores from the United States, would become a differential duty as against Great Britain, and, as such, would necessarily fall under the general objection to all such duties. In order, therefore, to carry out the object which I assume that your council has in view, without incurring the danger of framing a measure of which her Majesty's government could not consistently with their established policy advise the confirmation, it will be advisable that it should be so worded as to make it clear that, on its taking effect, all the articles to which it relates will be admitted duty free from all countries, whether the produce of the United States or not. ${ }^{1}$

\section{No. 5. Grey's Conception of Fiscal Policy Best Calculated to Promote Development of Canada-August 1, 1851}

At Westminster in the session of 1851 an act was passed reducing the duties at ports in the United Kingdom on lumber from Baltic ports. The Legislative Assembly of Canada, at the time this measure was pending before the Imperial Parliament, adopted an address to the Crown urging that the proposed revision of duties would be detrimental to Canadian trade, and emphasizing the fact that

1 Journals of Legislative Assembly (Canada), 1856, pp. 1-2.

G $g 2$ 


\section{2}

\section{COLONIAL OFFICE PROPAGANDA AND THE}

thirty-five thousand men were employed in the lumber industry on the Ottawa and Saguenay rivers.

' This,' the address continued, ' is of course independent of the many thousand farmers, merchants, and other industrious persons engaged in the supply of necessaries. The wages of these men are calculated at $£ 1,200,000$ per annum, of which a very large proportion is expended in the purchase of British goods. Wo need not point out to your Majesty that the British market is really the only one we have to look to for the export of our great staples, shut out as we are from the ports of the United States by prohibitory wood duties of twenty per cent.' 1

Grey replied to the address on August 1, 1851, as follows :

Her Majesty's servants did not feel themselves justified in abandoning the bill for this purpose which was then before Parliament, and has since passed into a law. This reduction of duty on foreign lumber was proposed with a view to the advantage of the British dominions at large. But while it is obviously calculated to promote this object by reducing the cost in the United Kingdom of the most important materials for the employment of industry, there appear to her Majesty's government no grounds for apprehending that the measure will inflict the injury upon Canada which is antieipated by the provincial legislature. . . .

It is also a consideration, which ought not to be lost sight of by the Provincial Parliament, that in a country possessing sueh great natural resources as Canada, and of which the population and capital are still so inadequate to the full development of these resources, there can be no occasion for endeavouring by artificial regulations to extend the field of employment, and that the permanent prosperity of the province will be best promoted by allowing enterprise and labour to flow in their natural channels, instead of seeking to divert them to branches of trade dependent for their success upon the uncertain and factitious encouragement accorded by protective duties.

You will assure the provincial Parliament that while her Majesty's government take the most lively interest in the welfare and commercial prosperity of Canada, they are for these reasons convinced that a steady adherence to the commercial policy, on which the measure now complained of is founded, will be found to be the best course calculated to promote the interests of the colonies in common with those of the British Empire at large. ${ }^{2}$

\section{No. 6. Opposition in Downing Street to Free Trade be- tween Canada and the West Indian Colonies-Moles- worth's Dispatch of August 15, 1855}

A committee of the Legislative Assembly of Canada-a committee of which Willian Hamilton Merritt was ehairman-opened negotiations in 1855 with governments of British West Indian colonies with a view to the establishment of reeiproeal trade. In July and August 1855 these overtures by the Merritt committee were the subject of interchanges between Head, Governor-General of Canada, and Sir William Molesworth, who in July had sueeeeded Russell as Colonial Seeretary in the Palmerston Administration, and who was at the Colonial Offiee until his death in October 1855. ${ }^{3}$

1 Journals of Legishative Assembly (Canada), May 28, 1851, p. 35.

Journals of Legishative Asembly (Canada), August 27, 1851, p. 333.

3 Cf. J. P. Merritt, Biography of W. H. Merritt, 415-416; Fawcett, Life of Moles. worth, pp. 334-340. 
The mutual abolition of customs duties upon the productions of Canada and of the West Indian colonies was objected to by the Colonial Office. The grounds upon which objection was based were stated in a dispatch from Molesworth to Head, dated August 11, 1855 :

Her Majesty's government would regard the proposed arrangement as very objectionable; on the grounds, first, that it would separate commercially, so far as such an arrangement is concerned, the colonies who entered into it from the rest of the Empire; secondly, that it would be injurious, not only to the interest of consumers in the colonies, who were a party to the arrangement, but to the interests of producers in every other part of the Empire; and, thirdly, that it would be inconsistent with the imperial policy of free trade.

It is the earnest desire of her Majesty's government to maintain and extend a course of policy which shall closely unite together by ties of mutual interest the whole of her Majesty's colonial empire with the mother country. To such a policy any measures tending to form the colonies into separate groups with peculiar and exceptional commercial relations, would be opposed, and her Majesty's government, therefore, trust that they will not be asked to submit for her Majesty's approval, acts or ordinances giving effect to measures of that character. 1

\section{No. 7. Canadian Tariff Act of 1859-Newcastle-Galt Controversy over Duties to Protect Canadian In- DUSTRY}

The resolutions on which the Galt Tariff Bill of 1859 was based were submitted to the Legislative Assembly of Canada on March 17. By March 24 the Bill had passed all its stages in the Assembly and the Legislative Council. On March 26 it received the Royal Assent; and on the same day the GovernorGeneral, Sir Edmund Head, from Government House, Toronto, transmitted a copy of the Bill to Sir Edward Bulwer Lytton, who from June 1858 was Secretary for the Colonies in the Derby Administration of 1858-1859. The GovernorGeneral wrote, in the dispatch of March 26, 1859 :

It is to be regretted that the necessity which exists for meeting the financial engagements of the province, and the depression of last year, have compelled the government to propose rates of duties so high as those imposed by the present act. I am aware of the objections which may be offered to the principle of ad valorem duties; but I must necessarily leave the representatives of the people in Parliament to adopt that mode of raising supplies which they believe to be the most beneficial to their constitucnts. There is nothing in the system adopted which professes to impose differential duties, or fetter the freedom of trade. ${ }^{2}$

In June 1859 the Palmerston Administration of 1859-1863 succeeded the Derby Administration. In the Palmerston Administration the Duke of Newcastle from June 1859 to April 1861 was Secrctary of State for the Colonies. On August 1, 1859, the Chamber of Commerce and manufacturers at Sheffield addressed a long memorial to Newcastle in opposition to the new Canadian tariff. The paragraphs in the Sheffield memorial indicate the spirit which actuated the Chamber in its protest against protectionist duties levied on British exports to British colonies.

\footnotetext{
1 Journals of Legislative Assembly (Canada), 1856, Appendix, No. 28, p. 9.

2 Sessional Papers (Province of Canada), 1860, No. 38, p. 1.
} 


\section{COLONIAL OFFICE PROPAGANDA AND THE}

For proof that we are not mistaken about what the policy of the Canadian government is, we would refer your Grace to the tone of the whole press of Canada ; to the speeches of members of the Canadian Parliament on both sides of the House, and especially to the steady increase of duties levied on Sheffield goods under every successive tariff. It will be sufficient to say on this last point that within eighteen years or less the duty levied on Sheffield goods has been steadily advanced from two and a half per cent. to twenty per cent. [Paragraph No. 2.]

The merchants and manufacturers of Sheffield have no wish to obtain special exception for themselves, and do not complain that they are called upon to pay the same duty as the American or the German. Neither do they claim to have their goods admitted free of duty. All they ask is that the policy of protection to native manufacturers in Canada should be distinctly discountenanced by her Majesty's government as a system condemned by reason and experience, directly contrary to the policy solemnly adopted by the mother country, and calculated to breed disunion and distrust between Great Britain and her colonies. It cannot be regarded as less than indecent and a reproach that, while for fifteen years the government, the greatest statesmen, and the press of this country have been not only advocating but practising the principles of free trade, the government of one of her Majesty's most important colonies should have been advocating monopoly and protection. Under the stimulus of this system, extensive and numerous hardware manufactories have sprung up in Canada both east and west, and the adoption of increasing duties has been the signal for more to be commenced. ${ }^{1}$ [Paragraph No. 6.]

It was at Newcastle's suggestion that the Sheffield Chamber of Commerce drew up its memorial of August 1. He made the suggestion on July 20, 1859, ${ }^{2}$ when the Mayor of Sheffield, the Master Cutler at Sheffield, and a second representative of the Chamber of Commerce, waited on him at the Colonial Office 'to rcpresent the injury anticipated to the trado of this town from the recent advance of import duties of Canada'.

Ncwcastle transmitted a copy of the Sheffield memorial to the GovernorGencral on August 13, 1859. The dispatch from the Colonial Office, which accompanied the memorial, reads:

I request that you will place this rcpresentation in the hands of your Executive Council, and observe to that body that I cannot but feel there is much force in the argument of the Sheffield manufacturers. Practically this heavy duty opcrates differentially in favour of the United States, in consequence of the facility for smuggling, which so long a line of frontier a ffords, and the temptation to embark in it which a duty of twenty per cent. offers. Regarded as a fiscal expedient the measure is impolitic ; for, whilst any increase of contraband trade must be at the expense of the Exchequer, the diminution of foreign importations will probably more than neutralize the additicnal revenue derived from the higher duty.

Whencver the authenticated act of the Canadian Parliament on the subject

1 Sessional Papers (Canada), 1860, No. 38, pp. 2-3.

2 'A deputation from Sheffield and Birmingham has lately had an interview with the IDuke of Newcastle on the subject of the Canadian tariff. The result has been an attempt of the boldest deseription by the Colonial Minister to influenee the legislation of Canada. Let us make it elear that we know that it is by overpurchasing abroad, or sending money out of the country, that we have been ruined. No true friend to Canada's connexion with England eould go for a continuance of the present pecuniary misery in the colony eaused by our overimporting from Sheffield, Birminghatm, Manchester, Leeds, and Glasgow."-Morgan, The Relations of the Industry of Camuda with the Mother Country and the United States, speech by Isaac Buchanan, 1's. 8 i- -58 . 
arrives, I may probably feel that I can take no other course than signify to you the Queen's assent to it, notwithstanding the objections raised against the law in this country. But I consider it my duty, no less to the colony than to the mother country, to express my regret that the experience of England, which has fully proved the injurious effect of the protective system and the advantage of low duties upon manufactures, both as regards trade and revenue, should be lost sight of, and that such an act as the present should have been passed. I much fear the effect of the law will be that the greater part of the new duty will be paid to the Canadian producers by the colonial consumer, whose interests, as it seems to me, have not been sufficiently considered on this occasion. ${ }^{1}$

Galt's reply to Newcastle's dispatch-a reply dated Quebec, October 25, 1859 extends to nine large and closely printed pages in the Canada Sessional Papers of 1860. The larger part of it was devoted to traversing the statements in the Sheffield memorial. Galt's general reply to Newcastle's dispatch is embodied in paragraphs $1,2,3,4,22$, and 23 .

It is to be deeply regretted that his Grace should have given to so great a degree the weight of his sanction to the statements in the memorial, without having previously afforded to the Government of Canada the opportunity of explaining the fiscal policy of the province, and the grounds upon which it rests. The representations upon which his Grace appears to have formed his opinions are those of a provincial town in England, professedly actuated by selfish motives; and it may fairly be claimed for Canada that the deliberate acts of its legislature, representing nearly three millions of people, should not have been condemned by the Imperial Government on such authority until the fullest opportunity of explanation had been afforded. It is believed that nothing in the legislation of Canada warrants the expressions of disapproval which are contained in the dispatch of his Grace, but that on the contrary due regard has been had to the welfare and prosperity of her Majesty's Canadian subjects.

From expressions used by his Grace in reference to the sanction of the provincial customs act, it would appear that he had even entertained the suggestion of its disallowance; and though happily her Majesty has not been so advised, yet the question having been thus raised, and the consequences of such a step, if ever adopted, being of the most serious character, it becomes the duty of the provincial government distinctly to state what they consider to be the position and rights of the Canadian legislature.

Respect to the Imperial Government must always dictate the desire to satisfy them that the policy of this country is neither hastily nor unwisely formed; and that due regard is had to the interests of the mother country as well as of the province. But the Government of Canada, acting for its legislature and people, cannot through those feelings of deference which they owe to the Imperial authorities in any way waive or diminish the right of the people of Canada to decide for themselves both as to the mode and extent to which taxation shall be imposed. The provincial Ministry are at all times ready to afford explanations in regard to the acts of the legisla. ture to which they are party. But, subject to their duty and allegiance to her Majesty, their responsibility in all general questions of policy must be to the provincial Parliament, by whose confidence they administer the affairs of the country; and in the imposition of taxation, it is so plainly necessary that the administration and the people should be in accord, that the former cannot admit responsibility, or require approval, beyond that of the local legislature. Self-government would be utterly annihilated if the views of the Imperial Government were to be preferred to those of the people of Canada. It is therefore the duty of the present government distinctly to affirm the right of the Canadian legislature to adjust the taxation of the

1 Sessional Papers (Canada), 1860, No. 38, pp. 1-2. 
people in the way they deem best, even if it should unfortunately happen to meet the disapproval of the Imperial Ministry. Her Majesty cannot be advised to disallow such acts, unless her advisers are prepared to assume the administration of the affairs of the colony, irrespective of the views of its inhabitants.

The Imperial Government are not responsible for the debts and engagements of Canada. They do not maintain its judicial, educational, or civil service. They contribute nothing to the internal government of the country, and the provincial legislature, acting through a Ministry directly responsible to it, has to make provision for all these wants. They must necessarily claim and exercise the widest latitude as to the nature and extent of the burthens to be placed upon the industry of the people. The provincial government believes that his Grace must have thcir own conviction on this important subject; but as serious evil would have resulted had his Grace taken a different course, it is wiser to prevent future complication by distinctly stating the position that must be maintained by every Canadian adminis. tration. ${ }^{1}$

The fiscal policy of Canada has invariably been governed by considerations of the amount of revenue required. It is no doubt true that a large and influential party exists which advocates a protective policy. But this policy has not been adopted by either the government or legislature, although the necessity for increased taxation, for the purposes of revenue, has to a certain extent compelled action in partial unison with their views, and has caused more attention to be given to the proper adjustment of the duties, so as neither unduly to stimulate nor depress the few branches of manufaeture which exist in Canada.

The increase of taxation is never a popular step; and his Grace might have well believed that no government would adopt it without the strongest conviction that good faith demanded it. It is unpleasant enough to be exposed to attack in Canada for an unavoidable increase of duties. But it is certainly ungenerous to be reproached by England, when the obligations which have caused the bulk of the indebtedncss of Canada have been incurred either in compliance with the former policy of Great Britain, or more rccently assumed to protect from loss those parties in England who had invested their means in our railway and municipal bonds. ${ }^{2}$

At the next session of the legislature, 1860 , when the Assembly wasin committee of ways and means (April 17) Galt recalled his controversy with Newcastle over the Tariff Act of 1859. 'The Colonial Secretary', he said, 'took occasion to express views of a strong character in reference to the measure to which I alludethe tariff-and even went so far as to intimate that under certain circumstances, although he did not absolutcly state that they existed in regard to this measure, the question of the right of the colonial legislature to decide upon its own measures of taxation might come before the Imperial Government, and that her Majesty might possibly be advised to disallow acts of this kind. I will read a part of the answer the Government of this country thought it their duty to make to these remarks.'

Galt then read to the committee paragraphs 2,3 , and 4 of his answcr to Newcastle. 'These, Mr. Chairman,' he continued, 'are the views the Government felt it their duty to lay before the imperial authorities; and I am gratified to be able to add that when these papers are rcad by members of the House it will be found that on the point on which they objected to the tariff they have been

1 Scssional Papers (Canada), 1860, No. 38, pp. 4, 5.

2 Ibid., p. 8. 
obliged to admit that we were in the right, and that any assumed interference with our rights and privileges is not for one moment to be entertained.'

Twenty years after Newcastle declined to recommend the disallowance of the Canadian tariff of 1859 Grey discussed the policy then and later adopted in Downing Street in respect to tariffs of colonial legislatures in which protectionist, differential or retaliatory duties were embodied. He expressed the opinion ' that a great mistake had been made by those who were ministers of the Crown when acts of this kind were passed, in not adhering to the rule that had previously been observed and withholding from them the Royal Assent.' 2

Grey recalled the two reasons advanced to support the policy of non-interference by the Imperial Government ; (1) that by disallowance of these acts the Imperial Government would have interfered with the financial arrangements of the colonies, and prevented them from raising the revenue required for the public service by the most convenient means; and (2) that 'although the great majority of the people of this country may be convinced that the system of protection is utterly unsound and mischievous, and although Parliament now adheres to this system with scarcely a dissenting voice, still we have no right to impose it upon the colonies.' 3

To Grey neither of these reasons was convincing.

Before we accept this conclusion [the conclusion that interference with colonial tariff acts by the Imperial Government was inconsistent with the principle of self-government of the colonies] it will be well to inquire how far it is consistent with the stability of the British Empire. If the colonies and the United Kingdom are to form an empire in the true sense of the word, there must be some one paramount authority invested with sufficient power over all the separate communities that form the empire to insure that on matters which concern them all they shall not follow different and conflicting lines of conduct but shall co-operate with each other.

Every colony enjoying representative institutions may fairly claim the right of taking such measures as it may judge best whenever these affect only its separate interests. But unless all the colonies act in concert and in subordination to the imperial authority in everything that concerns the general interest, they cannot be said to constitute a real empire. But among the subjects which are clearly of common concern to all parts of the Empire-the one which comes next in importance after their joint defence against aggression-is that of their commercial policy. I have already pointed out how seriously the general interest has suffered from the course taken by the colonies in throwing aside the free trade policy of the Empire, and thus encouraging foreign nations in maintaining a system of restrictions which though chiefly injurious to themselves are hurtful to us also. ${ }^{4}$

1 Sessional Papers (Canada), 1863, No. 23, pp. 43-44.

2 Earl Grey, 'How shall We Retain the Colonics,' Nineteenth Century, June 1879, pp. 939-940.

Ibid.

4 Ibid., p. 940. Adderley, in his treatise on the colonial policy of Lord John Russell, published in 1869, contended that a mistake was made when the Tariff Act of 1859 was not disallowed. 'Perhaps,' wrote Adderley, who was an advocate of the concession of responsible government to the colonies now of the dominions, and Under Secretary for the Colonies in 1866, "the tariff bill of Mr. Galt, and the elected Legislative Council, are the two exceptional mistakes made during Head's administra. tion.' Adderley, Colonial Policy of Lord John Russell, p. 39. 


\section{No. 8. Differential Duties in the Tariffs of Australian Colonies-Kimberley's Dispatches of JUly 13, 1871, AND APRIL 19, 1872}

The first long dispatch in which Kimberley, Secretary of State for the Colonies in the Gladstone Administration of 1868-1874, discussed the proposals of colonies in Australasia to enact tariffs in which differential duties were to be embodied, was dated July 13, 1871 .

Four questions were at issue concerning these proposals : (1) whether a precedent existed in the case of the British North American provinces for granting the relaxation of the rule or law which estopped legislatures in colonies in Australia from enacting tariffs with differential duties; (2) whether treaty obligations with any foreign power interfered with such relaxation; (3) whether a general power should bo given to the Australasian governments to make reciprocal tariff arrangements, imposing differential duties, without the consent of the Imperial Government in each particular case ; and (4) whether on grounds of general imperial policy the proposals could be properly adopted. ${ }^{1}$

The policy of the Government in regard to differential duties in colonial tariffs was stated by Kimberley in discussing questions 3 and 4 .

Proceeding to the third question, whether, if the principle of allowing the imposition of differential duties were conceded, the colonies could be permitted to impose such duties without the express sanction of the Imperial Government in each particular case, you will be prepared, by what I have already said, ${ }^{2}$ to learn that I consider it open to serious doubt whether such absolute freedom of action could be safely given.

Her Majesty's government are alone responsible for the due observance of treaty arrangements between foreign countries and the whole Empire, and it would be scarcely possible for the colonial governments to foresee the extent to which the trade of other parts of the Empire might be affected by special tariff agreements between particular colonies.

It must, moreover, be anticipated that these differential agreements, being a vowedly for the supposed benefit of certain classes of the community, would be liable to be affected by temporary political circumstances. The door having been once opened, each producing or manufacturing interest, and cren individuals desirous of promoting any new enterprise, might in turn press for exceptionally favourable treatment under the form of intercolonial reciprocity, while the real grounds for such changes as might be proposed would be intclligible only to those concerned with local politics.

It would appear, therefore, to be by no means clcar that her Majesty's

1 Cf. Corrcspondence with the Australian Colonies with Refercnce to Proposed InterColonial Tariffs, 1872 , p. 3.

2 - The different colonies of Australia are at present, in respect of their customs duties, in the position of separate and independent countries. So long as they remain in that relation, a law which authorized the importation of goods from one colony into another on any other terms than those applicable to the imports from any foreign country, woukl be open, in the view of her Ilajesty's government, to the objection of principle which attaches to differential dutics. But her Majesty's government would not object to the establishment of a complete custroms union between the Australian eolonies, whether embracing two or more contiguous colonies, or (which woukl be preferable) the whole Australian continent, with its adjacent islands. If any negotiations should be set on foot with this object, you are at hiberty to give them your cordial support.'-Circular Dispatch to Governors of Austrahian Colonics, July 15,1870 , loc. cit., 1870, p. 4. 
government could be relieved from the obligation of examining the particulars of each contemplated agreement, however limited; and while it would be very difficult for them to make such an examination in a satisfactory manner, a detailed inquiry of this kind could hardly fail to be irksome to the colonies, and to lead to misunderstandings.

It remains for me, lastly, to ask how far it is expedient, in the interests of each colony concerned, and of the Empire collectively, that the imperial Parliament should be invited to legislate in a direction contrary to the established commercial policy of this country ?

Her Majesty's government are bound to say that the measure proposed by the colonial governments seems to them inconsistent with those principles of free trade which they believe to be alone permanently conducive to commercial prosperity, nor, as far as they are aware, has any attempt been made to show that any great practical benefit is expected to be derived from reciprocal tariff arrangements between the Australasian colonies.

At all events $I$ do not find anywhere among the papers which have reached me those strong representations and illustrations of the utility or necessity of the measure which I think might fairly be expected to be adduced as weighing against its undeniable inconveniences.

It is, indeed, stated in an address before me that the prohibition of differential customs treatment 'operates to the serious prejudice of the various producing interests of the Australian colonies'. I understand this and similar expressions to mean that it is desired to give a special stimulus or premium to the colonial producers and manufacturers, and to afford them the same advantages in a neighbouring colony over the producers and manufacturers of all other parts of the Empire and of foreign countries, as they would have within their own colony under a system of protective duties. What is termed reciprocity is thus, in reality, protection.

It is, of course, unnecessary for me to observe that, whilst her Majesty's government feel bound to take every proper opportunity of urging upon the colonies as well as upon foreign governments, the great advantages which they believe to accrue to every country which adopts a policy of free trade, they have relinquished all interference with the imposition by a colonial legislature of equal duties upon goods from all places, although those duties may really have the effect of protection to the native producer. But a proposition that, in one part of the Empire, commercial privileges should be granted to the inhabitants of certain other parts of the Empire, to the exclusion and prejudice of the rest of her Majesty's subjects, is an altogether different question, and I would earnestly request your government to consider what effect it may have upon the relations between the colonies and this country.

Her Majesty's subjects throughout the Empire, and nowhere more than in Australasia, have manifested, on various occasions of late, their strong desire that the connexion between the colonies and this country should be maintained and strengthened. But it can hardly be doubted that the imposition of differential duties upon British produce and manufactures must have a tendency to weaken that connexion, and to impair the friendly feeling on both sides, which I am confident your government, as much as her Majesty's government, desire to preserve.

I have thought it right to state frankly and unreservedly the views of her Majesty's government on this subject, in order that the colonial governments may be thoroughly aware of the nature and gravity of the points which have to be decided; but I do not wish to be understood to indicate that her Majesty's government have, in the present state of their information, come to any absolute conclusion on the questions which I have discussed. ${ }^{1}$

Much agitation at the political capitals of the Australasian colonies, and much

$$
1 \text { Ibid., pp. 5-6. }
$$


correspondenee between these capitals and the Colonial Office had preceded Kimberley's circular dispatch of July 13,1871. The dispatch provoked much further agitation, and also much more correspondence addressed to the Colonial Office. ${ }^{1}$

Quotations from two of the seventy-odd communieations addressed to the Colonial Offiee during the controversy of 1868-1873, and also quotations from other of these communieations embodied in Kimberley's second dispatch, may be taken as typieal of the spirit in whieh many of the communications were written. They show the attitude of the eolonial governments towards the poliey of the imperial government of withholding from the eolonies now of the Commonwealth of Australia power to enaet tariffs with differential duties.

J. M. Wilson wrote from the Colonial Secretary's office at Hobart, September 11, 1871 :

As far as the colony of Tasmania is concerned, the necessity and utility of the measure are suffieiently obvious. Our eustoms duties are imposed for revenue purposes only. But when our nearest neighbours practieally elose against our produeers and manufaeturers their best and natural market by the comprehensive operation of an intentionally proteetive tariff, we seek relief in reeiproeity conventions, whieh, while they would extend the basis of eommereial operations between us and our neighbours, would in no way prejudiee the interests of European produeers and European manufaeturers, inasmueh as the desired eonvention would, for the most part, 'deal with a limited list of raw materials and produee not imported to these eolonies from Europe.'

Lord Kimbcrley's treatment of this question indicates throughout a natural anxiety to avoid a dceision whieh might scem to eommit her Majesty's government to a departure 'from the established eommereial policy' of the mother eountry. But sinee his lordship assures us that her Majesty's government have not 'eome to any absolute eonelusion on the questions whieh he has diseussed ', we may venture to hope that a firm but respeetful persistenee in the eourse of legislation already adopted by New Zealand, Tasmania, and South Australia, will shortly secure for the Australasian eolonics that freedom from impcrial restrietions on their fiseal relations with eaeh other whieh the eoneiliatory poliey of her Majesty's government has already eoneeded to the colonies of British North Ameriea. ${ }^{2}$

The memorandum from New Zealand on Kimberley's cireular dispateh extends to three and a half pages in the Australian eorrespondenee. It was prepared by Julius Vogel, Treasurer or Finanee Minister of the eolony, and dated Wellington, Deecmber 8, 1871 :

In failing to assert the right to eontrol eolonial tariffs, Great Britain does not take advantage of her power to eonsolidate an immense trade, from which she and her dependeneies might equally benefit. But it must be observed that, if the right were asserted, it would logieally follow that the colonies should enjoy some share, either by representation or eonsultation, in deeiding the poliey by whieh they would be affeeted. Lord Kimberley writes: 'Her Majesty's government are alone responsible for the due observance of treaty arrangements between foreign eountries and the whole Empire; and it would scarcely be possible for the eolonial governments to foresee the extent to whieh the trade of other parts of the Empire might be affeeted by speeial tariff arrangements between partieular eolonies.'

1 Correspondence with the Australian Colonies with Reference to Proposals for InterColonial Tariff Arrangements, $1872((-576)$, is a volume of sixty folio pages.

2 ('orrespondence with the Australian Colonies, 1872, p. 50. 


\section{PRINCIPLES OF FREE TRADE, 1846-1895}

The remark as to the trade of other parts of the Empire might be applied with as much cogency to the actual tariffs fixed by the colonies as to the special arrangements entered into between them. Lord Kimberley, recognizing the difficulty which Great Britain would have in dealing with the matter, points to the want of local knowledge which her Majesty's government would labour under. The same want of information would equally affect the ability to decide the colonial tariffs, unless, in either case, there was available the assistance of colonial representatives. In short, Great Britain must logically do one of two things-either leave the colonies unfettered discretion, or-if she is to regulate tariffs or reciprocal tariff arrangements, or to make treaties affecting the colonies-give to the colonies representation in matters affecting the Empire. In other words, she must apply in some shape to the Empire that federation which as between the colonies themselves her Majesty's ministers constantly recommend. To urge the right of Great. Britain to regulate these matters under present circumstances, is to urge that the interests of the colonies should be dealt with in the absence of the requisite knowledge of their wants and requirements.

Kimberley's circular dispatch in answer to these many communications, also in discussion of a joint memorandum adopted at an intercolonial conference at Melbourne on September 27, 1871, ${ }^{1}$ was dated April 19, 1872. Its concluding paragraphs were :

Her Majesty's government believe that protectionist tariffs and differential duties will do far more to weaken the connexion between the mother country and her colonies than any expressions of opinion in favour of a severance, such as are alluded to in the resolutions of the delegates from three of the Australian colonies.

Whilst, however, her Majesty's government deeply regret that any of the Australasian colonies should be disposed to recur to what they believe to be the mistaken policy of protection, they fully recognize, so far as the action of the imperial government is concerned, the force of the observations made by the Chief Secretary of Victoria in his memorandum of October 7, 1871, 'that no attempt can be more hopeless than to induce free self-governed states to adopt exactly the same opinions on such questions as free trade and protection which the people of England happen to entertain at that precise moment ;' and they are well aware, to use again Mr. Duffy's words, 'that the colonists are naturally impatient of being treated as persons who cannot be entrusted to regulate their own affairs at their own discretion.'

Similarly, Mr. Wilson, chief minister of the Tasmanian government, in

1 We are of opinion that the right of the legislatures of these colonies to direct and control their fiscal policy, as amongst themselves, without interference on the part of her Majesty's ministers in England, is a right which it is our duty to assert and maintain.

We desire that the connexion between the mother country and her offspring in this part of the world should long continue ; and we emphatically repudiate all sympathy with the views of those who, in the Imperial Parliament and elsewhere, have expressed a wish that the bonds which unite us should be severed.

As members of the British Empire, the relations of which with other countries are conducted by the Imperial Government, we deny that any treaty can be properly or constitutionally made which directly or indirectly treats these colonies as foreign communities.

With the internal arrangement of the Empire, whether in its central or more remote localities, foreign countries can have no pretence to interfere, and stipulations respecting the trade of one part of the Empire with another, whether by land or sea, are not stipulations which foreign governments ought to be allowed to become parties to in any way.-Joint memorandum adopted at Intercolonial Conference at Melbourne, September 27, 1871, attended by delegates from New South Wales, Tasmania, and South Australja, Correspondence with the Australian Colonies, 1872, p. 15. 
his memorandum of September 11, 1871, observes that 'it is only on an abstract theory of the superior advantages of a free trade poliey that the Seeretary of State objects to a proposal which seems to sanetion proteetion, under the name of reeiproeity. These are views', he goes on to state, 'which ean find no aceeptance with colonial legislatures, under a system of eonstitutional government.' It is obvious that a prolonged controversy on a subjeet on which the opinions entertained on either side are, unfortunately, so entirely at variance, would not tend to promote the principles of free trade, opposition to which would become identified in the minds of the colonists with the assertion of their rights of self-government, and that it eould scarcely fail to impair those relations of cordial and intimate friendship whieh both the imperial and the colonial governments are equally desirons to maintain.

But although for these reasons her Majesty's government might not foel justified in refusing to allow the colonists to adopt the policy which they think best for their own interests, they desire to point out that, in order to meet the views of the colonial governments as expressed in the papers now before me, it would be necessary not only to repeal so much of the Australian Colonies Government Act, $13 \& 14$ Vict., e. 59, as prevents the imposition of differential duties, but to exempt the eolonies in questicn from the operation of any future commercial treaties whieh may be eoncluded by this country, containing stipulations against such duties, leaving them at liberty, subjeet to the obligations of existing treaties, to make such arrangements, as they may think fit, for reciprocity with each other, or with foreign nations; and before so serious a step is taken, they would ask the cclonists gravely to eonsider the probable cffects of a measure which might tend matcrially to affect the relations of the colonies to this eountry and to the rest of the Empire. In the meantime they have thought it right not to proceed in this matter until the Australasian governments concerned have had an opportunity of communicating any further observations which they may desire to make in explanation of their views. 1

\section{No. 9. Nearing the End of the Colonial Office Propaganda -Ripon's Circular Dispatch of June 28, 1895}

One of the last, if not actually the last, of the many dispatches issued from the Colonial Office as part of the propaganda of 1846-1895 was written by the Marquis of Ripon, Colonial Seeretary in the Gladstone-Rosebery Administration of 1892-1895. It was dated June 28, 1895. It was written in respect of a resolution, adopted at the Colonial Conference at Ottawa in 1894, urging a 'customs arrangement between Great Britain and her colonies by which trade within the Empire may be placed on a more favourable footing than that which is carried on with foreign countries.' 2

Ripon's dispatch was, in part, as follows:

It was generally recognizcd at the conference that this policy involves a complcte reversal of the fiscal and commercial system which was delibcrately adopted by Great Britain half a century ago, and which has been maintained and extended ever since. By a consistent adherence to this system, one duty after another has been swept away in this country, until, at the present day, the few import duties remaining are retained, cither for rcvenue purposes alone, on articles not produced herc, or in order to protect the excise revenue.

1 Correspondence with the Australian Colonies, 1872, p. 10.

2 Ottawa Conference, 1894, Dispatches from the Secretary of State for the Colonies on Questions of Trade and Commercial Treaties (1895), p. 3. 
A differential duty is open to all the objections from the customers' point of view which can be urged against a general duty; and while it renders necessary the same restrictions on trade; it has the additional disadvantage of dislocating trade by the tendency to divert it from its regular and natural channels.

These general objections to the policy advocated are sufficiently serious, and there are others, no less serious, which flow from the existing condition under which the trade of the Empire is distributed. ${ }^{1}$

\section{$\mathrm{V}$}

\section{PROTESTS AT WESTMINSTER AGAINST PROTECTIONIST DUTIES IN CANADIAN TARIFFS, 1859-1887}

\section{No. 1. Comparison of Fiscal Freedom of Colonies of the Old aNd New Era-Gladstone's Observations in 1859}

Gladstone appeared before a select committee of the House of Commons on colonial military expenditures that was in session in 1855-1860. He was asked if the old colonies-colonies of the period that ended in 1783-were not more independent than the colonies of the later period. ' On the contrary,' Gladstone answered, 'it would undoubtedly not have been permitted to those colonies to exercise any power to legislate adversely to the mother country, whereas we have recent experience in Canada that even that power may be exercised by our present colonies, with a view of raising up a protected interest against the commerce of the mother country.' ${ }^{2}$

\section{No. 2. A Question in the House of Commons in 1864}

In the House of Commons at Westminster, April 28, 1864, R. Sinclair Aytoun, Liberal member for the Kirkaldy boroughs, asked Cardwell, Secretary of State for the Colonies in the Palmerston Administration of 1859-1865, for a return of the number of people employed in manufacturing in Canada, such descriptions of goods as were charged with duty on entering Canada. Aytoun further asked ' if any efforts have at any time been made to induce the Canadian Government to remove the duties charged upon British goods entering Canada.' Cardwell undertook to lay on the table of the house the correspondence with regard to Canadian tariffs. He could, he assured Aytoun, give no other information. ${ }^{3}$

\section{No. 3. Canadian Duties Higher than American and French Protectionist Duties-A Comflaint by Bright in 1865}

We complain that Canada levies higher duties on British manufactures than the United States did before the present war [Civil War, 1861-1865], and much higher than France does. But when we complain to Canada of this, and say that it is very unpleasant usage from a part of our Empire, the Canadians reply

1 Ibid., p. 4.

2 Report of Committee on Colonial Military Expenditure, and on the Defence of the British Dependencies, and the Proportions of Cost of such Defence defrayed from Imperial and Colonial Funds Respectively: Evidence, Appendix, and Index, 1861 ; cf. Bruce, Broadstone of Empire, i, p. 140.

${ }^{3}$ Cf. Parliamentary Debates, III. clxxiv 1770-1771. 
that their expenditure is so much, and their debt with interest on it so much, that they are obliged to levy these heavy duties. . . . I believe if Canada now, by a friendly separation from this country, became an independent state, choosing its own form of government-monarchical, if it liked, or republican, if it preferred a republic-it would not be less friendly to England, and its tariff would not be more adverse to our manufacturers than it is now. ${ }^{1}$

\section{No. 4. Questions in the House of Commons Respecting the National Policy Tariff of Canada of 1879-Ex- position of Position of Canadian Government, BY Hicks-Beach, Secretary of State for the Colonies}

The national policy tariff of the Dominion of Canada of 1879 was submitted to the House of Commons, at Ottawa, by Tilley, Minister of Finance, on March 14. On March 11 a summary of the changes made by the Bill had been cabled from Ottawa to the Colonial Office. The Governor-General, the Marquis of Lorne, gave the Royal Assent to the Bill on May 15, 1879.2

In the House of Commons at Westminster on March 20, 1879, a question regarding the new tariff was addressed by Bright to Sir Michael Hicks-Beach (afterwards Viscount St. Aldwyn), Colonial Secretary in the Conservative Administration of 1874-1880. Bright asked the Colonial Secretary if he could lay on the table a copy of the new tariff now before the Canadian Parliament, if any communication had taken place between her Majesty's government and the GovernorGeneral of Canada on the subject of the proposed increased customs and protective duties in Canada; whether it is proposed to represent to the Canadian Government the impolicy of a war of tariffs between different portions of the Empire; and whether it was true that the instructions to Lord Lorne ${ }^{3}$ omitted, for the first time, the clause requiring that Bills imposing differential duties should be reserved for Her Majesty's approval.

Sir Michael Hicks-Beach, in reply to Bright's questions, intimated that he had received a summary of the new tariff on March 11, and that he had cabled to Ottawa, stating that 'Her Majesty's government regretted to observe that the general effect of the tariff was to increase duties, already high; but deemed that the fiscal policy of Canada rested, subject to treaty obligations, with the Dominion legislature.' The Colonial Secretary continued :

The Canadian Government fully understands the fiscal policy of this country ; and I may add that I beliere, though I could not positively say so at present until I lave seen the actual tariff itself, that there is nothing in the prescnt proposals which has not been previously sanctioned, at least in principle, by Canadian legislation. As the result of much correspondence betwcen my predecessor [Earl of Carnarvon, Colonial Secretary, February 1874 to January 1878] and the Dominion Government [the Liberal Ad. ministration at Ottawa of 1873-1878], the instructions to be issued to Lord Dufferin's [Governor-Gencral at Ottawa, 1872-1878] successor werc thoroughly revised; and in that revision the clause specifying ccrtain

1 John Bright, in debate on Canadian fortifieations, House of Commons, Mareh 23, 1865. Speeches on Public Questions by John Bright, M.P., pp. 152, 153.

242 Vict., c. 15, an Aet to alter the duties of customs and exeise.

3 Appointed (iovernor-General, October 5, 1878. 


\section{PROTECTIONIST DUTIES IN CANADA, 1859-1887 465}

classes of bills-among them every bill imposing differential duties-as those which should be reserved for Her Majesty's approval were omitted. This was done without any reference to a protectionist policy, the Dominion Government, as the right honourable gentleman is aware, then being free traders. The alteration of the instructions, however, in no way interferes with the power of reservation and of disallowance, these powers being fully set out in the British North American Act of 1867.1

The reply of Lord Lorne, Governor-General, on March 19, 1879, to the dispatch from the Colonial Office contained the following statement:

I have the honour to state that the present government [the Macdonald Administration of 1878-1891] were returned by a large majority [Conservatives 137, Liberals 69] in September 1878. A protective tariff, in order to encourage the industries of the Dominion, was advocated by the leaders of the then opposition; and the government they have since formed [October 17, 1878] do not desire to avail themselves of direct taxation. They also desire to point to the very hostile action of the American Government toward the Dominion of Canada in all matters relating to the tariff; and to the fact that the manufacturers of the United States have established combinations, under such perfect organization, that should any special industry arise in Canada, the Canadian market is at once flooded with a corresponding article of American produce, sold below value, the effect of such combination being equal to that which is produced by a government bounty. ${ }^{2}$

In the same parliamentary paper there was included a memorandum to the Colonial Office, prepared as an answer to the Hicks-Beach Dispatch by Tilley, Minister of Finance, who wrote :

Fostering and promoting Canadian industries, and especially manufactures, will not lessen the necessity for large imports of various commodities which are now largely supplied to Canada by Great Britain. But if the result should prove the means of restoring prosperity, the effect upon British mercantile and manufacturing interests must be most favourable.

\section{No. 5. Protests against the Tariff of the Dominion of Canada of 1887-Extracts from Speeches of Granville, Onslow, and Carnarvon}

Sir Charles Tupper was Minister of Finance at Ottawa at the time of the revision of the tariff in 1887. The new tariff was submitted to the House of Commons of the Dominion Parliament on May 12. At this revision there were large increases in the duties on iron, in the interest chiefly of companies owning furnaces and rolling mills in Nova Scotia, Quebec, and Ontario. ${ }^{3}$ There was much discussion on this tariff at Westminster, chiefly in the House of Lords.

In the House of Commons, on May 20, 1887, Lord Claud Hamilton, a supporter of the Unionist government of 1886-1892, addressed a question to W. H. Smith, First Lord of the Treasury and leader of the house, in regard to the new Canadian tariff.

Hamilton asked whether it was true-

that her Majesty's government have been solicited by the government of

1 Parliamentary Debates, III, cexliv, 1311-1312.

2 Copy of dispatch from Governor-General of Canada respecting new customs tariff laid before Parliament at Westminster. April 4, 1879.

${ }^{3}$ Cf. Speech by Tupper, H. C. Debates (Ottawa), 1887 I, p. 384 et seq.

1569.29

$\mathrm{H} \mathrm{h}$ 
the Dominion to grant a subsidy to the Canadian Pacifie Railway, and whether in giving this request their consideration her Majesty's government would bear in mind the aetion of the government of the Dominion in raising the duty on imported iron, and also endeavour to have an estimate made of the loss to those engaged in the iron and export trade of this country whieh such increase will entail.

The Dominion government [answered Smith] has earnestly solieited her Majesty's govermment to grant a subsidy to a line of steamships which the Canadian Pacific Railway Company is willing to establish between Vaneouver and Hong Kong. It is not suggested that such subsidy should be given as an assistanee to the railway. But the proposed serviee is being eonsidered on its merits--the question being whether the advantages to this eountry, and to the Empire generally, of maintaining an efficient serviee of powerful vessels in the North Pacific would justify an applieation to Parliament for an

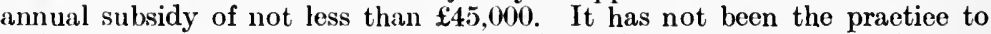
look upon the ligh tariffs which Canada finds it neeessary to adopt as directly affecting the consideration of any general question in which the point arises whether, or how far this eountry should eo-operate with the Dominion. But her Majesty's government cannot but feel that a change in the Canadian duties, sueh as that alleged, must indirectly affect the eonsideration of the main question, which must be ultimately deeided by Parliament. ${ }^{1}$

W. L. Bright, Liberal member for Stoke-upon-Trent, on June 13, 1887, asked W. H. Smith, ' whether her Majesty's government will make some representation to the Canadian Government with a view to the modification of this tariff, injurious alike to the interests of Canada and of this country.' ' The government,' answered the leader of the house, "are not prepared to press the Canadian government to modify the proposed fiseal arrangements, for whieh that government alone is responsible. The last words in the question of the honourable member are an expression of opinion, which eannot be dealt with within the limits of an answer.' 2

In the House of Lords on June 17, 1887, after a question by Lord Lamington, there was a speech criticizing the new duties by Earl Granville, who was at the Colonial Office from Deeember 1868 to July 1870, in the Gladstone Administration of 1868-1874.

He said :

The noble lord has expressed regret at the inability of the Secretary of State for the Colonies [Sir Henry Holland, ereated Lord Knutsford in 1888] to offer any direct opposition to the ehange. This measure, so suddenly brought forth, has created much discontent both here and in the eolony. To us the evil eonsists in diminishing the receptive powers of a good market, which is able to benefit itself by getting goods cheaper than it otherwise could acquire them. It is foolish to preach to others as to their own interests. But it is obvious that the injury to Canadians will be much greater. The Secretary of state for the Colonies is quite right in deelining to interfere with the Parliament of Canada. But I camnot doubt that they [the Imperial Government] are offering advice, and making representations on the subject. The publie in this eountry are making suggestions as to the way in which we should meet this poliey, which appears to them to be hostile to this country. I do not believe that the stimulus has been in any way hostile to this comtry. If there be any wish to oppose, it is bent in a different direction. It is favoured by a belief in protection itself. It is a little owing

1 Parliamentary Debates, (House of Commons), May 20, 1887, III, cecxr, 730-731.

2 Ibid., June 13, 1887, III, ecexr, 1743. 


\section{PROTECTIONIST DUTIES IN CANADA, 1859-1887}

to dulness in Lower Canada. ${ }^{1}$ It has a political and respectable source, in the desire to conciliate Nova Scotia. It is much promoted by a few capitalists, who see their way to immediate gigantic personal profits. But you cannot expect the manufacturing and commercial classes of Great Britain to take so impartial a view, and to regard such a sudden blow to the legitimate commerce of the two countries as a friendly proceeding. Suggestions have already been made for retaliatory and differential duties on Canadian products. Now, I need not say that I personally repudiate any such action as contrary to good principles and to our best interests. But the government of the Dominion ought not to forget that everybody may not be quite as sensible as I fancy myself to be on this particular point, and that follies may be committed which would cost everybody concerned very dear indeed. An official explanation of this measure has been based upon the fallacy that this measure is not hostile to us because we are rapidly losing our trade in Canada, which will surely go into the hands of American iron masters. But the facts are not so. ... We have more than half of the whole imports. As I said in the beginning, I entirely agreee with the government that they are right in not attempting to interpose any veto on this action of the Canadian Government. But it would be a sad bathos at the conclusion of the late conference ${ }^{2}$ if it were found that its conciliatory president, with so able and popular a representative in Canada as Lord Landsdowne, was not able, by friendly and moderate councils, to modify the sudden blow which has been struck at the best interests of Great Britain and Canada. ${ }^{3}$

Carnarvon, on behalf of the Government, replied to Granville :

First of all, as regards the disadvantage to this country, I frankly admit it. No one can doubt it for a moment. It is almost in the nature of a truism. I am disposed to go further, and agree substantially with the noble lord that it is disadvantageous to all, and not least to Canada itself. This, however, is an impost clearly not directed against this country. It is an impost which I believe to have been put on for reasons of domestic finance by the Canadian Parliament; and it must be remembered that it is an impost which has already been reduced, as I understand, from twenty to twenty-five per cent., in deference to the wishes and representations of this country.

It is very easy to criticize the Canadian Government and Parliament. But the Parliament here must remember that they have had great difficulty, and that, as far as I know, for many years past they have not applied for any assistance from the mother country, and the loans made to them have been faithfully repaid, and that they have so arranged their finance that their securities will stand comparison with any securities in the European markets, while they have been led to undertake such great works as those of the Canadian Pacific Railway, of which it may almost be true to say the like has never before been produced. Therefore, I say it is not fair for us to criticize from a distance that finance. Still less do I think we should require them to make sacrifices for us, when it is perfectly clear that we can make no sacrifices ourselves. Our system of free trade is such that we have given away to every other nation whatever powers we may originally have possessed to make a bargain with. We have nothing left practically to give to Canada ; and therefore we are not entitled to give credit to ourselves as against Canada in the matter. If we were prepared to make any movement toward those close fiscal relations which have been discussed in this country,

1 At this time (1887) the term Lower Canada was sometimes used to indicate the Maritime Provinces.

2 The First Colonial Conference, assembled in London, at the celebration of the First Jubilee of Queen Victoria. Its first session was held at the Foreign Office on April 4, 1887. Sir Henry T. Holland was President of the Conference.

${ }^{3}$ Parliamentary Debates (House of Lords), June 17, 1887, III, cccxvi, 376-378.

$\mathrm{H}$ h 2 


\section{EXTRA-PARLIAMENTARY PROTESTS AGAINST}

and which have many partisans in the eolonies, it would be a different case. But we have none of these things. ${ }^{1}$

On July 4, 1887, Lamington returned to the subjeet of the increased duties on iron in the new Canadian tariff. He asked the Government to lay upon the table of the House the eorrespondence with Ottawa in regard to the new tariff. ${ }^{2}$

The Earl of Onslow, Under-Seeretary of State for the Colonies (1887-1888), replied to Lamington's speech. There was very little to be added, Onslow said, to what Carnarvon had stated on June 17, namely, that the policy of Great Britain had been to leave in the hands of the Government of Canada the management of their own fiseal affairs. 'In times gone by,' eontinued Onslow, ' it was the practice to issue instructions to the Governor-General, directing him to reserve eertain bills, including those having refcrence to fiscal matters, for the approval of her Majesty. When the Marquis of Lorne went out to Canada (1878) these instruetions, so far as they had referenee to Bills imposing differential duties, were revoked. . . As eonstitutional government existed in Canada, he (Onslow) did not think that his noble friend (Lamington) would expeet her Majesty's government to do more than forward the reeommendations whieh had been reeeived from the various ehambers of eommerce.'

Granville in tervened in this discussion of July 4, to suggest that the Government seemed to overlook the point in the controversy.

He said :

They were not asked to veto any Canadian customs laws, or in any way to interfere with the raising or lowering of duties. No one wished to see the slightest interference with Canada. But they were struck with the faet that the Colonial Under-Secretary had, the other night, argued in favour of the duties rather than otherwise. He could not coneeive that though this eountry had adopted the wise and sensible plan of leaving all tariff regulations to the colonies themselves, it had thereby debarred itself from the right of making any representation of a friendly character when an alteration so important to the colony, and the mother country, was concerned. He failed to see why such a representation might not be inade without in the slightest degree giving offence. He regretted that the government had not cxpressed their vicws one way or the other, as to the advantage or disadvantage of this change, on the colony, as well as on the mother country. ${ }^{3}$

In answer to a question by Lord Claud Hamilton, in the House of Commons, on May 19, 1887, Smith, leader of the house, referred to the protests of ehambers of commerce. 'The government,' he said, ' would not be justified in making any official representation on the subject to the government of the Dominion. Any representation, by parties who may be affected by the fiscal policy of Canada, should be addressed to the Dominion Government.' 4

1 Parliamentary Debates (House of Lords), June 17, 1887, III, ccexvi, 379-380.

- Cf. Parliamentary Debates (House of Lords), July 4, 1887. III, ccexvi, 1550.

3 Parliamentary Debates (House of Lords), July 4, 1887, III, ccexvi, 1332-1334.

4 Ibıd., (House of Commons) May 19, 1887, IIII, cecxr, 522. 


\section{EXTRA-PARLIAMENTARY PROTESTS IN GREAT BRITAIN AGAINST PROTECTIONIST DUTIES IN CANADIAN TARIFFS, 1847-1887}

\section{No. 1. A Protest from Glasgow against an Increase in Duties on Iron in the Canadian Tariff of 1847}

In the Tariff Act of Canada of 1847 the first tariff enacted by the legislature after the passing at Westminster of the Enabling Act of 1846, duties were increased on machinery and iron castings. Ironfounders in Glasgow protested at the Colonial Office. But their memorial was not in the hands of Grey, Secretary of State for the Colonies, ' until after the decision of her Majesty's government to advise the Queen to confirm the act had been taken.' 1

There were twenty-eight signatures to the Glasgow memorial, in which it was recalled that under the tariffs of the old commercial system, the duty on castings was five per cent.; and further recalled that 'hitherto Canada had been one of the chief markets for their castings'. The petition continued :

That the memorialists have just learned with great surprise and alarm that the Canadian legislature has recently passed a tariff which imposes an additional duty of seven and a half per cent. upon all castings, this converting the sufficiently restrictive duty of five per cent. already existing into the exorbitant and totally prohibitive duty of twelve and a half per cent. . . .

That besides the direct injurious effects of the proposed increased duties upon the interests of your memorialists, the principle of the tariff is opposed to the free trade policy recently adopted by the legislature of this country, having for its object the abolition rather than the extension of all commercial restrictions, and the memorialists respectfully submit that while it would be most inconsistent in itself, it would also be extremely unjust to the manufacturers of this country after being deprived of protection at home, if instead of enjoying increased facilities of trade, they should be excluded by new and totally prohibitory duties from access to the very markets which they had previously enjoyed.

That your memorialists understand that the tariff adopted by the Canadian legislature cannot be carried into effect till it has obtained the sanction of Her Majesty's government, and they, therefore, hasten without delay to address your lordship upon this subject. They respectfully request your lordship to take this memorial into consideration, and to withhold your sanction, or to advise those whose province it may be to decide to withhold their sanction, from the said tariff in so far as the additional duty upon iron casting is concerned. ${ }^{2}$

1 Cf. Grey's dispatch to Elgin, Governor-General, February 11, 1848. The commissioners of customs examined and passed on the Act on January 28, 1848. At the Board of Trade it was apparently not discovered that the Act jenpardized any British industry ; for on February 9, 1848, it was passed on to the Colonial Office, with a memorandum from Labouchere, President of the Board of Trade in the Russell Administration of 1846-1852, which read ' I transmit herewith the draft order for the confirmation of the act.'

2 Memorial of ironfounders of Glasgow, transmitted by Grey to Elgin, February 11, 1848 . 


\section{No. 2. Protest fron Glasgow against Reciprocity not Extended to the United Kingdom, 1848}

A second memorial from Glasgow, protesting against the way in which the legislature of Canada was exercising its new measure of fiscal freedom, was transmitted by Grey to Elgin on March 6, 1848. It was signed by sixty-two merchants, manufacturers, and other inhabitants, and was much more general in character than the memorial of the ironfounders that Grey had forwarded to Elgin on February 11, 1848.

The memorialists assured the Colonial Secretary that they had obserred with regret and alarm 'the formidable augmentation of import duties on British produce and manufactures'. They also affirmed :

[1] That while the mother country admits the staple products of Canada, either duty free, or at a discriminating duty, that colony proposes to lay dutics on British manufactures, varying from five to thirty per cent., and that the average rate of said duties is equivalent to twelve and a half per cent.; [2] that the other great colonies in the East and West Indies and Australia ha ve hitherto imposed low duties averaging about three and a half per cent. ; [3] that the act complained of proposes to place the mother country in a more unfavourable position than the rery colonies under her dominion, namely, the other British North American colonies, the native produce and manufactures of which are proposed to be admitted duty free, provided said colonies shall receive Canadian produce and manufactures on the same terms; [and 4] that the said colonial act proposes to place the mother country in a more unfavourable position than the United States of America, in so far as it repeals the differential duties hitherto maintained in farour of British manufacturers. ...

We shall deem it a hardship if, as British subjects, paying taxes, of which a portion is expended in the gorernment and defence of that colony, our goods shall be admitted on less favourable terms than those of the Únited States manufacturer, who contributes nothing to that expense, and who may thus, by unfair competition, be enabled to drive the British merchant and manufacturer out of that colonial market. For these reasons, as well as for the maintenance of the British connexion in America, your memorialists pray that when the said aet shall come under your lordship's consideration, it may not receive the assent of the Crown.

\section{No. 3. Protests at Manchester agaixst the Caxadian TARIFFs of 1855-1862; Galt's DeFENCE of CaNadia Fiscal Policy before the Chamber of Commerce, SEPTEMber 25, 1862}

Alexander Tulloch Galt, Minister of Finance in administrations of the prorince of Canada from August 7,1858 , to May 23, 1862, visited England in the autumn of 1862, and addressed a number of publie meetings on the fiscal poliey and material resources of Canada. At the invitation of the Chamber of Commeree he addressed a meeting in the Mayor's parlour, in the Town Hall at Manehester, over which the Mayor, Mr. Thomas Cioadley, presided, on September 25, 1862.

Three objections, said Galt, had been made in England with respeet to Canada. They were (1) that the tiscal legislation of Canada had not been consistent with the views of political ceonomists in England, nor advantageous to Canada or to England; (2) that the eost of maintaining the colonies had been large and the 
advantage small; and (3) that even supposing the tariff was satisfactorily arranged, some persons held that the colonies would be better off if separated from the mother country.

The first point, he continued, had perhaps attracted the most attention. Admitting that direct taxation might be the best means of providing for the wants of the State, yet in Great Britain the larger part of the revenue was raised by indirect taxation. In Canada incomes were so small, the country being settled by people mostly poor and uneducated, that it would be more difficult than it was in England to make them acquiesce in direct taxation. Direct taxation had been introduced into the municipal system, but it could not yet be employed to provide for the wants of the State. Consequently, they had to look to indirect taxation, of which customs duties were the chief. A revenue was derived from the sale of lands, which was wholly devoted to the settlement of those lands. The public works had not yielded the revenues expected from them, although the revenue would probably increase. To provide, therefore, for the interest on the public debt, the maintenance of the absolute charges on the civil government, the administration of justice, and the encouragement of education, duties had to be raised upon imports.

The next question would be whether they had been governed in Canada by sound principles in the mode in which they had imposed customs duties. With such a frontier as theirs, manifestly there were great facilities for carrying on an illicit trade if Canada imposed duties on articles imported free into the United States. Those articles upon which the revenue of England by indirect taxation was largely raised, viz., spirits, tea, sugar, and tobacco, were free from duty in the United States. Canada imposed duties upon these articles; but she had to take care that the duties were not so high as to encourage smuggling from the United States. Having got from them as much as possible they had to supply the deficiency by taxing other articles of import. The principle had been to admit raw material free; to charge ten per cent. duty upon articles which had received a certain amount of manufacture, but which could not go into use until remanufactured, as it were, and to impose a duty of twenty per cent. upon articles fully manufactured.

The American duty upon textile goods had been twenty-four per cent. The object of the Canadian Government was simply to maintain the credit of the country, and not to introduce a protective system as was often stated. The best proof of that was that the effect of the tariff had not been to produce manufactories in Canada. They made nails, steamboats, and some coarse woollen fabrics, but there was not a single cotton or silk mill in the colony, nor any woollen ones beyond the unimportant ones he had mentioned. Another proof was that the trade between the colony and the home country had not been prejudicially affected by the duties. From these facts he thought he might fairly claim that although they might have made mistakes in their fiscal legislation, yet their object had been to reduce the charges on trade, to increase the quantity of their imports and exports, and so to develop the resources of Canada. It had been a matter of great disappointment to many Canadians to find that their intentions had been misunderstood. There certainly was a protectionist party in Canada; but it never had been, and he thought never would be, in the 


\section{EXTRA-PARLIAMENTARY PROTESTS AGAINST}

ascendant. Besides it must be remembered that the system upon which they had been brought up was protective. They had followed the mother country in many respects as far as she had gone, but their necessities would not allow them to take the duties off imported goods.

Discussion on Galt's speech was opened by Mr. H. Ashworth.1 There had been, said Ashworth, as Galt had justly remarked, a good deal of misapprehension with regard to the value of the colonies, and especially with regard to tariff duties imposed in the eolonies. They all knew how restive that part of the world (Laneashire) had recently been upon the subject of the Indian tariffa tariff which was five per cent. at the present time-and how very small an amount of agitation there had been touching the tariffs whieh had been made by crown colonies on goods for the consumption of our fellow subjects. These were anomalous cireumstances; and he thought that on an occasion like the present it was well that they should hear of the reasons which could be adduced for favouring a poliey so widcly different from that of the mother country. Galt had remarked in a reeent speceh on the progress of Canada; and among other observations he had said that the government charge per head of the population was $£ 115 s .23 d$. in Canada, while in Great Britain it was $£ 28 s .9 d$. He (Ashworth) asked whether they were prepared to sanction any enlargement of Great Britain's expenditure in Canada and on other colonies-colonies whieh were able to sustain themselves. He next went into some detail regarding expenditures of the British Government in Canada. There was, he said, a point whieh human nature could no longer endure, and he appealed to them whether the time had not eome when they should adopt a language which was more pertinent, he would not say more serere, but more becoming towards the colony of Canada. The language of the Canadian legislature was anything but becoming to a eountry so largely under obligations to this country; and in the words of Mr. Goldwin Smith, he would say that "there is one way of making Canada impregnable, and that is by feneing her round with the majesty of an independent nation.'

Mr. Hugh Mason. 2 diseussing Ashworth's remarks eoneerning the desirability of Canada becoming an independent country, said he did not think that any one woukd wish abruptly to snap the tie which bound Canada to England. But at the same time there was a growing feeling in England in farour of the eolonies generally but especially Canada, assuming at no very distant day the power, dignity, and responsibility of an independent nation. It seemed to him that both the mother country and the colonies would be the gainers by the separation. He did not know what might be the speeial objeet of Galt's mission to England; but if it was in the slightest degree to put Canadian hands into the poekets of the British taxpayers, he hoped he would leave Manehester, at all events, with the unmistakable inpression that when Canada came to the distressed operatives of Lancashire. or the mill owners of Lancashire, for a portion of their taxation, he woukd find himself mistaken.

After a member of the (hamber of Commerce (Mr. Fergusson) had observed that the remarks regarding the separation of the eolonies from England must not

I A member of the Anti-Corn Law League of 1s38-184ti, and author of Recoll.ction.s of Richard 'obden. H.I'., which was published in 1576 .

2 Liberal Member for Ashton-under-Lyne, 1s50-1s55. 
be taken as representing the opinion of the chamber, Mr. M. Ross brought the discussion back to the Canadian tariff. Ross remarked on the inconsistency of the Canadian Government applying for a railway guarantee whilst they were imposing additional import duties on British manufactures. He hoped to see a better feeling cherished between the two countries.

The Mayor then recalled that when a deputation from Manchester had had an interview with the Secretary of State for India, they were asked how they could expect the Government to reduce the tax on cloth, which was then being imported into India at ten per cent. when in Canada upon the same goods there was an impost duty of twenty per cent., remembering, at the same time, that the Indian people paid the entire expenses of their own protection, whilst Canada required a large expenditure by Great Britain for its protection.

In his comments on the discussion, Galt said that although he was sorry for the tone of Ashworth's remarks, he was not sorry that the discussion had taken place. It was very much better that the statements which had been made should be openly made when they could be replied to than that any misapprehension should exist. ${ }^{1}$

\section{No. 4. A Second Protest from the Manchester Chamber of Commerce. Macdonald's Defence of the National. Policy Tariff of 1879, August 6, 1880}

Mr. Benjamin Armitage, member for Salford, President of the Manchester Chamber of Commerce, and six members of the House of Commons who were also members of the Manchester Chamber, on August 6, 1880, waited on Sir John A. Macdonald, during a visit of the Canadian Premier to London 'to urge upon him the desirableness of effecting a reduction in the present hostile tariff of Canada.'2

Mr. Armitage asserted that-

the tariff of Canada had had the effect of diminishing our trade with Canada, and that the agricultural classes were made to suffer thereby. The tariff had not been productive of increased revenue, and it had rendered the country less attractive to English emigrants. He pointed out how the high rates of tariff interfered with the trade of Manchester, almost to the extent of putting an end to certain branches of it.

Mr. John Slagg, one of the representatives of Manchester in the House of Commons, assured Macdonald that-

there was a strong feeling of impatience, if not almost of resentment, in our large commercial circles, at the continuous restrictions that were put upon English trade with Canada. No one grudged the complete liberty that had been accorded to our colonial possessions in regard to self-government ; but the public were beginning to regret that the liberty had been given to such an extent as to admit of the possibility of the practical exclusion of our goods. There was nothing in the present position of the Canadian industries to encourage a continuance of the policy which was designed to benefit them; but which, in fact, made them dependent and gave them only a feeble life.

- Summarized from a two-column report of the meeting in the Guardian (Manchester), September 26, 1862.

2 The Times (London), August 9, 1880. 


\section{EXTRA-PARLIAMENTARY PROTESTS AGAINST}

Macdonald, in replying to Armitage and Slagg, said that-

the chief difficulty was that England had nothing to give Canada in the way of reciprocity. Everything had already been given away. The protective system was accepted by the greater part of the civilized world, England being almost the exception in adhering in principle, and in practice, to free trade under all circumstances. ... The tariff in Canada had been adopted with enthusiasm by both agriculturalists and manufacturers. It was imposed to benefit the revenue; and the first year's experience showed that that was the result. In its readjustment care was taken that it should be the means of assisting their infant industries, and also of preventing the American rings and corners which disturbed the trade of the country. They had not bcen unmindful of their obligations to the mother country in making the readjustment; for they had put heavier duties by classification upon articles which the United States produced, and which Canada ought to produce, and reduced the duties upon those articles which they principally got from England. Since the adoption of the tariff the proportion of imports from England had increased, while the proportion from the United States had decreased. ... It was in consequence of the protective system that the United States had to a very large degree developed their manu. facturing. Until the tariff was adopted, American rings and corners had crushed Canadian manufactures; but this was now prevented by the exclusion of United States merchants, and, as a consequence, America was now sceking a renewal of the reciprocal relations which formerly existed.... He held out a hope that in ten years' time the great north-west would be ablc to supply this country with the food we now imported from other countries, but then, they in Canada would want a countervailing duty. He pointed out that Canada was in a different position from England in regard to the adoption of free trade, and showed that it was impossible to levy dircct taxation on Canada. An income tax would be a failure, because there was nothing to levy it on. Therefore, they were obliged to have rccourse to the tariff. ${ }^{1}$

\section{No. 5. Bright and the Denial by Canada of Free Exchange} of Commerce with the United Kingdom, January 29, 1885

The other day there was a meeting of the Imperial Federation League. I wish they would give us the names of all the gentlemen who were therc. Among those who were there was Sir John Macdonald, who is Prime Minister of Canada. Sir John Macdonald is Prime Minister of Canada mainly, if not entirely, because he was most active in a protection movement. He has been madc Prime Minister; and while we admit everything Canada wishes to send to this country without a farthing of protective duty upon it, he, as their Prime Minister, has been supporting a highly protective system in regard to English manufactures. Yet, he appears at the Federation League mceting and gircs his countenance to the proposition that Canada and the United Kingdom shall be made one. I could not conceive of any man having the face to appear at a meeting for that purpose, holding such a position. . . We ask them: 'Gentlemen, you wish to beeomo one country with us, to have the same interests that we have. We are all to join in your defence. Are you willing to lave free exchange with us ?' And they answer, 'No.'- Speech by Bright at Birmingham, January 29, 1885. ${ }^{2}$

'The Times (London), August 9, 1880.

- The Times (London), January 30, 1855. 


\section{No. 6. Protests from the British Iron Trade Association, and from English Chambers of Commerce, against IN- CReases in the Iron and Steel Duties in 'rHe Tariff of the Dominion of Canada of 1887}

The tariff of the Dominion of Canada of 1887, which increased duties on iron was introduced to the House of Commons at Ottawa on May 12. The iron and general metal trades section of the Liverpool Chamber of Commerce, on May 18, telegraphed to Holland, Secretary of State for the Colonies, asking him to receive a deputation. 'Will forward to Canadian Government,' Holland wired in reply, 'any representations you may wish to make respecting increase of duties on imports, but see no advantage in receiving deputation.'

The Liverpool Chamber of Commerce on May 19 again urged that a deputation be received at the Colonial Office. The matter was characterized as 'very urgent '. 'Having heard with astonishment,' continued the telegram to the Colonial Office, ' of the proposed increase in the Canadian tariff, we beg to call attention to the fact that if this proposal becomes law it will probably lead to the exclusion of British iron and steel manufactures from that market, and to serious injury to the trade of this country.' From the Bristol Chamber of Commerce on the same day there was also a request that a deputation be received at the Colonial Office. To the Liverpool Chamber of Commerce there was a reply from the Colonial Office on May 20. 'Sir Henry Holland,' it read, 'desires me to refer you to the answer 1 given by the First Lord of the Treasury in the House of Commons yesterday.'

In response to much pressure, Holland received, in private, at the House of Commons, on May 22, 1887, a deputation representing the British Iron Trade Association. 'A proposal is now pending', read the memorial submitted by the deputation to the Colonial Secretary, "to increase the rates of duty paid on iron and steel imported into Canada. The duty on pig iron is to be increased from $8 s .4 d$. to $16 s .8 d$. per ton, or 100 per cent.; the duty on puddled bars is to be increased from $8 s .6 d$. to $37 s .8 d$., or 350 per cent. ; and the duty on bar iron is to be increased from $17 s .6 d$. to $45 s$. $10 d$., or 155 per cent.'

After stating that these increased duties endangered an export trade of about a million sterling a year, it was set forth in the memorial that the increase was so enormou's that it was ' manifestly designed for protection and not for purely revenue purposes'. The memorial continued :

There are high economic and state reasons why the government should endeavour to interfere, if possible, in order to avert this. Canada has been, like many other colonies of the British Crown a costly possession for England. We have maintained a navy which has cost us, during the last

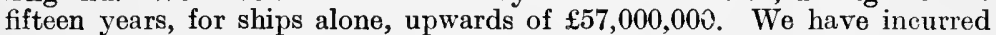
enormous responsibilities for the same end ; and the recent fishery dispute with the United States showed how great and imminent was the chance that we might at any time be called upon to meet them. British eapital has, moreover, done a great deal to help Canada to construct her railway system,

1 'The government would not be justified in making any official representation on the subject to the government of the Dominion. Any representation by parties who may be affected by the fiscal policy in Canada should be addressed to the Dominion Government.'-Parliamentary Debates (House of Commons), May 19, 1887, III, $\operatorname{cccs} \nabla, 522$. 


\section{EXTRA-PARLIAMENTARY PROTESTS AGAINST}

without as yet having received any equivalent. To now shut out English manufactures as it is proposed to do, would be to take the surest possible means of alienating both the affections and the interests of the two countries, and would probably bring about, as an ultimate result, a complete political severance, which could be good for neither. ...

The Canadian iron industry is not as yet developed to any material extent. Thcre are scarcely any indigenous resources provided for meeting the most pressing wants of the country in iron and steel. The effect of imposing the proposed new duties would certainly be to induce an unnatural and, therefore, unhealthy development of new enterprises on Canadian soilprobably in localities quite unsuited for the iron manufacturo-and if the supply of the requirements of the Dominion is limited to such works the probable effect would be not only an enormous increase of price to the consumer, but the production of very inferior and inadequate materials, whilc the only parties to be benefited would be a few capitalists and adventurers, whose fortunes and whose property would be improved at the expense of the great mass of the populations alike of the mother country and the Dominion.

The future of the Dominion must be mainly dependent upon agriculture. The agricultural community is not only interested in getting implements, railways, and other things into which iron and steel enter largely, at the lowcst possible price, but they are immediately interested in securing an outlet for their surplus produce. As it is at present, that produce is bcing imported into Great Britain in increasing quantities.

The interest of the grain growers in cheap outward freights was then taken up in the memorial. It continued :

To illustrate this latter argument it may be sufficient to observe that our exports of iron and steel to Canada in 1886, 228,039 tons, in 1885, 170,679 tons, and in $1884,162,542$ tons, and our imports of wheat and flour therefrom, almost balanced each other in weight. Prcsumably, therefore, there werc pretty fully and fairly remunerative freights both ways. But if there were to be freights one way only the trade in the importation of Canadian breadstuffs would almost ccrtainly cease at present rates, since the trade is worked upon a very narrow margin, and a difference of only five shillings per ton would be likely to exclude Canada from it altogether.

The present movement for the adoption of a prohibitory tariff is avowedly promoted, if not solely initiated and carried on, by a few interested firms, who desire to engage in the iron industry. These firms are better able to do the business of lobbying than the agricultural interest, which is widely scattered, and but little capable of cohesion and united action. But the Imperial Government may surely fitly point out to the Canadian Government that the agricultural interest would suffer by this step, and that it should. therefore, bc discouraged in every possible way. The value of the wheat and flour imported into this country from the Dominion is officially returned at over a million and a half sterling for the year 1886 . It is not only conceivable but probable, that if the import of English iron and steel were stopped, the export of wheat and flour would stop also, and the loss from this source would be about $7 s .6 d$. a head for every inhabitant of the Dominion. ${ }^{1}$

Holland, on May 25, 1887, transmitted the memorial of the British Iron and Steel Association to Ottawa. 'They' (the Association), he wrote, in an accom. panying dispateh addressed to Lansdowne, 'desirc me to forward these reasons for the consideration of your ministers, and to inform them of the strong feclings entertained by the Chambers of Commerce and by the iron and shipping trades

$$
1 \text { Correspondence liespecting the Canatian Tariff, 1857, pp. 3-6. }
$$


of this country that the proposed measure will cause grave dissatisfaction here, and tend materially to injure the trades mentioned.' 1

Protests or memorials from Chambers of Commerce were forwarded to the Colonial Office after Smith's answer in the House of Commons of May 19, and the interview of May 22 of the deputation from the British Iron Trade Association with Holland. One of these protests was from the Associated Chambers of Commerce. ' It seems a most unfortunate moment,' read one paragraph in this protest, 'for such an addition to have been made to duties in iron and steel schedules, as it throws doubt upon those feelings of affection for the mother country which have been so recently expressed.' 2

Other memorials were from Chambers of Commerce of Warrington, Leeds, Wigan, Bolton, North Staffordshire (Hanley), Barrow-in-Furness, Manchester, Cardiff, Bristol, Walsall, and Sheffield. The memorial from the Hanley Chamber is noteworthy as embodying one of the earliest, if not the first suggestion, after 1846, from a commercial organization, for preferences in colonial tariffs in favour of British imports. A paragraph in the memorial of June 13, 1887, reads as follows :

This Chamber considers that if the Government of Canada persists in increasing the said duties, it should, in justice to Great Britain, make a differential rate in her favour. .... As it is estimated that nearly forty-five per cent. of the puddled bar and finished iron imported into Canada is from the district of your petitioners [North Staffordshire], they consider that they are entitled to claim your special consideration for their memorial. ${ }^{3}$

Holland transmitted these memorials to Ottawa on July 7,1887 . He wrote to Lansdowne.

Your government are a ware from previous communications which $I$ have already forwarded to you, that great dissatisfaction is felt in this country amongst mercantile firms interested in the iron trade, in consequence of the action of the government of the Dominion in proposing the imposition of these duties, ${ }^{4}$ and the matter has also formed the subject of discussion in both Houses of Parliament, where much adverse opinion has been expressed. I think it right to call your attention to the feeling which exists in this country, and have no doubt that your government will give consideration to the various representations which have been made on the subject. ${ }^{5}$

It may be noted here that the tariff bill that aroused such opposition in England received the Royal Assent on June 16, 1887; and that on June 30 the Macdonald Cabinet at Ottawa took under consideration some of the memorials against the increases in the duties on iron that were forwarded by the Colonial Office. At this session of the Cabinet a memorandum prepared by Tupper, Minister of Finance, was adopted as a minute of council, and transmitted through the Governor-General to the Colonial Office. In this minute it was denied that the increased duties were an attack on British industry.

'A careful examination of the British Canadian iron and steel trade in Canada in connexion with the tariff changes,' continued the minute, 'will not justify

1 Correspondence Respecting the Canadian Tariff, 1887, pp. 3-6.

2 Memorial, Associated Chambers of Commerce, June 2, 1887, ibid., p. 7.

3 Correspondence Respecting Canadian Tariff, 1887, p. 10.

4 The duties imposed by the Act (50-51 Viet., c. 39$)$ were: pig iron, $\$ 4$ per ton; iron in slabs, blooms, loops or puddled bars, rolled or hammered hoop iron and boiler plate, $\$ 13$ a ton.

${ }_{5}$ Correspondence Respecting Canadian Tariff, 1887, pp. 33-34. 
the accusation.' Statistics were cited to show that from 1877 to 1886 , both years inclusive, seventy per cent. of the imports of iron into Canada were from the United States, and thirty per cent. from Great Britain. In 1886 fifty-eight per cent. of these imports came from Great Britain, and forty-two per cent. from the United States. A paragraph in the minute reads :

Adjoining the southern border line of Canada there extends from ocean to ocean the United States of America-a great nation of over fifty millions of pcople. They have attained an enormous industrial development under a highly protective tariff, which is still maintained, and under which compara. tively high rates of wages prevail, controlling, in a marked degree, the price of labour in Canada. Placed in this position, and under such circumstances, Canada is compelled in self-defence to adopt a tariff policy in some measure approximating that of the United Statcs, in order to protect domestic industries and to develop the natural resources of the Dominion.... In the adjustment of duties it will be seen that a large discrimination has been made, on the whole, in favour of British industry as against foreign industry, the higher rates of duty being imposed on manufactures the largest proportion of which, in the aggregate, are being imported from foreign countries. By the changes made it cannot be claimed that any great British industry has been uncxpectedly attacked. .... In ceasing to be dependent on foreign sources for the production of materials which exist in profusion within her borders, and by the development of her great natural resources, Canada may hope to attain a more prosperous position, and become a source of strength to the British Empire. ${ }^{1}$

${ }^{1}$ Correspondence Respecting the Canadian Tariff, 1887, pp. 39-40. 


\section{INDEX}

Aberdeen, Lord, 320-321, 331 ; administration of, 251 ; on separation from colonies, 298-299, 303, 355 ; Russell resolutions, 308 ; diseussions of eolonial connexion, 341-343 ; on equality of trade, 439 .

Aet of 1809,12 ; of 1822 (Robinson's Act), 11, 13, 52; of 1824 (Joseph Hume), $8,12,32$; of 1825 (Huskisson's Act), 13, 44-45, 52 ; of 1846,2 ; of $1849,42-43$.

Adams, Charles F., cited, 162, 178 ; efforts toward treaty of reciprocity, 185-187.

Adderley, Sir Charles, 197, 226 ; cited, 103, 287, 293-294, 360, 368 ; author of Survey of Colonial History, 188-189; protest against convict settlement plan, 258-259; efforts toward political civilization of colonies, 306 ; advoeates of long tenure for eolonial secretaries, 320 ; on local defence for eolonies, 393 ; Tariff Bill of 1859,457 . See also Norton, Lord.

Adelaide (Australia): attitude of Government at, on Tasmania Bill of 1867, 120 ; bill for differential duties passed at, 128; eolonial poliey originated at, 297.

Aglionby, 312.

Alaskan fisheries and boundary questions, Joint High Commission ereated to settle, 200.

Alien eontract labour laws, Joint High Commission appointed to settle, 200.

Allin and Jones, cited, 134, 283, 350, $445-446$.

Althorp, 288.

American Revolution, 3, 32, 37 ; influence on Ireland, 4 ; commercial system funetioning at time of, 6 ; cause of inroads on old eommereial system, 17 ; influence on history of England, 81.

Anson, William R., 232.

Anti-Corn Law League, eampaign against corn law system, 22-23, 34$35,222$.

Argyll, Duke of, 264.
Armitage, Benjamin, 473.

Ashburton, Lord (Alexander Baring), 328 ; mission at Washington, 178 ; discussions of colonial connexion, 341-343 ; on separation of eolonies, 355.

Ashley, W. J., 297, 359.

Ashworth, H., 472.

Asquith, Herbert H., Premier, 401.

Assent, Royal. See Veto.

Association for the Promotion of Canadian Industry, 139, 147.

Atlantic fisheries question, Joint High Commission created to settle, 200.

Auckland, 97.

Australia, 9, 19, 26 ; fiscal freedom, $10,141,214-215,252,267,280,381-$ 382 ; tariff preferences on wheat and flour, 27-29; preference on wool, 27, 30 ; American influenee, 38 ; prohibition of differential duties, 67-69, $111,117,159,221,360$; protective tariff, 76, 78, 111, 122, 145, 160 ; Declaratory Act, 91 ; tariff freedom, $93,120,224$; framing of constitution by Grey, 95, 313; freedom of reciprocal trade, 116,279 ; retaliatory duties, 134-135; tariff duties against England, 138, 141, 149, 285. 372 ; protectionist movement, 153 , 158; revolt against Imperial Act, 213; responsible government and effeet, 85, 216-217, 222, 269, 362 ; tariff with differential duties, 158, $246,271,275,281,284,380,389$, $458-462$; aetion for freedom from English commereial treaties, 266; cessation of use of colonies as penal settlements, 267, 287, 371, 379 ; agitation against veto, 268 ; grievanees, 378 ; status of nation, 408.

Australian Colonies Act, 214.

Australian Colonies Government Act (1850), 67, 69; importance of, 78 ; prevented enactment of customs tariff bills, 95, 117, 134; amendment to, $211,379,389,406$; revolt against restrietions of, $220,360,380,406$.

Australian Customs Duties Bill, 214. 362 . 
Aylmer, Lord, 318, 320.

Aytoun, R. Sinclair, 463.

Bagot, Sir Charles, Governor-General of Canada, 65, 166, 172, 299, 351.

Baines, eited, 338.

Baldwin, leader of Liberal and Radical Party in Canada, 65, 109, 162-163, $172,202,216,247,249,261,299$, $303,331,351,354,381$; advocate of eonstitutional frcedom, 110, 197 ; Rebellion Losses Act of 1849, 206, $230-233,237,249$; poliey toward advoeates of annexation of Canada to U.S., 356.

Balfour, Arthur J., 371-372.

Ballantyne, C. C., cited, 147.

Bartlett, J. H., cited, 89-90.

Baring, Alexander. See Ashburton, Lord.

Bechuanaland, annexation of, 393.

Begg, Alexander, cited, 300.

Bell, Sydney Smith, discussion of eolonial administration, 91-92, 291, 295, 305 ; Judge of Supreme Court in Cape Colony, 366.

Benson and Esher, eited, 172, 227, 353.

Bentinek, William G., 96.

Bertie, Sir Franeis, 201-202.

Biddulph, Robert, eited, 287, 393.

Birmingham, England, not represented in Parliament, 16.

Blaehford, Lord. See Rogers, Frederiek.

Blake, Edward: advocate of responsible government for eolonies, 197 ; advoeate of full power in eolonies to negotiate commercial treaties, 208 ; leader of 'Canada First ' movement, 210; Memorandum of July 1876, 263-264, 268.

Board of Trade : report of eontraventions of legislation or treaties to Colonial Offiee. 55; advocate of principle of free trade, $67-68$; administrators of old eommereial system, 82 ; attitude on differential duties, 84-86, 224; sanetion of, to tariff bills, no longer necessary, 274.

Bonding privileges applieable to railway and inland water transport, Joint High Commission ereated to settle question of. 200.

Bonuses for New Zealand and Tasmanian industries, 128-133.

Boose, J. R., cited, 364.

Borden, sir Richard, Premier of Canada, 235.
Botany Bay, maintenance of convicts at, 329.

Bounty Act of 1847, 137.

Bounty systems in aid of colonial in. dustries : attitude of Colonial Office and Board of Trade against, 85 ; never part of fiscal and commercial policy of Canada, 99 ; objeetion to, of Colonial Office removed, 114; payment of, 1883-1911, under Acts of Parliament, 132 ; Bounty Act of 1847,137 ; in British Columbia, 218 ; in Canada, 400 ; legislation providing for, in British North Ainerica, 449-450.

Bowell Government, 196.

Bright, John, 4, 367, 388, 394; organizer of Anti-Corn Law League, 22 ; advocate of free trade, 94,278 ; protests against tariff of 1879,238 ; on attempts of Canada to secure Imperial guarantee of loan, 375 ; retirement from aetive public life, 392 ; complaint of 1865 against protectionist duties, 463-464; denial by Canada of free exchange of eommeree, 474.

Bright, W. L., 466.

Brisbane (Australia), attitude of government at, on Tasmania Bill of 1867, 120.

British Columbia, 18 : tariff war, 123124 ; national poliey, 130 ; bonuses, 131 ; entranee to Confederation, 218.

British Possessions Aets, 54, 56, 219, 313 ; purpose, 13-16; attaek on, 32,39 ; duration of, 33 ; provisions of last of, 51-53, 90; statement of Lord Stanley on poliey of Peel Administration as embodied in, 427.

Brodeur, Louis, Minister of Marine and Fisheries, 133, 200-202, 207.

Brougham, Lord: motion for disallowanee of Rebellion Losses Aet, 240-242 ; Russell Resolutions, 308; at tributcd rebellion in Lower Canada to early maladministration, 317 ; diseussions of eolonial eonnexion, 341-346 ; on separation of eolonies, 355.

Brown, George : Mlission to Washington, 169-171 ; Inter-provincial Comncil at Quebee, 174, 179; opponent of protectionist polieies, $375,387$.

Bruee, Sir (harles, cited, 73.

Brree, Cumming. 243.

Bruce, Sir Frederick, British Minister at Washington, 166, 179-181, 186. 
Bryce, Viscount, British Ambassador at Washington, 166.

Buchanan, Isaac, advocate of protectionist policy, 114, 126, 133, 140, 148, 151, 261 ; founder of Associa. tion for Promotion of Canadian Industry, 139 ; efforts in behalf of tariffs of 1858 and $1859,153$.

Buller, Charles, advocate of responsible government for colonies, 306 , 337.

Campbell, Duncan, cited, 364.

Canada, Dominion of, lumber trade in, 25 ; industries protected by tariff, 124, 392 ; bonuses, 130-132 ; ' made in Canada' movement, 133, 148 ; efforts to prevent differential duties by Colonial Office, 136 ; organization of manufacturers in, 140 ; duties against England, 141-142, $149,158,285,369$; new tariff, 144145 ; agitation against British preferences, 147 ; propaganda for increased protection, 149, 152-153, 158, 160 ; objections to quality of British exports, 150 ; protest by Grey against differential duties, 154-155, 402, 451; effect of Enabling Act on fiscal freedom, 157, 216; exports to U.S., 175 ; imports from U.S., 176 ; framing of constitution, 176, 313 ; effect of Civil War on reciprocity with U.S., 187 ; claim for own plenipotentiaries to negotiate commercial treaties, $190-191,380$, 406 ; negotiations for reciprocity with Spain, 187-188, 191 ; French-Canadian Reciprocity Treaty of 1893, 193 ; treaty powers of, 192-193 ; responsible government, 216, 222 ; part played by Canada in fight for fiscal freedom and responsible government, 265, 369, 372, 405-406 ; treaty making, 267; diplomatic freedom, 267 ; number of Canadian bills vetoed by Great Britain (18571893), 273 ; reciprocal trade with Australia, 279 ; immigration from England, 337 ; agitation for annexation to U.S., 375 ; protests against protective tariffs by English manufacturers, $375,378,469-471$; grievances, 378 ; Reciprocity Treaty with France of $1907,208,407$; status of nation, 408; Imperial Act of 1840 , 426-427 ; Tariff Act of 1845, 430431 ; import duties on supplies for
British forces in, 433 ; movements for retention of preferences on grain and flour, 435-436 ; protests against protective duties by, 463-465.

Canadian-French reciprocity treaty of $1907,208,407$.

Canadian Industry, Association for Promotion of, 139, 147.

Canadian Manufacturers' Association, 67,133 ; objections to protectionist tariff, 146 ; agitation for upward revision of woollen schedules, 151 152.

Canadian National Association, 209210.

Canadian Pacific Railway, granting of first charter for construction of, 398.

Canning, George, 8, 288, 308.

Cape Colony, protection desired for, $26-27,29$; regulation of import duties, 44 ; tariff legislation for, 113, 116 ; dissatisfaction with English manufacturers, 150-151; convict transportation system, 188, 258, 371 ; exercise of treaty power, 192 , 267 ; responsible government, 220 ; uprising at Simonstown, 260 ; colonization, 265; reciprocity with Australia, 279; defence of, 286 ; proposed extension of boundary, 298; war with natives, 371 ; grievances, 378-379 ; voluntary contributions to Imperial Navy, 400 .

Cardwell, Edward, Secretary for the Colonies, 178, 183, 399 ; responsible for Naval Defence Act of 1865, 225 ; reform of 1870, 287 ; Canadian tariffs, 463.

Carnarvon, Earl of, Secretary of State for the Colonies, 287, 294, 363, 385 ; introduced bill for confederation of British North American provinces, 360 ; on annexation of Canada to U.S., 388 ; protest against Canadian Tariff of 1887, 467.

Cartier, Sir Georges, advocate of protectionist policy, 114, 261 ; InterProvincial Council at Quebec, 174, 176 ; framer of Constitution of Canada, 176 ; protectionist tariffs of United Provinces, 182 ; Conservative leader, 261.

Cartwright, Sir Richard, cited, 397.

Cathcart, Governor-General of Canada, 227 ; remission of duty on grain, 352 ; on protectionist duties, $433-$ 434 ; on preferences in British tariffs on Canadian grain, 435, 439. 
Cayley Tariff of $1858,53,122,124,128$, $140,151,153,362,374$; conflict between United Provinces and $\mathrm{Co}$ lonial Office over, 77 ; first success of protectionist movement, 203, 245.

Cayley, William, advocate of protec. tionist policy, 77, 114, 153, 182, 436. See also Cayley Tariff.

Ceylon, trade of, 5, 44; proposed transfer to East India Company, 298, 346 ; Wellington's plan for, 300 .

Chamberlain, Joseph, 198, 288, 402, 405 ; fishery and boundary disputes with U.S., 192 ; advocate of protectionist policy, 199, 401 ; opponent of extension of Empire, 392.

Charlottetown (Canada), restrictions on fiscal freedom of legislature of, 34 .

Charlotteville (Canada), iron furnaces at, 89.

Churchill, Winston, President of Board of Trade, 152.

Clarendon, Earl of, Secretary for Foreign Affairs, 178 ; extension of colonial trade, 184; diplomatic recognition of colonies, 186-187, 246.

Coastwise navigation, privileges of colonies, 225 .

Cobden, Richard, advocate of free trade, 4, 94, 394 ; organizer of AntiCorn Law League, 22; on British colonial system, 34 ; death of, 392 .

Cockshutt, W. F., cited, 146.

Colebrooke, Sir William, LieutenantGovernor of New Brunswick, 449.

Collier, James, cited, 259-260.

Colmer, J. C., cited, 368, 396.

Colonial Trade Bill, 5.

Confederation of 1867, 182, 185.

Conservative party, 1,27 ; return to power, 42, 46 ; efforts to harmonize fiscal policies, 108 ; acceptance of Manchester doctrines, 394.

Constitution Act of $1850,67,69$.

Corn laws, attack on, 22 ; re-opening of question of, 32 ; duration of, 32 ; revision and repeal, 48, 222 .

Crampton, Sir John, 181, 407 ; British Mission at Washington, 163 ; advocatc of responsible government, 164-166.

Croker, John Wilson, 302.

Customs duties: Act of August 28, 1846 , to reduce, 82 ; Australian Bill on, 362 .

Dartmouth (C'anada), bonuses, 131.

Davies, Louis H., cited, 137.
Declaratory Act (1778), 14, 52 ; result of, 91-92, 244-245, 270, 292, 317$318,378,417-418$.

Defence of colonies, internal, 371.

Denison, George T., cited, 144, 326.

Denison, Sir William, Governor of New South Wales, 229, 397.

Dent, John C., 222.

Derby, Earl of. See Stanley, Lord.

Differential duties, 14, 17 ; object of, 51-52 ; repeal of, in colonies, 53 ; prohibition of, in colonies, 55, 85, 117 ; instructions to governors con. cerning, 58, 74; stoppage of, in Australia, 67-68, 78; allowance of, in colonies, 75 ; enactment of, in colonies, 94, 128, 134, 360 ; purpose of Grey's protest against, 154-155, 161,451 ; absence of statutory prohibition of, 223 ; necessity of, for reciprocity, 270 ; crisis over, 278.

Differential Duties Bill (1871), 101, 103.

Dilke, Sir Charles, 192, 366-367, 369$370,392,398$.

Dingley tariff, 148, 400.

Disallowance, power of. See Veto.

Disraeli, B., Premier and Conservative Leader, 288, 394 ; opposed to protectionist policy, 96-97; consent to Tasmanian Tariff Bill, withheld, 118 ; on colonial self-government, 370, 385, 391-393.

Dix, Morgan, cited, 326 .

Dufferin, Marquis of : French-Cana. dian reciprocity treaty, 193, 198 ; Governor-Gencral of Canada, 387399.

Dunning, William A., cited, 189.

D'Urban's extension of boundaries of Cape Colony, 298.

Durham, Lord, 63-65, 204, 288, 311 ; Report on British North American Affairs, 20, 59-60, 291 ; services to constitutional development of Canada, 166 ; mission to Canada, 204, 222,357 ; advocate of responsible government, 237.

Duties, Enabling Act of 1846, to reduce Customs. See Enabling Act.

Egerton and Grant, cited, 246, 286$287,376,379,381$.

Egypt, Canadian and Australian troops in, 400 .

Elgin, Earl of, Governor-General of Canada, 65, 72, 165-166, 171, 175, $223,227,245,250-251,322$; on Rebellion Losses Bill, 230-233, 243; 
advocate of responsible government, 236-237, 242, 247, 340, 352-355 ; reciprocity in trade between U.S. and British North American Provinces, 440 ; dispatches to, 446, 448, 469.

Elgin-Marcy reciprocity treaty, 17-18, $38,94,101-103,161,443$; influence of, on Newfoundland economic history, 81; denounced by U.S., 173, 181.

Ellenborough, Lord, 298, 311, 342.

Elliot, Sir Charles, 325-326.

Ellis, Charles R. (Lord Seaford), 305.

Emigration : to U.S. from England (1815-1837), 336 ; attitude of people towards, 368-369.

Enabling Act of 1846, 2, 33, 41-43, $53-54,59,63,81-82,84,142,156$, $160,182,214-215,223,231,244-245$, $313,405,438$; authorized repeal of Westminster Tariff Act of 1843, 205 ; no tariffs in Newfoundland after passage of, 218-219 ; text of, 441.

Esher, Benson and, cited, 172, 227, 353.

Esquimalt (Nova Scotia), imperial naval station at, 400 .

Evans, Colonel, 328.

Ewart, John S., cited, 210, 338.

Export trade, efforts to stimulate, in British North American provinces, 182.

Farrer, T. H. (Lord Farrer), cited, 257, 274.

Fielding, William S., Minister of Finance, 144, 200, 202 ; negotiator of second Canadian-French reciprocity treaty, 207.

Fielding Tariff of 1897, 219.

Findlay, John G., cited, 290, 326.

Fiscal policy: in Canada, 54, 61; uniform, 66 ; freedom of, 69,78 , 407 ; as regards Crown Colonies and Dominions, 74, 405-406, revolt against, in Canada, 75, 218; propaganda for, 296; change in, 433-434, 446-448.

Fish, Joint High Commission created to settle question of preservation of, in contiguous waters, 200.

Fisheries Convention of 1818, 331 .

Fitzgerald, Nicholas, report of, 266, 285.

Fonblanque, A., 376.

Fontaine, La, Leader of Liberals and Radicals, 65.

Foster, George E., Minister of Finance, 110, 191, 193, 195.
Fox, William, Premier of New Zealand, 103, 105, 107.

Fredericton (Canada), restrictions on legislature of, 34 ; resolution adopted at, on treaty-making power, 168.

Free trade, establishment of, 1 ; movements towards, 2-3, 6-7, 18, 66 ; Peel's measures, 63, 352 ; propaganda for, $67,99,112-113,246,258$, 263, 296 ; legislation on, 74 ; Grey's advocacy of, 94-95; between Canada and U.S., 104 ; inadaptability of, in Canada, 155-156 ; Great Britain's policy, 442-443; opposition to, between Canada and West Indies, 452453.

French-Canadian Reciprocity Treaty of 1893,193 ; of $1907,208,407$.

Frere, Sir Henry B., Governor of Cape Colony, 365.

Galt, Alexander T., 174, 179-181, 197 , $215,231,401$; framer of Galt tariff, 77, 82 ; speech in Legislative Assembly, 120; influence on tariff bill of United Provinces, 161 ; advocate of diplomatic freedom for dominions, $168,176,208,216,265$; advocate of protectionist policy, 173, 199 ; Mission at Washington, 185-186; efforts to negotiate reciprocity treaty with Spain, 187-188; advocate of Confederation, 280; defence of Canadian fiscal policy before Chamber of Commerce, 470. See also Galt Tariff.

Galt Tariff of $1859,38,53,68,77,98$, $109,122,124,128,135,151,203,224$, $236,245-246,261,278,302,362$, 369 , 373-374, 379, 382 ; protests against, 84,155 ; regarded at Washington as antagonistic to spirit of treaty of 1854,106 ; ended propaganda for free trade, 114,117 ; Newcastle-Galt controversy, 453.

Garvie, William, 361-363, 385 .

Gee, Joshua, 31-32, 47, 88-89.

Gladstone, William, 8, 46, 278, 288 , $304,397-398$; advocate of free trade, $4,274,435,439$; against extension of preferences, 27,29 ; fiscal reforms credited to, 45 ; revision of Possessions Act, 52 ; on responsible government, 213, 240, 246-247 ; on Rebellion Losses Act, 230, 233 ; protest against settlement and government of Vancouver Island, 300-301 ; on separation of colonies, 330-331, 338- 
340, 352-353, 388, 391 ; on defence of self-governing colonies, 370,383 ; on annexation of Canada to U.S., 384 ; objections to Tariff Act of $1845,430-431$; dispatch of March 3, 1846 , on change in British fiscal systems, 433-434; comparison of fiscal freedou of colonies of old and new era, 463.

Glenelg, Lord, Secretary for the Colonies, 307-308, 317, 343.

Gordon, Sir J. Willoughby, 286.

Gosnell, R. E., cited, 182, 300, 395.

Goulburn, Henry, Chancellor of Exchequer, 46, 300.

Government, forms of, in colonies, 62 ; movement for responsible, 61-65.

Goveruors, colonial, instructions and powers of, $54-55,74,253$; veto power, 57-58, 253 ; functions, 228229 ; new type of, 229 ; effect of responsible government on powers of, 253 ; recommendation of money bills before and after responsible government, 254 ; loss of veto power, 255,268 ; revisions of instructions to, $264,272,276$.

Graham, 288.

Grant, W. L. See Egerton and Grant.

Granville, Lord, Secretary of State for Foreign Affairs, 207, 370 ; Colonial Secretary, 387-388; on separation of colonics, 391, 395 ; protest against Canadian tariff of 1887,467 .

Gray, John Hamilton, cited, 79, 161, $168,174,178,180,183,185,212,228$.

Great lakes : subsidies to shipbuilding companies on, 132; Joint High Commission created to settle questions of limitation of number of war vcssels on, and reciprocity of saving and wrecking on, 200.

Greelcy, Horace, 138-139, 147.

Grey, Earl, 65-66, 381 ; Secretary for Colonies, 1 ; advocate of free trade, $4,8,67,94,100,112,116,258,367$, 402,437 ; efforts in behalf of Enabling Act, 42 ; fiscal reforms credited to, 45; responsible for Australian Colonies Government Act, 95 ; retaliatory duties, $135-136$; protests against differential customs duties, 154-155, 402; plan to establish convict settlements in Cape Colony, 188 ; on responsible government, 195, 237, 241.393; author of Imperial Act of 1850,213 ; on Rebellion Losses Act, 230 ; new colonial policy, 245, 249-251 ; power of veto, 262-263 ; acknowledgement of right of United Provinces to enact differential duty tariffs, 278 ; era of indifference to colonies, 288 ; plan for settlement and government of Vancouver Island, 300, 303; discussions of colonial connexion, 346 ; on separation, 389-391 ; on self-defence of colonies, 397 ; exposition of new fiscal policy of Great Britain, 446448 ; on differential duties in colonial tariffs, 451, 457 ; conception of fiscal policy best calculated to promote development of Canada, 451 .

Grey, Sir Edward, 201-202.

Grey, Sir George, Colonial Secretary and Colonial Governor, 251-252, 259-260, 315, 365.

Grote, George, 330, 334 ; efforts for improvements of political civilization of colonies, 306 ; against holding colonies by force, 332, 338 ; discussions on colonial connexion, 341.

Halifax (Nova Scotia), 34, 39, 58 ; bounties, 87 ; origin of colonial policy, 297 ; Imperial naval station at, 400 .

Hall, Samuel C., cited, 308.

Hamilton (Canada), 39 ; organization of manufactures in, 140 ; protection to clothing factories in, 151 .

Hamilton, Lord Claud, 465, 468.

Hammond, Edmund, Permanent Un. der-Secretary of Foreign Office, 184.

Hawes, Sir Benjamin, Under-Secretaryfor Colonies, 309-310.

Head, Edmund W., Governor-General of Canada, 255, 300, 449, 452-453.

Head, Sir Francis Bond, 170.

Herbert, Sir Robert, Permanent UnderSecretary of Foreign Office, 192.

Herries, John C., 233, 240, 243, 297298, 302-303.

Herschell, Lord, member of Joint High Commission of 1898, 200.

Hicks-Beach, Sir Michael, Colonial Secretary, 264, 464.

Hincks, Francis: advocate of responsible govcrnment, 163, 237 ; Rebellion Losses Act, 232; Premier of United Provinecs, 397.

Hobart Town (Australia), 118, 120 ; differential duties, 128 ; origin of colonial policy, 297.

Holland, Sir Henry, Secretary of State 
for Colonies, 475-476. See also Knutsford, Lord.

Holton, L. H., 375.

Home Rule Bill of 1886, 16.

Howe, Joseph, advocate of responsible government, 38 ; opponent of bill for confederation, 361,386 .

Hudson Bay Company, 300.

Hume, Joseph, 8, 46, 308, 348, 380 ; Bill of 1824, 12, 31-32, 88; protest against plan for settlement and government of Vancouver Island, 300 ; efforts for improvement of political civilization of colonies, 306 .

Hume's Act of 1824, 8, 12, 32 .

Hunt, Henry, cited, 328, 330 .

Hurd, P. and A., 191, 203, 206, 211.

Huskisson, William, 8, 11-12, 31, 92, 288,427 ; navigation law of $1825,44-$ 45,52 ; earliest of fiscal and colonial reformers, 88 ; on separation of colonies, 297-298, 302-303 ; on Canadian Constitution, 304, 307 ; committee to inquire into state of civil government in Lower Canada, 316.

Huskisson's Act, 13, 44-45, 52.

Hutt, Sir William, Colonial Reformer, 29.

Immigration code, colonies free to enact own, 226.

Imperial Act of 1850, 213-214, 224, $280,363,381$.

Imperial Federation League, 403.

India, 145; refusal of preferences to, 28-29.

Inglis, Sir Robert, 311.

Internal defence of colonies, 371 .

Interprovincial council of trade, organization, 174; meeting, 174 ; difference in interests, 176; im. portance of, 177 ; results, 177-178, $185,211$.

Ionian Islands, 332 .

Ireland, political and commercial demands of, 3-4, 7, 10 ; famine in, 31 , 287.

Irish Coercion Bill, 1.

Joint High Commission representing Great Britain, Canada, and United States, 200.

Jones, Allen and, cited, 134, 283, 350, 445-446.

Kimberley, Earl of, Secretary of State for the Colonies, 66, 76, 93, 95, 97,
136, 401 ; on question of differential duties, 109, 111-112, 154, 186, 223, 258, 389, 398; demands of Australian Colonies for larger fiscal freedom, 213-215, 217, 234, 246, 278-279, 363, 389 ; advocate of free trade, 274 ; in favour of extension of Zululand Protectorate, 392 ; on responsible government, 402 ; dispatch on proposal of Australian colonies to enact differential duty tariffs, 458-462.

Kingston (Canada), 351 ; organization of manufacturers, 140, 231 ; origin of colonial policy, 297 .

Knutsford, Lord, Colonial Secretary, $192,466$.

Labouchere, Henry (Baron Taunton), President of Board of Trade, 24, 45; on separation of colonies, 331 ; attitude on Colonial Customs Bill, 426-427.

Labour laws, alien contract, Joint High Commission appointed to settle, 200.

Landsdowne, Marquis of, on retention of colonies, $344,348,350$.

Laurier, Sir Wilfrid, leader of Liberal Party, 110, 200; Confederation of North American Provinces, 110, 279 ; efforts in behalf of diplomatic freedom of Canada, 197, 209; freedom to negotiate commercial treaties, 202 ; negotiator of second reciprocity treaty between Canada and France, 207 ; Declaration of 1891, 280 ; request of Laurier Government to Great Britain to enact preferential tariffs, 382 .

Leader, John Temple, attitude of, toward secession, 334, 338 .

Lefevre, G. J. Shaw, on separation, $386,391$.

Legislation for colonies and colonial questions, 304-313.

Lewis, Sir George Cornewall, 210, 290, 300-302.

Liberal party, 36 ; acceptance of Manchester doctrines, 394 .

Liverpool, Earl of, 3-4, 8, 297.

Lloyd George, David, 225.

Lorne, Marquis of, Governor-General of Canada, 75, 189, 264, 468; national policy tariff of Canada of 1879,464 .

Lowe, Robert (Lord Sherbrooke), 384$385,387,391$.

Lucas, Sir Charles P., cited, 20, 248$249,357,392,394,405$. 
Lumber, preferences on, 15, 352 ; opposition to preferences, $23,36,341$; condition of industry, 24-25; re. ductions in duty on Baltic Sea, 46-47; high duties on, 330 .

Lyall, Sir A., 387.

Lyndhurst, Lord, on responsible government, 241; on protectionist tariffs, 376.

Lyons, Lord, Minister at Washington, opponent of responsible government, 164, 169-171, 178, 181, 189.

Lyttelton, Alfred, Colonial Secretary. $297,359,372,377$.

McCullogh, Secretary of Treasury, 179, 185.

McDonald, Sir John, 106, 200, 261, 401 ; advoeate of protectionist policy, $114,119,140,163,180,182$, 374, 404 ; Inter-Provincial Council at Quebce, 174 ; signer of Trcaty of Washington of $1871,176,207,211$; Mission at Washington, 187, 189 ; efforts in behalf of diplomatic freedom of Canada, 197, 208-209; re. taliatory duties on imports from U.S., 245 ; national policy tariff of $1879,390,473-474$.

McDonald, Sandfield, Premier of United Provinces, 169.

Mackenzie, Alexander, 106, 164, 208, $271,373,375,383$.

Mackenzie, William Lyon, 20, 197, $261,290,349$; memorial to Robinson (Baron Goderich), 422-423.

MeKinley Aet, 119, 400.

McKinley Tariff of 1890,400 .

Mackintosh, Alexander, 199.

Maekintosh, Sir James, 306-307, 314, 329.

Malmesbury, Earl of, fisheries dispute, 301-302.

Manchester Sehool, 391 ; object of. 381-383, 394 ; decline of, 392 .

Manitoba, Riel rebellion in, 399 .

Mansfield, Earl of, 341, 343-345.

Marcy-Elgin, reciproeity treaty. See Elgin-Marey.

Maritime Provinees: repeal of tariff of British Possessions Act by, 14; lumbering trade of, $23-24,30$; conditions in, 38-39; tariff duties on lumber, 42, 330 ; differential duties. 47. 75; attitude toward Colonial Office, 99 ; reciproeity ventures by L.S.. 104, 270; granting of bountics. 114; casing of tariff duties for export to U.S., 167 ; principal exports and imports of, 176 ; attitude toward protectionist tariffs, 182 ; friction with U.S. over fisheries, 301 .

Marmora (Canada), iron furnaces at, 89.

Marriage and divorce laws, desire for uniformity of, in colonies, 277.

Martin, Robert Mont., 62.

Mason, Hugh, 375, 472.

Mauritius, Island of, 5, 44, 430.

Maycock, Willoughby, cited, 192.

Melbourne Administration, advocate of free trade, 42 ; opponent of responsible government, 333 ; on resettlement of Canadas, 341 .

Melbourne (Australia), attitude of Government of, toward Tasmania Bill, 120 ; origin of colonial policy attributed to, 297.

Melbourne, Viscount, Premier, 36, 42, 345-347, 350.

Merritt, William H., efforts for reciprocity treaty of $1854,162,181,407$; reciprocal trade between Canada and West Indies, 452.

Metcalfe, Sir Charles T., opponent of responsible government, 65, 164-165, $170,172,222,299,340,351,355$; Governor-General of Canada, 227228 ; Canada Tariff Act of 1845 , 430 ; discriminatory duties, 431 .

Michell, Sir Lewis, cited, 404.

Miles, Sir Charles, 116.

Mill, John Stuart, 367.

Molesworth, Sir William, 92, 290, 295. 306 ; on separation of colonies, 330 , $334-336,341,380$; opposition to free trade between Canada and West Indies, 452.

Monck, Viscount Charles Stanley, advocate of responsible government, $164,170-171,173,181,250$; InterProvincial Council at Quebec, 174. 177 ; on retention of colonies by England, 388.

Montreal (Canada), Rebellion Losses Act. 117, 230, 245; organization of manufacturers, 140 ; proteetion to elothing faetories, 151 ; railway connexion with New York, 175; fight for responsible government, 237 ; origin of eolonial poliey, 297 ; free traders, 437-438; Annex Association of. 444-446.

Morier, Sir Robert. 191.

Morin. 318.

Jowat, Sir Oliver, ¿so. 
Natal (South Africa), objections to quality of British exports, 150 ; responsible government, 220 ; colonization, 265 ; defence of, 286 ; wars with natives, 371 ; voluntary contributions to Imperial Navy, 400.

Naturalization laws, freedom of colonies in enacting, 224.

Naval Defence Act of 1865, 225.

Navigation laws, principle of, 5 ; modification of, 13 ; repeal, 31 ; attack on, 32 ; duration of, 33 ; Huskisson's Act, 44.

New Brunswick (Canada), vested with power to repeal duties, 1 ; free port system extended to, 12 ; preferences in British tariffs on lumber from, 17, 23 ; preferences, 30 ; export of lumber, 31 ; tariffs, 33 ; repeal of duties protecting British manufactures, 53; legislature in, 59,63 ; control of legislature in, $82-83$; aid to local industries, 87 ; national policy, 130 ; bonuses, 131 , 135 ; retaliatory duties, 135,158 ; preventing of bounties, 136, 158, 258 ; direct representation in negotiations of commercial treaties, 167168 ; representation of, at InterProvincial Council at Quebec, 174, 185 ; attitude toward Confederation, 182 ; absence of tariffs with discriminatory duties, 245 ; value of, 298-299.

Newcastle, Duke of, advocate of free trade, 85, 109, 112-113, 155, 173, $186,215,224,231,245-246,258$, 262 ; in charge of bill making changes in constitution of United Provinces, 251; protest against parliamentary indifference to colonial legislation, 315 ; colonial defences, $325-327,393$; on separation of colonies, 332 ; controversy with Galt over protectionist duties, 453457.

Newfoundland (Canada): vested with power to repeal duties, 1 ; free port systen extended to, 12 ; protectionist duties in, determined by British Possessions Acts, 13 ; power of legis. lature of, to enact tariff laws, 33 ; repeal of duties protecting British manufactures, 53 ; establishment of legislature in, 59, 63 ; control of legislation in, 82-83; responsible government, 73,222 ; representation of, at Inter-Provincial Council at Quebec, 174-176 ; reciprocity with U.S., 187 ; exercise of treaty power, 192 ; lack of tariffs in, 218219; reciprocity with Australia, 279 ; new constitution, 309 ; volun. tary contributions to Imperial Navy, 400 ; developments in constitution of, giving status of nation, 408 .

New South Wales (Australia), import duties regulated by local ordinances, 44 ; repeal of act estopping, from enacting differential tariffs, 93 ; vested with power to enter trade agreements with other Australian colonies, 115 ; veto of Tasmania Bill, 118 ; responsible government, 268 ; end of disallowance of acts of colonial legislation by Parliament, 269 ; bills vetoed, 273 ; constitution, 356 ; fiscal freedom, 360 .

New Zealand, political development, 30 ; American influence, 38; im. port duties, 44 ; responsible government, $73,85,222$; differential duties, 78, 93, 97, 119, 123 ; tariff legislation, 97-98, 128 ; movement toward protective tariff and bonuses, 108-109, 121, 153 ; customs duties, 123, 132; brewing and protection of, 124, 129 ; tariff rates, 129 ; bonuses, 129, 159 ; national policy, 130-131; ' made in New Zealand,' 132-133, 159, 224 ; tariff freedom, 141, 220 ; reciprocity movement with U.S., 159 ; weak dependency, 260 ; bills vetoed, 273,278 ; defence of, 286 , 387 ; constitution, 315 ; war with natives, 371,383 , 399 ; grievances, 378 ; objections to Imperial Act, 381 ; developments in constitution of, giving status of nation, 408 .

Normandy, Lord, Colonial Governor, $386,391$.

Norton, Lord, cited, 275, 281, 383, 397.

Nova Scotia, vested with power to repeal duties, 1 ; free port system extended to, 12 ; preferences in British tariffs on lumber from, 17, 23 ; advantages derived from preferences under old commercial system, 30 ; export of lumber, 31 ; tariffs in, 33, 341, 352 ; responsible government, $37,269,368$; repeal of duties protecting British manufactures, 53 ; legislature of, 58, 63 ; control of legislation in, 82-83; aid to local industries, 87 ; bounties, 
$87-88,131$; national policy, 130 ; 'made in Canada,' 132 ; protection to woollen mills, 151 ; differential duties, 158 ; representation of, at Inter-Provincial Council at Quebec, 174, 185; attitude towards confederation, 182 ; absence of tariff with discriminatory duties, 245 ; value of, 298-299; prosperity on entering Confederation, 362 ; with. drawal of colonial preferences disa ppointing to, 374 ; duties in interest of blast furnaces, 402 ; tariff of 1834 , 420-421.

O'Connell, 329, 330.

Oliphant, Lawrence, 386.

Ontario (Canada), government bounties, 87 ; national policy, 130 ; 'made in Canada,' 132 ; import duties, 137, 402; protection to woollen mills, 151 ; gateway to U.S. for immigrants, 337 ; effect of Confederation on, 362 .

Oregon boundary dispute, 299.

Ottawa (Canada), in favour of tariff preference for manufactures from England, 28 ; protective duties, 75 ; government bounties, 87,140 ; free trade propaganda, 115 ; national policy, $130,141,284$; bonuses for industry, 131-133; duties on salt and coal enacted by, 137 ; preferential tariff of 1897 and effects, 144-145 ; colonial conference, 195 ; tariff acts and fiscal legislation, 197 ; Manitoba School question, 198 ; movement for diplomatic freedom, 207-209, 212 ; Fielding tariff of 1897, 219; status of British North American provinces defined, 279 ; enactment of second national poliey tariff, 380 ; Gladstone Administration regarded as indifferent to colonial connexion, by, 387 ; scandal arising out of granting first charter for construction of Canadian Pacific Railway, 398 ; Parliamentary protests against tariff of 1887 enacted at, 402.

Paish, Sir George, cited, 403.

Pakenham, Sir Richard, British Minis. ter at Washington, 439-440.

Pakington. Sir John, 268, 301-302, 348 ; advocate of bounty systems, $96,136,263$.

Palmer, George, 24.
Palmerston Government, surrender to protectionist movement, 114 ; colonial defence, 325 ; compelled to accept Galt tariff, 306, 369, 380 .

Palmerston, Lord, 245, 290 ; in favour of retention of colonies, 344 ; protectionist tariffs, 376 ; reciprocity with U.S., 439-440.

Papineau, Louis Joseph, 20, 197, 261, 307, 316-317, 322, 349.

Parkes, Sir Henry, cited, 266.

Peace of Versailles, resumption of trade with colonies, 4 ; indifference to colonies persisted after, 20.

Peel, Sir Robert, advocate of free trade, $1-2,4,8,17,27,31,42,82,352$; fiscal reforms credited to, 45 ; tariff policy in $1842,46-47$; revision of eorn laws, 48 ; free trade measures of 1846,63 ; on responsible govern. ment, 65, 237 ; Cayley Aet of 1858, 77 ; on Rebellion Losses Bill, 242 ; new colonial policy, 1849,245 ; on retention of colonies, 298-299, 302303, 331, 342 ; Quebec difficulties, 320-321.

Pitt, William, 349.

Place, Francis, 288.

Poley, Arthur P., cited, 304.

Pollock, Sir Frederick, 247-248, 359.

Population of colonies, 61-62.

Postal system in colonies, improved. 292.

Poyning's Law, 4, 276.

Pratt, A., cited, 129.

Preferences, in colonies, 15, 22-23, 26-27; opposition to, 27 ; value to colonies, 30.

Prince Edward Island, 1, 12, 53, 174 , 185 ; tariff laws enacted, 33 ; establishment of legislature, 58, 63 ; control of legislation in, 82-83; prevention of bounties, 136, 158 . 258 ; absence of tariff with discriminatory duties, 245 ; reciprocity overtures by U.S., 104 ; diffcrential duties, 158.

Prisoners, Joint High Commission created to settle question of convey. ance of, by officers of law through U.S. or Canada, 200.

Quebec (Canada), fiscal frecdom of legislaturc of, restricted, 34 ; pro. tcctive duties, 75-76; iron manufacturing, 89 ; discontent at, 92 : iron manufacturing, 89 ; national policy. 130 ; import duties. 137; 
protection to woollen mills, 151; Inter-Provincial Council at, 176-177; constitutional convention at, 279 ; origin of commercial policy, 297; political unrest at, $311,320,322,329$; gateway for immigrants to U.S., 337 ; advantages to, of Confederation, 362. Quebec Government Act of 1791, 33, $260,313,380$.

Queensland (Australia), tariff freedom, 92,123 ; vested with power to enter into trade agreements with other Australian colonies, 115 ; veto of Tasmania Bill, 118 ; bills vetoed, 273.

Radical party, 1, 8, 36 .

Rebellion Losses Act, 61 ; established responsible government in colonies, 199, 206, 249 ; history of, 230-238 ; failure of Parliament to disallow, 239-242, 247 ; debates on, 244.

Reciprocity : treaty of 1854-1866, $102-103,137,162$; advantages of, to Canada, 103; efforts for new treaty, 161, 379 ; attitude of ministers towards treaty-making by colonies, 165-166 ; outlook for duration of treaty of 1854,169 ; of 1874 , 176; effect of Inter-Provincial Council, 178 ; mission to Washington for second reciprocity agreement, 179180 ; attempts at reciprocity with Cuba, Brazil, and Mexico by Canada, 183 ; conditions and powers of Canadian representatives to negotiate reciprocal agreements, 184, 270 ; effect of Civil War on reciprocity with Canada, 187 ; reciprocity with Spain, 187-188, 191 ; French-Canadian reciprocity treaty, 1893, 193-194, 198 ; of $1907,208,407$; reciprocity between U.S. and Canada, 1784, 246, 407 ; overtures for reciprocity between U.S. and Canada, 438-439 ; protests by Glasgow manufacturers against Canadian, 470.

Reform Act (1832), 317.

Reid, Sir George, 146, 364.

Responsible government: movement for, 61-65 ; established by Rebellion Losses Act, 199 ; carried with it fiscal freedom, 402.

Retaliatory duties, in early Australian tariffs, 134-138.

Riddell, W. R., cited, 201, 254.

Rideau Canal, maintenance of, 328.

Ripon, Marquis of, Colonial Secretary,
194-196, 198-200, 288 ; dispatoh regarding customs arrangement with colonies, 462-463.

Robinson, Frederick John (Viscount Goderich and Earl of Ripon), 4-6, 92,322 ; Act of $1822,44,46,52$; legislation for colonies, 308 ; on responsible government, 329 ; Memorial of William I. Mackenzie, $422-423$.

Robinson's Act of 1822, 11-13, 52 .

Robinson, W. B., 431.

Roebuck, John A., 92, 233, 291 ; agent in London for Lower Canada, 305; efforts for improvement of political civilization of colonies, 306 ; advocate of responsible government, 308,380 ; introduced reform bill, 312 ; colonial policies, 320 ; well informed on Canadian conditions, $333-334$; on retention of colonies, $334,338,343$.

Rogers, Frederick (Lord Blachford), Under-Secretary for the Colonies, 71, 256-257, 268-269 ; on permanency of colonial connexion, 324, 326-328, 331-333, 341, 343, 355.

Rose, John, advocate of protectionist policy, 114, 149, 151, 153, 182, 261.

Rosebery Administration, 194.

Royal Colonial Institute, 403.

Russell, Andrew H., cited, 396.

Russell, Earl, 25, 36.

Russell, Lord John, 1-3, 8, 322, 437 ; legislation of 1846-1849, 31 ; Enabling Act of $1846,42,63$; fiscal reforms credited to, 45,77 ; developments in movement for treatymaking power, 167 ; Rebellion Losses Act, 230, 241, 379 ; on responsible government, $237,242,355$, 381 ; declarations of colonial policy, 245 ; new colonial policy, 246, 249 ; ten resolutions of $1837,307-308,330$; on colonial connexion, 348, 351, 353-355, 391.

Russell resolutions of $1837,332-333$.

Sackville-West, Sir Lionel, 192.

St. John (New Brunswick), 131, 135 ; origin of colonial policy, 297.

St. John's (Newfoundland), fiscal freedom of legislature of, restricted, 34 ; revenue tariffs enacted, 219.

St. Martin's-le-Grand, 292, 294 ; control over postal service in Canada, 378.

Sault Ste Marie (Canada), mills at, 132. 
Scott, Francis, passing of veto upon colonial legislation, 256, 275 ; efforts for improvement of political civilization of colonies, 306 .

Seaford, Lord. See Ellis, Charles R.

Secession of the colonies: willingness of British statesmen to abandon colonies, 296-303 ; expectation that colonies would secede, 323-327 ; attitude of House of Commons toward, 327-335 ; House of Commons and commercial value of colonial conncxion, 335-340 ; discussions of colonial connexion in House of Lords, 341-347; separatists of various schools of political thought, 384-393.

Sceley, J. R., 366.

Separation of the colonies. See Seces. sion.

Shcrbrooke, Lord. See Lowe, Robert.

Sierra Leone (West Africa), proposed abandonincnt of, 298, 346 .

Simcoe, John Graves, 333.

Slagg, John, 473.

Smith, Adam, cited, 189.

Smith, Goldwin, 210, 346, 384, 388, 392-394, 472.

Smith, W. H., 119.

Smith, William, cited, 247, 293, 318.

Snowden, Sir William, 364.

South Africa, 19, 43; responsible government, 9, 222 ; new fiscal system, 71,141 ; cost of native wars. 383 ; end of war with natives. 399 ; status of nation, 408 .

South African War, 400.

South Australia, import duties regulated by local ordinances, 44 ; tariff frecdom, 93 ; vested with power to enter into trade agreements with otler Australian colonies, 115 ; differential duties, 123 ; agitation against veto by Parliament, 269 ; bills vetoed (1857-1893), 273, 277.

Spain, efforts to negotiatc reciprocity trcaty with, 187-188.

spring-Rice, 291, 316-318, 321 .

Stanley, Lord (Earl of Derby), 29, 31, $46,92,96,108,291$; Act of 1843 , 47,50 ; on responsiblc government. 65 ; motions for disallowance of colonial legislation, 240-242 ; Dcclaratory Act, 244 ; on abandonment of colonies, 301 ; lcgislation for colonies, 308-309 ; colonial connexion, $338-340$, 391-392 ; statement of policy of Pecl Administra. tion, 1841-1846, 427-428.
Subsidies to shipbuilding companies on great lakes, 132.

Sullivan, Robert B., advocate of protection, 126, 163, 261.

Suttor, Francis B., 195, 265.

Sydenham, Lord, 92, 232 ; concession of responsible government, 65,172 , $223,237,299$; services to constitutional development of dominions, 166 ; on inaintenance of colonial connexion, 350-351, 357 ; instructions to, as Governor-General of Canada, 419 ; case for acceding to colonial claim for larger powers in enacting tariffs, 425.

Sydney (Australia), attitude of Government of, on Tasinania Bill, 120 ; mills at, 132 ; origin of colonial policy, 297.

Syme, David, father of protection in Australia, 126, 128-129, 149, 151, 153 ; protection against low wages, 139.

Tariff, end of British preferences in colonies, 1 ; in Canada, 2 ; less restrictive, 7 ; repeal of, by Canada. 14 ; colonial preferences, 15,46 ; revision of, 16-17; Payne-Aldrich, 19 ; preferences on wheat and flour from Canada, 22-23, 27 ; protectionist tariff and attack on it, $31-33,245$, $398,463-465$; tariff of 1842,46 , $421-422$; uniformity of, $56,63,66$; policy in colonies, 74 ; with differential duties in colonies, 75, 245, 278 . 398 ; protective tariffs in colonies, 75-76 ; enactment of, in colonies, 93-94 ; in Victoria, 125-126 ; second national policy tariff, $140,380,390$, 464-465 ; preferential, of 1897 , 144145 ; protective tariff against England in Canada, 218, 250, 285, 369, 397 ; first retaliatory tariff, 245 ; effort to revise duty on grain in Canada, 352 ; objections to Canadian tariffs, 375, 391 448-449; protective tariffs by U.S., 376 ; attitude of British to protective tariff, 400 ; discriminatory duties in colonial tariffs. 431-432; protests against tariff of $1887,465-466$; protests of Britisl manufacturers against increases in iron and stecl duties, 475-477.

Tariff bill of 1859, 110, 114, 262, 278. $453-454$.

Tasmania (Van Dieman's Land) : pre- 
ferential treatment for wheat and flour from, 29 ; import duties regulated by local ordinances, 44 ; tariff freedom, 93 ; differential duties, 100 , $118,123,460$; vested with power to enter into trade agreements with other Australian colonies, 115; movement towards protective tariff, 108 ; brewing in, 125 ; bonuses, 129 , 159 ; bills vetoed, 273, 278 ; new constitution, 309 ; failure of legisla. tion for, 314 .

Tasmania Bill (1867), 100, 109, 118120.

Taunton, Baron. See Labouchere, Henry.

Taylor, Sir Henry, 291, 355 ; on permanency of colonial connexion, 324326, 331, 341.

Thompson, Perronet, 329-330, 334, 341 .

Thompson government, 196.

Thynne, A. J., cited, 116.

Tilley, 280, 464-465.

Todd, A., cited, 246.

Toronto (Canada), restrictions of fiscal freedom of legislature of, 34 ; propaganda for protectionist tariffs, 68 ; organization of manufacturers of, 140; 'Canada First' movement originated at, 209-210 ; expenditure procedure at, 232; demands for fiscal freedom, 261 ; origin of colonial policy, 297.

Torrens, Colonel, 329-330.

Treaties of 1888 (fisheries and boundaries disputes), 192. See also Reciprocity.

Treaty-making in colonies: early stages of movement for power in, 161-163 ; attitude of British ministers toward, 164; developments in movement for power in, 167-173 ; claim of direct representation in, conceded, 177 ; British recognition of new place of colonies in diplomacy, 183 ; claims pressed for more power in, 188; halt in progress toward diplomatic freedom, 193 ; freedom to negotiate treaties achieved, 198 ; transference of new power to dominions, 203.

Tremenheere, Hugh Seymour, 190, 368.

Trevelyan, Sir George, 381.

Tupper, Sir Charles, 187, 205, 265, 271 ; father of Confederation, 102, 280 ; tariff preferences, 145 ; reciprocity negotiations at Madrid, 188 ; claims for more diplomatic power in dominions, 188-193, 216 ; High Commissioner for Canada in London, 190, 198 ; reciprocity treaty between Canada and France, 196-197, 207 ; tariff revision of 1887,465 .

Tupper, Sir Charles Hibbert, 176, 188.

Underwood-Simmons tariff, 104.

United Provinces of Upper and Lower Canada, protective tariffs, 2, 33, 41, 199, 217; improved political and commercial conditions, 9-10 ; differential duties, $9,53,75,138,161$, 270 ; political development, 30 ; agitation against old system, 36-37; American influence, 37-38, 41 ; against British Possessions Act, 3840 ; imports from U.S., 39-40; preferential terms on wheat and flour, 47, 49 ; responsible government, 56, 269, 331, 351, 368 ; legislature, 59 ; protective tariffs, $77,158,161$, 245-246 ; fiscal freedom, 80-81; $110,190,202$; tariff freedom, 93, 110 ; tariff duties, 128 ; estopping of retaliatory duties, 136,138 ; protectionist duties, 141, 230, 270; effort to secure power to negotiate reciprocity treaties,161-163,174,270; communication with U.S., 175 ; desire for self-government, 190, 257, 313 ; absence of tariff with discriminatory duties, 245 ; influence of U.S., 260 ; effect of cities on political agitation, 262 ; success of tariff legislation, 263, 270, 379; infrequency of veto of bills by Parliament, 270 ; demand for application of Declaratory Act, and control of postal system, 270 ; direct representation in reciprocity treaties, 270 , 380 ; friction with U.S. at time of Civil War, 324; forcible union of Upper and Lower Canada, 328, 338 ; bill to revise duty on grain, 352 ; agitation for annexation to U.S., 354, 356, 375 ; constitution, 369 ; grievances of, 378 ; protest against disallowance of banking acts, 423 ; other protests, 424.

United States, 4 ; trade with, 18-19, 21 ; influence on colonies, 37-38, 41, 203,260 ; influence of tariff policy on Canada, 81, 159; reciprocity overtures, 103-104; reciprocity treaty with Canada, 137, 159 ; im. ports from Canada, 175 ; exports 
to Canada, 176 ; immigration from England, 296, 336-337.

Valleyfield (Canada), Dominion Tariff Commission at, 152.

Vancouver Island, tariff war, 123-124 ; confirmation as a British possession, 299 ; plan for colonization, 300,303 .

Van Dieman's Land. See Tasmania.

Veto, by colonial governors, 57, 225 ; by the Crown, 225 ; passing of, on colonial legislation, 252-259 ; factors and influences that restricted, on colonial legislatures, 259-264; Australian Colonies and, 265-271 ; last stage of the, 272-281.

Victoria (Australia), tariff freedom, 76,93 ; movement towards protective tariff, 108, 114, 121, 139, 149 ; vested with power to enter into trade agreements with other Australian colonies, 115 ; reciprocity, 118 ; customs duties, 123; protective tariff, 125-126, 128; responsible government, 268 ; agitation against veto by Parliament, 269 ; bills vetoed, 273, 277 ; desired changes in marriage and divorce laws, 277 ; fiscal freedom, 360,369 .

Victoria, Queen, 21, 37, 69, 72, 172, $236,283,323,326,364$.

Viger, delegate in London from Quebec, 318.

Villiers, C. P., 4, 348.

Vogel, Sir Julius, Colonial Treasurer and Premier, 129, 133, 151 ; father of protection in New Zealand, 153, 460 .

Wade, John, 329-330, 376.

Wages, protection in Great Britain against low, 138-142; in British industries, 142-148.

Wallace, Robert, cited, 305.

Warburton, 24, 306, 336-338, 341.

Ward, Henry G., 332-333, 343.
Washington, Mission to, 177-183.

Watkin, Edward W., 386.

Weaver, Emily P., cited, 400.

Wedgwood, Julia, cited, 12.

Weir, William, advocate of protection. ism, 114, 133, 140, 153, 176.

Wellington (Australia), attitude of government of, toward Tasmania Bill, 120 ; bills for differential customs duties passed at, 128-129; origin of colonial policy, 297.

Wellington, Duke of, 65 ; suggested abandonment of Guinea, 297-298; proposed plan for Ceylon, 300 ; on abandonment of colonies, 302-303 ; opposition to concession of responsible government, 340 ; desired per. manent union of colonies with Great Britain, 345-346, 348, 350.

West Indies, 130 ; trade with U.S. and European colonies, 4; creation of free ports, 6-7 ; sugar trade, 8,17 ; casier trade relations with U.S., 9; British concession to, 10 ; curtailment of preferences on sugar, 36 ; reciprocity overtures by U.S., 104 ; protection of sugar interests by Parliament, 304-305.

Wheat and flour, tariff preferences, $22-23,26-28,47$; duties on, $47-49$; concessions on, 50 ; importation from Canada, 50.

Whig party, 1; on free trade, 2; control by, 36 ; acceptance of Manchester doctrines, 394 .

White, R., 106.

Wilson, J. M., 123, 460.

Wood, A., 256.

Woollen manufacturers, protests of against higher duties on British woollens, 152 .

Young, Jolin, 438.

Zululand, extension of protectorate, 392. 


\section{UNIVERSITY OF CALIFORNIA \\ Santa Barbara College Library \\ Santa Barbara, California}

Return to desk from which borrowed.

This book is DUE on the last date stamped below.

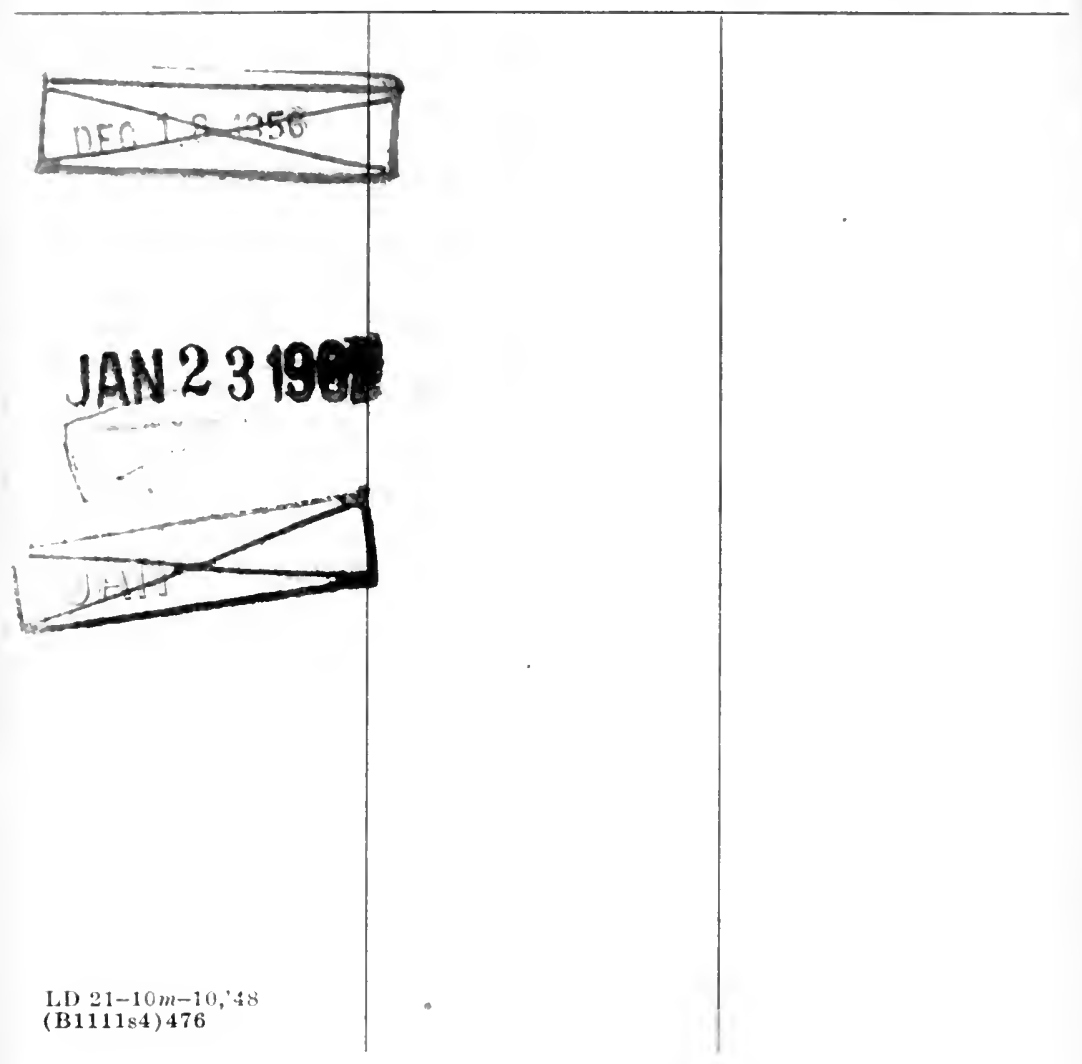




\section{JV Porritt \\ 1000 Fiscal and}

diplomatic freedom

of the British

oversea dominions. 
